\title{
Geology of the
}

Aspen 15-minute Quadrangle, Pitkin and Gunnison Counties, Colorado

GEOLOGICAL SURVEY PROFESSIONAL PAPER 1073
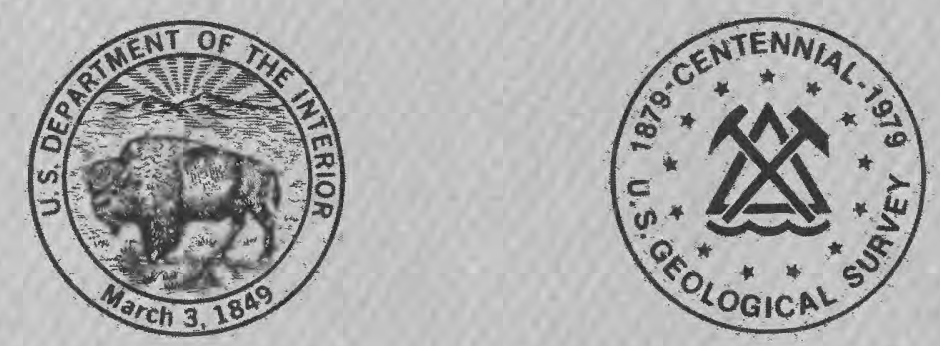
Geology of the

Aspen 15-minute Quadrangle,

Pitkin and Gunnison Counties,

Colorado

By BRUCE BRYANT

GEOLOGICA L S UR VEY P R OFE S I O N A L P A P E R 1073

$A$ study of an area at the intersection of the

Colorado mineral belt with the west flank of the

Sawatch uplift

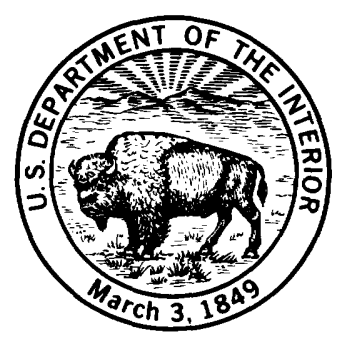




\title{
UNITED STATES DEPARTMENT OF THE INTERIOR \\ CECIL D. ANDRUS, Secretary
}

\section{GEOLOGICAL SURVEY}

\author{
H. William Menard, Director
}

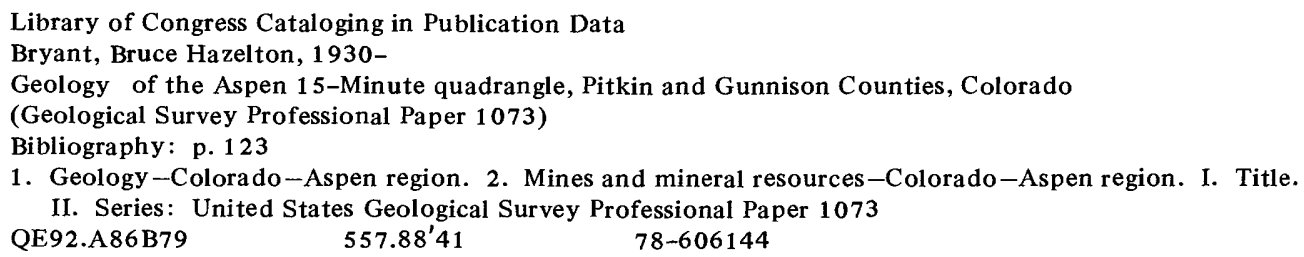

For sale by the Superintendent of Documents, U.S. Government Printing Office

Washington, D.C. 20402

Stock Number 024-001-03254-6 


\section{CONTENTS}

Abstract .

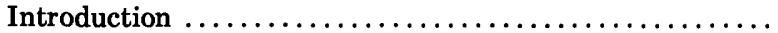

Location and physical geography $\ldots \ldots \ldots \ldots \ldots \ldots$

Previous geologic investigations $\ldots \ldots \ldots \ldots \ldots \ldots \ldots$

Present investigations $\ldots \ldots \ldots \ldots \ldots \ldots \ldots \ldots \ldots \ldots$

Fieldwork and acknowledgments ...............

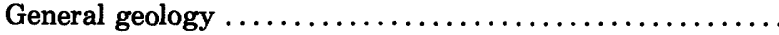

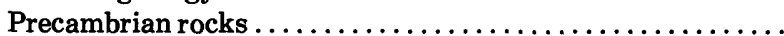

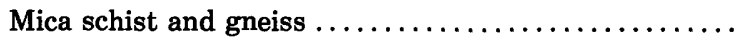

Mixed quartz diorite, pegmatite, quartz monzonite, and

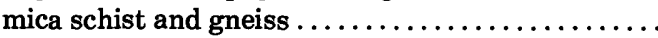

Biotite quartz diorite .........................

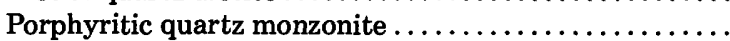

Muscovite-biotite granite ......................

Quartz monzonite ............................

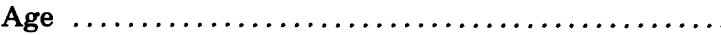

Cambrian through Mississippian shelf sequence ...........

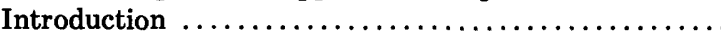

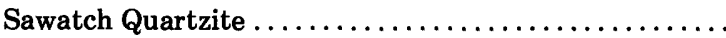

Peerless Formation.$\ldots \ldots \ldots \ldots \ldots \ldots \ldots \ldots \ldots \ldots$

Manitou Dolomite ..........................

Stratigraphic relations and correlations of Cambrian and Ordovician rocks.

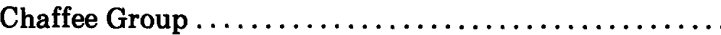
Parting Formation . . . . . . . . . . . . . . . . . . . .

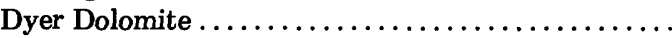

Gilman Sandstone $\ldots \ldots \ldots \ldots \ldots \ldots \ldots \ldots \ldots \ldots$

Leadville Limestone ........................

Pennsylvanian through Triassic sequence of the Eagle Basin .

Belden Formation .............................

Gothic Formation of Langenheim (1952) . . . . . . . .

Eagle Valley Formation.$\ldots \ldots \ldots \ldots \ldots \ldots \ldots \ldots$

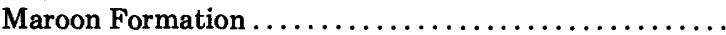

Environments of deposition of Gothic and Maroon For-

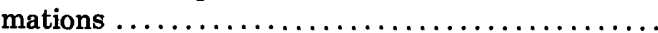

State Bridge Formation .......................

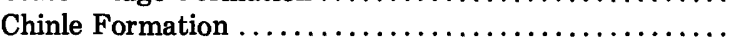

The nonmarine and marine rocks of the Jurassic and Cretaceous

Entrada Sandstone.$\ldots \ldots \ldots \ldots \ldots \ldots \ldots \ldots \ldots \ldots \ldots$

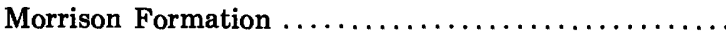

Burro Canyon Formation and Dakota Sandstone ........

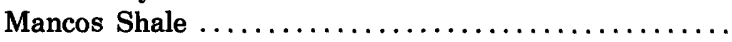

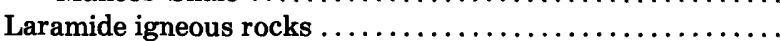

Hornblende quartz diorite..$\ldots \ldots \ldots \ldots \ldots \ldots \ldots$

Quartz porphyry ..............................

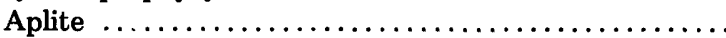

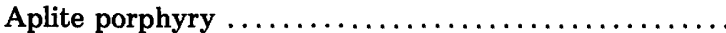

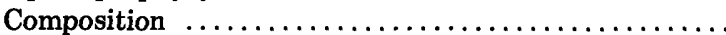

Middle Tertiary igneous rocks $\ldots \ldots \ldots \ldots \ldots \ldots \ldots \ldots \ldots$

Granodiorite

Alteration..$\ldots \ldots \ldots \ldots \ldots \ldots \ldots \ldots \ldots \ldots \ldots \ldots$

\begin{tabular}{|c|c|c|}
\hline Page & & \\
\hline 1 & Middle Tertiary igneous rocks-Continued & \\
\hline 2 & Porphyritic granodiorite $\ldots \ldots \ldots \ldots \ldots \ldots \ldots \ldots \ldots$ & \\
\hline 2 & Hornblende porphyry $\ldots \ldots \ldots \ldots \ldots \ldots \ldots \ldots \ldots$ & \\
\hline 4 & Alaskite $\ldots \ldots \ldots \ldots \ldots \ldots \ldots \ldots \ldots \ldots \ldots \ldots \ldots \ldots \ldots$ & \\
\hline 4 & Composition $\ldots \ldots \ldots \ldots \ldots \ldots \ldots \ldots \ldots \ldots \ldots \ldots \ldots \ldots \ldots \ldots \ldots \ldots$ & \\
\hline 4 & Tertiary and Quaternary diabase dikes $\ldots \ldots \ldots \ldots \ldots \ldots$ & \\
\hline $\mathbf{5}$ & Metamorphism $\ldots \ldots \ldots \ldots \ldots \ldots \ldots \ldots \ldots \ldots \ldots \ldots \ldots$ & \\
\hline 7 & Chemistry of metamorphism $\ldots \ldots \ldots \ldots \ldots \ldots \ldots \ldots$ & \\
\hline 7 & Conditions of metamorphism $\ldots \ldots \ldots \ldots \ldots \ldots \ldots \ldots$ & \\
\hline & Structure $\ldots \ldots \ldots \ldots \ldots \ldots \ldots$ & \\
\hline 7 & Precambrian structures $\ldots \ldots \ldots, \ldots \ldots \ldots \ldots \ldots \ldots$ & \\
\hline 8 & Phanerozoic structure $\ldots \ldots \ldots \ldots \ldots \ldots \ldots \ldots \ldots$ & \\
\hline 8 & Pre-Laramide structural events $\ldots \ldots \ldots \ldots \ldots \ldots$ & \\
\hline 9 & Late Cretaceous and Paleocene(?) events ......... & \\
\hline 9 & Laramide structures $\ldots \ldots \ldots \ldots \ldots \ldots \ldots \ldots$ & \\
\hline 11 & Faults $\ldots \ldots \ldots \ldots \ldots \ldots \ldots \ldots \ldots \ldots \ldots$ & \\
\hline 12 & The Elk Range thrust zone ............... & \\
\hline 12 & The Castle Creek fault zone ............... & \\
\hline 12 & Other faults $\ldots \ldots \ldots \ldots \ldots \ldots \ldots \ldots \ldots \ldots$ & \\
\hline 14 & Folds $\ldots \ldots \ldots \ldots \ldots \ldots \ldots \ldots \ldots \ldots \ldots \ldots$ & \\
\hline 15 & Oligocene intrusion and deformation..$\ldots \ldots \ldots \ldots$ & \\
\hline & Late Tertiary movements..$\ldots \ldots \ldots \ldots \ldots \ldots$ & \\
\hline 16 & Joints, shears, faults, and veins $\ldots \ldots \ldots \ldots \ldots \ldots \ldots$ & \\
\hline 17 & Quaternary surficial deposits $\ldots \ldots \ldots \ldots \ldots \ldots \ldots \ldots \ldots$ & \\
\hline 18 & Glacial geology $\ldots \ldots \ldots \ldots \ldots \ldots \ldots \ldots \ldots \ldots \ldots \ldots$ & \\
\hline 19 & Moraine deposits $\ldots \ldots \ldots \ldots \ldots \ldots \ldots \ldots \ldots$ & \\
\hline 20 & Outwash terrace deposits $\ldots \ldots \ldots \ldots \ldots \ldots \ldots \ldots$ & \\
\hline 21 & Age and correlation of glacial deposits .......... & \\
\hline 22 & Rock glaciers $\ldots \ldots \ldots, \ldots, \ldots, \ldots, \ldots, \ldots \ldots$ & \\
\hline 23 & Age of the rock glaciers $\ldots \ldots \ldots \ldots \ldots \ldots \ldots \ldots \ldots$ & \\
\hline 25 & Landslide deposits $\ldots \ldots \ldots \ldots \ldots \ldots \ldots \ldots \ldots \ldots \ldots$ & \\
\hline 28 & Solifluction deposits $\ldots \ldots \ldots \ldots \ldots \ldots \ldots \ldots \ldots \ldots \ldots$ & \\
\hline 29 & Colluvium $\ldots \ldots \ldots \ldots \ldots \ldots \ldots \ldots \ldots \ldots \ldots \ldots \ldots$ & \\
\hline & $\ldots \ldots \ldots \ldots \ldots \ldots \ldots \ldots \ldots \ldots \ldots \ldots \ldots$ & \\
\hline 40 & Alluvial and debris fan deposits $\ldots \ldots \ldots \ldots \ldots \ldots \ldots$ & \\
\hline 40 & $\ldots \ldots \ldots \ldots \ldots \ldots \ldots \ldots \ldots \ldots \ldots \ldots \ldots \ldots \ldots$ & \\
\hline 44 & Economic geology $\ldots \ldots \ldots \ldots \ldots \ldots \ldots \ldots \ldots \ldots \ldots \ldots$ & \\
\hline & Deposits of Laramide age $\ldots \ldots \ldots \ldots \ldots \ldots \ldots \ldots$ & \\
\hline 46 & The Highland tunnel $\ldots \ldots \ldots \ldots \ldots \ldots \ldots \ldots \ldots \ldots$ & \\
\hline 46 & 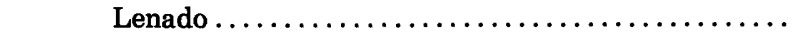 & \\
\hline 47 & Ore deposits of middle Tertiary age $\ldots \ldots \ldots \ldots \ldots \ldots \ldots$ & \\
\hline 49 & t head of Cooper Creek..... & \\
\hline 51 & Disseminated sulfide deposits . . . . . . . . . & \\
\hline 54 & Fissure veins $\ldots \ldots \ldots \ldots \ldots \ldots \ldots \ldots \ldots \ldots \ldots$ & \\
\hline 54 & Copper-silver deposits in Dakota Sandstone ........ & \\
\hline $\mathbf{5 5}$ & tent of copper sulfides .............. & \\
\hline 56 & Conclusions $\ldots \ldots \ldots \ldots \ldots \ldots \ldots \ldots \ldots \ldots$ & \\
\hline 56 & Ore deposits of unknown age.. & \\
\hline 56 & Gold Hill $\ldots \ldots \ldots \ldots \ldots \ldots$ & \\
\hline 58 & rences cited ... & \\
\hline 61 & $\ldots \ldots \ldots \ldots . . .6$ & \\
\hline
\end{tabular}




\section{STRATIGRAPHIC SECTIONS}

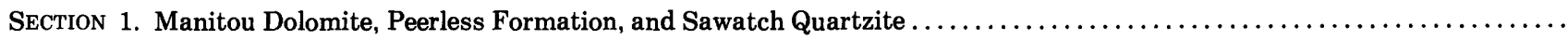

2. Morrison Formation (part), Entrada Sandstone, Chinle Formation, Maroon Formation, and Gothic Formation (part) of

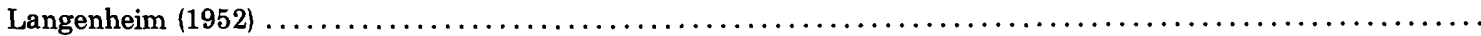

3. Dakota Sandstone (part), Burro Canyon Formation, Morrison Formation, Entrada Sandstone, Chinle Formation, and

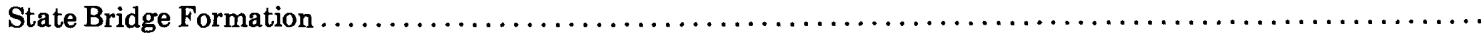

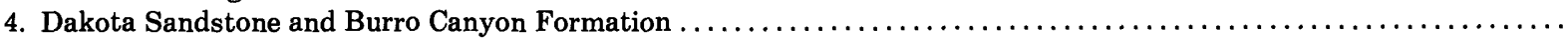

Page

130 139

\section{ILLUSTRATIONS}

Figure 1. Map showing location of the Aspen area.

2. Diagram of classification of sedimentary rocks

3. Map showing regional geologic setting of the Aspen area

4. Photographs of outcrops of mica schist and gneiss .....

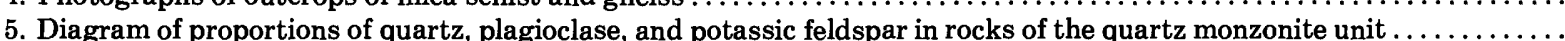

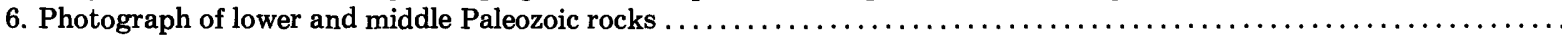

7. Diagram of proportions of quartz, feldspar, and mica and clay in Sawatch Quartzite $\ldots \ldots \ldots \ldots \ldots \ldots \ldots \ldots \ldots$

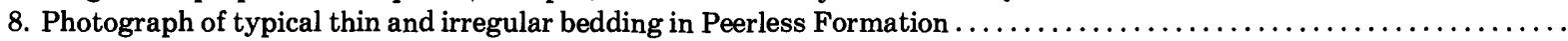

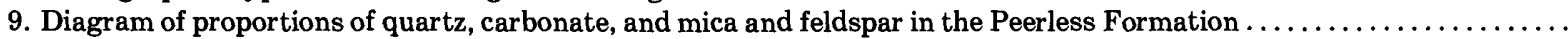

10. Photograph of upper part of Manitou Dolomite showing lenses and stringers of white chert and wavy irregular bedding

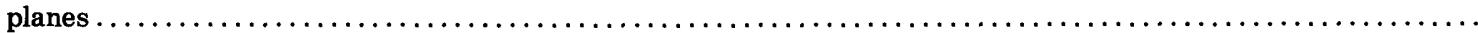

11. Sketch of possible stratigraphic relations of Cambrian rocks in west-central Colorado in a northwest-southwest section through Aspen...

12. Sketch of possible stratigraphic relations of Cambrian rocks in west-central Colorado in a north-south section through Aspen .

13. Photograph showing contact of Parting Formation of the Chaffee Group with the Manitou Dolomite...

14. Diagram of proportions of quartz, carbonate, and mica and feldspar in the Parting Formation of the Chaffee Group....

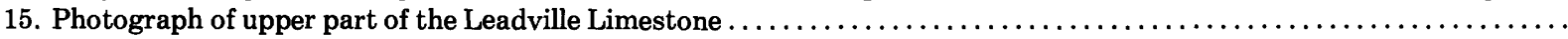

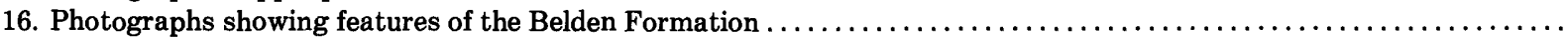

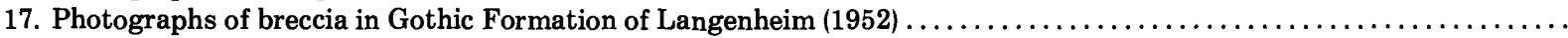

18. Diagram of proportions of quartz, carbonate, and mica and feldspar in the Gothic Formation of Langenheim (1952) ..... 19-22. Photographs:

19. Panorama of the Elk Mountains west and southwest from ridge between East Maroon and Conundrum Creeks .

20. Maroon Formation on northeast ridge of North Maroon Peak $\ldots \ldots \ldots \ldots \ldots \ldots \ldots \ldots \ldots \ldots \ldots \ldots \ldots \ldots \ldots \ldots$

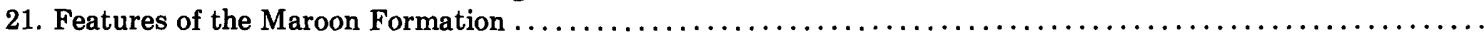

22. Evaporite in the lower part of the Maroon Formation near Hayden Peak $\ldots \ldots \ldots \ldots, \ldots, \ldots \ldots \ldots \ldots \ldots \ldots$

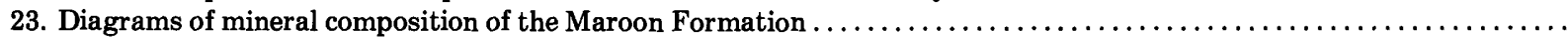

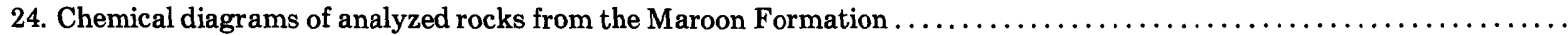

25. Summary diagram of 41 azimuths of crossbedding in the Maroon Formation $\ldots \ldots \ldots \ldots \ldots \ldots \ldots \ldots \ldots \ldots \ldots \ldots$

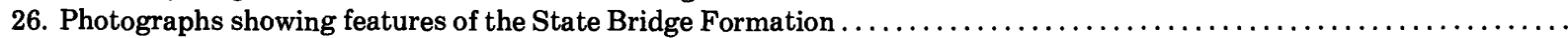

27. Photographs comparing typical textures of sandstone in the Maroon Formation with sandstone in the State Bridge

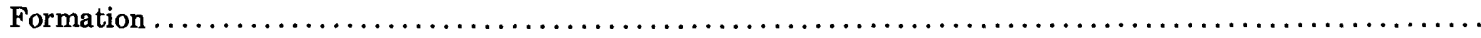

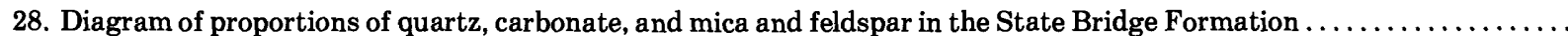

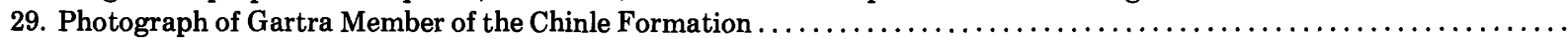

30. Diagram of proportions of quartz, carbonate, and mica and feldspar in the Chinle Formation $\ldots \ldots \ldots \ldots \ldots \ldots \ldots$

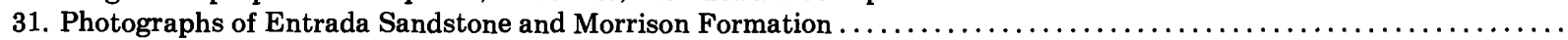

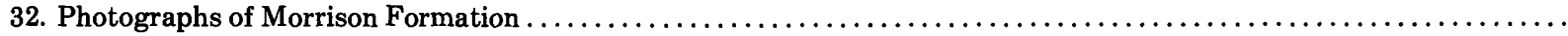

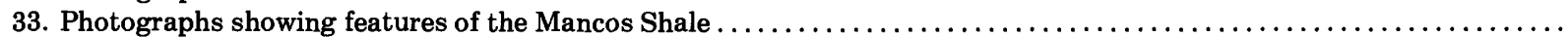

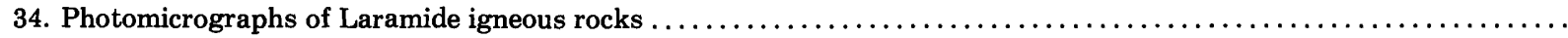

35. Chemical diagrams for analyzed Laramide igneous rocks . 


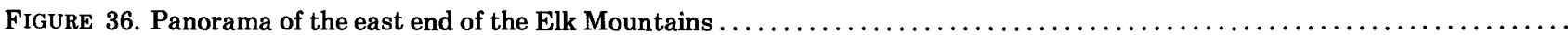

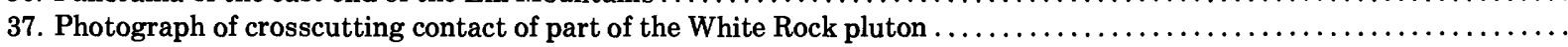

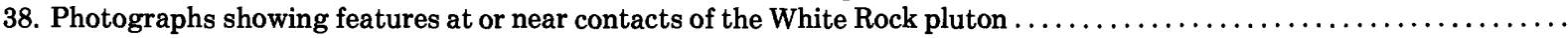

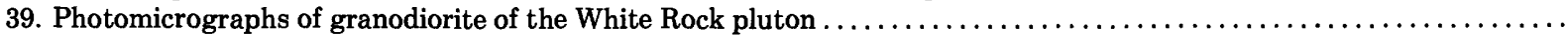

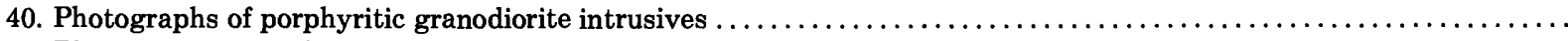

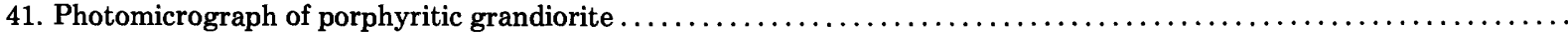

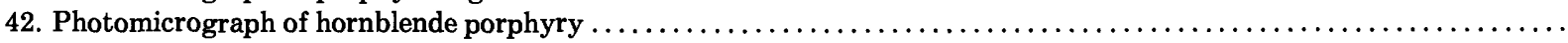

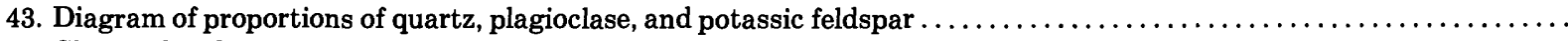

44. Chemical and normative diagrams of analyzed middle Tertiary igneous rocks $\ldots \ldots \ldots \ldots \ldots \ldots \ldots \ldots \ldots \ldots \ldots \ldots \ldots$

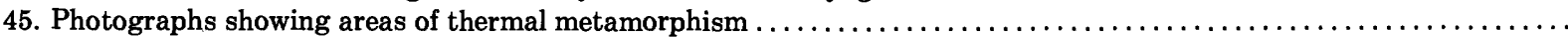

46. Diagram of chemical changes in red beds of the Maroon Formation during contact metamorphism $\ldots \ldots \ldots \ldots \ldots \ldots$

47. Diagrams of structures in Precambrian mica schist and gneiss in the Hayden Peak quadrangle $\ldots \ldots \ldots \ldots \ldots \ldots \ldots \ldots$

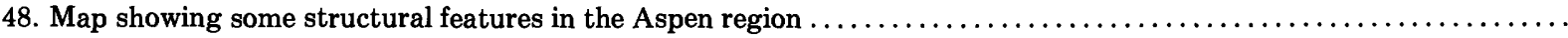

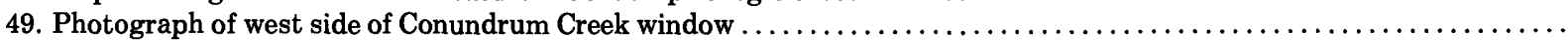

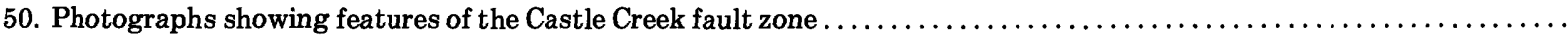

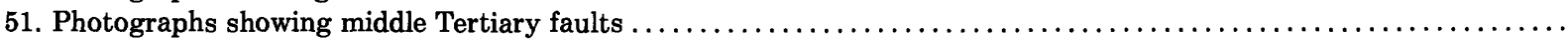

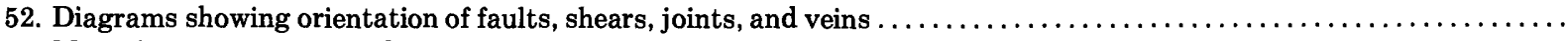

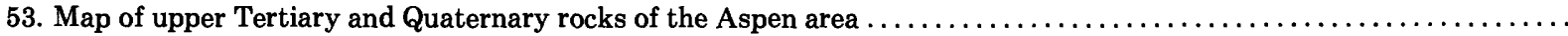

54. Map showing glaciers in the Aspen area during the maximum extent of Bull Lake(?) Glaciation $\ldots \ldots \ldots \ldots \ldots \ldots \ldots$

55-58. Photographs:

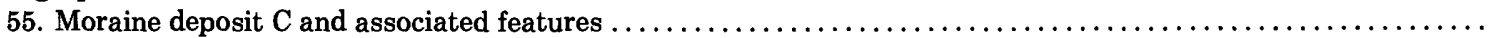

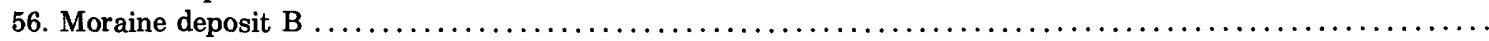

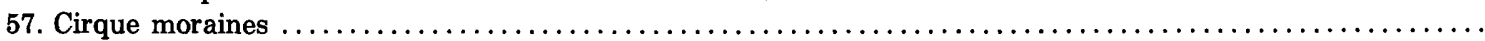

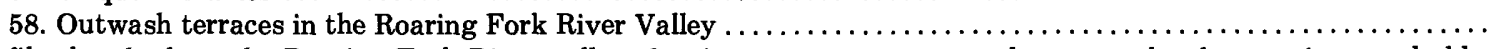

59. Profile sketch along the Roaring Fork River valley showing present stream grade, terrace levels, moraines, and older

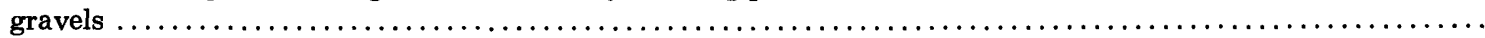

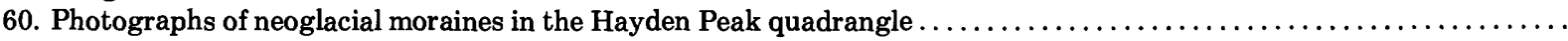

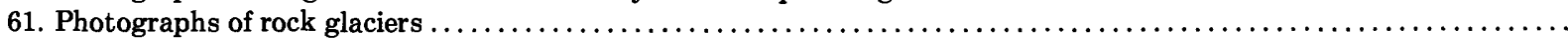

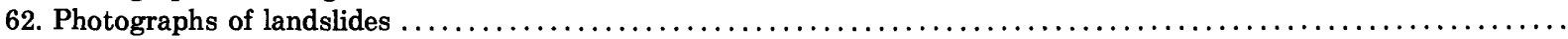

63. Map showing areas of production, prospects, disseminated sulfides, and Oligocene and Laramide igneous rocks ........

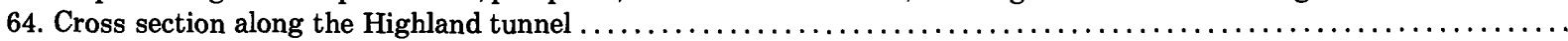

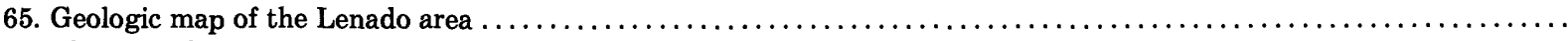

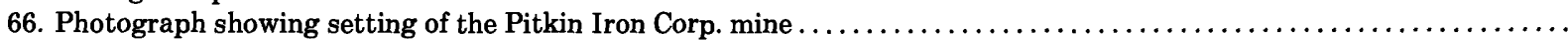

67. Geologic map of the Eagle Mountain area showing location of prospects along the Snowmass Creek fault zone ........

68. Map showing locations of prospects and localities of analyzed samples, Gold Hill area $\ldots \ldots \ldots \ldots \ldots \ldots \ldots$

\section{TABLES}

TABLE 1. Chemical analyses, modes, and norms of Precambrian rocks

2. History of stratigraphic nomenclature of Cambrian through Mississippian quartzite-carbonate shelf sequence in Aspen

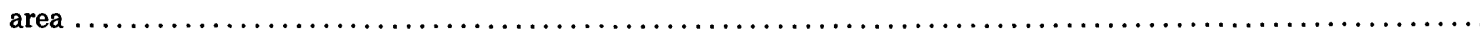

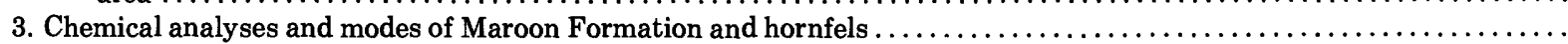

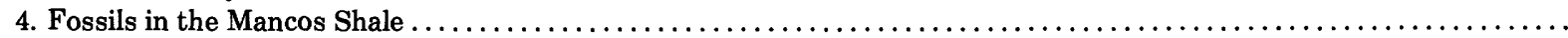

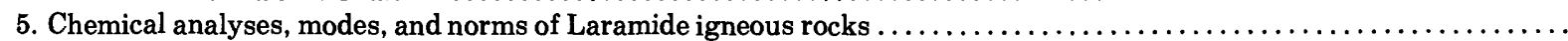

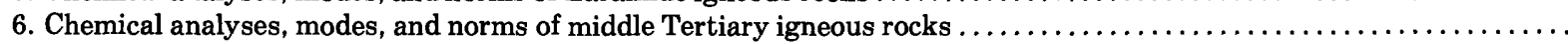

7. Relation between mapped structural elements and measured joints, shears, and veins $\ldots \ldots \ldots \ldots \ldots \ldots \ldots \ldots \ldots$

8. Correlation of Pleistocene and Holocene events, Roaring Fork and Fryingpan River drainages ..................

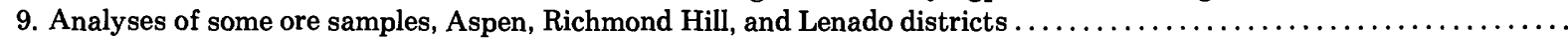

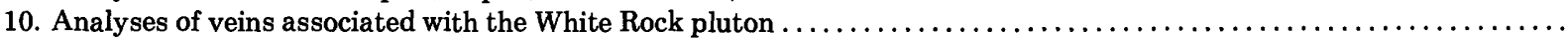

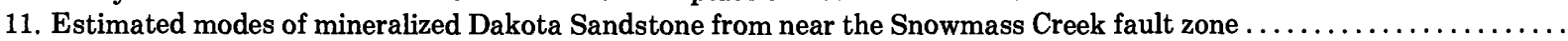

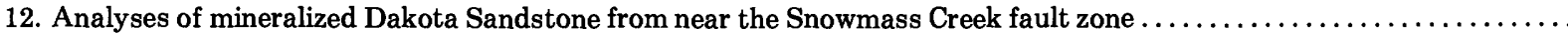

13. Microprobe analyses of silver-bearing copper sulfides from the Snowmass Creek mine $\ldots \ldots \ldots \ldots \ldots \ldots \ldots \ldots \ldots \ldots$

14. Analyses of rock samples from the Gold Hill area 


\section{METRIC-ENGLISH EQUIVALENTS}

[SI, International System of Units, a modernized metric system of measurement]

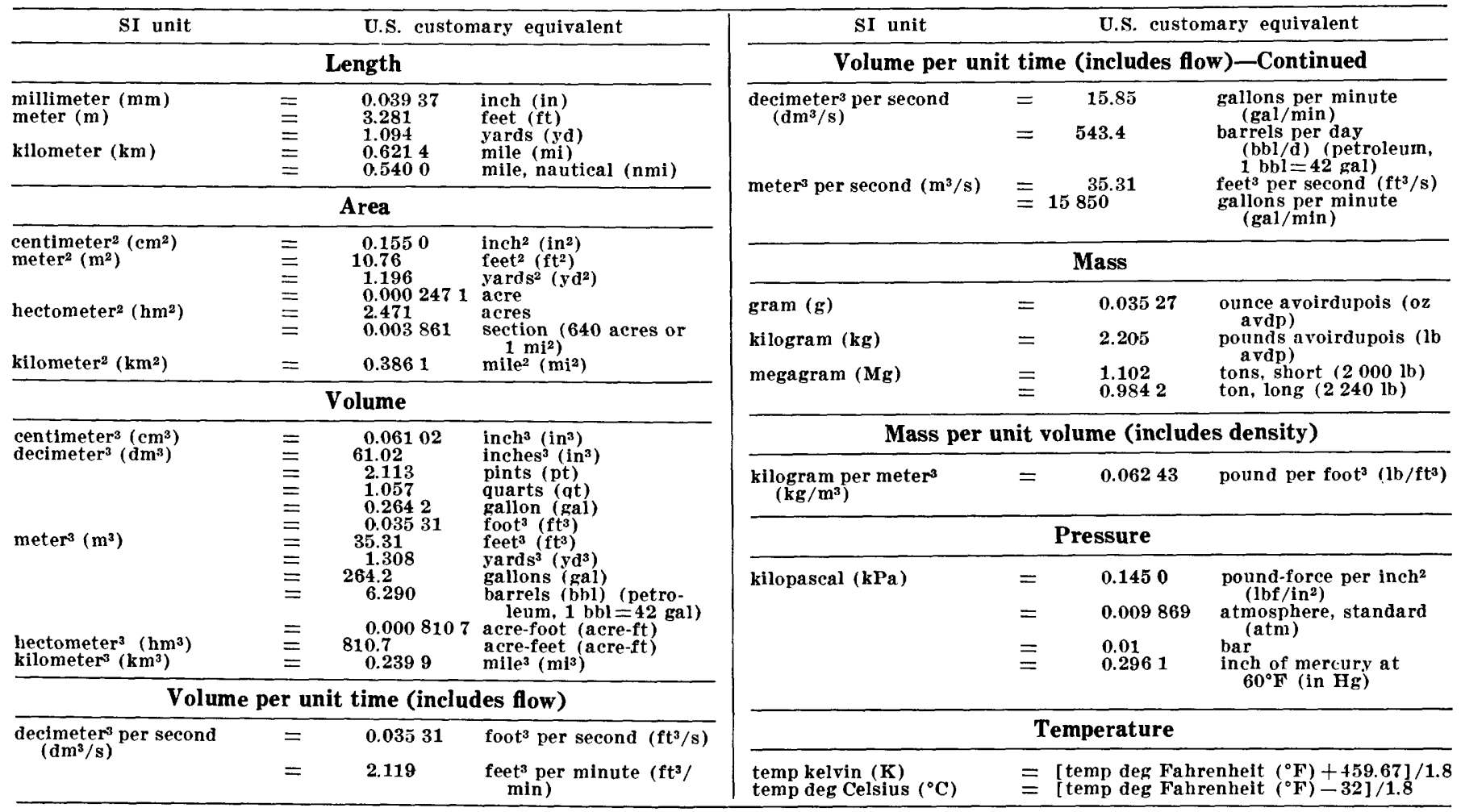




\title{
GEOLOGY OF THE ASPEN 15-MINUTE QUADRANGLE, PITKIN AND GUNNISON COUNTIES, COLORADO
}

\author{
BY BRUGE BRYANT
}

\section{ABSTRACT}

The Aspen area, located $170 \mathrm{~km}$ southwest of Denver, Colo., lies at the intersection of the northeast-trending Colorado mineral belt and the west margin of the north-trending Sawatch uplift of Laramide age; it is within the southwest part of the northwesttrending late Paleozoic Eagle basin.

Precambrian shales and graywackes, perhaps as old as 2 billion years (b.y.), were converted to sillimanite-bearing gneiss and muscovite-biotite schist 1.65-1.70 b.y. ago. They were deformed into northeast-plunging folds and were migmatized, and they were intruded by quartz diorite, porphyritic quartz monzonite, and granite. Muscovite-biotite quartz monzonite intruded this older Precambrian terrane about 1.45 b.y. ago and is the predominant Precambrian rock near Aspen. Uplift, some faulting, and much erosion occurred during the 900-million year (m.y.) interval between emplacement of the plutonic rocks and deposition of Upper Cambrian sediments.

From Late Cambrian through Mississippian the region was part of a broad area alternately covered by shallow seas or occupied by low-lying land. Quartzite, dolomite, and limestone 200-320 m thick, comprising the Sawatch Quartzite and Peerless Formation (Cambrian), Manitou Dolomite (Ordovician), Chaffee Group (Mississippian(?) and Devonian), and Leadville Limestone (Mississippian) were deposited during this interval.

After an hiatus during which soil formation and solution of the Leadville Limestone took place in the Late Mississippian, a thick sequence of marine and nonmarine clastic rocks was deposited in the newly developing Eagle basin during the late Paleozoic and early Mesozoic. Deposition of about $300 \mathrm{~m}$ of carbonaceous shale, limestone, dolomite, and minor siltstone and evaporite of the Belden Formation began in a shallow sea in Early and Middle Pennsylvanian time. Facies relations indicate that the northwest-trending Uncompahgre uplift southwest of Aspen, if present at that time, had very low relief. The overlying Middle Pennsylvanian Gothic Formation of Langenheim (1952) contains calcareous sandstone, siltstone, shale, limestone, and evaporite. Its clastic debris, significantly coarser than that in the Belden, signals the initial rise of the Uncompahgre uplift bordering the Eagle basin on the southwest; the Gothic here lacks the conglomerates and fossiliferous marine limestones found closer to the uplift. Red terrigenous clastic rocks and minor limestone and evaporite of the Maroon Formation as much as $3,200 \mathrm{~m}$ thick, deposited mainly in a fluvial flood-plain environment during the rest of the Pennsylvanian and the Early Permian, indicate withdrawal of the sea caused by further uplift of the Uncompahgre highland.

Following an hiatus accompanied by local folding, the red conglomerate, sandstone, and siltstone of the State Bridge Formation (Late Permian and Early Triassic) was deposited in a fluviallacustrine environment adjacent to a much-expanded Uncompahgre uplift; a significant part of the State Bridge is material recycled from the Maroon Formation exposed to erosion on the flank of the uplift. The State Bridge, absent towards the south, becomes thicker and finer grained towards the north.

The Chinle Formation (Late Triassic) rests with angular unconformity on the State Bridge Formation. The Chinle contains a basal discontinuous quartz-pebble conglomerate (Gartra Member) and is chiefly calcareous siltstone and limestone, with some beds of sandstone and conglomerate composed of fragments derived from the limestone beds. The Chinle was deposited on flood plains and in lakes by streams. Storms may have disrupted the sediments in the lakes producing the limestone pebble conglomerates. The lack of feldspar in the Chinle indicates that the nearby part of the Uncompahgre uplift was not a sediment source, or was covered by a deeply weathered feldspar-free mantle. The formation, absent towards the south, thickens toward the north.

Thicknesses of the Maroon, State Bridge, and Chinle change across faults in the Highland Peak quadrangle, showing that the faults were active during or after deposition of these units. Uplift and erosion of the Uncompahgre highland during the Early Jurassic accounts for the zero isopach of the Chinle. This tectonic episode clearly had ended prior to deposition of the Morrison Formation (Upper Jurassic). The faults were reactivated much later during the middle Tertiary and, perhaps, during the Laramide.

The Entrada Sandstone (Upper Jurassic), $30 \mathrm{~m}$ or less thick, was deposited discontinuously throughout the Aspen area. The Morrison Formation (Upper Jurassic), 122-162 m thick, was deposited in swamps on flood plains and in lakes. Sandstone and siltstone of the Burro Canyon Formation (Lower Cretaceous), 18-24 m thick, then was deposited in a continental environment by streams flowing from the west. This was succeeded by the Dakota Sandstone (Lower Cretaceous), 67-73 $\mathrm{m}$ thick, which was deposited in a shoreline and marginal marine environment. About $1,600 \mathrm{~m}$ of marine shale, sandstone, and limestone of the Mancos Shale were deposited in the Aspen area in the Late Cretaceous; deposition probably continued until the beginning of Laramide tectonism.

Laramide tectonism and intrusive activity began about $72 \mathrm{~m} . \mathrm{y}$. ago. Three major structural elements produced during this event are the Sawatch uplift, the Elk Range thrust, and the Castle Creek fault zone. Early in the rise of the Sawatch uplift a thick section of sedimentary rock overlying the Belden Formation slid off the uplift in a west to southwest direction along the Elk Range thrust. Further uplift caused faulting along the uplift margin and formation of the Castle Creek fault zone, which forms part of the uplift margin. At Aspen the Castle Creek fault zone has a stratigraphic displacement of $4.2 \mathrm{~km}$. The zone is the principal structure bounding the Sawatch uplift south of Aspen, but towards the north it diverges from the northeasterly trending margin of the uplift, and instead trends northwest to follow a late Paleozoic zone of weakness. A fourth major structure, the Roaring Fork syncline, preserves rocks as young as Late Cretaceous and is itself cut by the Castle Creek fault zone.

Emplacement of the Laramide porphyritic intrusions in the 
Aspen mining district preceded and accompanied faulting. These porphyries constitute a bimodal suite: hornblende quartz diorite (54-57 percent $\left.\mathrm{SiO}_{2}\right)$ and more felsic rocks $\left(70-75\right.$ percent $\left.\mathrm{SiO}_{2}\right)$. The felsic porphyries have low contents of $\mathrm{MgO}$, total $\mathrm{Fe}$, and $\mathrm{K}_{2} \mathrm{O}$ relative to their $\mathrm{SiO}_{2}$ contents. The silver-lead-zinc deposits of the Aspen, Richmond Hill, and Lenado districts are spatially related to the Laramide porphyries and faults.

About $35 \mathrm{~m} . \mathrm{y}$. ago, in Oligocene time, sills, dikes, laccoliths, and plutons of granodiorite invaded the area south and southwest of Aspen. The largest body, the White Rock pluton, was emplaced along the Elk Range thrust and caused uplift and high-angle faulting. The oligocene igneous rocks are a typical calc-alkaline suite of the continental interior derived from the lower crust or upper mantle. Their $\mathrm{SiO}_{2}$ content ranges from 55 to 70 percent and the rock composition, from diorite to quartz monzonite. A few veinlets of aplite cut the main pluton. The more mafic parts of the suite have relatively high $\mathrm{K}_{2} \mathrm{O}$ contents.

The White Rock pluton caused extensive hornblende hornfels facies contact metamorphism of the Belden, Gothic, and Maroon Formations. Pyroxene, amphibole, garnet, and vesuvianite are characteristic minerals of the hornfels. Sodic scapolite commonly forms late porphyroblasts. Zeolites, such as chabazite, thomsonite, stilbite, and natrolite, coat late fractures and vugs in the hornfels. Red beds of the Maroon Formation were converted into green and gray calc-silicate hornfels and quartzite. Loss of the volatiles $\mathrm{CO}_{2}$, $\mathrm{H}_{2} \mathrm{O}$, and $\mathrm{O}_{2}$ occurred during the metamorphism.

After the main pluton cooled enough to allow fractures to form, dikes of porphyritic granodiorite were intruded. After intrusion of the dikes, extensive pyritization and locally intensive albitization, silicification, and sericitization occurred at two principal centers and were accompanied by introduction of $\mathrm{Cu}$ and Mo. Fluid inclusion studies suggest that the alteration took place at temperatures of $275^{\circ}-350^{\circ} \mathrm{C}$ and depths of about $1,000 \mathrm{~m}$.

A contact metasomatic magnetite deposit occurs in marble of the Belden Formation just outside the White Rock pluton. Veins associated with the middle Tertiary igneous episode are thin and discontinuous and contain silver, lead, zinc, and, locally, gold. Carbonaceous beds in Dakota Sandstone contain disseminated bornite and lesser amounts of chalcocite adjacent to a fault of this age. The bornite contains as much as 1.9 weight percent $\mathrm{Ag}$ and the chalcocite as much as 2.7 weight percent $\mathrm{Ag}$.

A few diabase dikes that cut the area are probably related to an episode of late Tertiary to Holocene volcanism in the region and perhaps correlate with a series of basalt flows deposited 1.5 m.y. ago in a valley about $370 \mathrm{~m}$ above the present valley of the Roaring Fork River.

A sequence of glacial moraine and outwash deposits fills the lower parts of the main valleys. Deposits on top of Red Mountain, just north of Aspen, and on an interstream divide southwest of Snowmass $450 \mathrm{~m}$ above the modern Roaring Fork River valley may date from the early Pleistocene before much of the valley cutting in the upper part of the Roaring Fork drainage. The oldest deposits inside the present valley of the Roaring Fork are now $200 \mathrm{~m}$ above the present stream and are probably middle Pleistocene in age. The next youngest are $100 \mathrm{~m}$ above the modern river bed. Moraines and terraces dating from the latest full glacial episode are breached only by narrow gorges, which are $50 \mathrm{~m}$ deep downstream from Aspen. Other end moraines are found upvalley from Aspen, and several moraines of latest Pinedale age occur in the cirque floors. Rock glaciers, some of which may have formed before the Altithermal and some of which may have formed after that event, are abundant, and a few are moving at rates of tens of centimeters a year. A few moraines date from neoglacial times.

\section{INTRODUCTION}

\section{LOCATION AND PHYSICAL GEOGRAPHY}

The Aspen, Colo., area is located in the drainage of the Roaring Fork of the Colorado River in the southern Rocky Mountains about $170 \mathrm{~km}$ southwest of Denver, Colo., and $20-30 \mathrm{~km}$ west of the Continental Divide where it follows the crest of the Sawatch Range (fig. 1). The southwestern half of the area comprises the eastern part of the Elk Mountains, a northwesttrending range of high peaks extending from the head of the Taylor River to the Crystal River.

Altitude ranges from $2,256 \mathrm{~m}$ on the Roaring Fork River to $4,348 \mathrm{~m}$ at the summit of Castle Peak in the southwest corner of Hayden Peak quadrangle. The northeastern half of the area is densely timbered (fig. $62 A$ ) except in the sage-oak brush zones below the timber (fig. $33 B$ ). The southwestern half of the area is largely above timberline except for the bottoms and sides of the major valleys (fig. 19).

Pleistocene glaciation has contributed much to the shape of the landscape. The major mountain valleys are glacial troughs modified by postglacial alluvial fans, talus cover, and landslides. Tributary streams occupy hanging valleys above the main troughs. The mountains themselves are shaped by numerous cirques, some of which contain active rock glaciers, and the interstream ridges consist of narrow arêtes along some stretches. Morainal and outwash landforms dominate the major stream valleys of the Roaring Fork and Snowmass Creek west of Aspen. The northernmost part of the area was not glaciated, and its landforms are the result of the processes of normal stream erosion, landsliding, and downslope movement of soil and colluvium.

The climate and, consequently, the vegetation vary greatly in short distances. The crest of the Elk Mountains receives more moisture than the ranges farther east in the Colorado Rockies. About $130 \mathrm{~cm}$ of precipitation falls on the crest of the Elk Mountains, much of it in the form of snow. The amount of precipitation decreases considerably northeast from the crest of the Elk Mountains so that the city of Aspen has only about $50 \mathrm{~cm}$ (Berry, 1959). Just a few miles down the Roaring Fork River from Aspen precipitation is even less so that the climate there is truly semiarid.

Temperatures in the Roaring Fork valley are mild except for nights on the valley floor in midwinter, which may register $-18^{\circ} \mathrm{C}$ or lower. The sun warms the air into the $-6^{\circ}$ to $+3^{\circ} \mathrm{C}$ range on most winter days. At Aspen $32^{\circ} \mathrm{C}$ is about the hottest temperature recorded; most summer highs are around $28^{\circ} \mathrm{C}$. 


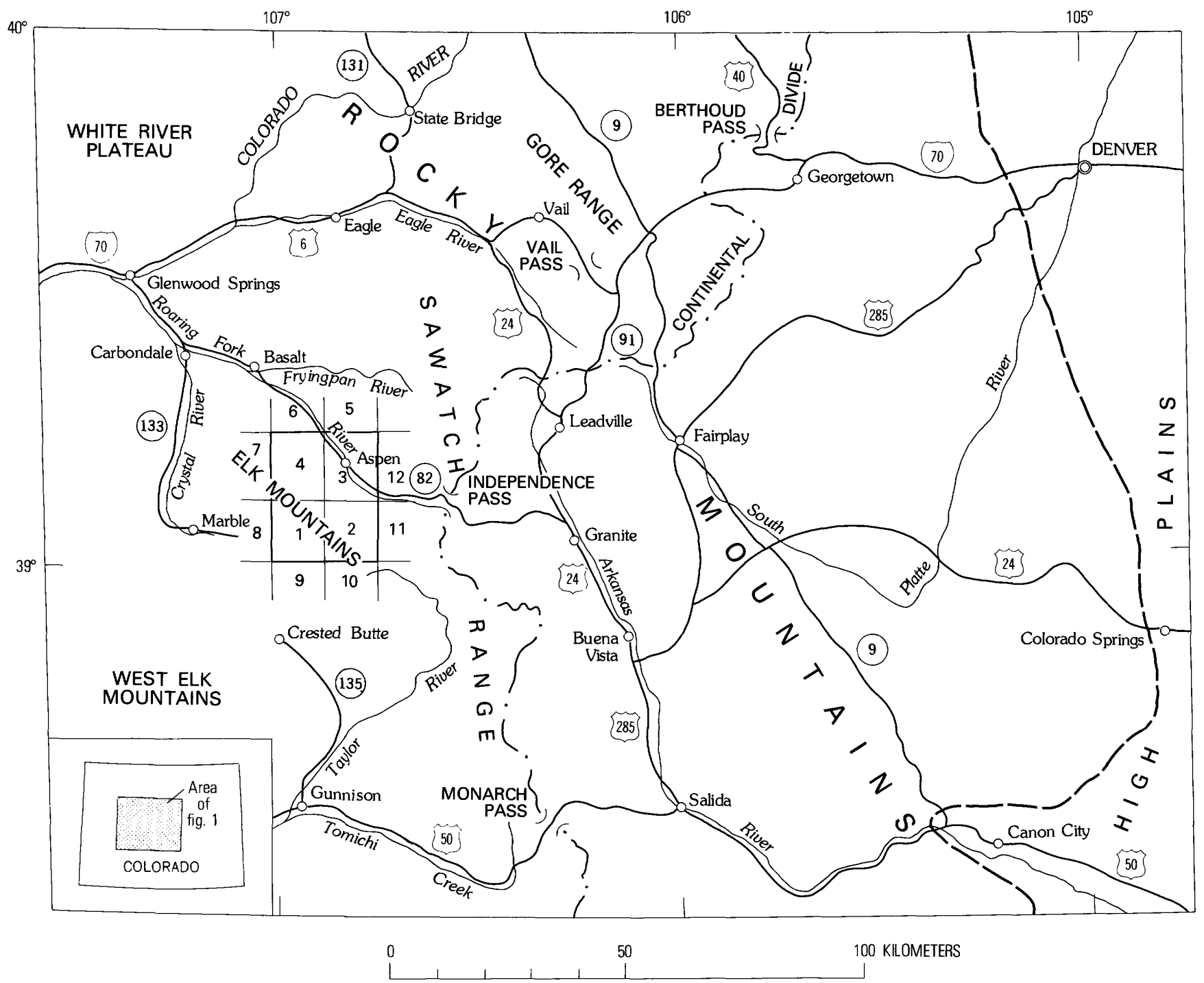

Figure 1.-Location of the Aspen area, southern Rocky Mountains, Colo. Heavy solid outline, Aspen 15-minute topographic quadrangle. Numbers are key to 7.5-minute quadrangles in and adjacent to the Aspen area: 1, Maroon Bells (1960); 2, Hayden Peak (1960); 3, Aspen (1960); 4, Highland Peak (1960); 5, Ruedi (1961); 6, Woody Creek (1961); 7, Capitol Peak (1960); 8, Snowmass Mountain (1960); 9, Gothic (1961); 10, Pearl Pass (1961); 11, New York Peak (1960); 12, Thimble Rock (1960).

The summers in the high mountains are short, but sustain a luxuriant growth; wildflowers are abundant, especially so in the meadows in the high basins where the snow melts late. Summer rains in the form of local convectional showers or from an occasional frontal system are quite variable in intensity and duration, and while working there I found conditions to range from a daily rain of 1-3 hours in length to just a threat of rain almost daily.

Aspen is reached by traveling $64 \mathrm{~km}$ southeast on Colorado Highway 82 from Glenwood Springs on the Colorado River or by traveling $64 \mathrm{~km}$ on the same highway west over Independence Pass (fig. 1) from Granite on the Arkansas River. Independence Pass is closed during the season of heavy snows from October to late May because of its high altitude and the numerous avalanche tracks along the route.

From the main road along the Roaring Fork valley between Aspen and Snowmass, Colo., paved roads extend up Maroon Creek, Castle Creek, and Brush Creek, whereas Owl Creek, Snowmass Creek, and Woody Creek have parallel dirt roads. Other roads extend to Warren Lake on Smuggler Mountain, $6 \mathrm{~km}$ east of Aspen, and to the top of Aspen Mountain at the ski-lift 
complex $4 \mathrm{~km}$ south of Aspen. Jeep roads continue up other valleys, such as Express Creek and Castle Creek, along the crest of Richmond Hill (all within $18 \mathrm{~km}$ to the south of Aspen), and up the other developed ski areas (not open for public driving). Trails continue up the major valleys into the heart of the high country that comprises the Maroon Bells-Snowmass Wilderness, a part of our Wilderness preservation system.

Aspen started as a silver mining town in the 1880's. It was briefly the metropolis of western Colorado in the early 1890 's. The years following the demonetization of silver in 1893 saw a gradual decline in mining through World War I. During the following 25 years Aspen continued to exist as the county seat of Pitkin County, a modest supply center for local ranchers, and the site of small mining operations. After World War II, the first ski lifts were built, and a new era started for the city and the region. A number of cultural attractions, the best known of which is the music school, help attract summer visitors. The 1960's saw a dramatic increase in the pace of building of ski facilities, lodges, condominium apartments, and houses, including the development of a whole new village, West Village of Snowmass-at-Aspen, on a site about $14 \mathrm{~km}$ west of Aspen that consisted of only meadows and aspen groves in 1964 .

The area covered in this report is that of the Aspen, Hayden Peak, Highland Peak, and Maroon Bells 7.5-minute quadrangles.

\section{PREVIOUS GEOLOGIC INVESTIGATIONS}

The Hayden Survey produced a topographic and geologic map of Colorado in the early 1870's. Reports of their work in the Aspen area are given in the Annual Report of 1874 (Hayden, 1874; Peale, 1874, Hayden, 1876; Holmes, 1876). Holmes' report on the geology of the northwestern part of the Elk Range is accompanied by a 1:125,000-scale geologic map on a topographic base and is worthwhile reading, for he outlines his reconnaissance impressions of some of the major structures of the region. Since the publication of that map no more detailed geologic maps of the whole region were published until the maps on which this report is based.

After the discovery of rich silver ore at Aspen in 1879 and the development of the mines there, most of the geologic work in the Aspen area was concentrated in the mining district. Early descriptions of the geology in the mines there are by Emmons (1886), Brunton (1888), Sivyer (1888), Henrich (1889), and Newberry (1890). The classic study of the Aspen mining district was made by J. E. Spurr in 1895 not long after the peak in mining activity. Published in 1898 it remains a valuable source of information about details of the geology in many individual mines. Spurr mapped the area of the Aspen 7.5-minute quadrangle in reconnaissance and mapped the mining areas at a large scale. He also discussed the processes of alteration of the carbonate rocks and ore deposition. In a subsequent paper (1909) he developed his ideas on ore deposition more fully.

Knopf (1926) extended Spurr's mapping to include Richmond Hill and described more recent mine workings and the igneous rocks in that area.

After Spurr's time, no major work was published on the Aspen mining district until that of Vanderwilt (1935b). Drawing on his work in the Snowmass Mountain area (Vanderwilt, 1937) adjacent to the southwest corner of the Aspen region and on examination of some features of the Aspen area with D. F. Rohlfing, a mining engineer who lived and worked in Aspen from the 1880 's intermittently through the 1930's, Vanderwilt (1935b) revised and updated some of Spurr's concepts concerning the structure and ore occurrences in the mining district.

The Aspen area has been the subject of various specialized commodity reports (Harder, 1909, iron; Heyl, 1964, zinc; and Boyd and Bromley, 1953, uranium). Volin and Hild (1950) gave the results of a U.S. Bureau of Mines drilling program in the Smuggler Mine at Aspen.

Unpublished theses by Prather (1964), Waterman (1955), Iradji (1955), and Gaskill (1956) include parts of the Aspen area. Graton (1958) described the petrography of the igneous rocks in Gaskill's thesis area, which overlaps the southwest corner of the Aspen area.

Stratigraphic studies especially pertinent to the Aspen area have been published by Johnson (1944), Brill (1944, 1952), Langenheim (1952, 1954), and Poole and Stewart (1964).

A brief description of the glacial geology of the Aspen area appeared in Richmond, Malde, and Tweto (1965).

\section{PRESENT INVESTIGATIONS}

FIELDWORK AND ACKNOWLEDGMENTS

The present study was begun in July 1963 . Three to four months each summer were spent on fieldwork, which was completed in September 1968. The four 7.5-minute quadrangles comprising the Aspen 15-minute quadrangle were mapped and the maps were subsequently published (Bryant, 1969, 1970, 1971a, 1972a); these geologic maps should be consulted while reading this report. About 19 months were spent in the field, 10 months of which I had the help of field 
assistants, Kirby W. Bay (1964), Edward S. Grew (1965), Charles E. Beverly (1966), David G. Morse (1967), and Stephen G. Pollack (1968). I thank these men for their industrious efforts.

I thank Ogden Tweto who introduced me to Colorado geology, F. G. Poole and G. N. Pipiringos for consultation on Triassic and Jurassic stratigraphy, B. L. Bartleson for consultation on Pennsylvanian stratigraphy, K. L. Pierce for advice on Pleistocene and Holocene geology, W. A. Cobban and J. E. Gill for advice on Cretaceous stratigraphy, and F. E. Mutschler, V. L. Freeman, and D. L. Gaskill, who mapped adjacent areas, for cooperation and discussion on many aspects of the work. I thank James Babcock, Frank Willoughby, and John Heron for discussing various aspects of Aspen geology with me. John P. Kellogg, then of Richmond Hill Exploration Co., made available the results of their exploration work in the Highland Tunnel and at Lenado. Pitkin Iron Corp. allowed me to visit their mine and use their mine road as access in mapping. I thank the Aspen Ski Corp. and Highlands Ski Corp. for permission to use the roads serving their ski-lift facilities.

The purpose of this report is not to give a comprehensive account of all aspects of the geology of the Aspen area but rather to present new data obtained in this study and discuss its bearing on former ideas and conclusions. Consequently, the stratigraphy and petrology of the lower Paleozoic rocks are only very briefly treated. More emphasis is given to the upper Paleozoic and Mesozoic rocks, the Tertiary rocks, the structures of the area, and the Quaternary history. No attempt is made to treat the economic geology in a comprehensive manner but some new data are presented on this subject.

The present study adjoins modern detailed geologic study of adjacent areas to the west and southwest (Gaskill and Godwin, 1966a, b; Gaskill and others, 1967; Godwin, 1968; Mutschler, 1970) and to the north (Freeman, 1972a, b).

As the study progressed, short topical reports have appeared, many of which other workers in the region and I prepared in conjunction; and the quadrangle maps have also appeared (Bryant, 1966; Bartleson and others, 1968; Obradovich and others, 1969; Lipman and others, 1969; Bryant, 1969, 1970, 1971a, b, c, 1972a). The Aspen 7.5-minute quadrangle was the basis for a folio of environmental maps (Bryant, 1972b-i).

Many of the data on composition of the sedimentary rocks are presented on a triangular carbonate-quartzmica and feldspar diagram. Figure 2 gives a classification of rocks in terms of that diagram.

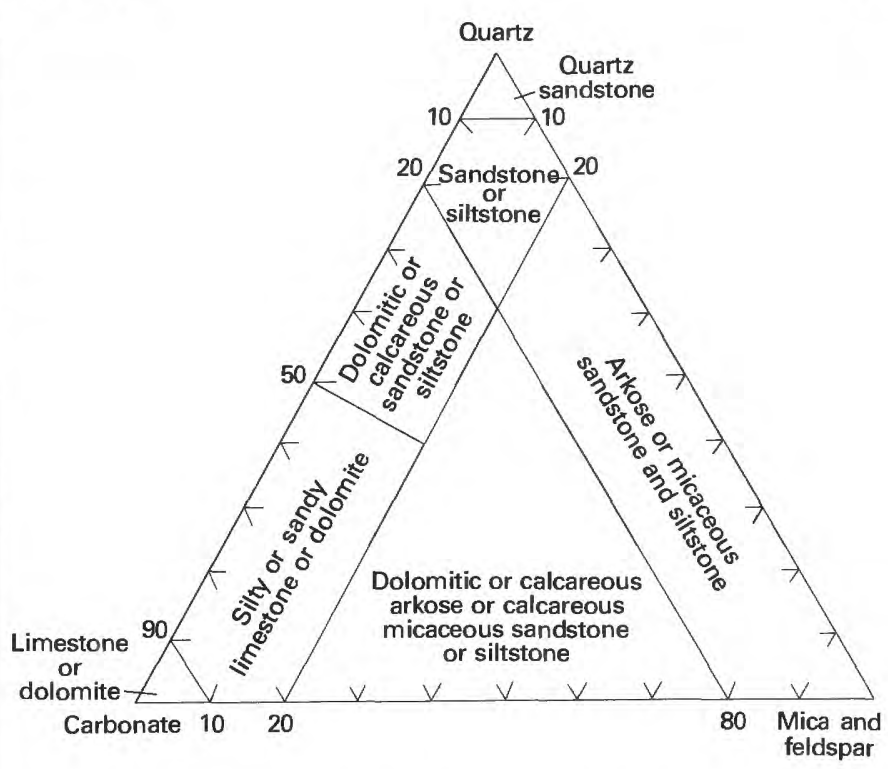

FiguRE 2.-Classification of sedimentary rocks in terms of proportions of quartz, carbonate, and mica and feldspar.

\section{GENERAL GEOLOGY}

The southern Rocky Mountains consist of a number of Laramide uplifts modified by Tertiary plutonism and volcanism and by late Tertiary block faulting. One of these uplifts, the Sawatch Range of central Colorado, apparently was originally asymmetric with a steeper and more structurally complex west side and a relatively gentle and simple east side. In late Tertiary time the east side was sundered by a fault system along the trend of the Rio Grande trough forming the upper Arkansas River valley. Aspen lies where the west margin of the Sawatch Range makes a sharp change in trend from N. $10^{\circ} \mathrm{W}$. south of Aspen to N. $30^{\circ} \mathrm{E}$. to the north (fig. 3).

The Sawatch Range exposes a variety of Precambrian granitic and metamorphic rocks, which occupy the eastern quarter of the Aspen area. Overlying them is a thin sequence of shelf quartzite and carbonate formations representing several cycles of deposition and erosion from Cambrian through Mississippian time.

In late Paleozoic and early Mesozoic time Aspen was in the southwest part of a northwest-trending basin-the central Colorado trough or Eagle basin. Detritus from the Uncompahgre uplift to the southwest filled the trough to a depth of $3-5 \mathrm{~km}$ in Pennsylvanian and Permian time. The Uncompahgre uplift was an at least intermittently positive area until Lake Jurassic time when the whole region was covered first by thin terrestrial deposits and then by marine deposits about $1.6 \mathrm{~km}$ thick. 


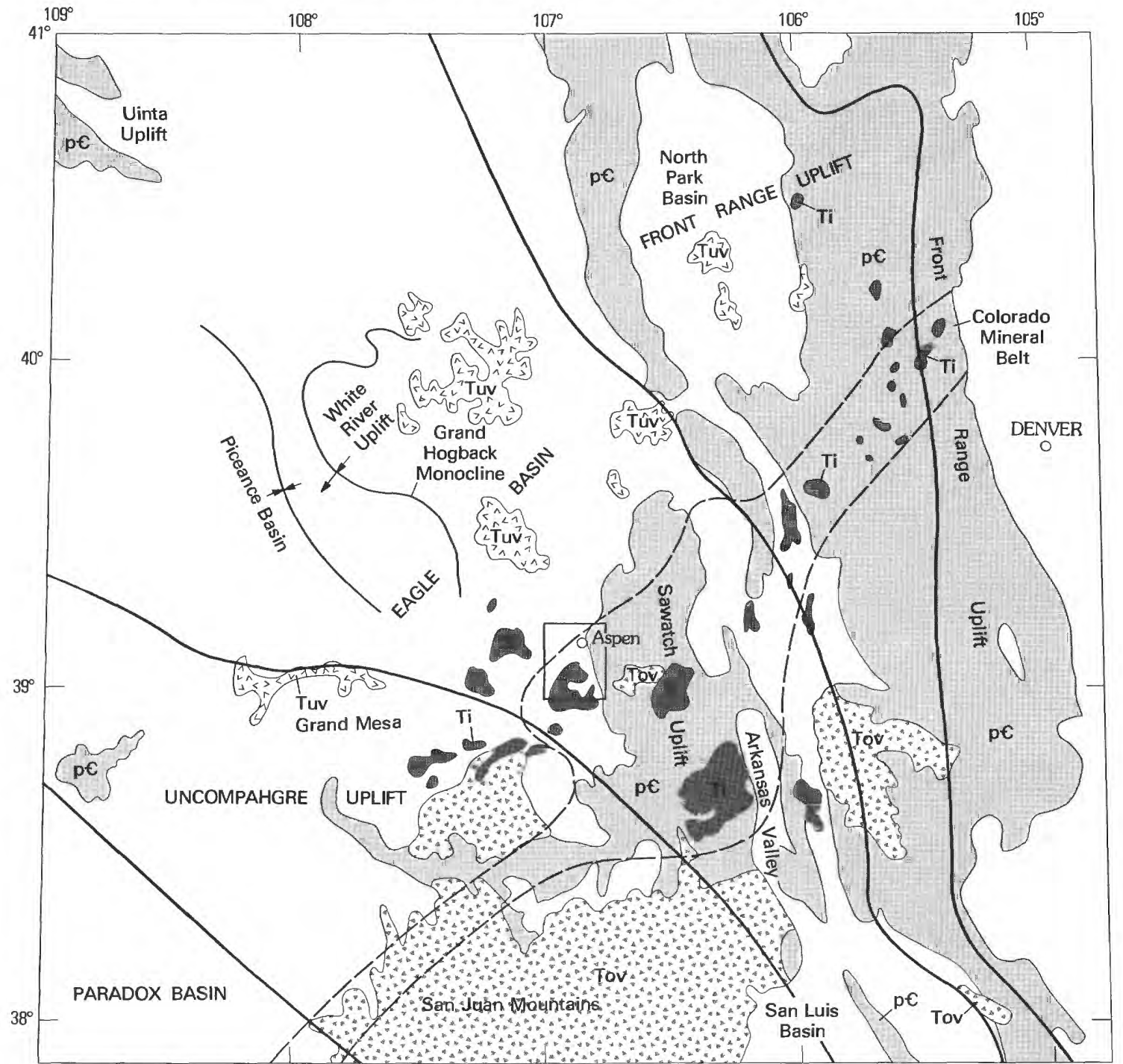

0

100 KILOMETERS

EXPLANATION

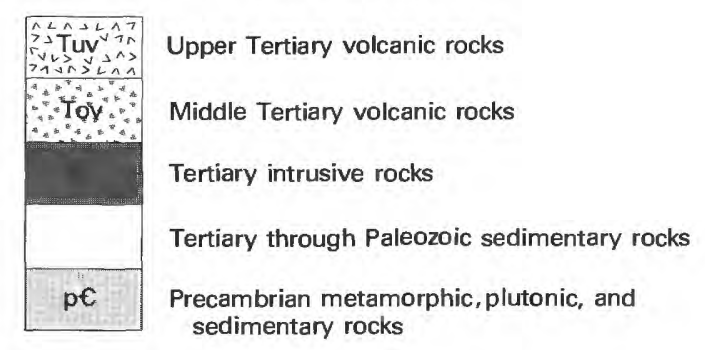

EAGLE BASIN

BOUNDARY OF UPPER LATE PALEOZOIC

TECTONIC ELEMENTS-Name in

capital letters

- _ BOUNDARY OF COLORADO MINERAL BELT

FIGURE 3.-Regional geologic setting of the Aspen area. Rectangular outline, Aspen 15-minute quadrangle. Modified from U.S. Geological Survey and American Association of Petroleum Geologists (1961), Tweto and Sims (1963), and Mallory (1972). 
In Late Cretaceous and Paleocene(?) time intrusion of porphyries, uplift, and faulting commenced. The 4-6-km-thick upper Paleozoic-Mesozoic section probably slid southwestward off the Sawatch Range uplift about this time. Intrusion of porphyries and emplacement of associated rich $\mathrm{Ag}, \mathrm{Pb}$, and $\mathrm{Zn}$ mineralization were concentrated at a node of most complex faulting at the sharp bend in the trend of the Sawatch Range uplift. This bend in the margin of the uplift intersects a belt of Precambrian shear zones and Tertiary intrusion and mineralization extending northeast to Boulder, Colo., and is known as the Colorado mineral belt (fig. 3).

During the Oligocene small to fairly large concordant to discordant bodies of granodiorite invaded the upper Paleozoic and Mesozoic rocks. Iron and disseminated sulfide deposits and small silver-, lead-, and zinc-bearing veins formed at that time.

The region was uplifted and dissected in late Tertiary and Quaternary time and was subject to a number of episodes of glacial erosion in Quaternary time.

\section{PRECAMBRIAN ROCKS}

Precambrian rocks of the western part of the Sawatch Range uplift occupy a belt $2-5 \mathrm{~km}$ wide along the eastern edge of the Hayden Peak and Aspen quadrangles. A reconnaissance map of the Sawatch Range by Stark and Barnes (1935) classified the rocks in the Aspen area as "Silver Plume granite, Sawatch schist and migmatite, and Pikes Peak granite." I have mapped these rocks in six units in the Aspen area and hesitate to make any firm correlations either with units in the Front Range or with units nearby in the Sawatch Range, where detailed studies have been made in the Mount Harvard quadrangle (Barker and Brock, 1965; Brock and Barker, 1972) and the Holy Cross quadrangle (Tweto and Pearson, 1964; Tweto, 1974). Recent reconnaissance mapping and isotopic dating, however, indicate that most of the granitic rocks of the Aspen area are correlative with the Precambrian Y St. Kevin Granite (Tweto and Pearson, 1964) of the northern Sawatch Range (Tweto and others, 1978), but those exposed in the southeastern part of the Hayden Peak quadrangle may be older ( $R$. H. Moench, oral commun., 1975).

\section{MICA SCHIST AND GNEISS}

Mica schist and gneiss occupy an east-westtrending belt less than $1.5 \mathrm{~km}$ wide north of Express Creek in the Hayden Peak quadrangle. They are intruded by granite on the south and grade into mixed quartz diorite, pegmatite, schist, and gneiss on the north. The rocks are best exposed on the north side of the Express Creek valley.

In the schist and gneiss unit pegmatite lenses, sills, veinlets, and dikes are widespread and are a fraction of a centimeter to $3 \mathrm{~m}$ thick (fig. 4). Some contain quartz and feldspar crystals as much as $15 \mathrm{~cm}$ in diameter and muscovite as much as $20 \mathrm{~cm}$ in diameter. Sills of coarse-grained granite are abundant in the schist and gneiss near the contact of the granite. Some bodies of biotite-muscovite granite and quartz monzonite occur in the schist and gneiss away from the contact.

Layers of the schist and gneiss range in thickness from 1 to $10 \mathrm{~cm}$ (fig. 4). The schist and gneiss consist of muscovite, biotite, quartz, and feldspar. The micas are alined and form plates as much as $5 \mathrm{~mm}$ long. Alined needles of sillimanite or sillimanite altered to muscovite are visible in hand specimens. The gneiss is generally finer grained and less micaceous than the schist.

The mica schist and gneiss have a mica content ranging from 15 to 80 percent. Muscovite is relatively more abundant than biotite in most mica-rich rocks. Grain size of muscovite is about twice that of the biotite. The micas are both synkinematic and postkinematic. In some specimens growth of muscovite appears to have lasted longer than that of biotite, for a larger proportion of muscovite is less well alined on the foliation planes than biotite. Quartz and plagioclase, in grains as much as $2 \mathrm{~mm}$ in diameter, are the other major constituents. Plagioclase content ranges from none to as much as quartz. Its composition is $\mathrm{An}_{16-22}$.

Sillimanite in the form of fibrolite occurs in both muscovite and biotite. In one rock examined, it forms lenticular aggregates that contain little or no mica.

Secondary minerals are chlorite after biotite and sericite after plagioclase. Accessory minerals are zircon, apatite, sphene, opaque minerals, and tourmaline.

Abundance of muscovite, virtual absence of potassic feldspar, and presence of sillimanite in the samples examined indicate that these rocks were metamorphosed in the sillimanite-muscovite zone of the amphibolite facies. Few data are published concerning mineral assemblage and metamorphic grade in the Precambrian of the Sawatch Range with which data from these rocks might be compared.

\section{MIXED QUARTZ DIORITE, PEGMATITE, QUARTZ MONZONITE, AND MICA SCHIST AND GNEISS}

A heterogeneous unit of quartz diorite, pegmatite, quartz monzonite, and mica schist and gneiss occupies the McArthur Mountain area in the east-central part of the Hayden Peak quadrangle. Much of the unit is con- 

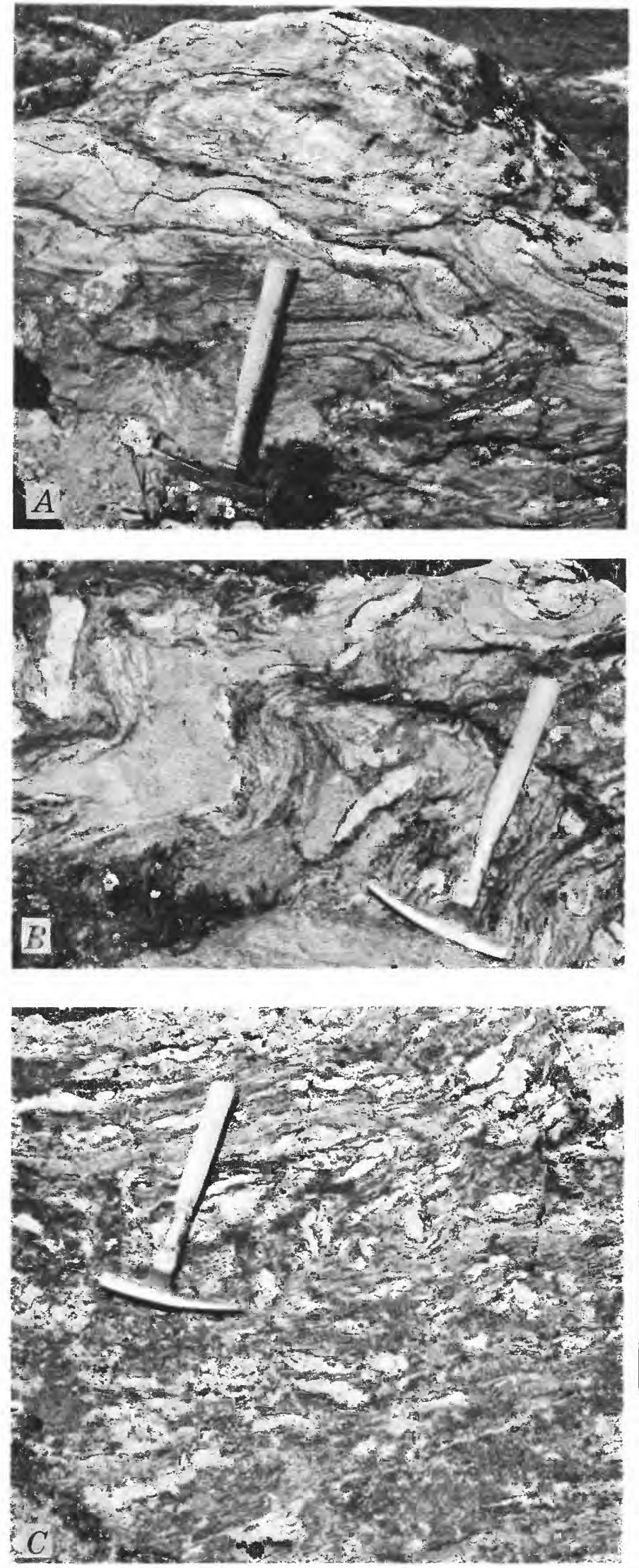

cealed by a thin colluvial cover composed of conspicuous fragments of pegmatite and the granitic rocks and less conspicuous fragments of mica schist and gneiss. Pegmatites, especially, form prominent outcrops protruding from the colluvium.

Intrusive relations between the rock types in this unit indicate that in general the sequence of the rock types from oldest to youngest is (1) mica schist and gneiss, (2) quartz diorite, (3) quartz monzonite, and (4) pegmatite. The various rock types are so intermingled and exposures are so poor that they are lumped as one unit. In places the mica schist and gneiss component has layers of granitic and pegmatitic material and is a migmatite. Contacts of the unit with adjacent ones are not sharply defined as the adjacent rock types make up one of the elements of this unit.

\section{BIOTITE QUARTZ DIORITE}

The north side of Ashcroft Mountain, in the eastern part of Hayden Peak quadrangle, is composed predominantly of medium- to coarse-grained biotite quartz diorite cut by dikes of muscovite-biotite quartz monzonite and aplite and by dikes of quartz-potassic feldspar-muscovite pegmatite as much as $10 \mathrm{~m}$ thick. The quartz diorite contains some inclusions of mica gneiss. The contacts of the quartz diorite with adjacent rock units are not well exposed.

In thin section the biotite quartz diorite is seen to consist of anhedral to subhedral plagioclase with a grain size as large as $4 \mathrm{~mm}$. The plagioclase has a composition of about $\mathrm{An}_{40}$ but is considerably saussuritized. Quartz occurs in anhedral grains as much as $2 \mathrm{~mm}$ in diameter interstitial to the plagioclase. Some quartz grains have a graphic intergrowth of plagioclase in optical continuity with adjacent larger subhedral plagioclase grains. Brown biotite is as much as $6 \mathrm{~mm}$ long and locally is chloritized. Epidote and muscovite are other secondary minerals. Accessories are allanite, zircon, apatite, sphene, and opaque minerals.

\section{PORPHYRITIC QUARTZ MONZONITE}

Porphyritic biotite quartz monzonite occupies about $2.5 \mathrm{~km}^{2}$ in the southeast corner of the Hayden Peak quadrangle. Reconnaissance mapping shows that the pluton extends over $40 \mathrm{~km}$ southeastward across

Figure 4.-Outcrops of mica schist and gneiss, Hayden Peak quadrangle. Rocks of $A$ and $B$ are highly contorted. Folds have northeast-trending axes parallel to mineral lineation in the rocks. $B$, numerous pegmatite lenses are folded along with the layers of schist and gneiss. $C$, Schist filled with lenses and pods of pegmatite. 
Taylor Park, and foliation is well developed in most of the pluton (R. H. Moench, oral commun., 1975).

The characteristic feature of the porphyritic biotite quartz monzonite in the Aspen area is the presence of potassic feldspar grains as long as $3 \mathrm{~cm}$ in a matrix of plagioclase, quartz, potassic feldspar, and biotite with grain sizes of 1-5 mm. The porphyritic quartz monzonite is cut by dikes of pegmatite and equigranular fine- to medium-grained granitic rock. In places the porphyritic quartz monzonite contains inclusions of a fine-grained biotite-plagioclase rock as long as $25 \mathrm{~cm}$, which locally make up about 1 percent of the rock.

Under the microscope the potassic feldspar is seen to be microcline and includes some string perthite. The microcline contains smaller grains of plagioclase, quartz, and biotite. In part it appears to replace plagioclase, and some myrmekite is present in the adjacent plagioclase. Plagioclase is anhedral to subhedral, has a composition of $\mathrm{An}_{20-30}$, and displays normal zoning. Quartz occurs in aggregates of anhedral grains that are interstitial to plagioclase in part. Anhedral biotite forms aggregates; some grains are partly altered to chlorite. Accessories are apatite, zircon, sphene, and opaque minerals.

One inclusion examined is composed of postkinematic biotite and calcic oligoclase. The plagioclase is zoned with one oscillation formed by a more calcic intermediate zone. Muscovite, quartz, microcline, and opaque minerals are minor constituents of the inclusion.

Chemical analysis of a typical sample of porphyritic biotite quartz monzonite (sample no. 1, table 1) confirms that compared to the adjacent granite (sample no. 2, table 1) described next, the quartz monzonite contains less $\mathrm{SiO}_{2}$ and $\mathrm{K}_{2} \mathrm{O}$, and more $\mathrm{CaO}, \mathrm{FeO}, \mathrm{Fe}_{2} \mathrm{O}_{3}$ and $\mathrm{MgO}$.

\section{MUSCOVITE-BIOTITE GRANITE}

A distinctive, homogeneous coarse-grained muscovite-biotite granite crops out at the head of Express Creek and near Taylor Lake and Taylor Pass in the southeastern part of the Hayden Peak quadrangle. It is best exposed in cliffs west of Taylor Pass and on glaciated knobs south of Taylor Lake. Where weathered it is a light grayish pink because of its content of potassium feldspar, and on erosion surfaces, such as near Taylor Pass, it has disintegrated to a coarse-grained sand.

The granite contains Carlsbad twinned microcline crystals commonly $1 \mathrm{~cm}$ long and as much as $3 \mathrm{~cm}$ long. Quartz is $0.5-1 \mathrm{~cm}$ in diameter. Micas are as much as $0.5 \mathrm{~cm}$ in diameter but in many places occur as clots of smaller grains. The granite is cut by pegmatites and contains lenses and veins of coarsegrained quartz.

Contacts of the granite generally are sharp. However, at the contact to the north numerous sills of granite and pegmatite penetrate mica schist and gneiss along foliation planes. At its contact with porphyritic biotite quartz monzonite south of Taylor Lake, the granite grades to porphyritic quartz monzonite, so that no age relation between the two rock types could be established. Both rocks are cut by pegmatites and medium-grained granitic rock near that contact.

In thin section the granite is composed chiefly of microcline, quartz, and plagioclase. Microcline occurs as anhedral grains, includes grains of quartz and plagioclase, and is perthite in some samples. Quartz forms anhedral grains, which are weakly strained. Plagioclase with composition in the range $\mathrm{An}_{20-25}$ occurs in anhedral to subhedral grains and is sericitized or saussuritized in some samples. Biotite generally makes up less than 2 percent of the granite and is partly chloritized in some samples. Muscovite also makes up only a percent or two of the rock. The proportion of the two micas ranges widely. Some rocks contain only muscovite and in some biotite predominates. Accessory minerals are zircon, apatite, and opaques. Rock from an isolated exposure near the head of Cooper Fork (southeast part of Hayden Peak quadrangle), mapped as part of the granite unit, contains small garnet grains included in the quartz and plagioclase. Mineral composition based on mineral content of the few samples examined from this rock unit is quite variable, yet the impression gained in the field is that the unit is quite homogeneous. Probably, the unit is fairly homogeneous overall, but heterogeneous at the scale of a thin section because of the coarse grainsize.

Chemical analysis (sample no. 2, table 1) of a typical sample of the unit is very similar to the average muscovite-biotite granite cited by Nockolds (1954). However, both the mode and the norm would place the sample in the quartz monzonite mineral-composition field.

\section{QUARTZ MONZONITE}

Most of the Precambrian rocks of the Aspen area are plutonic rocks of relatively uniform aspect and are mapped as muscovite-biotite quartz monzonite. Rocks of the unit are locally well exposed on the sides of the major valleys, such as the Roaring Fork, Hunter Creek, and Difficult Creek, and on the west side of Aspen Mountain. However, substantial areas underlain by quartz monzonite are covered by moraine or colluvium, and the rock is weathered to a grus on the 
TABLE 1.-Chemical analysis, modes, and norms of Precambrian rocks

Major oxides determined by rapid methods by $P$, L. D, Elmore, G, W. Chloe, James Kelsey, J, L, Glenn, Hezekiah Smith, and Lowe11 Artis, U.S. Geological Survey, 1969. Minor elements determined by semiquantitative spectrographic methods by Joseph L. Harris, U.S. Geological Survey, 1969. Mode by point count; P, present but not intersected in counting. Major oxides and CIPW norms in weight percent; mode in volume percent; CIPW norms calculated on the basis of analyses recalculated to 100 percent after deduction of volatiles. Results for minor elements are reported in ppm (parts per million) to the nearest number in the series $100,70,50,30,20,15,10, \ldots$, which represent approximate midpoints of interval data on a geometric scale, The assigned interval for semiquantitative results will include the quantitative values about 30 percent of the time. $\mathrm{L}$, detected, but below limit of determination; $\mathrm{N}$, not detected; leaders indicate value not determined. Looked for but not found: $\mathrm{Ag}$, As, Au, B, Bi, Cd, Mo, Pd, Pt, Sb, Te, U, W, Zn, Ge, Hf, In, Li, $\mathrm{Re}, \mathrm{Ta}, \mathrm{Th}, \mathrm{Tl}, \mathrm{Pr}, \mathrm{Sm}, \mathrm{Eu}]$

\begin{tabular}{|c|c|c|c|c|}
\hline \multirow{2}{*}{$\begin{array}{l}\text { Map unit-- } \\
\text { Sample No.-- }\end{array}$} & \multirow{2}{*}{$\begin{array}{l}\text { Porphyritic } \\
\text { quartz } \\
\text { monzonite } \\
1\end{array}$} & \multirow{2}{*}{$\begin{array}{c}\text { Granite } \\
\frac{2}{2}\end{array}$} & \multicolumn{2}{|c|}{ Quartz monzonite } \\
\hline & & & 3 & 4 \\
\hline Field No. & 2048 & 2050 & 2077 & 2078 \\
\hline Lab. No....... & W172424 & W172425 & W172426 & W172427 \\
\hline \multicolumn{5}{|c|}{ Major oxides } \\
\hline $\mathrm{SiO}_{2}$ & 66.0 & 72,5 & 66.1 & 69.2 \\
\hline $\mathrm{Al}_{2} \mathrm{O}_{3}$ & 16.0 & 14,1 & 14.2 & 14.6 \\
\hline $\mathrm{Fe}_{2} \mathrm{O}_{3}$ & 1.7 & 1.1 & 2.6 & 1.9 \\
\hline $\mathrm{Fe} 0=-$ & 2.6 & .92 & 2.4 & 2.4 \\
\hline 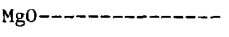 & .98 & .36 & 1.4 & 1.0 \\
\hline 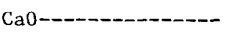 & 3.1 & 1.3 & 3.0 & 2.4 \\
\hline $\mathrm{Na}_{2} \mathrm{O}-\ldots$ & 3.0 & 2.6 & 3.1 & 3.2 \\
\hline $\mathrm{K}_{2} \mathrm{O}=---$ & 4.2 & 5.6 & 3.6 & 3.6 \\
\hline $\mathrm{H}_{2} \mathrm{O}^{-}-$ & .05 & .07 & .10 & .04 \\
\hline $\mathrm{H}_{2} \mathrm{O}^{+}$ & .94 & .57 & 1.0 & .63 \\
\hline TiO & .81 & .36 & .91 & .71 \\
\hline $\mathrm{P}_{2} \mathrm{O}_{\mathrm{s}}-$ & .52 & .11 & .64 & .17 \\
\hline $\mathrm{MnO}-$ & .09 & .04 & .05 & .03 \\
\hline $\mathrm{CO}_{2}----$ & $<.05$ & $<.05$ & .36 & $<.05$ \\
\hline Bulk density- & 2.67 & 2.56 & 2.73 & 2.72 \\
\hline Powder density---- & 2.68 & 2.64 & 2.76 & 2.76 \\
\hline \multicolumn{5}{|c|}{ Minor elements } \\
\hline Ba---- & 1,500 & 500 & 1,000 & 700 \\
\hline Be-----_- & 5 & 3 & 3 & 2 \\
\hline Co--- & 15 & $\mathrm{~N}$ & 10 & 15 \\
\hline 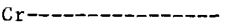 & 15 & $\mathrm{~L}$ & 50 & 30 \\
\hline $\mathrm{Cu}-----------$ & 30 & 15 & 700 & 200 \\
\hline La--_-_-_-_-_-_-_- & 70 & 200 & 100 & 700 \\
\hline $\mathrm{Nb}---1-$ & 10 & 10 & 10 & 15 \\
\hline Ni---_-_-_-_-_--- & $\mathrm{L}$ & $\mathrm{N}$ & 30 & $\mathrm{~L}$ \\
\hline $\mathrm{Pb}-1-1-1-1-1-1$ & 30 & 50 & 70 & 50 \\
\hline Sc---_---_-- & 7 & 5 & 10 & 15 \\
\hline $\mathrm{Sn}---$ & $\mathrm{N}$ & $\mathrm{N}$ & 50 & $\mathrm{~N}$ \\
\hline Sr $-1-+-1-$ & 300 & 200 & 300 & 300 \\
\hline V---1- & 50 & 15 & 50 & 30 \\
\hline 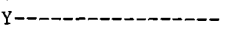 & 50 & 20 & 30 & 50 \\
\hline Zr- & 200 & 150 & 200 & 300 \\
\hline 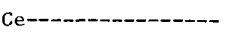 & 300 & 700 & 500 & 1,000 \\
\hline $\mathrm{Ga}+-1-$ & 15 & 10 & 15 & 15 \\
\hline $\mathrm{Yb}-1-$ & 5 & 2 & 3 & 5 \\
\hline $\mathrm{Nd}-$ & $\mathrm{N}$ & 200 & 150 & 700 \\
\hline \multicolumn{5}{|c|}{ Modes } \\
\hline Quartz--n--- & 44.0 & 26.8 & 29.0 & 36.4 \\
\hline Plagioclase------- & 32.0 & 31.0 & 40.3 & 38.6 \\
\hline Potassic feldspar- & 6.7 & 39.8 & 14.9 & 14.3 \\
\hline Biotite- & 14.6 & 1.7 & 15.2 & 9.1 \\
\hline Muscovite--_- & 1.3 & .6 & $\mathrm{P}$ & $\mathrm{P}$ \\
\hline opaque mineral--- & 1.5 & .2 & .4 & 1.4 \\
\hline Zircon--- & $\mathrm{P}$ & $P^{.2}$ & $\mathrm{P}^{* 4}$ & .4 \\
\hline Apatite-- & $\mathrm{P}$ & $\mathrm{P}$ & .4 & --- \\
\hline Chlorite-- & ----------- & $\mathbf{P}$ & $P$ & ---- \\
\hline Sphene------------- & $\mathrm{P}$ & - & --- & --_-_- \\
\hline Epidote- & 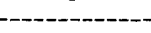 & --n- & $\mathrm{P}$ & --- \\
\hline Carbonate-- & 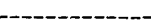 & --_--_-- & $\mathrm{P}$ & ---- \\
\hline Allanite-- & - & - & $\mathrm{P}$ & ---- \\
\hline
\end{tabular}

TABLE 1.-Chemical analysis, modes, and norms of Precambrian rocks-Continued

\begin{tabular}{|c|c|c|c|c|}
\hline \multirow{2}{*}{ Map unit-- } & \multirow{2}{*}{$\begin{array}{c}\text { Porphyritic } \\
\text { quartz } \\
\text { monzonite }\end{array}$} & \multirow{2}{*}{$\begin{array}{l}\text { Granite } \\
2\end{array}$} & \multicolumn{2}{|c|}{ Quartz monzonite } \\
\hline & & & 3 & 4 \\
\hline Field No,.-.-- & 2048 & 2050 & 2077 & 2078 \\
\hline Lab. No,.-.-- & W172424 & W172425 & W172426 & W172427 \\
\hline \multicolumn{5}{|c|}{ CIPW Norms } \\
\hline 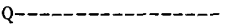 & 25.09 & 31.08 & 27.75 & 30.11 \\
\hline 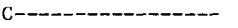 & 2.15 & 1.12 & 1.31 & 1.50 \\
\hline 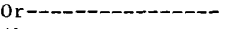 & 25.07 & 34.48 & 21.71 & 21.44 \\
\hline 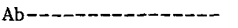 & 25.64 & 23.84 & 26.77 & 27.29 \\
\hline An---_---------- & 12.10 & 5.77 & 10.92 & 10.88 \\
\hline 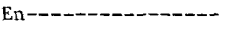 & 2.47 & .90 & 3.56 & 2.51 \\
\hline 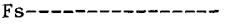 & 2.22 & .26 & .87 & 1.74 \\
\hline 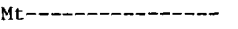 & 2.49 & 1.61 & 3.85 & 2.78 \\
\hline Il---------------- & 1.56 & .69 & 1.76 & 1.36 \\
\hline Ap----------------- & 1.24 & .26 & 1.55 & .41 \\
\hline 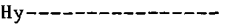 & 4.69 & 1.16 & 4.43 & 4.25 \\
\hline Hy-En--_-_-_---- & 2.47 & .90 & 3.56 & 2.51 \\
\hline 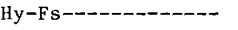 & 2.22 & .26 & .87 & 1.74 \\
\hline
\end{tabular}

1. Porphyritic muscovite-biotite quartz monzonite. Subhedral normally zoned plagioclase $\mathrm{An}_{20-30}$ as long as $3 \mathrm{~mm}$, anhedral quartz as much as $3 \mathrm{~mm}$ in diameter in aggregates interstitial to plagioclase in part, somewhat perthitic microcline as much as $2 \mathrm{~cm}$ in diameter containing inclusions of the other minerals, and anhedral biotite in aggregates as much as $2 \mathrm{~mm}$ in diameter. Absence of large microcline from thin section accounts for discrepancy between mode and chemical analysis. Sample from cliff, $960 \mathrm{~m} \mathrm{~S}$. $54^{\circ} \mathrm{W}$. of southeast corner of Hayden Peak quadrangle.

2. Coarse-grained muscovite-biotite granite. Subhedral plagioclase An 25 somewhat sericitized as long as $5 \mathrm{~mm}$, anhedral quartz as much as $5 \mathrm{~mm}$ in diameter and microcline microperthite as much as $1 \mathrm{~cm}$ in diameter, contajning inclusions of quartz and plagioclase, and anhedral biotite as much as $1 \mathrm{~mm}$ in diameter in agregates as much as $5 \mathrm{~mm}$ in diameter. From blasted talus block at $3,523 \mathrm{~m}$ altitude on road $610 \mathrm{~m}$ north of Taylor Pass, Hayden Peak quadrangle.

3. Biotite granodiorite. Anhedral to subhedral normally zoned plagioclase (An 32-20), partly altered, as much as $3 \mathrm{~mm}$ in diameter. Anhedral quartz as much as $3 \mathrm{~mm}$ in diameter partly interstitial to and partly replacing plagioclase and quite strongly strained. Anhedral, partly bent biotite as much as $2 \mathrm{~mm}$ in diameter and anhedral perthitic microcline as much as $3 \mathrm{~mm}$ in diameter. Roadcut on Colorado Highway $82 ; 300 \mathrm{~m}$ west along road from east margin of Aspen quadrangle.

4. Biotite granodiorite. Anhedral to subhedral plagioclase An25 as much as $4 \mathrm{~mm}$ in diameter containing patches of microcline, anhedral strongly strained quartz as much as $3 \mathrm{~mm}$ in diameter, subhedral to anhedral microcline as much as $3 \mathrm{~mm}$ in diameter, and anhedral biotite as much as $1 \mathrm{~mm}$ in diameter in aggregates. Roadcut on Colorado Highway $82365 \mathrm{~m} \mathrm{~N}$. $70^{\circ}$ E. from symbol for Difficult Campground on Aspen quadrangle.

uplands of Smuggler Mountain $5 \mathrm{~km}$ east of Aspen and on the south end of Richmond Hill $11 \mathrm{~km}$ south of Aspen.

The quartz monzonite weathers orange pink and is light gray where fresh. Although the rocks mapped as quartz monzonite are fairly uniform in general aspect, they display some differences in detail. The proportion of potassic feldspar and mafic minerals differs in places so that the rock locally has granite or granodiorite composition (fig. 5). The usual texture is equigranular and directionless with a grain size of 1-5 


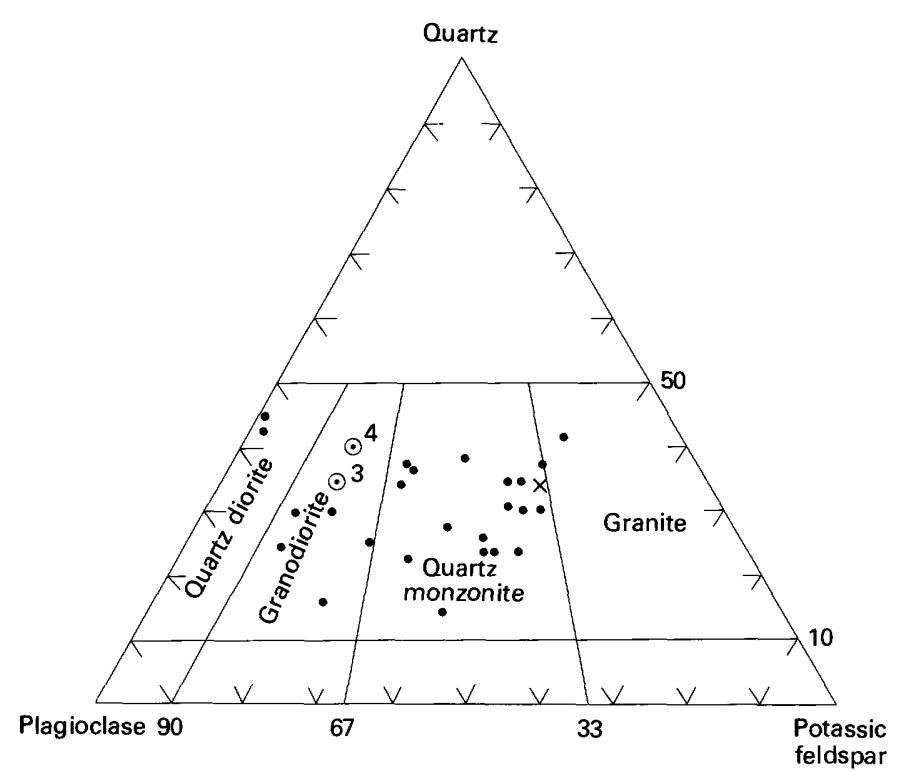

FIGURE 5.-Proportions of quartz, plagioclase, and potassic feldspar in rocks of the quartz monzonite unit. Circled points are analyzed samples and numbers from table $1 ; \mathrm{x}$, dike cutting quartz monzonite.

$\mathrm{mm}$. Locally, the rock is porphyritic and has grains of potassium feldspar as much as $2 \mathrm{~cm}$ long. In a few places it has a poorly developed gneissic structure. In one area on the north side of Hunter Creek cataclastic textures are well developed; the rock ranges from blastomylonitic gneiss to phyllonite. Near faults the quartz monzonite is altered and brecciated.

Small pegmatite veinlets, pods and stringers, commonly with indistinct margins, occur in scattered outcrops. Larger pegmatites with perthite and muscovite as much as $10 \mathrm{~cm}$ in diameter occur rarely. Some areas of the quartz monzonite, such as north of Warren Lake, lack pegmatites. On Smuggler Mountain some locally vuggy quartz veins containing hematite occur in the granitic rock.

Inclusions of mica schist and gneiss are numerous in the southeastern corner of the Aspen quadrangle and the northwestern corner of the Hayden Peak quadrangle.

Chemical analyses (sample nos. 3, 4, table 1) are of samples of the granodioritic side of the range in composition of rocks in this unit (fig. 5).

\section{AGE}

A number of recent studies have developed a chronology for the Precambrian rocks of Colorado that is quite consistent in broad outlines for the area from the San Juan Mountains to the northern Front Range (Bickford and others, 1969; Hansen and Peterman, 1968; Hedge and others, 1968; Mose and Bickford, 1969; Peterman and Hedge, 1968). These studies have revealed that sedimentary and volcanic rocks, probably deposited 1,750-2,000 m.y. (million years) ago, were deformed, metamorphosed, and intruded 1,650-1,750 m.y. ago. No older rocks have yet been found in the Precambrian of the Colorado Rockies. Many of the intrusions are foliated, but some are not; younger plutonic rocks that were emplaced 1,400-1,500 m.y. ago are generally unfoliated. The region was uplifted and micas became closed systems in the interval 1,100-1,400 m.y. ago, except where affected by Late Cretaceous and Tertiary plutonic activity. A major younger Precambrian pluton, known to exist only in the Front Range, is the Pikes Peak Granite, which is 1,030 m.y. old.

Rubidium-strontium determinations by Wetherill and Bickford (1965) on granitic rocks from the Sawatch Range gave a whole-rock isochron at $1,640 \pm 35 \mathrm{~m}$.y. Rubidium-strontium determinations on minerals indicated that at about $1,350 \mathrm{~m}$.y. ago extensive redistribution and, in some cases, complete reequilibration of strontium between the mineral phases took place. Some results were interpreted to indicate intrusion of pegmatites at about $1,450 \mathrm{~m}$.y. ago. Rubidium-strontium data from the Kroenke Granodiorite in the central Sawatch Range fit a 1,700-m.y. isochron (Barker and others, 1974) and from the Cross Creek Granite in the northern Sawatch a 1,710-m.y. isochron (Tweto and Lovering, 1977). In the northern Sawatch Range, Pearson, Hedge, Thomas, and Stern (1966) obtained an Rb-Sr isochron for the St. Kevin

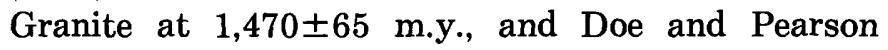
(1969), an age of $1,420 \pm 40 \mathrm{~m} . \mathrm{y}$. based on isotopic dating of zircon. Mica ages range from 1,175 to 1,435 m.y. and may represent imperfect reequilibration by heating associated with emplacement of the St. Kevin and cooling by uplift and modification by Laramide heating (Pearson and others, 1966).

Currently, the most reasonable interpretation of the mica schist and gneiss in the Aspen area is that they were laid down as shale and graywacke 1,700-2,000 m.y. ago and were subjected to deformation and sillimanite-grade metamorphism about 1,700 m.y. ago.

The porphyritic quartz monzonite near Taylor Lake resembles the Hell Gate Porphyry of Stark and Barnes (1935) (R. H. Moench, oral commun., 1974). 
Tweto and Pearson (1964) considered the Hell Gate Porphyry a textural facies of the St. Kevin Granite. However, recent reconnaissance mapping shows that the porphyritic quartz monzonite near Taylor Lake is contiguous with quartz monzonite with well-developed gneissic structure in Taylor Park (R. H. Moench, oral commun., 1975). Consequently, that rock and the closely associated granite are considered to be older or emplaced during a late stage of the main metamorphism and deformation 1,700-1,650 m.y. ago.

The biotite quartz diorite intruded the mica schist and gneiss, perhaps during a late stage or after the metamorphism. No absolute age data are available for that rock type; it is younger than the mica schist and gneiss and older than the quartz monzonite. Intrusive rocks of that composition are most commonly associated with the episode of intrusive activity associated with the metamorphism 1,700-1,650 m.y. ago.

Quartz monzonite contiguous with that forming most of the granitic rock in the Aspen area fits the whole-rock isochron for the St. Kevin Granite (J. C. Reed, Jr., oral commun., 1973). In Lincoln Gulch (18 km southeast of the Aspen area) quartz monzonite clearly intrudes migmatite. That migmatite probably formed 1,650 or 1,700 m.y. ago is indicated by the work of Wetherill and Bickford (1965).

\section{CAMBRIAN THROUGH MISSISSIPPIAN SHELF SEQUENCE}

\section{INTRODUCTION}

A distinctive sequence of thin quartzite and carbonate formations deposited in a shelf environment during Cambrian to Mississippian time forms a belt 0.4-3.2 km wide between the Precambrian of the Sawatch Range and younger sedimentary rocks in the Aspen and Hayden Peak quadrangles (fig. 6). The wider parts of the belt occur where numerous faults cause repetition of outcrops of these formations. Rocks of the sequence form East Aspen and West Aspen Mountains, features named on the mining district topographic base maps (Spurr, 1898), which are prominent peaks when viewed from the town of Aspen, although they are only the ends of sharp ridges when viewed from above. These rocks form Castle Butte, which is the 3,347-m knob west of Tourtelotte Park, they form the east valley side of Castle Creek between Express Creek and Fall Creek, and they also form the walls of the cirque at the head of the south fork of $\mathrm{Ex}^{-}$ press Creek about $1.6 \mathrm{~km}$ west of Taylor Lake. The total thickness of the sequence ranges from about 200 to $300 \mathrm{~m}$ and is $245-275 \mathrm{~m}$ on the average.

Table 2 shows the history of the stratigraphic nomenclature of the Cambrian through Mississippian rocks at Aspen so that the reader can relate the work of Spurr (1898) and Johnson (1944) to this paper.

\section{SAWATCH QUARTZITE}

The Sawatch Quartzite of Late Cambrian age (Eldridge, 1894) forms the basal Paleozoic formation in the Aspen area. The Sawatch is resistant to weathering and erosion and forms cliffs in many places. It is composed predominantly of tan-weathering white quartzite with interspersed vuggy brown-weathering beds cemented by dolomite or calcite. Its base is marked in many places by $0.3-1.8 \mathrm{~m}$ of locally crossbedded quartz pebble conglomerate containing pebbles as much as $2.5 \mathrm{~cm}$ in diameter and some grayish-pink microcline grains as much as $1 \mathrm{~cm}$ in diameter. A few beds of pebbles and granules of quartz occur above the base in the lower part of the formation, but in most places the grain size is $<0.5 \mathrm{~mm}$. Beds of carbonatecemented sandstone in fine-grained vitreous quartzite are common in the upper part of the formation.

The upper contact of the Sawatch is drawn below the point where yellowish-brown-weathering sandstones, sandy limestones, and interbedded shales begin to dominate the rock type. This change is generally abrupt, but the rocks appear conformable. (See stratigraphic section 1 , p. 130.)

The thickness of the Sawatch in the Aspen area ranges from about 45 to $75 \mathrm{~m}$. Variations in thickness may occur through short distances; interpretation of Johnson's (1944) Taylor Pass section indicates about $30 \mathrm{~m}$ of Sawatch very close to where I measured $43 \mathrm{~m}$. Bush and Bush (1974) showed $33 \mathrm{~m}$ of Sawatch near Taylor Pass. A thickness of $72 \mathrm{~m}$ measured on the cliffs on the north side of Woody Creek just east of Aspen quadrangle is an unusually great thickness of Sawatch for the area.

Just south of the Aspen region Johnson (1944) divided the Sawatch into a lower white quartzite member, glauconitic sandstone member, upper white quartzite member, and Peerless Shale Member. He believed that the glauconitic sandstone member graded into the upper quartzite member northward. Near Taylor Pass (p. 312) he found his Peerless Shale Member of the Sawatch channeling the top of the glauconitic sandstone member. I did not observe this channeling in the section measured for this study, about $1.6 \mathrm{~km}$ west of Taylor Pass, nor did Johnson report it in his measured section near Taylor Pass (1944, p. 358-9). Johnson's published sections do not seem to support his statement about the glauconitic sandstone member grading into the upper quartzite member in the Aspen area, but rather they suggest to me that his upper quartzite member grades northward into rocks that I mapped as 


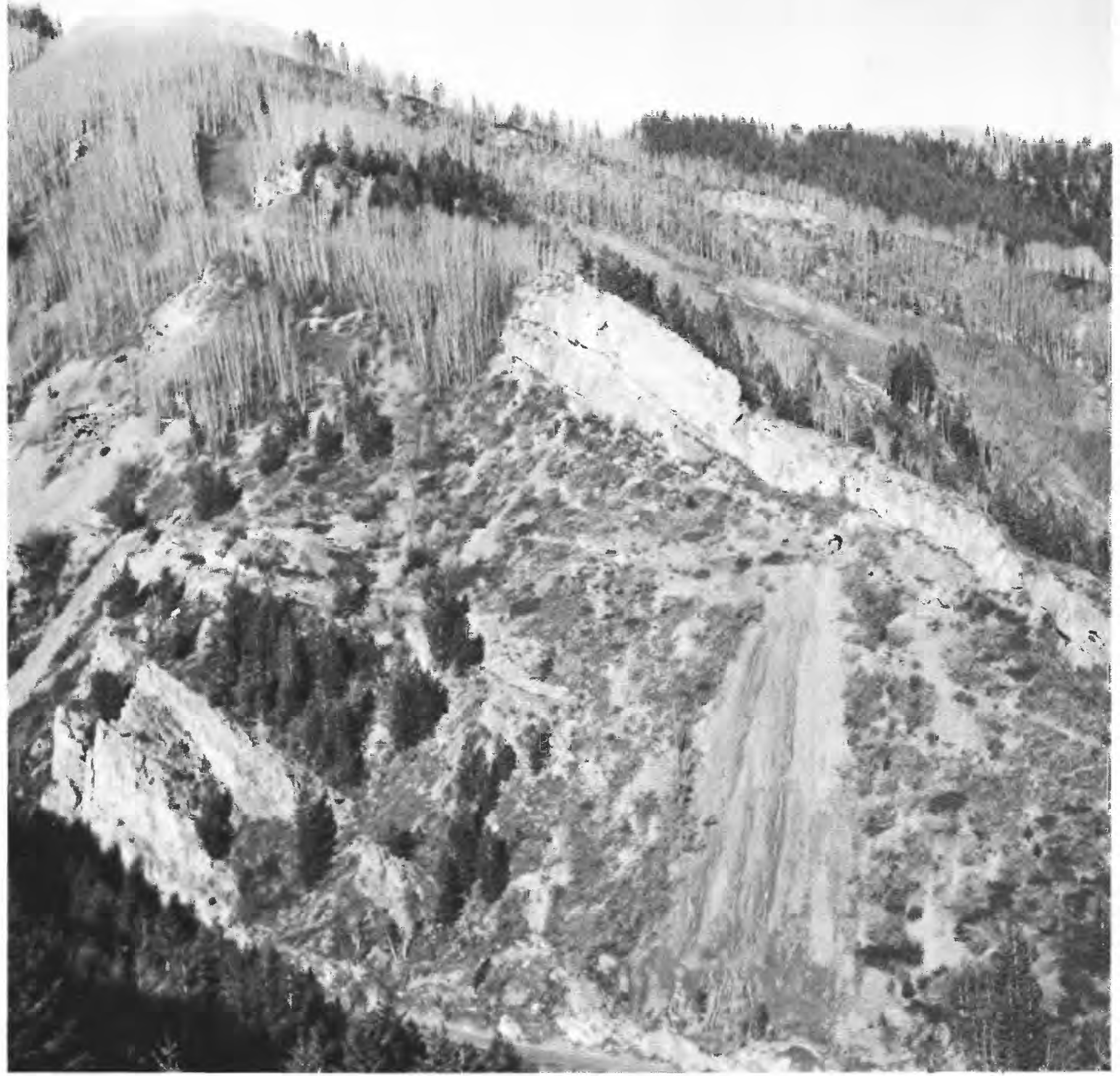

Figure 6.-Lower and middle Paleozoic rocks, $1 \mathrm{~km}$ south of Aspen. View west across Spar Gulch from 2,822 m altitude on East Aspen Mountain. Lower left cliff is Manitou Dolomite (detailed view, fig. 10), and upper cliff is upper part of the Leadville Limestone (detailed view, fig. 15) and is about $25 \mathrm{~m}$ high. These rocks are on the east limb of the Aspen Mountain syncline. Sill of aplite porphyry crops out on long, sloping ridge beyond Leadville cliff and is in the Belden Formation. Wooded ridge on right skyline is faulted west limb of the syncline. Mine openings at the base of the Leadville cliff are at the contact between the limestone in the upper part and dolomite in the lower part of that formation-the contact fault of Spurr (1898). The first discovery of ore in the Aspen district was along this horizon just outside the view to the right. Extensive dumps to the left are from the Visino and Bonnybel mines, which are in a complex of faults cutting the limestone and dolomite. The lower part of the Leadville and the Chaffee Group are poorly exposed on the slope between the two cliff-forming horizons. 
TABLE 2.-History of stratigraphic nomenclature of Cambrian through Mississippian quartzite-carbonate shelf sequence in the Aspen area

\begin{tabular}{|c|c|c|c|c|c|}
\hline \multicolumn{2}{|c|}{ Spurr (1898) } & \multicolumn{2}{|c|}{ Johnson (1944) } & \multicolumn{2}{|c|}{ This report } \\
\hline \multirow{2}{*}{ 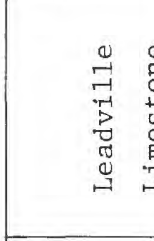 } & $\begin{array}{l}\text { Limes tone } \\
\text { and }\end{array}$ & \multicolumn{2}{|c|}{ Leadville Limestone } & \multicolumn{2}{|c|}{ Leadville Limestone } \\
\hline & & \multirow{2}{*}{ 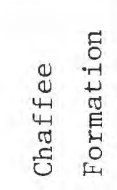 } & & \multirow{2}{*}{ 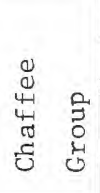 } & Gilman Sandstone \\
\hline \multicolumn{2}{|c|}{ Parting quartzite series } & & Parting Member & & Parting Formation \\
\hline \multicolumn{2}{|c|}{ Silurian beds } & \multicolumn{2}{|c|}{ Manitou Dolomite } & \multicolumn{2}{|c|}{ Manitou Dolomite } \\
\hline & & \multirow{2}{*}{\multicolumn{2}{|c|}{ Sawatch Quartzite }} & \multicolumn{2}{|c|}{ Peerless Formation } \\
\hline \multicolumn{2}{|c|}{ Cambrian sediments } & & & Sawatc & h Quartzite \\
\hline
\end{tabular}

Peerless Formation (Singewald, 1947). Bush and Bush (1974) correlated much of the glauconitic sandstone interval in the Sawatch south of the Aspen area with the Peerless of the Aspen area. They believed that the quartzites above the glauconitic sandstone interfinger with Peerless near Taylor Pass and to the north.

Fossils have not been found in the Sawatch Quartzite in the Aspen area.

Thin sections of Sawatch Quartzite show that it is composed predominantly of quartz (fig. 7). The quartz occurs in single-crystal clastic grains and multigrain fragments perhaps derived from vein quartz or quartzite. In some rocks the quartz grains occur interlocking as a mosaic; in others they are set in a matrix of finegrained quartz and sericite. Microcline and muscovite occur as clastic grains in the matrix. Carbonate grains occur between the quartz grains in some rocks. Most of them appear to have recrystallized there, but a few have rounded outlines suggesting that they are detrital. Clastic zircon and opaque mineral(s) are accessory. Tourmaline was found in one section.

\section{PEERLESS FORMATION}

The Peerless Formation (Behre, 1932; Singewald, 1947) overlies the Sawatch Quartzite at the fairly abrupt change from predominantly white quartzite containing a few carbonate-cemented sandstone beds below to predominantly grayish-orange and moderateorange-brown-weathering dolomitic sandstone and dolomite-and durky-red to yellowish and lightgreenish-gray shale above. Spurr $(1898$, p. 5-7) described the beds we now map in the Peerless at Aspen but included them in his Cambrian sediments, which were shown in the atlas that accompanied the monograph as Sawatch Formation.

The Peerless contains a few beds of white quartzite near the base. Many of the shale beds contain abundant grains of clastic mica as much as $0.5 \mathrm{~mm}$ in diameter. The Peerless contains some beds of flat pebble conglomerate consisting of fragments of dusky-red shaly dolomite in a matrix of sandy dolomite. Beds generally range from a fraction of a centimeter to 30 $\mathrm{cm}$ in thickness (fig. 8). The Peerless crops out less than the underlying Sawatch Quartzite and overlying

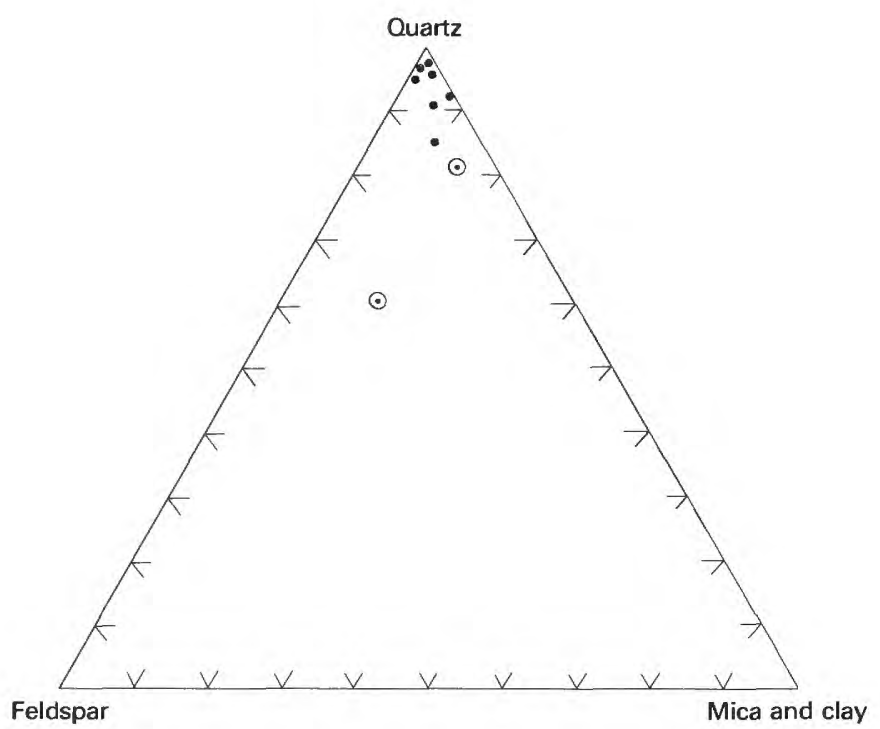

Figure 7.-Proportions of quartz, feldspar, and mica and clay in samples from the Sawatch Quartzite of the Aspen area. Circled points represent samples from the base of the formation. 


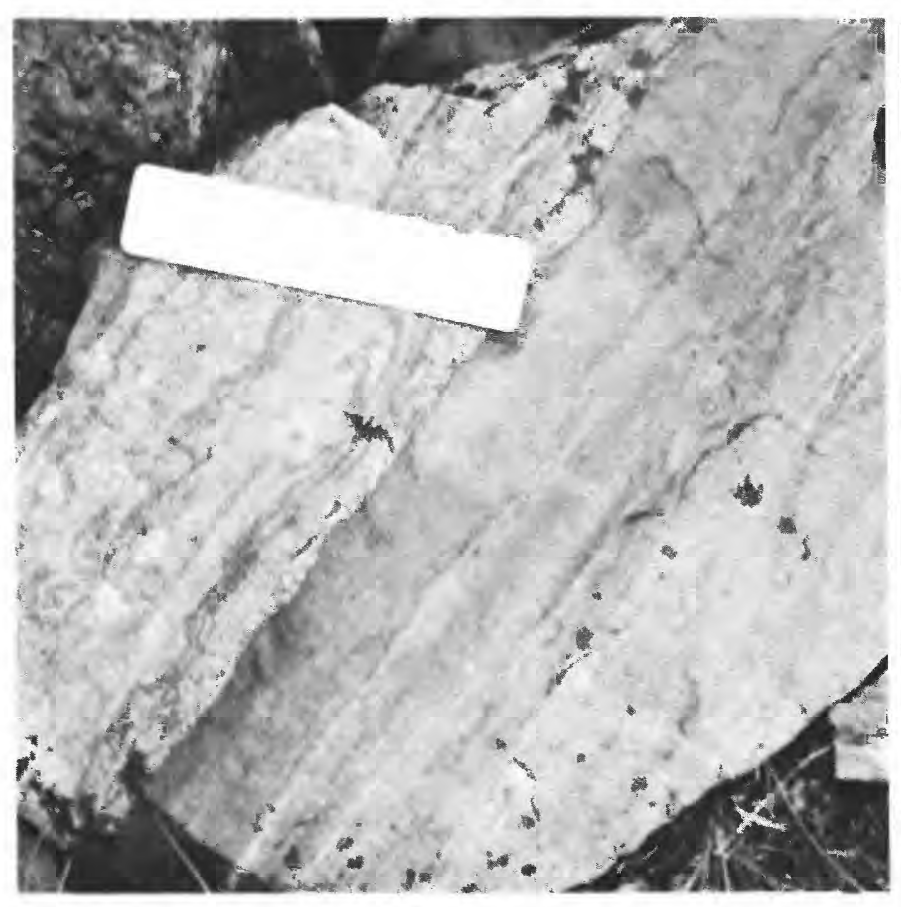

FIGURE 8.-Typical thin and irregular bedding in Peerless Formation. Darker colored beds are dolomitic shale and shaly dolomite; lightcolored beds are dolomitic sandstone. Scale is $18 \mathrm{~cm}$ long.

Manitou Dolomite, but it forms distinct brownweathering rough-textured float derived from beds of sandy dolomite.

Much of the Peerless contains a larger proportion of carbonate than is apparent in hand specimens, and among the sandstones more of the rock is sandy dolomite than dolomitic sandstone (fig. 9). In most samples clastic grains of quartz and very minor amounts of muscovite and microcline, which are as much as $3 \mathrm{~mm}$ in diameter but generally $0.5-1 \mathrm{~mm}$, are set in a matrix of mosaic-textured carbonate. Some rocks contain rounded grains of glauconite in places altered to hematite and sericite.

Zircon, opaque minerals, and tourmaline are accessory minerals. Between the larger grains is some matrix composed of a clay mineral or a very fine grained mica.

The upper contact of the Peerless is transitional into the Manitou Dolomite and is difficult to place exactly. (See stratigraphic section 1, p. 130.) It is drawn where gray dolomite becomes the predominant rock type.

The Peerless as mapped by me is about $30-45 \mathrm{~m}$ thick. My judgment of its thickness from the sections described by Johnson (1944) agrees well with the two thicknesses I measured. Johnson (1944) recognized the Peerless Shale Member at the top of the Sawatch as transitional between the Sawatch and the overlying Manitou. However, he did not identify it in his measured sections except at Ashcroft (1944, p. 357), where he assigned some of the beds I mapped as Peerless to the Manitou Dolomite. The Peerless as I mapped it in the Aspen area consists of the upper part of the Sawatch and the lower part of the Manitou as they were identified by Johnson in many sections. Bush and Bush (1974) extended a unit of dolomitic sandstones from Taylor Park into the southern part of the Aspen area, and they named that unit the Deadmans Gulch Formation. These rocks were mapped in the Peerless Formation by me.

A few graptolites were found in the Peerless Formation by Johnson in his Ashcroft and Taylor Pass sections; and the ones at Taylor Pass were of Trempealeauan (Late Cambrian) age.

\section{MANITOU DOLOMITE}

The Manitou Dolomite (fig. 6; Cross, 1894) forms the prominent flatiron on the end of West Aspen Mountain and cliffs in many other places, such as the lower part of Castle Butte, and dip slopes along Castle Creek from Ashcroft Mountain north to Fall Creek. The Manitou consists of gray, medium-gray- to light-gray- to yellowish-gray-weathering medium-bedded dolomite, with irregular bedding planes. The lower part contains a few beds of yellowish-brown dolomite sandstone and dolomite and has some shale partings. White chert stringers and nodules occur in the upper part of the formation (fig. 10). It also contains some medium-darkgray chert lenses and stringers.

Most of the Manitou contains a small percentage of

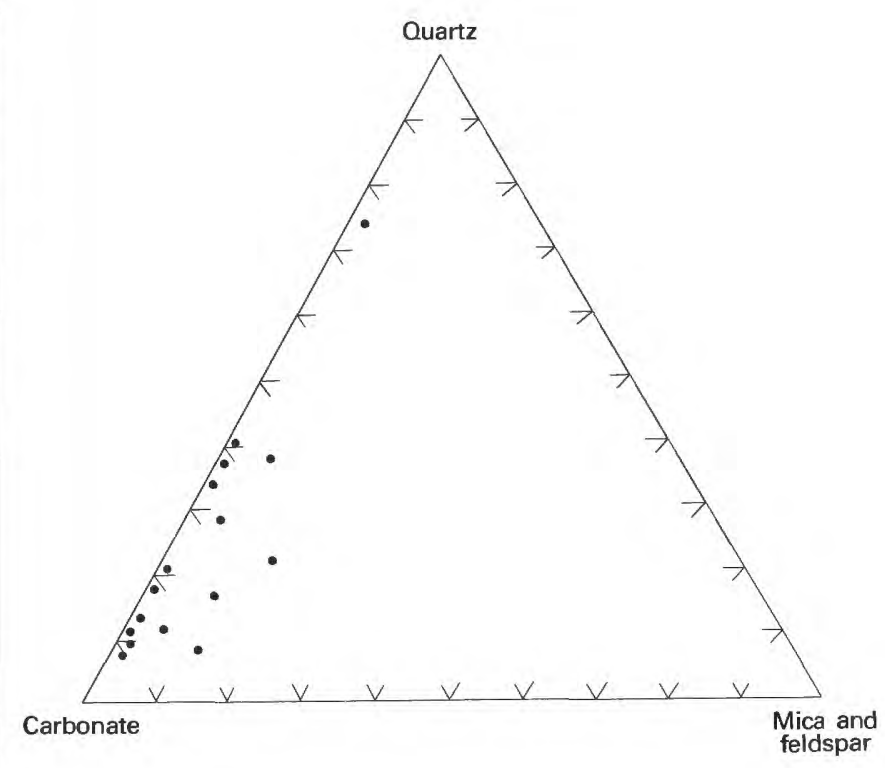

FIGURE 9.-Proportions of quartz, carbonate, and mica and feldspar in the Peerless Formation in the Aspen area. 


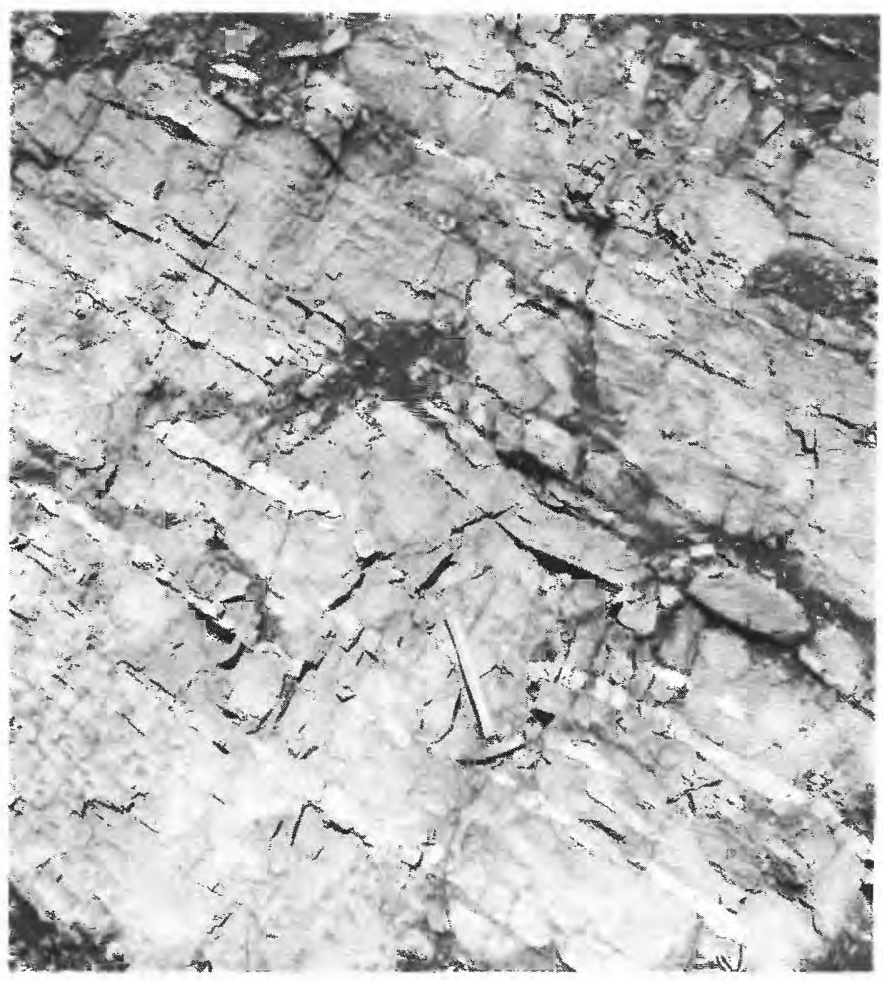

FIGURE 10.-Upper part of the Manitou Dolomite showing lenses and stringers of white chert and wavy irregular bedding planes (in upper part of photo). Outcrop in Spar Gulch, Aspen quadrangle. Compare with figure 6 .

silt-sized clastic quartz grains, and some beds contain traces of clastic muscovite. The sandier beds near the base have a few percent of clastic microcline in addition to much quartz and traces of muscovite. Zircon and tourmaline occur in these sandy beds.

The basal contact of the Manitou is difficult to locate precisely for as much as $10 \mathrm{~m}$ of the well-exposed section of Manitou measured contains beds of dolomitic sandstone and shale partings. (See stratigraphic section 1.) The base of the Manitou is drawn where lightgray- to yellowish-gray-weathering dolomite dominates over grayish-orange dolomite, sandy dolomite, and dolomitic sandstone. Gerhard $(1972$, p. 9) studied a nearby section and arrived at similar conclusions concerning the base of the Manitou, and Spurr $(1898, p$. 7) found a similar gradation farther north near Aspen.

No fossils were found in the Aspen area in the Manitou by Johnson (1944) or me, but data from the White River uplift to the northwest show that the Manitou is of Early Ordovician age (Bass and Northrop, 1963, p. J15).

Thin-section samples of the Manitou are composed of carbonate grains that range from 0.01 to $0.3 \mathrm{~mm}$ and average $0.1 \mathrm{~mm}$ in diameter; they contain scattered quartz grains less than $0.1 \mathrm{~mm}$ in diameter. Muscovite, opaque minerals, and zircon occur in trace amounts.
Gerhard (1972) analyzed the environment of deposition of the Manitou in central Colorado; he found it to range from subtidal to supratidal but to be dominantly intertidal, in a section studied near Taylor Pass (Gerhard, 1972, p. 21, 23).

\section{STRATIGRAPHIC RELATIONS AND CORRELATIONS OF CAMBRIAN AND ORDOVICIAN ROCKS}

The stratigraphic relations of the Cambrian and Ordovician formations pose some problems. According to Johnson (1944), in the Taylor Park region southeast of the Aspen area, the Sawatch consists of four members: a lower quartzite member, a middle glauconitic sandstone member, an upper quartzite member, and a Peerless Shale Member. In Taylor Park the total thickness of the three lower members is $76-90 \mathrm{~m}$, but to the east and south they thin to as little as $34 \mathrm{~m}$ at the west margin of the Garfield 15-minute quadrangle about $60 \mathrm{~km}$ south-southeast of Aspen. All three lower members are identifiable in that section, but the Peerless Shale Member is missing. Farther east the Sawatch is cut out by an unconformity below the Manitou (Dings and Robinson, 1957).

Just south of the Aspen area the thickness of the Sawatch Quartzite undergoes an abrupt change, as described by Johnson (1944); and the lower part loses its distinct tripartite character. In the southern part of the Aspen area the Sawatch of this report is about $30-45 \mathrm{~m}$ thick and is overlain by about $30 \mathrm{~m}$ of Peerless. This relation of relatively uniform Sawatch overlain by Peerless continues to the north edge of the Aspen area, but thicknesses increase so that at Woody Creek $72 \mathrm{~m}$ of Sawatch is overlain by $49 \mathrm{~m}$ of Peerless.

Johnson $(1944$, p. 312$)$ stated that the glauconitic sandstone member of the Sawatch grades to white quartzite so that the upper and lower members lose their identity to the northwest and that the Peerless Member rests unconformably on the glauconitic sandstone member near Taylor Pass, not far from the section I measured. In that section no stratigraphic break was detected either at the base of, within, or at the top of the Peerless, although detailed stratigraphic work nearby might reveal this unconformity. If the relations Johnson described are correct, it is possible that an unconformity may be present in rocks mapped as Peerless Formation by me in the Aspen area, as shown by Johnson (1944, pl. 1).

Bush and Bush (1974) correlated part of the glauconitic sandstone member of Johnson (1944) with the Peerless; they named the overlying part of the glauconitic sandstone, the upper white quartzite, and the Peerless Member the Deadmans Gulch Formation. They correlated beds at the top of the Peerless Forma- 
tion in the Mosquito Range east of Leadville, Colo., and in the southern and eastern parts of the Sawatch Range with the Deadmans Gulch Formation. They believed that the Deadmans Gulch Formation of the Taylor Park region was deposited at the same time as the upper part of the Peerless Formation of the Aspen and White River uplift areas. In the latter area the Upper Cambrian Dotsero Formation was correlated by Bush and Bush (1974) with the Peerless. They found no fossils that allow firm time correlations between these units in the region.

Northeast of the Aspen area, in the Pando, Colo., area, Tweto (1949) described a dolomitic sandstone about $3 \mathrm{~m}$ thick containing shaly dolomitic sandstone beds about $15 \mathrm{~m}$ above the base of the Sawatch. There, the Sawatch is about $56 \mathrm{~m}$ thick and is conformably overlain by about $30 \mathrm{~m}$ of Peerless.

On the White River Plateau near Glenwood Springs, Bass and Northrop (1963) measured $157.6 \mathrm{~m}$ of Sawatch, which contains a $21-\mathrm{m}$ dolomite bed $90.5 \mathrm{~m}$ above the base. The Sawatch they mapped is overlain by the Dotsero Formation, $29 \mathrm{~m}$ of dolomite and limestone with minor amounts of shale, of Late Cambrian (Trempealeauan) age.

Berg (1960) and Bush and Bush (1974) interpreted the Dotsero to be stratigraphically equivalent to the Peerless. Berg believed that the Peerless is older to the east; paleontologic control for this interpretation was indicated (Berg, 1960, fig. 1) but not documented. He did state that in Manitou Park on the west side of the Rampart Range about $170 \mathrm{~km}$ east of Aspen he obtained fossils of late Franconian age (Late Cambrian) from the Peerless. Johnson (1944, p. 313-314) stated that he collected Trempealeauan fossils from the Peerless in the Aspen area, which would tend to confirm Berg's interpretation. Gerhard (1972) agreed with Berg.

In the Garfield quadrangle the Manitou Dolomite of Early Ordovician age oversteps the Sawatch and lies on Precambrian rocks, owing to pre-Manitou erosion of the Sawatch. On the White River Plateau the Clinetop Member of the Dotsero Formation immediately underlies the Manitou Dolomite and was deposited in the intertidal and supratidal zones in a sea regressing to the southwest (Campbell, 1976). Thus, the regional stratigraphic relations suggest that the conformity and gradation between Peerless and Manitou in the Aspen area may be more apparent than real, and perhaps the channeling reported by Johnson (1944) was at the base of the Manitou rather than the Peerless.

On the other hand, Tweto and Lovering (1977) reported that fossils from the Peerless in the Minturn and Holy Cross quadrangles are of Franconian age. They correlated the dolomite unit in the Glenwood Canyon area (Bass and Northrop, 1963) with the
Peerless and believed that the quartzite beds above that unit and the equivalent of the Dotsero Formation have been cut out by pre-Manitou erosion in the area of the Sawatch Range.

A slightly different interpretation has been given by Lochman-Balk (1972, p. 73). She designated the Peerless as partly Franconian and partly Trempealeauan and believed that the portion now preserved is partly older than the Dotsero. According to Lochman-Balk, the dolomite in the Sawatch mapped in the Glenwood Springs area is older than the Peerless and is a tongue from a thick dolomite section in Utah. This interpretation is supported in a recent study by Campbell, Bickford, and Janssen (1976), which showed two dolomite intervals in the Sawatch of the White River Plateau to thicken to the southwest ${ }^{1}$ and to pinch out to the north and east.

Possible relations of the Peerless of the Aspen area with units of other areas are

1. The Peerless near Aspen is the equivalent of the Peerless of the Manitou Park and Gilman areas and to the dolomite and the overlying quartzite in the Sawatch and part of the Dotsero of the Glenwood Springs area (figs. $11 A, 12$ ). That means that the upper part of the Sawatch of Glenwood Springs intertongues with Peerless between there and Aspen just as it apparently does between Taylor Park and the Aspen area. At Aspen the Peerless is thicker than at Gilman, and less has been removed by preOrdovician or Ordovician erosion. The Trempealeauan fossils reported by Johnson (1944) from the south edge of the Aspen area are from the very top of the Peerless. It is possible that the bottom could be Franconian.

2. The Peerless of the Aspen area is correlative only with the Dotsero of Glenwood Springs, and the regressive sequence represented by the Peerless and the Dotsero is younger in the White River Plateau area than at Gilman (fig. 11B). Near Aspen those rocks are of an age intermediate between those at Gilman and Glenwood Springs. The lack of widespread paleontologic control and closely spaced stratigraphic sections between the Sawatch Range and the White River Plateau precludes a definite solution to the problem at this time.

\section{CHAFFEE GROUP}

The Chaffee Group (Campbell, 1970; Tweto and Lovering, 1977) consists of the Parting Formation, which was mapped by Spurr (1898) in the Aspen area,

'Misprint in their abstract stated southeast. 
and the Dyer Dolomite and the Gilman Sandstone, both of which he mapped with the Leadville Limestone (table 2). At the time of my work the Chaffee was considered a formation and the Parting and Dyer were
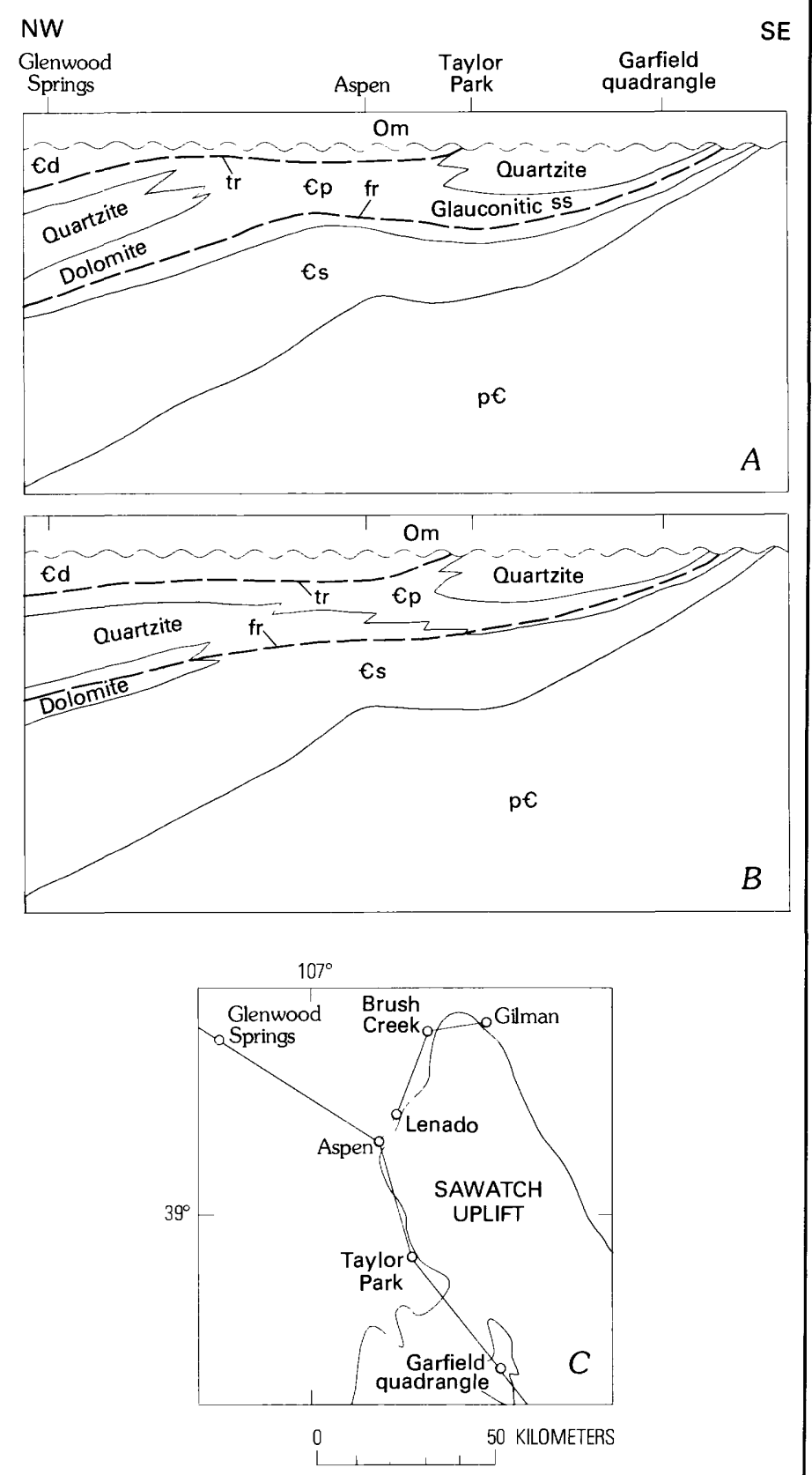

Figure 11.-Possible stratigraphic relations of Cambrian rocks in west-central Colorado. $A, B$, Alternative sections on a northwestsoutheast line through Aspen. Diagrammatic sketches, not to scale. $€ d$, Dotsero Formation, $€ s$, Sawatch Quartzite, $€ p$, Peerless Formation, all of Cambrian age; Om, Ordovician Manitou Dolomite; pC, Precambrian rocks. Dashed lines approximate paleontologically defined time lines; fr, Franconian Stage; tr, Trempealeauan Stage. Wavy line, unconformity. $C$, Location of sections in figures 11 and 12. members (Kirk, 1931). The Gilman Sandstone was mapped as a member of the Leadville Limestone.

A number of fossil collections from the region were summarized by Johnson (1944, p. 328-330) and indicate a Late Devonian age for the Chaffee Group. The only collection reported in the Aspen area is from East Aspen Mountain and consists of fragmentary bones and plates of fish (Spurr, 1898, p. 21). We found similar material in the Parting on Richmond Hill near the head of Queens Gulch. The Late Devonian age of the Chaffee indicates a substantial unconformity between it and the underlying Manitou of Early Ordovician age. Just to the south of Aspen the Harding Quartzite of Middle Ordovician age and the Fremont Limestone of Late Ordovician age are found between the Manitou and Chaffee (Johnson, 1944).

Campbell (1970) subdivided the Parting and Dyer of the Chaffee into members and was the first to suggest that the Chaffee be elevated to group status, the Parting and Dyer to formations. Tweto and Lovering (1977) transferred the Gilman Sandstone from the Leadville Limestone to the Chaffee and designated the Gilman, Parting, and Dyer as formations in the Upper Devonian and Lower Mississippian(?) Chaffee Group.

\section{PARTING FORMATION}

Emmons (1886) gave the name "Parting quartzite series" to less resistant beds separating more resistant carbonate formations near Leadville. Spurr (1898) extended the name to the Aspen area.

Generally, the Parting Formation does not crop out well, although quartzite beds form distinctive float. However, good stratigraphic sections of Parting may be seen about $1.3 \mathrm{~km} \mathrm{~N} .20^{\circ} \mathrm{E}$. of Ashcroft; in various

$N$

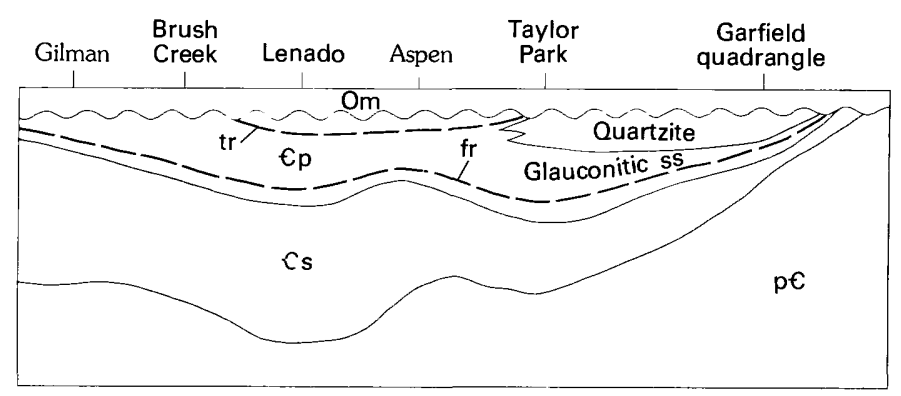

FIGURE 12.-Possible stratigraphic relations of Cambrian rocks in west-central Colorado. Section on a north-south line through Aspen. Diagrammatic sketch, not to scale. €d, Dotsero Formation; €s, Sawatch Quartzite; €p, Peerless Formation, all of Cambrian age; Om, Ordovician Manitou Dolomite; $p €$, Precambrian rocks. Dashed lines approximate paleontologically defined time lines; fr, Franconian Stage; tr, Trempealeauan Stage. Wavy line, unconformity. 
places on the ridge between the two principal south forks of Express Creek (fig. 13); on the southwest side of the 3,347-m knob (Castle Butte) west of Tourtelotte Park; and on the ridge east of lower Spar Gulch (East Aspen Mountain).

The Parting Formation consists of (in approximately ascending order although rock types are interbedded in many parts of the formation): white to tan poorly sorted crossbedded quartzite; gray, greenish-gray, and dusky-red shale and dolomitic shale; gray to tan siltstone; and grayish-yellow dolomite. Its thickness ranges from 15 to $30 \mathrm{~m}$, judging by map relations. According to Johnson (1944), the Parting of the Aspen district is transitional between the more quartzitic sections of the northern Sawatch Range, which resemble the rocks of the type locality in the Leadville district, and more shale- and carbonate-rich sections to the south, which resemble the Upper Devonian Elbert Formation of the San Juan region. The Parting is of Late Devonian age.

Campbell (1970) divided the Parting into three members: A, lower member of medium- to coarse-

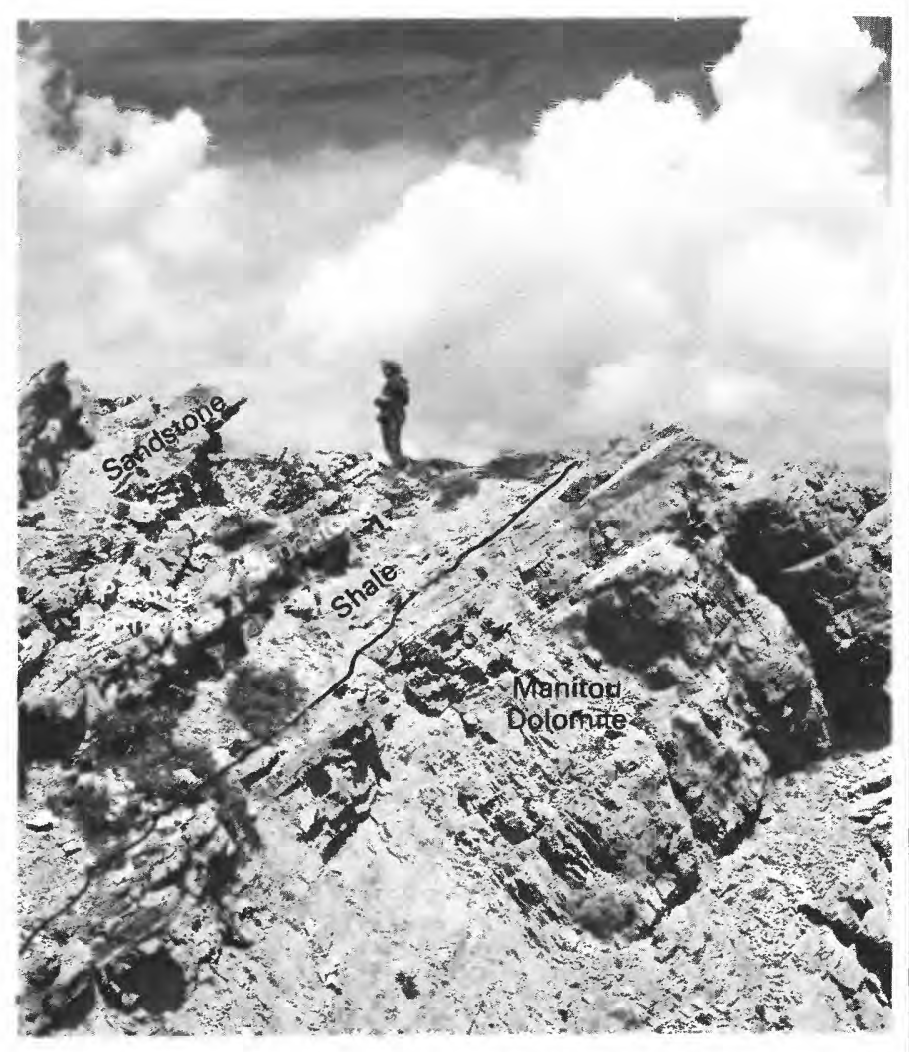

FigURE 13.-Ridge between two south tributaries of Express Creek, Hayden Peak quadrangle, showing contact of Parting Formation of the Chaffee Group with the Manitou Dolomite. Parting consists of easily erodible shales interlayered with resistant sandstone and dolomite, and the formation as a unit tends to form a bench between more resistant dolomite above and below. grained quartzose sandstone with some sandy shale; $\mathrm{B}$, a middle member of basal gray shale, succeeded in sequence by thin dark-gray irregularly bedded dolomite, gray shale, and a thin sandy dolomite and dolomitic sandstone; and $\mathrm{C}$, an upper member of shale, dolomite, and sandstone. Interpolation of Campbell's isopach maps (1970, figs. $5-7$, p. 317$)$ indicates that he measured $2.4 \mathrm{~m}$ of member $\mathrm{A}, 4.6 \mathrm{~m}$ of member $\mathrm{B}$, and $5.8 \mathrm{~m}$ of member $\mathrm{C}$ near Ashcroft, probably at or very close to section 9 of Johnson (1944).

Thickness variations of the Parting in the Aspen area and to the south (Johnson, 1944; Prather, 1964; Waterman, 1955; Slebir, 1957), to the southeast (Dings and Robinson, 1957), and to the southwest (Vanderwilt, 1937) indicate that trends of the isopachs shown by Campbell, at least in Pitkin County, are not significant. The variations in thickness in the region are local and numerous, and they appear not to show any trends. Within a larger area the more generalized trends shown by Baars (1972) are realistic. These trends indicate that the source area of the Parting was to the north and east as envisioned by Campbell (1970) and that the Uncompahgre did not exist as a large positive area during the Devonian as postulated by Pampe (1970).

In thin section the quartzites of the Parting are composed of rounded clastic grains of quartz as much as $2 \mathrm{~mm}$ in diameter in a matrix of finer quartz and carbonate which appears to have recrystallized to various degrees. Clastic grains of microcline compose a few percent of the quartzites. Muscovite, zircon, tourmaline, and opaque minerals are minor components.

The dolomites generally have a grain size of 0.02-0.04 mm and contain a few grains of quartz of similar size. Muscovite, microcline, zircon, and opaque minerals are less common than quartz as accessory minerals. Gradational between the dolomite and quartzite are beds of sandy dolomite and dolomitic or calcareous sandstone (fig. 14).

\section{DYER DOLOMITE}

The Dyer Dolomite (Behre, 1932) of the Chaffee Group was mapped with the Leadville Limestone by Spurr (1898; table 2, this report) as an unnamed lower part.

The Dyer forms small cliffs and is well exposed on the east side of Castle Creek, at Fall Creek, at about 1.3 $\mathrm{km}$ northeast of Ashcroft, and on the cliff west of Tourtelotte Park.

In the Aspen area the Dyer consists of thinly laminated light-gray and darker gray dolomite and contains some beds of dark-gray limestone as much as $3 \mathrm{~m}$ thick. It contains some red shale partings and 


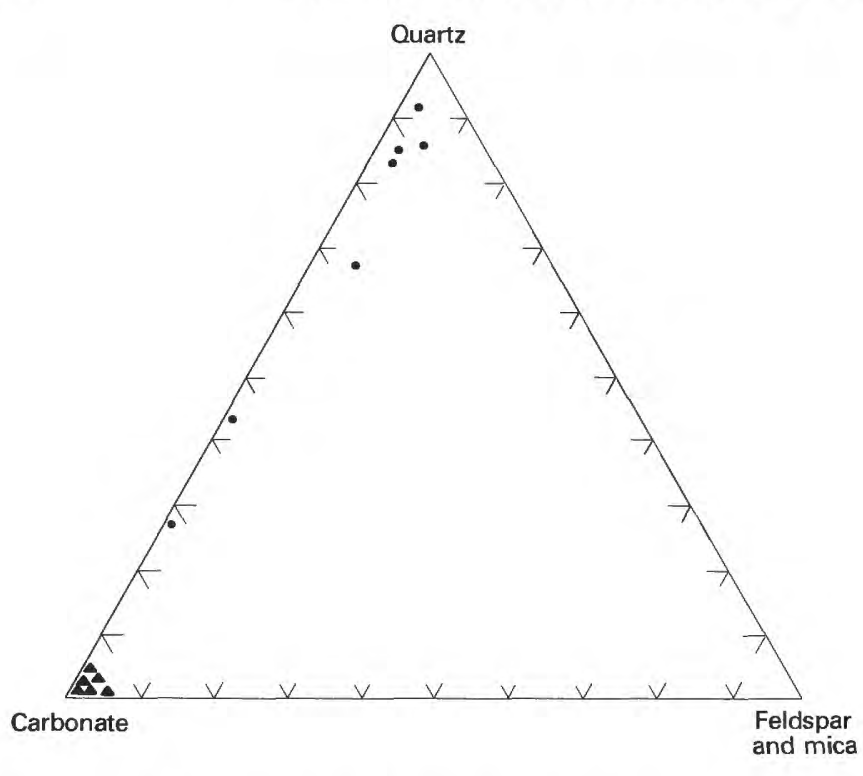

Figure 14.-Proportions of quartz, carbonate, and mica and feldspar in the Parting Formation of the Chaffee Group. Dot, sandstone; triangle, limestone and dolomite.

layers of flat pebble dolomite conglomerate. The dolomite is locally sandy. It ranges in thickness from 15 to $30 \mathrm{~m}$.

Campbell (1970) divided the Dyer into a lower fossiliferous dolomitic limestone and dolomite called the Broken Rib Member and an upper thin-bedded finegrained light-gray to dark-gray dolomite called the Coffee Pot Member. Interpolation of his isopach maps indicates that he measured about $5.5 \mathrm{~m}$ of the Broken Rib Member and $29.3 \mathrm{~m}$ of the Coffee Pot Member near Ashcroft. Although the Broken Rib Member of Campbell is not present north of Aspen along the margin of the Sawatch Range, it is well developed in the White River Plateau, and Johnson's sections suggest that it may be recognizable south of the Aspen area.

The isopachs shown in Pitkin County by Campbell (1970) for the Dyer are of uncertain validity, as those for the Parting. Changes in thickness along northsouth trends are similar to those along east-west trends. Isopachs shown by Bloom (1961) are based on many fewer sections in the White River Plateau but many more along the Sawatch Range. Nevertheless, in the Aspen area, they appear to be erroneous because he used a thickness of $76 \mathrm{~m}$ for a section at Aspen. Even the figures of 52 and $69 \mathrm{~m}$ reported by Johnson and described in his measured sections are, I think, too great.

In thin section the dolomites of the Dyer are fine grained, ranging generally from 0.01 to $0.05 \mathrm{~mm}$ but locally as coarse as $0.1 \mathrm{~mm}$. Most sections have a few grains of quartz of similar size and few opaque minerals. In one sample of thinly laminated lightand dark-gray dolomite, the darker beds are coarser grained with a grain size of about $0.08 \mathrm{~mm}$ as compared to $0.01 \mathrm{~mm}$ for the lighter gray beds. Quartz occurs in the coarser grained beds.

In the Aspen area no fossils were seen in the Dyer. Elsewhere, especially on the White River Plateau, the lower part (Broken Rib Member of Campbell) is quite fossiliferous and has been assigned a Late Devonian age, although evidence against a Mississippian age is not definite (Bass and Northrop, 1963, p. J25-J26). Lack of fossils in the Dyer Dolomite and presence of sparse Early Mississippian fossils in rocks in western Colorado considered to be equivalent to the Dyer have led Tweto and Lovering (1977) to designate its age as Late Devonian and Early Mississippian(?).

\section{GILMAN SANDSTONE}

The horizon of dolomitic sandstone and sedimentary breccia within the dolomite section of the Leadville Limestone as defined by Eldridge (1894) allowed rocks believed to be predominantly Devonian to be separated from those of Mississippian age (Behre, 1932). This horizon has been mapped with the Leadville Limestone in the Aspen area by me and by other workers in the Sawatch Range (such as Tweto, 1974). Tweto and Lovering (1977) now place the Gilman Sandstone as a formation in the Chaffee Group because of an unconformity recognized at the top of the Gilman and because of the change from primary dolomites in and below the Gilman to normal marine limestone above the Gilman. I did not recognize the unconformity at the top of the Gilman in the Aspen area, and the dolomites in the lower part of the Leadville greatly resemble the dolomites of the Dyer near Aspen.

In the Aspen area the Gilman Sandstone consists of several beds of dolomitic sandstone, sandy dolomite, and sedimentary breccia. It ranges from 1.2 to $4.6 \mathrm{~m}$ in thickness and furnishes dolomitic sandstone float that is easily distinguished from the carbonate beds above and below. The breccia beds consist of fragments of dolomite and, locally, of dark-gray chert as much as a few centimeters long in a matrix of sandy dolomite or dolomitic sandstone. In thin section the Gilman is seen to consist of rounded quartz grains and a few carbonate grains as much as $1 \mathrm{~mm}$ in diameter in a very fine grained carbonate matrix.

The Parting represents a transgressive sequence with several regressive episodes. Detrital sediments were derived from a highland northeast of the Sawatch Range. The deposition of the lower Dyer in a sublittoral environment marked the maximum advance of the Devonian sea. Much of the Dyer above the lower part in the Aspen area represents a regressive car- 
bonate sequence deposited in a shallow sublittoral environment (Campbell, 1970).

After deposition of the Dyer, the region was elevated above sea level for a geologically brief time. The lower Dyer is latest Devonian and the lower Leadville is probably Kinderhookian in age. The Gilman Sandstone was deposited by a transgressive sea in Late Devonian or Early Mississippian time. Source for the sand grains in the Gilman may have been Devonian rocks eroded from an uplift of small relief at the present site of the Sawatch Range (Nadeau, 1972, p. 99).

According to Banks (1970), the sand grains were deposited by winds and were the primary source of silica of the chert that formed penecontemporaneously with deposition of the dolomite matrix. These beds were reworked by wave action to produce the sedimentary breccias that are such a distinctive feature of the Gilman.

\section{LEADVILLE LIMESTONE}

The Leadville Limestone as mapped by Spurr (1898) in the Aspen area included the Dyer Dolomite, the Gilman Sandstone, and the Leadville Limestone of this report. I included the Gilman Sandstone with the Leadville Limestone on my maps (1970; 1971a). Two units equivalent to the lower and upper parts of this report have been named the Castle Butte and Redcliff Members by Nadeau (1972), who also included a Gilman Member at the base of his Leadville.

The Leadville forms cliffs and ledges in many places in the Aspen area. It consists of gray to dark-gray thick- to thin-bedded dolomite and a few beds of limestone in the lower part, and blue-gray thick-bedded to massive limestone in the upper part.

The lower part of the Leadville contains thinly laminated dolomite resembling some beds in the Dyer Dolomite and some thicker beds of dolomite. It contains dark-gray chert lenses and stringers. The contact between the dolomite and overlying limestone is not uniform. In some places, such as the hill west of Tourtelotte Park, it is quite abrupt; in other places, such as the 3,190-m knob in the Express Creek valley, gray limestone and gray to light-gray thinly laminated dolomite are interbedded.

The upper massive limestone makes the most prominent outcrops and has a characteristic blue-gray color. Some excellent exposures occur on Express Creek and again to the south near the southwest branch of Express Creek. The ridge between Spar and Vallejo Gulches (Aspen quadrangle) has a number of cliffs of Leadville along it (fig. 15). The hill west of Tourtelotte Park (Castle Butte) is capped by Leadville and is the type locality of Nadeau's Castle Butte Member.

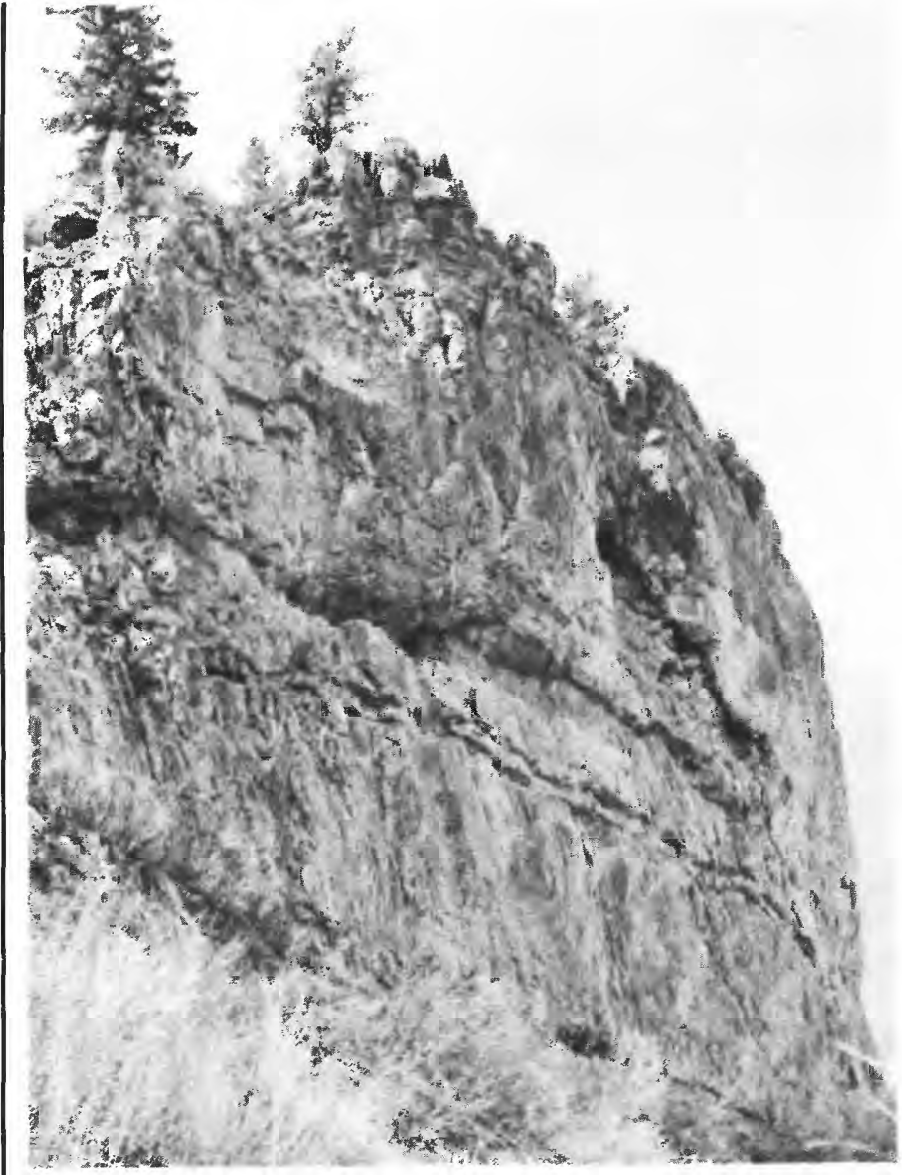

FIgURE 15.-Upper part of the Leadville Limestone. "Blue limestone" of Spurr (1898) and Castle Butte Member of Nadeau (1972). Thick-bedded coarsegrained biosparite. Cliff about $25 \mathrm{~m}$ high. (Closeup of cliff in the middle of fig. 6.)

In the Spar Gulch area, the contact between dolomite and limestone is quite abrupt. Old mine workings along that contact, which Spurr (1898) interpreted to be a bedding-plane fault, suggest that the ore may have occurred in cave deposits formed by postLeadville-pre-Belden solution along the contact. An exposure where the road into Spar Gulch crosses the ridge of Leadville shows an irregular breccia at the base of the limestone. In the breccia are large fragments of Leadville in a matrix of dark-gray shale resembling the overlying Belden Formation. In places bedded shale surrounds the fragments, and in other places the shale itself is fragmented. These relations may be interpreted to show that cavities along the contact below the limestone unit existed at the time of deposition of the basal part of the Belden Formation, that the cavities were filled or partly filled during deposition of the Belden, and that some further solution occurred after deposition of the Belden.

The blue-gray limestone part of the Leadville is ab- 
sent north of the Roaring Fork valley in the Aspen quadrangle but is present on Larkspur Mountain 2.5 $\mathrm{km}$ north of the Aspen quadrangle. The absence of the limestone member along the $10.4 \mathrm{~km}$ distance was interpreted by Spurr (1898) to be due to faulting along a bedding-plane fault he called the Silver fault and by Vanderwilt (1935b) as an unconformity. Vanderwilt (p. 229) stated that the upper contact of the Leadville is marked by a conglomerate of chert fragments and fine-grained quartzite. Surface exposures of this contact are very rare. I have seen a similar conglomerate above the Leadville south of Express Creek, but nowhere else. Most prospects and mines near the contact north of the Roaring Fork have dolomite breccia and shale in their dumps.

Especially critical are the map relations just north of Hunter Creek where Belden is in contact with Sawatch and Manitou. These relations appear to be caused by faults since there are abrupt changes in what formations are adjacent to the Belden, and they support Spurr's fault interpretation of the contact in this area. A recent study by Maslyn (1976) interprets this feature as having formed by pre-Belden faulting and sinkhole formation.

Vanderwilt (1935b) and Johnson (1944) described erosional features on the top of the Leadville where exposed in mines near Aspen. Johnson (p. 337) described a conglomerate containing Precambrian boulders supposed to be at the base of the Belden. To me such a conglomerate seems anomalous because scattered pebbly sandstones I have seen at the base of the Belden are composed of mature sediments rich in quartz and chert and very poor in feldspar. The character of the Belden, described below, and the preservation of Leadville around the Sawatch Range suggests to me that preBelden erosion did not cut down to Precambrian rocks and that the material described by Johnson, if the description is accurate, may have another origin.

Spurr $(1898$, p. 132) observed in mine workings a truncation of the formation by faulting at depth. Spurr interpreted the fault, which he called the Silver fault, to be a near-bedding-plane fault occurring throughout the Aspen quadrangle. I interpret the lack of the blue limestone of the Leadville between the Roaring Fork and Larkspar Mountain to be due to more local faulting along the margin of the Sawatch which is moderate to high angle and subparallel to the bedding. The possibility of a regional bedding-plane fault will be discussed later.

The lower part of the Leadville has few fossils, but the blue limestone in places has a large component of fossil fragments. The most obvious fossils are corals and crinoid stem fragments. Foraminifera are widespread. On Richmond Hill at one locality brachiopods and bryozoa were seen. Girty (1903) and
Johnson (1944) list fossils found in the Aspen area and in the Crested Butte 15-minute quadrangle to the south.

The following Foraminifera and algae were identified by B. A. Skipp (written commun., 1973) in thin sections of the blue limestone from the Aspen area. One section contained Calcisphaera laevis Williamson, Calcisphaera pachysphaerica Pronina, Spinoendothyra spinosa Chernysheva, Earlandia, Latiendothyra sp., Septaglomospiranella sp., Septaglomospiranella dainae Lipina, Chernyshinella, Eotubertina, and Paracaligella, an assemblage characteristic of foraminiferal zone 9 or late Osagean (Mamet and Skipp, 1970). Species found in other sections are, in addition to some of those listed, Tuberendothyra, Radiosphaera, Parathurammina, Septabrunsiina sp., and Palaeospiroplectammina. These forms, according to Skipp, are indicative of zones 8 or 9 , middle to late Osagean. The Leadville is considered to be predominantly of Osagean or late Early Mississippian age in west-central Colorado, although some basal beds may be of Kinderhookian age (early Early Mississippian) (Conley, 1972; Craig, 1972).

Some beds of the dolomite in the lower part of the Leadville are coarser grained than the thinly laminated beds and have a grain size of $0.2 \mathrm{~mm}$. Near ore bodies the dolomite is more coarsely recrystallized and has a grain size as coarse as $1 \mathrm{~mm}$. The blue limestone consists of shell fragments and Foraminifera as much as $2 \mathrm{~mm}$ in diameter in a matrix of recrystallized calcite. Quartz and opaque minerals are the principal accessory minerals in carbonate rocks of the Leadville. The petrology of the Leadville has been well described by Nadeau (1972) and Conley (1972). Most of the features they described can be found in the Leadville in the Aspen area. They interpreted the lower dolomitic part of the Leadville as having been deposited in a relatively sheltered environment in the upper intertidal zone; whereas the blue limestone of the upper part formed in a shallow marine high-energy environment.

\section{PENNSYLVANIAN THROUGH TRIASSIC SEQUENCE OF THE EAGLE BASIN}

In Pennsylvanian time the sedimentation pattern in the Aspen region changed markedly from that of the preceding part of the Paleozoic. Instead of widespread thin relatively uniform quartzite-carbonate formations, thicker, more variable, and geochemically less mature sediments were deposited. Aspen lay on the southwest side of a northwest-trending depositional basin, called the Eagle basin or Central Colorado trough (fig. 3). Detritus from bordering uplifts was 
deposited in thicknesses of as much as several kilometers in this trough. In the Aspen region the detritus came from the uplift to the southwest, which is called the Uncompahgre highland. Deposition began in the Early Pennsylvanian in a shallow marine and nearshore environment, and the basin margin lacked much structural relief. During this time the Belden Formation, consisting primarily of shale and carbonate, was deposited. Increasing relief of the Uncompahgre highland produced coarser clastic sediments during deposition of the Gothic Formation of Langenheim (1952), which includes arkoses, siltstones, marine limestone, and shale. Further uplift of the Uncompahgre and filling of the basin led to deposition of coarse conglomerates and sandstone of the Maroon Formation in a terrestrial environment. Siltstones locally dominate the upper part of the Maroon. Some deformation and erosion of the rocks in the basin ensued, and further uplift of the Uncompahgre in Permian and Triassic time led to deposition of the State Bridge Formation, which in the Aspen area contains conglomerate, sandstone, and siltstone. A period of uplift and erosion followed, and then the Chinle Formation of Late Triassic age was deposited. The uplift southwest of Aspen was a positive area either during, or more likely after, deposition of the Chinle, for that formation is absent on the Uncompahgre highland. Upper Jurassic rocks are the oldest ones which do not reflect the influence of Uncompahgre uplift.

\section{BELDEN FORMATION}

The Belden Formation (Brill, 1942, 1944) crops out in the Aspen area in a north-south belt along the margin of the Sawatch Range parallel to and west of the older Paleozoic formations and in an isolated area on Conundrum Creek in the Hayden Peak and Maroon Bells quadrangles. The Belden Formation is generally poorly exposed except where contact metamorphism has converted it to hornfels and marble. It underlies valleys which contain surficial deposits, such as Castle Creek from Ashcroft to north of Sawyer Creek; and grassy areas, such as Van Horn Park and Annie Basin (Aspen quadrangle). The best exposures are in mine tunnels, and these usually reveal structural complications not perceived when only surface observations are made.

The Belden was mapped as the Weber Formation by Spurr (1898) and as Weber(?) Formation by Knopf (1926). Brill (1944) recognized that the "Weber Shale" of the Aspen area was correlative with Belden Shale of the type locality on the northeast side of Eagle basin.

The Belden is composed of relatively thin bedded carbonaceous limestone, dolomite, and shale with a few beds of sandy shale and sandstone (figs. $16 A, B$ ). The sand content increases in the upper part, and the upper contact is transitional with the more sandstone-rich Gothic Formation of Langenheim (1952). In nearby areas a massive sandstone is used to mark the bottom of the Gothic (Langenheim, 1952; Mutschler, 1970; Gaskill and Godwin, 1966a). However, in the Aspen area such a distinctive sandstone is missing, and the contact is gradational. Dark-gray shale is interbedded with greenish-gray and tan calcareous siltstone and sandstone in the interval of gradation, and the contact is placed where the light-colored siltstone, sandstone, and limestone become dominant.

The base of the Belden lies on an erosional surface on the Leadville Limestone, except between the Roaring Fork River and Larkspur Mountain in the Ruedi quadrangle, where the contact may be a fault. Southwest and west of Aspen residuum on this surface is thick enough to form a mappable rock unit called the Molas Formation, but in the Aspen area rocks that might be assigned to the Molas are difficult to find in surface exposures. In the area of the San Juan Mountains, Merrill and Winar (1958) described the Molas as consisting of three units: a lower unit of unstratified siltstone and mudstone with layers of limestone and chert boulders; a middle unit of poorly stratified siltstone, mudstone, sandstone, and conglomerate sequence; and an upper unit of well-stratified calcareous shale, siltstone, and sandstone. If any Molas occurs in the Aspen area, it is the controversial breccia at the Leadville-Belden contact, which might represent the lower unit. Around the Treasure Mountain dome southwest of the Aspen area, as much as $15 \mathrm{~m}$ of Molas was mapped by Mutschler (1970), Gaskill and Godwin (1966a), and Gaskill, Godwin, and Mutschler (1967). There, the fragments in the residual breccia consist of chert and quartzite.

In the Aspen area the stratigraphic base of the Belden unmodified by faulting is exposed in places south of Express Creek. One place is on the east side of the shoulder on hill 11490 (Hayden Peak quadrangle). There, the base of the Belden consists of about a meter of medium-bedded dark- to medium-gray dolomite, a $10-\mathrm{cm}$ bed of sandy dolomite, another meter of lightgray-weathering dolomite, and a lens of sandstone. Elsewhere, lenses of coarse-grained sandstone and chert-pebble conglomerate, perhaps $0.5 \mathrm{~m}$ thick, occur at or near the base of the Belden.

At the Taylor Pass road where it crosses Waterfall Gulch, siltstone, sandstone, and shale at the BeldenLeadville contact somewhat resemble the Molas Formation.

As Spurr pointed out $(1898$, p. 30$)$, the lower part of the Belden is richer in carbonate (mostly limestone but some dolomite) than the upper part. The proportion of carbonate to shale varies from place to place, and con- 

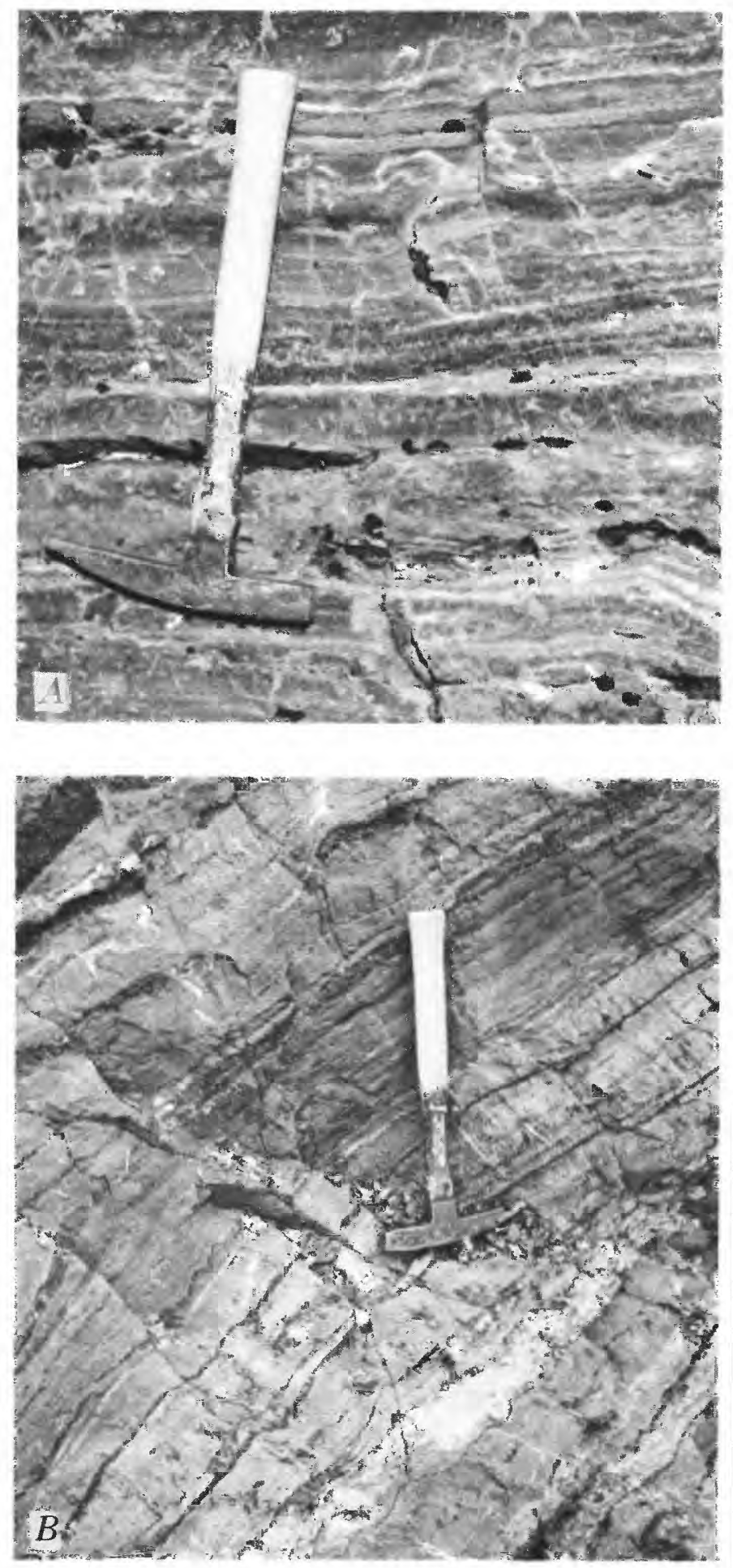

tact metamorphism emphasizes the contrast between the carbonate-rich parts and the shale-rich parts. On Conundrum Creek and at the head of Castle Creek, separate units of marble and hornfels were mapped in the Belden. On Taylor Peak just south of the Hayden Peak quadrangle, large outcrops are divisible into

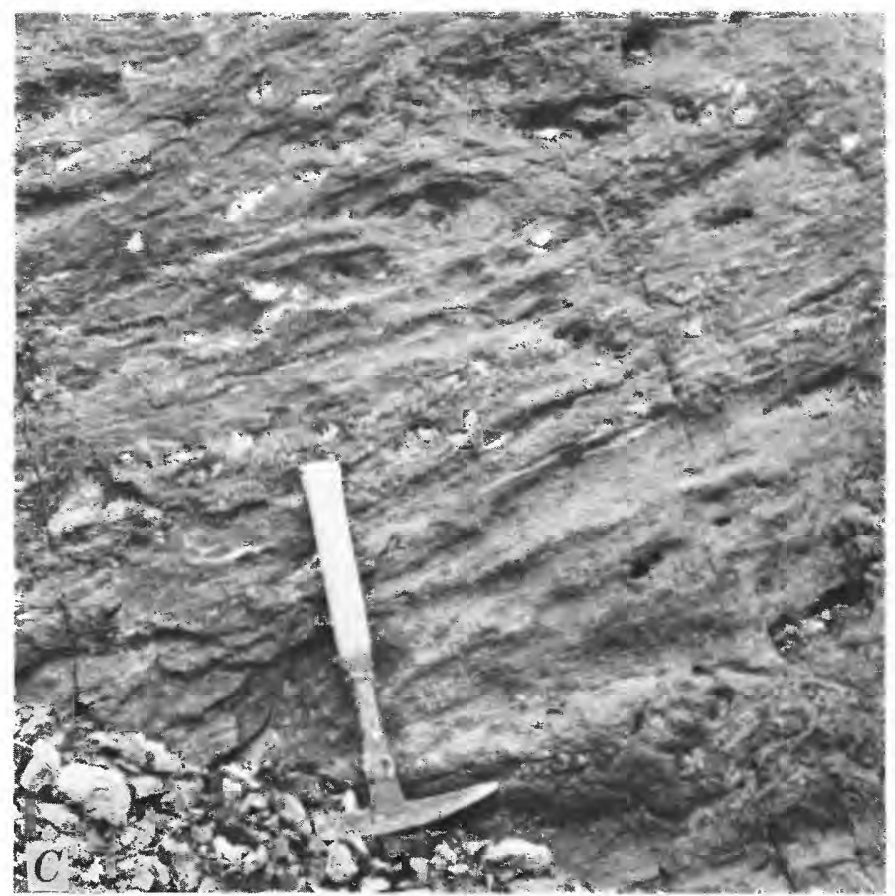

Figure 16.-Features of the Belden Formation. All these exposures are in marble near the White Rock pluton (fig. 48). The Belden is poorly exposed where it is unmetamorphosed. Darker colored beds are finer grained and contain more carbonaceous material and silt than the lighter colored beds. $A$, Thin-bedded marble at altitude of $3,392 \mathrm{~m}$ east of Cooper Creek, Hayden Peak quadrangle. $B$, Somewhat thicker bedded marble on 3,900-3,960-m nose on the east side of the ridge north of Taylor Peak, Pearl Pass quadrangle. $C$, Breccia zone at same locality as $B$. Zone apparently parallel to bedding formed before contact metamorphism.

three units from bottom to top: marble with a few hornfels beds; hornfels, quartzite, and a few marble beds; and carbonaceous hornfels. Although neither the base nor the top of the formation is exposed there, those outcrops probably represent most of the total thickness of the Belden.

Thicknesses of Belden Formation range from 122 to $580 \mathrm{~m}$, probably owing to the effects of faulting in that formation. Where faults are not shown, such as in sections $B-B^{\prime}$ and $C-C^{\prime}$ of the Hayden Peak quadrangle (Bryant, 1970), the formation is almost completely concealed beneath the surficial deposits in Castle Creek valley, and it may be highly faulted, judging from exposures in tunnels along the belt. An approximate thickness of the Belden is $300 \pm 150 \mathrm{~m}$. No regional isopach maps should be drawn based on sections of the Belden in the Aspen area.

The large number of carbonate beds in the lower Belden makes it locally difficult to differentiate Belden from Leadville. Generally, Belden limestone is darker gray, finer grained, and more thinly bedded than the Leadville (figs. 15, 16); it may have partings of carbonaceous shale or shaly limestone. Probably, the 
most difficult place to make the distinction is east of Van Horn Park where the distinctive blue limestone of the Leadville is missing, and the Belden has many beds of dolomite and limestone as much as $6 \mathrm{~m}$ thick. Another problem area of numerous thick carbonate beds in the Belden occurs on the ridge at the head of the southwest fork of Express Creek.

Breccias are common in the Belden where exposures are good, such as in areas of contact metamorphism (fig. 16C) and in tunnels. Some of the best natural exposures are of marble on Taylor Peak just south of the Hayden Peak quadrangle, where the breccias, in the lower part of the exposure, are composed of fragments of the adjoining rock in a calcareous matrix now converted to marble.

Anhydrite and gypsum occur in the Belden, probably in the lower part. Knopf (1962) reported $30.5 \mathrm{~m}$ of gypsum in the Hope tunnel on Castle Creek in the northern edge of the Hayden Peak quadrangle. Knopf (1926, fig. 1) put the gypsum near the top of the Belden, but his section (1926, fig. 5) shows that only $60-90 \mathrm{~m}$ of shale separate the gypsum from the Leadville. His map (Knopf, 1926, fig. 4) showed a welldeveloped fault gouge between what he called the Weber(?) and Maroon. Near the south edge of the Aspen 7.5-minute quadrangle, the Highland tunnel (discussed in a later section) revealed gypsum and anhydrite in a breccia about $1.5 \mathrm{~km}$ in from the portal, and a drift driven on a curving course south of the tunnel intersected about $30 \mathrm{~m}$ of anhydrite and gypsum interbedded with limestone and shale. On the Fryingpan River, about $13 \mathrm{~km}$ north of the Aspen quadrangle, Freeman (1972b) mapped in the Belden a unit about $24 \mathrm{~m}$ thick containing evaporite beds.

Extensive fossil collections in the Glenwood Springs area indicate that the Belden is Morrowan and Atokan in age (Bass and Northrop, 1963, p. J36-J41). Other lists of fossils from the Belden are in Girty (1903) (called Weber Formation by him), Langenheim (1952), and Brill (1944). In the Aspen area some brachiopods were found in limestone of the Belden at one locality south of the Woody Creek-Hunter Creek divide in the Aspen quadrangle.

Isopach maps of the Belden on the southwest side of the Eagle basin are poorly controlled (Brill, 1958, p. 104). As pointed out previously, the possibility of great thinning or thickening, owing to structural effects in the Aspen area, does not permit any firm thickness figure to be stated for the area, but the Belden is probably between 150 and $450 \mathrm{~m}$ thick. In the Crested Butte 15-minute quadrangle Langenheim (1952) found a thickness of $169 \mathrm{~m}$ about $18 \mathrm{~km}$ to the south of the Aspen area; Mutschler (1970) recorded 260 $\mathrm{m}$ in the Treasure Mountain dome $13 \mathrm{~km}$ to the southwest of the Maroon Bells quadrangle; and Freeman (1972b) measured 183-213 $\mathrm{m}$ just to the north of the Aspen quadrangle. Clearly, the pattern of isopachs is not as simple as indicated by Brill (1944, fig. 2; 1958). Facies relations in the Belden (Mallory, 1972) and local data from south of the Aspen area (Langenheim, 1952, p. 572) indicate that the Uncompahgre uplift was not a strong positive element in Early Pennsylvanian time, although the Front Range, Apishapa, and Pedernal uplifts to the east and south of the Uncompahgre uplift apparently were. The zero isopach of the Belden southwest of Aspen is due to post-Belden erosion. Maps of the Treasure Mountain dome (Mutschler, 1970; Gaskill and Godwin, 1966a) show that at least some and perhaps all of that erosion is post-Maroon and pre-Entrada in age.

Petrographic and X-ray examination of rocks of the Belden Formation show that the shales are composed of clastic grains of quartz and muscovite in a very fine grained matrix of quartz, dolomite or calcite, sericite, chlorite, pyrite, and carbonaceous material. Neither feldspar nor clay minerals constitute a significant proportion of the specimens examined. Since these rocks were buried to a depth of about $6 \mathrm{~km}$ before uplift, any preexisting clay minerals were probably unstable and were converted to mica. The sandstone lenses at the base of the formation are composed of quartz and chert. Tourmaline and zircon are accessory minerals in the sandstones.

\section{GOTHIC FORMATION}

OF LANGENHEIM (1952)

The Gothic Formation of Langenheim (1952) occupies a belt of $0.8-1.6 \mathrm{~km}$ wide along the margin of the Sawatch Range in the Aspen and Hayden Peak quadrangles and crops out in the Conundrum Creek area northwest of Hayden Peak and in the southern part of the Maroon Bells quadrangle. It is well exposed in the Woody Creek valley southwest of Lenado and in Lenado Gulch in the Aspen quadrangle, and on the cliffs on the west side of Castle Creek in the Hayden Peak quadrangle. Southeast of the Hope mine on the Castle Creek road is a good roadside exposure.

The Gothic Formation was named by Langenheim (1952), and the type locality is on the ridge west of Copper Creek about a mile south of the Maroon Bells quadrangle. Langenheim (1952, p. 551) and Bartleson, Bryant, and Mutschler (1968) have given reasons for using the term Gothic rather than Minturn Formation, which is well established in the Vail region on the northeast side of the Eagle basin.

The Gothic Formation has transitional contacts with the underlying Belden Formation and the overlying Maroon Formation. At its base the Gothic Formation consists of green, gray, and very light grayish red calcareous shale, shaly limestone, sandy limestone, and calcareous siltstone interbedded with dark-gray 
carbonaceous shales and siltstones resembling the Belden. No well-defined sandstone bed marks the base of the Gothic in the Aspen area as it does in the Crested Butte region (Langenheim, 1952) and to the southwest on the Treasure Mountain dome (Mutschler, 1970). In the Aspen area the lower contact is drawn where light-colored sandstone, siltstone, and silty or sandy limestone predominate above the dark-gray calcareous and shaly limestones of the Belden. The Gothic contains megascopically obvious clastic mica grains, which are lacking in the Belden.

The upper contact is marked by a relatively abrupt transition in color from dominantly gray, green, and brown beds to dominantly reddish gray, grayish-red, and pale-red colors in the Maroon Formation. The Maroon Formation is more poorly sorted, coarser grained, and has fewer limestones than the Gothic.

The Gothic Formation in the Aspen region consists of gray, tan, and brown calcareous sandstone and siltstone, silty and sandy limestone, and limestone. It contains a few thin greenish-gray and grayish-red beds, especially near its upper contact. Thin beds of dark-gray limestone and silty limestone are scattered throughout the formation. Many of the rocks weather grayish orange to moderate orangeish brown. Except in the southwesternmost exposures conglomerate beds are absent; a few pebbles were seen in the inclusion of Gothic in the White Rock pluton in the southern part of the Maroon Bells quadrangle, and pebbly arkose occurs in the Gothic in the southwestern corner of the quadrangle. Ripple marks and mudcracks are found locally in the Gothic.

Gypsum and anhydrite occur in lenses at $10 \mathrm{~m}$ thick in Monument Gulch in the Hayden Peak quadrangle. Associated with the evaporites are layers of breccia that also are at least $10 \mathrm{~m}$ thick. These breccias weather to towers that give the gulch its name (fig. 17A). They resemble the stacks described by Mallory (1971, fig. 6); their origin is uncertain. Mallory suggested that such stacks could be produced by brecciation associated with flowage, accompanying the change from anhydrite to gypsum that occurs in the evaporite as it is subjected to near-surface environment, or that they may be the remains of filled, recent-

FIGURE 17 (right).-Breccia in Gothic Formaton of Langenheim (1952), Hayden Peak quadrangle. A, View down Monument Gulch from altitude $3,377 \mathrm{~m}$ at its head, showing the "monuments" composed of brecciated and unbrecciated Gothic Formation. Left slope of gulch is a dip slope, and the breccia is at one general stratigraphic horizon. A few small exposures indicate that the breccia is underlain by $10 \mathrm{~m}$ or so of evaporite. $B$, Closeup of breccia in one of the "monuments"; fragments are calcareous siltstone, silty limestone, and limy sandstone in a calcareous matrix.
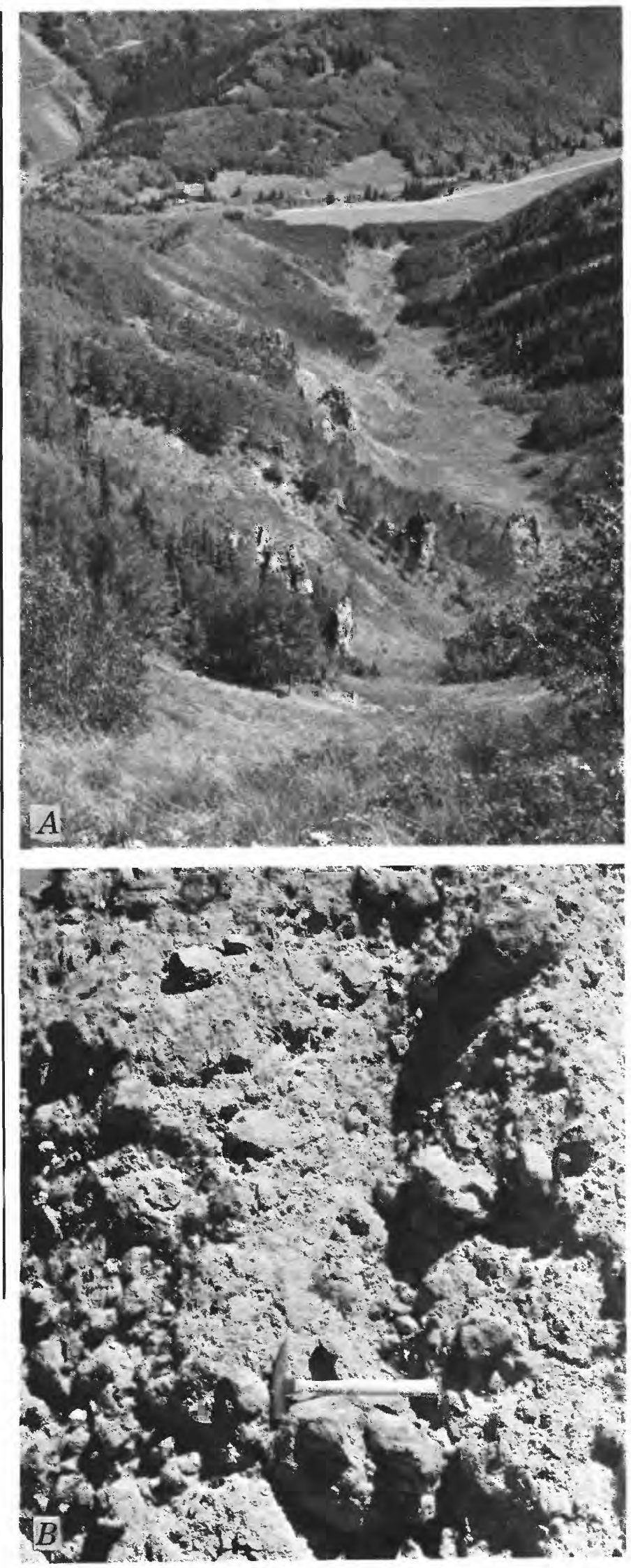
ly formed, solution sinks. I have no evidence for their origin except that in Monument Gulch they occur in a stratigraphic horizon immediately overlying the evaporite, which seems to favor the first hypothesis.

In Monument Gulch the evaporites contain some beds of carbonaceous limestone resembling beds in the Belden. The breccias in places contain fragments of that rock type as well as fragments of sandy or silty limestone typical of the Gothic in the Aspen area. The breccias contain fragments of silty limestone and limy sandstone $5-20 \mathrm{~cm}$ in diameter (fig. $17 B$ ) but locally as much as $60 \mathrm{~cm}$ in diameter in a calcareous matrix. Some local zones of brecciation lack much calcareous cement. some of the rock in the towers is just fractured rather than brecciated; in some towers the lower parts are more thoroughly brecciated than the upper parts.

In other places in the outcrop area of the Gothic Formation, outcrops of breccia are found without any associated evaporites. Perhaps evaporites are present but not exposed, or perhaps they have been removed by solution. Alternatively, those breccias may have been formed by fault movements or by igneous intrusion.

In thin section, rocks of the Gothic Formation are seen to consist of various proportions of clastic grains of quartz, microcline, plagioclase, carbonate, muscovite, and less abundant biotite and chlorite, and accessory zircon, tourmaline, and opaque minerals, in a matrix of very fine grained carbonate, which may contain a small amount of clay mineral. The clastic grains are generally $<0.5 \mathrm{~mm}$ in diameter, and in many of the limestones they are $0.05-0.1 \mathrm{~mm}$ in diameter. The clastic grains of quartz, especially, are quite angular. Mica grains tend to be alined parallel with the bedding.

Composition of rocks of the Gothic Formation ranges from limestone, or, rarely, dolomite, to calcareous sandstone and siltstone (fig. 18); but almost no rocks in the formation are limestones lacking detrital silicate minerals or sandstones lacking carbonate cement. Many rocks called sandstone in the field have carbonate contents greater than 50 percent and consequently are sandy limestones.

The farthest southwest exposures of the Gothic Formation in the Aspen area are on a hill south of the head of Rustler Gulch in the Maroon Bells quadrangle. Approximately $60-90 \mathrm{~m}$ of Gothic are exposed between the Elk Range thrust and the overlying Maroon Formation; these exposures consist of light- to dark-gray arkose, pebbly arkose, dark-gray silty shale, gray to dark-gray limestone, and silty limestone. A local bed of dark-gray sandy oolitic limestone near the top of the Gothic contains a number of marine fossils and overlies a siltstone containing a few plant fragments.

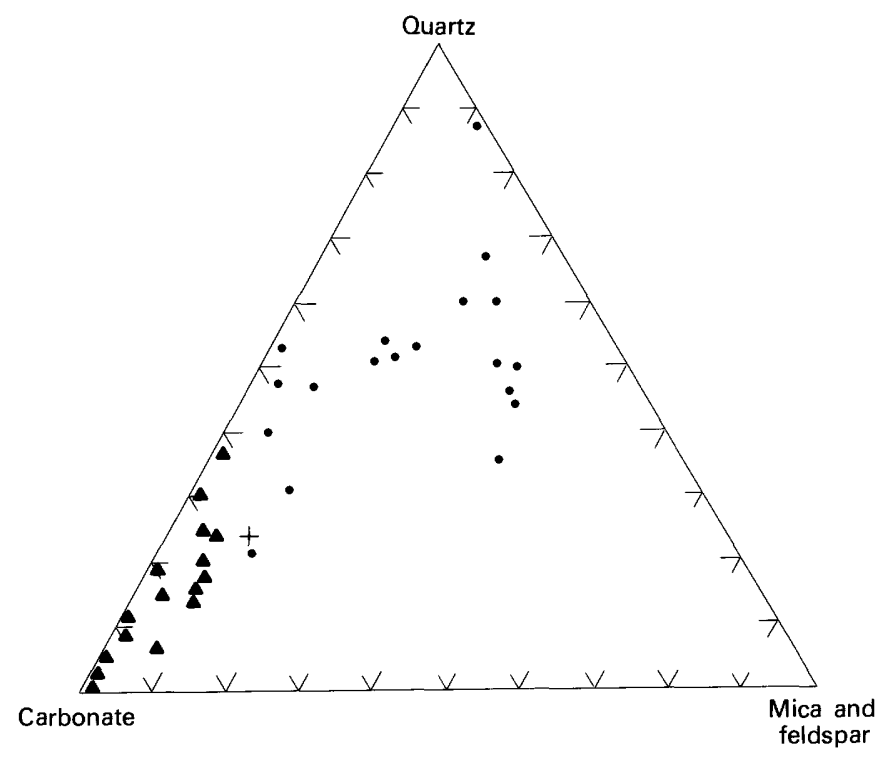

FIgURe 18.--Proportions of quartz, carbonate, and mica and feldspar in the Gothic Formation of Langenheim (1952)) in the Aspen 15-minute quadrangle. Dot, sandstone; cross, siltstone; triangle, limestone or dolomite.

The following fossils from the limestone were identified by Ellis L. Yochelson (gastropods and scaphopods) and Mackenzie Gordon, Jr. (rest of fauna; pelecypods in consultation with John Pojeta). (USGS colln. no. 22251-PC; field sta. 151):

Brachiopods:

Linoproductus cf. L. prattenianus (Norwood and Pratten) Anthracospirifer rockymontal us (Marcou) Composita ovata Mather

Pelecypods:

Palaeoneilo sp.

Myalina sp.

Aviculopecten sp.

Pectenoid pelecypod indet.

Schizodus? sp.

Scaphopods:

Plagioglypta sp. indet.

Gastropods:

Euphemites sp. indet.

Bellerophon (Pharkidonotus) sp. indet.

Knightites (Retispira) cf. K. (R.) nodocostatus (Gurley)

Pleurotomacean aff. Hypselentoma sp. indet.

Shansiella carbonaria (Norwood and Pratten)

Colpites cf. C. kansasensis (Sayre)

Naticopsis (Naticopsis) sp. indet.

Naticopsid aff. Trachydomia sp. indet.

Stegocoelia sp. indet.

Murchisonid gastropod indet.

Pseudozygopleurid gastropod indet.

Ianthinopsis (Soleniscus) sp. indet.

At least four other indeterminate genera.

Cephalopods:

Mooreoceras $\mathrm{cf}$. M. normale Miller, Dunbar, and Condra

Domatoceras sp.

Liroceras sp. indet. 
Concerning this collection Yochelson (written commun., 1966) stated:

Because so many specimens are exfoliated it is difficult to get a precise age. In general terms this is probably Middle or Late Pennsylvanian rather than either Early Pennsylvanian or Early Permian *** This collection shows more variety than the gastropods previously available in the Leadville region.

According to Gordon (written commun., 1966):

*** The collection rather closely resembles one that Gordon made (from the White Quail Limestone Member of the Minturn Formation) on Radio Ridge, one mile southwest of Ptarmigan Peak in the Gore Range *** A nautiloid Domatoceras $\mathrm{n}$. sp. is a rather spectacular member of the White Quail fauna and the one in collection 22251-PC appear to be the same species $* * *$ The age of the White Quail Member in the Minturn quadrangle is Middle Pennsylvanian (Des Moinesian).

A small collection of fossils from a bed of sandy limestone in the inclusion mapped in the White Rock pluton at the head of East Maroon Creek contained bellerophontid gastropod indet., Trepospira sp., and other indeterminate gastropods. The material did not permit an age determination. Plant fragments were also present at the locality.

No other fossils were found in the Gothic Formation of the Aspen area except some plant fragments in the lower part west of the west fork of the Express Creek.

Elsewhere in the region, Girty (1903) listed a number of fossils collected from the lower Maroon (Gothic of this report) of the Crested Butte area, and Langenheim (1952) found a Des Moinesian fauna in the Gothic Formation. Bartleson (1972) also in the Crested Butte area found a fusulinid sequence of Des Moinesian age in several limestones that have some continuity along strike of the Eagle basin. At the southwest margin of the Elk Range thrust sheet, Mutschler (Bartleson and others, 1968) found Atokan fusulinids in a limestone in an outcrop of Gothic separated by the thrust and the Snowmass pluton from the stratigraphic boundaries of that formation. This is the only locality as yet in the Gothic to produce Atokan fossils.

Neither Bartleson (1968) nor I found any fossils in the more basinward sections of the Gothic north of the crest of the Elk Mountains.

The apparent thickness of the Gothic Formation in the Aspen area ranges from $140 \mathrm{~m}$ on the Express Creek-Castle Creek ridge to about 900 m near Sawyer Creek. Much of the thickness variation may be due to faulting: either bedding-plane faults associated with the Elk Range thrust, unmapped high-angle faults along the margin of the Sawatch Range, or both. Very few complete and well exposed sections of the Gothic are available for study in the region; so little can be said about thickness variations. The Gothic is apparently thinner to the north in the Fryingpan drainage (Freeman, 1972b). Yet in the Eagle area near- ly equivalent evaporitic and clastic rocks are believed to be $2,740 \mathrm{~m}$ thick (Mallory, 1971). There, the stratigraphic interval represented by that thickness depends on interpretation of an horizon continuous with the Jacque Mountain Limestone Member which marks the top of the Minturn Formation and is probably somewhat higher stratigraphically than the top of the Gothic on the south side of the Elk Mountains. North of the Elk Mountains mapping suggests that the top of the Gothic rises stratigraphically in the Hayden Peak quadrangle and descends at the north margin of the Aspen quadrangle. The thickest wellexposed section probably lacking internal faulting is at Haymaker Gulch near the Taylor River $20 \mathrm{~km}$ south of the Hayden Peak quadrangle about at the margin of the Eagle basin during deposition of the (Bartleson, 1968). Even that section is incomplete. Consequently, the precise location of the southwest margin of the Eagle basin during depositon of the Gothic Formation is not known, owing to post-Gothic erosion. The greater grain size and conglomerate content of the Gothic in the southernmost exposures indicate that the margin of the basin was in that direction and perhaps not many kilometers away.

All the Gothic of the Aspen area except that south of Rustler Gulch is in the upper plate of the Elk Range thrust and is a more basinward facies than that of the type locality. It has a finer grain size and fewer beds of pure limestone than the Gothic to the southwest. Except for a few pebbly beds at the head of East Maroon Creek, conglomerates are absent; whereas they are common in the outcrops to the west and south. These facies relations show that the effects of the ancestral Sawatch uplift proposed by De Voto (1972) are minor in the Aspen area compared to those associated with the Uncompahgre uplift. However, the lack of Gothic exposures northwest of the Aspen area precludes a thorough three-dimensional facies analysis.

\section{EAGLE VALLEY FORMATION}

The Eagle Valley Evaporite was defined by Lovering and Mallory (1962) on the northeast side of the Eagle basin as the basin center evaporite sequence that intertongues with the Minturn and Maroon Formations. It also intertongues with the Gothic Formation on the southwest side of the basin (Bartleson and others, 1968). Bartleson, Bryant, and Mutschler (1968) used the term Eagle Valley Formation for rocks that make up a transition zone of indistinct color change between Gothic and Maroon Formations, whether or not evaporites are interbedded.

Rocks at the north edge of the Aspen quadrangle lying between the Maroon and Gothic Formations are assigned to the Eagle Valley Formation. They are com- 
posed of interbedded gray, greenish-gray, grayish-red, and reddish-brown calcareous siltstone and sandstone, and gray silty limestone and limestone. They are stratigraphically equivalent to the lower part of the Maroon Formation immediately to the south. Along strike to the northwest of Larkspur Mountain in the Ruedi quadrangle, the rocks mapped as Eagle Valley in Woody Creek interfinger with the Maroon Formation, and the bottom of the Maroon Formation is about $460 \mathrm{~m}$ lower straigraphically than south of Woody Creek. The Eagle Valley here is probably of Middle Pennsylvanian age because it is stratigraphically equivalent to the lower part of the Maroon Formation.

\section{MAROON FORMATION}

The Maroon Formation is the most widespread rock unit in the Aspen region, and it makes up four of the five 4,270-m (14,000-ft) peaks in the area (fig. 19). Parts of the formation are well exposed in many places on the high mountains and in the deep valleys, where they produce the spectacular character of the scenery of much of the region.

The Maroon Conglomerate was named by Eldridge (in Emmons and others, 1894, p. 6), and it included all the beds above the Belden (called Weber Limestone by him) and below the Morrison Formation in the Crested Butte quadrangle. However, the type locality was given as Maroon Creek, although no type section was published. Spurr (1898) used the term Maroon Formation in the Aspen 7.5-minute quadrangle because conglomerates are rare there. He included the rocks now mapped as Gothic Formation by me, and he excluded some moderate-red rocks in the upper part. He called those upper rocks Triassic but pointed out that the contact is gradational and difficult to map. Included in the Triassic sandstones of Spurr are the upper part of the Maroon, the State Bridge, and the Chinle Formations of the present report. West of Castle Creek in the Aspen quadrangle the upper contact of the Maroon mapped by Spurr almost coincides with that mapped here, but on Red Mountain and along Woody Creek hundreds of meters of Maroon Formation were included with the Triassic sandstones.

The Maroon Formation consists of sandstone, siltstone, conglomerate, mudstone, and limestone interbedded on scales of $30 \mathrm{~cm}$ to $10 \mathrm{~m}$. an incomplete section of the Maroon Formation in "Stratigraphic sections" illustrates many of the variations in rock type and color occurring in the Maroon. (See stratigraphic section 2, p. 131.) Colors in the lower part tend to be grayish red and pale red, whereas in the upper part reddish-brown and moderate-red colors dominate. This color change is probably the one noted by Spurr and served as a basis for his separation of Maroon Formation from Triassic sandstones. The change in color is too gradational and variable along strike to be worth mapping, although locally, such as along Woody Creek, the change is relatively sharp across strike. An additional complicating factor is that a slight amount of contact metamorphism darkens the brighter reds to grayish-red hues.

No reliable stratigraphic markers were found in the Maroon Formation. Where exposures are excellent on the high peaks of the Elk Mountains a few sandstone, conglomerate, or limestone beds can be traced as much as $1.6 \mathrm{~km}$ (fig. 20). Sequences of beds may make a distinctive outcrop pattern that allows faults and relative movement on them to be deciphered on slopes where the rocks are well exposed. However, many conglomerate and limestone beds lens out in just a meter or a few meters. The whole aspect of the stratigraphic section may change in a short distance across strike. For instance, at the head of West Maroon Creek the ridge on the east side of the valley contains less limestone and more sandstone than does the west-side ridge. Large areas in the eastern part of the Maroon Bells quadrangle and in the adjoining Hayden Peak quadrangle lack the numerous conglomerates of the measured section in the western part of the Maroon Bells quadrangle. In the lower part of the Maroon where limestones are relatively numerous, the lack of these conglomerates makes determination of the Maroon-Gothic contact very uncertain in areas where the distinctive color difference between the two formations is destroyed by contact metamorphism.

Bedding-plane features are numerous, especially on thin muddy or silty beds (fig. $21 E$ ). They include desiccation cracks, current-ripple marks, worm tubes, raindrop impressions, and impressions of plant fragments.

Crossbedding is well developed in the sandstones and conglomerates (fig. 21C). Some torrential crossbedding occurs. Some of the more massive sandstone units have fine internal laminae (fig. 21A).

Conglomerate lenses are common in many parts of the Maroon Formation. In the lower part of the formation they contain limestone, quartzite, quartz, dolomite, and Precambrian basement pebbles indicating that Paleozoic sedimentary rocks contributed to the streams which deposited the conglomerate (fig. $21 B$ ). (See stratigraphic section 2, p. 131.) White limestone pebbles are characteristic of the conglomerates in the lower part of the Maroon and are unlike anything in the Cambrian-throughMississippian stratigraphic section. A few limestone beds in the lower part of the Maroon resemble these pebbles in color and texture. These pebbles must have come from some Pennsylvanian sedimentary rocks 

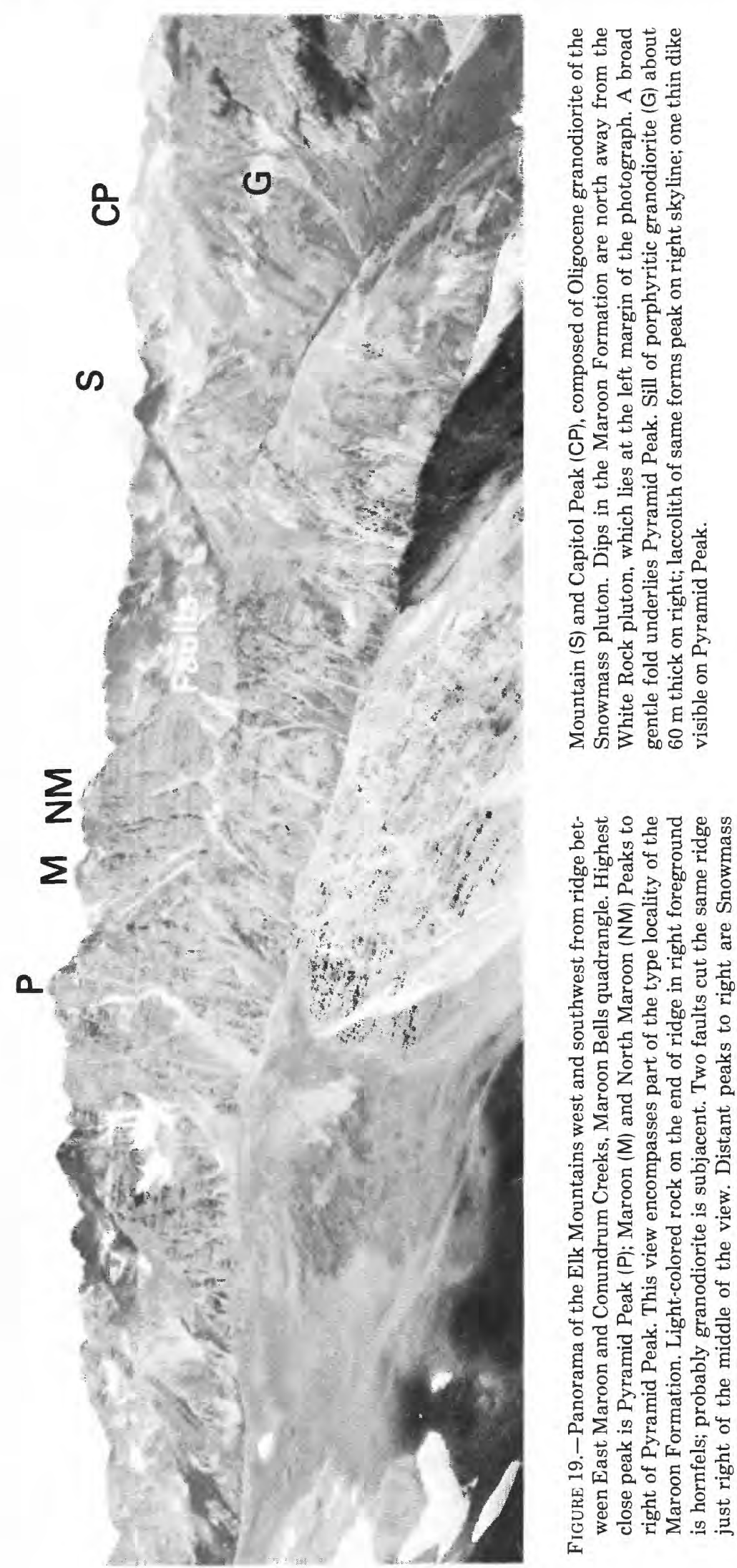


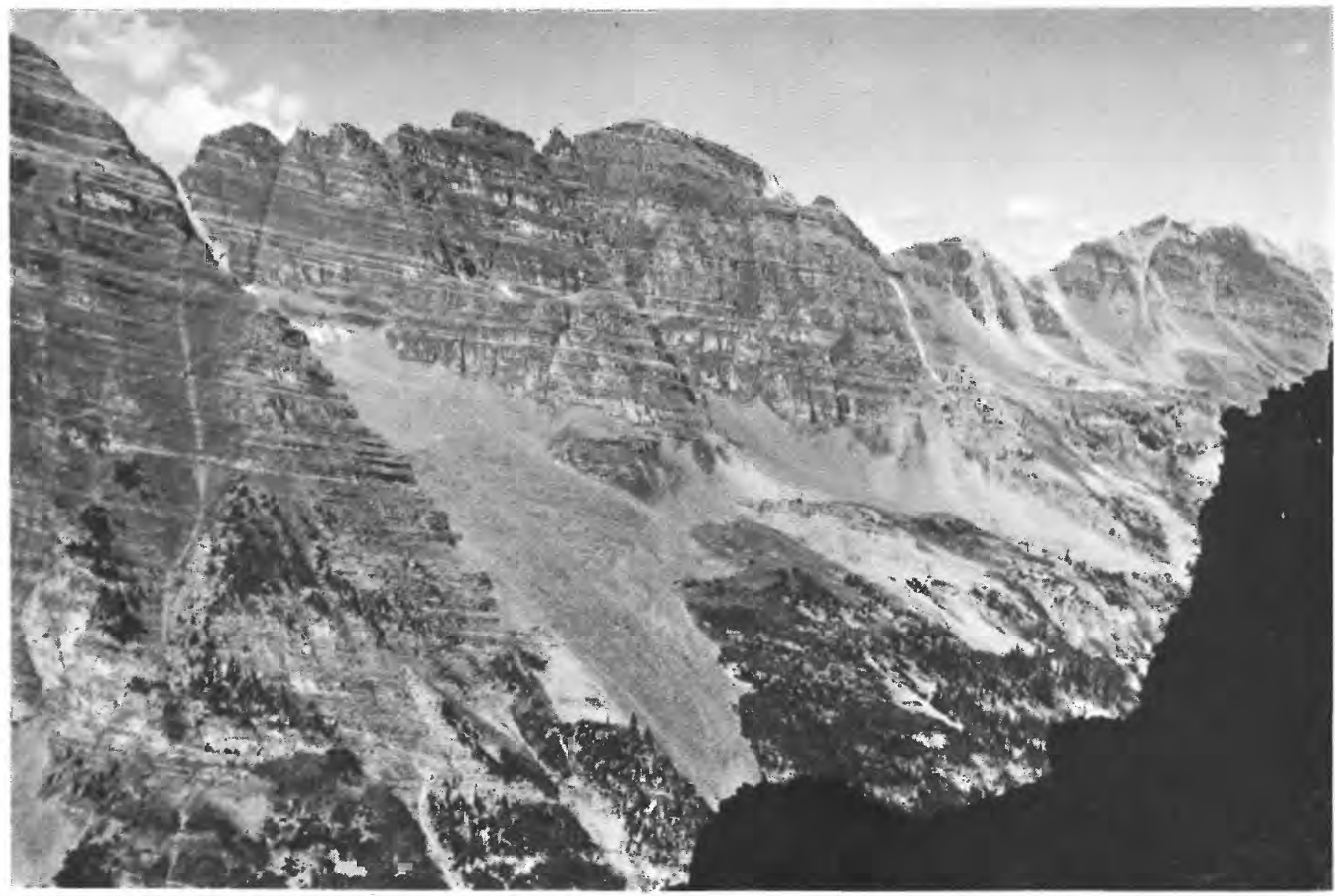

FIGURE 20.-Maroon Formation on the northeast ridge of North Maroon Peak and the ridge north of the peak. Looking west from $3,780 \mathrm{~m}$ altitude on the west side of the north ridge of Pyramid Peak, Maroon Bells quadrangle. Light-colored beds are coarsegrained sandstones and conglomerates lacking fine-grained red matrix. Rocks in the lower part of the valley, especially to the right, are metamorphosed adjacent to a small intrusive in Minnehaha Gulch, which lies off this photo to the right. Thin dike of hornblende porphyry cuts ridge at left. Thicker dikes of porphyritic granodiorite cut main ridge at notch on left and numerous places on ridge crest at far right. They are part of a swarm extending to the Snowmass pluton (Mutschler, 1970). Small laccolith on ridge crest at far right. Rock glacier in left center was one on which movement rate was measured (Bryant, $1971 \mathrm{~b})$. About $4 \mathrm{~km}$ of ridge is in view. deposited southwest of the present exposures of the conglomerate. Other limestones, which are gray, may also, at least in part, have been derived from Pennsylvanian rocks. Langenheim (1952) reported Des Moinesian fossils from limestone pebbles in the Maroon south of the Aspen area. According to Langenheim (1952) and Bartleson (1972), limestone pebbles are also numerous and widespread in conglomerates of the Gothic Formation south of the Aspen area.

The change from conglomerates containing a substantial proportion of limestone pebbles to those containing much fewer or no limestone pebbles occurs in the middle of the formation in the calculated interval of stratigraphic section 2. However, on the west end of Red Mountain and along Woody Creek in the Ruedi gradrangle, some pebble beds in the upper part of the Maroon contain limestone and dolomite pebbles. This suggests that locally during the deposition of the Maroon the Uncompahgre highland changed shape so that at least Pennsylvanian and perhaps lower Paleozoic sediments were eroded from a newly uplifted part of the highland rather late during deposition of the Maroon Formation.

Basement rock types in the Maroon conglomerates are mainly quartz-feldspar gneiss, granitic rocks, and fine-grained metamorphic rocks. Micaceous schist and gneiss and amphibolite are rare. The fine-grained metamorphic rocks are in part felsic volcanics with well-preserved porphyritic textures resembling those 

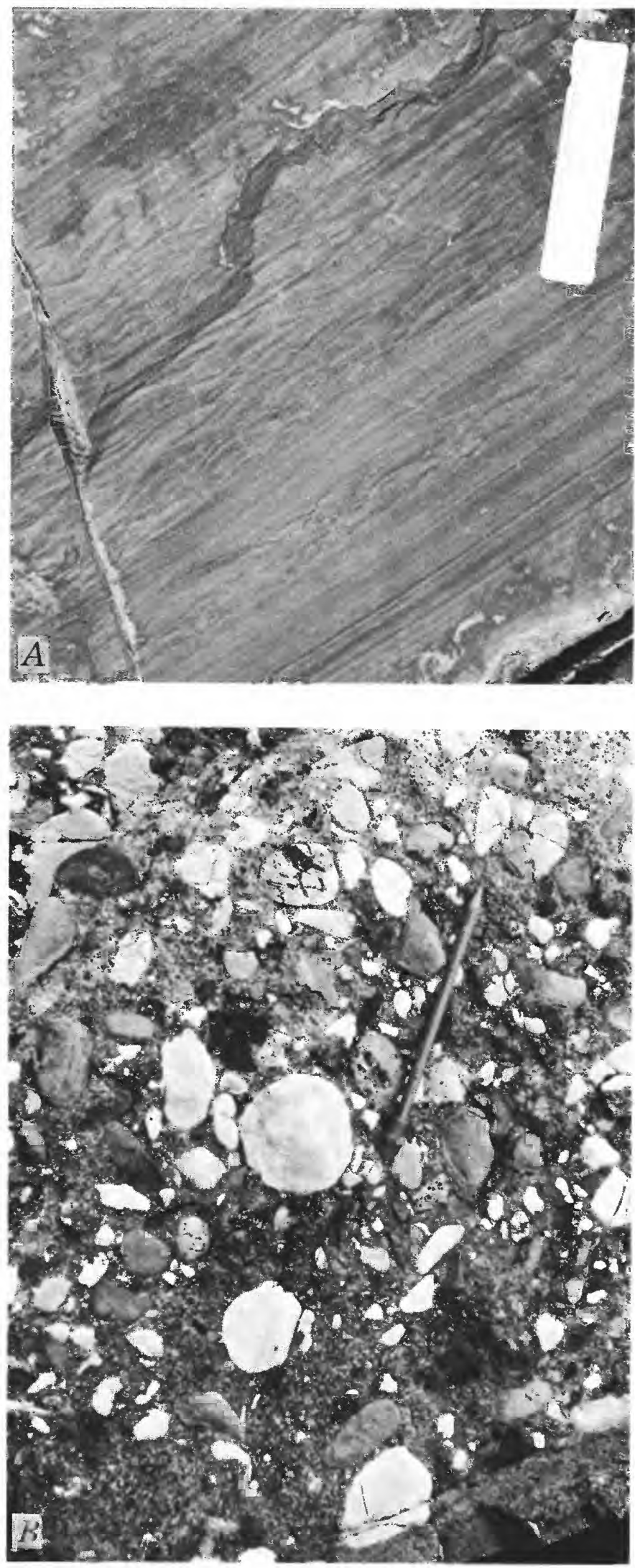
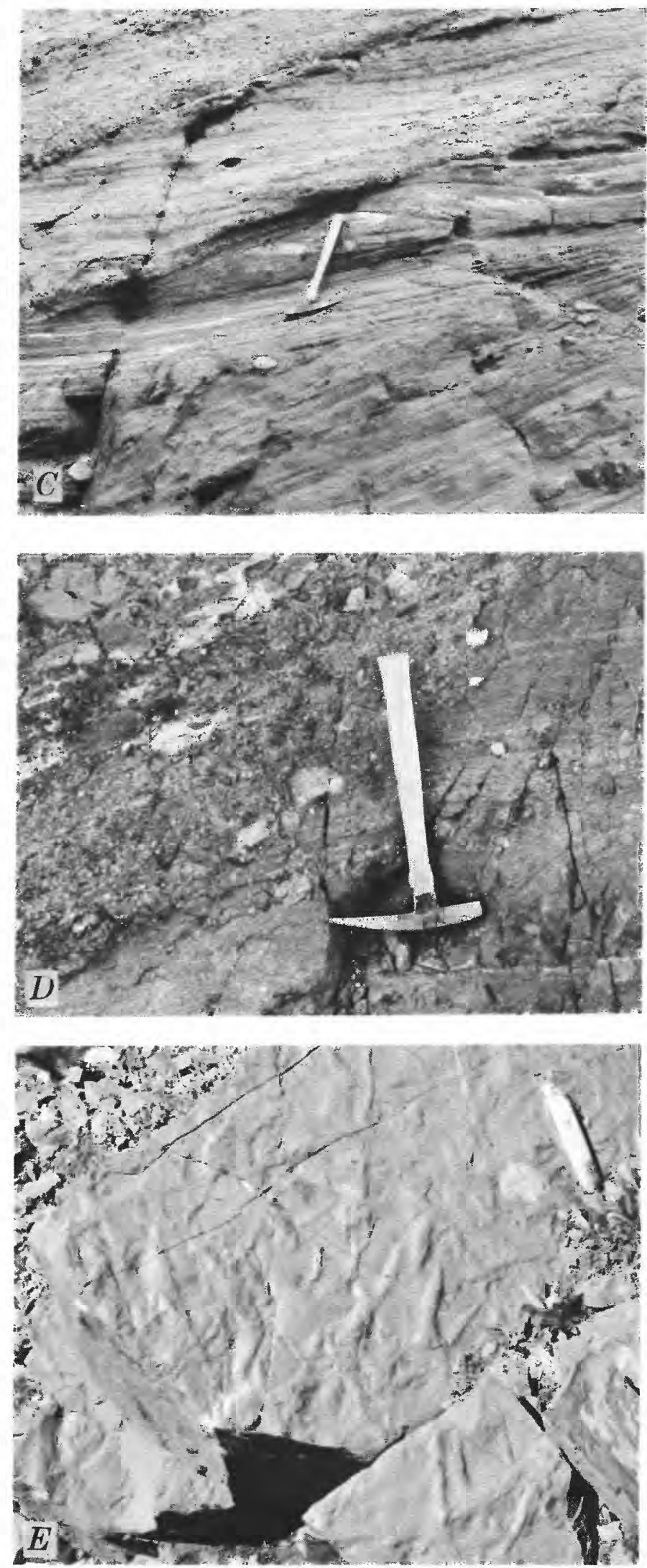
studied by J. C. Olson south of the Gunnison River (U.S. Geological Survey, 1971, p. A41). These rocks contain euhedral phenocrysts of albite and, locally, quartz in a very fine grained groundmass of quartz, feldspar, and, locally, biotite. Other similar-appearing rocks are fine-grained quartz-feldspar-biotite rocks that could be blastomylonite, metamorphosed felsic volcanics, or siltstones. Some of the coarser grained gneisses, which have well-developed granoblastic textures, compositionally resemble the felsic volcanic rock and may be from some as yet unstudied area where those volcanics are more highly metamorphosed. Some of the pebbles might come from the quartzitic and granitic units mapped in the Black Canyon of the Gunnison area by Hansen (1971), units that trend northeast toward the Aspen area.

The conglomerates typically occur in channels with lenticular cross sections, have sharp basal contacts, and grade upward into sandstone, siltstone, and, locally, limestone (figs. $21 B, C, D$ ). The lenses are several centimeters to a meter or two thick; most are $30-60 \mathrm{~cm}$ thick. Some conglomerates form beds as much as $4.6 \mathrm{~m}$ thick and are traceable as much as $1.6 \mathrm{~km}$ in areas of good exposure. The conglomerates usually contain pebbles $2-5 \mathrm{~cm}$ long, but some contain cobbles as much as $25 \mathrm{~cm}$ long. The maximum number and thickness of conglomerate beds in the Aspen area is about in the line of the measured section. (See stratigraphic section 2, p. 131). Conglomerate beds are relatively rare in the more easterly outcrop areas of the Maroon Formation in the Hayden Peak and Aspen quadrangles.

Limestone beds are common in the lower part of the Maroon Formation, although they make up only a small proportion of the formation. (See stratigraphic section 2.) They are generally several centimeters to a

Figure 21 (facing page).-Features of the Maroon Formation. $A$ Small-scale crossbedding in thinly laminated fine-grained sandstone near base of Maroon at mouth of Hunter Creek valley, Aspen quadrangle. $B$, Conglomerate in lower part of Maroon south of the Elk Range thrust. Pebbles of white limestone, gray dolomite, and some Precambrian plutonic rock, in cirque south of Rustler Gulch, Maroon Bells quadrangle. C, Crossbedded sandstone and conglomerate in the upper part of the Maroon on the east side of upper East Snowmass Creek at 3,719 m altitude, Highland Peak quadrangle. $D$, Conglomerate rich in pebbles of Precambrian metamorphic and plutonic rock in channel cutting thinly laminated pebbly sandstone, upper part of the Maroon, southwest corner of the Highland Peak quadrangle. $E$, Casts of worm burrows(?) in thinly laminated micaceous sandstone with muddy partings. Upper part of Maroon, north ridge of Highland Peak, southwest corner of Aspen quadrangle. meter thick and medium light gray to medium dark gray. Three meters is about the maximum thickness. Many of the limestones are silty or muddy and grade downward into siltstone, sandstone, and a basal conglomerate and have sharp contact with overlying sandstone or conglomerate. The limestone beds are commonly lenticular. A few thin beds of white limestone occur in the lower part of the Maroon in the southern part of the area. They are especially noticeable on the southwest side of the head of Conundrum Creek. Several beds of stromatolitic limestone several centimeters to $0.3 \mathrm{~m}$ thick occur in the lower Maroon a hundred meters or so stratigraphically above the concordant contact of the White Rock pluton on the ridge east of Electric Pass (Hayden Peak quadrangle).

Dolomite is rare in the Maroon, but on the East Maroon-Conundrum ridge near the south margin of the Maroon Bells quadrangle, a few beds of light-tanweathering dolomite are traceable for about $1.6 \mathrm{~km}$.

In thin section the limestones are micrites. Some have patches of sparry calcite, some of which have a shape suggesting that they could be repaced fossil fragments. Another variety consists of micrite intraclasts cemented by sparry calcite. Terrigenous constituents are almost always present, and all gradations to siltstone occur.

Beds of anhydrite and gypsum occur in the lower part of the Maroon Formation in the Hayden Peak quadrangle. One bed is just a few hundred meters above the Gothic Formation on the two shoulders just below 3,352 m altitude north of Sawyer Creek. The bed is about $6 \mathrm{~m}$ thick and can be traced about $450 \mathrm{~m}$ along strike to the south, where surficial deposits cover it. On the second shoulder south of Sawyer Creek spectacular solution cavities occur in that bed. The anyhydrite and gypsum are associated with thinbedded silty and micaceous gray limestone.

Near Hayden Peak as many as three beds of evaporite crop out, if one assumes no significant faulting. If the three occurrences represent the same stratigraphic horizon, two faults not shown on the geologic quadrangle map are necessary. The abundance of talus, the fractured character of the rock, and the presence of intrusive material make it difficult to be sure whether or not faults are present. Evaporites north and west of Hayden Peak form a bed 7-9 m thick adjacent to the White Rock pluton (fig. 22A). The bed has an irregular contact with underlying hornfels (fig. $22 B$ ). No effects of contact metamorphism are visible in the anhydrite except recrystallization and coarsening of grain size compared with similar rock in areas lacking metamorphism. This bed continues for at least $900 \mathrm{~m}$ south of where it crosses the ridge crest. A 

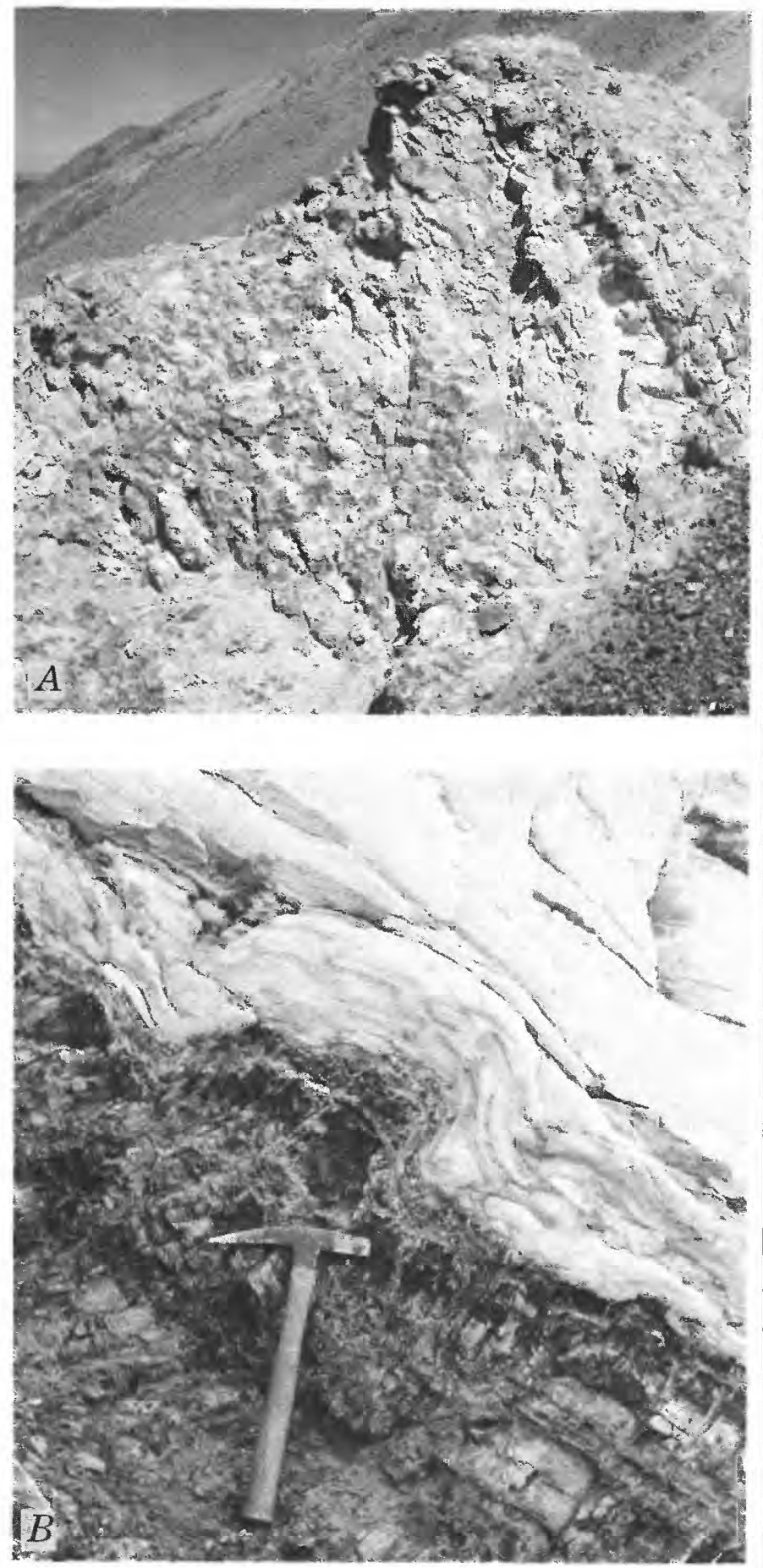

Figure 22.-Evaporite in the lower part of the Maroon Formation near Hayden Peak. $A$, Outcrop of at least $12 \mathrm{~m}$ of gypsum and anhydrite at about $3,600 \mathrm{~m}$ altitude northwest of hill 13232 on ridge north of Hayden Peak. Granodiorite of the White Rock pluton forms slope in background. $B$, Closeup of contact between evaporite (white) and hornfels (dark gray) at 4,020 m altitude northwest of Hayden Peak. Thin-section study shows that the hornfels has the usual composition, and no evidence exists for any exchange of material between siltstone and adjacent evaporite during thermal metamorphism. $60-\mathrm{cm}$ bed at about $3,900 \mathrm{~m}$ altitude on the south side of the ridge east of Hayden Peak may be correlative.

At the lower contact of the White Rock pluton west of hill 13316 on the ridge north of Hayden Peak is a 12-m-thick bed of evaporite. This bed seems to be on strike with an outcrop of breccia at the contact about $610 \mathrm{~m}$ to the south.

The third evaporite occurrence in the hornfels near Hayden Peak is on the northwest side of the 4,156-m peak north of Electric Pass.

On the west side of Conundrum Creek valley north of Hunter Peak is a bed of breccia in metamorphosed Maroon Formation that might represent an evaporitic horizon. The bed extends about $2.4 \mathrm{~km}$ along the valley side; it is less resistant than the surrounding rocks and forms shoulders or saddles where it crosses ridges between cirques. The incompetent horizon consists of thin-bedded calcareous siltstone, shale, limestone, and calcareous sandstone. The breccia is composed of fragments of those rocks in a calcareous matrix. In the southern exposures of this bed some calc-silicate minerals occur in the matrix, which suggests that brecciation took place before intrusion of the White Rock pluton. The whole soft zone is as much as $46 \mathrm{~m}$ thick, but the breccia is only $15 \mathrm{~m}$ thick at the most. If this zone is equivalent to one of the lower evaporite horizons across the valley to the east, some Gothic Formation not shown on the geologic quadrangle map may exist between it and the thrust fault near the bottom of the valley.

At the top of the Maroon Formation in the Aspen region is a unit of siltstone that was not mapped. This unit is well developed in the Woody Creek quadrangle (Freeman, 1971a) to the north, but to the south in the southern part of the Highland Peak quadrangle, it interfingers with sandstone. In the Highland Peak quadrangle and the western part of the Aspen quadrangle the upper $300-360 \mathrm{~m}$ of the Maroon Formation is composed of siltstone and fine-grained sandstone. On the ridge east of East Snowmass Creek at the farthest south outcrop of Morrison Formation, abou $60 \mathrm{~m}$ of siltstone are at the top of the Maroon. West of the Snowmass Creek fault zone in the Highland . zak quadrangle the siltstone is missing, owing to pre-Morrison faulting and erosion of the upthrown block.

The siltstone is typically thick bedded to massive, blocky weathering, and moderate red to grayish red. Locally, it is thin bedded and chippy weathering. Interbeds of fine-grained sandstone are widespread. Casts strongly suggesting worm burrows are a typical feature of the siltstone (fig. $21 E$ ).

Thin sections of typical siltstone show that it has 
angular to subangular quartz, plagioclase, and microcline grains averaging $<0.05-0.1 \mathrm{~mm}$ in diameter. Other minerals forming clastic grains are muscovite, carbonate, tourmaline, zircon, sphene, and opaque minerals. Carbonate cements the grains.

On Eagle Mountain in the western part of the Highland Peak quadrangle is a distinctive unit of lightgray, tan-weathering sandstone at least $200 \mathrm{~m}$ thick in fault contact with the uppermost part of the Maroon Formation. It resembles no other formation, so it has been assigned to the Maroon; and it probably is not far out of place stratigraphically, It contains rare interbeds of fine-grained grayish-red sandstone, and the nearby Maroon Formation contains a 4-8-m-thick bed of well-sorted fine-grained light-gray sandstone like that mapped. The sandstone unit is somewhat calcareous and micaceous in places. It is thick to thin bedded and has well-developed crossbedding. Some of it has thin internal laminae within the thicker crossbedded units.

The sandstone is composed almost entirely of subangular to subrounded quartz grains $0.1-0.3 \mathrm{~mm}$ in diameter (fig. 23). Other clastic grains include altered feldspar, chert, tourmaline, zircon, and opaque minerals. A small amount of carbonate cement and sericite or clay occurs between the quartz grains.

This unit resembles the sandstone of the Fryingpan River (Freeman, 1971a), which lies above the Maroon Formation and is believed to have been deposited in an eolian environment. This unit within the upper Maroon may represent deposition in a similar environment at a somewhat different time than the sandstone of the Fryingpan River.

In thin section the sandstones of the main part of the Maroon Formation range from well sorted to poorly sorted. The principal clastic constituents are angular to subangular grains of quartz, plagioclase, microcline, and in many places carbonate, and flakes of muscovite and biotite (fig. 27 $A$ ). Grain size ranges from $<0.05 \mathrm{~mm}$ to several millimeters. Fragments of chert, siltstone, and limestone occur. Coarser grained poorly sorted sandstones grade to conglomerates containing a large proportion of rock fragments. Common accessory minerals occurring as clastic grains are zircon, tourmaline, apatite, and opaque minerals. Less common ones are chlorite, sphene, rutile, and amphibole.

The plagioclase grains are altered to varying degrees, and most are now albite. Many of the alteration products appear to be clay minerals, but some are sericite.

The mica flakes are generally alined parallel with bedding. In many thin sections the biotite is partly to wholly replaced by opaque mineral, which is mostly hematite. This alteration is a common feature of these red beds (Walker, 1967; Bartleson, 1972) and is responsible for their color contrasts with the Gothic Formation (Bartleson, 1972).

Matrix is composed of carbonate, which is calcite in most of the rocks. It may contain some clay minerals. The proportion of matrix ranges from almost none in some sandstones to more than 50 percent. Siltstones have a large proportion of matrix, and through an increase in matrix they grade into micritic limestones.

Clastic mica makes up only a few percent of the rocks, but it is conspicuous in most samples. Muscovite is dominant, probably because much of the biotite is pseudomorphosed by an opaque mineral that appears to be hematite.

In polished sections of the analyzed samples of unmetamorphosed rocks of the Maroon Formation, hematite was the dominant opaque mineral. One section contained a small amount of magnetite, and one magnetite grain pseudomorphosed by hematite. A very small amount of magnetite or maghemite was detected in a few of the analyzed samples by passing a hand magnet over powdered samples of the rock. Leucoxene-coated opaque grains suggest that some titanium-rich opaque minerals may be present.

The rocks of the Maroon Formation range in composition from limestone to arkose, and all gradations between these rock types occur (fig. 23A). In general the siltstones have less feldspar and more carbonate than the sandstones. Field observations and study of representative samples in thin section show that the Maroon contains more arkose and fewer silty or sandy limestones than the Gothic Formation (figs. 18, 23A). Sandstones and siltstones of the Maroon are richer in plagioclase than potassic feldspar (fig. 23B). When compared with other sandstones, those of the Maroon Formation are much richer in carbonate. Huckenholz (1963) compiled the mineral composition of 295 sandstones and found that 95 percent contain less than 10 percent carbonate.

These compositional features are largely related to the source of the detritus composing the Maroon Formation. The abundance of limestone pebbles in the conglomerates of the lower Maroon indicates that both clastic limestone particles and $\mathrm{CaCO}_{3}$ in solution would be readily available for deposition in the Maroon rocks. The small number of basement-rock pebbles examined in thin section contained far more plagioclase than potassic feldspar. 'Thus, more plagioclase than potassic feldspar was available in the Precambrian terrane exposed to erosion in the Uncompahgre uplift.

Chemical analyses of the sandstones and siltstones of the Maroon Formation reflect the mineralogy and 


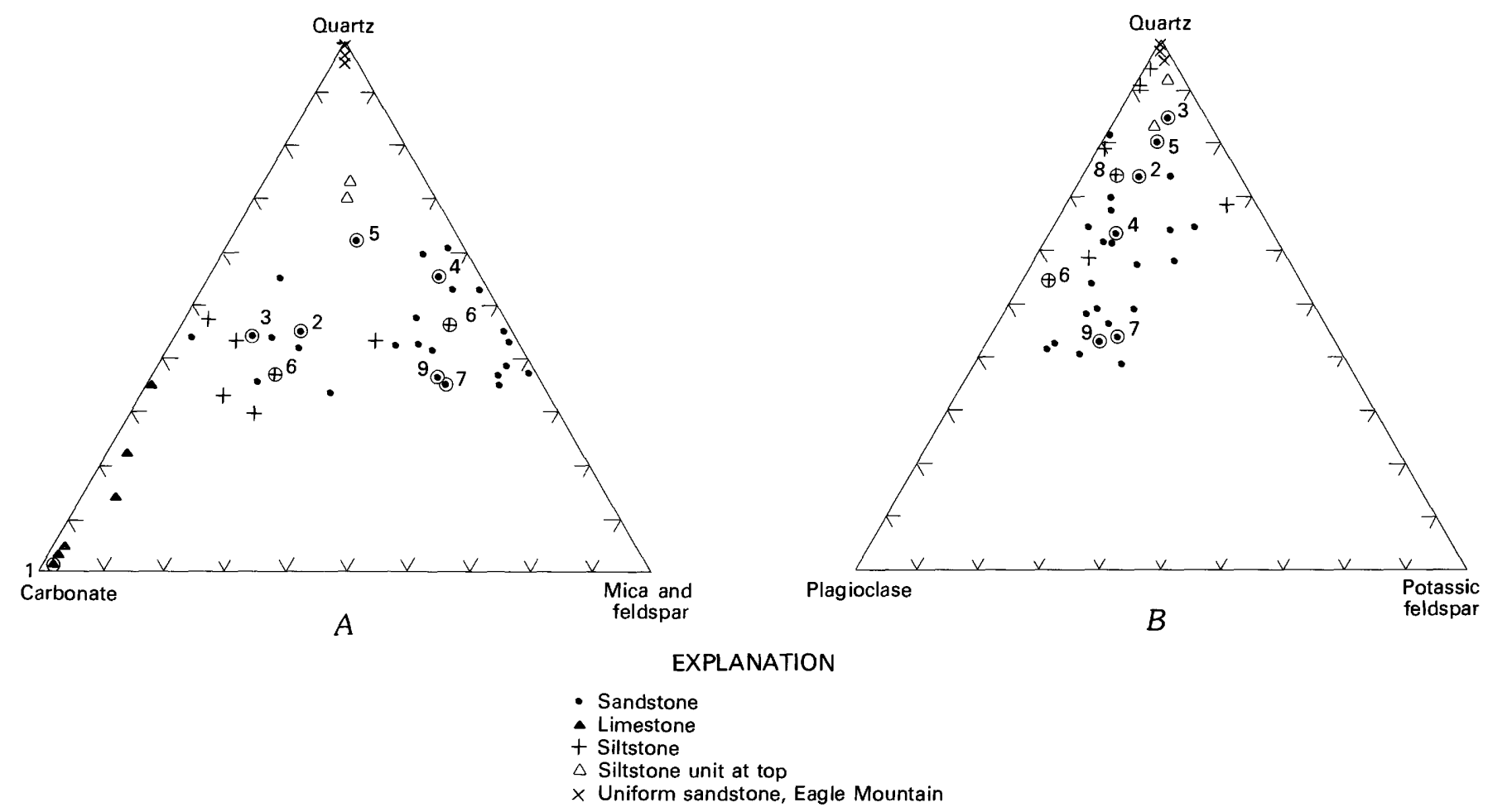

FIGURE 23.-Mineral composition of the Maroon Formation. Circled and numbered points are analyzed samples in table 2. $A$, Proportions of quartz, carbonate, mica, and feldspar in rocks of Maroon Formation. B. Proportions of quartz, plagioclase, and potassic feldspar in rocks of the Maroon Formation.

show that the composition of the sandstones differs significantly from averages of arkoses (tables 3 , fig. 24). $\mathrm{K}_{2} \mathrm{O} / \mathrm{Na}_{2} \mathrm{O}$ ratios are generally less than those of average arkoses (fig. $24 A$ ). This is a reflection of the relatively high plagioclase contents, and it is probably related to the plagioclase-rich composition and relatively little chemical weathering of rocks in the source area. The $\mathrm{Al}_{2} \mathrm{O}_{3} / \mathrm{Na}_{2} \mathrm{O}+\mathrm{K}_{2} \mathrm{O}+\mathrm{CaO}$ ratios are generally much lower than most sandstones (fig. 24B). This is because of the high calcite contents, for $\mathrm{Al}_{2} \mathrm{O}_{3} / \mathrm{Na}_{2} \mathrm{O}+\mathrm{K}_{2} \mathrm{O}$ ratios are in the range of most sandstones (fig. 24C). The closeness of the analyses to the ideal muscovite line suggests that the rocks may contain some undetected clay minerals, because modal analyses suggest that feldspars dominate over mica. Raup (1966) found a variety of clay minerals in similar rocks derived from a different source area on the northeast side of the Eagle basin. A plot of $\mathrm{CO}_{2} / \mathrm{CaO}$ shows that most of the rocks fall very close to a line for ideal calcite (fig. 24D). This shows that most of the $\mathrm{CaO}$ is combined with $\mathrm{CO}_{2}$ in calcite rather than being derived from plagioclase or some other Ca-silicate mineral. The high $\mathrm{Fe}_{2} \mathrm{O}_{3} / \mathrm{FeO}$ ratios (table 3 ) are due to the predominance of hematite over other iron-bearing minerals in these rocks.
The age of the Maroon Formation is considered to be Middle and Late Pennsylvanian and Permian. South of the Aspen area the Maroon Formation conformably overlies the Gothic Formation, which has Des Moinesian fossils (Langenheim, 1952, 1954; Bartleson, 1972). No fossils with well-defined time connotations have been found in the Maroon Formation in the Aspen area or elsewhere on the southwest side of the Eagle basin. The top of the Maroon Formation at Glenwood Springs is defined as the base of the tongue of Weber Sandstone (Brill, 1952). The age of the Weber in Colorado is unknown, but Pennsylvanian and Permian fossils have been found in it in northeast Utah east of the Yellowstone River (Hallgarth, 1967, p. 183). Since the tongue of the Weber Sandstone at Glenwood Springs is only $30 \mathrm{~m}$ below the South Canyon Creek Member of the State Bridge Formation, which has a fauna considered to be of Guadalupian age (Bass and Northrop, 1950), the Weber tongue is probably Permian, and thus some undetermined thickness of the Maroon is Permian. Freeman (1971a) extended these stratigraphic relations to Woody Creek just north of the Aspen area, where a limestone correlated with the South Canyon Creek Member is $18-60 \mathrm{~m}$ above the base of the State Bridge. This limestone pinches out 16 


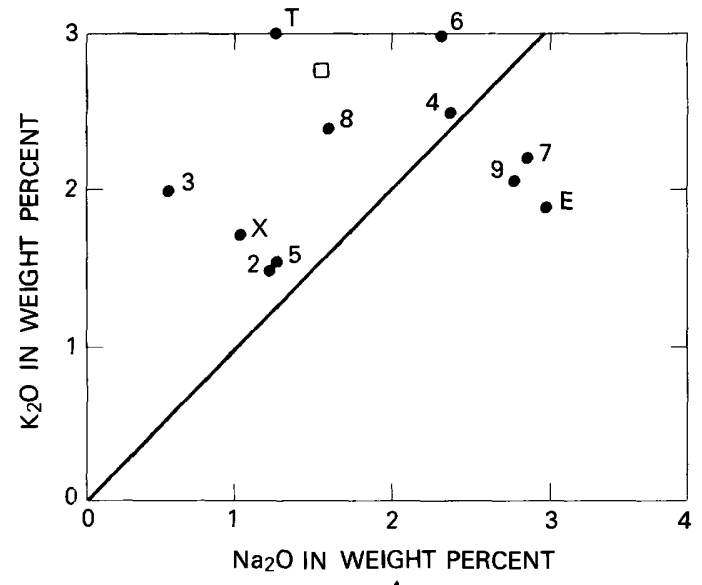

A

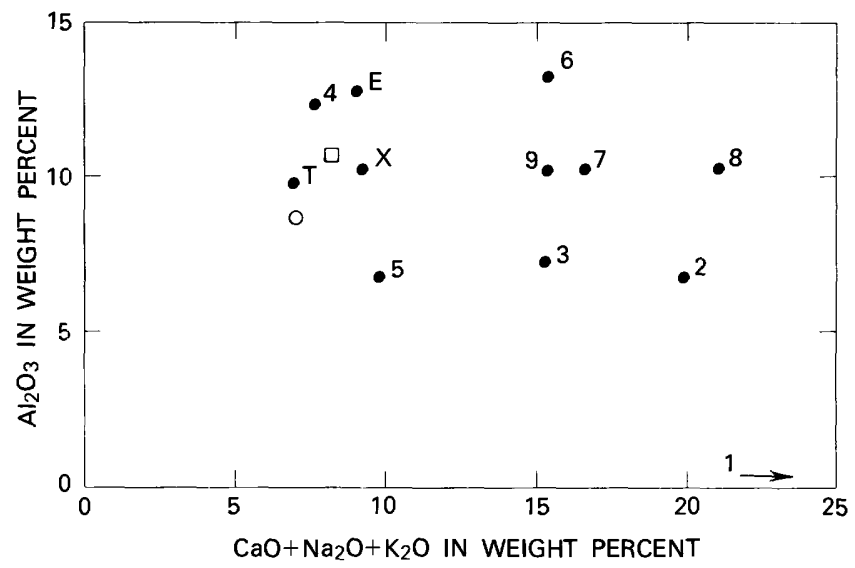

$B$

FIGURE 24.--Chemical diagrams of analyzed rocks from the Maroon Forniation. Numbers of points refer to numbers of analyzed samples, table 3. Averages of $T$, taphrogeosynclinal, $X$, exogeosynclinal, and $E$, eugeosynclinal sandstones (Middleton, 1960). Square, niean coniposition of arkose (Pettijohn, 1963);

$\mathrm{km}$ northwest of the Aspen area. Locally, in the Woody Creek quadrangle an angular unconformity separates the State Bridge Formation from the Maroon Formation (Freeman, 1971a, 1972a); in those localities the top of the Maroon may be older than elsewhere and may be only of Pennsylvanian age. In the Aspen area the unconformity between the State Bridge and the Maroon is not obvious; there, the upper part of the Maroon Formation may be of Permian age. However, Hallgarth (1967, p. 179) assumed that the Maroon was Pennsylvanian age. Consequently, thickness compilations (McKee and others, 1967) show very little Permian rock in the Aspen area.

Plant fragments are fairly widespread in the Maroon

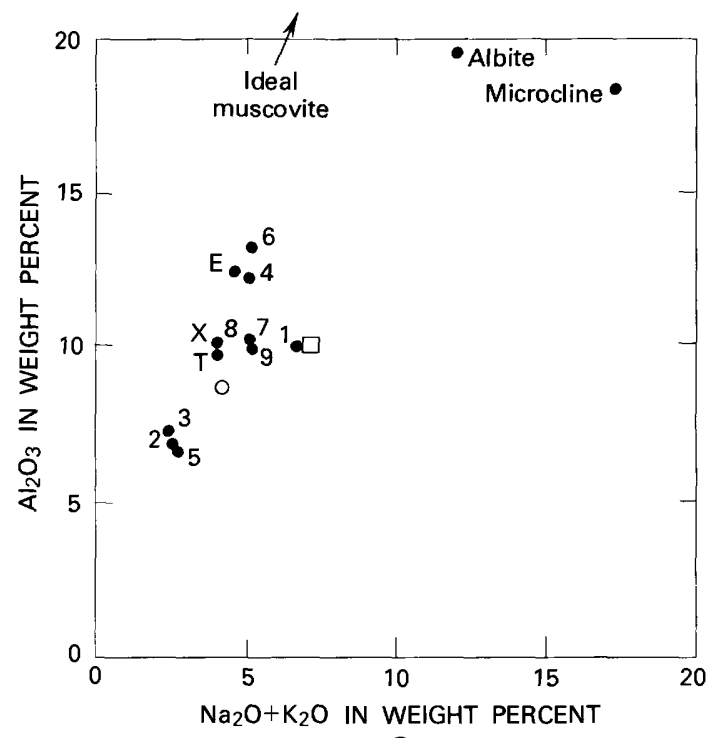

C

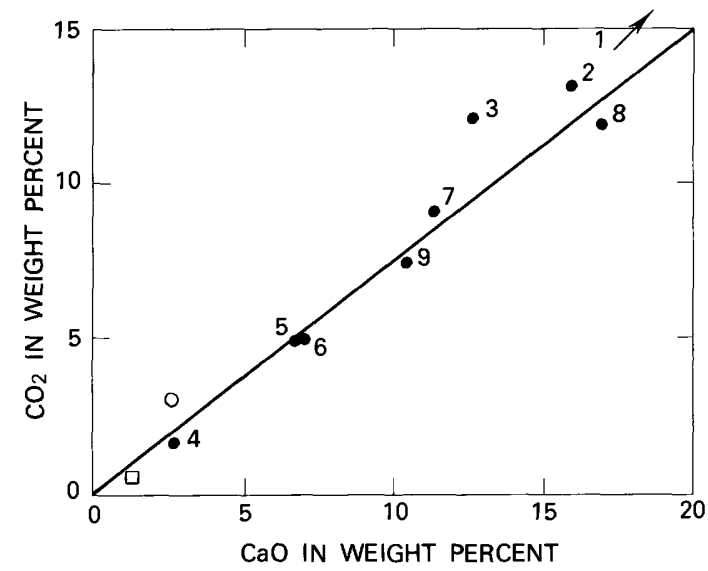

$D$

circle, average of five typical arkoses (Pettijohn, 1957). $A$, $\mathrm{K}_{2} \mathrm{O} / \mathrm{Na}_{2} \mathrm{O}$ diagram. Line represents ratio of 1.0 . $B$, $\mathrm{Al}_{2} \mathrm{O}_{3} / \mathrm{CaO}+\mathrm{Na}_{2} \mathrm{O}+\mathrm{K}_{2} \mathrm{O}$ diagranl; $C, \mathrm{Al}_{2} \mathrm{O}_{3} / \mathrm{Na}_{2} \mathrm{O}+\mathrm{K}_{2} \mathrm{O}$ diagram; $D, \mathrm{CO}_{2} / \mathrm{CaO}$ diagram. Line represents proportions of $\mathrm{CaO}$ and $\mathrm{CO}_{2}$ in ideal calcite.

Formation in the Aspen area, but fossils well enough preserved for generic identification were not found.

West and north of the Aspen area a few of the limestone beds in the lower part of the Maroon contain fossils indicating a marine origin (Langenheim, 1954; Mutschler, 1970; Freeman, 1971a).

The Maroon is so thick and dips so gently in many areas that it is difficult to obtain accurate information on thicknesses. In the Aspen area the measured and calculated section is $3.2 \mathrm{~km}$ thick. Initial dip of rocks of the Maroon Formation is not an important factor contributing to errors in thickness calculation here. Siltstones have dips similar to coarse sandstones and conglomerates (but not to crossbeds), and the dip of 
TABLE 3.-Chemical analysis and modes of the Maroon Formation and hornfels

[Major oxides determined by rapid methods by P. L. D. Elmore, G. W. Chloe, Hezekiah Smith, James Kelsey, J. L. Glenn, Samuel Botts, and Lowell Artis, U.S. Geological Survey, 1967. Minor elements determined by semiquantitative spectrographic methods by Joseph L, Harris, U.S. Geological Survey, 1967, and J. C. Hamilton, U.S. Geological Survey, 1971, Mode by point count: P, present but not intersected in counting. Major oxides and CIPW norms in weight percent; mode in volume percent, Minor elenents are reported in parts per million to the nearest number in the series $100,70,50,30,20,15$, and $10, \ldots$, which represent approximate midpoints of interval data on a geometric scale. The assigned interval for semiquantitative results will include the quantitative value about 30 percent of the time. $\mathrm{N}$, not detected; leaders (--) indicate not determined. In modes, leaders (--) indicate absent. Looked for but not found: Ag, As, $\mathrm{Au}, \mathrm{Cd}, \mathrm{Ge}, \mathrm{Hf}, \mathrm{Hg}, \mathrm{In}, \mathrm{Li}, \mathrm{Pd}, \mathrm{Pt}, \mathrm{Re}, \mathrm{Sb}, \mathrm{Sn}, \mathrm{Ta}, \mathrm{Te}, \mathrm{Tl}, \mathrm{U}, \mathrm{W}, \mathrm{Zn}]$

\begin{tabular}{|c|c|c|c|c|c|c|c|c|c|c|c|c|c|}
\hline \multirow[b]{2}{*}{ Sample No.--------- } & \multicolumn{5}{|c|}{ Stratigraphic section 2} & \multicolumn{8}{|c|}{ Traverse from red beds to hornfels, Conundrum Basin } \\
\hline & 1 & 2 & 3 & 4 & 5 & 6 & 7 & 8 & 9 & 10 & 11 & 12 & 13 \\
\hline Lab. No,----_-_--- & W168739 & W168736 & W168737 & W168740 & W168739 & W169329 & W169328 & W169331 & W169330 & W169333 & W169332 & W169335 & W169334 \\
\hline Field No,-- & ME642 & ME 1978 & ME 1198 & MB 1042 & MA440 & $1704 b$ & $1704 a$ & $1705 \mathrm{~b}$ & $1705 a$ & $1706 \mathrm{~b}$ & $1706 a$ & $1707 \mathrm{~b}$ & $1707 \mathrm{a}$ \\
\hline \multicolumn{14}{|c|}{ Major oxides } \\
\hline $\mathrm{SiO}_{2}-\cdots$ & 2.6 & 54.7 & 58.9 & 70.1 & 72.7 & 53.7 & 56.0 & 46.0 & 59.1 & 61.7 & 66.4 & 57.7 & 64,1 \\
\hline $\mathrm{Al}_{2} \mathrm{O}_{3}-$ & .51 & 6.7 & 7.2 & 12.2 & 6.7 & 13.2 & 10.2 & 10.2 & 10.0 & 12.3 & 8.7 & 9.9 & 6.7 \\
\hline $\mathrm{Fe}_{2} \mathrm{O}_{3}$ & .10 & 2.2 & 1.0 & 3.9 & 1.6 & 5.5 & 2.8 & 3.9 & 3.4 & 2,9 & 1.9 & .59 & 2,3 \\
\hline 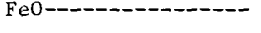 & .08 & .40 & 1.0 & .16 & .18 & 1.2 & .64 & 1.0 & .56 & 2.6 & .96 & 3.1 & 1.6 \\
\hline 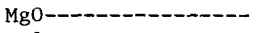 & .75 & 2.5 & 2,1 & 1.5 & 1.0 & 5.6 & 2.4 & 4.2 & 2.1 & 3.6 & 1.6 & 7.2 & 1.2 \\
\hline 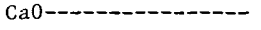 & 52.0 & 15.8 & 12.6 & 2.7 & 7.1 & 7.2 & 11.3 & 16.6 & 10.2 & 6.2 & 9.4 & 13.2 & 13.3 \\
\hline $\mathrm{Na}_{2} \mathrm{O}-\cdots-1$ & .00 & 1.2 & .56 & 2.4 & 1.2 & 2.3 & 2.9 & 1.6 & 2.8 & 1.7 & 2.3 & 3.2 & 2.9 \\
\hline $\mathrm{K}_{2} \mathrm{O}-\cdots$ & .32 & 1.5 & 2.0 & 2.5 & 1.5 & 3.0 & 2.2 & 2.4 & 2.1 & 5.6 & 2.6 & 2.9 & 1.2 \\
\hline $\mathrm{H}_{2} \mathrm{O}_{+}^{-}--$ & .14 & .29 & .40 & .54 & .48 & .21 & .07 & .02 & .26 & .18 & .05 & .16 & .02 \\
\hline $\mathrm{H}_{2} \mathrm{O}^{+}-\cdots$ & .25 & .71 & 1.5 & 1.3 & 1.3 & 2.0 & 1.1 & 1.0 & 1.1 & .92 & .80 & .39 & .43 \\
\hline $\mathrm{TiO}_{2}-\cdots$ & .04 & .39 & .29 & .60 & .54 & .81 & .53 & .62 & .60 & .71 & .44 & .95 & .12 \\
\hline $\mathrm{P}_{2} \mathrm{O}_{5}$ & .00 & .16 & .00 & .00 & .00 & .21 & .15 & .17 & .11 & .12 & .15 & .37 & .04 \\
\hline 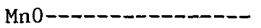 & .10 & .12 & .02 & .02 & .03 & .08 & .08 & .12 & .08 & .09 & .08 & .09 & .07 \\
\hline $\mathrm{CO}_{2}---------$ & 43.1 & 13.4 & 12.2 & 1.6 & 5.0 & 5.0 & 9.2 & 12.0 & 7.5 & 1.0 & 4.6 & .19 & 6.0 \\
\hline Bulk density-- & 2.3 & 2.66 & 2.66 & 2.54 & 2.65 & 2.63 & 2.60 & -- & 2.67 & 2.72 & 2.68 & 2.88 & 2.69 \\
\hline Powder density----- & 2.70 & 2.70 & 2.70 & 2.70 & 2.68 & 2.78 & 2.75 & 2.75 & 2.70 & 2.75 & 2.75 & 2.98 & 2.75 \\
\hline \multicolumn{14}{|c|}{ Minor elements } \\
\hline 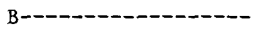 & $\mathrm{N}$ & $\mathrm{N}$ & $\mathrm{N}$ & $\mathrm{N}$ & 30 & $\mathrm{~N}$ & $\mathrm{~N}$ & $\mathrm{~N}$ & $\mathrm{~N}$ & $\mathrm{~N}$ & $\mathrm{~N}$ & $\mathrm{~N}$ & $\mathrm{~N}$ \\
\hline 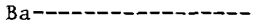 & 70 & 200 & 200 & 300 & 100 & 500 & 500 & 300 & 70 & 1,500 & 500 & 500 & 150 \\
\hline 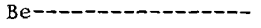 & $\mathrm{N}$ & $\mathrm{N}$ & $\mathrm{N}$ & $\mathrm{N}$ & $<1$ & 1.5 & 1 & 1 & 1 & 1.5 & 1 & 1 & $\mathrm{~N}$ \\
\hline 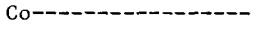 & $\mathrm{N}$ & $\mathrm{N}$ & $\mathrm{N}$ & 7 & $\mathrm{~N}$ & 20 & 7 & 10 & 7 & 1.5 & 7 & 15 & $\mathrm{~N}$ \\
\hline 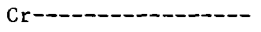 & $\mathrm{N}$ & 20 & 15 & 50 & 3 & 70 & 100 & 50 & 50 & 70 & 50 & 100 & 15 \\
\hline 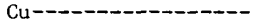 & 70 & 5 & 1.5 & 7 & 15 & 3 & 3 & 3 & 3 & 50 & 3 & 3 & 7 \\
\hline 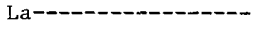 & $\mathrm{N}$ & $\mathrm{N}$ & $\mathrm{N}$ & $\mathrm{N}$ & $\mathrm{N}$ & 150 & $\mathrm{~N}$ & 70 & $\mathrm{~N}$ & 50 & $\mathrm{~N}$ & $\mathrm{~N}$ & 70 \\
\hline 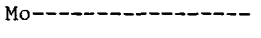 & N & 3 & $\mathrm{~N}$ & $\mathrm{~N}$ & $\mathrm{~N}$ & 5 & $\mathrm{~N}$ & $\mathrm{~N}$ & $\mathrm{~N}$ & $\mathrm{~N}$ & $\mathrm{~N}$ & 5 & $\mathrm{~N}$ \\
\hline 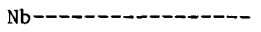 & $\mathrm{N}$ & $\mathrm{N}$ & $\mathrm{N}$ & 10 & 10 & $\mathrm{~N}$ & $\mathrm{~N}$ & $\mathrm{~N}$ & $\mathrm{~N}$ & $\mathrm{~L}$ & $\mathrm{~N}$ & $\mathrm{~N}$ & $\mathrm{~N}$ \\
\hline $\mathrm{Ni}$ & $\mathrm{N}$ & $<30$ & $\mathrm{~N}$ & 30 & $<30$ & 50 & $<30$ & $<30$ & $<30$ & 50 & $<30$ & 50 & $<30$ \\
\hline 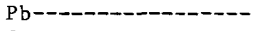 & N & $\mathrm{N}$ & $\mathrm{N}$ & 5 & 3 & $\mathrm{~N}$ & $\mathrm{~N}$ & $\mathrm{~N}$ & $\mathrm{~N}$ & 10 & $\mathrm{~N}$ & $\mathrm{~N}$ & $\mathrm{~N}$ \\
\hline Sc----_-- & $\mathrm{N}$ & 7 & 5 & 10 & 5 & 15 & 10 & 10 & 15 & 20 & 10 & 10 & 5 \\
\hline Sr---n-1- & 1,500 & 100 & 70 & 70 & 70 & 150 & 150 & 200 & 150 & 300 & 15 & 150 & 70 \\
\hline 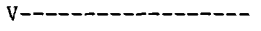 & 20 & 30 & 20 & 50 & 30 & 70 & 70 & 50 & 70 & 100 & 70 & 70 & 20 \\
\hline 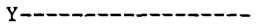 & $\mathrm{N}$ & 30 & 20 & 30 & 30 & 50 & 30 & 50 & 50 & 30 & 30 & 70 & 20 \\
\hline 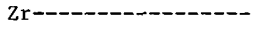 & $\mathrm{N}$ & 300 & 50 & 500 & 500 & 500 & 300 & 200 & 500 & 150 & 700 & 1,000 & 50 \\
\hline 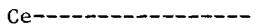 & $\mathrm{N}$ & $\mathrm{N}$ & $\mathrm{N}$ & $\mathrm{N}$ & $\mathrm{N}$ & 500 & 100 & 100 & $\mathrm{~N}$ & $\mathrm{~N}$ & $\mathrm{~N}$ & 100 & $\mathrm{~N}$ \\
\hline 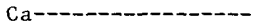 & $\mathrm{N}$ & 5 & 7 & 10 & 5 & 15 & 10 & 10 & 10 & 30 & 10 & 15 & 10 \\
\hline 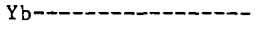 & $\mathrm{N}$ & 2 & 1 & 3 & 3 & 5 & 3 & 5 & 5 & 3 & 3 & 7 & 2 \\
\hline 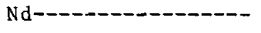 & --- & -- & -- & --- & -- & $\mathrm{N}$ & $\mathrm{N}$ & $\mathrm{N}$ & -- & 70 & --- & $\mathrm{N}$ & $\mathrm{N}$ \\
\hline \multicolumn{14}{|c|}{ Modes } \\
\hline 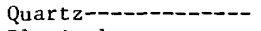 & 0.1 & 45.0 & 43.3 & 49.7 & 58.2 & 14.5 & 35.2 & 15.3 & 34.2 & 24.3 & 31.6 & 1.3 & 41.2 \\
\hline Plagioclase------- & -- & 8.6 & 4.7 & 21.7 & 7.6 & 11.1 & 28.3 & 4.4 & 31.2 & 4.9 & 2.0 & 16.6 & 13.0 \\
\hline Potassic feldspar-- & --- & 6.4 & 4.2 & 8.3 & 7.6 & 1.0 & 16.0 & 1.1 & 15.7 & 2.6 & 9.2 & -- & 18.0 \\
\hline Carbonate-- & 99.9 & 34.6 & 43.0 & 5.5 & 16.7 & 2.4 & 15.9 & 16.7 & 15.9 & 5.9 & 23.5 & .5 & 16.0 \\
\hline Mus covite--- & $\mathrm{P}$ & 1.7 & 3.6 & 1.7 & 1.7 & 1.0 & .7 & 2.4 & .1 & -- & -- & -- & -- \\
\hline Biotite-------- & --- & -- & -- & 1.6 & 2.4 & --- & -- & .3 & $\mathrm{P}$ & -- & -- & --- & -- \\
\hline Matrix---1-- & -- & -- & --- & -- & -- & 70.0 & --- & 24.9 & -- & $\rightarrow$ & -- & -- & -- \\
\hline 0paque------------ & $\mathbf{P}$ & 3.7 & 1.2 & 11.4 & 4.9 & --- & 3.8 & 34.9 & 2.9 & 5.5 & 3.0 & .1 & .1 \\
\hline Chlorite--------- & --- & $\mathrm{P}$ & -- & --- & .3 & -- & .1 & --- & --- & --- & --- & --- & -- \\
\hline Tourmaline--------- & $\cdots$ & $\mathrm{P}$ & $\mathrm{P}$ & $\mathrm{P}$ & $\mathrm{P}$ & --- & --- & --- & --- & -- & .3 & --- & -- \\
\hline Zircon--n-- & $\mathrm{P}$ & $\mathrm{P}$ & $\mathbf{P}$ & $\mathrm{P}$ & .6 & -- & $\mathrm{P}$ & -- & $\mathrm{P}$ & $\mathbf{P}$ & -- & -- & -- \\
\hline Epidote--------- & --- & -- & --- & .1 & --- & --- & --- & --- & -- & 1.5 & 3.7 & -- & .1 \\
\hline Apatite---_------ & --- & --- & .1 & --- & $\mathrm{P}$ & --- & --- & --- & $\mathrm{P}$ & $\mathbf{P}$ & .3 & $P$ & $\mathrm{P}$ \\
\hline Amphibole------n-- & --- & --- & --- & --- & -- & -- & --- & --- & --- & 55.3 & 4.8 & -- & -- \\
\hline Pyroxene---_-_-_-- & --- & --- & $-\infty$ & -- & --- & --- & --- & --- & -- & -- & -- & 80.0 & 6.3 \\
\hline Scapolite--------- & --- & --- & --- & -- & -- & --- & --- & -- & --- & --- & 21.6 & -- & --- \\
\hline Sphene------------- & -- & --- & -- & -- & --- & --- & -- & -- & -- & -- & $\mathrm{P}$ & 1.5 & --- \\
\hline Garnet------ & --- & -- & -- & -- & 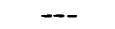 & $-\infty$ & -- & --- & -- & -- & $-\infty$ & -- & 5.3 \\
\hline Points counted---- & 773 & 705 & 641 & 691 & 636 & 525 & 738 & 615 & 744 & 547 & 709 & 617 & 725 \\
\hline
\end{tabular}


SAMPLE DESCRIPTIONS

1. Medium-light-gray limestone. Carbonate with a grain size of $0.002 \mathrm{~mm}$ except a few lenses with $0.3-\mathrm{mm}$ grain size. A few scattered clastic grains of quartz $0.1 \mathrm{~mm}$ in diameter, and a few of muscovite. From $30-\mathrm{cm}$ bed $123 \mathrm{~m}$ above the base of the Maroon in measured section (interval 38, Stratigraphic Section 2). About 3,536 m altitude in gully north of Rustler Gulch in Snowmass Mountain quadrangle, about $90 \mathrm{~m}$ west of Maroon Bells quadrangle boundary.

2. Grayish-red sandstone. Clastic grains of quartz, plagioclase, microcline, carbonate, and muscovite averaging 0.2-0.3 mm, and as large as $0.5 \mathrm{~mm}$, cemented by calcite. About $518 \mathrm{~m}$ above base of Maroon Formation (interval 121, Stratigraphic Section 2). From ridge between Rustler Gulch and east fork of Rock Creek very close to quandrangle boundary, southwest corner of Maroon Bells quadrangle.

3. Pale-red sandstone. Clastic grains of quartz, plagioclase, and muscovite with a grain size of $0.5-0.2$ mm cemented by calcite. About $274 \mathrm{~m}$ above base of Maroon Formation (interval 75, Stratigraphic Section 2). From about $3,688 \mathrm{~m}$ altitude in gully north of Rustler Gulch about $100 \mathrm{~m}$ west of Maroon Bells quadrangle boundary in the Snowmass Mountain quadrangle.

4. Moderate-red arkose. Clastic grains of quartz, plagioclase, microcline, muscovite, and biotite average $0.1-0.4$ mm in diameter but reach $0.6 \mathrm{~mm}$, occurring $784 \mathrm{~m}$ below the top of the Maroon Formation (interval 257, Stratigraphic Section 2). From the boundary between the Maroon Bells and Highland Peak quadrangles about $900 \mathrm{~m}$ from their west corners.

5. Moderate-red sandy siltstone. Angular clastic grains of quartz, plagioclase, microcline, muscovite, and biotite, 0.5-0.1 mm in diameter cemented by calcite, $254 \mathrm{~m}$ below the top of the Maroon Formation (interval 286, Stratigraphic Section 2). About 3,737 $\mathrm{m}$ altitude in gully west of 4,037-m peak on East Snowmass Creek-Willow Creek divide. Highland Peak quadrangle.

6. Grayish-red ( $5 \mathrm{R} \mathrm{4/2}$ ) siltstone. Quartz as much as $0.4 \mathrm{~mm}$ in diameter, muscovite as much as $0.1 \mathrm{~mm} l o n g$, plagioclase, and microcline in a matrix of carbonate, clay(?), hematite, and altered biotite. From $3,743 \mathrm{~m}$ altitude on east side of Conundrum Basin in Gothic quadrangle, $120 \mathrm{~m}$ south of the Maroon Bells quadrangle boundary.

7. Grayish-red sandstone. Clastic grains of quartz, microcline, altered plagioclase, muscovite, and carbonate with a grain size of $0.3 \mathrm{~mm}$ cemented by calcite. Same locality as no. 6 .

8. Grayish-red siltstone. Clastic grains of quartz as much as $0.08 \mathrm{~mm}$ in diameter, muscovite as much as $0.25 \mathrm{~mm} l o n g$, plagioclase, potassic feldspar, biotite, and carbonate in a matrix of carbonate, sericite(?), and opaque mineral. From altitude 3 , $755 \mathrm{~m}$ on east side of the head of Conundrum Creek $90 \mathrm{~m}$ north of south margin of Maroon Bells quadrangle.

9. Pale-red ( $5 R$ 6/2) arkose. Angular to subrounded clastic grains of quartz, partly altered plagioclase, muscovite, microcline, carbonate, and biotite as much as $1 \mathrm{~mm}$ in diameter but averaging 0.1-0.2 mm. Calcite cement. Same locality as no. 8 .

10. Medium-dark-gray hornblende hornfels. Green hornblende with a grain size of $0.02-0.04 \mathrm{~mm}$. Clastic grains of quartz, microcline, and plagioclase averaging $0.04-0.08 \mathrm{~mm}$ in diameter but as much as $0.15 \mathrm{~mm}$ in diameter. From $3,767 \mathrm{~m}$ altitude on the east side of the head of Conundrum Creek $335 \mathrm{~m}$ north of the south boundary of the Maroon Bells quadrangle.

11. Medium-light-gray metamorphosed sandstone. Clastic grains of quartz, plagioclase, and microcline averaging $0.08-0.25$ mm in diameter but reaching $1.5 \mathrm{~mm}$ in diameter. Sodic scapolite forms sieve-textured porphyroblasts as much as $1.5 \mathrm{~mm}$ in diameter. Hornblende has a grain size of $0.08-0.1 \mathrm{~mm}$. Same locality as no. 10

12. Light-greenish-gray (5G 8/I) pyroxene hornfels. Pyroxene with an average grain size of $0.04 \mathrm{~mm}$. From $3,780 \mathrm{~m}$ altitude on the east side of the head of Conundrum Creek $780 \mathrm{~m}$ north of the south boundary of the Maroon Bells quadrangle.

13. Light-bluish-gray (5B 7/1) fine-grained metamorphosed sandstone. Somewhat recrystallized clastic grains of quartz, plagioclase, and potassic feldspar averaging $0.3 \mathrm{~mm}$ in diameter; containing interstitial garnet, pyroxene, and calcite. Same $10{ }^{\circ}$

the Maroon Formation is not detectably different from that of the overlying Entrada Sandstone or Morrison Formation. Some faults of small displacement cross the section measured. However, I estimate that the section is accurate to within $150 \mathrm{~m}$ stratigraphically. This thickness contrasts with the $362 \mathrm{~m}$ measured by Langenheim (1952) at Copper Creek just south of the Maroon Bells quadrangle in the lower plate of the Elk Range thrust just $3.2 \mathrm{~km}$ south of the section measured in the Maroon Bells and Highland Peak quadrangles. An intermediate thrust sheet south of the White Rock pluton in the Pearl Pass quadrangle has Maroon Formation of an intermediate thickness reported to be $1,066 \mathrm{~m}$ by G. H. Eldridge (in Emmons and others, 1894). Other complete sections along strike to the northwest are thinner than the one measured in the Aspen area (Langenheim, 1954). Since we lack stratigraphic markers in the Maroon Formation, we do not know how much of the thickness variations are due to pre-Entrada structural movements and how much are due to variation in thickness of deposition. Reconnaissance mapping by me and V. L. Freeman indicates that west of the north-trending fault at the west edge of the Highland Peak quadrangle the Maroon is much thinner. This thinness is apparently due to pre-Late Jurassic erosion of the Maroon in the uplifted block on the west side of the fault.

To the north a complete section of the Maroon in the southern part of the Ruedi quadrangle is apparently $4.5 \mathrm{~km}$ thick (Freeman, 1972b). Yet five miles farther north the Maroon is about $1.52 \mathrm{~km}$ thick, and just south of the Fryingpan River it is only $0.91 \mathrm{~km}$ thick. The relative effects of pre-State Bridge structural movements, nondeposition, or unmapped Laramide 
structures on this drastic thinning are unknown because of lack of stratigraphic markers traceable from the margin into the interior of the Eagle basin.

\section{ENVIRONMENTS OF DEPOSITION OF GOTHIC AND MAROON FORMATIONS}

During deposition of the Gothic Formation shallowwater normal-marine conditions occurred in a belt extending from Taylor Park to the Crystal River valley. Sandstone, shale, and fossiliferous limestone were deposited in this belt. Northeast of this belt the clastic rocks are finer grained, and the limestones lack fossils. Bartleson (1972) postulated thinning of the Gothic Formation to the northeast, but none is apparent until the latitude of the Fryingpan River. Fluvial and transitional marine rocks were deposited southwest of the normal-marine rocks and were probably eroded at times to contribute material to the Gothic. Facies relations in the Gothic Formation (Bartleson, 1968) are quite similar to those of the Minturn Formation (Boggs, 1966), but because of lack of stratigraphic markers and deposits preserved at the basin margin on the southwest side, the story is not as complete as on the northeast.

In later Des Moinesian time the Uncompahgre uplift expanded its boundaries, and the Gothic deposited adjacent to the highland was eroded to furnish a substantial contribution to the Maroon Formation, which in the Aspen region was deposited in a fluvial to transitional marine environment at first and then later probably entirely in fluvial and other continental environments. Maximum depositional thicknesses of the red beds of the Maroon Formation are preserved in the Aspen region; whereas maximum thicknesses for older rocks, time equivalents of the Gothic and the lowest part of the Maroon are in the evaporite-bearing basins near Eagle and Cattle Creek (southeast of Glenwood Springs (Mallory, 1971).

Mineralogical and petrographic studies by Walker (1967a, b) and Raup (1966) and the occurrence of evaporite deposits in the rocks of the Eagle basin show that the red beds were deposited in an arid to semiarid environment. Hematite, causing the red color, formed by in situ alteration of iron-bearing detrital minerals.

Neither facies relations nor current directions obtained from crossbeds (fig. 25) show any effects of the ancestral Sawatch uplift proposed by De Voto (1972). Sedimentation in the Aspen region appears to have been controlled by the history of the Uncompahgre uplift.

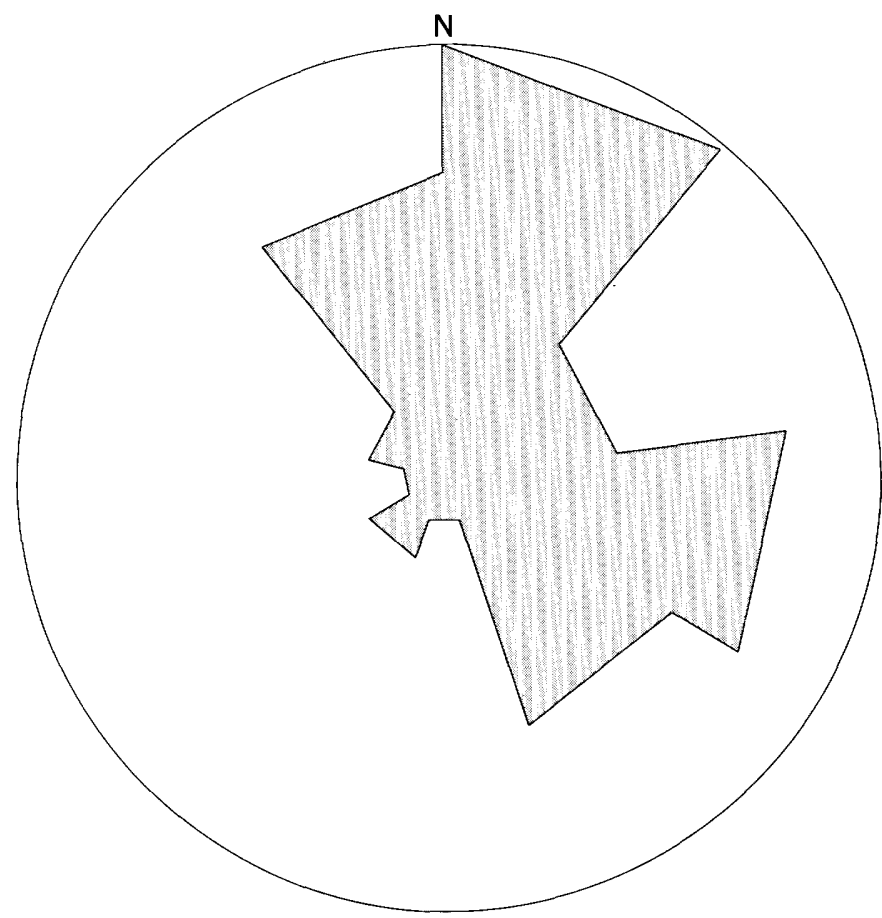

FigURE 25.-Summary of 41 azimuths of crossbedding in the Maroon Formation in the Aspen 15-minute quadrangle.

\section{STATE BRIDGE FORMATION}

The State Bridge Formation (Donner, 1936, 1949; Brill, 1942) has been extended to the Aspen region by Freeman (1971a). In the Woody Creek quadrangle he discovered an angular unconformity separating State Bridge from Maroon strata, and he subdivided the State Bridge into several units.

In the Aspen 7.5-minute quadrangle the State Bridge Formation forms the eastern part of Red Butte and a dip slope on the upper part of the Highlands Ski area on the ridge between Castle and Maroon Creeks; it forms parts of the ridge between Maroon and Willow Creeks in the Highland Peak quadrangle. Especially well exposed sections are found on the north side of the lower Willow Creek valley and the east side of East Snowmass Creek. (See stratigraphic section 3, p. 138.)

In the Aspen area no angular discordance between the State Bridge and Maroon Formations can be demonstrated. Local evidence for disconformity exists. In one place, blocks of siltstone from the Maroon Formation as much as $1.5 \mathrm{~m}$ in diameter are incorporated in the base of the State Bridge Formation. In a number of places along the north side of Willow Creek, conglomerate of the State Bridge Formation is in sharp contact with siltstone of the Maroon Formation. In 
other places a physical break between the formations is not detectable, and siltstone apparently grades upward into sandstone and conglomerate.

The upper contact of the State Bridge Formation is an angular unconformity beneath the Chinle Formation. This is shown by the truncation of an unnamed sandstone member of the State Bridge in the Aspen quadrangle along the west side of the Maroon Creek valley. Along the East Snowmass Creek valley the Chinle lies on siltstone of the State Bridge to the north and cuts down into an underlying conglomerate, and finally to the south truncates the entire formation.

The State Bridge Formation consists of grayish-red and reddish-brown to orange sandstone and siltstone and polymictic conglomerates. A few beds of pinkishgray to white quartz sandstone occur locally. The siltstone and sandstone alternate in beds several centimeters thick that have considerable lateral continuity (figs. $26 B, C$ ). Locally, siltstone intervals are as much as $10 \mathrm{~m}$ thick. Sandstone beds range from well sorted to poorly sorted. The poorly sorted ones have a bimodal grain-size distribution. The larger grains are of easily visible rounded quartz $1-2 \mathrm{~mm}$ in diameter. Many of the poorly sorted sandstones have chips of siltstone. Conglomerate beds are as much as $9 \mathrm{~m}$ thick and are composed of fragments as much as $20 \mathrm{~cm}$ long of granitic rock and gneiss, fine-grained metamorphic rock, quartzite, gray limestone, and chert (fig. 26A). Some local conglomerates overlying siltstone beds are composed of angular fragments of siltstone in a sandstone matrix. Some conglomerate beds have a lateral continuity over a number of kilometers. In the saddle south of hill 9970 west of Castle Creek, a few thin limestone beds were found.

Parallel oscillation ripple marks are a characteristic bedding feature of the State Bridge Formation (fig. $26 D$ ). Current ripple marks also occur, but the parallel ripple marks are absent from the underlying red beds. Crossbedding is well developed in some of the conglomerates and sandstones.

At the top of the State Bridge Formation is a finegrained uniform crossbedded moderate-orangeish-pink to pale-reddish-brown sandstone that is probably the Lower Triassic Sloane Peak Member (Freeman, 1971a). This sandstone is well exposed on places on the lower part of the Highlands Ski area and on Maroon Creek just to the northwest; it is about $18 \mathrm{~m}$ thick. It is cut out beneath the pre-Chinle unconformity at the west margin of the Aspen quadrangle. On Red Butte a similar sandstone is yellowish gray and about $30 \mathrm{~m}$ thick, and about $30 \mathrm{~m}$ of State Bridge sandstone, siltstone, and conglomerate lie between it and the Chinle.

The rocks of the State Bridge range from poorly sorted to well sorted. Larger clastic grains of quartz and feldspar and smaller rock fragments 1-2 $\mathrm{mm}$ in diameter are predominantly rounded to subrounded; whereas the smaller grains are subangular (fig. 27B). A few quartz grains exhibit thin overgrowths. Most of the plagioclase grains are highly altered, either due to weathering before deposition or syngenetic or diagenetic alteration of the grains in sandstone beds of the Maroon Formation, which were probably sources of much of the material in the State Bridge Formation. Some grains of carbonate appear to be clastic. Muscovite, biotite, zircon, tourmaline, and opaque minerals occur as clastic grains. The rocks contain various amounts of cement and matrix. Carbonate forms cement, and some of the matrix appears to be rich in clay and hematite.

Rock fragments seen in thin section include plentiful chert, fine-grained quartz-feldspar metamorphic rock, granitic rock, and carbonate rock.

The sandstone correlative with the Sloane Peak Member is a very fine grained well-sorted sandstone to siltstone composed of subangular quartz $0.05-0.1 \mathrm{~mm}$ in diameter. A minor amount of microcline and altered plagioclase form clastic grains. Opaque minerals, tourmaline, zircon, and, locally, rutile are distributed throughout the rock and concentrated in heavy mineral seams in some places. The matrix, which is sparse, is composed of calcite and clay minerals.

Rocks of the State Bridge Formation are less feldspathic and have less carbonate than those of the Maroon Formation. (Compare figs. 28 and 23A.) The Sloane Peak Member is a quartz sandstone, and in that respect it is similar to the sandstone in the Maroon Formation on Eagle Mountain (Highland Peak quadrangle).

No fossils were found in the State Bridge Formation in the Aspen region. Near Glenwood Springs a thin limestone bed in the State Bridge Formation called the South Canyon Creek Member contains Permian fossils (Bass and Northrop, 1950). A discontinuous limestone bed in the northern part of the Woody Creek quadrangle has been correlated with that member (Freeman, 1971a). The rocks an arbitrary $30 \mathrm{~m}$ above the South Canyon Creek Member have been assigned an Early Triassic age (M. E. MacLachlan, in McKee and others, 1959), since the rocks above that member are continuous with the Moenkopi Formation of the eastern Uinta Mountains (Stewart and others, 1972a). Rocks beneath that member are Permian. Where the 

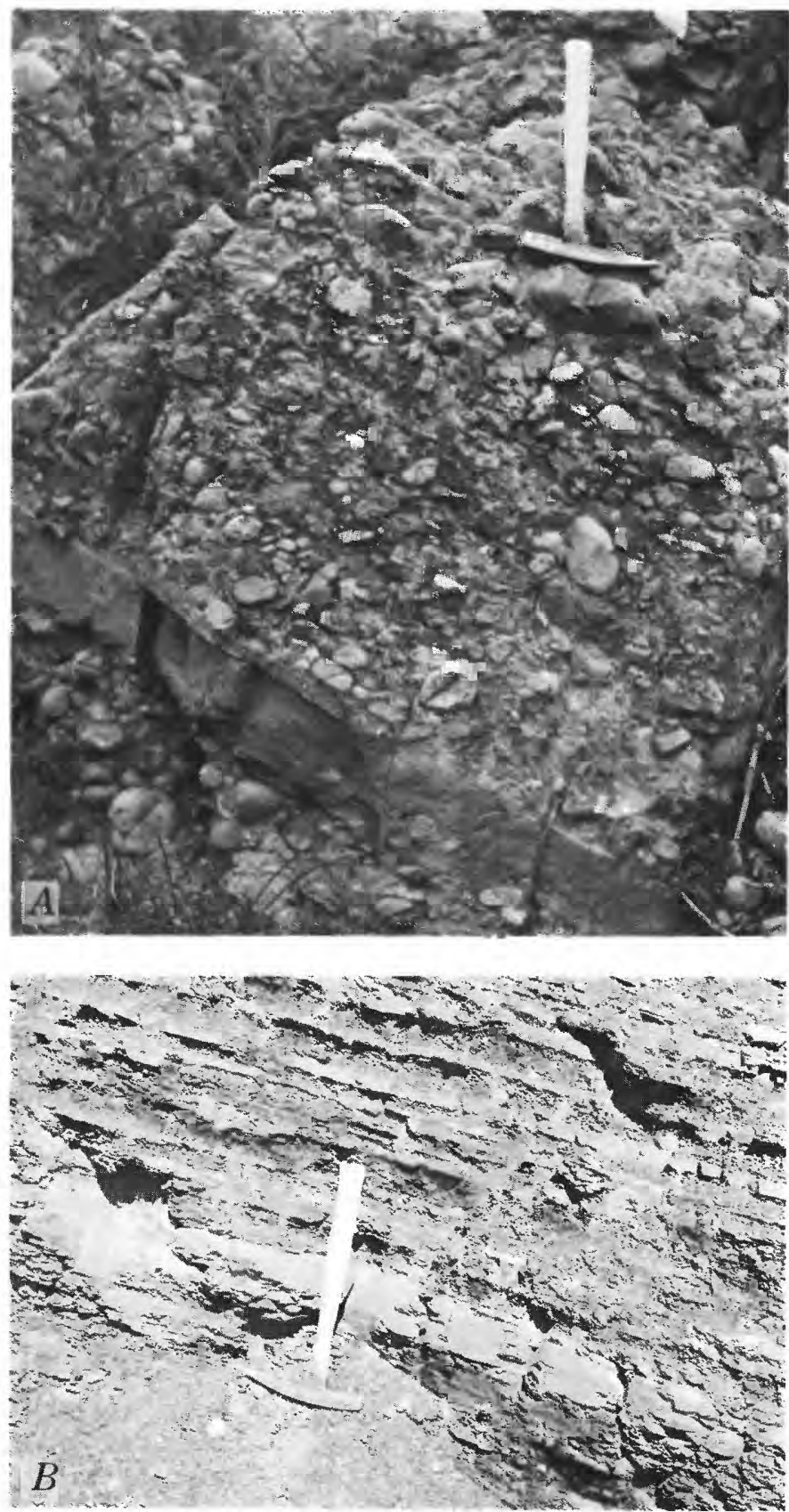

Figure 26.-Features of the State Bridge Formation. $A$, Conglomerate composed mostly of pebbles and cobbles of Precambrian rock. At about $3,350 \mathrm{~m}$ altitude on ridge north of Highland Peak, Aspen quadrangle. $B$, Thin-bedded sandstone and siltstone south of hill 9970 on ridge west of Castle Creek, Aspen

member is absent it is more undertain how much of the State Bridge Formation is Permian and how much is Triassic.

The zero isopach of the State Bridge passes through the Aspen region on the projection of the zero isopach shown by Stewart, Poole, and Wilson (1972a, pl. 4). However, in detail, the isopach is highly irregular
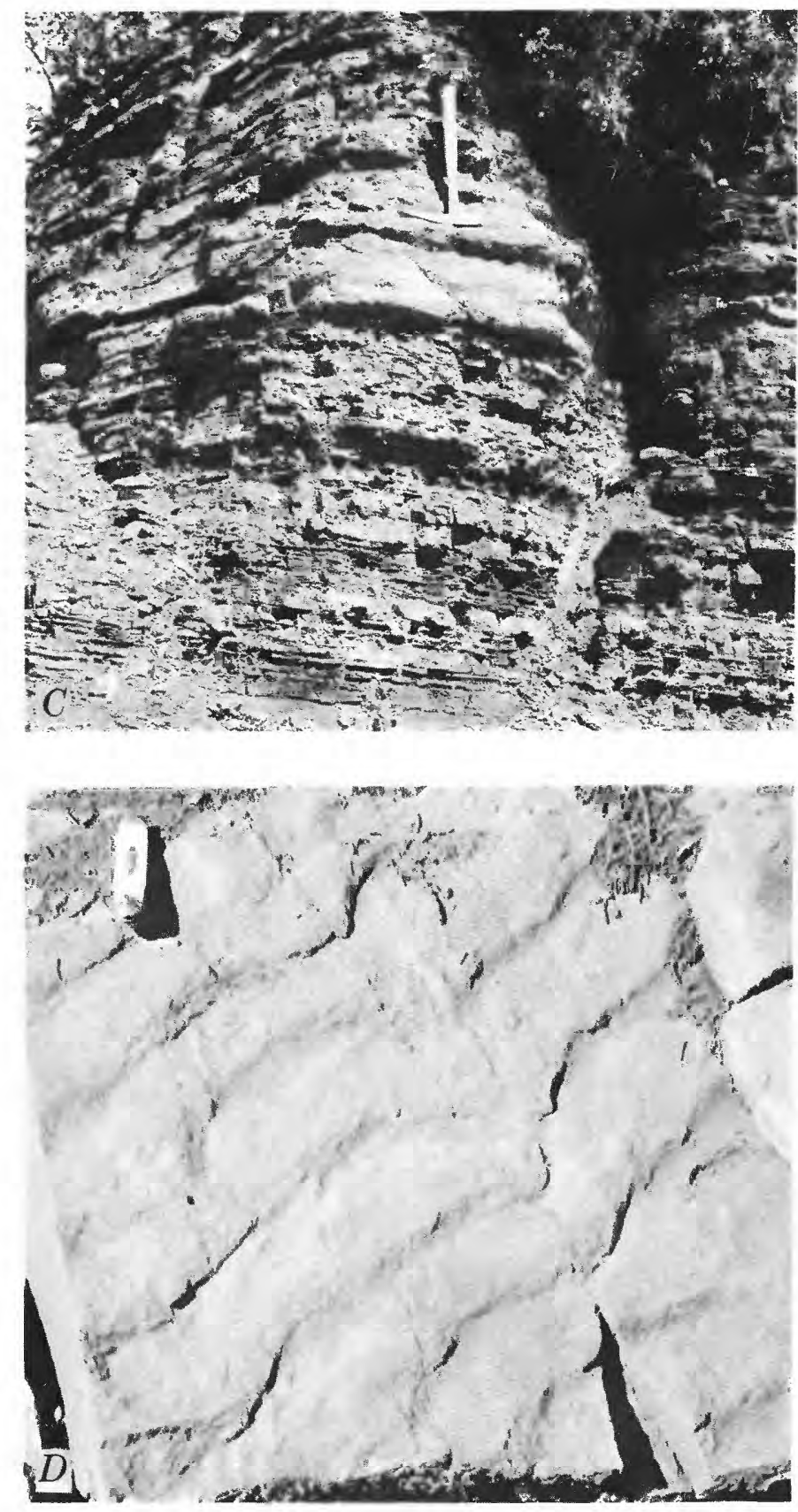

quadrangle. $C$, Bed of coarse-grained crossbedded sandstone in thin-bedded sandstone and siltstone near $B$. $D$, Parallel ripple marks on sandstone bed near base of State Bridge southeast of hill 11675 on ridge west of Castle Creek, Aspen quadrangle.

because of movements along north-trending faults in the Highland Peak quadrangle during or after State Bridge deposition. A good example is the fault that crosses the ridge east of Burnt Mountain at $3,210 \mathrm{~m}$ altitude. East of the fault is about $215 \mathrm{~m}$ of State Bridge and west of it only about $75 \mathrm{~m}$. That fault moved before the deposition of the Chinle Formation in 

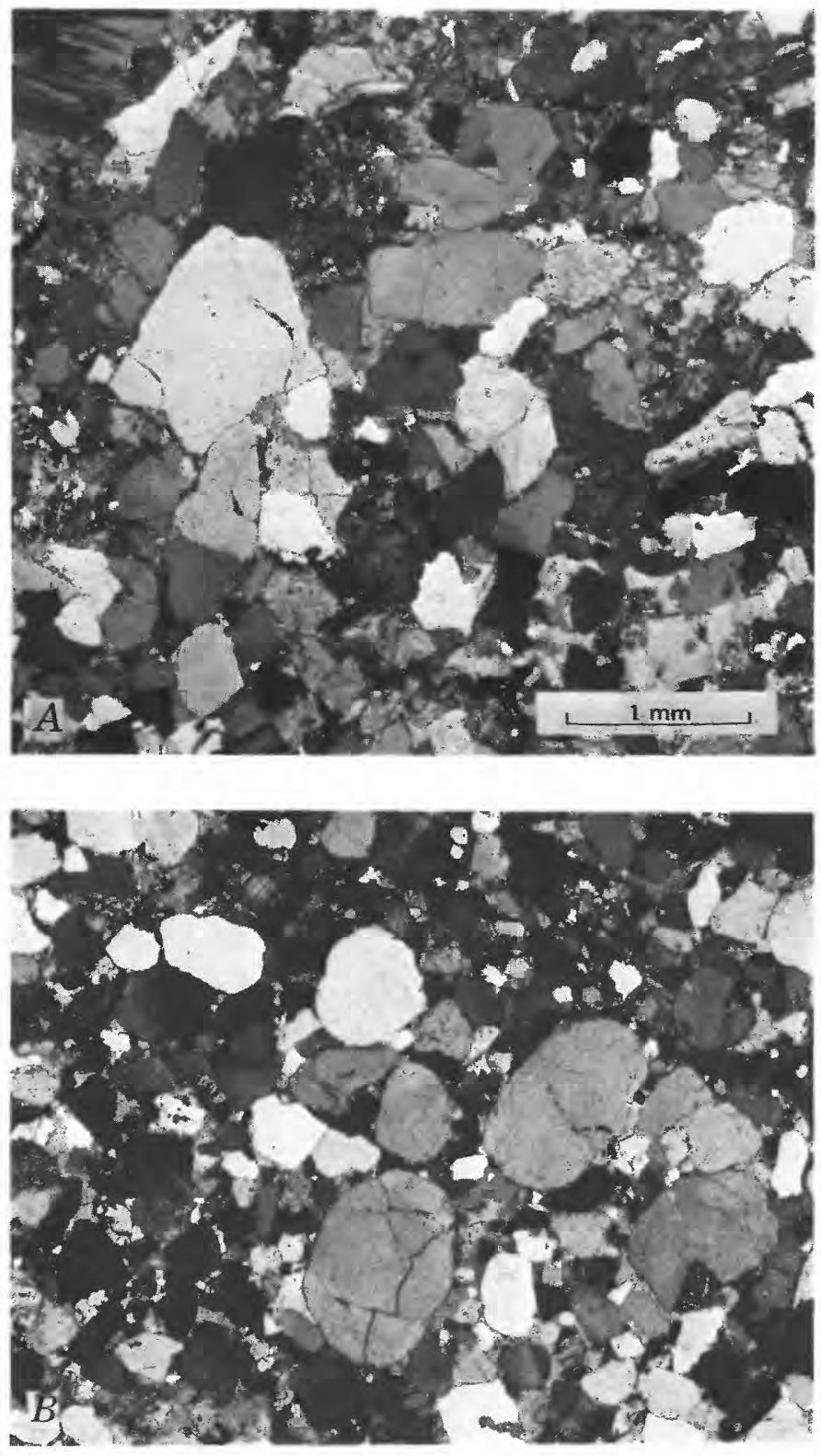

Figure 27.-Comparison of typical textures of sandstone in the Maroon Formation with sandstone in the State Bridge Formation. $A$, Poorly sorted arkose from about the middle of the Maroon Formation, from 3,853 m altitude on the east side of Sievers Mountain north of Maroon Lake. Angular to subangular clastic grains of quartz, microcline, and plagioclase with scattered interstitial calcite. $B$, Poorly sorted bimodal arkosic sandstone of the State Bridge Formation from near the base on the east side of East Snowmass Creek (stratigraphic section 3, bed 2; p. 139). Rounded to subrounded clastic grains of quartz, microcline, and plagioclase with interstitial calcite. Both $A$ and $B$ viewed through crossed nicols; both are at same scale.

Late Triassic time because thicknesses of Chinle are similar on both sides of it. Other faults affecting present thicknesses of the State Bridge moved before the

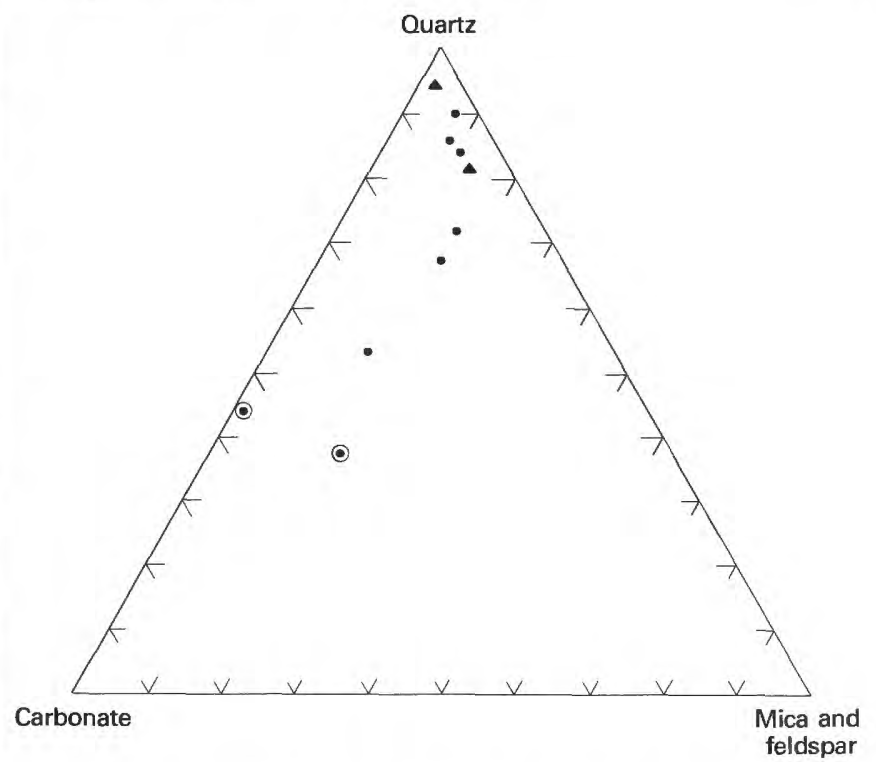

Figure 28.-Proportions of quartz, carbonate, and mica and feldspar in the State Bridge Formation. Dot, sandstone; circled dot, siltstone; triangle, sandstone correlative with Sloane Peak Member.

deposition of the Morrison Formation in Late Jurassic time.

The greater abundance and thickness of conglomerates in the Aspen area compared to the Woody Creek and Ruedi quadrangles to the north indicates that the original margin of the sedimentary basin was not far to the southwest and that this margin was controlled by the Uncompahgre uplift. (See stratigraphic section 3.) A few crossbed azimuths give northerly readings. Much greater thicknesses of generally finer grained rocks $29 \mathrm{~km}$ north of Aspen on Hardscrabble Mountain (Freeman, 1971a) indicate the presence of a State Bridge depocenter not previously detected in regional stratigraphic studies (Stewart and others, $1972 \mathrm{a}, \mathrm{pl}$. 4). The extent of the depocenter cannot be determined because only older rocks are preserved along strike in the Sawatch Range and the White River Plateau.

Much of the State Bridge Formation consists of detritus reworked from the underlying Maroon Formation. This would account for the sphericity of the larger quartz and feldspar grains. The pebbles and cobbles in the conglomerates could have been reworked from those in the Maroon conglomerates, but they may also have been derived from the Uncompahgre uplift and adjacent Pennsylvanian sedimentary rocks. The facies relations suggest that during State Bridge deposition the uplift expanded somewhat to the northeast over its extent during deposition of the Maroon Formation. An angular unconformity along the Castle Creek fault 
zone between State Bridge and Maroon rocks indicates that the Maroon Formation in that area should have furnished some detritus. The contrast in thickness of the Maroon Formation on the two sides of the Castle Creek fault zone in the Woody Creek quadrangle (Freeman, 1972a) suggests that some of the lower State Bridge north of the zone might have been deposited during erosion of the Maroon in and south of the zone.

Stewart, Poole, and Wilson (1972a) and Cadigan (1971) interpreted the environment of deposition of the State Bridge as dominantly fluvial or deltaic in an arid environment. The South Canyon Creek Member, however, represents a period of marine transgression into the region late in the Permian. Freeman (oral commun., 1968; 1971a) believed that oscillation ripple marks and the presence of well-sorted sandstone beds indicate deposition in widespread shallow bodies of water in a marginal marine environment.

\section{CHINLE FORMATION}

The Chinle Formation (Gregory, 1915) unconformably overlies the State Bridge and Maroon Formations in the Aspen region. The rocks of that formation were mapped by Spurr (1898) as red Triassic sandstones. The Chinle is well exposed in gullies on the east side of East Snowmass Creek, on the north side of lower Willow and Maroon Creeks, and on Red Butte.

The Chinle Formation has been subdivided into three members in the Aspen region (Poole and Stewart, 1964). (For stratigraphic sections see sections 2 and 3 (this report) and section C-17 (Stewart and others, 1972b).) At the base are discontinuous beds or lenses of quartz sandstone and conglomerate comprising the Gartra Member. The Gartra Member is $0-4.6 \mathrm{~m}$ thick and consists of white to light-gray, and, less commonly, various shades of red quartz sandstone and conglomerate. It is locally mottled very dusky red purple. It is mostly a coarse-grained sandstone with scattered granules, but in places it contains pebbles and cobbles of quartz, quartzite, and chert as much as $15 \mathrm{~cm}$ long (fig. 29). Less common pebbles are composed of granitic rock or siltstone. Crossbedding is well developed in the Gartra. Many of the sandstone lenses are channels that cut down into weathered State Bridge or Maroon rocks.

The mottled member (Poole and Stewart, 1964) overlies the Gartra, or where the Gartra is absent, the State Bridge or Maroon Formations. It erodes easily and forms a bench or is covered by debris from upslope. In one place rocks of this member are interbedded in the Gartra Member. The mottled member consists of very dark red to dusky-red and grayish-red siltstone and claystone and has very pale orange to

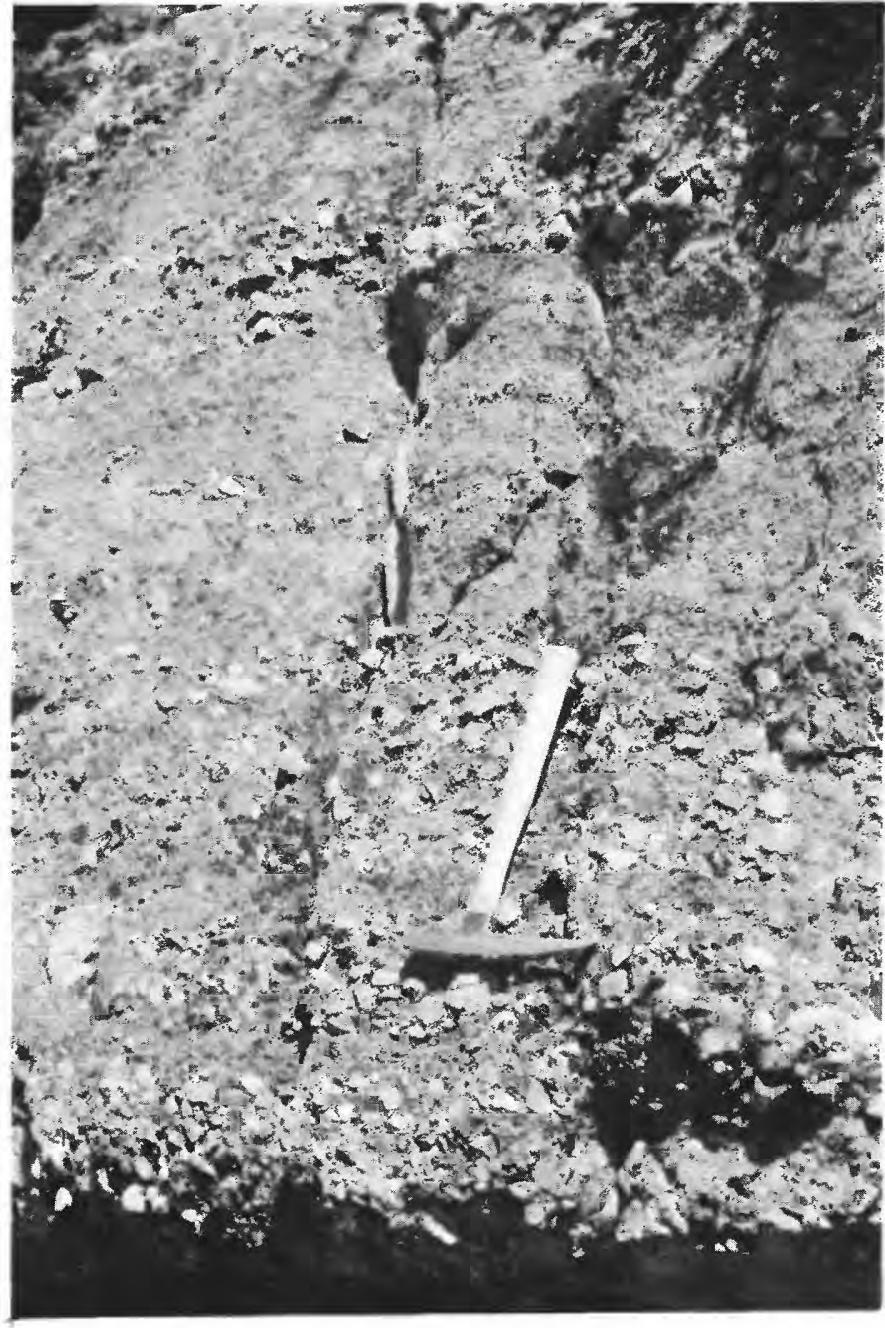

Figure 29.-Gartra Member of the Chinle Formation. Coarsegrained sandstone and quartz-pebble conglomerate, east side of East Snowmass Creek valley, Highland Peak quadrangle.

light-greenish-gray mottling in stringers and lenses. Locally, the mottling extends down into the Maroon or State Bridge rocks for a few feet. Some orange-red chert occurs in the mottled member. The member is 0-10 $\mathrm{m}$ thick.

The red siltstone member (Poole and Stewart, 1964) comprises the bulk of the Chinle Formation in the Aspen area. It consists of moderate-red and reddishbrown, dark-reddish-brown, and grayish-red siltstone and calcareous siltstone. Much of the siltstone is not well bedded and has a hackly fracture, in contrast to the blocky weathering in the siltstone at the top of the Maroon Formation. The siltstone contains beds of mottled moderate-red to pinkish-gray limestone and pinkish-gray to light-gray limestone and silty limestone. Beds of sandstone and pebble conglomerate composed of fragments of similar limestone are common. Some are mottled pale red to grayish red and 
light greenish gray. A few beds of moderate-reddishbrown calcareous sandstone occur in this unit.

The sandstones of the Gartra Member are poorly to moderately well sorted. The larger grains (1-3 mm in diameter) are rounded. They are composed of quartz and, less commonly, quartzite and chert. Feldspar grains are less abundant, but locally they comprise a few percent of the rock. Accessory minerals include clastic muscovite, zircon, tourmaline, and opaque minerals. Between the clastic grains are clay minerals, calcite, or fine-grained silica. Voids occur between grains in some rocks.

The limestones and silty limestones are micrite. Coarse-grained limestones are composed of clastic fragments of micritic limestone and a small proportion of rounded quartz grains. Silt-sized quartz grains and, rarely, muscovite occur. In some of the siltier rocks clastic zircon, tourmaline, apatite, sphene, and opaque minerals occur, and locally they form heavy mineral partings. Calcareous sandstones have calcite both as clastic grains and cement.

Composition of specimens of the Chinle contrasts with that of older red beds (fig. 30). Siltstones are not well represented in the diagram, but overall the Chinle has more calcite and less feldspar that the State Bridge and Maroon Formations.

No fossils were found in the Chinle Formation in the Aspen area. Stewart, Poole, and Wilson (1972b, p. 77-87) summarized the paleontologic evidence for the Late Triassic age assigned to the Chinle.

In the Aspen region the zero isopach of the Chinle must pass through the Maroon Bells and Hayden Peak quadrangles. No Chinle is recognized on the south side of the Elk Mountains in the Maroon Bells quadrangle or the Snowmass Mountain quadrangle (Mutschler, 1970). This isopach is offset by a north-trending fault just west of Snowmass Creek. West of that fault the Chinle is absent, owing to pre-Morrison erosion. East of the fault the Chinle is about $122 \mathrm{~m}$ thick. It thins to the south to $24 \mathrm{~m}$ on the 4,037-m peak on the East Snowmass Creek-Willow Creek divide near the south margin of the Highland Peak quadrangle. On Maroon Creek and the Highlands Ski area, it is also about $122 \mathrm{~m}$ thick. Thus, the $122-\mathrm{m}$ isopach trends about $\mathrm{N}$. $70^{\circ} \mathrm{W}$. to the fault near Snowmass Creek. At that fault it is offset to the north. In the Woody Creek quadrangle the $122-\mathrm{m}$ isopach passes between Snowmass Creek and the west edge of the quadrangle. No fault is detected, but thinning to the west is rapid (Freeman, 1972a). The Chinle thickens to $274 \mathrm{~m}$ in the east-central part of the Woody Creek quadrangle. These thickness changes help define the southwest side of the Chinle depocenter shown by Stewart, Poole, and Wilson (1972b, pl. 3). That depocenter is relatively

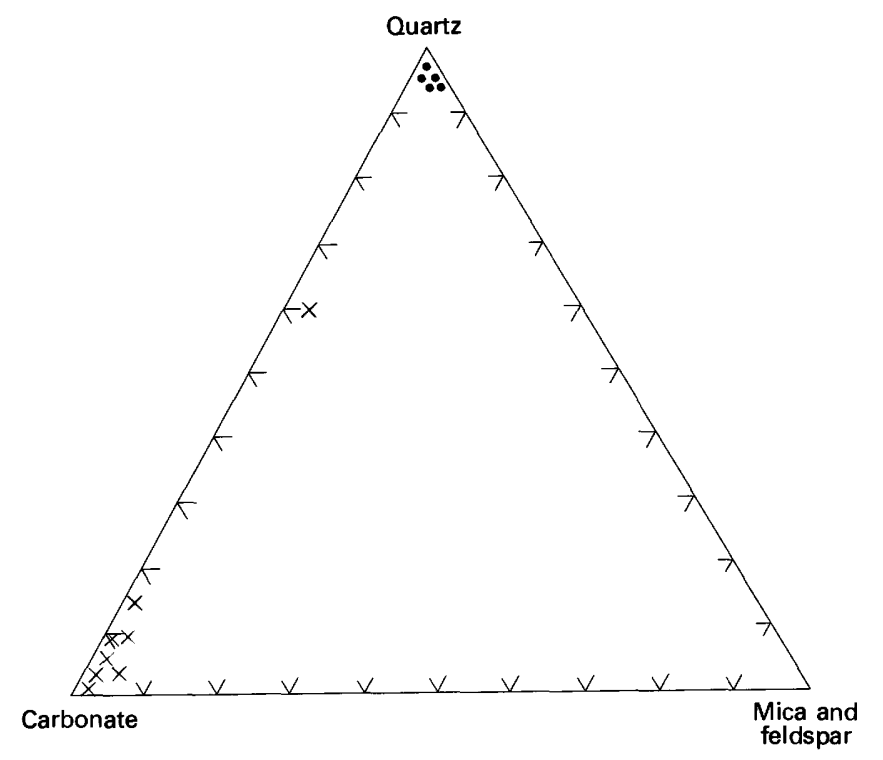

Figure 30.-Proportions of quartz, carbonate, and mica and feldspar in the Chinle Formation. Dot, Gartra Member; $x$, other rocks.

well defined on the northeast and southwest but poorly defined on the northwest and southeast because the Chinle has been removed by erosion in those areas.

Whether the Chinle north of the Aspen area is thick because of preservation by post-Chinle and preEntrada deformation or because that area was a structural depression during Chinle deposition is difficult to evaluate. The Aspen area exhibits no obvious increase in the quartz and feldspar content of the Chinle to the south, as one might expect if the Uncompahgre uplift were a source area and if the stratigraphic thinning in that direction were due to proximity to the margin of the basin. The Chinle is a mature sediment from a mineralogical point of view and gives no definite evidence of derivation from Precambrian rocks of the Uncompahgre highland. Most of the material was derived by thorough weathering and reworking of the underlying Maroon and State Bridge rocks. Contributions from Precambrian basement rocks, if any, were thoroughly broken down so that feldspars were converted to clay. The silt and clay were deposited by streams of low gradient, and in lakes. Limestone was deposited in the lakes, and disruption by storms of those limestone beds shortly after deposition may account for the calcarenite and limestone pebble beds. These features suggest that if the Uncompahgre uplift area was a positive element during Chinle deposition, its margin was some distance to the southwest, and it had low relief. The isopleth map of the Gartra (Thordarson and others, 1972) and the direction of dip of crossbedding in the Gartra (Stewart and others, 1972b, pl. 4) suggest that the main directions of transport 
were northwest away from a source lying to the southeast rather than one lying to the southwest in the direction of the Uncompahgre uplift. However, in southeastern Utah and southwestern Colorado isopleths in the Shinarump Member (Thordarson and others, 1972) and a much higher feldspar content in rocks equivalent to the Chinle (Cadigan, 1957) than in the Aspen region indicate that the southwestern part of the Uncompahgre uplift was a source area for the Chinle in that region.

Fossil content and sedimentary features of the Chinle indicate deposition in a terrestrial environment by streams and in lakes (Stewart and others, 1972b). The Gartra Member is a typical stream deposit, laid down on a soil zone on the State Bridge and Maroon Formations. The stratigraphic relations (Stewart and others, 1972b) and the clay mineralogy (Schultz, 1963) of the mottled member indicate that it is an old soil zone, in part reworked. Much of the overlying siltstone and limestone was probably deposited in lakes and flood plains.

\section{THE NONMARINE AND MARINE ROCKS OF THE JURASSIC AND GRETACEOUS}

\section{ENTRADA SANDSTONE}

The Entrada Sandstone (Gilluly and Reeside, 1928) forms a thin discontinuous horizon above the red beds in the Aspen area. Spurr (1898) included it with the overlying Morrison Formation, which he called the Gunnison Formation-a name that has since been abandoned. He did note that the Gunnison Formation contained a basal gray or yellow sandstone.

In the Aspen area the Entrada is well exposed on Red Butte and in numerous places along the north valley side of lower Willow Creek and on the east side of the East Snowmass Creek valley. It crops out as small ledges between the smooth slopes formed by the Chinle and Morrison Formations and as small cliffs in gullies where those more easily weathered formations are well exposed (fig. 31A). (See stratigraphic sections 2 and 3 (this report) and section C-17 (Stewart and others, 1972b).)

The Entrada consists of yellowish to pinkish-gray crossbedded medium- to coarse-grained sandstone containing scattered 1-2-mm spherical quartz grains and sparser grains of pink, red, and dark-gray chert in a finer grained matrix. Near its base it locally contains quartz and chert pebbles as much as $5 \mathrm{~cm}$ in diameter. The underlying Chinle is bleached in places to a depth of as much as $0.3 \mathrm{~m}$ below the unconformity at the base of the Entrada (fig. $31 B$ ).
The Entrada unconformably overlies the Chinle Formation and the Maroon Formation. Where mapped in the Aspen area it overlies the Chinle; but some thin unmapped lenses of Entrada lie in the southwestern part of the Maroon Bells quadrangle, and other unmapped lenses may exist at the west edge of the Highland Peak quadrangle where the Morrison is shown in contact with the Maroon Formation. On Capitol Creek, to the west of Snowmass Creek, Entrada rests on Maroon. The upper contact of the Entrada is not everywhere well defined. Sandstones of similar aspect occur in the lower part of the Morrison Formation. I drew the upper contact at the lowest interbedded shale or limestone (fig. $31 \mathrm{~A}$ ). (See stratigraphic sections 2 and 3 , this report.)

Thin-section examination shows the grain size distribution to be bimodal even in the finer grained sandstones, although that feature is more obvious in the field in the coarser grained sandstones. Some rocks have spherical grains $0.6 \mathrm{~mm}$ in diameter in a groundmass containing grains $0.1-0.2 \mathrm{~mm}$ in diameter. Clastic grains of microcline and chert show similar size relations. Accessory clastic grains are zircon, tourmaline, opaque minerals, and apatite. Small amounts of clay minerals occur as matrix, and calcite cement is widespread.

The Entrada lacks fossils, but its relations with paleontologically dated rocks show that it is Late Jurassic in age.

In the Aspen area the thickness of the Entrada ranges from 0 to $15 \mathrm{~m}$, except at Red Butte where it is mapped as being thicker than $30 \mathrm{~m}$ in places. In the southwest corner of the Maroon Bells quadrangle the Entrada is not everywhere present (fig. $32 A$ ), and it is less than $3 \mathrm{~m}$ thick where present. This contrasts with the thin but continuous Entrada around the Treasure Mountain dome and to the east (Gaskill and Godwin, 1966a; Mutschler, 1970). The Entrada is absent in the Gunnison region and the eastern part of the Black Canyon (Baker and others, 1936; Hansen, 1971). The area where it is missing outlines a restricted Uncompahgre uplift (McKee and others, 1956, pl. 5); however, it is difficult to say that it is missing either because of nondeposition or because of post-Entrada-preMorrison erosion. The Entrada might have been deposited only in low areas on the Upper Jurassic surface, or it might have been deposited as a thin blanket and only locally removed by the streams that subsequently deposited the Morrison Formation. The absence of Entrada on the fault block west of Snowmass Creek poses the same question. Farther west at Capitol Creek the Entrada is only $4 \mathrm{~m}$ thick, and State Bridge and Chinle beds are absent. 


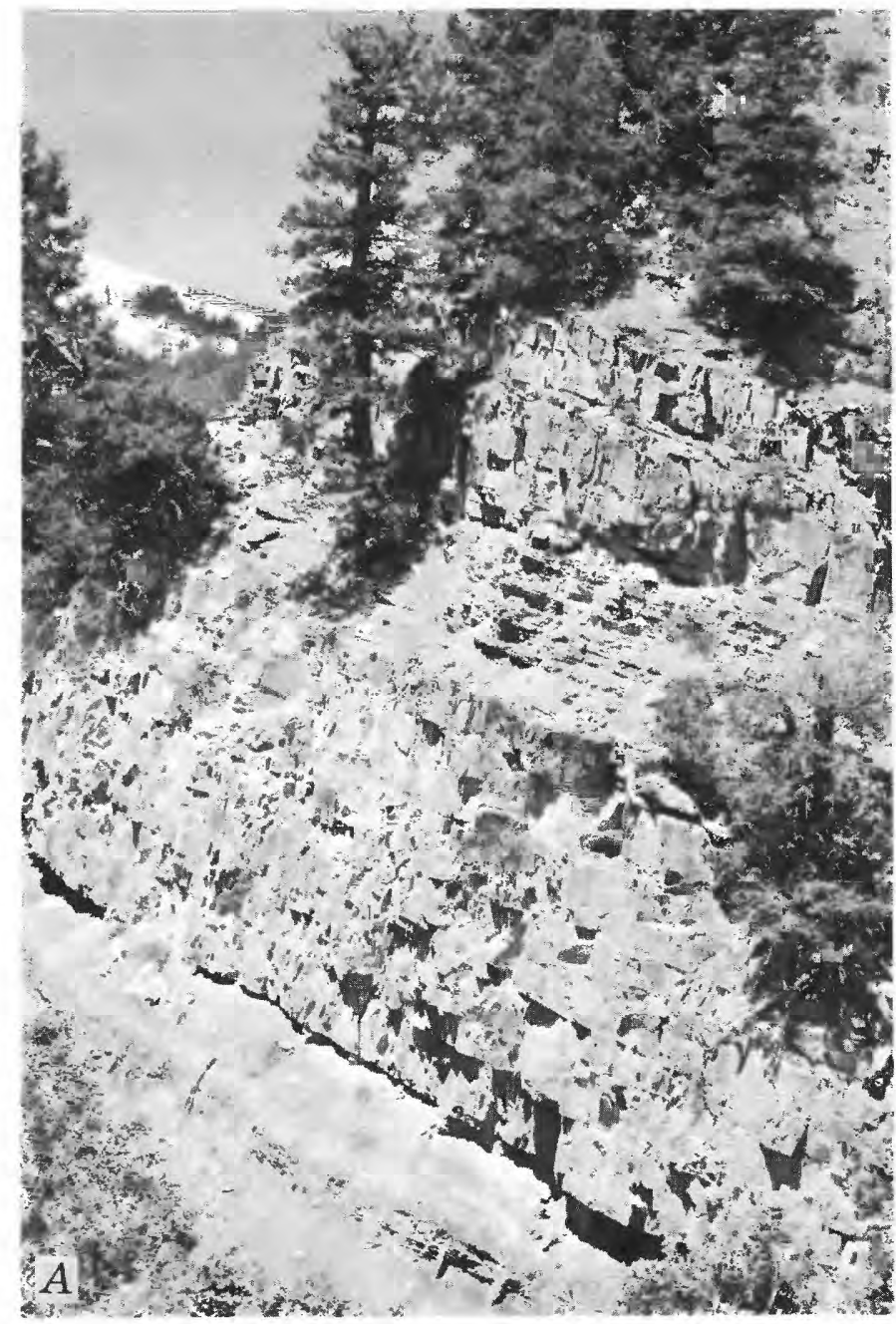

MORRISON FORMATION

The Morrison Formation (Cross, 1894) crops out in the Aspen area on Red Butte, along the valley side of lower Maroon and Willow Creeks, and on the east side of East Snowmass Creek. It forms dip slopes on the east part of Burnt Mountain and west of East Snowmass Creek. Except where cut by gullies and slide scars (fig. $32 B$ ), it is usually poorly exposed and forms with the Chinle a soil-covered, grassy slope between the better outcrops of State Bridge or Maroon below and Dakota Sandstone and Burro Canyon Formation above. Spurr (1898) included the Morrison in the Gunnison Formation, the name applied to rocks between the Maroon and Dakota in the Crested Butte area by G. H. Eldridge (in Emmons and others, 1894)-but this name has been abandoned.

In the Aspen area the Morrison conformably overlies the Entrada Sandstone, but where the Entrada is absent, it disconformably overlies the Chinle Formation.

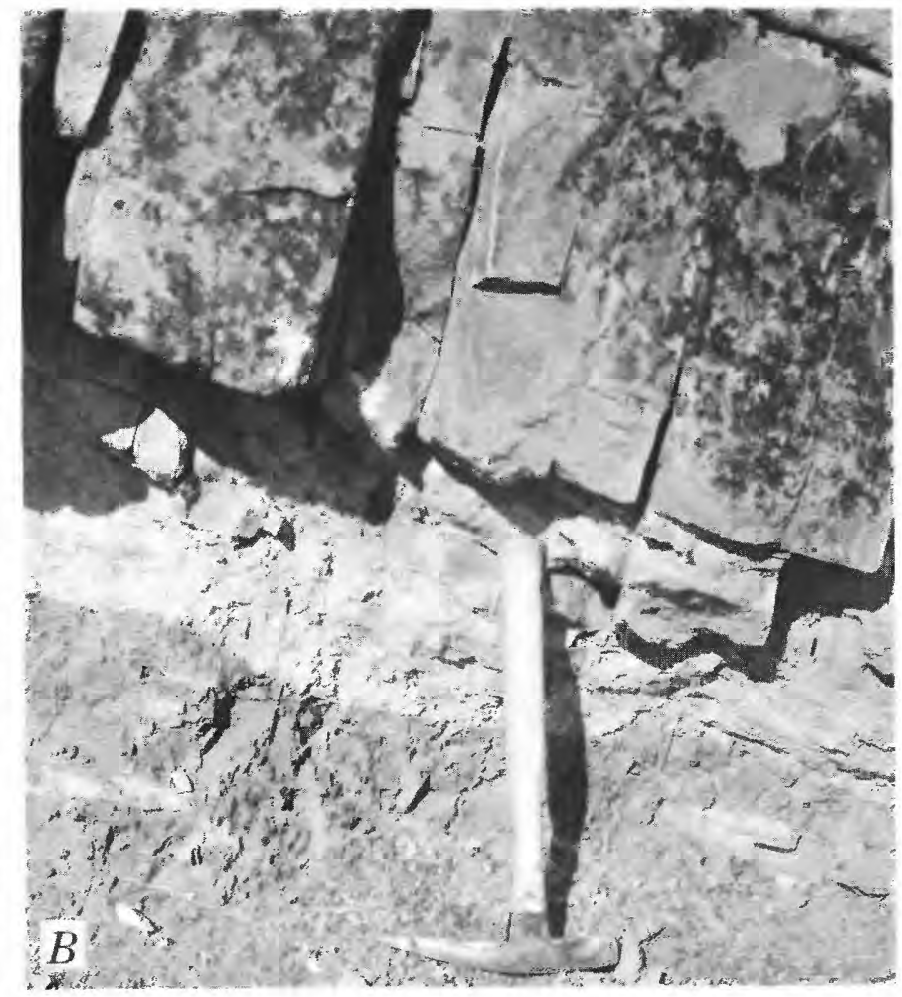

FIGURE 31 (left and above).-Entrada Sandstone and Morrison Formation. A, Entrada Sandstone overlies easily erodible siltstone of the Chinle Formation. Base of Morrison is mapped at base of siltstone beds in middle of photograph. Sandstone above is mapped in the Morrison Formation. Entrada is about $5 \mathrm{~m}$ thick. North side of Willow Creek valley, Highland Peak quadrangle. $B$, Contact between Entrada Sandstone and underlying Chinle Formation on west side of gap at the head of Brush Creek, Highland Peak quadrangle. Chinle has been bleached for about $15 \mathrm{~cm}$ below unconformity, and the Chinle is locally squeezed into fractures in the Entrada.

At the west margin of the Highland Peak quadrangle it lies on the Maroon Formation. On the south side of the Elk Mountains in the southwestern part of the Maroon Bells quadrangle, it lies on an unconformity cutting the Maroon Formation (fig. 32A).

The Morrison Formation consists of calcareous siltstone and sandstone and yellowish-grayweathering limestone and silty limestone grading upward into grayish-red and greenish-gray siltstone and claystone. Near the base of the formation is yellowishgray calcareous sandstone containing beds of gray shaly limestone. (See stratigraphic sections 2 and 3.)

Some of the basal sandstone has scattered spherical quartz and chert grains and resembles the Entrada. This resemblance has caused some confusion in location of the base of the Morrison (Baker and others, 1936; Langenheim, 1957). In places this sandstone is crossbedded. If the sandstones contained beds of shaly 

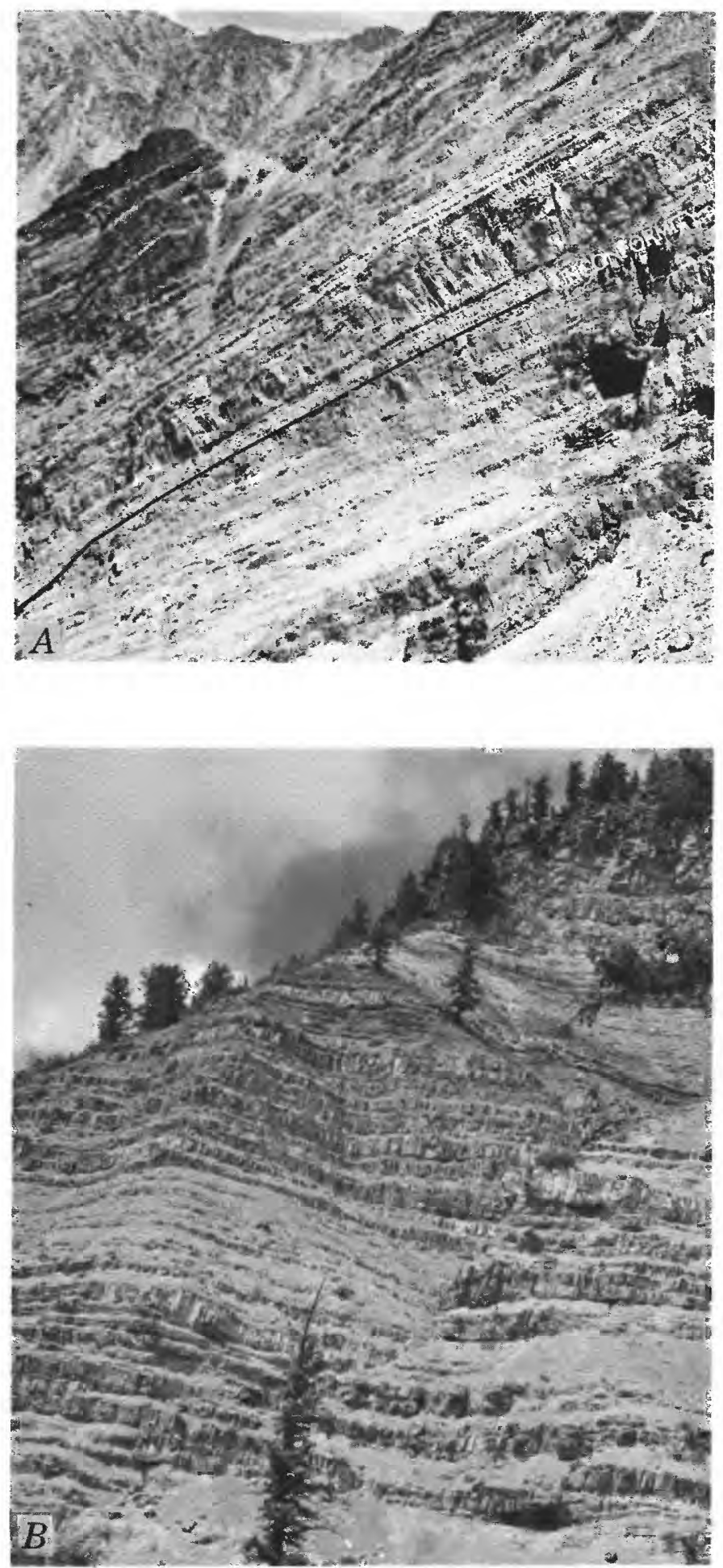

FiguRE 32.-Morrison Formation. A, Unconformity between Morrison and Maroon Formations in area of contact metamorphism at head of Rustler Gulch, Maroon Bells quadrangle. $B$, Typical exposure of Morrison claystone, siltstone, and sandstone overlain by more massive, cliff-forming sandstone of the Burro Canyon Formation and Dakota Sandstone near top of outcrop. North side of Willow Creek valley, Highland Peak quadrangle. About $140 \mathrm{~m}$ of strata shown here. limestone or shale, I included them in the Morrison (fig. $31 \mathrm{~A}$ ). Lenses of gray or mottled red, white, and gray chert occur locally in the sandstone.

The limestones range from thin laminations to beds as much as a meter thick. They are medium gray on a fresh surface and locally contain stringers and lenses of medium-gray to medium-bluish-gray chert. They grade to siltstone and sandstone beds.

The siltstone and claystone in the upper part of the Morrison are locally mottled greenish gray and grayish red. In the southwestern part of the Maroon Bells quadrangle a chert pebble conglomerate bed about a meter thick occurs in the upper part of the Morrison.

The basal sandstones of the Morrison range from poorly sorted to well sorted. The poorly sorted ones are similar to the Entrada Sandstone and contain larger rounded grains of quartz, chert, and microcline 0.5-2 $\mathrm{mm}$ in diameter in a matrix of quartz, microcline, and chert grains, $0.1-0.3 \mathrm{~mm}$ in diameter. Most of the sandstones, however, are better sorted than those of the Entrada. The poorly sorted ones are concentrated at the very base of the Morrison. At the west margin of the Highland Peak quadrangle where the Morrison rests unconformably on the Maroon Formation, the basal Morrison contains some quartz pebbles, and some of the larger clastic grains are angular. Clastic muscovite and biotite are also present. The sandstones have various amounts of calcite cement. Accessory clastic grains of an opaque mineral, zircon, sphene, and tourmaline occur. The stratigraphically higher sandstones are fine grained and contain rounded to subangular quartz $0.1-0.3 \mathrm{~mm}$ in diameter cemented by calcite. A few calcite carbonate grains appear to be clastic. Microcline and rarely plagioclase also form clastic grains.

The limestones are locally biomicrites rich in charophyte or ostracod remains. Most of them contain various amounts of silt-size quartz grains.

The claystones contain scattered angular clasts of quartz $0.02-0.13 \mathrm{~mm}$ in diameter and fragments of untwinned potassic feldspar and plagioclase. Muscovite, apatite, tourmaline, zircon, and opaque minerals also form clastic grains. These minerals are enclosed in a matrix of clay and minor carbonate. Studies in the Colorado Plateau region to the west indicate that most of the clay in the upper part of the Morrison is montmorillonite derived from alteration of volcanic ash. The siltstones and claystones in the lower part of the Morrison generally contain illite, derived by erosion of sedimentary source terrane (Keller, 1962).

In the canyon of Snowmass Creek in the Woody Creek quadrangle, Baker, Dane, and Reeside (1936) found a 3.4-m-thick sequence of sandstone, oolitic 
limestone, and shale containing marine fossils, which they assigned to the Curtis Formation. This sequence was not found in the Highland Peak quadrangle $11 \mathrm{~km}$ to the south.

In the Aspen area the Morrison is $122-161 \mathrm{~m}$ thick, and it can be divided into two units: a lower unit of sandstone and limestone 36-41 $\mathrm{m}$ thick and an upper unit of claystone and siltstone and a few sandstone and limestone beds. These two units might be correlated with the Salt Wash and Brushy Basin Members, respectively, but regional studies (Craig and others, 1955) do not recognize these members as far east as the Aspen area. However, these studies (Craig and others, 1955 , p. 137) do correlate a claystone and limestone facies east of the limit of the Salt Wash Member with that member. The rocks in the Aspen region apparently are gradational between the claystone and lenticular sandstone facies of the Salt Wash Member mapped to the west (Craig and others, 1955, p. 138) and the claystone and limestone facies. The mapped area of the Brushy Basin Member is terminated where the Salt Wash Member loses its identity (Craig and others, 1955 , p. 156). However, the rock types in the upper part of the Morrison at Aspen are identical to those in the Brushy Basin Member.

Thickness variations in the Aspen region throw some doubt on the configuration of the poorly controlled area of thin Morrison shown parallel to the Uncompahgre highland in regional isopach maps (Craig and others, 1955 , p. 159). In the Woody Creek quadrangle the thickness of the Morrison has been measured as $162 \mathrm{~m}$ at Snowmass Creek (Craig, 1959) but is mapped as $90 \mathrm{~m}$ in the quadrangle as a whole (Freeman, 1972a). If this discrepancy represents the range in thickness of the Morrison in that quadrangle, that range is greater than in the Aspen and Highland Peak quadrangles. A series of sections along a northwest-southeast line on the south side of the Elk Mountains show a range of 91-140 $\mathrm{m}$ in the thickness of the Morrison (Langenheim, 1957; Vanderwilt, 1935a; D. L. Gaskill, written commun., 1968; F. E. Mutschler, written commun., 1970). The evidence is insufficient to define a thinning in a southwesterly direction.

Facies and mineralogical studies (Craig and others, 1955; Keller, 1962; Cadigan, 1967) indicate that the Morrison was derived from the west and southwest and was deposited by streams in a continental environment, in stream beds, on flood plains, and in lakes. Volcanic ash from air falls, in part redistributed by sedimentary processes, contributed considerable material to the claystones.

No diagnostic fossils were found in the Morrison of the Aspen region, but the Morrison is famous for its well-preserved dinosaurs, which show that it is of latest Jurassic age.

\section{BURRO CANYON FORMATION AND DAKOTA SANDSTONE}

The Burro Canyon Formation (Stokes and Phoenix, 1948) and the Dakota Sandstone (Meek and Hayden, 1862) were mapped as one unit in the Aspen area because in most of the outcrop belt formed by these formations float from the Dakota Sandstone upslope from the Burro Canyon Formation covers the siltstone and claystone beds of the Burro Canyon. Those beds are diagnostic for the distinction between the two formations. The sandstones of the Burro Canyon and Dakota form cliffs and ledges along the top of the north side of the Willow Creek valley (fig. 32B), on lower Maroon Creek, and on Eagle Mountain; and they form extensive dip slopes throughout the central part of the Highland Peak quadrangle.

Rocks of stratigraphic position similar to those of the Burro Canyon Formation west of the Colorado River are called Cedar Mountain Formation (Stokes, 1952). Young (1960) extended the term Cedar Mountain to include stratigraphically equivalent rocks to the east margin of the Colorado Plateau about $80 \mathrm{~km}$ west of Aspen. What is here called Dakota Sandstone he named the Naturita Formation, and he referred to the Cedar Mountain and the Naturita as the Dakota Group. The Cedar Mountain at its type locality is predominantly shale and mudstone overlying a basal conglomerate (Stokes, 1952). The Burro Canyon at its type locality contains conglomerate, sandstone, shale, limestone, and chert (Stokes and Phoenix, 1948; Stokes, 1952) and is more nearly like the predominantly sandstone unit in the Aspen area, which was mapped as Burro Canyon by me. This practice has been followed by recent workers elsewhere in the region (Freeman, 1972a; Hansen, 1971).

The Burro Canyon Formation consists of light-gray to white quartz sandstone with chert- and quartzpebble conglomerate and interbeds of light-bluish-gray claystone, silty shale, and sandy siltstone.

The sandstones are generally fairly fine grained but contain granules of quartz, chert, and feldspar. The sandstones weather grayish orange. The claystones and siltstones occur in intervals of comparable thickness to the sandstone beds (about $3 \mathrm{~m}$ ) to thin interbeds in the sandstones. The proportion of sandstone varies considerably from place to place. The contact between the Morrison and Burro Canyon is sharp and is drawn at the base of the lowest sandstone or conglomerate. The conglomerates contain pebbles of 
chert, quartz, and quartzite as much as $2 \mathrm{~cm}$ in diameter, and they occur at the base of the formation in some places and above the base in other places. (See stratigraphic sections 2 and 3. )

In the southwestern part of the Maroon Bells quadrangle, contact metamorphism of the Dakota Sandstone has obscured the distinctive colors of the Burro Canyon claystone and siltstone interbeds, if any are present. In that area a quartz and chert pebble conglomerate commonly occurs at the base of the Dakota, and the pebbles are as much as $4 \mathrm{~cm}$ in diameter. Locally, conglomeratic beds are found as much as $5 \mathrm{~m}$ above the base of the Dakota.

The lower part of the Dakota Sandstone consists of white, yellowish-gray, light-brown, and gray crossbedded sandstone with a few lenses of quartz- and chertpebble conglomerate. The lower sandstones weather grayish orange, and the sandstone at the base forms cliffs. A few thin beds of medium-gray to dark-gray shale or claystone occur in this interval. The upper part consists of dark-gray, in part carbonaceous, sandstone and shale, locally containing plant fragments.

The upper contact of the Dakota is gradational with the overlying Mancos Shale. (See stratigraphic section 4, p. 139.) The contact was drawn above the highest thick sandstone bed, although significant intervals of dark-gray siltstone and shale occur below that sandstone.

The sandstones of the Burro Canyon and Dakota range from poorly sorted to well sorted, and those of the Dakota are on the average somewhat better sorted than those of the Burro Canyon. Quartz grains range from subangular to rounded and form the main part of the sandstone. In some of the finer grained sandstones $(<0.5 \mathrm{~mm}$ grain size), the quartz grains are partly intergrown to form an incipient mosaic texture. Overgrowths of quartz on the clastic grains are common. Some sandstones have a fine-grained silica cement. Quartz also occurs in granules and small pebbles of quartzite and vein quartz, some of which were cataclastically deformed.

Chert makes up from a trace to 40 percent of the sandstones. It ranges from dark gray to white and tan. Red chert occurs in a few places. The chert ranges in texture from cryptocrystalline to silt-sized grains in a cryptocrystalline matrix. Some appears to be silicified siltstone or volcanic rock. Other fragments may be silicified limestone.

Potassic feldspar is locally present in trace amounts. A light-olive-gray sandstone (stratigraphic section 4, bed 26 ; p. 139) from near the top of the Dakota contains several percent of plagioclase and clastic grains of muscovite and biotite.

Tourmaline, zircon, and opaque minerals are common accessory minerals. Some samples of the Dakota contains carbonaceous material either as discrete fragments or as fine-grained material interstitial to the clastic grains of quartz. Analyses of several carbonaceous sandstones gave an organic carbon content ranging from 0.1 to 0.4 percent.

In the Aspen area the contact between the Burro Canyon and the Dakota is at the base of a ledgeforming sandstone, and it is poorly exposed. At the Colorado-Utah border, Carter (1957) found a welldeveloped disconformity at the base of the Dakota.

No diagnostic fossils were found in the Burro Canyon Formation or Dakota Sandstone in the Aspen area. The Burro Canyon Formation is considered to be of Early Cretaceous age on the Colorado Plateau to the west. The Dakota Sandstone is also of Early Cretaceous age both to the east (Waagé, 1955) and to the west (Young, 1960), and consequently it is reasonable to infer an Early Cretaceous age for the Dakota in the Aspen region.

In the Aspen area the combined thickness of the Burro Canyon and the Dakota is 67-73 m, of which the Burro Canyon makes up 18-24 m. Most regional studies (Young, 1960; McGookey and others, 1972) show an area including the Aspen region where Burro Canyon or Cedar Mountain rocks are missing. On the south side of the Elk Mountains measured sections of the Dakota Sandstone range from 49 to $69 \mathrm{~m}$ (Vanderwilt, 1937; F. E. Mutschler, written commun., 1970; D. L. Gaskill, written commun., 1968), but no Burro Canyon is definitely recognized. In the southwestern part of the Maroon Bells quadrangle, the Dakota is about $44 \mathrm{~m}$ thick, and no Burro Canyon was recognized. Whether the Burro Canyon is absent in those areas because of nondeposition or because of subsequent erosion is unknown. Farther south along the Gunnison River near the Black Canyon, Hansen (1971) mapped about $60 \mathrm{~m}$ of combined Burro Canyon and Dakota. To the west on the White River near Glenwood Springs, Bass and Northrop (1963) mapped $45 \mathrm{~m}$ of undifferentiated Dakota. However, just $8 \mathrm{~km}$ north of the Highland Peak quadrangle, Freeman (1972a) mapped $69 \mathrm{~m}$ of Burro Canyon and $60 \mathrm{~m}$ of Dakota Sandstone for a total thickness of $129 \mathrm{~m}$, almost double that of the Aspen area. Perhaps this unusual thickness for this region represents the filling of a former valley. This hypothesis is supported by a somewhat thinner Morrison section there than several kilometers to the south.

The Burro Canyon Formation was deposited in a continental environment by streams flowing from the west. The predominance of sandstones compared to the underlying Morrison Formation suggests some uplift to the west. However, the source area consisted of sedimentary rock for the most part. The debris was transported a considerable distance so that only resist- 
ant materials survived. The Dakota Sandstone was deposited in a marginal marine environment as offshore bars, beaches, and lagoonal and swamp deposits, as the sea encroached from the north.

\section{MANCOS SHALE}

The Mancos Shale (Cross, 1899) underlies the sagebrush and scrub-oak-covered hills in the northern part of the Highland Peak quadrangle (fig. $33 B$ ) and the valley of the Roaring Fork west of Red Butte. It also occupies the lower slopes in the upper part of the Owl Creek and Brush Creek drainages to the south where it is covered by surficial deposits in many areas. Spurr (1898) mapped these rocks as the Colorado and Montana Formations. In the present study the Mancos Shale was mapped as three units: a thin lower shale member, the Fort Hays Limestone Member, and a thick upper shale member.

The lower shale member of the Mancos consists of dark-gray silty shale and thin beds of gray siltstone and fine-grained sandstone. The siltstone and finegrained sandstone beds are numerous in the Mancos where it grades into the underlying Dakota Sandstone. Near the top are several beds of fossiliferous calcarenite that has a fetid odor when broken. This horizon is partly equivalent to the Juana Lopez Member of the Mancos in the San Juan Basin (Rankin, 1944; Dane and others, 1966). This fossiliferous zone has been recognized southwest of the Aspen area by D. L. Gaskill and F. E. Mutschler (written commun., $1968 ; 1970$ ), where it contains fossils typical of the type locality and the upper part of the reference section of the Juana Lopez described by Dane and others (1966). A few 1-4-cm bentonite beds are exposed in the lower member of the Mancos. However, the exposures of this stratigraphic interval are rather poor because so much of it forms a north-facing heavily vegetated dip slope partly covered with surficial deposits. One of the better places to see part of the interval is near the 2,769-m shoulder at the head of Sterner Gulch in the Aspen quadrangle. The lower member of the Mancos is about $122 \mathrm{~m}$ thick.

The Fort Hays Limestone Member of the Mancos forms the most distinctive lithologic marker in the formation. In many places it forms small ledges or cuestas that protrude through surficial deposits and above the less resistant shale of the Mancos. It is well exposed on lower Maroon Creek, on the west ridge of Red Butte, and on Owl Creek. The Fort Hays consists of light-gray-weathering dark-gray limestone in beds 0.3-0.6 m thick. It contains interbeds of shaly limestone. Fossils are locally abundant. The most spectacular fossil is the pelecypod Inoceramus deformis,
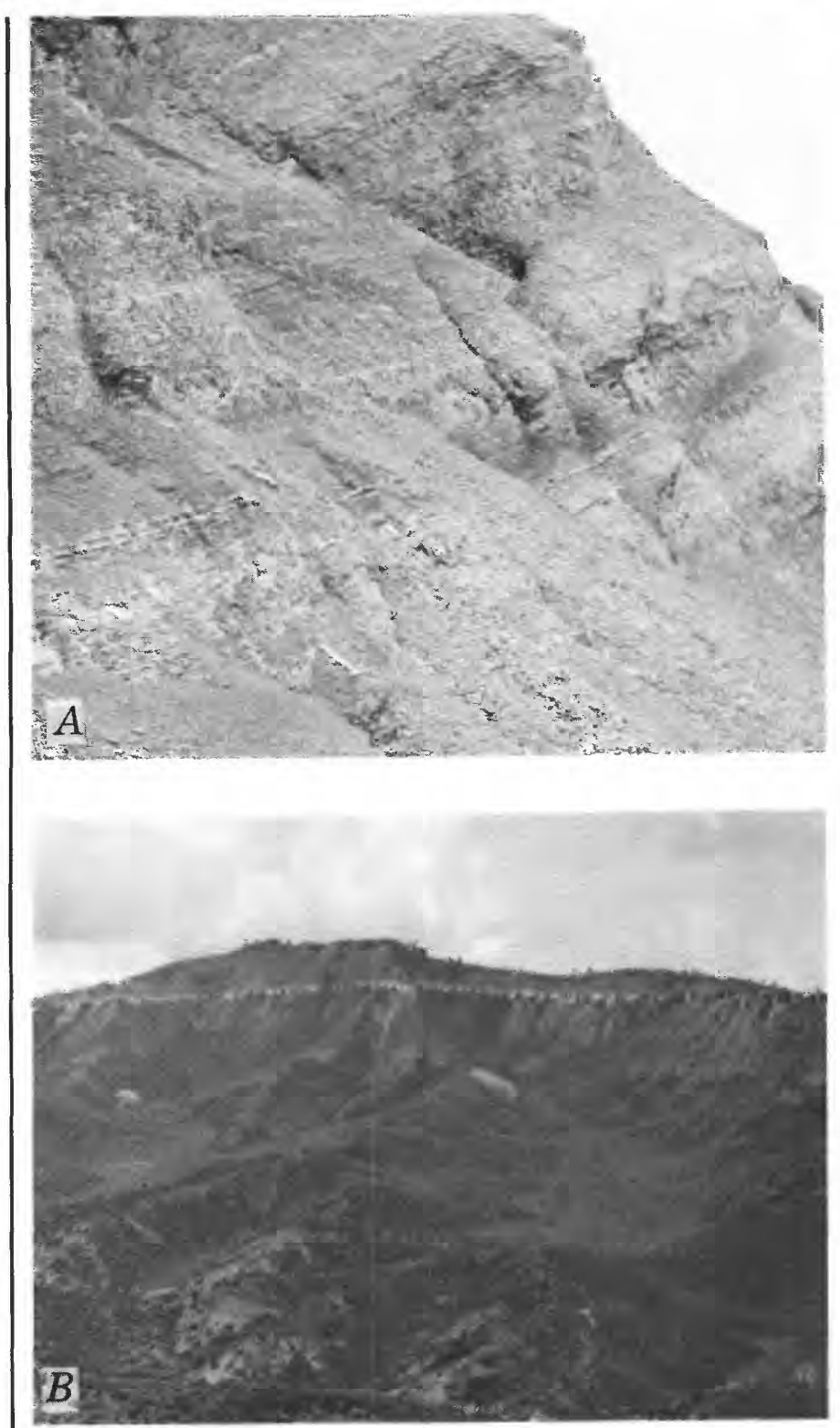

Figure 33.-Features of the Mancos Shale. $A$, Silty shale and shaly siltstone containing a few thin beds of fine-grained sandstone in the middle of the Mancos (Baculites perplexus zone). Cut along former Denver and Rio Grande Western Railroad, Aspen quadrangle. $B$, View north across Brush Creek valley from Cozy Point showing typical terrane of Mancos Shale on a south-facing slope at $2,440 \mathrm{~m}$ altitude and lower and the persistent sandstone bed about $12 \mathrm{~m}$ thick in the upper part of the Mancos, Highland Peak quadrangle.

measuring as much as $10 \mathrm{~cm}$ across. The Fort Hays as mapped is about $12 \mathrm{~m}$ thick. Both the overlying and underlying beds contain thinner limy beds; so the contacts are somewhat gradational, although the stratigraphic interval containing the thicker limestone beds is relatively well defined.

The upper shale member of the Mancos, about 1,450 
$m$ thick, including the uppermost part in the Woody Creek quadrangle (Freeman, 1972a), comprises most of the outcrop area of that formation; it is locally well exposed on south-facing slopes and gullies on the relatively low hills in the northern part of the Highland Peak quadrangle (fig. $33 B$ ). It is also locally well exposed along the Roaring Fork River and Colorado Highway 82. The upper member of the Mancos consists of dark-gray shale and silty shale, some shaly siltstone, and a few lenticular beds of fine- to mediumgrained olive-gray sandstone (fig. $33 A$ ). Some thinbedded shaly limestone occurs in the lower part, and a few beds of silty limestone and calcareous shale occur elsewhere in the upper member. Limestone concretions are abundant in places. Sandstone beds may be traced as much as $300 \mathrm{~m}$ along strike, and they reach a maximum thickness of $7.6 \mathrm{~m}$. They are thick to thin bedded, silty, and carbonaceous, and they contain plant fragments. In some places gradations to silty shale are exposed along their strike. About $1.2 \mathrm{~km}$ of the upper member is exposed in the Highland Peak quadrangle.

One sandstone bed in the upper part of the upper member of the Mancos was mapped separately. It crops out continuously for $1.6 \mathrm{~km}$ at the north edge of the Highland Peak quadrangle (fig. $33 B$ ), and it was identified in fault blocks on either side of that outcrop. It forms ledges and small cliffs and is about $12 \mathrm{~m}$ thick in its eastern exposures and $6 \mathrm{~m}$ thick in the most western exposures in the quadrangle. The sandstone is olive gray and contains phosphatic nodules $1-3 \mathrm{~cm}$ in diameter at its top.

The sandstones of the Mancos are generally fine grained, silty, and calcareous, and they grade into siltstone and shale. They typically contain angular to subangular quartz grains $0.05-0.4 \mathrm{~mm}$ in diameter. Feldspar, predominantly plagioclase, constitutes about 10 percent of the sandstone. Clastic grains of biotite and muscovite comprise as much as a few percent of the rock. Chert grains of the same size as the quartz and feldspar grains make up 5-15 percent of the rock. Calcite as clastic grains and as interstitial material comprises a substantial proportion of some of the sandstones. Some also have clay in the matrix. The one sample studied from the mapped sandstone was relatively well sorted and lacked matrix and calcite. Opaque minerals, zircon, tourmaline, and chlorite are accessory minerals.

The marine Cretaceous rocks of the western interior of the United States have abundant fossils and characteristically contain distinctive, geologically short lived cephalopod faunas that are excellent time markers. Numerous fossil collections were made in the
Highland Peak quadrangle (table 4). These combined with more than 100 collections from the Woody Creek quadrangle (Freeman, 1972a) allowed us to correlate the mapped sandstone in the upper member of the Mancos in the various fault blocks and to determine the structure in the Mancos Shale. The stratigraphic section shown by Freeman (1972a) applies also to the Highland Peak quadrangle. The top of the section as exposed in the Highland Peak quadrangle occurs about at the top of the Exiteloceras jenneyi zone. None of the fossil collections in the Highland Peak quadrangle were from the Didymoceras nebrascense zone. However, the one Didymoceras stevensoni came from about $30 \mathrm{~m}$ below the mapped sandstone bed, suggesting the possibility of some overlap between the two zones.

In the Woody Creek quadrangle (Freeman, 1972a), a mappable sandstone occurs in the Baculites perplexus zone. At Cozy Point and along the ridge to the west in the Highland Peak quadrangle are one or more sandstones at about the same stratigraphic level. Faults, some of which may be unmapped, and stratigraphic pinchouts make it uncertain whether the sandstones exposed are all the same, although they probably represent the sandy zone shown on Freeman's section. Other discontinuous sandstones occur in or near the Baculites perplexus zone on the hills near the head of Wildcat Creek.

The mapped sandstone that lies within the Didymoceras stevensoni zone is at the same stratigraphic horizon as a thin sandstone at Thompson Creek $32 \mathrm{~km}$ west of the Aspen area. That horizon has been correlated with the Cozzette Member of the Nelsen facies of the Price River Formation (Young, 1955; Zapp and Cobban, 1960; Warner, 1964). A sandstone at a similar stratigraphic position occurs on the south side of the Elk Mountains (D. L. Gaskill, written commun., 1968). This sandstone was probably deposited in an offshore marine environment during regression of the Cretaceous sea. According to Warner (1964), the seaward limit of nonmarine deposits of the Cozzette Member was about $56 \mathrm{~km}$ northwest of the Aspen region. This sandstone probably represents an initial stage of the late Campanian regression (Haun and Weimer, 1960) of the sea designated $R_{3}$ by Weimer (1960). The sandstone in the Aspen area appears to pinch out to the northwest (Freeman, 1972a); so it may be an offshore bar separate from but the same age as the Cozzette.

The sandstone mapped as Mesaverde(?) Formation by Freeman (1972a) in the Woody Creek quadrangle lies at least one and perhaps as much as three zones 
TABLE 4.-Fossils in the Mancos Shale

[Numbers are U.S. Geological Survey Mesozoic locality numbers, shown in Bryant (1971a, 1972a); all identifications by W. A. Cobban. Leaders (--) indicate not present]

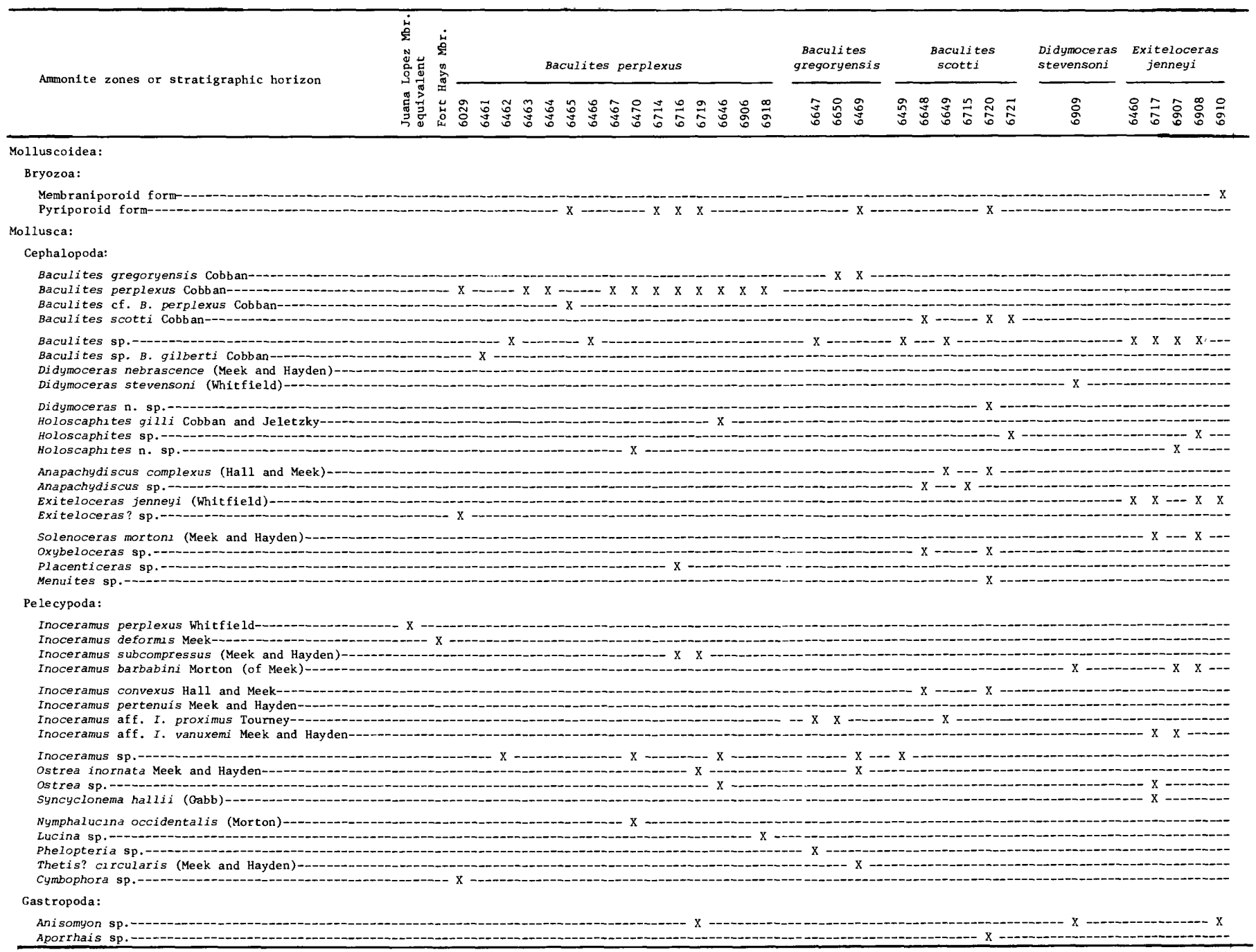

above Exiteloceras jenneyi (W. A. Cobban, written commun., 1968). It is probably about the same age as the Rollins Sandstone Member, the basal member of the Mount Garfield Formation of the Mesaverde Group $32 \mathrm{~km}$ west of Aspen, but whether that sandstone is marine or nonmarine in the Woody Creek quadrangle is uncertain because of limited exposures.

$\mathrm{K}$-Ar dating of tuffaceous beds in the marine Upper Cretaceous rocks of the Western Interior has shown that each of the cephalopod zones lasted 0.5-1 m.y. (Gill and Cobban, 1966). The Baculites perplexus zone occupies about $550 \mathrm{~m}$ stratigraphically in the Aspen area; whereas the Baculites scotti zone occupies only about $122 \mathrm{~m}$. This suggests that much more rapid deposition took place during the life range of Baculites perplexus 76.5-77.5 m.y. ago than at other times during the Upper Cretaceous in this area. The estimated age of the base of the Fort Hayes Member is $86 \mathrm{~m} . \mathrm{y}$. ago (Gill and Cobban, 1966). Only about $300 \mathrm{~m}$ of sediments were deposited during the 9.5-m.y. time interval from then to the beginning of the Baculites perplexus zone.

Exiteloceras jenneyi is estimated to have lived 72 m.y. ago (Obradovich and Cobban, 1975; Dickinson and others, 1968). The lack of diagnostic fossil collections above this zone hinders a definite statement concerning the time of deposition of the youngest marine rocks preserved in the Aspen region, but a million or two million years later than the lifetime of $E x$ iteloceras jenneyi seems reasonable for the age of the 
youngest rocks preserved. However, marine sedimentation may have reoccurred after that time, for two tongues of Mancos marine shale occur in the Mesaverde section on North Thompson Creek about 60 and $180 \mathrm{~m}$ above the base of the lowest persistent sandstone (Donnell, 1959). That sandstone probably correlates with the stratigraphically highest sandstone preserved in the Aspen region.

\section{LARAMIDE IGNEOUS ROGKS}

In the Late Cretaceous, or possibly early Paleocene, sills and dikes of hornblende quartz diorite, quartz porphyry, aplite, and aplite porphyry intruded near the margin of the Sawatch Range in the Aspen and Hayden Peak quadrangles. K-Ar ages of micas from two of these rocks gave ages ranging from 67 to $72 \pm 2$ m.y. (Obradovich and others, 1969). Spurr (1898) mapped only two varieties of igneous rocks in the Aspen quadrangle: the mafic type he called diorite porphyry, and the felsic type he called quartz porphyry. Knopf (1926) subdivided these rocks into the following units (equivalent units of this report in parentheses): diorite porphyry (quartz diorite); albite alaskite porphyry, containing phenocrysts of quartz and muscovite (quartz porphyry); albite aplite porphyry (aplite porphyry); and aplite (aplite).

Age relations between these rocks types are not well established. Knopf (1926) assumed that the quartz diorite was the oldest followed by the quartz porphyry, the aplite porphyry, and the aplite in that order. The only field relation between the rock types observed by Knopf was that the aplite cut the quartz porphyry in the Hope mine. I saw no well-defined age relations in the field, but K-Ar ages of $72 \pm 2$ m.y. of the quartz porphyry and of $70.0 \pm 2.3 \mathrm{~m} . \mathrm{y}$. and $67.4 \pm 2.2 \mathrm{~m} . \mathrm{y}$. of aplite agree with the field relations in the Hope mine.

The dominant mode of occurrence of these igneous rocks is as sills, which are cut by faults. However, the aplite and quartz porphyry body on the east side of Richmond Hill in the Hayden Peak quadrangle appears to have been emplaced along a fault. The aplite body along Castle Creek in the Hayden Peak quadrangle is shown in cross section $A-A$ of Bryant (1970) as occupying a fault because field evidence for faulting on its east contact was not found. Since that contact is not well exposed this judgment was based on float, and is thus subject to question: this aplite body could be a steeply dipping sill in the Belden Formation bounded by a fault on the east, like the sills along strike in the Aspen quadrangle to the north.

\section{HORNBLENDE QUARTZ DIORITE}

Most of the mapped hornblende quartz diorite occurs as sills. One thin sill on the north end of Aspen Mountain is near the base of the Sawatch Quartzite. A sill as much as $45 \mathrm{~m}$ thick on the top and west side of Richmond Hill is in the Manitou Dolomite and the Chaffee Group. The sill at the north edge of the Hayden Peak quadrangle is at the top of the Leadville Limestone, and it was encountered at that horizon in the Hope mine about $600 \mathrm{~m}$ below its outcrop, where it is about $45 \mathrm{~m}$ thick (Knopf, 1926). Some irregularities in the outcrop pattern of the hornblende quartz diorite east of the Midnight shaft suggest that some faults may have existed before its emplacement and exerted some influence on its shape. Sparse float suggests that thin discontinuous sills occur at intermediate stratigraphic positions between the ones on the north end of Aspen Mountain and Richmond Hill. These were shown as a thin continuous sill on Spurr's (1898) detailed maps and sections. A few small bodies of quartz diorite lie along faults; some of them are interpreted to be fault slices. Dikes of hornblende quartz diorite occur in the Precambrian rocks on Hunter Creek and Smuggler Mountain.

The hornblende quartz diorite forms a fairly thick soil and does not crop out well. One convenient place to see exposures of the rock is on the sharp corner of the Queens Gulch road at about $3,048 \mathrm{~m}$ altitude southwest of the Midnight tunnel.

The hornblende quartz diorite is a greenish-gray to bluish-gray porphyritic rock containing phenocrysts of chloritized hornblende as much as $5 \mathrm{~mm}$ long and of saussuritized plagioclase as much as $1 \mathrm{~mm}$ long in a fine-grained groundmass of quartz, albite, calcite, epidote, sericite, magnetite, and ilmenite. Apatite is a common accessory mineral. Sphene and allanite are less abundant. Some rocks of the unit have a substantial epidote content in place of calcite, and in some rocks epidote or aggregates of epidote form pseudomorphs after plagioclase phenocrysts. The shape of some of the smaller chlorite grains suggests that they may be after biotite. No outcrops of unaltered rock were seen.

Chemical analyses (table 5, col. 2) show that these rocks are fairly mafic quartz diorites. Where the $\mathrm{K}_{2} \mathrm{O}$ (which amounts to 2 weight percent) is located is uncertain; Spurr (1898) thought that some of the altered feldspar was orthoclase, but I could not identify any for certain. The $\mathrm{K}_{2} \mathrm{O}$ may be in fine-grained sericite or clay alteration products. Alteration might have changed the $\mathrm{K}_{2} \mathrm{O} / \mathrm{Na}_{2} \mathrm{O}$ ratios, but the analyses of the 
TABLE 5.-Chemical analysis, modes, and norms of Laramide ig. neous rocks

[Major oxides determined by rapid methods by P. L. D. Elmore, G. W. Chloe, Hezekiah Smith, Lowell Artis, J. L. Glenn, James Kelsey, and Samuel Botts, U.s. Geological Survey, 1967 and 1969. Minor elements determined by semiquantitative spectrographic methods by Joseph L. Harris, U.S. Geological Survey, 1967, and William B. Crandell, U.S. Geological Survey, 1968. Mode by point count; P, present but not intersected in counting. Major oxides and ClPW norms in weight percent; mode in volume percent. (1), rock too fine grained to count, ClPW norms calculated on basis of analyses recalculated to 100 percent after deduction of volatiles. Results for minor elements are reported in parts per million to the nearest number in the series $100,70,50,30,20,15$, and $10, \ldots$, which represent approximate midpoints of interval data on a geometric scale. The assigned interval for semiquantitative results will include the quantitative value about 30 percent of the time. N, not detected; leaders (--), absent. Looked for but not found:

\begin{tabular}{|c|c|c|c|c|c|c|c|}
\hline 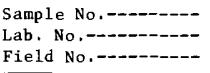 & $\begin{array}{c}1 \\
W 171459 \\
2060\end{array}$ & $\begin{array}{c}2 \\
W 171457 \\
1184\end{array}$ & $\begin{array}{c}3 \\
w 171456 \\
1560\end{array}$ & $\begin{array}{c}4 \\
\text { W1 } 11455 \\
\text { HNMP }\end{array}$ & $\begin{array}{c}5 \\
\text { W168735 } \\
1175\end{array}$ & $\begin{array}{c}6 \\
w 171458 \\
2059\end{array}$ & $\begin{array}{c}7 \\
w 168734 \\
1045\end{array}$ \\
\hline $\mathrm{SiO}_{2}$ & 51.9 & 54.1 & 67.7 & 69.2 & 72.4 & 72.4 & 73.4 \\
\hline $\mathrm{Al}_{2} \mathrm{O}_{3}$ & 16.4 & 15.6 & 15.9 & 16.2 & 14.8 & 15.4 & 14.7 \\
\hline $\mathrm{Fe}_{2} \mathrm{O}_{3}$ & 5.2 & 3.1 & 2.3 & 1.3 & .55 & .67 & .87 \\
\hline Fe0-C- & 5.7 & 5.0 & .40 & .20 & .78 & .48 & .48 \\
\hline Mg0----- & 4.1 & 2.8 & .35 & .25 & .23 & .14 & .15 \\
\hline $\mathrm{CaO}-\mathrm{C}$ & 5.1 & 5.9 & 2.4 & 2.5 & 2.1 & 1.3 & 1.9 \\
\hline $\mathrm{Na}_{2} \mathrm{O}$ & 3.0 & 2.9 & 4.1 & 3.4 & 3.2 & 3.4 & 2.9 \\
\hline $\mathrm{K}_{2} \mathrm{O} \cdots$ & 2.0 & 1.9 & 2.5 & 2.7 & 3.7 & 4.2 & 3.4 \\
\hline $\mathrm{H}_{2} \mathrm{O}^{-}-$ & .20 & .19 & .15 & .43 & .33 & .11 & .44 \\
\hline $\mathrm{H}_{2} \mathrm{O}^{+} \ldots$ & 3.3 & 2.7 & 1.1 & 1.3 & .65 & 1.0 & .56 \\
\hline $\mathrm{TiO}_{2} \cdots$ & 1.5 & 1.0 & .15 & .03 & .12 & .10 & .12 \\
\hline $\mathrm{P}_{2} \mathrm{O}_{5} \ldots$ & .58 & .56 & .07 & .04 & .18 & .03 & .18 \\
\hline MnO-- & .21 & .17 & .09 & .03 & .03 & .14 & .12 \\
\hline $\mathrm{CO}_{2}-\cdots----$ & .09 & 3.1 & 2.0 & 1.6 & .05 & .50 & $<.05$ \\
\hline Bulk density------ & 2.76 & 2,77 & 2.68 & 2.62 & 2.62 & 2.58 & 2.61 \\
\hline Powder density--.-- & 2.84 & 2.84 & 2.72 & 2.70 & 2.68 & 2.70 & 2.65 \\
\hline \multicolumn{8}{|c|}{ Minor elements } \\
\hline B--- & $N$ & $N$ & $\mathrm{~N}$ & 50 & $\mathrm{~N}$ & $\mathrm{~N}$ & $\mathrm{~N}$ \\
\hline 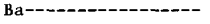 & 1,000 & 1,000 & 500 & 70 & 1,000 & 3,000 & 1,000 \\
\hline Be-- & N & N & 1 & 1.5 & 1 & 2 & 1 \\
\hline Co--------- & 30 & 15 & $\mathrm{~N}$ & $\mathrm{~N}$ & $\mathrm{~N}$ & $\mathrm{~N}$ & $\mathrm{~N}$ \\
\hline 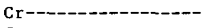 & $\mathrm{N}$ & 50 & $\mathrm{~N}$ & 30 & $\mathrm{~N}$ & 7 & $\mathbf{N}$ \\
\hline Cu--_- & 20 & 3 & 10 & 70 & 2 & 1.5 & 1 \\
\hline 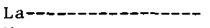 & 70 & 70 & 50 & $\mathrm{~N}$ & $\mathrm{~N}$ & $\mathrm{~N}$ & $\mathrm{~N}$ \\
\hline Mo---_- & 5 & 5 & $\mathbf{N}$ & $\mathrm{N}$ & $\mathrm{N}$ & $\mathrm{N}$ & 3 \\
\hline Nb----1-- & 7 & 7 & 10 & 15 & 10 & 10 & 10 \\
\hline Ni-_-_._. & 5 & 20 & N & 20 & $\mathrm{~N}$ & $\mathrm{~N}$ & $\mathrm{~N}$ \\
\hline 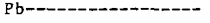 & 70 & 5 & 7 & 20 & 10 & 30 & 7 \\
\hline Sc-- & 20 & 20 & $\mathrm{~N}$ & $\mathrm{~N}$ & $\mathrm{~N}$ & $\mathrm{~N}$ & 3 \\
\hline Sr--.-- & 1,500 & 1,000 & 500 & 300 & 300 & 1,500 & 300 \\
\hline 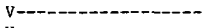 & 200 & 150 & 7 & N & 7 & $\mathrm{~N}$ & 7 \\
\hline Y----------------- & 30 & 30 & 15 & 15 & 20 & 20 & 20 \\
\hline Zr- & 150 & 200 & 150 & 50 & 50 & 70 & 50 \\
\hline 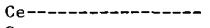 & 100 & 100 & $\mathrm{~N}$ & $\mathrm{~N}$ & $\mathbf{N}$ & $\mathrm{N}$ & $\mathrm{N}$ \\
\hline $\mathrm{Ga}=-$ & 20 & 20 & 20 & 30 & 10 & 20 & 10 \\
\hline Yb--- & 3 & 3 & 1.5 & 1.5 & 1.5 & 2 & 2 \\
\hline \multicolumn{8}{|c|}{ Modes } \\
\hline Quartz---_-_--- & 1.1 & 15.8 & 34.5 & (1) & 37.4 & (1) & 38.0 \\
\hline Plagíoclase------ & 46.5 & 37.7 & 18.3 & -- & 29.6 & --- & 30.3 \\
\hline Potassic feldspar-- & --- & $\cdots$ & 17.5 & -- & 27.5 & --- & 25.5 \\
\hline Biotite---_- & -- & -- & --- & -- & .3 & --- & 2.5 \\
\hline Muscovite--------- & --- & 7.0 & 17.0 & --- & 1.9 & -- & 2.8 \\
\hline Chlorite-------- & 19.2 & 20.3 & -- & --- & 2.7 & -- & .1 \\
\hline Epidote---------- & 25.5 & 3.2 & --- & --- & .5 & --- & --- \\
\hline Opaque--_-_.-- & 7.7 & 5.2 & 1.9 & -- & .1 & -- & .8 \\
\hline Allanite--- & --- & P & $\cdots$ & --- & $\mathbf{P}$ & -- & --- \\
\hline Carbonate---------- & --- & 10.8 & 10.7 & -- & -- & --- & --- \\
\hline Zircon--- & --- & -- & .1 & --- & -- & -- & -- \\
\hline Sphene------- & $\mathrm{P}$ & $\mathrm{P}$ & -- & --- & -- & -- & -- \\
\hline Apatite--- & -- & $\mathrm{P}$ & $-\cdots$ & --- & -- & --- & --- \\
\hline \multicolumn{8}{|c|}{ Norm } \\
\hline Q-- & 9.96 & 11.05 & 30.03 & 34.92 & 35.59 & 34.04 & 40.37 \\
\hline C-- & 1.48 & $\cdots$ & 2.35 & 3.38 & 2.19 & 3.02 & 3.28 \\
\hline or-ar-ar & 12.35 & 12.43 & 15.40 & 16.65 & 22.29 & 25.26 & 20.46 \\
\hline $\mathrm{Ab}-\cdots$ & 26.52 & 27.17 & 36.15 & 30.02 & 27.61 & 29.28 & 24.98 \\
\hline 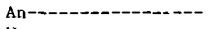 & 22.48 & 26.50 & 11.93 & 12.67 & 9.42 & 6.37 & 8.40 \\
\hline 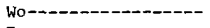 & -- & .77 & -- & --- & --- & --- & --- \\
\hline En--_- & 10.67 & 7.72 & .91 & .65 & .58 & .36 & .38 \\
\hline Fs-- & 4.27 & 5.85 & -- & --- & .85 & .43 & .19 \\
\hline Mt-- - & 7.88 & 4.98 & 1.20 & .68 & .81 & .99 & 1.28 \\
\hline Hm-...-- & --- & $\cdots$ & 1.57 & .89 & --- & --- & -- \\
\hline 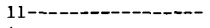 & 3.98 & 2.10 & .30 & .06 & .23 & .19 & .23 \\
\hline Ap-- & 1.44 & 1.47 & .17 & .10 & .44 & .07 & .43 \\
\hline 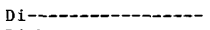 & --- & 1.52 & $\cdots$ & --- & --- & -- & -- \\
\hline Di-Wo---- & --- & .77 & --- & --- & -- & --- & -- \\
\hline Di-En---------- & -- & .42 & -- & --- & --- & --- & -- \\
\hline Di-Fs---- & --- & .32 & $\cdots$ & --- & --- & -- & -- \\
\hline Нy- --- & & & & .65 & 1.44 & .79 & .57 \\
\hline Hy-En--- & 10.67 & 7.30 & .91 & .65 & .58 & .36 & .38 \\
\hline Hy-Fs--- & 4.27 & 5.53 & --- & -- & .85 & .43 & .19 \\
\hline
\end{tabular}

TABLE 5.-Chemical analysis, modes, and norms of Laramide igneous rocks-Continued

\begin{tabular}{|c|c|c|c|c|c|c|c|}
\hline $\begin{array}{l}\text { Sample No.-- } \\
\text { Lab. No, } \\
\text { Field No. }\end{array}$ & $\begin{array}{c}1 \\
w 171459 \\
2060\end{array}$ & $\begin{array}{c}2 \\
w 171457 \\
1184\end{array}$ & $\begin{array}{c}3 \\
1171456 \\
1560\end{array}$ & $\begin{array}{l}4 \\
\text { W171455 } \\
\text { HNMP }\end{array}$ & $\begin{array}{c}5 \\
\text { W168735 } \\
1175\end{array}$ & $\begin{array}{c}6 \\
W 171458 \\
2059\end{array}$ & $\begin{array}{c}7 \\
w 168734 \\
1045\end{array}$ \\
\hline \multicolumn{8}{|c|}{ Recalculated to 100 percent after deduction of $\mathrm{H}_{2} \mathrm{O}$ and $\mathrm{CO}_{2}$} \\
\hline $\mathrm{SiO}_{2}-\cdots$ & 54.24 & 56.90 & 70.55 & 72.20 & 73.81 & 73.68 & 74.73 \\
\hline $\mathrm{Al}_{2} \mathrm{O}_{3}$ & 17.14 & 17.27 & 16.57 & 16.90 & 15.09 & 15.67 & 14,97 \\
\hline $\mathrm{Fe}_{2} \mathrm{O}_{3}$ & 5.43 & 3.43 & 2.40 & 1.36 & .56 & .68 & .89 \\
\hline $\mathrm{Fe} 0-\cdots-1$ & 5.96 & 5.54 & .42 & .21 & .80 & .49 & .49 \\
\hline Mg0-----D--------- & 4.28 & 3.10 & .36 & .26 & .23 & .14 & .15 \\
\hline $\mathrm{CaO}--$ & 5.33 & 6.53 & 2.50 & 2.61 & 2.14 & 1.32 & 1,93 \\
\hline $\mathrm{Na}_{2} \mathrm{O}---$ & 3.14 & 3.21 & 4.27 & 3,55 & 3.26 & 3.46 & 2.95 \\
\hline $\mathrm{K}, \mathrm{O}-$ & 2.09 & 2.10 & 2.61 & 2.82 & 3.77 & 4.27 & 3.46 \\
\hline$a_{2}-\cdots+\cdots$ & & 1.11 & .16 & .03 & .12 & .10 & .12 \\
\hline 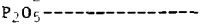 & .61 & .62 & .07 & .04 & .18 & .03 & .18 \\
\hline Uno-- & .22 & .19 & .09 & .03 & .03 & .14 & .12 \\
\hline
\end{tabular}

SAMPLE DESCRIPTIONS

1. Altered andesite. Plagioclase laths as much as $0.6 \mathrm{~mm}$ long in a matrix of chlorite, epidote, sphene, and opaque mineral. From dike- Correlated with hornblende quartz diorite of Aspen mining district. On ridge $960 \mathrm{~m}$ north of hil1 10977 northeast of Warren Lake. Aspen quadrangle.

2. Greenish-gray fine-grained rock containing hornblende phenocrysts as much as $5 \mathrm{~mm}$ long pseudomorphosed by chlorite. Saussuritized phenocrysts of plagioclase as much as $0.6 \mathrm{~mm}$ long, anhedral quartz 0.08 to $0.25 \mathrm{~mm}$ in diameter. Hornblende
quartz diorite sill on west side of Richmond Hill. From prospect pit at $3,444 \mathrm{~m}$ altitude $550 \mathrm{~m} \mathrm{~N} .35^{\circ} \mathrm{E}$. of the Midnight shaft, Aspen quadrangle.

3. Gray fairly fine grained rock containing greenish feldspar phenocrysts as much as $5 \mathrm{~mm}$ long and some pyrite. Sericitized subhedral plagioclase phenocrysts, quartz in groundmass as much as $0.3 \mathrm{~mm}$ in diameter, euhedral to subhedral phenoFrom cut in old mine road at $2,877 \mathrm{~m}$ just east of crest of ridge between Pioneer and Vallejo Gulches. Aspen quadrangle.

4. Fine-grained white rock containing phenocrysts of muscovite and quartz. Subhedral to euhedral phenocrysts of plagioclase as much as $1.5 \mathrm{~mm}$ long altered to albite; euhedral phenocrysts of quartz as much as $1.5 \mathrm{~mm}$ in diameter showing some resorption; euhedral phenocrysts of muscovite as much as $3 \mathrm{~mm}$ in diameter in a matrix of quartz and feldspar. Quartz porphyry of Little Annie sill. quadrangle. Muscovite dates as $72.2+2.2 \mathrm{~m} . \mathrm{y}$. (Obout $2,652 \mathrm{~m}$ altitude, Aspen

5. Fine-grained gray rock containing darker gray patches. Plagioclase as subhedral phenocrysts as much as $0.6 \mathrm{~mm}$ long (composition An 58 to An43) and as laths of albite in the groundmass: quartz $0.1-0.3 \mathrm{~mm}$ in diameter with blocky outlines; interstitial potassic feldspar $0.1-0.3 \mathrm{~mm}$. Dike of aplite, east side of Castle Creek. From 2,926 m altitude $1,160 \mathrm{~m} \mathrm{~N}$. $20^{\circ} \mathrm{w}$. from junction of Sawyer Creek and Castle Creek, Hayden Peak quadrangle.

6. Fine-grained light-gray rock with a few scattered phenocrysts of feldspar and quartz. Euhedral phenocrysts of plagioclase as much as $1.5 \mathrm{~mm}$ long (An40), partly altered; few phenocrysts of quartz with a round outline, chlorite af ter biotite; groundmass of feldspar, quartz, sericite, calcite, and opaque mineral. Dike correlated with aplite porphyry of the Aspen mining district. From crest
of ridge $275 \mathrm{~m} \mathrm{~S}$. $15^{\circ} \mathrm{E}$. of hill 10977 northeast of Warren Lake, Aspen quadrangle.

- Gray fine-grained rock containing phenocrysts of biotite. Euhedral to subhedral phenocrysts and glomerophenocrysts of plagioclase as much as $1 \mathrm{~mm}$ in diameter (An 45-52) and lath-shaped groundmass grains of albite; euhedral phenocrysts of biotite as much as $1 \mathrm{~mm}$ in diameter; groundmass of plagioclase, potassic feldspar, quartz, and muscovite with a grain size of $0.04-0.2$ mam. Dike of aplite. From east side of top of 3,418-m shoulder on west side of the head of McFarlane Creek. Hayden Peak quadrangle. Two separate biotite concentrats
gave ages of $70.0+2.3 \mathrm{~m} . \mathrm{y}$. and $67.4 \pm 2.2 \mathrm{~m} . \mathrm{y}$. (Obradovich and others, 1969).

more silicic altered rocks do not suggest that. The hornblende quartz diorite of the Aspen area does not conveniently fit the usual classifications because of the high $\mathrm{K}_{2} \mathrm{O}$ content in relation to low $\mathrm{SiO}_{2}$ and high $\mathrm{Fe}$ content.

\section{QUARTZ PORPHYRY}

Quartz porphyry was mapped along the Castle Creek fault zone in the southern part of the Aspen quadrangle and in the northern part of the Hayden Peak quadrangle. It is part of an irregular sill in the lower part of the Belden Formation. These relations are well exposed in the Hope mine and Midnight tunnel 
(Knopf, 1926), and in the Highland tunnel. In the Highland tunnel and on the surface to the south, that sill splits into two or more sills. The quartz porphyry on Richmond Hill in the Hayden Peak quadrangle appears to occupy a fault, since neither side is concordant with the sedimentary rocks, which are displaced across the intrusive. Small cross-cutting bodies were mapped outside the main porphyry belt about $1.5 \mathrm{~km}$ south of the portal of the Hope tunnel, a concordant body in the fault block south of Fall Creek, and a dike southeast of Ashcroft Mountain. Quartz porphyry crops out on the road southeast of the Midnight tunnel at $3,280 \mathrm{~m}$ altitude and on the road northwest of the Hope mine at $2,990 \mathrm{~m}$.

The quartz porphyry is white to light gray and contains conspicuous euhedral phenocrysts of quartz, and locally, muscovite $2.5 \mathrm{~mm}$ in diameter and inconspicuous phenocrysts of plagioclase $0.5-2 \mathrm{~mm}$ in diameter in a groundmass of quartz, feldspar, and, in places, sericite $0.02-0.2 \mathrm{~mm}$ in diameter (fig. $34 A$ ). Some of the quartz phenocrysts are embayed, suggesting partial resorption by the magma after their formation. The plagioclase phenocrysts are altered to albite. Calcite occurs in veinlets and in the groundmass. Pyrite is disseminated in much of the altered rock. The dikes and small intrusives are less altered than the larger bodies. In addition to quartz phenocrysts, they contain very sparse biotite phenocrysts in a very fine grained groundmass. The dike southeast of Ashcroft Mountain has unaltered phenocrysts of plagioclase with $\mathrm{An}_{28}$ composition. The small intrusives mapped south of the Hope mine contain a few phenocrysts of potassic feldspar.

\section{APLITE}

Aplite was mapped principally in the northern part of the Hayden Peak quadrangle where it occurs along a fault on the east side of Richmond Hill and as sills in the lower part of the Belden Formation. It also occurs as dikes on Smuggler Mountain. Aplite forms ledges on the lower east side of Castle Creek north of Fall Creek in the Hayden Peak quadrangle.

The aplite is a white to gray fine-grained rock having a grain size of $0.1-0.3 \mathrm{~mm}$. It consists of somewhat blocky quartz and laths of plagioclase with interstitial potassic feldspar. The plagioclase is albite. A few phenocrysts of unaltered plagioclase with a composition of $\mathrm{An}_{43-58}$ are as much as $1 \mathrm{~mm}$ long (fig. $34 B$ ). Euhedral phenocrysts of biotite as much as $1 \mathrm{~mm}$ long occur sparsely in places. Muscovite, opaque minerals, zircon, allanite epidote, chlorite, and calcite are accessory minerals.

\section{APLITE PORPHYRY}

The aplite porphyry occurs as a sill in the lower part of the Belden Formation in the syncline south of the city of Aspen. A fault slice probably derived from the same sill occurs on the ridge north of Queen's Gulch. This sill is at least a hundred meters thick on the lower part of Aspen Mountain but thins to the north. It extends beneath the valley of the Roaring Fork River and is cut off by a fault in the mine workings under Smuggler Mountain (Spurr, 1898). Possible feeder dikes for this sill are found on the surface and in mine workings (Spurr, 1898) at about $2,850 \mathrm{~m}$ altitude on the ridge west of Spar Gulch and on Smuggler Mountain. Dikes mapped in the Precambrian rocks on Smuggler Mountain were also included in this unit.

The aplite porphyry is a very light gray to lightgreenish-gray rock containing phenocrysts of sericitized plagioclase as much as $3 \mathrm{~mm}$ in diameter. The only unaltered phenocrysts found were from the dikes on Smuggler Mountain, and they have a composition $\mathrm{An}_{30-40}$. Quartz usually occurs as grains $0.1-0.3 \mathrm{~mm}$ in diameter in the groundmass, but a few phenocrysts 1-2 $\mathrm{mm}$ in diameter occur locally. The quartz tends to be in blocky subhedral grains (fig. 34C). Plagioclase laths and interstitial potassic feldspar complete the matrix. Sericite and calcite are common alteration products. Pyrite and zircon are accessory minerals.

\section{COMPOSITION}

Since the textural varieties of the felsic porphyries overlap in chemical and mineralogic composition, they will be discussed together. Among the analyzed samples, the degree of alteration is quite varied, as indicated by the varied contents of $\mathrm{CO}_{2}$ and $\mathrm{H}_{2} \mathrm{O}+$. The degree of alteration does not appear to have drastically affected the contents of $\mathrm{CaO}, \mathrm{Na}_{2} \mathrm{O}, \mathrm{K}_{2} \mathrm{O}, \mathrm{MgO}$, and total $\mathrm{Fe}$ in these rocks. (Compare samples 3 and 4 with 5 , table 5.)

These rocks all have a low content of $\mathrm{MgO}$ and total Fe. They are light colored because of the scarcity of mafic minerals in them. Their total alkali content and the ratio between $\mathrm{Na}_{2} \mathrm{O}$ and $\mathrm{K}_{2} \mathrm{O}$ are similar to those of granodiorite, but their $\mathrm{CaO}$ content is lower than most granodiorites. Normative and modal quartz are high for rocks of similar modal plagioclase and normative An content.

Modally, these rocks are leucocratic quartz mon- 

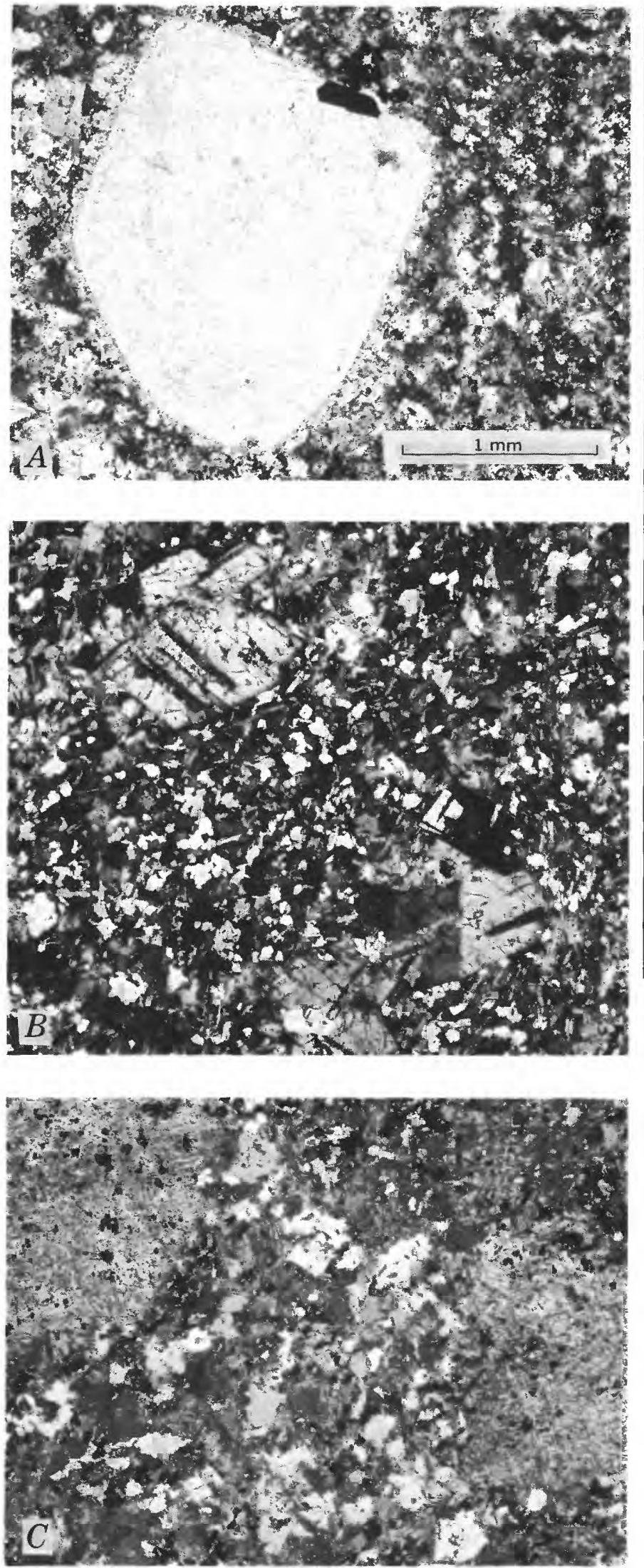

zonites. Chemically, they are granodiorite and quartz monzonite judging by proportions of $\mathrm{CaO}, \mathrm{Na}_{2} \mathrm{O}$, and $\mathrm{K}_{2} \mathrm{O}$ compared with Nockolds' (1954) averages. However, $\mathrm{MgO}$ and total $\mathrm{Fe}$ are lower than for such rocks. In the AlkFM diagram (Alk, $\mathrm{K}_{2} \mathrm{O}+\mathrm{Na}_{2} \mathrm{O} ; \mathrm{F}$, $\mathrm{FeO}+2 \mathrm{Fe}_{2} \mathrm{O}_{3}+\mathrm{MnO} ; \mathrm{M}, \mathrm{MgO}$ ) (fig. $35 A$ ), these rocks are lie near the Alk corner; in the ACF diagram (A, excess $\mathrm{Al}_{2} \mathrm{O}_{3}$ over that used for feldspar plus ferric iron; $\mathrm{C}, \mathrm{CaO} ; \mathrm{F}$, ferromagnesian oxides) (fig. $35 B$ ), they lie near the $\mathrm{AC}$ line; and in the AFK diagram (A, $\mathrm{Al}_{2} \mathrm{O}_{3}+\mathrm{Fe}_{2} \mathrm{O}_{3}-\left(\mathrm{CaO}+\mathrm{Na}_{2} \mathrm{O}+\mathrm{K}_{2} \mathrm{O}\right) ; \mathrm{K}, \mathrm{K}_{2} \mathrm{O} ; \mathrm{F}$, $\mathrm{MgO}+\mathrm{FeO}+\mathrm{MnO}$ ) (fig. $35 \mathrm{C}$ ) they lie near the $\mathrm{AK}$ line.

Few quantitative data are available from dated Laramide intrusives in adjacent areas. In the Leadville district $48 \mathrm{~km}$ to the east, all the porphyries are felsic, and a number of varieties have been recognized (Emmons, 1886; Emmons and others, 1927; Tweto, 1960). At Leadville as well as at Aspen most of the porphyry is altered so it is difficult to obtain comparable analyses. The light-colored porphyries of the Aspen district are most similar chemically and petrographically to the Pando Prophyry of the Leadville district, formerly White and Mount Zion Porphyries, both terms now abandoned in preference to the name Pando, which has been dated as 70 m.y. old (Emmons, 1886; Pearson and others, 1962).

About $60 \mathrm{~km}$ southeast of Aspen in the Garfield quadrangle are a number of intrusive rocks. The bulk of them comprise an igneous complex, and Mount Princeton batholith, which cuts the faults at the margin of the Sawatch Range (Dings and Robinson, 1957) and is probably mid-Tertiary, late Eocene and early Oligocene in age (Steven, 1975). The oldest rock

FIGURE 34 (left).-Photomicrographs of Laramide igneous rocks; all viewed through crossed nicols; all at same scale. $A$, Quartz porphyry from $1,681 \mathrm{~m}$ inside portal of Highland tunnel, Aspen quadrangle. Part of irregular sill in Richmond Hill mining district emplaced earlier than much of or all of the faulting along the Castle Creek fault zone. Euhedral phenocryst of quartz with somewhat rounded edges in a matrix of albite, quartz, and sericite. Also contains phenocrysts of plagioclase not shown. $B$, Aplite from hill 11212 on east side of Richmond Hill, Hayden Peak quadrangle. Intrusive apparently emplaced along a fault related to the Castle Creek fault zone. Inconspicuous phenocrysts of plagioclase and biotite in a groundmass of quartz, albite, potassic feldspar, and minor sericite. Laramide igneous rocks are seldom this unaltered in the Aspen area. Analyzed sample 7, table 5. C, Aplite porphyry from about $3,080 \mathrm{~m}$ altitude on Aspen Mountain. Sill near base of the Belden Formation in the Aspen mining district. Euhedral to subhedral phenocrysts of plagioclase now altered to calcite and sericite in a matrix of subhedral to anhedral quartz and altered plagioclase and potassic feldspar. Block-shaped quartz in upper center is a distinctive feature of the microtexture of many samples of Laramide porphyry in the Aspen area. 


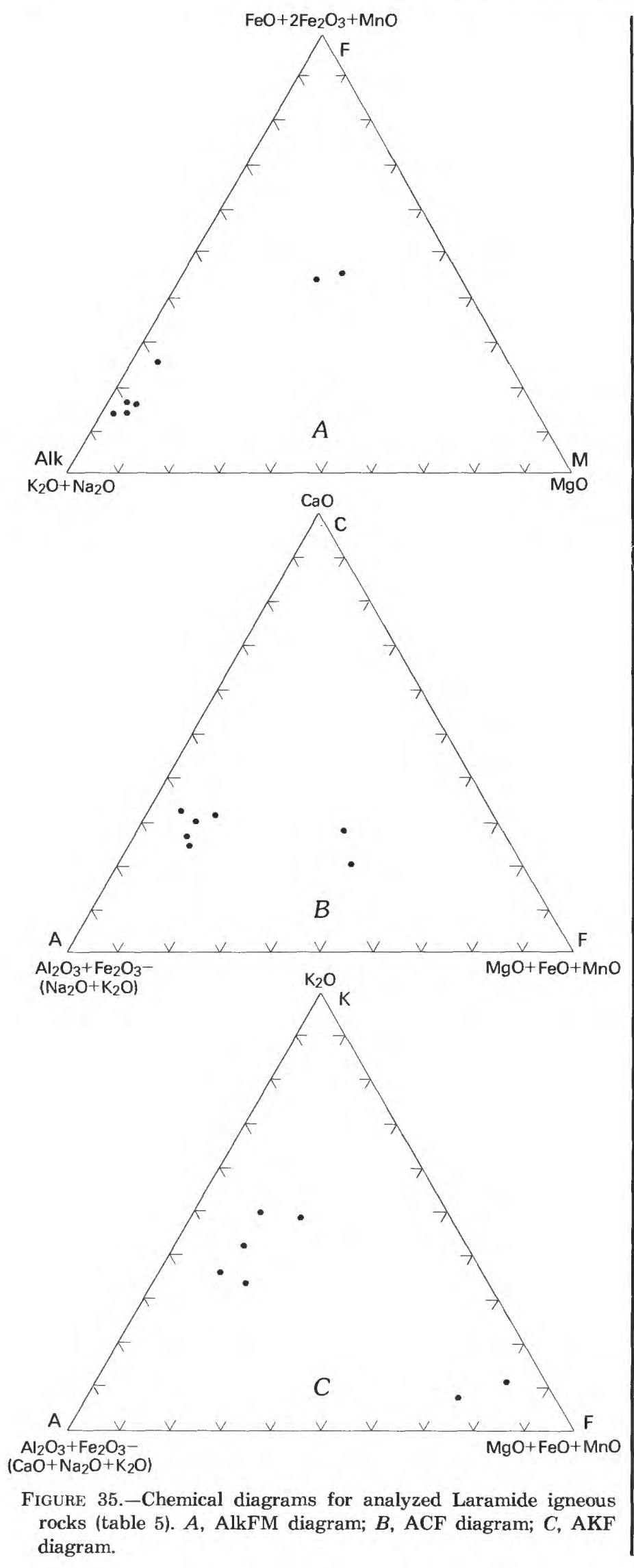

in the area is an undated quartz diorite porphyry older than at least some of the movement on the range-front faults. Judging by the petrographic description of Dings and Robinson (1957), this rock resembles the quartz diorite of the Aspen area, if the latter could be found unaltered. A highly altered rhyolite is cut by a fault and the Mount Princeton Quartz Monzonite (Dings and Robinson, 1957), and thus may be as old as the Laramide rocks at Aspen. The Tertiary Tincup Quartz Monzonite Porphyry believed by Dings and Robinson (1957) to be older than the Mount Princeton batholith has recently been dated as early Oligocene (Cunningham and others, 1977).

The Laramide igneous rocks of the Aspen area constitute a bimodal suite. The quartz diorite contains a 54-57 percent $\mathrm{SiO}_{2}$ after deduction of volatiles, and the felsic porphyries have 70-75 percent $\mathrm{SiO}_{2}$ on the same basis (table 5).

\section{MIDDLE TERTIARY IGNEOUS ROCKS}

Middle Tertiary igneous rocks of calc-alkaline affinity and predominantly granodioritic composition make up a number of plutons, sills, dikes, and laccoliths in the Elk Mountains south and southwest of Aspen. These rocks are of the same general age and chemistry as widespread extrusive and intrusive igneous rocks elsewhere in the region (Steven and Epis, 1968; Lipman and others, 1969).

These intrusive rocks were first described by the Hayden Survey (Hayden, 1874; Holmes, 1876). Cross (1894) called them diorites before the term granodiorite was in general use, and his description of the rocks is quite accurate. The name diorite caused Spurr (1898) to miscorrelate the hornblende quartz diorite of Laramide age of the mining district with the rocks of the White Rock pluton. Knopf (1926) recognized that the intrusives of the Elk Mountains were indeed granodiorite and that they differed from the Laramide hornblende quartz diorite of the Aspen area. Vanderwilt (1937) discussed the Snowmass pluton west of the Aspen area and thought that the three main plutons of the Elk Mountains were derived from a single source. This idea is supported by the chemical and age data now available (Lipman and others, 1969; Obradovich and others, 1969).

Graton (1958) described the petrography of a part of the White Rock pluton near White Rock Mountain in the Gothic quadrangle in an area mapped by Gaskill (1956). Cunningham (1976) studied a related intrusive, the Oligocene Italian Mountain Intrusive Complex, just southeast of the White Rock pluton and $7 \mathrm{~km}$ south of the Hayden Peak quadrangle, and deciphered 
a sequence of intrusions of predominantly granodioritic and quartz monzonitic composition.

Since the work of Emmons, Cross, and Eldridge (1894), it has been known that the intrusive rocks cut the Ruby beds in the northeastern part of the West Elk Mountains. Emmons, Cross, and Eldridge considered those rocks to be Cretaceous in age, but they are now mapped as the lower part of the Wasatch Formation, and they are probably of Paleocene age. These relations only place an older limit on the age of the intrusive rocks as post-Paleocene (Godwin and Gaskill, 1964). K-Ar ages of micas from several of the intrusives in the Elk Mountains fall in the range of 29 to 34 m.y., or Oligocene (Obradovich and others, 1969).

The Aspen area includes much of one of the major plutons of the Elk Mountains-the White Rock pluton (fig. 36) dated as $34 \mathrm{~m} . \mathrm{y}$. old by Obradovich and others (1969). That pluton has an outcrop pattern forming a shape resembling a doughnut (fig. 48), although in detail the borders on the pluton are highly irregular in many places. Rocks of the White Rock pluton form the jagged peaks at the head of Castle Creek just south of the Hayden Peak quadrangle, part of Conundrum Peak, the ridge north of Hayden Peak, Keefe Peak, and the crest of the Elk Mountains at the head of East Maroon Creek. This pluton is concordant with the Elk Range thrust and with the bedding in the Maroon Formation in gross aspect, but its upper contact cuts through a thousand meters of the Maroon Formation in places (fig. 37). A large number of dikes and sills emanate from the pluton, especially near Castle Peak and west of Copper Lake.

Detailed mapping available of the southern part of the Snowmass pluton (fig. 48; Gaskill and Godwin, 1966a; Mutschler, 1970) and reconnaissance of its other sides indicate that it occupies a position along the Elk Range thrust similar to that of the White Rock pluton except that it is much more concordant with the bedding of the rocks in the upper plate of the thrust. Only $4.8 \mathrm{~km}$ separate the Snowmass pluton from a small granodioritic stock in the West Maroon Creek valley, which is probably a cupola of the White Rock pluton. It is likely that the Snowmass and White Rock plutons are connected at depth along the Elk Range thrust.

Extensive areas of contact metamorphism are associated with parts of the White Rock pluton. The widest areas of metamorphism are adjacent to discordant contacts. On the other hand, the contact metamorphic aureole of the Snowmass pluton is narrow, and the contacts generally concordant.

Associated with the White Rock pluton are numerous mineralized fracture zones, most of which contain quartz, calcite, and pyrite; a few fracture zones contain galena, sphalerite, and chalcopyrite and have silver or gold values. Several areas of the pluton contain much disseminated pyrite and lesser amounts of chalcopyrite and molybdenite. The latter mineral is concentrated in restricted areas where the granodiorite is highly altered (Bryant, 1971c). One contact metasomatic iron deposit in marble of the Belden Formation is associated with the White Rock pluton at the head of Cooper Creek at the south edge of the Hayden Peak quadrangle.

The White Rock pluton generally has sharp concordant to discordant contacts lacking chilled margins (fig. $38 \mathrm{C}$ ) with country rock, which usually is not deformed adjacent to the intrusion. However, locally, especially where the contact is with the Belden Formation, the adjacent rock is highly deformed apparently at least in part due to force of intrusion (fig. 38A). In places on the east side of the White Rock pluton, hornfels adjacent to the pluton is brecciated (fig. $38 \mathrm{~B}$ ). Most of these breccias have a matrix of calcareous material rather than of granodiorite and resemble in many respects the breccias of Monument Gulch (fig. 17). However, they are adjacent to the pluton contact rather than occurring along a stratigraphic horizon above evaporite as in Monument Gulch.

In the western part of the Maroon Bells quadrangle three varieties of middle Tertiary igneous rocks were mapped: (1) hornblende porphyry occurring as dikes and sills, (2) granodiorite in stocks, and (3) porphyritic granodiorite occurring as sills, dikes, and laccoliths. At least some of the hornblende porphyry is offset by faults that probably formed as the granodiorite stocks were emplaced. Other bodies of hornblende porphyry occupy the same fracture system as the dikes of granodiorite porphyry and thus are probably younger than the sills that are cut by the faults. Both the hornblende porphyry and granodiorite and many of the faults are cut by dikes of porphyritic granodiorite. However, some faulting did occur after the emplacement of the sill of porphyritic granodiorite north of Maroon Lake. Thus, the relations between faulting and intrusions show some sequential development, but in detail those time relations are complex.

In the rest of the Maroon Bells quadrangle and in the Hayden Peak quadrangle, hornblende porphyry was not a distinctly mappable rock type. Some of the thinner dikes and sills next to the contact of the White Rock pluton resemble some of the hornblende porphyry, but they grade texturally into fine-grained and medium-grained granodiorite and can be traced into the pluton.

The porphyritic granodiorite cuts granodiorite in most places as well-defined dikes, some of which have chilled margins, showing that the granodiorite was 


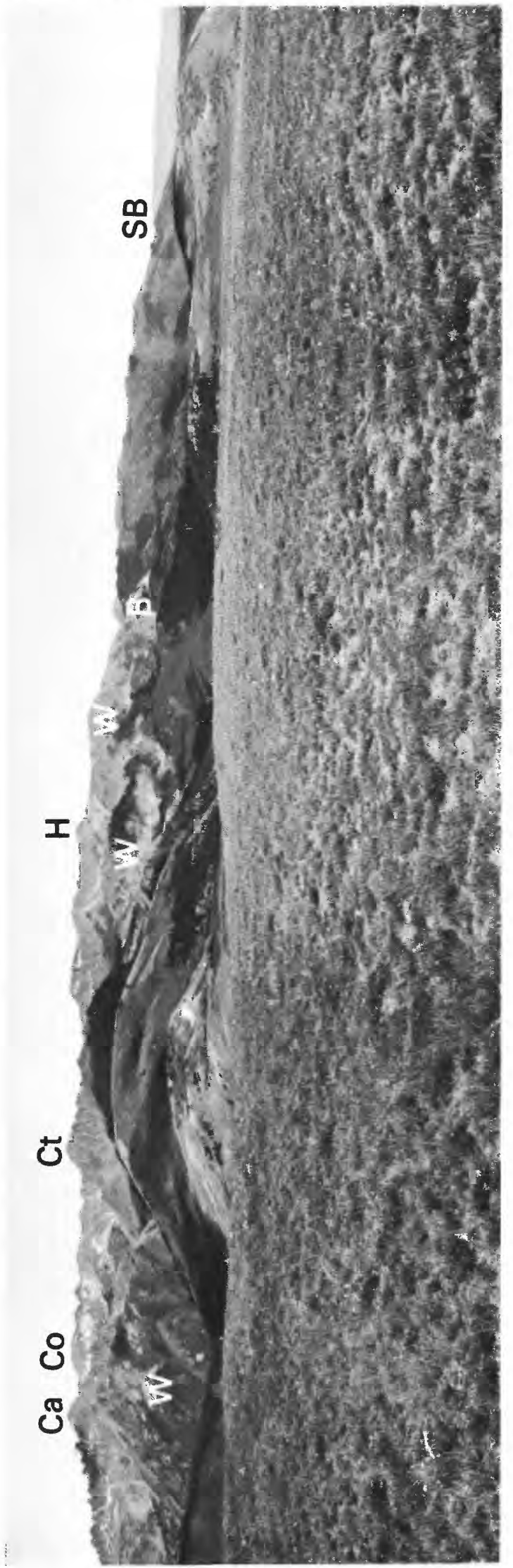

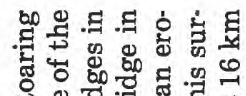

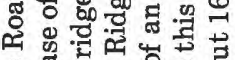

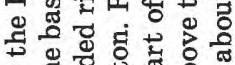

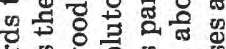
क्षे

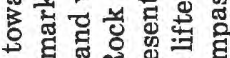

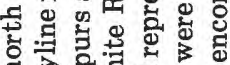
为

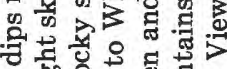
달

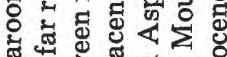

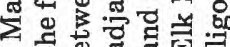

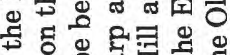

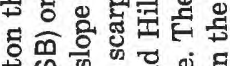

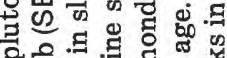

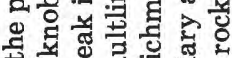

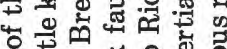

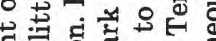

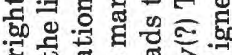

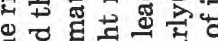

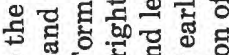
$\circ$ 仙 त

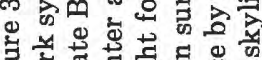

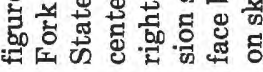

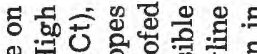
\&

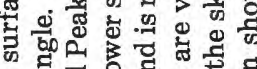
क

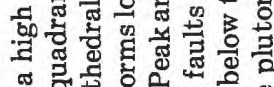
๙

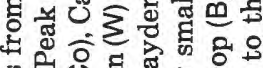
on

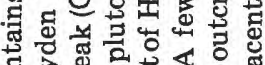
票出 $\sum^{2}$

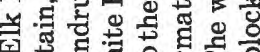

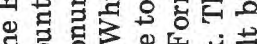

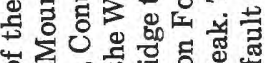
प $\sum^{0}$

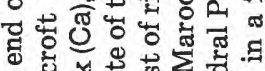

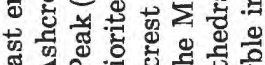

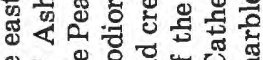

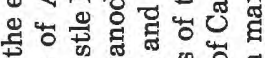

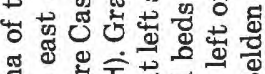

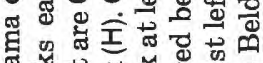

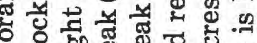

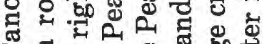

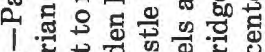

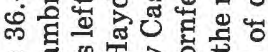

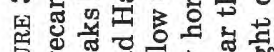

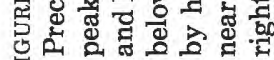




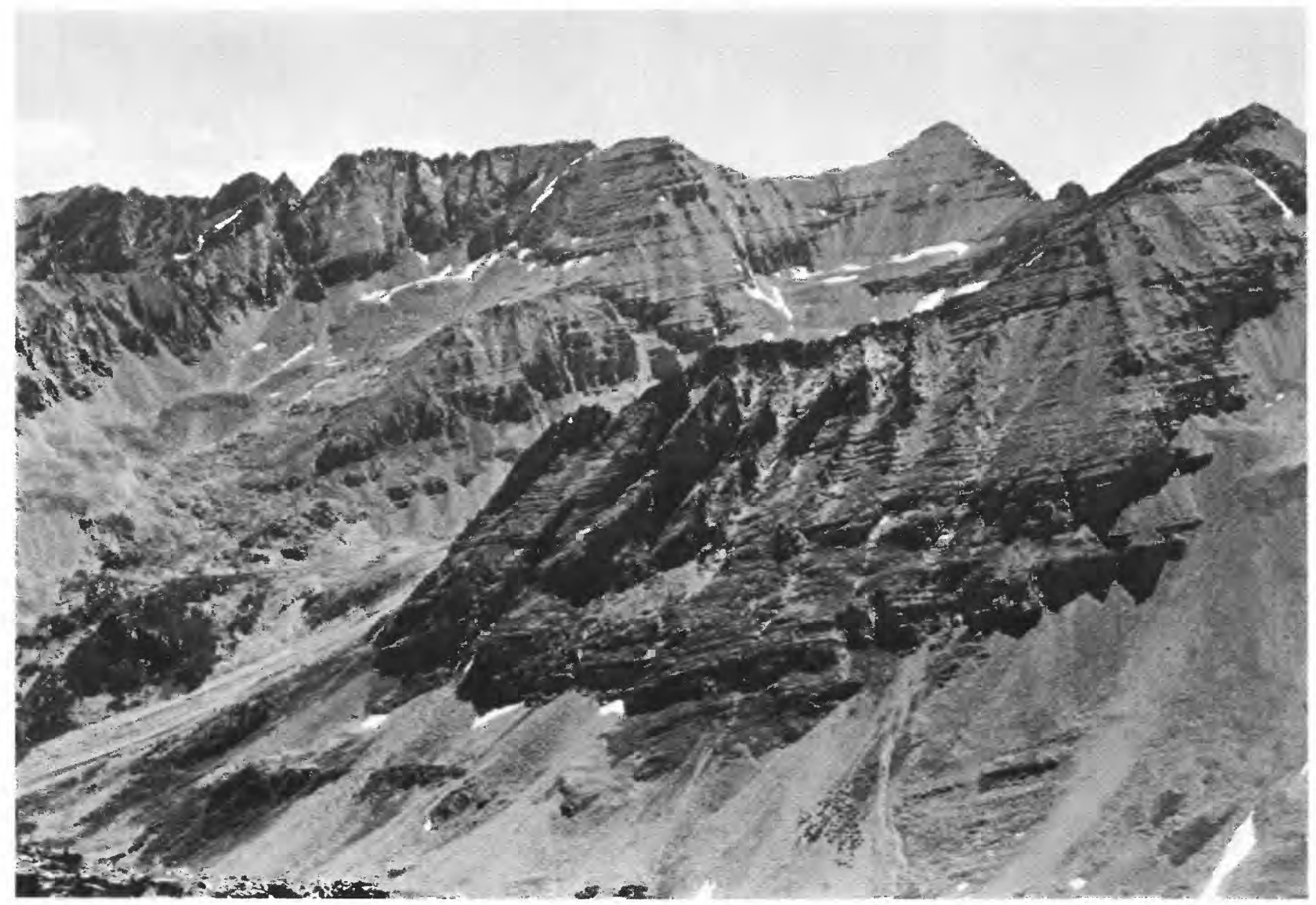

Figure 37.-Crosscutting contact of part of the White Rock pluton on west side of Conundrum Peak. Bedded rock is hornfels of the Maroon Formation. Sharp peak right of center is Castle Peak and rounded peak on center skyline is Conundrum Peak. Granodiorite contact is on left side of Conundrum Peak. Irregular body of granodiorite caps ridge in foreground. Maron Bells and Hayden Peak quadrangles. View east across Conundrum Creek valley. Skyline about 2 km long.

cool enough to fracture and to quench the porphyritic granodiorite at the time of its emplacement. However, one small stock of granodiorite north of Crater Lake in the Maroon Bells quadrangle grades to, rather than is cut by, the dikes of porphyritic granodiorite mapped to the west of it. Also, in a few places in the White Rock pluton, ill-defined zones of porphyritic granodiorite grade into normal granodiorite. On the southwest side of the ridge southeast of Copper Lake near the southern margin of the Maroon Bells quadrangle a 5-7-cm thick dike of very fine grained rock containing phenocrysts of hornblende and plagioclase cuts a dike emanating from the White Rock pluton. Apparently, that rock intruded after the apophysis of the pluton had cooled. Consequently, although a general sequence of intrusion of somewhat different rock types can be demonstrated locally, it is not well defined everywhere.

\section{GRANODIORITE}

In the White Rock pluton no well-defined internal contacts were mapped despite variations in texture and mineral composition in the granodiorite. Locally, small areas of more mafic rock (CI 15-20) were noted near the margins of the pluton. These did not seem to have sharp contacts with normal granodiorite (CI $5-15)$. Perhaps more detailed study would allow mapping of variants of the granodiorite in the pluton.

Textures of the granodiorite range from hypidiomorphic-granular (fig. $39 E$ ) to microporphyritic (fig. 39D). The grain size ranges from fairly coarse to fine. All gradations between the different textures occur, although the end members are markedly different. The finer grained dikes and apophyses adjacent to the White Rock pluton resemble the dikes 

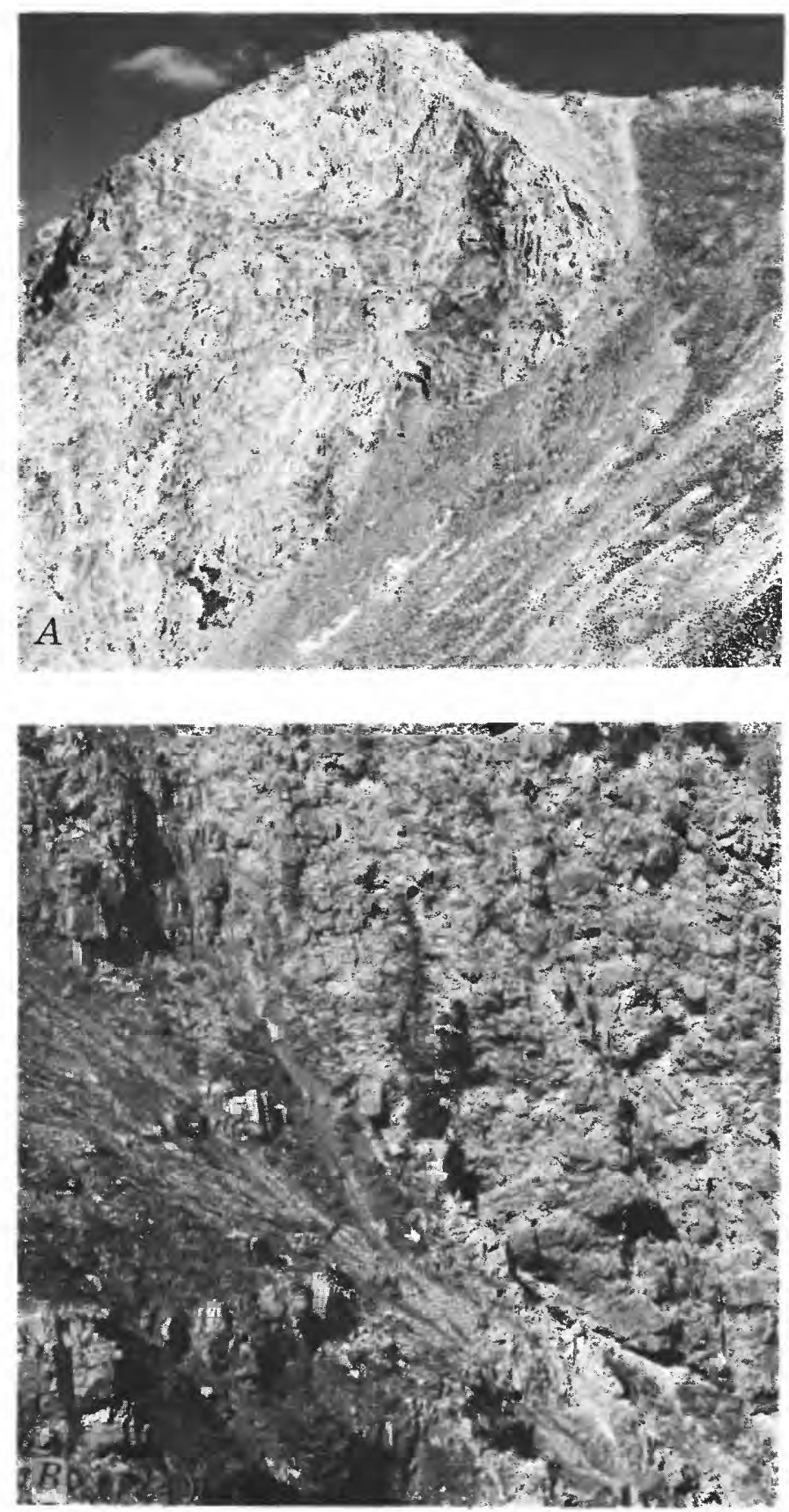

FIGURE 38.-Features at or near contact of the White Rock pluton, Hayden Peak quadrangle. $A$, Contorted Belden marbles on 3,751-m knob on Castle Creek-Conundrum Creek ridge. Contact of pluton is at change of color on even-crested part of ridge. Marbles are in upfaulted block adjacent to the pluton. Dark-gray beds are 1-2 $\mathrm{m}$ thick. $B$, Breccia just above the pluton north of

mapped as porphyritic hornblende diorite in the western part of the Maroon Bells quadrangle. The former grade into coarser grained varieties of granodiorite.

In places inclusions are numerous in the White Rock pluton. They consist of hornfels derived from the
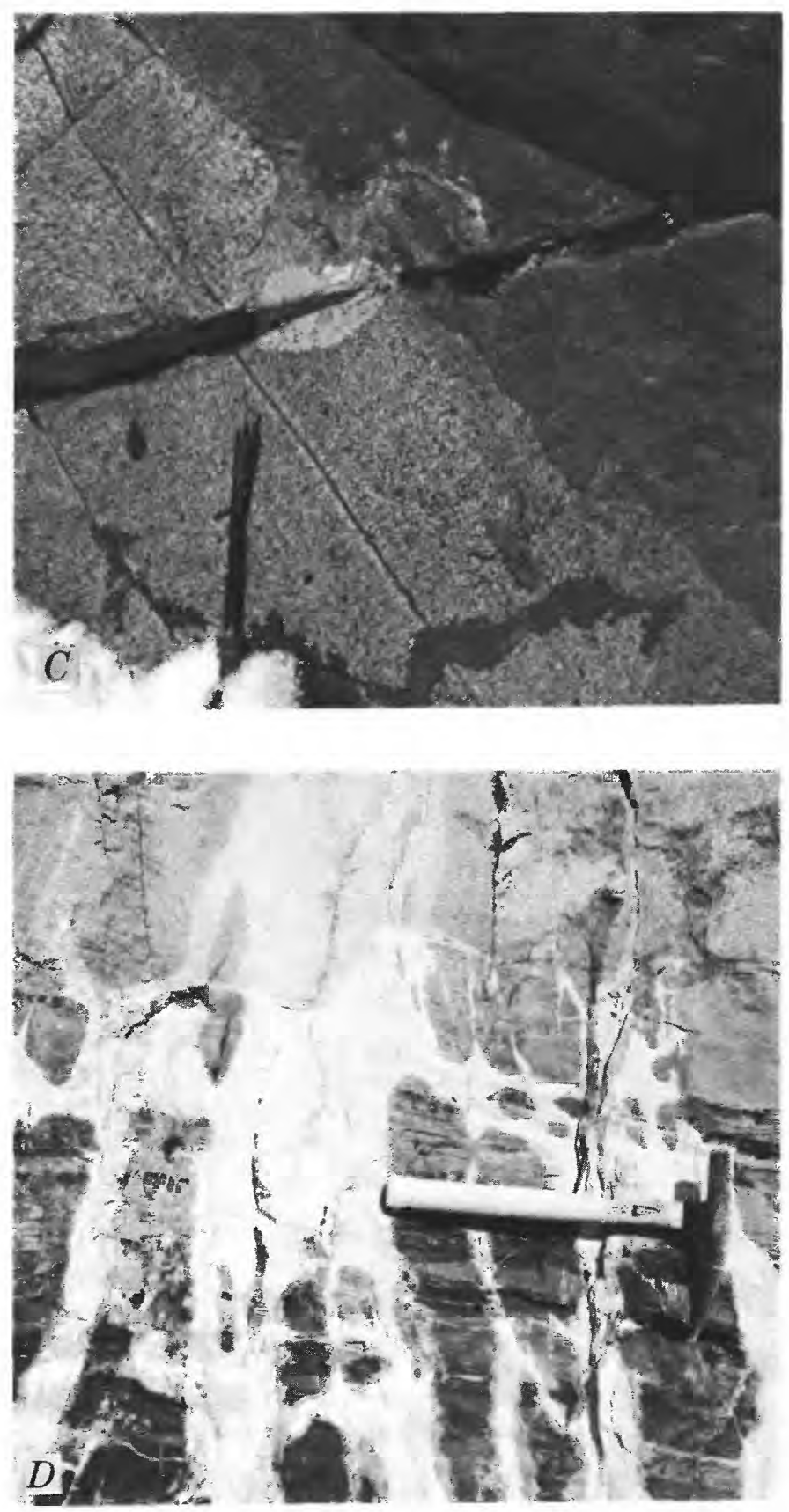

3,665-m knob on Cooper Creek-Castle Creek ridge. Breccia (right) cuts undisturbed hornfels (left). Tree in center about $20 \mathrm{~m}$ tall. $C$, Contact of pluton in cirque southwest of Cathedral Lake. Note lack of chilled margin. $D$, Zones of alteration cut granodiorite and hornfels at contact at 3,540 m altitude west of Castle Creek.

wallrock and of somewhat more mafic hornblende granodiorite to diorite, probably derived from some earlier crystallized variants, perhaps from beneath the present level of exposure. The hornfels inclusions range from a centimeter to a kilometer long. (See geologic maps of Hayden Peak and Maroon Bells 
quadrangles (Bryant, 1969, 1970).) The igneous rock inclusions are generally several centimeters or less in diameter.

Alteration in the White Rock pluton is quite spotty. Chloritization of hornblende and biotite and saussuritization of plagioclase are widespread. Albitization, sericitization, and silicification are locally found in the areas of disseminated sulfides (Bryant, 1971c). Sills in and adjacent to the Conundrum Creek window are albitized in many places.

The granodiorite is a white to gray rock containing various amounts of mafic minerals, which are principally biotite but include hornblende, monoclinic pyroxene, and magnetite. Grain size ranges from a few tenths to several millimeters. Most of the granodiorite mesoscopically appears to be equigranular, but locally larger grains of potassic feldspar occur. In those places the granodiorite resembles the porphyritic granodiorite, but no well-defined contacts of rock containing the larger potassic feldspar grains were seen.

The granodiorite contains euhedral to subhedral plagioclase grains (fig. 39) that locally are alined by flowage. The crystals usually display oscillatory zoning in a normal trend. Cores of the plagioclase grains have compositions of $\mathrm{An}_{55-65}$, and the rims generally have a composition of $\mathrm{An}$ 20-32. In a few rocks the plagioclase has albite rims. In many rocks the plagioclase crystals are $0.5-1.5 \mathrm{~mm}$ long, but in a few they reach $5 \mathrm{~mm}$. Albite locally occurs in the interstices of the well-shaped plagioclase grains.

Quartz typically is interstitial to the plagioclase and has a grain size of $0.1-0.5 \mathrm{~mm}$ (figs. $39 A, B, C, E$ ). However, a significant minority of the samples contain quartz as euhedral to anhedral phenocrysts as much as $6 \mathrm{~mm}$ in diameter (fig. 39F). The phenocrysts locally include oligoclase and biotite. Some have embayed margins, suggesting incipient resorption in the magma after crystallization. Quartz also occurs in granophyric intergrowths with potassic feldspar.

Potassic feldspar is generally interstitial to plagioclase and ranges from $0.05 \mathrm{~mm}$ to several millimeters in grain size (figs. $39 A, B, C$ ). The larger grains engulf plagioclase, biotite, hornblende, quartz, and opaque minerals. Potassic feldspar also occurs in granophyric intergrowths with quartz.

Brown biotite ranges from anhedral to subhedral grains that are later than the plagioclase to euhedral phenocrysts that are apparently contemporaneous with the plagioclase (figs. $39 C, E$ ). Grain size ranges from 0.3 to $4 \mathrm{~mm}$ but is mostly in the range of $0.5-$ $2 \mathrm{~mm}$. Some is intergrown with hornblende.

Amphibole ranges from greenish brown, olive green, and green to very pale green. The lighter green amphibole is locally derived by alteration of the darker green type, although the two amphiboles have the same extinction angle. Most of the amphibole is anhedral to subhedral, and it ranges from 0.5 to $5 \mathrm{~mm}$ in grain size. Some of it is interstitial to the plagioclase, and in some rocks it appears to have formed quite late. Locally, the amphibole is derived from pyroxene.

Monoclinic pyroxene occurs as anhedral to subhedral grains $0.1-2.5 \mathrm{~mm}$ in diameter. It is generally colorless or light tan and nonpleochroic and has $z \wedge C$ ranging from $42^{\circ}$ to $47^{\circ}$. Hypersthene was found with monoclinic pyroxene in one locality.

Chlorite forms pseudomorphs after biotite and hornblende grains. In some rocks it contains inclusions of carbonate and sphene. Both $\mathrm{Mg} / \mathrm{Fe}$ and $\mathrm{Fe} / \mathrm{Mg}$ varieties occur, and much of the chlorite has a very low birefringence; it is on the border between the two types.

Opaque minerals are principally magnetite except in areas of pyritized rock where pyrite is a major constituent and chalcopyrite a minor one. Molybdenite occurs in certain areas of highly altered rock (Bryant, 1971c).

Common accessory minerals are zircon, apatite, and sphene. Allanite and rutile occur sparingly.

\section{ALTERATION}

Alteration of the granodiorite is widespread but quite spotty and irregular in distribution. The most common variety is propylitic and involves saussuritization of plagioclase and chloritization of mafic minerals. Plagioclase is also altered to sericite and carbonate and to clay mineral(?) and carbonate. Sphene or carbonate is often associated with secondary chlorite.

Less common varieties of alteration generally but not always associated with mineralized areas (Bryant, 1971c) are albitization-concentrated in the Cataract Creek area and the west side of the Conundrum Creek valley by the mouth of Cataract Creek-and silicification and sericitization-locally concentrated in the East Maroon Creek disseminated sulfide deposits.

Fluid inclusion studies of altered rocks in areas of disseminated sulfides made in reconnaissance fashion by J. T. Nash and C. G. Cunningham, Jr., show that alteration took place under postmagmatic conditions at temperatures of $200^{\circ}-375^{\circ} \mathrm{C}$. Some of the inclusions in the area of albitization contain as much as 35 weight percent $\mathrm{NaCl}$. Some of the inclusions indicate boiling at temperatures of $225^{\circ}-350^{\circ} \mathrm{C}$. The higher boiling temperature would indicate a maximum pressure of 120 bars or a depth of about $1,200 \mathrm{~m}$ if $P_{\mathrm{H}_{2} \mathrm{O}}=P_{\text {Total }}$, but less deep if $P_{\mathrm{H}_{2} \mathrm{O}}<P_{\text {Total }}$. This compares with a 

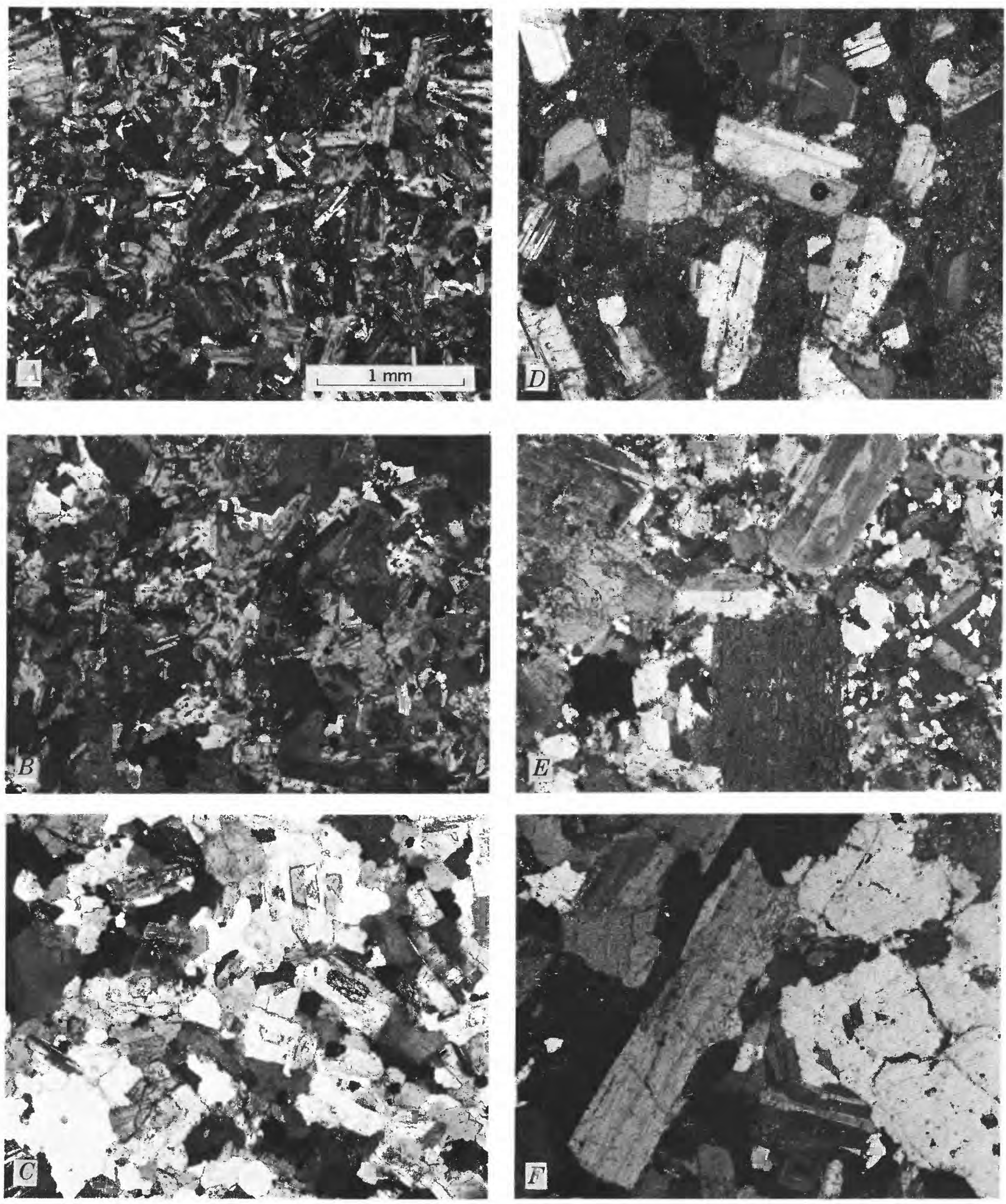
higher temperature $\left(385^{\circ} \mathrm{C}\right)$ and a greater maximum depth $(2,700 \mathrm{~m})$ for hydrothermal activity in the Italian Mountain Intrusive Complex just south of the Aspen area, based on detailed study (Cunningham, 1976).

Alteration probably took place over the whole temperature range, since many samples contain inclusions with different filling temperatures. Quartz carbonate veins from other parts of the pluton have fluid inclusions with filling temperatures in the range $200^{\circ}-350^{\circ} \mathrm{C}$; so vein formation and alteration took place at similar temperatures.

Another type of alteration is very local but quite interesting. White altered-appearing rock occurs as irregular dikes and blobs in normal-appearing granodiorite. This type of alteration is generally near or at the contacts of the granodiorite and in places extends across the contact into adjacent hornfels (fig. $38 D$ ). It is found west and north of the head of Castle Creek 0.8-1.6 km north of the south edge of the Hayden Peak quadrangle. The white altered rock lacks biotite and hornblende but is rich in pyroxene or sphene. In one sample the pyroxene appears to have formed from hornblende. In one area a green zone, be-

FIGURE 39 (facing page).-Photomicrographs of granodiorite of the White Rock pluton showing textural variations. All views through crossed nicols; all at same scale. $A$, Amphibole augite biotite granodiorite from apophysis northwest of the Montezuma mine, Hayden Peak quadrangle. Euhedral to subhedral normally zoned plagioclase, subhedral to anhedral augite partly altered to amphibole, anhedral biotite, opaque minerals, and interstitial quartz and potassic feldspar. Analyzed sample 1, table 6. $B$, Hornblende biotite granodiorite from southeast part of Maroon Bells quadrangle at $3,505 \mathrm{~m}$ altitude east of Conundrum Creek. Euhedral to subhedral plagioclase with oscillatory zoning in a normal trend, subhedral to anhedral biotite, anhedral hornblende, opaque minerals, and interstitial quartz and potassic feldspar. $C$, Biotite granodiorite from southeast of the Montezuma mine, Hayden Peak quadrangle. Euhedral to subhedral normally zoned plagioclase with some oscillatory zoning, anhedral to subhedral biotite, and interstitial quartz and potassic feldspar. $D$, Porphyritic granodiorite from southeast of the Montezuma mine, Hayden Peak quadrangle. Euhedral plagioclase having some oscillatory zoning in a normal trend; quartz, biotite, and hornblende, in a very fine grained matrix of quartz, feldspar, and opaque mineral. Analyzed sample 7, table 6. E, Biotite granodiorite from $3,170 \mathrm{~m}$ altitude east of Hunter Peak, Maroon Bells quadrangle. Subhedral to euhedral plagioclase with normal and oscillatory zoning and subhedral to anhedral biotite in a mosaictextured groundmass of quartz and potassic feldspar. Rock locally has phenocrysts of quartz and late large potassium feldspar grains not shown here. $F$, Biotite quartz monzonite from $3,110 \mathrm{~m}$ altitude east of Conundrum Creek, Maroon Bells quadrangle. Large anhedral quartz includes plagioclase and biotite; subhedral plagioclase and anhedral biotite. Scattered late porphyroblasts of potassic feldspar not shown. Analyzed sample 12, table 6 . tween normal gray unaltered biotite-hornblende granodiorite and the white rock, contains monoclinic pyroxene after hornblende; the white altered rock lacks pyroxene but contains several percent of sphene. Where the white zones cut into hornfels, sphene is also the principal dark mineral in the altered hornfels. This alteration appears to have occurred in a hot dry environment, perhaps through sudden decline in $P_{\mathrm{H}_{2} \mathrm{O}}$ through fracturing of the roof at an early stage in the cooling of the granodiorite. During the alteration process $\mathrm{Fe}, \mathrm{Mg}$, and $\mathrm{H}_{2} \mathrm{O}$ were lost, and $\mathrm{Ti}$ may have been introduced.

\section{PORPHYRITIC GRANODIORITE}

Porphyritic granodiorite occurs as sills, dikes, and laccoliths in the Maroon Bells and the western parts of the Highland Peak and Hayden Peak quadrangles (fig. 40). The dikes occupy an east-west fracture system connecting the Snowmass pluton with the White Rock pluton and cutting both plutons. North of North Maroon Peak, dikes of this system reach $100 \mathrm{~m}$ in thickness. These dikes probably feed sills and laccoliths in the Maroon Formation. Sills are well exposed north of Maroon Lake, Maroon Bells quadrangle (fig. 19). A laccolith at least $200 \mathrm{~m}$ thick forms the $4,065-\mathrm{m}$ peak north of Willow Lake (fig. 40C). The largest body of this rock type is a sill along the east side of the canyon of Snowmass Creek (figs. 40A, B). Parts of that sill crop out in the northwestern part of the Maroon Bells quadrangle and in the southwestern part of the Highland Peak quadrangle. The sill is about $600 \mathrm{~m}$ thick and at least $9 \mathrm{~km}$ long. Biotite from this sill has a $\mathrm{K}$-Ar age of $31 \mathrm{~m} . \mathrm{y}$., about $3 \mathrm{~m} . \mathrm{y}$. younger than the biotite age obtained on rocks from the White Rock pluton, and this is in agreement with the field relations between porphyritic granodiorite dikes and granodiorite of that pluton.

The porphyritic granodiorite is a light-gray rock containing conspicuous rare to moderately abundant grayish-orange pink-weathering phenocrysts of potassic feldspar that reach a length of $7 \mathrm{~cm}$ but are commonly $2-5 \mathrm{~cm}$. The phenocrysts contain numerous inclusions of mafic minerals. White to light-yellowishgray plagioclase phenocrysts are generally $2-5 \mathrm{~mm}$ long. Light-gray quartz forms phenocrysts as much as $1 \mathrm{~cm}$ in diameter but often is about $5 \mathrm{~mm}$ in diameter. Hornblende or chloritized hornblende forms phenocrysts $25 \mathrm{~mm}$ long but locally is as much as $1 \mathrm{~cm}$ long. Biotite or chloritized biotite forms phenocrysts as much as $3 \mathrm{~mm}$ in diameter.

Most of the intrusives of porphyritic granodiorite 

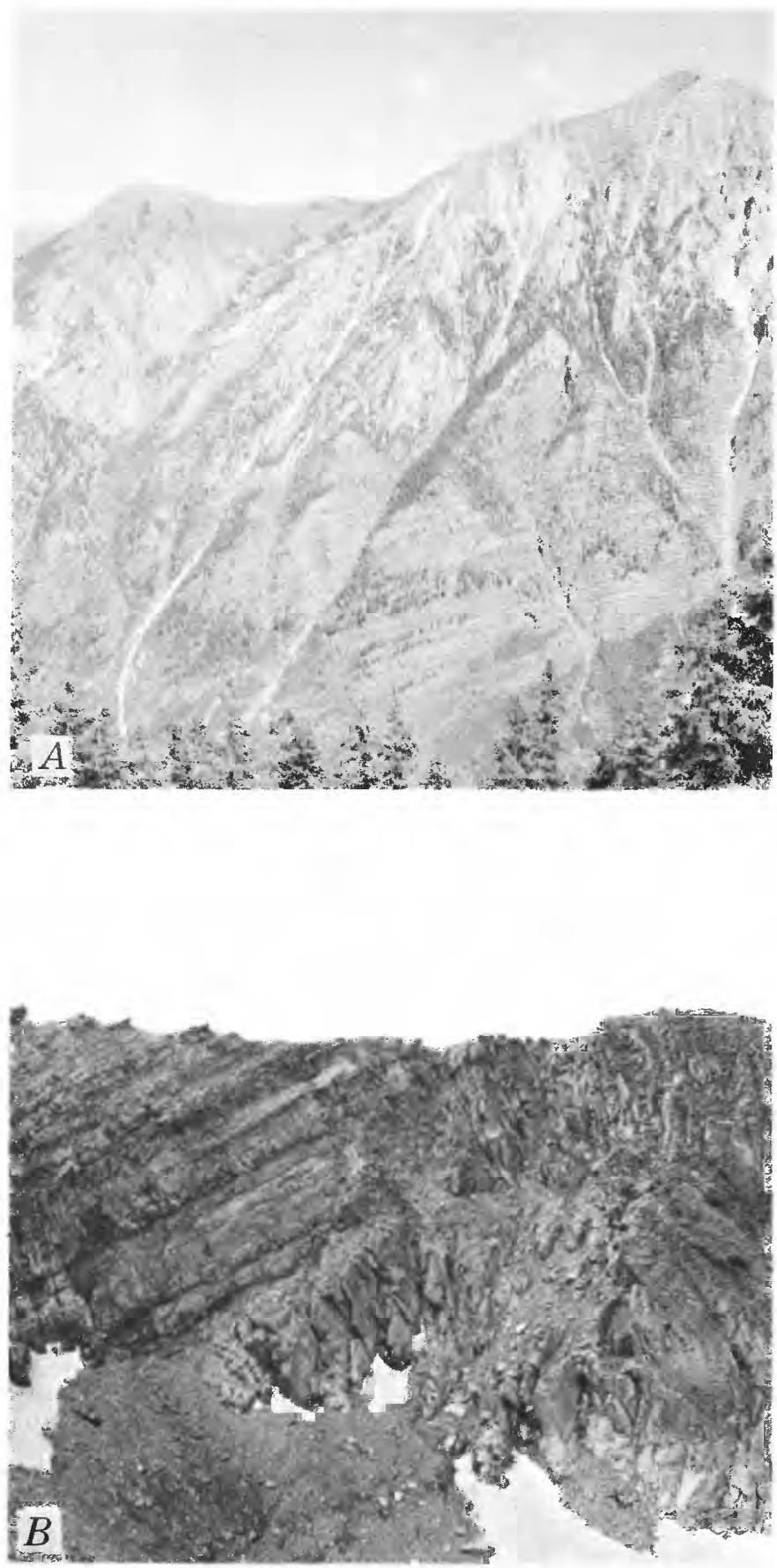

have chilled margins which resemble the hornblende porphyry dikes. In these margins the plagioclase and hornblende, and in some rocks the quartz, phenocrysts are the same size as those in the interior of the body, but the potassic feldspar phenocrysts are lacking. The groundmass is darker gray and finer grained in the chilled margin than in the interior of the body. The chilled margins range from $2 \mathrm{~cm}$ in smaller intrusives to $0.6-0.9 \mathrm{~m}$ thick in the larger ones. They occur even along some of the dikes intruding the granodiorite of

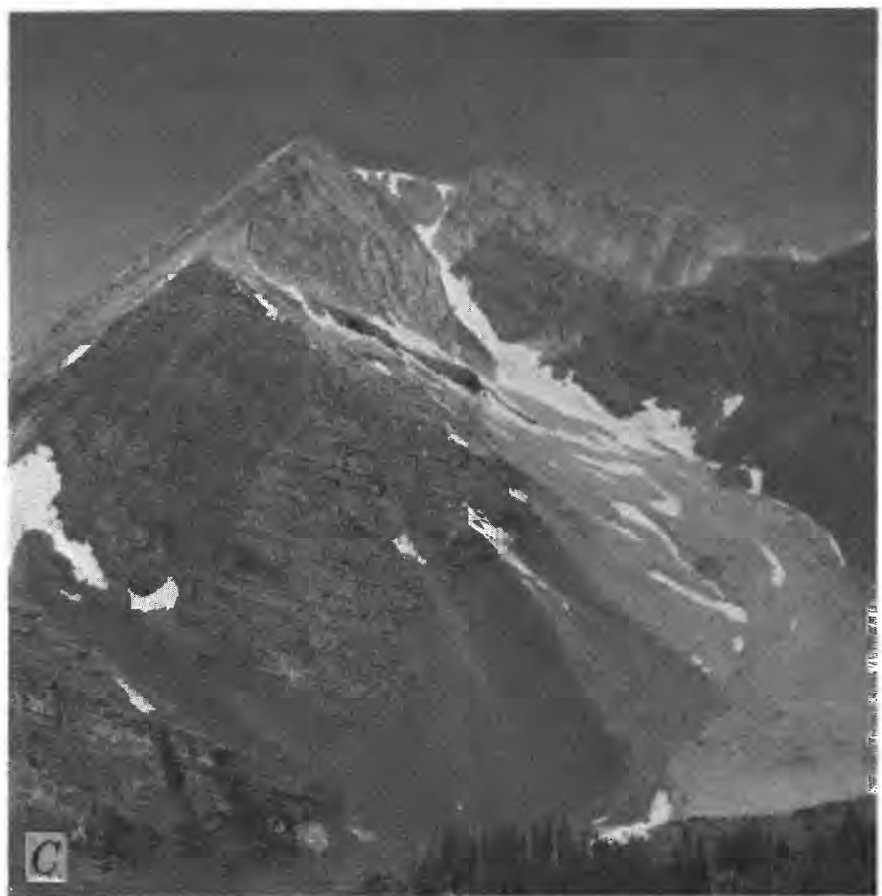

FIGURE 40.-Porphyritic granodiorite intrusives. $A$, Sill about $600 \mathrm{~m}$ thick in Maroon Formation on east side of Snowmass Creek, Capitol Peak quadrangle. Biotite from this sill dated as $31.2 \pm 1.1$ m.y. (Obradovich and others, 1969). B, Upper contact of sill shown in $A$ locally cross cuts bedding in Maroon Formation, west edge of Highland Peak quadrangle. View encompasses about 100 $\mathrm{m}$. C, Laccolith forming 4,065-m peak north of Willow Lake, Maroon Bells quadrangle. Bottom contact partly concordant and partly discordant with red beds of the Maroon Formation. The rock glacier $0.8 \mathrm{~km}$ long is composed mostly of igneous rock from the cirque headwall and not of red beds from the valley sides.

the White Rock pluton, showing that the pluton had substantially cooled at the level now exposed before fracturing and emplacement of the dikes. In thin section the porphyritic granodiorite bodies have an unexpectedly fine grained groundmass with a grain size of 0.01-0.04 mm (fig. 41). In the chilled zone the groundmass is cryptocrystalline and may contain some glass.

Quartz phenocrysts are locally euhedral, but many have numerous embayments (fig. 41), suggesting that the phenocrysts were partly resorbed by the remaining magma that crystallized to become the groundmass. Plagioclase phenocrysts are euhedral to subhedral and commonly altered (fig. 41). Compositions of $\mathrm{An}_{40-55}$ were found in unaltered grains. Where fresh, euhedral hornblende phenocrysts are dark olive green. They are mostly altered to $\mathrm{Mg} / \mathrm{Fe}$ or $\mathrm{Fe} / \mathrm{Mg}$ chlorite. Euhedral biotite phenocrysts show some evidence of partial resorption.

The potassic feldspar phenocrysts include quartz, plagioclase, sphene, and chlorite. They are generally euhedral. One dike had a potassic feldspar phenocryst 
showing well-developed orientation of included plagioclase grains parallel with the margin of the euhedral phenocryst (Hibbard, 1965).

Carbonate and sphene are often associated with chlorite from alteration of the mafic minerals. Apatite, zircon, and magnetite are accessory minerals. Allanite was noted in one sample. Epidote is a secondary mineral in some of the porphyritic granodiorite.

\section{HORNBLENDE PORPHYRY}

Hornblende porphyry dikes and sills were mapped in the western part of the Maroon Bells quadrangle and the southwestern part of the Highland Peak quadrangle. They generally range from 0.6 to $6 \mathrm{~m}$ thick and are various shades of green and gray. They contain hornblende phenocrysts, in places pseudomorphosed by chlorite, mostly $3-5 \mathrm{~mm}$ but as much as $1 \mathrm{~cm}$ long; plagioclase phenocrysts $3-5 \mathrm{~mm}$ long; and, in some rocks, quartz phenocrysts or xenocrysts as much as 5 $\mathrm{mm}$ in diameter. Phenocrysts or xenocrysts of potassic feldspar were observed in one sill.

Plagioclase phenocrysts have compositions ranging from $\mathrm{An}_{65}-\mathrm{An}_{27}$ and display normal and oscillatory zoning. Plagioclase also occurs as $0.05-1-\mathrm{mm}$-long

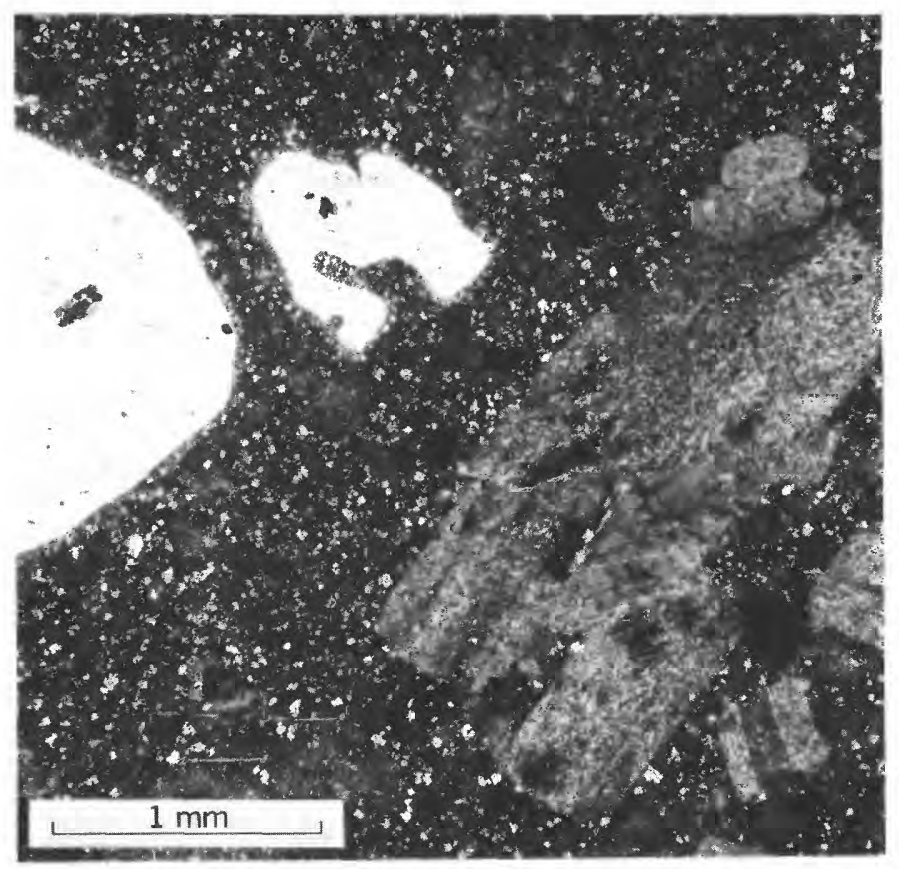

FIGURE 41.-Photomicrograph of porphyritic granodiorite from sill $60 \mathrm{~m}$ thick north of Maroon Lake, Maroon Bells quadrangle. Saussuritized euhedral phenocrysts of plagioclase and partly resorbed quartz phenocrysts in a matrix of fine-grained quartz and plagioclase. Rock also contains euhedral phenocrysts of potassic feldspar and chloritized biotite and hornblende (not shown). Analyzed sample 11, table 6.

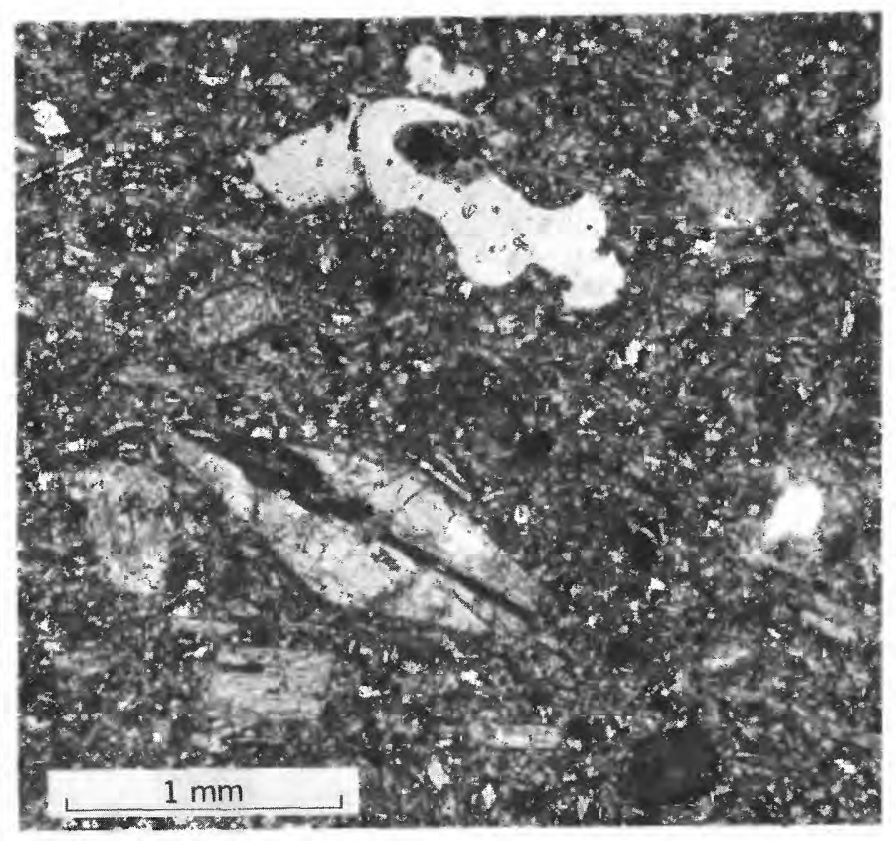

FiguRE 42.-Photomicrograph of hornblende porphyry from a 6-mthick sill on ridge between East Maroon and West Maroon Creeks, Maroon Bells quadrangle. Euhedral to subhedral hornblende phenocrysts and partly resorbed quartz phenocrysts in a fine-grained plagioclase-rich groundmass. Analyzed sample 3, table 6.

laths in the groundmass. In many of the hornblende porphyry bodies, the plagioclase is completely altered to albite, sericite, and carbonate.

Quartz occurs as resorbed phenocrysts or xenocrysts (fig. 42) as much as $4 \mathrm{~mm}$ in diameter, some of which have reaction rims of devitrified glass(?). Quartz also occurs in the groundmass, where it has a grain size of about $0.02 \mathrm{~mm}$.

Hornblende occurs as euhedral to subhedral phenocrysts (fig. 42) and is brown or greenish brown to olive green. Most hornblende is pseudomorphosed by green chlorite having almost no birefringence.

A small amount of monoclinic pyroxene occurs in subhedral grains $0.1-0.5 \mathrm{~mm}$ in diameter, and it is partly altered to hornblende. Biotite occurs as subhedral phenocrysts up to $0.5 \mathrm{~mm}$ in diameter and in the fine-grained groundmass.

Opaque minerals are magnetite and pyrite. Apatite and sphene are accessory minerals, and carbonate, sericite, and epidote are common secondary minerals.

\section{ALASKITE}

A few dikes of alaskite only several centimeters thick cut the granodiorite. No pegmatites were noted. The alaskites studied have a xenomorphic or hypidiomorphic-granular texture and a grain size of 
$0.2-2 \mathrm{~mm}$. They are composed of anhedral to subhedral quartz ( 35 percent), anhedral to subhedral albite (20 percent), and anhedral perthitic potassic feldspar (45 percent). The feldspars are somewhat altered. Dikes of similar texture and composition are numerous in the Paradise stock southwest of the Aspen area (F. E. Mutschler, written commun., 1970).

\section{COMPOSITION}

A plot of modal proportions of quartz, plagioclase, and potassic feldspar of fresh to partly altered rock lacking fine-grained groundmass shows a range from diorite to quartz monzonite (fig. 43). The two alaskite samples plot in the granite field, but there is a significant gap between them and the quartz monzonite samples, which plot very close to the granodiorite field. Color index ranges from 0 in the alaskite to about 40 in one quartz diorite.

Chemical analyses (table 6) show that the middle Tertiary igneous rocks of the Aspen area have $\mathrm{SiO}_{2}$ contents ranging from 55 to 70 percent when recalculated to 100 percent after deduction of volatiles. The hornblende porphyry dikes and sills (analyses 2, 3, 5) fall in the more mafic end of the series in the 58-62 percent $\mathrm{SiO}_{2}$ range, but mafic phases of the White Rock pluton (analyses 1,4 ) have similar compositions. Similarly, analyses of porphyritic granodiorite (analyses 11,13 ) with $\mathrm{SiO}_{2}$ of about 70 percent are not much different from analysis 13 of quartz monzonite from the White Rock pluton $\left(\mathrm{SiO}_{2}, 68.2\right.$ percent), but

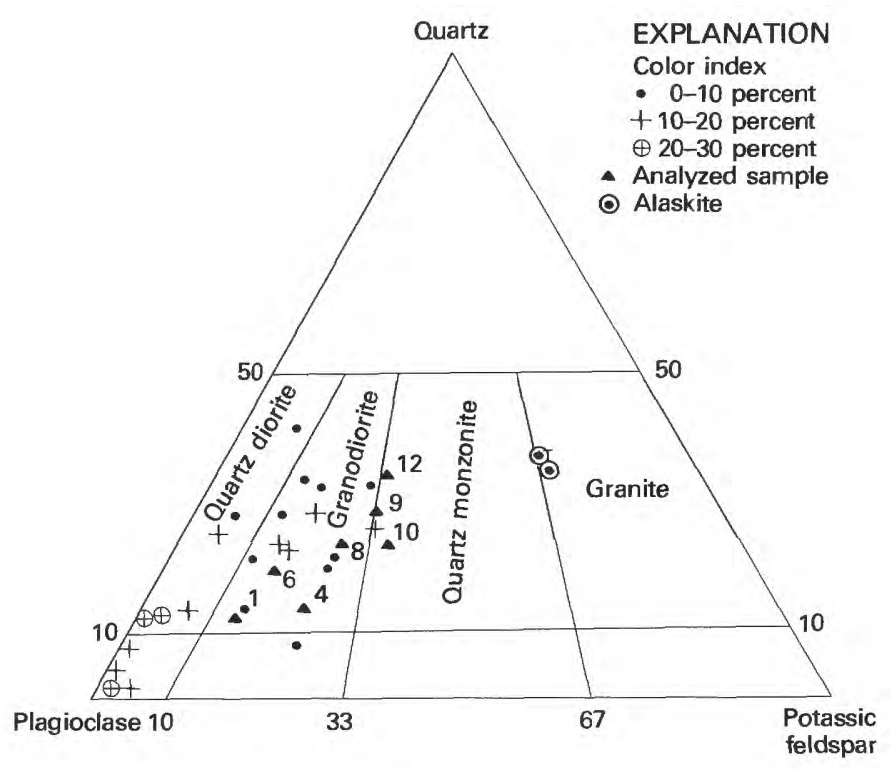

Figure 43.-Proportions of quartz, plagioclase, and potassic feldspar in unaltered phaneritic middle Tertiary igneous rocks. Numbers of analyzed samples refer to columns in table 6 . the porphyritic granodiorite is higher in $\mathrm{Na}_{2} \mathrm{O}$ and poorer in $\mathrm{K}_{2} \mathrm{O}, \mathrm{CaO}$, and total $\mathrm{Fe}$ than the quartz monzonite. Accurate modes are difficult to obtain on the porphyritic granodiorite because of the fine grain size of the groundmass, the very large size of the potassic feldspar, and the alteration. However, the norms indicate that analyzed sample 13 falls well within the granodiorite field and analyzed sample 11 is just within it.

Analyses from the Lincoln Gulch stock and the ashflow tuffs south of Independence Pass (Candee, 1971; Cruson, 1972) are included because we dated the stock as middle Tertiary (Obradovich and others, 1969), and the ash-flow tuffs probably represent a more differentiated facies of the same magma. Their $\mathrm{SiO}_{2}$ content is within the range of similar tuffs in the San Juan Mountains (Lipman and others, 1969). Various oxides plotted against $\mathrm{SiO}_{2}$ show that $\mathrm{FeO}, \mathrm{MgO}, \mathrm{TiO}_{2}$, and $\mathrm{CaO}$ decrease markedly with increasing $\mathrm{SiO}_{2}$; but relatively little change occurs in the alkalis except in the case of the ash-flow tuffs and, we may infer, the alaskite.

Well-developed variation trends are shown in triangular plots based on the chemical analyses (fig. 44). On the AKF diagram the trend is from the F corner to the AK line, the ash-flow tuffs being the only points lying beyond the center of the diagram (fig. $44 C$ ). In the ACF diagram the trend is away from the F corner to the AC line (fig. $44 B$ ), and in the AlkFM diagram the trend is from the middle of the diagram toward the Alk corner (fig. 44A).

Semiquantitative minor element analyses suggest that the more silicic $\left(>65\right.$ percent $\left.\mathrm{SiO}_{2}\right)$ rocks of middle Tertiary suite are richer in minor elements than the silicic Laramide porphyries (tables 5, 6) and contain more Co, La, Mo, Sc, V, Zr, Ce, Yb, and Nd. These differences are not obvious in the more mafic rocks.

Plots of normative Pl-Qz-Or (fig. 44D) define a trend similar to that shown by Bateman and others (1963) for Laramide stocks of Colorado and New Mexico except for a change in trend towards the Qz-Or line defined by the analyses of the ash-flow tuffs of Independence Pass. The trend extends away from the PlOr line, as do many other suites from inside the continent plotted by Bateman and others. The suites from near the continental margin have trends extending away from the $\mathrm{Pl}$ corner. These differences are due to differences in composition of the initial melts, which may be related to origin of the stocks from different crustal levels. Lipman and others (1972) suggested that two imbricate gently east dipping Benioff zones may have controlled the formation of early and middle Tertiary magmas. This suggestion, based on $\mathrm{K}_{2} \mathrm{O}$ content of igneous suites of 60 percent $\mathrm{SiO}_{2}$ (Hatherton and Dickinson, 1969), would put the depth of forma- 

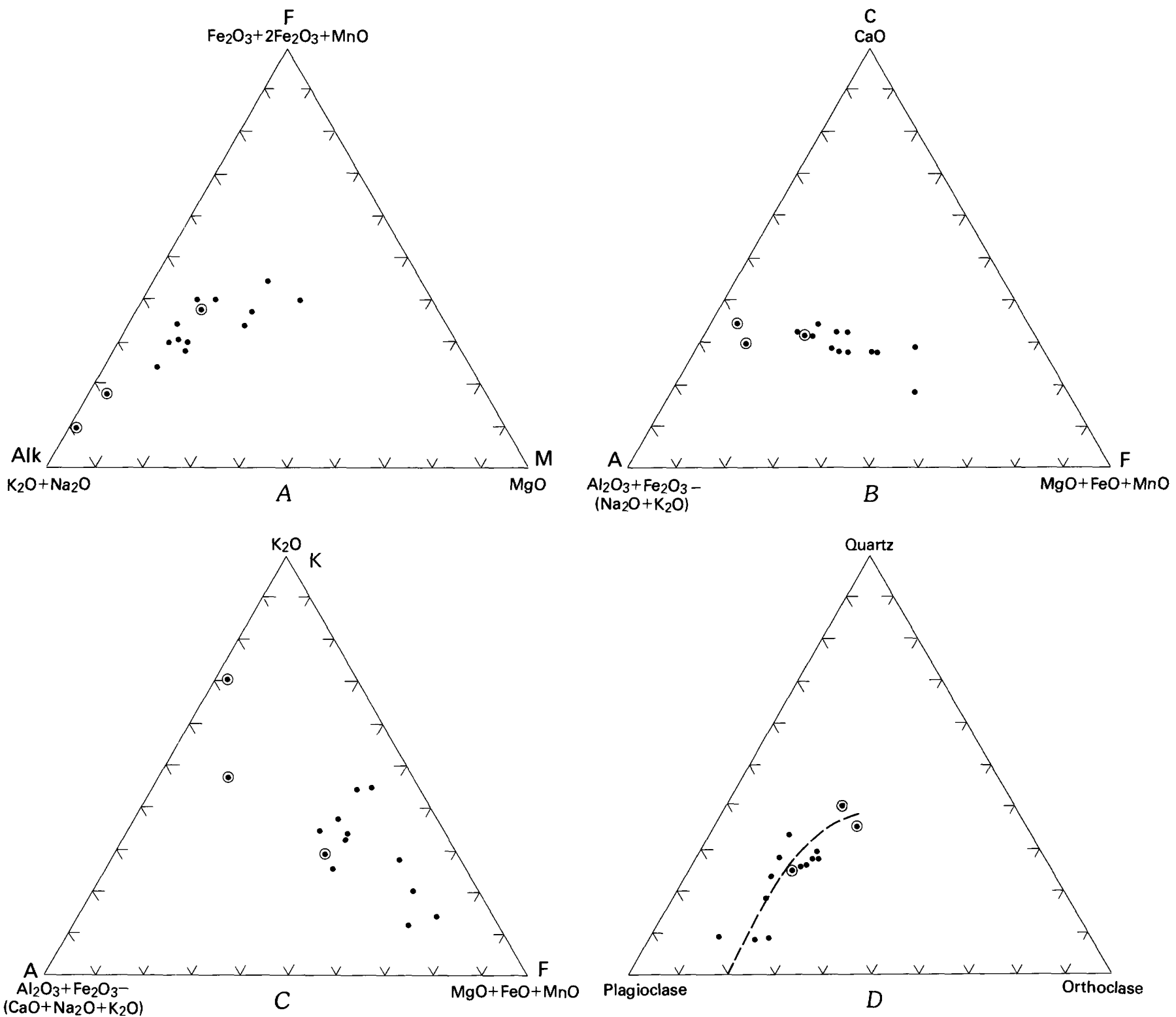

FIGURE 44.-Chemical and normative diagrams of analyzed middle Tertiary igneous rocks. A, AlkFM diagram; $B$, ACF diagram; $C$, AKF diagram; $D$, Normative plagioclase (Ab+An)-quartz-orthoclase diagram; line is variation trend of analysis of table 6 . Dot, Aspen area; circled dot, Independence-Lincoln Gulch area.

tion of the Elk Mountain igneous rocks at about 230 $\mathrm{km}$ on the east end of the two Benioff zones postulated by Lipman and others (1972). Some objections to this hypothesis have been stated by Gilluly (1971).

Dickinson (1975) pointed out that the relation between $\mathrm{K}_{2} \mathrm{O}$ content of magmas erupted in volcanic arcs and depth to associated seismic zone differs depending on whether the arc is on a continental margin or on oceanic crust. Continental margin arcs have magmas with higher $\mathrm{K}_{2} \mathrm{O}$ contents for a given $\mathrm{SiO}_{2}$ content than oceanic arcs. At seismic zone depths of $80-160 \mathrm{~km}$, for which many data are available, $\mathrm{K}_{2} \mathrm{O}$ content at 57.5 percent $\mathrm{SiO}_{2}$ reaches 0.6 percent for continental margin arcs alone (Dickinson, 1975, fig. 2). Stated another way, depth to the seismic zone below arcs having a given $\mathrm{K}_{2} \mathrm{O}$ content covers a range of $\pm 20 \mathrm{~km}$ for continental margin volcanic arcs. Few data are available from active volcanic arcs over seismic zones more than $200 \mathrm{~km}$ deep. The depth of formation of the magmas of the Elk Mountains would be in the range of $230-270 \mathrm{~km}$ according to reasonable projections of the data of Dickinson (1975, fig. 2), assuming a mechanism of formation along a Benioff zone.

Doe (1968) summarized evidence from lead and 
TABLE 6.-Chemical analysis, modes, and norms of middle Tertiary igneous rocks

\begin{abstract}
[Major oxides determined by rapid methods by P. L. D. Elmore, G. W. Chloe, Hezekiah Smith, Lowell Artis, J, L. Glenn, James Kelsey, and Samuel Botts, U.S. Geological Survey, 1967 and 1969. Minor elements determined by semiquantitative spectrographic methods by Joseph L. Harris, U.S. Geological Survey, present and William B. Crandell, U.s. Geological Survey, 1968. Mode by point count; present but not lntersected in cantis recalsulate to 00 in series $100,70,50,30,20,15$, and $10, \ldots$. semiquantitative results will include the quantitative value about 30 percent of the time. $\mathrm{N}$, not detected. Looked for but not found: Ag, As, Au, B, $\left.\mathrm{Bi}, \mathrm{Cd}, \mathrm{Ge}, \mathrm{Hf}, \mathrm{Hg}, \mathrm{I}_{\mathrm{n}}, \mathrm{Li}, \mathrm{Pd}, \mathrm{Pt}, \mathrm{Re}, \mathrm{Sb}, \mathrm{Sn}, \mathrm{Ta}, \mathrm{Te}, \mathrm{Ti}, \mathrm{U}, \mathrm{W}, \mathrm{Zn}\right]$
\end{abstract}

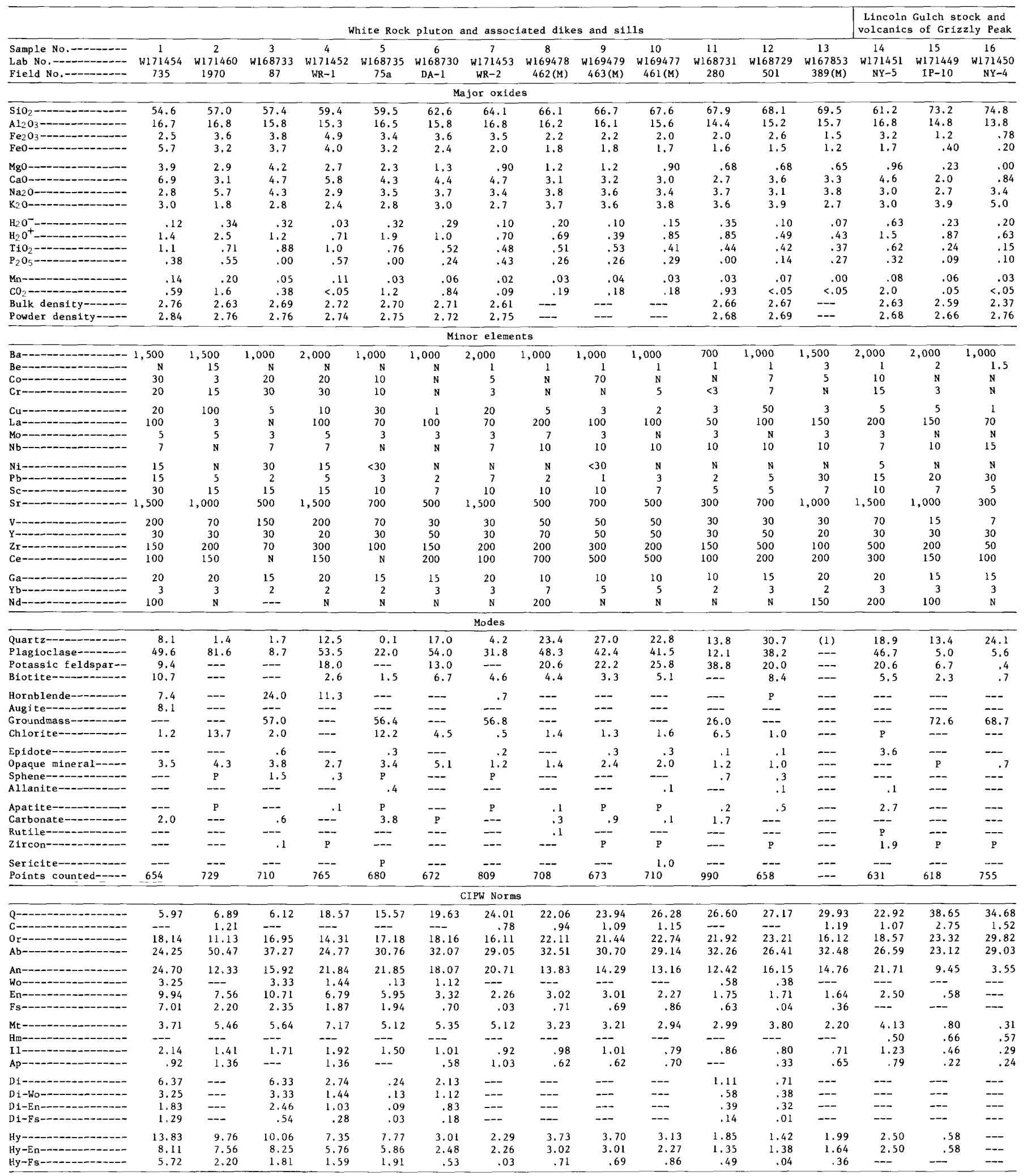


TABLE 6.-Chemical analysis, modes, and norms of middle Teritary igneous rocks-Continued

\begin{tabular}{|c|c|c|c|c|c|c|c|c|c|c|c|c|c|c|c|c|}
\hline \multirow[b]{2}{*}{$\begin{array}{l}\text { Sample No.-- } \\
\text { Lab No. } \\
\text { Field No.- }\end{array}$} & \multirow[b]{2}{*}{$\begin{array}{c}1 \\
\text { w171454 } \\
735\end{array}$} & \multicolumn{11}{|c|}{ White Rock pluton and associated dikes and silis-Continued } & \multicolumn{4}{|c|}{$\begin{array}{c}\text { Lincoln Gulch stock and volcanics } \\
\text { of Grizzly Peak-Continued }\end{array}$} \\
\hline & & $\begin{array}{c}2 \\
\text { W171460 } \\
1970\end{array}$ & $\begin{array}{c}3 \\
\text { w168733 } \\
87\end{array}$ & $\begin{array}{c}4 \\
\text { w1 } \\
\text { w/R-1 }\end{array}$ & $\begin{array}{c}5 \\
\text { W168734 } \\
75 a\end{array}$ & $\begin{array}{c}6 \\
\text { W168730 } \\
\text { ПA-1 }\end{array}$ & $\begin{array}{c}7 \\
\text { w171453 } \\
\text { WR-2. }\end{array}$ & $\begin{array}{c}8 \\
\text { W169478 } \\
462(14)\end{array}$ & $\begin{array}{c}9 \\
\text { W169479 } \\
463(M)\end{array}$ & $\begin{array}{c}10 \\
\ln 69477 \\
461(\mathrm{M})\end{array}$ & $\begin{array}{c}11 \\
w 168431 \\
280\end{array}$ & $\begin{array}{c}12 \\
\text { W168729 } \\
501\end{array}$ & $\begin{array}{l}13 \\
\text { N167853 } \\
389(M)\end{array}$ & $\begin{array}{l}14 \\
\text { W171451 } \\
\text { NY-5 }\end{array}$ & $\begin{array}{l}15 \\
\text { W171449 } \\
\text { IP-10 }\end{array}$ & $\begin{array}{l}16 \\
\text { W171450 } \\
N Y-4\end{array}$ \\
\hline \multicolumn{17}{|c|}{ Recalculated to 100 percent after deduction of volatiles } \\
\hline $\begin{array}{l}\mathrm{SiO}_{2} \\
\mathrm{Al}_{2} \mathrm{O}_{3}-\mathrm{P} \\
\mathrm{Fe} \mathrm{O}_{3} \\
\mathrm{FeO}\end{array}$ & $\begin{array}{r}55.87 \\
17.09 \\
2.56 \\
5.83\end{array}$ & $\begin{array}{r}59.65 \\
17.58 \\
3.77 \\
3.35\end{array}$ & $\begin{array}{r}58.79 \\
16.18 \\
3.89 \\
3.79\end{array}$ & $\begin{array}{r}59.95 \\
15.44 \\
4.95 \\
4.04\end{array}$ & $\begin{array}{r}61.79 \\
17.14 \\
3.53 \\
3.32\end{array}$ & $\begin{array}{r}64.13 \\
16.19 \\
3.69 \\
2.46\end{array}$ & $\begin{array}{r}64.73 \\
16.96 \\
3.53 \\
2.02\end{array}$ & $\begin{array}{r}66.84 \\
16.38 \\
2.22 \\
1.82\end{array}$ & $\begin{array}{r}67.22 \\
16.22 \\
2.22 \\
1.81\end{array}$ & $\begin{array}{r}68.47 \\
15.80 \\
2.03 \\
1.72\end{array}$ & $\begin{array}{r}69.96 \\
14.84 \\
2.06 \\
1.65\end{array}$ & $\begin{array}{r}68.59 \\
15.21 \\
2.62 \\
1.51\end{array}$ & $\begin{array}{r}70.21 \\
15.86 \\
1.52 \\
1.21\end{array}$ & $\begin{array}{r}64.10 \\
17.60 \\
3.35 \\
1.78\end{array}$ & $\begin{array}{r}74.07 \\
14.98 \\
1.21 \\
.40\end{array}$ & $\begin{array}{r}75.48 \\
13.93 \\
.79 \\
--\end{array}$ \\
\hline 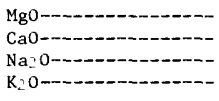 & $\begin{array}{l}3.99 \\
7.06 \\
2.87 \\
3.07\end{array}$ & $\begin{array}{l}3.03 \\
3.24 \\
5.96 \\
1.88\end{array}$ & $\begin{array}{l}4.30 \\
4.81 \\
4.40 \\
2.87\end{array}$ & $\begin{array}{l}2.73 \\
5.85 \\
2.93 \\
2.42\end{array}$ & $\begin{array}{l}2.39 \\
4.47 \\
3.63 \\
2.91\end{array}$ & $\begin{array}{l}1.33 \\
4.51 \\
3.79 \\
3.07\end{array}$ & $\begin{array}{l}.91 \\
4.75 \\
3.43 \\
2.73\end{array}$ & $\begin{array}{l}1.21 \\
3.13 \\
3.84 \\
3.74\end{array}$ & $\begin{array}{l}1.21 \\
3.22 \\
3.63 \\
3.63\end{array}$ & $\begin{array}{l}.91 \\
3.04 \\
3.44 \\
3.85\end{array}$ & $\begin{array}{r}.70 \\
2.78 \\
3.81 \\
3.71\end{array}$ & $\begin{array}{l}.68 \\
3.63 \\
3.12 \\
3.93\end{array}$ & $\begin{array}{r}.66 \\
3.33 \\
3.84 \\
2.73\end{array}$ & $\begin{array}{l}1.01 \\
4.82 \\
3.14 \\
3.14\end{array}$ & $\begin{array}{r}.23 \\
2.02 \\
2.73 \\
3.95\end{array}$ & $\begin{array}{r}.20 \\
.85 \\
3.43 \\
5.05\end{array}$ \\
\hline $\begin{array}{l}\mathrm{TiO}_{2}- \\
\mathrm{P}_{2} \mathrm{O}_{5} \\
\mathrm{MnO}-\end{array}$ & $\begin{array}{r}1.13 \\
.39 \\
.14\end{array}$ & $\begin{array}{l}.74 \\
.58 \\
.21\end{array}$ & $\begin{array}{c}.90 \\
-.05\end{array}$ & $\begin{array}{r}1.01 \\
.58 \\
.11\end{array}$ & $\begin{array}{c}.79 \\
-.03\end{array}$ & $\begin{array}{l}.53 \\
.25 \\
.06\end{array}$ & $\begin{array}{l}.48 \\
.43 \\
.02\end{array}$ & $\begin{array}{l}.52 \\
.26 \\
.03\end{array}$ & $\begin{array}{l}.53 \\
.26 \\
.04\end{array}$ & $\begin{array}{l}.42 \\
.29 \\
.03\end{array}$ & $\begin{array}{c}.45 \\
-.03\end{array}$ & $\begin{array}{l}.42 \\
.14 \\
.07\end{array}$ & $\begin{array}{r}.37 \\
.27 \\
--.\end{array}$ & $\begin{array}{l}.65 \\
.34 \\
.08\end{array}$ & $\begin{array}{l}.24 \\
.09 \\
.06\end{array}$ & $\begin{array}{l}.15 \\
.10 \\
.03\end{array}$ \\
\hline
\end{tabular}

SAMPLE DESCRIPTIONS

1. Dark-gray amphibole-pyroxene biotite granodiorite. Euhedral to subhedral normally zoned plagioclase as much as $1 \mathrm{~mm}$ long (An $55-30$ ), quartz and potassic feldspar interstitial to plagioclase, anhedral biotite as much as $0.5 \mathrm{~mm}$ in diameter; subhedral to anhedral augite as much as 1 mim in diameter partly
altered to fine-grained amphibole. Apophysis of White Rock pluton. From adit at $3,901 \mathrm{~m}$ altitude $300 \mathrm{~m}$. $65^{\circ} \mathrm{W}$. from the Montezuma mine, Hayden Peak quadrangle.

2. Greenish-gray dike rock mapped as hornblende porphyry. Euhedral plagioclase grains as much as 1 mm long altered to sericite and carbonate, interstitial quartz, and chlorite after hornblende. From 3,700 m altitude $640 \mathrm{~m} \mathrm{~N}$. $70^{\circ}$ E. from spot elevation 3,987 m on Willow Creek-East Snowmass Creek divide near southern margin of Highland Peak quadrangle.

3. Gray porphyritic rock mapped as hornblende porphyry. Euhedral to subhedral alined hornblende needles as much as $1 \mathrm{~cm}$ long, partly altered to chlorite; euhedral to subhedral plagioclase as much as $1.5 \mathrm{~cm}$ in diameter, saussuritized; quartz in resorbed phenocrysts or xenocrysts as much as 2 mm in

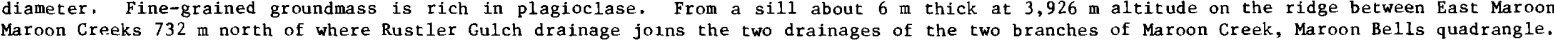

4. Gray biotite-hornblende granodiorite. Euhedral to subhedral plagioclase as long as $1.5 \mathrm{~mm}$, oscillatory zoning in a normal trend An $60-20$; interstitial potassic feldspar as much as $0.6 \mathrm{~mm}$ long, interstitial quartz as much as $0.4 \mathrm{~mm}$ in diameter, subhedral to anhedral hornblende as much as 3 mm long; anhedral biotite to $3 \mathrm{~mm}$ in diameter. From apophysis of the White Rock pluton at $3,426 \mathrm{~m}$ altitude on Pearl Pass jeep trail about $152 \mathrm{~m}$ southwest of junction with the Montezuma mine row, Hayden Peak quadrangle.

5. Gray porphyritic dike rock mapped as hornblende porphyry. Euhedral to subhedral plagioclase phenocrysts as much as 2 mm long ranging An $45-27$, phenocrysts of hornblende as much as $7 \mathrm{~mm}$ long pseudomorphosed by chlorite, euhedral phenocrysts of biotite as much as $0.5 \mathrm{~mm}$ in diameter in a
groundmass of plagioclase, carbonate, sericite, and quartz. From dike at the summit of Maroon Peak, Maroon Bells quadrangle,

6. Light-gray biotite granodiorite. Euhedral to subhedral plagioclase 0.5-2 mm long with oscillatory zoning and normal zoning. An 52-32, sodic rims, partly altered; interstitial quartz $0.5-0.1 \mathrm{~mm}$ in diameter, interstitial potassic feldspar; subhedral biotite as much as $0.5 \mathrm{~mm}$ in diameter, partly chloritized. From margin of white Rock pluton at 3,633 maltitude at portal of adit $90 \mathrm{~m}$ east of labeled mine on northeast side of Rustler Gulch $640 \mathrm{~m}$ S. $70^{\circ}$ W. from 4,012-m peak on East Maroon-Rustler Gulch divide, Maroor Bells quadrangle.

7. Light-gray porphyritic biotite granodiorite. Euhedral plagioclase phenocrysts as much as 1.8 mm long An55-30 with oscillatory zoning in a normal trend; euhedral phenocrysts of quartz as much as $1 \mathrm{~mm}$ in diameter, euhedral phenocrysts of biotite as much as $2.4 \mathrm{~mm}$ in diameter; subhedral phenocrysts of hornblende as much as $0.6 \mathrm{~mm}$ long in a very fine grained groundmass of quartz, feldspar, and opaque minerals, Contains inclusion of hornblende quartz diorite $3 \mathrm{~mm}$ in diameter. White Rock pluton. From roadcut at $3,499 \mathrm{~m}$ altitude on road to Montezuma mine, Hayden Peak quadrangle. Biotite dated $33.9+1.0 \mathrm{~m}, \mathrm{y}$. (Obradovich and others, 1969).

8. Porphyritic biotite granodiorite. Subhedral to euhedral plagioclase phenocrysts and glomerophenocrysts as much as 3 mm in diameter with oscillatory zoning in a normal trend $\mathrm{An}_{4} 0-30$; subhedral partly resorbed phenocrysts of quartz as much as $1.8 \mathrm{~mm}$ in diameter; subhedral to euhedral phenocrysts of trail 457 m north of Copper Lake; Maroon Bells quadrangle. Collected by F. E. Mutschler.

9. Porphyritic biotite quartz monzonite. Euhedral to subhedral phenocrysts and glomerophenocrysts of plagioclase as much as $3 \mathrm{~mm}$ in diameter with oscillatory zoning in a normal trend $\mathrm{An}_{60-38}$; subhedral resorbed phenocrysts of quartz as much as $3 \mathrm{~mm}$ in diameter; subhedral to euhedral phenocrysts of biotite as much as $1.5 \mathrm{~mm}$ in diameter, in a groundmass of quartz, potassic feldspar and albite with a grain size of 0.05-0.2 mm. White Rock pluton. From cut along trail $460 \mathrm{~m}$ north of Copper Lake, Maroon Bells quadrangle. Collected by F. E. Mutschler.

10. Porphyritic biotite quartz monzonite. Euhedral to subhedral phenocrysts and glomerophenocrysts of plagioclase as much as $3 \mathrm{~mm}$ in diameter. An 35 , locally saussuritized; subhedral, partly resorbed phenocrysts of quartz as much as $1.8 \mathrm{~mm}$ in diameter; subhedral to euhedral phenocrysts of biotite as much as $1.5 \mathrm{~mm}$ in diameter in a groundmass of quartz, plagioclase, and potassic feldspar with a grain size of $0.05-0.1 \mathrm{~mm}$. White Rock pluton. From cut along trail $460 \mathrm{~m}$ north of Copper Lake, Maroon Bells quadrangle. Numbers 8, 9, and 10 were collected by F. E. Mutschler to illustrate the variations within an 100 -meter-square area.

11. Porphyritic granodiorite. Euhedral phenocrysts of plagioclase as much as $1 \mathrm{~cm}$ long, saussuritized; subhedral phenocrysts of quartz as much as 7 mm in diameter, partly resorbed; euhedral phenocrysts of potassic feldspar as much as $2.5 \mathrm{~cm}$ long have numerous inclusions of quartz, plagioclase, sphene, and $3,377 \mathrm{~m}$ altitude $1,130 \mathrm{~m} \mathrm{~N}, 47^{\circ}$ W. of outlet of Maroon Lake, Maroon Bells quadrangle.

12. Gray biotite quartz monzonite. Subhedral plagioclase as much as $4 \mathrm{~mm}$ long with some oscillatory and normal zoning An $42-38$, partly saussuritized; generally anhedral quartz to $6 \mathrm{~mm}$ in diameter; potassic feldspar as much as $6 \mathrm{~mm}$ long includes quartz, plagloclase, and biotite; biotite as much as Dollar Pond, Maroon Bells quadrangle.

13. Porphyritic granodiorite. Carlsbad-twinned phenocrysts of potassic feldspar as much as $3 \mathrm{~cm}$ long and of quartz, plagioclase, and biotite as much as $1 \mathrm{~cm}$ in diameter in a very fine grained groundmass. Snowmass Creek sill NE $1 / 4 \mathrm{NW} 1 / 4 \mathrm{sec}$. 17, T. 10 S, R. 86 W. at bottom SE side Snowmass Creek in the Biotite dated at $31.2+1.1$ m.y. (Obradovich and others, 1969).

14. Porphyritic granodiorite. Euhedral to subhedral plagloclase phenocrysts as much as $5 \mathrm{~mm}$ long, An 45 , partly altered; subhedral partly resorbed phenocrysts of quartz as much as $5 \mathrm{~mm}$ in diameter, subhedral phenocrysts of biotite as much as $3.5 \mathrm{~mm}$ in diameter; in a groundmass of potassic feldspar and quartz with a grain size of $0.01-0.04 \mathrm{~mm}$. From chilled margin of Lincoln Gulch

15. Quartz latitic welded tuff. Anhedral to subhedral fragments of quartz, sanidine, and plagioclase as much as $2 \mathrm{~mm}$ in diameter and euhedral to subhedral phenocrysts of biotite as much as $1.5 \mathrm{~mm}$ in diameter in a very fine grained to glassy matrix. A few xenocrysts of microcline. Collapsed pumice ragments. Grizzly Mountain Rhyolite of Stark and Barnes (1935). From outcrop on jeep trail to Green Mountain $850 \mathrm{~m} N$. $75^{\circ}$ W. from BM 10,831 on Colorado Highway 82 west of Independence; Independence Pass quadrangle.

16. Rhyolitic welded tuff. Anhedral to subhedral quartz, sanidine, and plagioclase as much as 2.5 mm in diameter and euhedral to subhedral biotite as much as $0.4 \mathrm{~mm}$ in diameter in a very fine grained to glassy matrix. Collapsed pumice fragments. Grizzly Mountain Rhyolite of Stark and Barnes (1935). From New York collection canal 140 m east of Tabor Creek, New York Peak quadrangle. 
strontium isotopes bearing on the origin of the Cretaceous and Tertiary igneous rocks of the Rocky Mountain region. They cannot have been derived by melting of Precambrian rocks of the upper crust such as are now exposed in uplifts, including the Sawatch Range, but they may be derived from the lower crust or the mantle.

The gravity map of Colorado (Behrendt and Bajwa, 1972) shows a well-defined low along the Colorado mineral belt extending as far west as the White Rock pluton. Analysis of this low (Case, 1965; Isaacson and Smithson, 1976) indicates that it is caused by a batholithic mass. The intrusives visible at the surface may be offshoots of this mass emplaced at somewhat different times and having different cooling histories, related to their depth of origin in the batholith, their size, the temperature of the wallrock into which they were emplaced, and whether or not they vented.

\section{TERTIARY AND QUATERNARY DIABASE DIKES}

Two dikes of fine-grained diabase were found in the western part of the Aspen quadrangle. One dike is about $2.4 \mathrm{~m}$ thick and crops out on the Maroon Creek road just east of the bridge across the creek, and the other is exposed at $2,940 \mathrm{~m}$ altitude $1.5 \mathrm{~km}$ to the south. At the latter locality the diabase contains numerous rounded white inclusions of limestone and a few inclusions of quartz rimmed with carbonate. Alinement of plagioclase grains in that rock produces a trachytic texture.

The diabase consists of euhedral to subhedral laths of plagioclase An ${ }_{50-65}$ which are 0.5-1 mm long. Tan monoclinic pyroxene $0.1-0.3 \mathrm{~mm}$ in diameter occurs in the interstices of the plagioclase grains and locally forms phenocrysts as much as $1 \mathrm{~mm}$ long. Euhedral to subhedral magnetite 0.04-0.2 $\mathrm{mm}$ in diameter appears to have crystallized at the same time as or earlier than the plagioclase. Some biotite has formed by alteration of the pyroxene, and sericite and carbonate, by alteration of plagioclase. Some other very fine grained unidentified alteration products occur.

These diabase dikes are probably related to the upper Tertiary to Quaternary basalts of the region. The nearest mapped basalt flows are $16 \mathrm{~km}$ to the north near Woody Creek (Freeman, 1972a), and these have been dated as about 1.5 m.y. or early Pleistocene (Larson and others, 1975). That older basalts may have been present in the drainage of the upper Roaring Fork River is indicated by the presence of basalt in a highlevel gravel at the western edge of the Woody Creek quadrangle (Freeman, 1972a).

\section{METAMORPHISM}

The Oligocene plutons have produced contact metamorphism whereas the small Laramide plutons have not appreciably metamorphosed their wallrock. The dikes, sills, and laccoliths of Oligocene age generally metamorphosed their wallrocks for distances of several centimeters to about $20 \mathrm{~m}$ from their margins. The White Rock pluton, on the other hand, has a contact aureole ranging in map width from $100 \mathrm{~m}$ to $3 \mathrm{~km}$. If my cross sections are approximately correct (Bryant, 1969, 1970), the greatest thickness of contact metamorphic rocks in a direction perpendicular to the contact of the pluton would be about $1 \mathrm{~km}$.

The extent of contact metamorphism is very obvious in the field because most of the rocks affected are red beds of the Maroon Formation (figs. 45A, $B$ ). Upon metamorphism they were converted to green and gray calc-silicate hornfels and calc-silicate-bearing sandstone. The transition between red beds and hornfels in the contact aureole of the White Rock pluton is gradual through a hundred to a few hundred meters. The sandstone beds are most easily bleached, perhaps because of their greater permeability allowing heat to be transmitted more effectively either through intergranular fluids or gases. The impermeable mudstones retain their grayish-red color; whereas the interbedded sandstones have completely lost theirs. In this transition zone specular hematite, epidote, and tremolite are found on joint planes.

In areas of contact metamorphism, mapping the contact between the Maroon and Gothic Formations is very difficult, as the distinctive color of the Maroon is lost. Both the lower part of the Maroon and the Gothic contain limestones; thus, the presence or absence of marble cannot be used to separate the two formations in areas of contact metamorphism. The Gothic has a few beds of dark-gray shale or shaly limestone that tend to retain color upon metamorphism; however, the metamorphosed Maroon has a few beds of dark-gray biotitic hornfels that are similar in appearance. Overall, the Gothic is more calcareous and less feldspathic than the Maroon, but it is difficult to use these criteria in mapping based on individual outcrops. However, the Maroon contains conglomerates in many, but not all, areas and conglomerates are lacking in the Gothic north of the crest of the Elk Mountains near Aspen; therefore, in many areas of contact metamorphism in the Aspen area, the Maroon can be distinguished from the Gothic by the presence of conglomerates. Nevertheless, the contact of the Maroon and Gothic Formations is difficult enough to distinguish in areas of contact metamorphism so that there may be errors in the position of this contact, such 

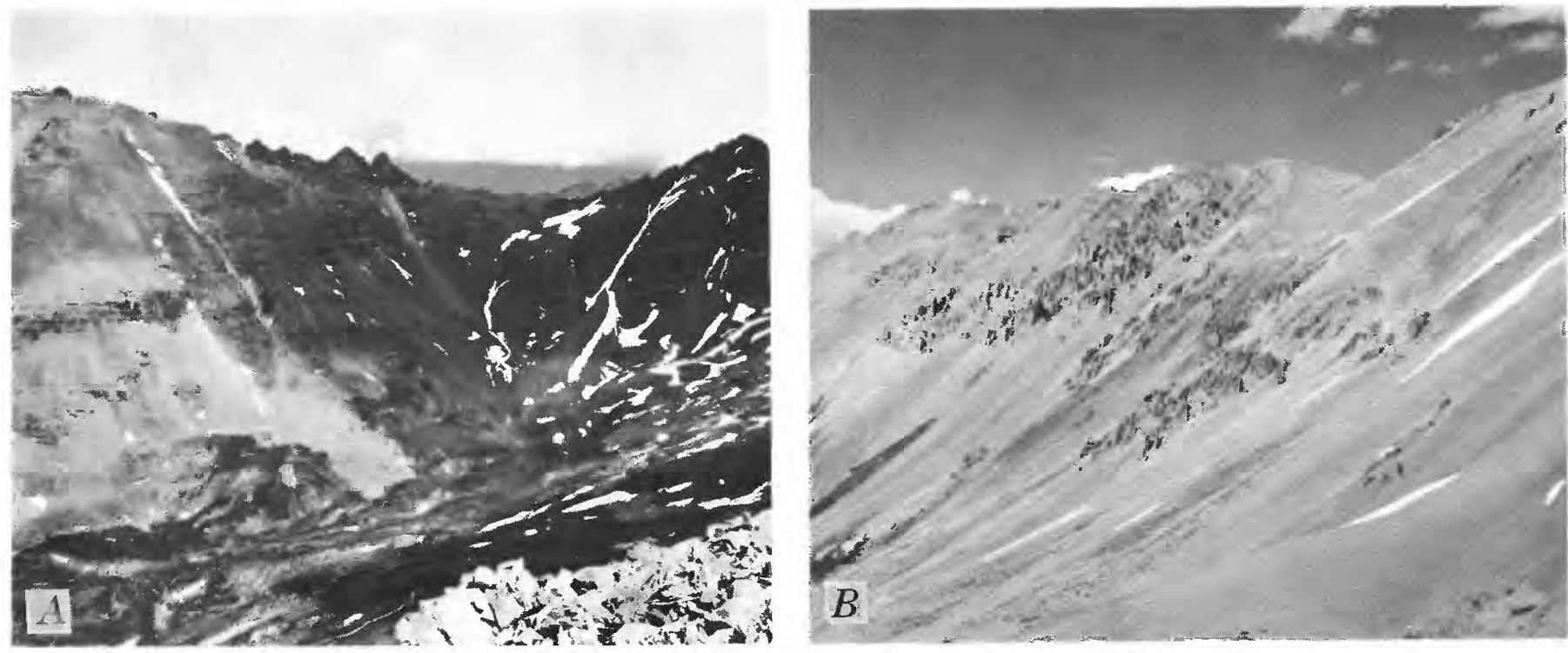

FIGURE 45.-Areas of thermal metamorphism. $A$, Gradation from red beds (dark rocks on right) to hornfels (light rocks on left) of the Maroon Formation on the east side of the head of Conundrum Creek, Gothic and Maroon Bells quadrangles. Samples 6-13, table 3, collected in a traverse across this contact. B, Pyritized and fractured hornfels of the Maroon Formation west of Electric Pass (Hayden Peak quadrangle) forms abundant talus.

as at the south contact of the White Rock pluton in the Maroon Bells quadrangle and in the Conundrum Creek window area.

In general, the contact-metamorphosed Belden Formation retains its thin-bedded and carbonaceous aspects (fig. 16). However, locally the limestone-rich parts are made more obvious by metamorphism and consequently are mappable as a unit separate from the carbonaceous shale and siltstones, as in the Conundrum Creek window and near Cooper Fork. The marble unit is apparently stratigraphically below the hornfels unit. The marble and hornfels are in most places highly deformed (fig. $38 A$ ) so that stratigraphic thicknesses are unknown. On the east side of Conundrum Creek at about $3,010 \mathrm{~m}$ altitude some marble beds are as much as $10 \mathrm{~m}$ thick, and quarrying of them was once attempted. Such thick beds of marble have led some to map this unit as metamorphosed Leadville Limestone. Beds of that thickness are exceptional in the marble unit. Most of the marble beds are several centimeters to a few meters thick and contain beds of carbonaceous hornfels between them.

The typical metamorphic minerals of the hornfels and associated rocks are diopsidic pyroxene, amphibole (generally tremolite but ranging in composition to actinolite and hornblende in some rocks), garnet, idocrase, scapolite, and biotite.

In the metamorphic aureole sedimentary textures of the sandstones and siltstones are commonly well preserved. The metamorphic minerals developed from the matrix between the clastic grains. Mudstones, shales, and limestones are completely recrystallized. In most of the metamorphosed rocks pyroxene, amphibole, and biotite have a grain size of $0.1 \mathrm{~mm}$ or less, but in a few those minerals have recrystallized more coarsely.

In many of the conglomerates, pebbles of dolomite have been converted to masses of green pyroxene and pebbles of limestone to yellowish-brown garnet. Limestone pods and lenses in siltstone beds have similarly been metamorphosed.

In many of the metamorphosed sandstones the plagioclase is albite, but in a few it has been reconstituted to form oligoclase or andesine. Microcline grains are locally recrystallized to a perthitic potassic feldspar, especially near igneous contacts. Recrystallized quartz having a mosaic texture is found in places close to the contact of the pluton.

Yellowish- to reddish-brown garnet (colorless to yellowish brown in thin section) tends to form porphyroblasts that in places give the hornfels a spotted aspect. Idocrase occurs as small porphyroblasts. In one rock idocrase surrounds a large garnet and appears to have formed by alteration of the garnet. Wollastonite was found in hornfels adjacent to the west contact of the granodiorite body on upper West Maroon Creek and in the Conundrum Creek area.

Aluminum-excess rocks are rare in the deposits of the Eagle basin. Only one sample of those studied contained an aluminum silicate mineral. That rock was 
from the Belden Formation and contains andalusite, corundum, and potassic feldspar. The feldspar is heavily sericitized.

Magnetite and pyrite are the common opaque minerals. Pyrite in the Maroon Formation is concentrated in the zone of pyritized rock surrounding the centers of alteration in the granodiorite. Pyrite is abundant in unmetamorphosed rocks of the Belden Formation, and it is difficult to tell whether any additional pyrite has been introduced where Belden rocks are converted to hornfels. The hematite of the red beds is converted to magnetite upon metamorphism. Locally, magnetite is found in segregations several centimeters thick in places associated with garnet. In some of these segregations it has a bladed habit suggesting that it may be pseudomorphing specular hematite.

The most widespread porphyroblastic mineral in the hornfels is scapolite. It forms euhedral to anhedral commonly sieve textured porphyroblasts as much as several millimeters long. The porphyroblasts include metamorphic pyroxene as well as other minerals, so they formed late during the metamorphism. Optical study shows that most of the scapolite is sodic and has a meionite content of about 20 percent. In some rocks the scapolite has been altered to an isotopic mineral with $n \approx 1.484$, which is probably sodalite.

In places the hornfels is vuggy and has open fractures; and euhedral crystals a few millimeters to a centimeter or two in size fill the vugs or line the fractures. These features are best developed at the head of Castle Creek on the south side of the granodiorite plug south of the Montezuma mine. Honey-yellow to reddishbrown garnet and dark-green pyroxene crystals are common minerals growing in the open spaces. In places magnetite accompanies the garnet. Locally, epidote grows in the vugs. Albite coats some fractures and occurs in some vugs. In one place scapolite $\left(\mathrm{Me}_{20}\right)$ crystals $2 \mathrm{~cm}$ long are associated with coarse-grained calcite on a joint. Zeolites including chabazite, stilbite, natrolite, and thomsonite fill fractures and coat the other minerals.

I detected no well-developed zoning based on silicate minerals in the contact metamorphic aureole. The diverse mineral assemblages are distributed in the various beds throughout the area of contact metamorphism. One possible zoning that might be mapped is an outer aureole in which mudstones retain their grayishred color and interbedded sandstones are bleached.

\section{CHEMISTRY OF METAMORPHISM}

A suite of samples across a steep contact between red beds of the Maroon Formation and rocks metamorphosed by the White Rock pluton was collected on the east side of the basin at the head of Conundrum Creek in the Gothic and Maroon Bells quadrangles, at about $3,750 \mathrm{~m}$ altitude (fig. $45 A$ ). I was not able to walk out individual beds, as I had hoped to; and if I had been able to, it is doubtful that individual beds in the Maroon Formation would have maintained a constant original chemical composition over the distance of $1 \mathrm{~km}$ covered by the sampling traverse. At each sample site a sandstone bed and a siltstone bed were collected.

The rocks at sample site 1704 (table 3) showed no sign of metamorphism; rocks at 1705 were a little bleached but definitely unmetamorphosed; at $\mathbf{1 7 0 6}$ they were mostly gray and greenish gray but a few beds maintained grayish-red hues; rocks at 1707 were fully metamorphosed. The contact between red beds and hornfels as shown on the quadrangle maps was usually determined in the alpine country from a distant view of the complete section exposed rather than on detailed observation of individual outcrops. That explains why sample 1706, which is definitely metamorphosed, lies just outside the area shown as metamorphosed on the geologic quadrangle map.

Since I cannot claim to have sampled a single bed of uniform composition passing from metamorphosed to unmetamorphosed rocks, I must consider what changes took place in the suite of samples between the sample sites rather than individual samples. Three changes are most obvious. The first was loss of $\mathrm{H}_{2} \mathrm{O}$. This process started before the red color of the sedimentary rocks was affected (table 3 ; fig. 46). The second change was reduction of iron: $\mathrm{Fe}_{2} \mathrm{O}_{3}$ (hematite) was reduced to $\mathrm{Fe}_{3} \mathrm{O}_{4}$ (magnetite), and the big change in $\mathrm{Fe}_{2} \mathrm{O}_{3} / \mathrm{FeO}$ ratio came at the big change in color from predominantly red rocks to predominantly gray rocks. This change in mineralogy is confirmed by polished section study of the analyzed rocks. However, in the metamorphosed rocks the $\mathrm{Fe}_{2} \mathrm{O}_{3} / \mathrm{FeO}$ ratio is less than that of magnetite (fig. 46) showing that $\mathrm{FeO}$ occurs in other minerals. Much of the $\mathrm{FeO}$ is in pyroxene, hornblende, and possibly garnet. The third change is loss of $\mathrm{CO}_{2}$. For unmetamorphosed rocks of the Maroon Formation most of the $\mathrm{Ca}$ is in the mineral calcite, which occurs as clastic grains and cement. As the rocks become metamorphosed $\mathrm{CO}_{2}$ was driven off, and the $\mathrm{Ca}$ present became part of $\mathrm{Ca}$ and $\mathrm{CaAl}$ silicate minerals, such as pyroxene, garnet, and plagioclase (table 3). Consequently, the $\mathrm{Ca} / \mathrm{CO}_{2}$ ratio is an indicator of the extent to which $\mathrm{CO}_{2}$ has been expelled. The unmetamorphosed red beds have a ratio $\mathrm{Ca} / \mathrm{CO}_{2}$ of 1.3 , which is the ratio in the mineral calcite. This indicates that practically all the $\mathrm{Ca}$ in those rocks is in calcite. $\mathrm{As}_{\mathrm{S}} \mathrm{CO}_{2}$ was driven off with increasing metamorphism, the ratio increased (fig. 46). 


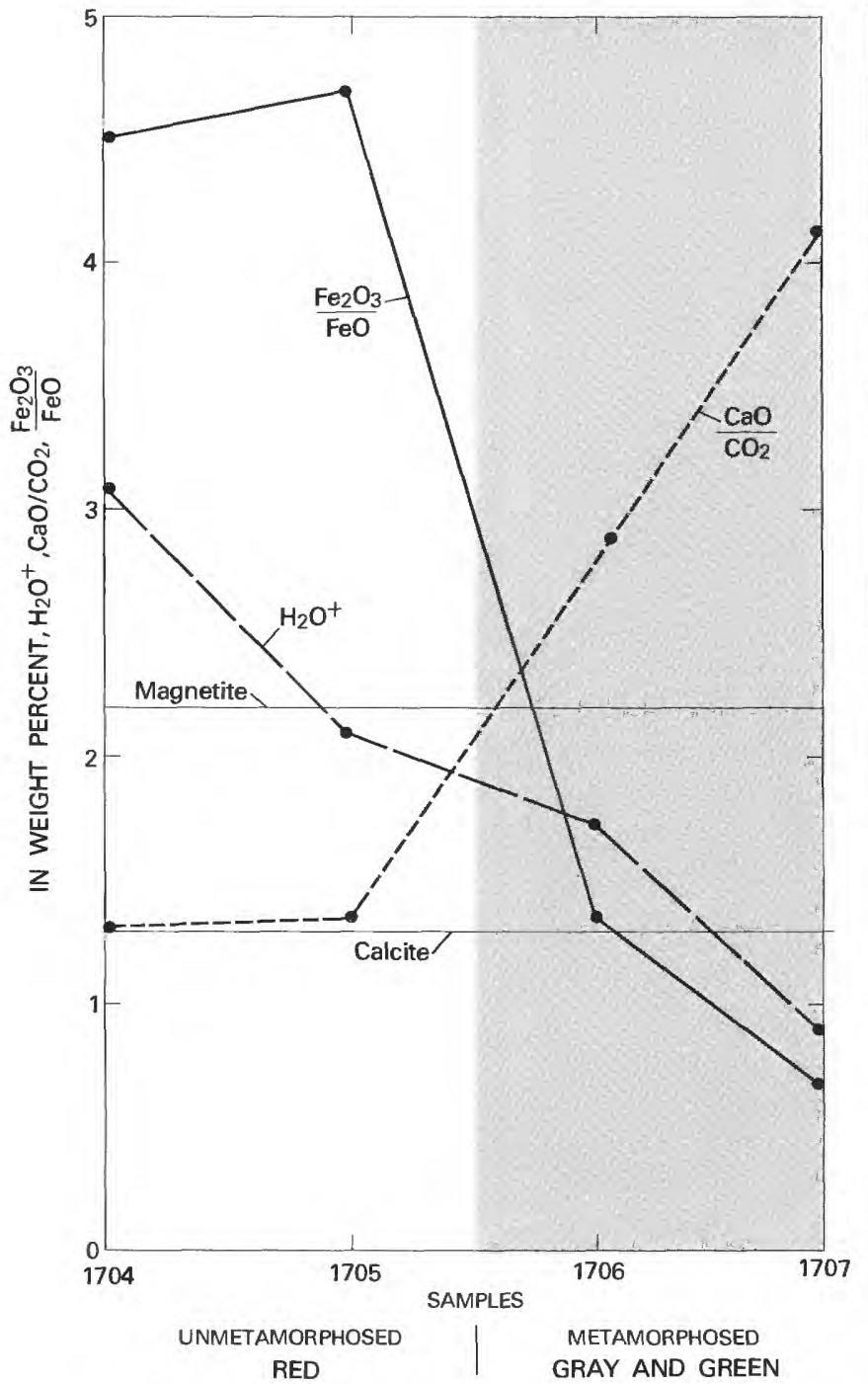

Figure 46.-Chemical changes in red beds of the Maroon Formation during contact metamorphism. Loss of $\mathrm{CO}_{2}, \mathrm{H}_{2} \mathrm{O}+$, and $\mathrm{O}_{2}$, as indicated by reduction of $\mathrm{Fe}$, occurs with metamorphism.

Sandstones lost $\mathrm{H}_{2} \mathrm{O}$ and $\mathrm{CO}_{2}$ proportionately more than did the siltstones. These volatiles lost during contact metamorphism may have contributed to formation of veins in overlying rocks and to deposition of minerals in fractures in adjacent unmetamorphosed rocks.

\section{CONDITIONS OF METAMORPHISM}

The mineral assemblages of the contact metamorphic rocks related to the White Rock pluton are those of the hornblende hornfels facies. Turner $(1968, p .17)$ pointed out that aureoles in calcareous rocks, such as those of the Eagle basin, show great mineralogic variation and that zoning in them is usually obscure. The chemical composition and permeability of the individual beds determine the mineral assemblage. These factors will cause variations in $\mathrm{P}_{\mathrm{H}_{2} \mathrm{O}}$ and $\mathrm{PCO}_{\mathrm{CO}_{2}}$, which in turn will cause variations in mineral assemblages containing calcium and magnesium silicates. These variables have a greater effect on mineral paragenesis than $\mathrm{P}_{\text {Total }}$ (See diagrams by Winkler (1967, p. 34, 35, 73).)

Fluid inclusion studies mentioned earlier (p. 63) indicate that the late hydrothermal alteration of the White Rock pluton occurred perhaps a million to a few million years after emplacement of the pluton at the level of present exposure took place at about 120 bars pressure or a depth of $1,200 \mathrm{~m}$ assuming hydrostatic conditions. The present altitude of most of the samples studied was $3,350-3,540 \mathrm{~m}$, which would suggest that the land surface at the time of hydrothermal alteration was not far above the highest of the present peaks. Even assuming considerable erosion during the interval between magma consolidation and hydrothermal alteration, pressure during contact metamorphism was probably 1,000 bars or less. The topographic relief now existing on the White Rock pluton is great enough to account for a pressure difference of $300-400$ bars assuming lithostatic conditions. According to Winkler (1967, p. 79), temperatures of the hornblende hornfels facies at 1,000 bars range approximately from $535^{\circ}$ to $600^{\circ} \mathrm{C}$.

Reactions of matrix minerals in the sedimentary rocks in the contact aureole were relatively complete, but the framework silicates were not affected in many rocks, as shown by unaltered clastic grains of albite inherited from the sandstones. In relatively few rocks did the plagioclase recrystallize to oligoclase or andesine.

No well-defined aureole of albite-epidote-hornfelsfacies rocks surrounds the hornblende-hornfels-facies rocks. The albite-epidote-hornfels-facies rocks may be represented by the epidote and epidote-tremolite veinlets found in the partly bleached rocks at the outer edge of the metamorphic aureole. Apparently, in that area reactions were even less complete than in the hornblende-hornfels-facies rocks.

The source of the $\mathrm{Na}$ and $\mathrm{Cl}$ for the late scapolite porphyroblasts is not known. We do not know of any $\mathrm{NaCl}$ in the evaporite beds in the immediate vicinity; the beds we saw were composed of $\mathrm{CaSO}_{4}$. The granodiorite magma is also a possible source of $\mathrm{Na}-$ bearing solutions. The occurrence of high-salinity fluid inclusions in some of the altered granodiorite suggests that the magma could have been a source for the $\mathrm{Na}$ and $\mathrm{Cl}$ in the scapolite. The apparent uniformity of the composition of the scapolite in beds of otherwise differing composition indicates that scapolite formation was 
externally controlled, probably by the $\mathrm{Na}$ and $\mathrm{Cl}$, whatever the source. Late alteration of scapolite to sodalite probably took place under the influence of solutions similar to those that introduced the $\mathrm{Na}$ and $\mathrm{Cl}$ for the scapolite.

\section{STRUCTURE}

The decipherable structural history of the Aspen region extends from at least 1,650 to 1,750 m.y. ago, the time of the metamorphism of the Precambrian sedimentary and metamorphic rocks, to the middle Tertiary, or about 30 m.y. ago. Younger structures have not been definitely dated in the Aspen area, although they are widespread in Colorado. The structural history of the area indicates that older structures tended to affect the locations and configuration of younger structures.

\section{PRECAMBRIAN STRUCTURES}

At the time that the Precambrian rocks were metamorphosed they were isoclinally folded, and foliation and lineation formed. The Aspen area includes only a small area of layered rocks of Precambrian age; so larger scale structures cannot be delineated, nor are the relations known between structures observed on the scale of an outcrop and larger structures.

Foliation, which is generally defined by micas alined parallel with compositional layering, generally trends northeast and dips steeply to moderately either northwest or southeast. However, some foliation trends northwest and dips northeast. Many of the statistical highs on the diagram summarizing foliation (fig. $47 \mathrm{~A}$ ) lie on a girdle that has an axis trending N. $40^{\circ} \mathrm{E}$. and plunging $30^{\circ} \mathrm{NE}$. Other girdles having axes trending N. $87^{\circ} \mathrm{W}$. plunging $10^{\circ} \mathrm{SE}$. and N. $72^{\circ} \mathrm{E}$. plunging $55^{\circ} \mathrm{NE}$. can also be drawn through other combinations of statistical highs.

Lineation formed by alined minerals or aggregates of minerals, such as sillimanite, trends east to northeast parallel with the poles of the three statistical girdles of the foliation (fig. $47 B$ ). In many outcrops the mineral lineation is parallel with axes of minor folds.

Minor folds were classified as isoclinal or open, but no well-defined age relations between the types were detected, nor do their respective axial planes or axes have orientations distinctive to the fold type (figs. $4 A$, $4 B, 47 C)$. Fold axes have a distribution similar to that of the mineral lineation. The distribution of axial planes resembles that of the foliation. The sparse information on minor structures in the Aspen area suggests that the Precambrian rocks have a complex structural history, but the data from this small area of Precambrian metamorphic rock are insufficient to reveal that history.

Few data have been published on structural trends in the Precambrian rocks of the Sawatch Range near Aspen. A generalized map by Stark and Barnes (1935) suggested that north and east of Aspen trends are generally northeast whereas to the southwest of Aspen the trends are northwest. Even their generalized data suggested some fairly large scale swirls in the trends of both regions. Detailed mapping in the Mt. Harvard quadrangle (Brock and Barker, 1972) southeast of Aspen showed general north-northwest trends on the northern half of the quadrangle and east-northeast trends in the southern half with numerous local variations.

A number of northeast-trending shear zones of Precambrian age are found in the Sawatch Range; the best studied one is the Homestake shear zone, which trends southwest from Homestake Creek and Mt. Holy Cross towards Aspen (Tweto and Sims, 1963). The sheared Precambrian rocks mapped north of Hunter Creek at the east margin of the Aspen quadrangle are probably related to these northeast-trending zones. Recent reconnaissance mapping suggests that the sheared rocks in the Aspen area do not extend far to the northeast; faults on trend with the sheared rocks and the Homestake shear zone do (fig. 48; Tweto and others, 1978).

The sheared rocks in the Aspen quadrangle range from mortar gneiss to phyllonite, and those rock types are associated with slightly sheared or unsheared granitic rock. An accessible exposure of sheared rock is on the trail east of the gully at the east margin of the Aspen quadrangle north of Hunter Creek. There chlorite-sericite phyllonite and blastomylonite occur in two zones 5-7 cm thick in an interval of $45 \mathrm{~cm}$ in an exposure of sheared granitic rock that is about $30 \mathrm{~m}$ wide.

A few zones of cataclastic foliation occur outside the area mapped as shear rock, both east of the mapped area and south of Hunter Creek. In the latter area, the rock is quite fractured; much of this fracturing may be associated with the north-south faults shown on the geologic map, which are probably of Laramide age, 


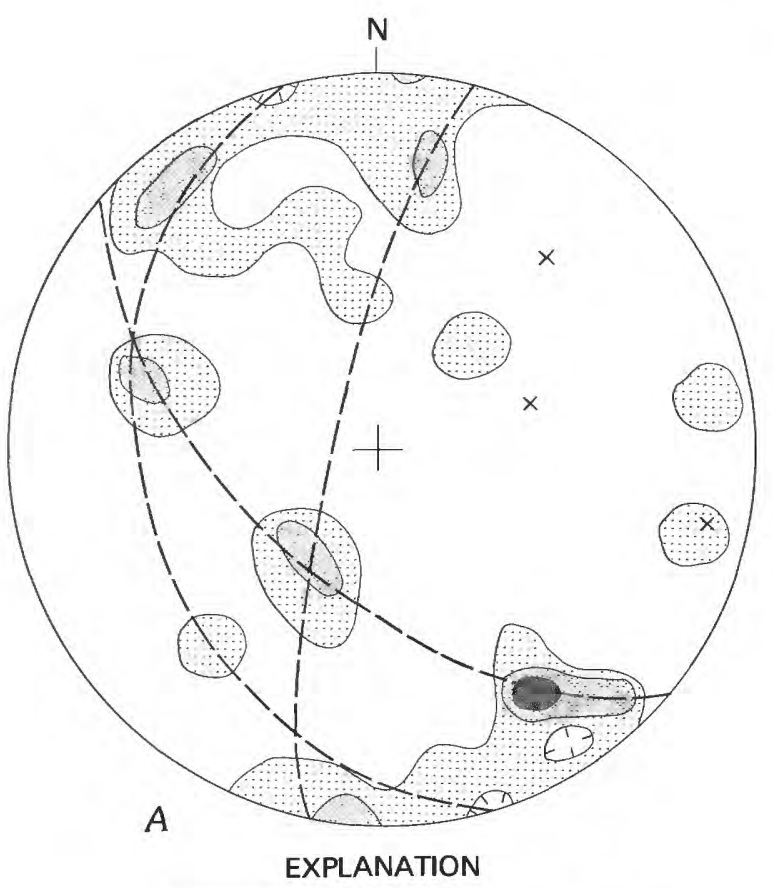

3-percent contour interval

6-percent contour interval

9-percent contour interval

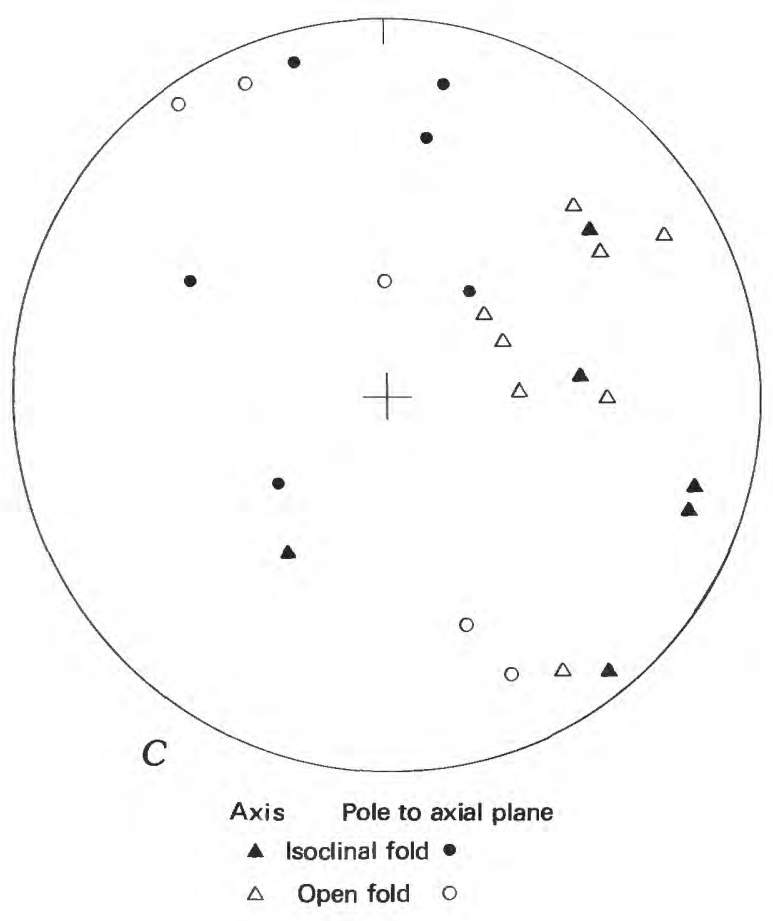

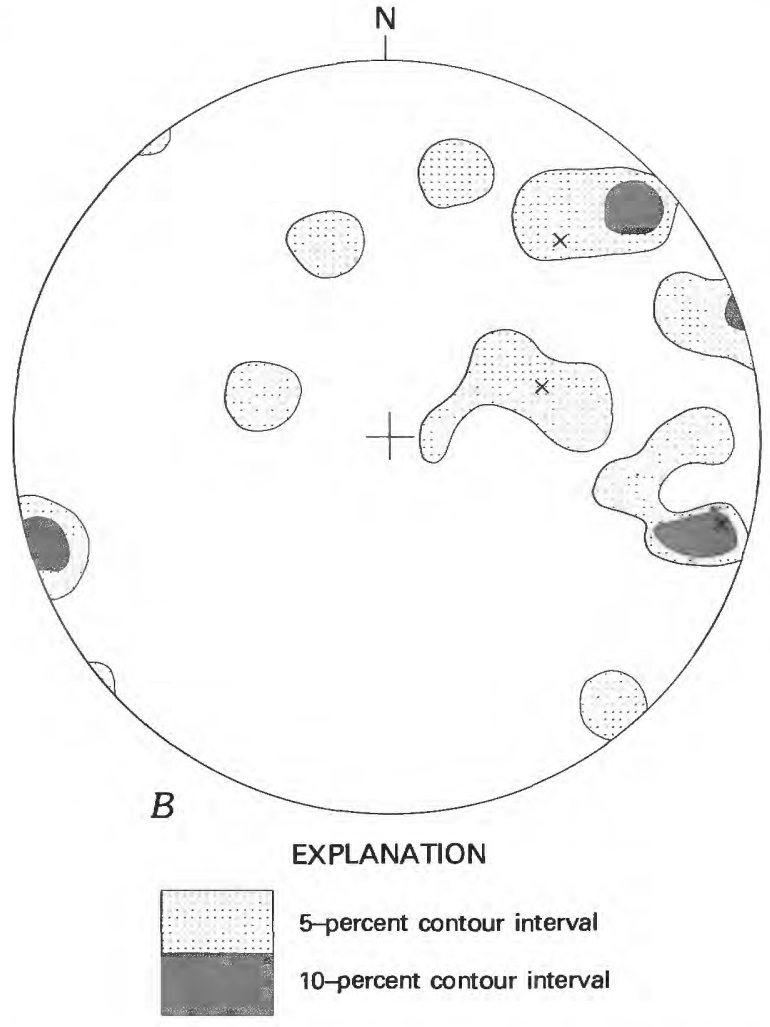

FIgURE 47.--Structures in Precambrian mica schist and gneiss in the Hayden Peak quadrangle. All diagrams are equal-area projections in the lower hemisphere with planes of projection horizontal and north at top. Contours show percentages of points falling within 1 percent of the area of the diagram. $A$, Poles to foliation; dashed lines indicate girdles; $x$, poles to girdle $(\mathrm{n}=31) . B$, Mineral lineation; $x$ 's from $A(n=19)$. $C$, Axes and poles to axial planes of minor folds.

although some may have formed earlier and may have been reactivated in the Laramide orogeny.

The few samples of sheared granitic rock studied in thin section show cataclasis and alteration effects without much recrystallization. Quartz is strongly strained and broken down into mortar. Feldspars are bent and broken. Plagioclase is altered, and biotite is bent and partly altered. These features indicate cataclasis under conditions of relatively low temperature and pressure. The phyllonite, however, would indicate cataclasis and recrystallization under conditions of somewhat higher temperature and $P_{\mathrm{H}_{2} \mathrm{O}}$.

The Homestake shear zone has a great variety of shear products formed in a variety of temperature and 


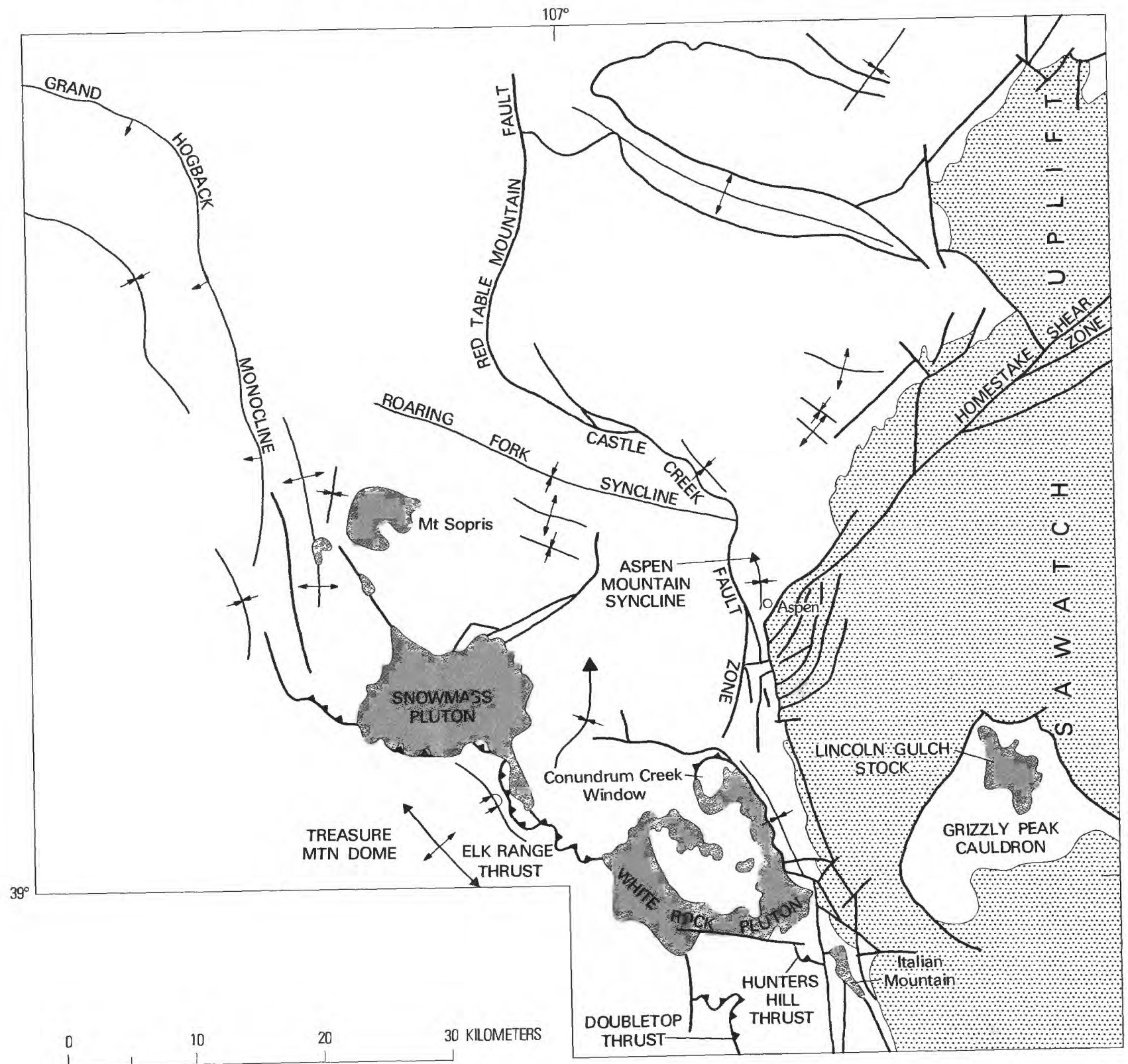

EXPLANATION

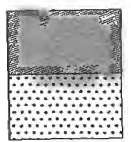

Oligocene plutons

Precambrian basement in Sawatch uplift

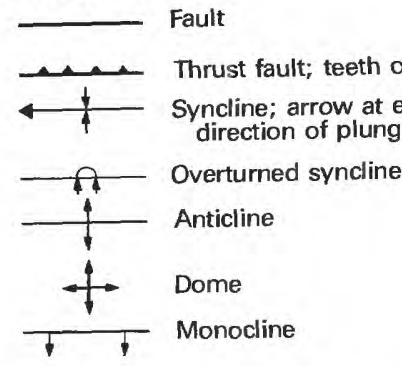

FIGURE 48.-Some structural features in the Aspen region. Modified from Tweto, Moench, and Reed (1978). Most of the primary sources are listed in the references at the end of this report. 
pressure conditions during a long period of time in the Precambrian (Tweto and Sims, 1963). The sheared rock in the Aspen area is so poorly exposed and occupies such a small area that close comparisons are futile. Early movements on the Homestake shear zone may have been shortly after the main metamorphism $1,650-1,750 \mathrm{~m} . \mathrm{y}$. ago. In a northeast-trending zone in the Front Range, Abbott (1972) demonstrated that a fine-grained blastomylonite formed about 1,200 m.y. ago. It is probable that most of the cataclastic effects in the zone in the Aspen quadrangle, except possibly the phyllonite zones, are younger and fall between 1,200 m.y. ago and deposition of the Sawatch Quartzite. All the cataclastic effects are younger than the quartz monzonite they cut, which is about 1,450 m.y. old. The general trend of the shear zone is followed by faults of Laramide age, which intersect the margin of the Sawatch uplift at Aspen.

\section{PHANEROZOIC STRUCTURE}

The Aspen region lies on the west side of one of the more westerly major uplifts exposing substantial areas of Precambrian rocks in the southern Rocky Mountains about $145 \mathrm{~km}$ west of the edge of the Great Plains (fig. 3). West of Aspen the Phanerozoic rocks are generally flat lying although they are locally deformed in sharp monoclines or broken by faults. Except for the Uinta Mountains in northeastern Utah and the Needle Mountains uplift in southwestern Colorado, most of the mountains from Aspen west to central Utah are composed of Tertiary volcanic or intrusive rocks or are deeply dissected high plateaus underlain by littledeformed Phanerozoic rocks.

Structural events during the late Paleozoic and early Mesozoic affected the pattern of sedimentation in the Eagle basin, where the Aspen area was then located. Most of the major structural features of the Aspen area were formed during the Laramide orogeny in the Late Cretaceous and Paleocene about 65-70 m.y. ago when the Sawatch Range was uplifted and during the middle Tertiary episode of intrusion. Late Tertiary fault movements have occurred in the southern Rocky Mountains, but no proof for major faulting at this time has been found in the Aspen area.

\section{PRE-LARAMIDE STRUCTURAL EVENTS}

During Cambrian through Mississippian time the Aspen region was alternately inundated by the sea and slightly uplifted and eroded. No evidence was found for any local folding or faulting during this time span. In a later detailed stratigraphic study, Maslyn (1976) ad- vocated faulting in the Late Mississippian to explain thickness variations in the Leadville Limestone. By Middle Pennsylvanian time uplift occurred southwest of Aspen, and thousands of meters of detritus from this uplift were deposited on the Aspen area during the late Paleozoic and early Mesozoic.

Northwest of Woody Creek a sharp fold trending northwest parallel to the edge of the Uncompahgre uplift formed in Permian time (Freeman, 1971b, 1972a). Erosion of this fold beveled the Maroon Formation, and differential structural movement across the fold may account for the substantial differences in the thicknesses of the State Bridge Formation on either side. The presence of evaporites of the Eagle Valley Formation in a fault slice in the Castle Creek fault zone of Late Cretaceous age near the fold suggests that the fold could have been a salt anticline (Freeman, 1971b). Tweto (1977) discussed the possible role of evaporites in the structure and stratigraphy of the region. At about the same time, the Uncompahgre uplift probably expanded northeast so that the edge of the uplift was closer to Aspen during the Late Permian and Early Triassic than during the Pennsylvanian and Early Permian. Angular unconformities below the Chinle of Late Triassic age and the Morrison of Late Jurassic age (fig. $32 A$ ) show that the Uncompahgre highland was moderately uplifted in the Triassic and the Jurassic.

Stratigraphic variations across north-south-trending faults in the Highland Peak quadrangle indicate that those faults must have been active before deposition of the Morrison Formation in the Upper Jurassic. Those faults were reactivated in the middle Tertiary, or, perhaps, the Laramide.

The fault having the greatest pre-Morrison displacement crosses Eagle Mountain at the west margin of the Highland Peak quadrangle. The southwest extension of that fault was apparently followed by the younger Snowmass Creek fault zone. East and south of the fault on Eagle Mountain the Entrada, Chinle, and State Bridge Formations are present; whereas they are absent on the west and north sides of the fault. Also, the siltstone at the top of the Maroon Formation, which is at least $300 \mathrm{~m}$ thick, is present on the south and east and absent on the west and north side of the fault. Whether the fault was active in the Permian, Triassic, or Early Jurassic cannot be demonstrated; but the stratigraphic relations of the State Bridge Formation suggest a northeastward expansion of the Uncompahgre highland in the Late Permian or Early Triassic. Perhaps the fault on Eagle Mountain was a range-front fault at that time and was reactivated in Jurassic time after deposition of the Chinle Formation. 
The Chinle in the eastern block resembles the Chinle elsewhere and does not suggest that the fault was active during deposition of that formation. This fault separates a region to the east where $3,000 \mathrm{~m}$ or more of Maroon Formation is preserved from one to the west where the Maroon is less than 2,000 m thick. Reconnaissance mapping by $\mathrm{R}$. H. Moench (oral commun., 1975) showed that the State Bridge and Chinle Formations are present on the east and absent on the west side of a north-trending fault just south of Basalt. That fault might have been a part of the fault system of pre-Late Jurassic age exposed near Eagle Mountain.

Stratigraphic thicknesses differ across a north-south fault on the east side of Burnt Mountain in the Highland Peak quadrangle. On the east side of the fault the State Bridge is about $200 \mathrm{~m}$ thick, and on the west side about $60 \mathrm{~m}$ thick. West of Burnt Mountain the State Bridge outcrop abruptly ends at another north-south fault. Movement on those two faults took place before deposition of the Chinle Formation in Late Triassic. These faults were also reactivated in the middle Tertiary and (or) the Laramide.

\section{LATE CRETACEOUS AND PALEOCENE(?) EVENTS}

The Laramide orogeny began in the Aspen area after deposition of rocks containing Exiteloceras jenneyi, a widespread ammonite zone found in the Mancos Shale. On the north flank of the San Juan Mountains sanidine from a tuff in this zone has been dated at 75.2 \pm 2.3 m.y. and biotite at $72.7 \pm 2.2$ m.y. (Dickinson and others, 1968). In the Woody Creek quadrangle about $150 \mathrm{~m}$ of rocks overlie the Exiteloceras jenneyi zone, and they contain fossils suggestive of the Baculites compressus or a younger zone (Freeman, 1972a). The Baculites compressus zone has been dated at about 71.5 m.y. (Obradovich and Cobban, 1975). Muscovite from a porphyry sill cut by the Castle Creek fault zone dates at 72.2 \pm 2.2 m.y. Biotite from an aplite intrusion occupying a branch of the Castle Creek fault zone has been dated at $70.0 \pm 2.3 \mathrm{~m} . \mathrm{y}$. and $67.4 \pm 2.2 \mathrm{~m} . \mathrm{y}$. (two separates from the same specimen; Obradovich and others, 1969). These dates bracket the commencement of Laramide orogeny on the west flank of the Sawatch Range.

The first stratigraphic evidence for Laramide Orogeny in the region is found in the Ohio Creek Formation, the nearest exposure of which is about $40 \mathrm{~km}$ southwest of Aspen in the Oh-Be-Joyful 7.5-minute quadrangle (Gaskill and others, 1967). There, a conglomeratic sandstone sequence $115-130 \mathrm{~m}$ thick is in gradational contact with the Mesaverde Formation of Late Cretaceous age. The Ohio Creek Formation contains a Paleocene flora $6 \mathrm{~m}$ above its base (Gaskill and
Godwin, 1963). Perhaps detritus from the initial uplift of the Sawatch anticline was derived from fine-grained Cretaceous rocks and deposited in the upper Mesaverde (Tweto, 1975). A small discrepancy exists between the Late Cretaceous ages of the porphyries of the Aspen district, which are believed to bracket Laramide structural events, and the first appearance of conglomerate beds to the west. $\mathrm{K}$-Ar ages of micas, when erroneous, are usually too young rather than too old.

\section{LARAMIDE STRUCTURES FAULTS}

The Aspen region has a large number of faults, which for purposes of discussion are divided into (1) Elk Range thrust zone, (2) Castle Creek fault zone, and (3) other faults along the margin of the Sawatch uplift.

THE ELK RANGE THRUST ZONE

"The great fold fault of the Elk Range" has been described by Hayden (1874, p. 65-68), Holmes (1876, p. 67-71), and Vanderwilt (1935b, p. 231-233; 1937, p. 83-92). Exposures of this structure are most spectacular in the southeastern part of the Snowmass Mountain quadrangle (Mutschler, 1970). I advanced the hypothesis that the Elk Range thrust might represent the base of a thick sheet of upper Paleozoic and Mesozoic sedimentary rock that slid southwest off the Sawatch uplift in latest Cretaceous or early Paleocene time (Bryant, 1966). This hypothesis was used to explain a structural discontinuity between rocks with simple structure above and rocks with more complex structure below in a small area on Conundrum Creek in the Maroon Bells and Hayden Peak quadrangles (fig. 49). That area was interpreted as a window in the thrust sheet, thus extending the fault $11 \mathrm{~km}$ northeast of its nearest previously known outcrop in the southwest corner of the Maroon Bells quadrangle.

Very few new firm data concerning the Elk Range thrust sheet have been found since 1966. In the Pearl Pass quadrangle just south of the Aspen area, Zoerner (1973) mapped one branch of the thrust system-the Hunters Hill thrust (fig. 48)-and interpreted the heel of the lower branch of that fault to be at the BeldenGothic contact or in the upper part of the Belden. His mapping showed that the lower plate was deformed into a steep fold before the Hunters Hill thrust reached its present position. His proposed position of the heel of the Elk Range thrust could be the site of a highangle fault related to numerous ones shown on detailed maps to the east (Zoerner, 1973; Cunningham, 1976). I, also, have made similar interpretations along the margin of the Sawatch uplift in the Aspen and Hayden Peak quadrangles. 


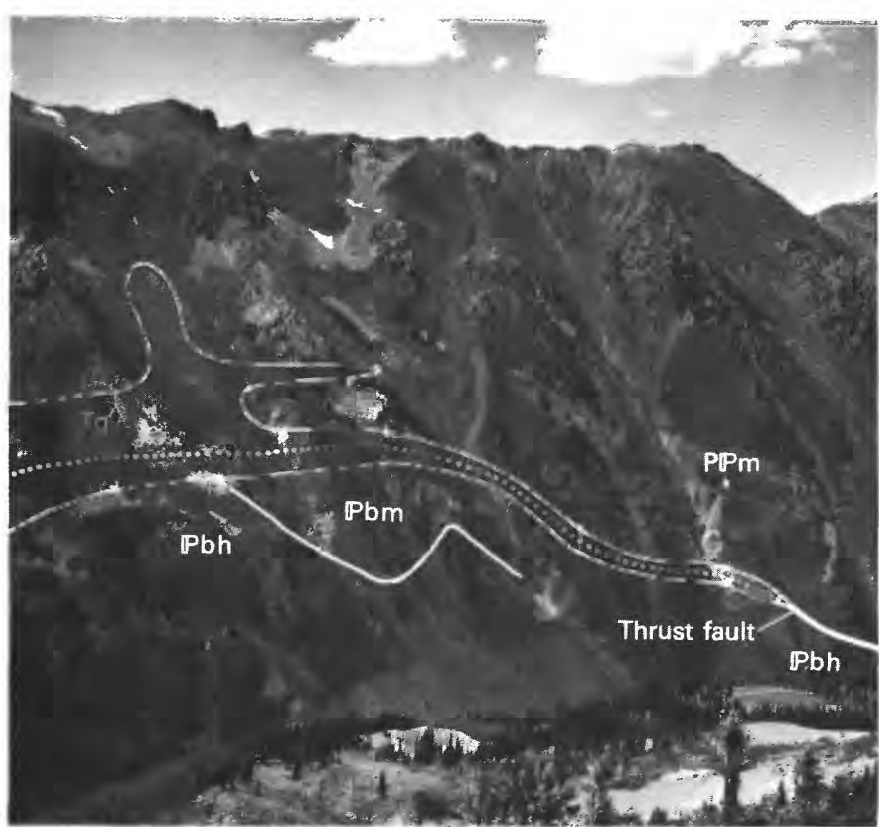

Figure 49.-View of west side of Conundrum Creek window from 3,650 m altitude on west side of Hayden Peak. Granodiorite has intruded along structural discontinuity between hornfels of the Maroon Formation with uniform dip above and deformed marble and carbonaceous hornfels of the Belden Formation below. Tg, granodiorite; PPm, Maroon Formation; Pbh, hornfels of the Belden Formation; Pbm, marble of the Belden Formation. Total topographic relief of valley side about $1,000 \mathrm{~m}$.

The Doubletop thrust (fig. 48), which is the other known southeastern branch of the Elk Range thrust zone after it bifurcates at the site of the White Rock pluton, has not been traced east of Cement Creek (Cement Mountain quadrangle) to a possible intersection with structures at the margin of the Sawatch Range.

At the northwest end of the Elk Range thrust zone, as known at present, stratigraphic displacement on the Elk Range fault decreases to the northwest as the units become younger in the upper block (Gaskill and Godwin, 1966a). Detailed mapping is needed north and northwest of that area. Could there be another split of the fault heading north from the northwest corner of the Snowmass pluton in the Avalanche Creek area? Unpublished reconnaissance mapping by V. L. Freeman and me (1974) north and west of the Snowmass pluton, however, shows that the Gothic Formation wraps around the west and north sides of the Snowmass pluton; so that hypothesis apparently is invalid. Present knowledge suggests that the fault dies out in the Mancos Shale west of the Crystal River.

Even when detailed geologic maps become available for the whole region, it will be difficult to separate fact from interpretation concerning the Elk Range thrust. For instance, variations in the apparent thicknesses of upper Paleozoic sedimentary rocks are subject to stratigraphic as well as structural interpretations. In the northern part of the Ruedi quadrangle (Freeman, 1972b) south of the Fryingpan River the Maroon Formation ranges from 1,000 to $2,000 \mathrm{~m}$ in thickness in a distance of $3 \mathrm{~km}$. Although a fault is mapped, it is within the Gothic Formation. Are there other faults subparallel with the bedding representing the Elk Range thrust, or is this a real stratigraphic thinning? The dying out of stratigraphic displacement on the Elk Range fault in the Marble quadrangle and to the northwest indicates that the toe of the thrust sheet did not break entirely free from the surrounding rocks and that thrusting does die out in that direction. Perhaps some of the movement was taken up by folding and less continuous faults in the lower Crystal River valley west of Mt. Sopris (fig. 48) (Poole, 1954). There, the situation is complicated by structures that may have been a result of salt tectonics (Mallory, 1966).

The bedding-plane faults mapped by Spurr (1898) in the Aspen mining district might represent the heel of the Elk Range thrust. However, the Contact fault, which he mapped between dolomite and limestone within the Leadville, does not represent a throughgoing fault. That stratigraphic horizon was the site of solution and cave formation during the erosion interval between the deposition of the Leadville Limestone and the Belden Formation, and perhaps during the Quaternary. I think that many of the breccias described by Spurr from mine workings formed by those processes. The Silver fault at the Leadville-Belden contact is more difficult to evaluate. In many areas of the mining district high-angle faults are along that contact, and in many places they are parallel with steeply dipping bedding. Natural exposures of the contact are almost nonexistent. In the southern part of the Hayden Peak quadrangle no fault is at that horizon; there, the heel of the Elk Range thrust is believed to be near the Belden-Gothic contact, as suggested by unusually thin Belden near lower Express Creek. North of there the Belden becomes increasingly involved in the high-angle faults of the Castle Creek fault zone. In the Highland tunnel, which transects the Castle Creek fault zone near the south margin of the Aspen quadrangle, 30 shears and faults parallel with steeply dipping bedding in the Maroon, Gothic, and Belden Formations were detected in addition to about 20 that cut the bedding. Some of these faults contain wide zones of breccia.

In the northern part of the Aspen quadrangle I interpreted a fault parallel with the bedding well up in the Belden to be the heel of the Elk Range thrust. Actually, it is likely that movement along the bedding planes associated with gravity sliding was not concentrated 
everywhere on one thin stratigraphic horizon; it may have been at a number of stratigraphic levels in the Belden and the Gothic near the heel of the sheet. Farther south and west, movement became concentrated in the Gothic Formation as demonstrated by the widespread occurrence of a hundred meters or more of Gothic just above the thrust.

The Belden seems to form a structural front between the brittle much-faulted lower Paleozoic rocks and the less faulted younger rocks. Very few east-west faults penetrate the Belden to its upper contact. Exceptions are at Lenado Gulch and at Queens Gulch (the Butte fault of Spurr, 1898). This difference in structure across the Belden outcrop belt could be due to difference in competence between Belden and adjacent formations or might be caused by a structural uncoupling between the Elk Range thrust sheet and the margin of the Sawatch Range during early phases of the Laramide deformation.

The salient structural characteristics of the Elk Range thrust where it has been mapped along its toe are general concordance between the fault plane and gentle to moderate northeast dips in the thrust sheet, and discordance with beds in the underblock (Gaskill and Godwin, 1966a; Mutschler, 1970; Bryant, 1969, cross secs.). The relations between thrust sheet and underblock are similar farther east in the Gothic and Pearl Pass quadrangles east of the White Rock pluton where the thrust bifurcates into two faults (Langenheim, 1952; Prather, 1964; Zoerner, 1973). The thrust sheet is locally parallel with the overturned limb of the Schofield syncline of the underblock in the Snowmass Mountain quadrangle (Mutschler, 1970). Over most of its outcrop length a hundred to a few hundred meters of Gothic Formation occupy the base of the thrust sheet. Similar relations between simple structure in the thrust sheet and folds in the underblock occur in the Conundrum Creek window (Bryant, 1966), but there the effects of contact metamorphism make it uncertain whether any Gothic Formation is preserved below the Maroon Formation of the thrust sheet.

If the Elk Range thrust sheet moved off the Sawatch uplift in latest Cretaceous, it must have started at an early stage of uplift of the Sawatch because its heel is steeply folded and faulted along the margin of the Sawatch uplift. Movement along the thrust probably ceased before formation of the steep faults along the margin of the Sawatch uplift, and before intrusion of the 67-m.y.-old aplite of the Castle Creek fault zone in the Aspen district.

The Elk Range thrust zone disappears near the south end of the Grand Hogback monocline (fig. 48). Movement on these features has been assumed to be synchronous (Hills, 1891; Vanderwilt, 1937). Holmes (1876), Hills (1891), and Murray (1966) thought that intrusion of the plutons in the Elk Mountains was essentially contemporaneous with thrusting. Vanderwilt and subsequent workers recognized that granodiorite cuts the fault zone and is entirely younger.

Most of the deformation producing the Grand Hogback monocline northwest of Glenwood Springs took place after deposition of the Green River Formation of Eocene age immediately to the west, for it is involved in the Grand Hogback fold (Hills, 1891). Yet the relations between the Elk Range thrust zone and the steeply dipping structures at the margin of the Sawatch Range in the Pearl Pass quadrangle (Prather, 1964; Zoerner, 1973) show that movement on the thrust fault must have been early Laramide. However, the lack of angular discordance between Upper Cretaceous and Paleocene or Eocene rocks in the Grand Hogback region or in the West Elk Mountains to the south about $20 \mathrm{~km}$ from the present outcrop of the Elk Range thrust show that deformation associated with the thrusting did not extend to those areas. Murray (1966, p. 120-122) pointed out that the thrusting does not seem to be related to the development of the Grand Hogback monocline.

Estimation of distance of transport of the rocks above the Elk Range thrust depends upon assumptions concerning the distances required for thickness and facies changes in the Maroon and Gothic Formations. Evidence discussed in previous sections indicates that substantial changes may occur in short distances across the trend of the Eagle basin. Since younger rocks are thrust over older ones in the Conundrum Creek window, that feature does not put any constraints on the amount of movement of the thrust sheet above it. Minimum displacements are given by stratigraphic separations between thrust sheet and underblock along the south side of the Elk Mountains, where Gothic Formation overrides Mesaverde Formation in the Marble quadrangle and Mancos Shale at various localities in the Snowmass Mountain, Maroon Bells, Gothic, and Pearl Pass quadrangles. If one assumes minimal thicknesses for the Maroon Formation, stratigraphic displacements are about $2 \mathrm{~km}$. Actual displacements must be at least several times that figure because bedding in the thrust sheet and underblock is nearly parallel along much of the trace of the thrust, and it is reasonable to assume that the thickness of the Maroon Formation cut by the fault lies somewhere between the $363 \mathrm{~m}$ measured by 
Langenheim in the underblock just south of the Aspen area and the measured and calculated section in the thrust sheet in the Aspen area of $3.2 \mathrm{~km}$. (See stratigraphic section 2, p. 131-137.)

\section{THE CASTLE CREEK FAULT ZONE}

The Castle Creek fault zone bisects the Aspen area and is the main structure bounding this part of the Sawatch uplift (figs. 48, 50A). This zone of faulting extends south of the Aspen area into the Pearl Pass and Taylor Park quadrangles (Cunningham, 1976; Zoerner, 1973), but the south end of the main fault as indicated by the amount of stratigraphic displacement is in the northern part of the Hayden Peak quadrangle. Displacement reaches a maximum on the west side of Aspen Mountain where Precambrian rocks are against the upper part of the Maroon Formation and at Red Butte where Gothic Formation is against State Bridge Formation (Bryant, 1971a). In those places stratigraphic displacement is about $4,300 \mathrm{~m}$ and $3,600 \mathrm{~m}$, respectively. These figures differ from those given by Spurr $(1898$, p. 59) because he did not know the thickness of the Maroon Formation nor did he recognize the basal beds of the Maroon (which are now called Gothic) east of Red Butte. To the northwest apparent displacement diminishes until at Snowmass in the Woody Creek quadrangle, Freeman (1972a) mapped no through-going fault. However, attitudes of the beds and altitudes of the contacts indicate that the Roaring Fork valley is the site of a fold, and (or) fault. Here, relative displacement on the fault changes. West of Snowmass the fault splits and encloses a graben. The southern split swings north at Basalt (Welder, 1954; Tweto and others, 1978) and joins the Red Table Mountain fault (fig. 48) of Bass and Northrop (1963) rather than following the Roaring Fork valley to Glenwood Springs as Vanderwilt (1935b) indicated. North of Basalt the east block moved down relative to the western block, opposite to the displacement in the Aspen area.

The change in trend of the Castle Creek fault zone from N. $10^{\circ} \mathrm{W}$. along the margin of the Sawatch uplift south of Aspen to N. $70^{\circ}$ W., about perpendicular to the uplift, near Snowmass occurs rather abruptly north of its intersection with the Roaring Fork syncline (fig. 48). North of Aspen the fault zone may follow a northwest-trending zone of weakness in the Precambrian basement rocks. This zone of weakness might have controlled the location of the fold of Permian age mapped by Freeman (1971b, 1972a). The magnetic map of Colorado (Zietz and Kirby, 1972) has
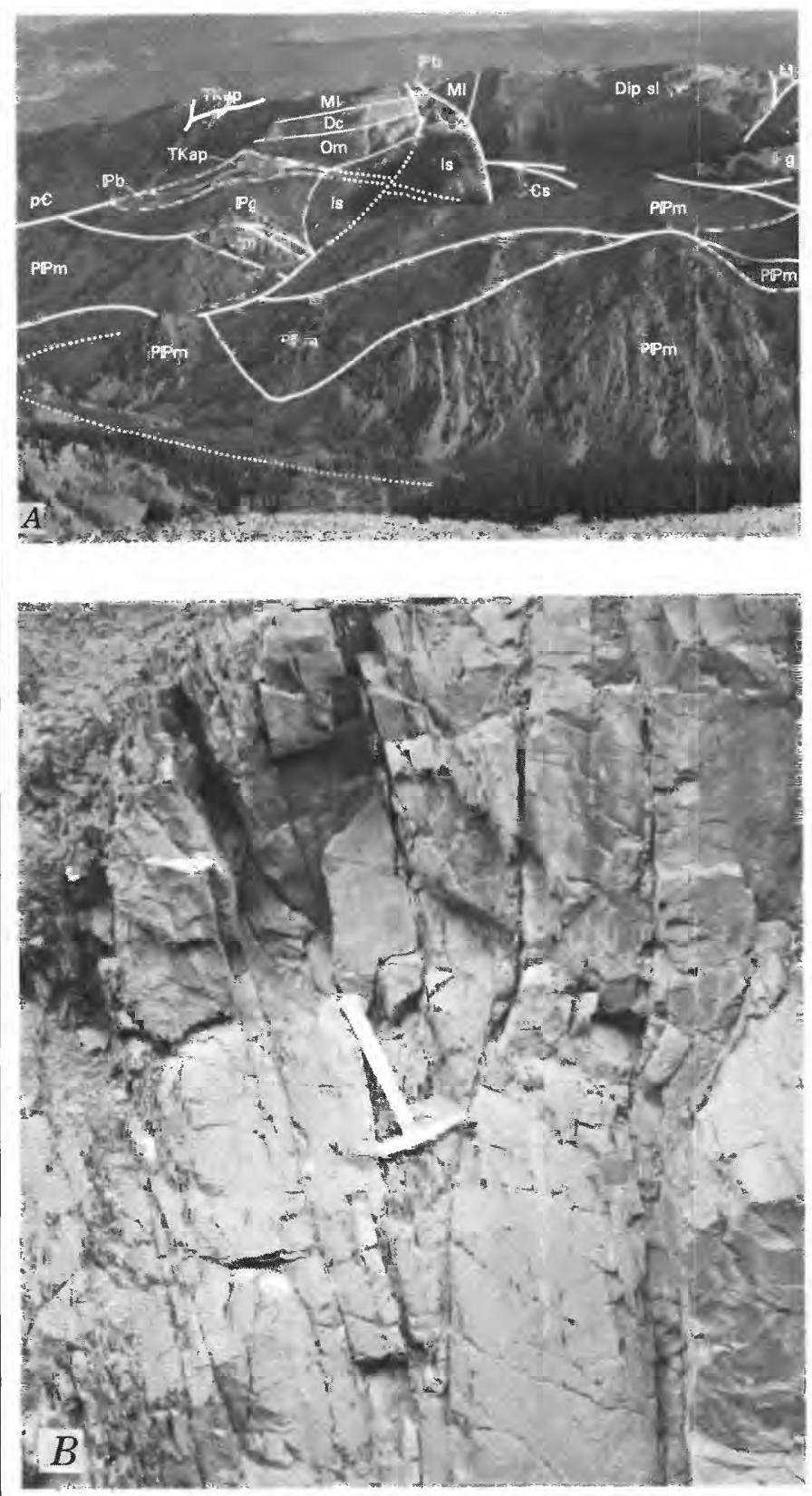

Figure 50.-Features of the Castle Creek fault zone. $A$, General view of zone south of Aspen from Highland Peak. Castle Creek valley in the foreground. Queens Gulch is valley with road in it left of center. Sharply upturned to overturned Pennsylvanian rocks faulted against more gently dipping Cambrian to Mississippian and Precambrian rocks. p€, Precambrian rocks; $€$, Sawatch Quartzite; Om, Manitou, Dolomite; Dc, Chaffee Group; Ml, Leadville Limestone; $\mathbb{P b}$, Belden Formation; $\mathbb{P g}$, Gothic Formation; PPP, Maroon Formation; TKap, aplite porphyry; ls, landslide. Dip slope consists of Manitou Dolomite, Chaffee Group, and a sill of hornblende quartz diorite. Heavy lines, faults; light lines, contacts; dotted lines, concealed faults. $B$, One of many unmapped faults subparallel to bedding planes in the Maroon Formation west of the main break; roadcut in Queens Gulch. Some beds wedge out along faults. 
a prominent northwest-trending grain in that area, suggesting control of the trend of the Castle Creek fault zone by Precambrian or Paleozoic structures in the basement rocks.

One of the major folds of the Aspen area occurs at the point where the margin of the Sawatch uplift diverges from the Castle Creek fault zone. South of the town of Aspen a north-plunging faulted syncline contains Paleozoic sedimentary rocks (fig. 6) as young as the Belden Formation. The syncline is separated from the fault zone by the ridge of Precambrian rock south of West Aspen Mountain. North of Aspen the syncline widens abruptly and directly abuts the Castle Creek fault zone. The syncline becomes shallow along plunge both north and south of Aspen; so its total length is only $8 \mathrm{~km}$ although at its deepest point it has a minimum structural relief of $1,300 \mathrm{~m}$. In a northeasterly direction its east limb becomes the monocline that flanks the Sawatch uplift.

The Castle Creek fault zone tends to dip subparallel with bedding in the underblock south of Aspen where some data are available. One of the best exposures of the fault is in Keno Gulch where the fault dips $75^{\circ}$ to the east. There, the fault has about $5 \mathrm{~cm}$ of carbonaceous shaly gouge derived from the Belden Formation along it, and Precambrian quartz monzonite is argillized for a distance of about $3 \mathrm{~m}$ from the fault. The $4 \mathrm{~m}$ of Maroon Formation exposed in the downthrown side is laced with faults along which is material from the Belden Formation. Spurr (1898, p. 93) reported that in tunnels in the Keno Gulch area the fault appears to dip $45^{\circ}-50^{\circ} \mathrm{E}$., which is similar to the dips in the Maroon Formation west of the exposure of the fault in Keno Gulch. Spurr reported several exposures of the Castle Creek fault in tunnels, but natural exposures are rare.

Part of the fault zone west of the main break is exposed along the Queens Gulch road where some details of bedding-plane slip in the Gothic and Maroon Formations are well shown (fig. $50 B$ ).

The most complete cross section of the fault zone was exposed in the Highland tunnel driven during the middle 1960's east from about $2,650 \mathrm{~m}$ altitude in the Castle Creek valley in the southern part of the Aspen quadrangle. There, about 50 faults were detected west of the Castle Creek fault proper, which at that level separates Precambrian quartz monzonite form Belden Formation. The most common type of fault observed in the tunnel was parallel to bedding in the Belden, Gothic, or Maroon Formation and had one to several centimeters of clayey gouge along it. Thick zones of breccia and gouge were common and occupied a total of about $230 \mathrm{~m}$ of the tunnel. The great number of faults visible in the tunnel shows that at the surface relatively few of the faults existing in this zone have been mapped. Those shown on the geologic map are generally based on map relations between formations, which are relatively thick and lack marker horizons, or by sudden changes in dip or strike of bedding.

One strand of the Castle Creek fault zone is exposed in a roadcut northwest of Red Butte. Moderately north dipping Mancos Shale in the west part of the cut is fractured along north-south trends, and in the east part of the cut the bedding is vertical and parallel with the zone of fracturing.

A number of cross faults of small displacement associated with the Castle Creek fault zone cut the rocks of Red Butte, which form an overturned fault slice along the zone. If marker horizons were available in the Pennsylvanian and Permian rocks along the fault south of Aspen, a similar pattern of cross faults might be detected.

\section{OTHER FAULTS}

East of the Castle Creek fault zone along the margin of the Sawatch uplift are a number of faults trending parallel to that margin along which the downthrown side is on the east towards the center of the Sawatch uplift, in contrast to the Castle Creek fault zone, which is clearly related to relative upward movement on the east, or Sawatch uplift side. These faults extend to south of the Taylor River (Zoerner, 1973; Prather, 1964) and north beyond the Fryingpan River (Mackay, 1953). Some of these faults were described by Stark (1934); he drew them as dipping more gently at depth and called them thrust faults. The one in the northeast part of the Aspen area, which he called the Bigelow thrust, was incorrectly mapped, and faults that may be related to the one he mapped are apparently all high angle. In the Aspen area faults of this system have displacements of as much as $450 \mathrm{~m}$ depending on what assumption is made concerning the change in dip of the sedimentary rocks on the block to the west (Bryant, 1970, 1971a, cross secs.). Many faults of this system on the east side of Aspen Mountain and Richmond Hill have displacements as small as $10 \mathrm{~m}$. In that area the situation is complicated by north-south faults associated with the east limb of the syncline on Aspen Mountain, and their sense of movement is up on the east. Fractures and faults believed to be related to the faults in the margin of the Sawatch uplift with down movement on the east cut through Precambrian rocks on the corner of the Sawatch uplift on Smuggler Mountain east of Aspen. No well-defined age relations between these faults and the Castle Creek fault zone were found. This fault system may be a complex zone marginal to the Sawatch uplift in which some exten- 
sion occurred in the area of maximum apparent displacement along the Castle Creek fault zone and at the sharp change in trend of the margin of the uplift that occurs at Aspen.

A number of cross faults of 10-100 m displacement cut the lower Paleozoic rocks from Richmond Hill north to Lenado. On Aspen and Smuggler Mountains the north sides moved up on the average. There, faults are reported to dip steeply in the mines on Aspen Mountain and to dip $35^{\circ}-40^{\circ}$ to the south on Smuggler Mountain (Spurr, 1898). The intersections of these faults with favorable stratigraphic or tectonic horizons were the loci of the richest ore bodies in the Aspen mining district. A few of the faults of the system offset the Castle Creek fault, but most are apparently confined to east of that fault. Many of these faults appear to be older than the longitudinal faults, but apparently considerable overlap in ages occurs between the two systems.

\section{FOLDS}

The most prominent fold in the Aspen area is the moderately to steeply dipping faulted monocline along the western flank of the Sawatch uplift. At Aspen this monocline changes trend from $\mathrm{N} .10^{\circ}-20^{\circ} \mathrm{W}$. to N. $30^{\circ}$ E., and it is there that the most complicated structures of the region are found. This change in trend of the margin of the Sawatch uplift occurs at its intersection with the projected trend of the Homestake shear zone (fig. 48). Just south of Aspen a north-plunging fault block or much faulted anticline and a north-plunging syncline border the main Sawatch uplift. The syncline widens and flattens dramatically northward so that at the north edge of the Aspen quadrangle several thousands of meters of Maroon Formation are in it (Bryant, 1971a, sec. $A-A^{\prime}, B-B^{\prime}, C-C^{\prime}$ ). The axis of the syncline swings westward and is cut by the Castle Creek fault zone, but it reappears in the Woody Creek and Ruedi quadrangles on the northeast side of the fault zone (Freeman, 1972a, b).

The second major fold in the Aspen area is the Roaring Fork syncline (fig. 48). The syncline is a broad fold about $32 \mathrm{~km}$ long, trending northwest, parallel with the late Paleozoic structural trends of the Eagle basin and the Uncompahgre uplift and with the Castle Creek fault zone and several folds and faults to the northeast of late Paleozoic and Laramide age (Freeman, 1971b; Tweto and others, 1978). The southwest limb of the syncline occupies much of the Highland Peak quadrangle and dips about $20^{\circ}$. The northeast limb dips at about $40^{\circ}$ in the west central part of the Woody Creek quadrangle (Freeman, 1972a). The trough of the syncline passes through the southern part of the
Woody Creek quadrangle about a mile north of the Highland Peak quadrangle and is cut by the Castle Creek fault zone in the southwest corner of the Ruedi quadrangle. The northeast limb of the syncline is cut by the Castle Creek fault zone in the Ruedi and Woody Creek quadrangles. Available data indicate that the structurally deepest part of the syncline is in the southeastern part of the Woody Creek quadrangle (Freeman, 1972a) where over 1,500 $\mathrm{m}$ of Mancos Shale is present and where Precambrian rocks must lie at depths of between 4.5 and $6 \mathrm{~km}$ below the land surface or about $3 \mathrm{~km}$ below sea level. The trough of the sycline is sharper to the east and broader to the west (Freeman, 1972a, b).

The Roaring Fork syncline is determined to be of Laramide age because it contains Upper Cretaceous rocks and is truncated by the Castle Creek fault zone, which is of Laramide age.

The Mancos Shale in the Highland Peak and Woody Creek quadrangles has several short folds of various trends (Freeman, 1972a). In the south-central part of the Woody Creek quadrangle, two rather sharp southwest-plunging folds differ from most of the structures in the area and continue northeast to the Castle Creek fault. V. L. Freeman (written commun., 1975) suggested that they may be crumples related to local left-lateral movement on the Castle Creek fault.

\section{OLIGOCENE INTRUSION AND DEFORMATION}

The major plutons of the Elk Mountains-the Snowmass and White Rock plutons-apparently were emplaced to a large extent along the Elk Range thrust. In the Maroon Bells, Snowmass Mountain (Mutschler, 1970), and Marble quadrangles (Gaskill and Godwin, 1966a), granodiorite cuts and intrudes along the thrust fault. In the Conundrum Creek window granodiorite similarly occurs along the fault. East of the window I have interpreted similar relations between the intrusives and thrust along the margin of the Sawatch uplift (Bryant, 1970, secs. $B-B^{\prime}$ to $E-E^{\prime}$ ). As more and more magma intruded along the fault, the overlying rocks were broken and warped. One of these breaks, along the east side of the White Rock pluton in the Hayden Peak quadrangle, probably acted as a barrier for the intruding magma, locally defining the edge of the pluton. Cataclastic textures in the granodiorite on that fault indicate that movement along it continued after consolidation of the granodiorite at the level of exposure. Farther west, in the Maroon Bells quadrangle, a branch of this fault cuts a sill of porphyritic granodiorite. As mentioned earlier, field relations and isotopic ages show that that rock type is younger than the granodiorite of the larger plutons. 
The fault is marked by a well-defined topographic break in the Hayden Peak quadrangle (figs. 36, 51A), that is probably due to differential erosion rather than late Tertiary or Pleistocene movements.

A number of faults with offsets of a few to tens of meters were mapped in the Maroon Formation overlying the White Rock pluton in the Cathedral Lake-Montezuma mine area (Hayden Peak quadrangle). Dikes of porphyritic granodiorite and granodiorite mark other fractures, some of which may have had displacement along them.

Another major fault zone associated with Oligocene intrusive activity is along Snowmass Creek. At the west edge of the Highland Peak quadrangle the extensive dip slope of Dakota Sandstone of Baldy Mountain is offset about $2 \mathrm{~km}$ north to Eagle Mountain across the fault zone and the Snowmass Creek valley. The fault zone feathers out into the Mancos Shale to the north in the Woody Creek quadrangle.

Reconnaissance mapping in the Capitol Peak quadrangle to the west shows that Gothic Formation is brought up along the fault zone as a thin slice which is interpreted as terminating just inside the west edge of the Highland Peak quadrangle (Bryant, 1972a, sec.
$C-C^{\prime}$ '). To the west the slice of Gothic appears to The fault on the north side of the Gothic crosses the Capitol Creek-Snowmass Creek divide $1.2 \mathrm{~km}$ north of Mount Daly, and the southern fault bounding the slice is cut by the Snowmass pluton in the valley of West Snowmass Creek northwest of Mount Daly. Porphyritic granodiorite of the Snowmass Creek sill (or pluton of Pollock, 1969) appears to cut at least the southern branch of the fault. Whether any postintrusive movement occurred on the fault might be difficult to establish because of surficial deposits in the Snowmass Creek valley.

Farther west in the Capitol Creek valley, reconnaissance suggests at least two high-angle northtrending faults cut by the Snowmass pluton and probably formed during its emplacement.

Numerous faults cut the Roaring Fork syncline in the Highland Peak (fig. $51 B$ ) and Woody Creek quadrangles. Reconnaissance map information (Tweto and others, 1978) shows that the western part of the syncline is similarly faulted. At least some of the faults may be related to emplacement of the plutons of the Elk Mountains during the Oligocene. The north-southtrending faults have displacements ranging from 10 to

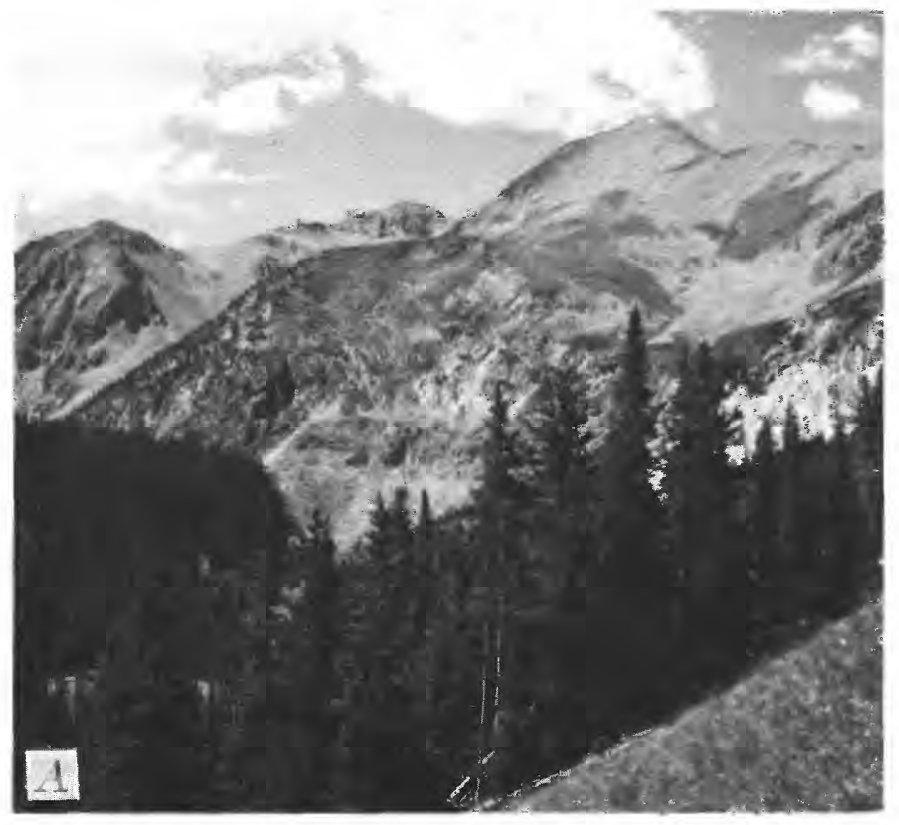

FIGURE 51.-Middle Tertiary faults. $A$, View southwest across fault contact of White Rock pluton at head of Sawyer Creek from east of 3,510-m altitude on Castle Creek-Conundrum Creek ridge, Hayden Peak quadrangle. Topographic break at base of steep rocky slope beyond the trees may be only a faultline scarp between more resistant granodiorite and less resistant sedimentary rock, or it may be a fault scarp due to renewed movement along the fault in the late Tertiary. $B$, View up West Willow Creek from $3,290 \mathrm{~m}$ altitude on south side of Willow Creek valley. Graben forms low part of ridge through which glaciers from West Willow

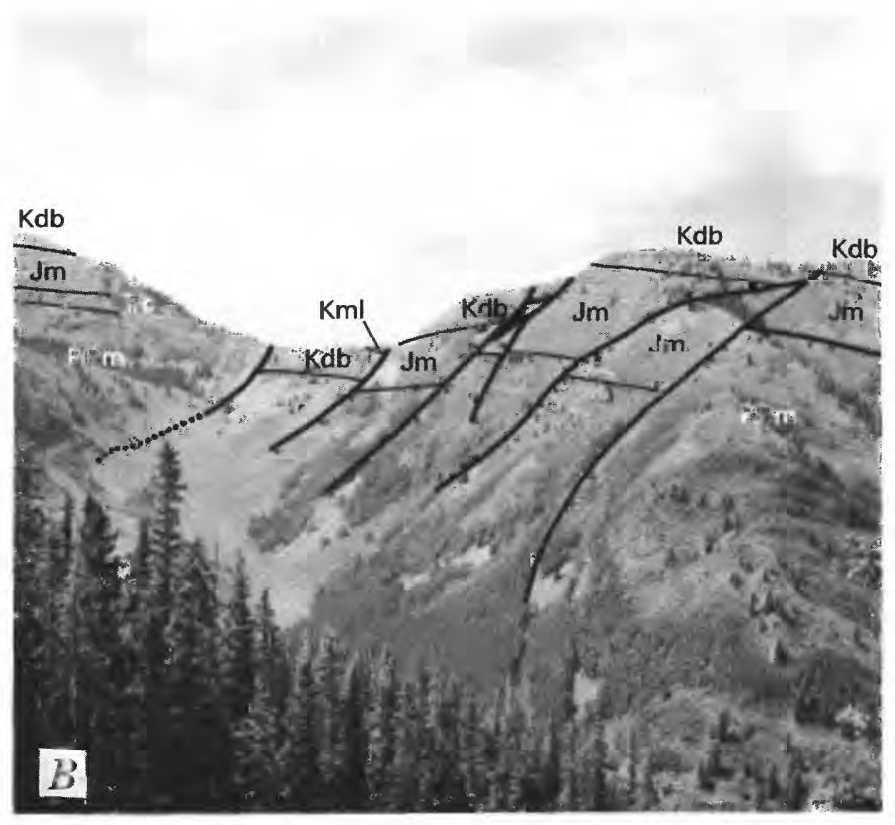

Creek spilled into the Brush Creek drainage at least four times during the Pleistocene. Kml, lower shale member of Mancos Shale; Kdb, Burro Canyon Formation and Dakota Sandstone; Jm, Morrison Formation (includes thin Entrada Sandstone in middle and Chinle Formation at base except where Chinle shown separately); $\mathrm{kc}$, Chinle Formation; PPm, Maroon Formation (thin State Bridge Formation included at top except left of graben where State Bridge is absent); heavy lines, faults, dashed where concealed; light lines, contact. 
as much as $700 \mathrm{~m}$. The sense of displacement on most of them is uplift on the west towards the Snowmass pluton, the same sense of displacement as on the northsouth-trending part of the Snowmass fault zone. A few of the faults had late Paleozoic or early Mesozoic movement in the same relative direction. The east-westtrending faults have displacements ranging from 10 to $300 \mathrm{~m}$ and an overall movement sense of down on the south side. This is the sense of movement on the easttrending part of the Snowmass fault zone, and it is difficult to explain their relation to intrusion unless through some complicated mechanism of subsidence of the uplift of the Elk Mountains after intrusion. Alternatively, some of these high-angle faults may have been initiated by jostling of the sheet of rocks that slid along the Elk Range thrust in Late Cretaceous time.

The entire southwest limb of the Roaring Fork syncline contains a number of intrusions, which at depth may merge with a batholith $50 \mathrm{~km}$ long, or even much longer if a continuous body extended beneath the entire mineral belt. The emplacement of this batholith may have accentuated the syncline by uplifting the southwest limb, so that the present extent and structural relief of the syncline may differ some from that before the emplacement of igneous bodies during the Oligocene. Perhaps, like the Sawatch Range, the Elk Mountains underwent some slight collapse after uplift during the Oligocene to account for the south-side-down sense of movement on the eastwest faults.

In the upper part of West Maroon Creek valley some faults formed after emplacement of hornblende porphyry sills and before consolidation of granodiorite at its present level of exposure. These faults are cut by dikes of porphyritic granodiorite. Most of the faults trend northwest, and the dikes trend southwest into the Snowmass Mountain quadrangle where some small faults were mapped parallel with them (Mutschler, 1970).

In the northern part of the Maroon Bells quadrangle a well-developed east-west dike swarm (fig. 20) extends between the Snowmass and White Rock plutons (Mutschler, 1970). Some of these dikes cut the pluton. The most spectacular exposures of the swarm are in the upper part of the Snowmass Creek drainage southeast of Snowmass Lake where the white dike rocks contrast with the red beds of the Maroon Formation.

The Oligocene intrusions have caused gentle folds and broad warps in the adjacent and overlying beds. In the northwestern corner of the Maroon Bells quadrangle and in the southwestern part of the Highland Peak quadrangle, beds generally dipping north toward the Roaring Fork syncline are tipped to the east by intrusion of the Snowmass pluton about 3 $\mathrm{km}$ to the west.

Broad gentle warps trending west to N. $60^{\circ} \mathrm{W}$. occur in the Maroon Formation overlying the White Rock pluton. They are truncated by crosscutting parts of the pluton, indicating that they formed before intrusion reached that level. They may have formed much earlier by minor rumpling of the Elk Range thrust sheet during its emplacement in the early part of Laramide deformation.

A moderately tight syncline closely follows the east boundary of the White Rock pluton in the Hayden Peak quadrangle and diverges from the margin of the Sawatch uplift. These spatial relations indicate that intrusion of the pluton was responsible for that fold.

Another syncline may occur in the Castle Creek valley in the Aspen and Hayden Peak quadrangles between steep and overturned north-south-trending Maroon Formation along the Castle Creek fault zone and north-dipping Maroon and younger rocks on the west side of the valley. Spurr (1898) interpreted the structure there as a syncline overturned to the west, but I postulate several faults in the Castle Creek valley (Bryant, 1971a, secs. $D-D^{\prime}, E-E^{\prime} ; 1970$, sec. $A-A^{\prime}$ ). This structure could be interpreted as being due mainly to faulting. However, $1 \mathrm{~km} \mathrm{~S} .70^{\circ} \mathrm{W}$. of the Newman tunnel no break was detected where dips change from north to west.

\section{LATE TERTIARY MOVEMENTS}

The whole region was uplifted during the late Tertiary. Basalts 10-24 m.y. old laid down on a surface of low relief (Larson and others, 1975) now cap the tops of the highest ridges $50-100 \mathrm{~km}$ north and west of the Elk Mountains. In addition to uplift, broad warping occurred in the late Tertiary. The basalts slope from about $3,350 \mathrm{~m}$ altitude on the Flattops to $2,740 \mathrm{~m}$ near Cottonwood Pass and back up to $3,350 \mathrm{~m}$ on Battlement Mesa and Grand Mesa $80 \mathrm{~km}$ west of Aspen (Larson and others, 1975). Murray (1969) interpreted a series of long narrow tilted blocks of basalt between 3,050 and $2,255 \mathrm{~m}$ in altitude south of Glenwood Springs as being due to unfolding movements on the Grand Hogback monocline. The regional age and physiographic relations of the basalt support that hypothesis.

In the Pliocene the eastern part of the Sawatch uplift was sundered by a rift to form what is now the upper Arkansas Valley. Taylor Park, a valley in the Sawatch uplift southeast of Aspen, may have been downfaulted by late Tertiary movements.

In the Elk Mountains the Treasure Mountain dome was formed in the Miocene by intrusion of a sodic 
granite (Obradovich and others, 1969).

In the Sawatch Range east of Aspen a few faults cut the Grizzly Peak cauldron (Cruson, 1972), but it is unknown whether they are much younger or about the same age as the Oligocene volcanic rock they cut.

None of these features or the structural effects related to them have been traced into the immediate vicinity of Aspen. The broad accordant ridge crests of the drainage divides east and north of Castle Creek (fig. 36) suggest the presence of an erosion surface at least as old as middle Tertiary. The high country of the Elk Mountains suggests middle Tertiary uplift of that region associated with the widespread emplacement of igneous rocks. The scarp on the east side of the White Rock pluton in the Hayden Peak quadrangle may be related to some late Tertiary reactivation of the fault there, or it may be a faultline scarp caused by middle Tertiary uplift of the more resistant rock of the west side.

Spurr (1898, p. 101-105) believed that several faults near Tourtelotte Park had moved recently. The scarps he described are best interpreted as faultline scarps between easily erodible Belden Formation and resistant Leadville Limestone.

\section{JOINTS, SHEARS, FAULTS, AND VEINS}

Joints, shears, faults, and veins measured in the field are summarized on stereographic projections (fig. 52). They are summarized according to the rock unit in which they occur, for the age of each unit sets different constraints on the age of the structures. Possible relations to larger scale structural elements are suggested

in table 7. The table can be considered a matrix, for earlier joints may have an effect on the orientation of later major structural features as well as the reverse. Consequently, the oldest possible age of the larger elements is given.

The table does not clarify all the relationships between minor and major structures, but it does suggest that the joints measured in the Pennsylvanian and Permian clastic rocks, which alone can be dated only as younger than the rocks they are in, formed during intrusion and uplift during Oligocene time, for the joints in those rocks are parallel to the dike swarm connecting the Snowmass and White Rock plutons, and parallel or perpendicular to faults of Oligocene and probable Oligocene age.

Oligocene or younger joint sets are parallel to the margin of the Sawatch Range north of Aspen and to joints in Precambrian rocks. That joint set in the Precambrian rocks may have helped determine the trend of the Sawatch uplift, but it is not possible to know which came first. Orientation of joints in the Precambrian rocks parallel with the trend of the Colorado mineral belt and the Homestake shear zone is not surprising, but joints of similar trend in Oligocene granodiorite are more difficult to explain. Perhaps those joints are related to inflation or deflation of the postulated batholith subjacent to the mineral belt. In the table no consideration is given to diagonal or shear joints. These may occur, and they would make the relations between minor and major structures even more complex.

\section{QUATERNARY SURFICIAL DEPOSITS}

The surficial deposits of the Aspen area are typical of high, steep, often-glaciated mountain country having a variety of rock types. Most of the deposits are the result of geologic processes active during the Pleistocene and the Holocene; some are the sites of deposition at the present.

\section{GLACIAL GEOLOGY}

The glacial deposits of the Aspen area are the result of numerous fluctuations in the climate over the past 2 m.y., although most of the deposits mapped are probably younger than 200,000 years old. The available details of the glacial history are more numerous for the younger events.

Spurr (1898) postulated two main periods of glaciation. During the older one an ice sheet overrode all the hills, including the summit of Richmond Hill and Aspen Mountain. This was followed by a glaciation restricted to the valleys. He believed that the welldeveloped terraces down valley from Aspen were deposited in a glacial lake. Knopf (1926) recognized that Richmond Hill bore no evidence of glaciation. $\mathrm{He}$ postulated two main episodes of valley glaciation, the earlier one much more extensive than the later. Ray (1940) briefly discussed glacial deposits along the Roaring Fork from Aspen to the Continental Divide and correlated moraines with his "Wisconsin II through IV substages."

Valley glaciers during middle and late Pleistocene time originating in the high mountain country of the

FIGURE 52 (facing page).-Orientation of faults, shears, joints, and veins. All diagrams are equal-area projections in the lower hemisphere with planes of projection horizontal and north at the top. Contours show percentage of points falling within 1 percent of the area of the diagram. $A$, Joints in Precambrian rocks. $B$, Faults and shears in middle and lower Paleozoic rocks. $C$, Joints in Maroon and Gothic Formations and hornfels. $D$, Joints in granodiorite. $E$, Shears and veins in hornfels. $F$, Shears and veins in granodiorite. 

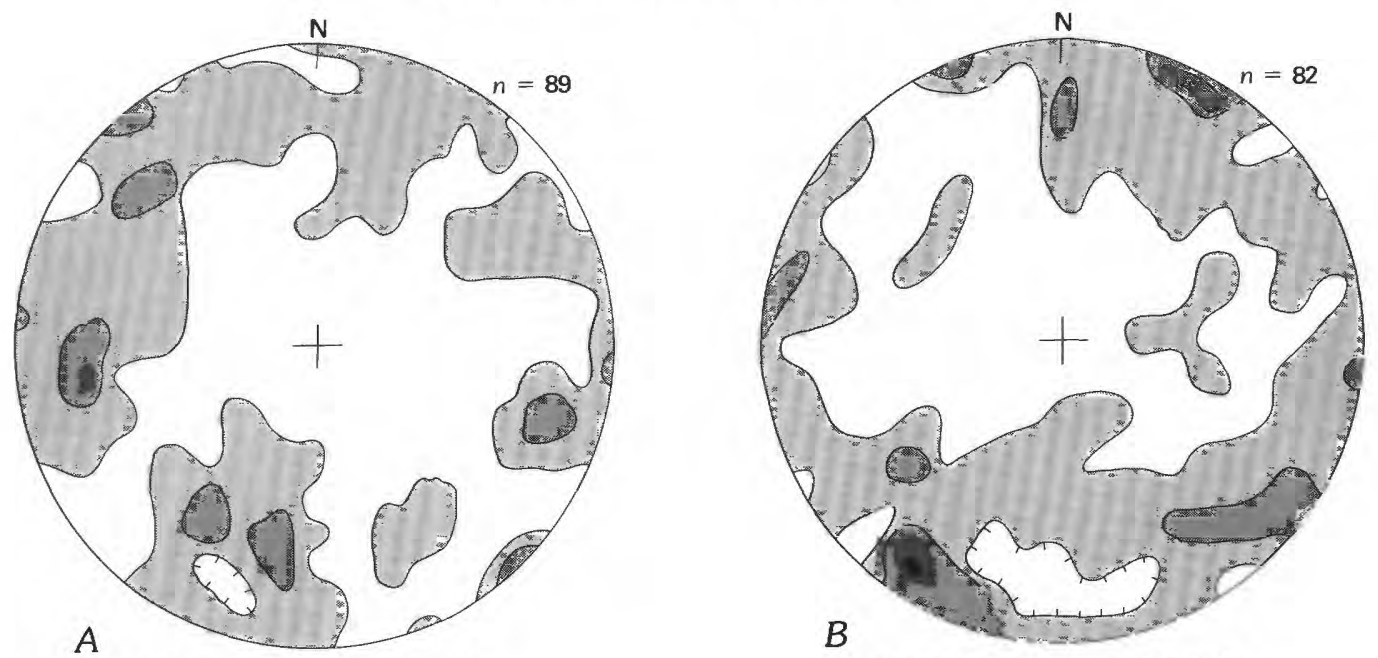

CONTOURS $1,3,5$ PERCENT
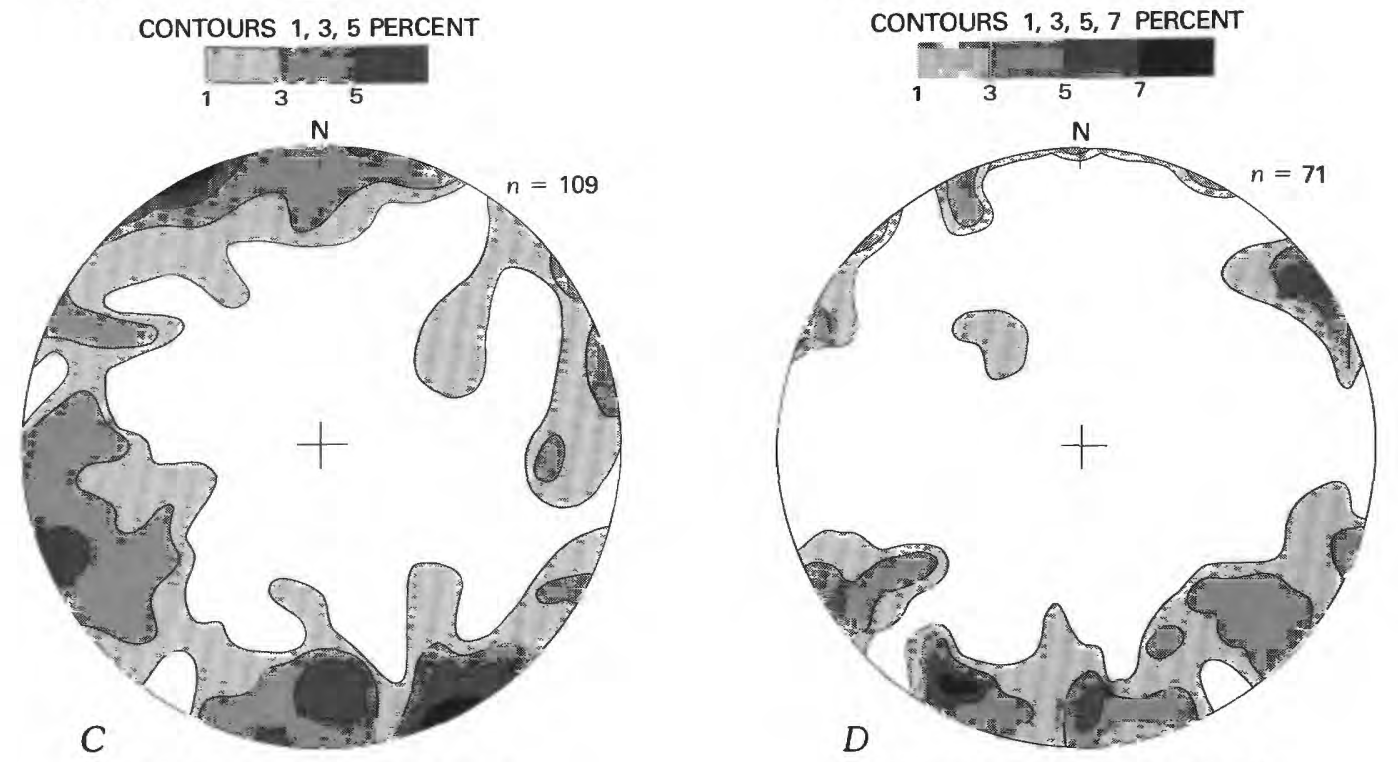

CONTOURS $1,2,4,8$ PERCENT
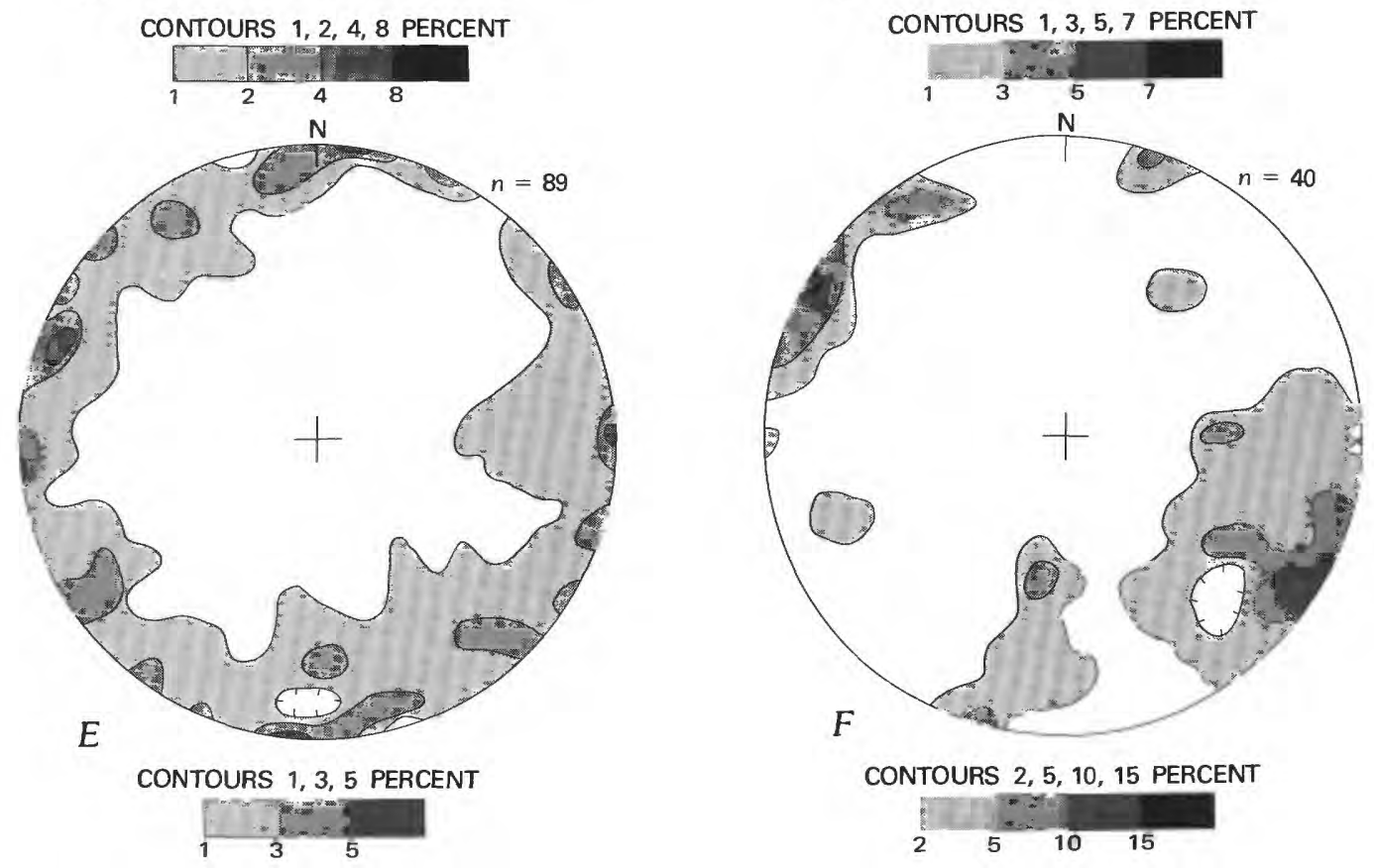
TABLE 7.-Relation between mapped structural elements and measured joints, shears, and veins

[ $\perp$, perpendicular to; leaders (----), not applicable]

\begin{tabular}{|c|c|c|c|c|c|c|c|c|}
\hline \multirow[b]{2}{*}{$\begin{array}{l}\text { Mapped or } \\
\text { inferred } \\
\text { structures }\end{array}$} & \multirow[b]{2}{*}{ Orientation } & \multirow[b]{2}{*}{ Age } & \multicolumn{5}{|c|}{ Measured structures } & \multirow[b]{2}{*}{$\begin{array}{l}\text { Shears and } \\
\text { veins in } \\
\text { granodiorite }\end{array}$} \\
\hline & & & $\begin{array}{l}\text { Joints in } \\
\text { Precambrian } \\
\text { rocks }\end{array}$ & $\begin{array}{l}\text { Faults and } \\
\text { shears in } \\
\text { lower } \\
\text { Paleozoic } \\
\text { rocks }\end{array}$ & $\begin{array}{l}\text { Joints in } \\
\text { Maroon and } \\
\text { Gothic } \\
\text { Formations }\end{array}$ & $\begin{array}{l}\text { Joints in } \\
\text { granodiorite }\end{array}$ & $\begin{array}{l}\text { Shears and } \\
\text { veins in } \\
\text { hornfels }\end{array}$ & \\
\hline $\begin{array}{l}\text { Colorado mineral belt---- } \\
\text { and Precambrian shear } \\
\text { zones. }\end{array}$ & N5OE & Precambrian---- & N50E vert & -- & $-\cdots$ & N45E60NW & -..- & --- \\
\hline $\begin{array}{l}\text { Eagle Basin-Uncompahgre-- } \\
\text { uplift trend. }\end{array}$ & N35-55W & Pennsylvanian-- & --- & N55W75NE & $\cdots$ & $\lfloor N 45 \mathrm{E} 60 \mathrm{NW}$ & --- & LN34E vert \\
\hline $\begin{array}{l}\text { West margin of Sawatch--- } \\
\text { Range south of Aspen. }\end{array}$ & N10w & Late Cretaceous & N10w65NE & --- & --- & $-\cdots$ & $\mathrm{N} 15 \mathrm{~W}$ vert & --- \\
\hline $\begin{array}{l}\text { West margin of Sawatch-m- } \\
\text { Range north of Aspen. }\end{array}$ & N3OE & Late Cretaceous & $\begin{array}{l}\text { N20E7ONW } \\
\text { ЦN60W60NE }\end{array}$ & IN55W75NE & $\cdots$ & $\begin{array}{l}\text { N25E vert } \\
\text { [N60w80NE }\end{array}$ & N20E vert & $\begin{array}{l}\text { N35E vert } \\
\text { N20E vert }\end{array}$ \\
\hline $\begin{array}{l}\text { Mapped faults in Highland } \\
\text { Peak quadrangle. }\end{array}$ & $\begin{array}{l}\mathrm{N}-\mathrm{S} \text { to } \mathrm{N} 20 \mathrm{~W} \\
\mathrm{~N} 45 \mathrm{E} \text { to } \mathrm{EW}\end{array}$ & O1igocene(?)--- & --- & $\cdots$ & $\frac{\lfloor\text { N70E vert }}{\mathrm{E}-\mathrm{W} 70 \mathrm{~N}}$ & E-W80N & N5W vert & -- \\
\hline $\begin{array}{l}\text { Dikes in Maroon Bells---- } \\
\text { and western part of } \\
\text { Hayden quadrangle. }\end{array}$ & N8OW-N60E & Oligocene------ & $\cdots$ & $\begin{array}{l}\text { E-W65S } \\
\lfloor\mathrm{N} 10 \mathrm{E} \text { vert }\end{array}$ & $\begin{array}{l}\text { N70E vert } \\
\text { E-W7ON }\end{array}$ & E-W80N & N80W vert & $-\ldots$ \\
\hline \multirow[t]{3}{*}{$\begin{array}{l}\text { Faulted east margin of--- } \\
\text { White Rock pluton. }\end{array}$} & N30W & 01igocene------ & $-\cdots$ & --- & N25W80NE & N30W vert & $\cdots$ & $\perp \mathrm{N} 60 \mathrm{E}$ to $\mathrm{SE}$ \\
\hline & & & \multicolumn{6}{|c|}{ Ages of measured structures } \\
\hline & & & $\begin{array}{l}\text { Younger } \\
\text { than } \\
21,700 \text { m.y. }\end{array}$ & $\begin{array}{l}\text { Late } \\
\text { Cretaceous } \\
\text { or younger }\end{array}$ & $\begin{array}{l}\text { Younger } \\
\text { than } \\
\text { Pennsylvanian }\end{array}$ & $\begin{array}{l}\text { Oligocene } \\
\text { or younger }\end{array}$ & $\begin{array}{l}\text { Oligocene } \\
\text { or younger }\end{array}$ & $\begin{array}{l}\text { Oligocene } \\
\text { or younger }\end{array}$ \\
\hline
\end{tabular}

Elk Mountains and the Sawatch Range descended the major valleys to altitudes of $2,440 \mathrm{~m}$ or below. In the Roaring Fork valley, glaciers from Castle, Maroon, and Hunter Creeks joined that of the Roaring Fork during at least two episodes of glaciation (figs. 53, 54). During the last major episode, however, the glaciers from those valleys did not coalesce. Lateral moraines preserved along the valleys in the mountains indicate that the ice was $300-400 \mathrm{~m}$ thick during the glaciations of the late Pleistocene.

Moraine and terrace deposits were mapped and correlated by several criteria. Physiographic expression and position were the two main criteria used. The younger moraines and terraces are at lower altitudes than the older ones. Of course, this means that the record of glacial events furnished by the deposits is incomplete, for it is likely that the evidence for glacial events of magnitudes smaller than the largest succeeding event was destroyed. The older moraines and terraces are more dissected and have more subdued topography than the younger ones. The differences in the size of gullies cutting terraces D, C, and B in the northwest corner of the Aspen quadrangle furnishes an excellent example of these differences in dissection. Valleys cutting the oldest surface, terrace $D$, are $30-$ $45 \mathrm{~m}$ deep and extend all the way through the terrace. Valleys cutting terrace $\mathrm{C}$ are $15-18 \mathrm{~m}$ deep and do not extend all the way through the terrace. Valleys cutting terrace B are generally less than $12 \mathrm{~m}$ deep and extend less than $60 \mathrm{~m}$ into the terrace. Even a relatively major stream such as Owl Creek notches into the B terrace for a distance of only $90 \mathrm{~m}$. The surface of moraine D and terrace $\mathrm{D}$ has many fewer boulders on it than the younger moraines and terraces.

The differences in physiographic expression of the moraines are best shown north of Burnt Mountain in the Highland Peak quadrangle. There, no morainal ridges are mapped on the D moraine, which is subdued in topographic expression and deeply dissected by stream valleys. Moraine $\mathrm{C}$ has some well-defined stream gullies in it, as well as well-defined morainal ridges. Moraines A and B contain undrained depressions.

\section{MORAINE DEPOSITS}

The moraine deposits are composed of poorly sorted material ranging in grain size from silt to boulders as much as $6 \mathrm{~m}$ in diameter. The larger fragments are usually rounded to various degrees. However, in some localities, such as the northeast side of the Roaring Fork valley upstream from Aspen and the upper part of the moraine on the end of the ridge between Castle and Conundrum Creeks, most of the large fragments are angular to subangular and of local derivation. The moraine deposits in the cirques also contain angular boulders.

Many of the larger moraine deposits show crude bed- 
ding of sand and gravel in large cuts (fig. 55B). Such is the case in a gully on the west nose of Smuggler Mountain and in the large exposure at the head of the landslide on the west side of the Snowmass Creek valley. In general, one cannot tell moraine deposits and terrace deposits apart in drill logs of water wells because of general similarity of the materials. Presumably the moraine deposits contain more silt than the terrace deposits. On the basis of the logs, both deposits are composed of sand, gravel, and boulders, with scattered beds of clay. Thickness of moraine deposits is difficult to determine since in most places they are plastered against valley sides. On the ridge of Smuggler Mountain Spurr (1898) reported that the Bushwacker and Park Regent shafts passed through $120 \mathrm{~m}$ of morainal material. That is likely to be a maximum thickness of the moraine deposits. Knopf's description of highly weathered till in the Boulder shaft suggests that the thick section of morainal material there may be formed by moraines of more than one age, for the surface in that area has numerous boulders and was correlated with moraine deposit $\mathrm{C}$ by me.

Moraine deposit E, the oldest moraine mapped in the Aspen area, is best developed on top of Red Mountain at altitudes of from 2,925 to $3,170 \mathrm{~m}$ (fig. 53). On the steep south side of Red Mountain near the trail, boulders of Precambrian rock several meters in diameter are numerous. In some places smaller fragments of Sawatch Quartzite are common. On the northeast shoulder of Red Mountain subdued morainal topography is present. Closed depressions are almost filled with sediment but are still swampy. The preservation of these features is due to their position on a broad ridge crest away from much drainage. The lobes of moraine deposit $\mathrm{E}$, mapped as extending down the mountain slopes are probably lag-and-slump deposits from the eroded moraine. Nevertheless, it appears that the moraine deposit may be 100-200 m thick in places. Patches mapped as moraine deposit $\mathrm{E}$ to the west are at lower altitude and may be younger. A moraine deposit mapped at 3,230-3,320 m altitude south of Warren Lake was correlated with that on Red Mountain. It is difficult to tell moraine deposit from colluvium on the Precambrian quartz monzonite, which tends to form spheroidal boulders upon weathering. Subtle differences in physiographic expression were the criteria used.

Moraine deposit D is best developed on the hills surrounding the lower part of the drainage of Owl Creek (fig. 53). The glacier depositing that moraine apparently spread well up into the Owl Creek valley, for a small patch in the eastern part of sec. 5, T. 10 S., R. $85 \mathrm{~W}$. contains Precambrian rocks that must have been brought in by the Roaring Fork glacier. The terminus of the main valley glacier must have spread out to a width of about $4 \mathrm{~km}$. The glacial lobe spilling over the east shoulder of Burnt Mountain from Willow Creek must have nearly joined the Roaring Fork-Castle Creek-Maroon Creek glacier in the Owl Creek valley. Similarly, the Snowmass Creek glacier must have joined or almost joined the lobe spilling over the west shoulder of Burnt Mountain from West Willow Creek. The terminus of the Snowmass Creek glacier spread into the Wildcat Creek valley on the east and the Hunter Creek valley on the west. The erratics scattered over a considerable area in that drainage may be remains of moraine deposit $\mathrm{D}$. Moraine $\mathrm{D}$ of the main valley glaciers has some morainal crests preserved either on drainage divides or in areas of gentle slope. These ridges are subdued features compared to those of the younger moraines.

Moraine deposit $\mathrm{C}$ was confined to the present valleys at the lower ends of the major glaciers (figs. 53 , 55). It formed rather massive morainal ridges, such as those south of the Aspen airport (fig. 55A), on Snowmass Creek (fig. $55 B$ ), on the west end of Smuggler Mountain, and near McFarlane Creek. It reached the farthest downvalley of any of the recorded valley glaciers on Snowmass Creek and the Roaring Fork. On Snowmass Creek it diverted the mouth of Wildcat Creek some $2 \mathrm{~km}$ north by damming its valley. It spilled over into the Brush Creek drainage from Snowmass Creek. The spillover glaciers on either side of Burnt Mountain were about $2 \mathrm{~km}$ shorter than during deposition of moraine $\mathrm{D}$.

End moraine B (fig. 56) was deposited well upvalley from end moraine $\mathrm{C}$. The Maroon and Castle Creek glaciers did not join the Roaring Fork glacier. The Roaring Fork glacier was $6 \mathrm{~km}$ shorter and the Snowmass Creek glacier $2 \mathrm{~km}$ shorter than during Bull Lake(?) time.

The moraine deposit just east of Aspen differs from other end moraines of the area because it contains much more well-bedded and well-sorted material of glaciofluvial origin. This material has been exposed in sand and gravel pits, and the few water well logs available on that moraine reflect the better sorted nature of the material. In the gravel pit, crossbedded fine- to coarse-grained sand and fine-grained gravel were exposed in 1967. The sand was at least $3 \mathrm{~m}$ thick and overlain by $1.2-1.7 \mathrm{~m}$ of gravel, and it was folded and faulted (fig. 56B). As much as $6 \mathrm{~m}$ of sand were recorded in water wells nearby. The faults were closely spaced and had displacements of less than $2 \mathrm{~cm}$. 


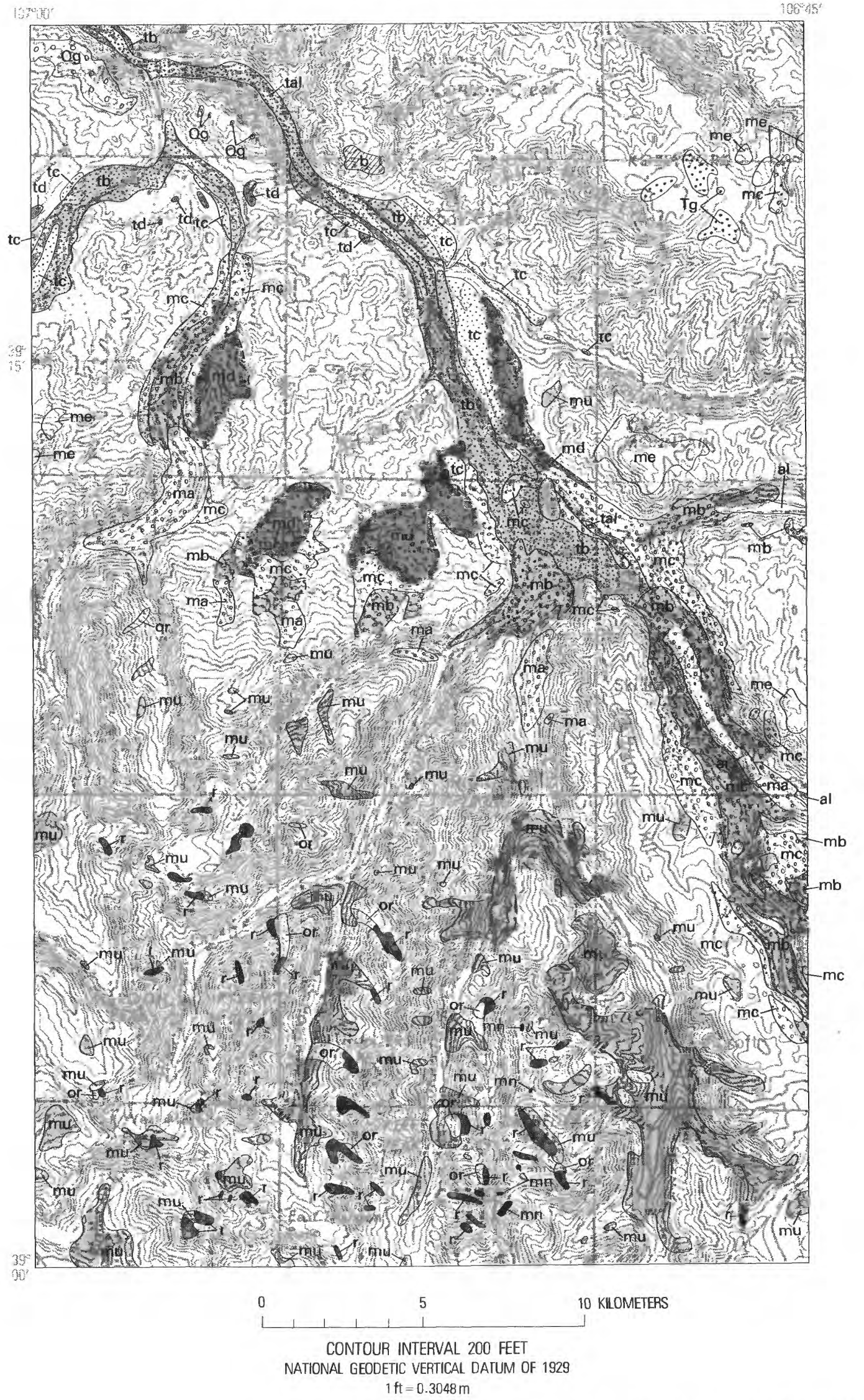

FIGURE 53 (above and right).-Map of upper Tertiary and Quaternary rocks of the Aspen area. Simplified from Bryant $(1969,1970,1971 \mathrm{a}, 1972 \mathrm{a})$ and from Freeman $(1972 \mathrm{a}, \mathrm{b})$. Base from A.M.S. 1:250,000, Leadville, 1957. 
EXPLANATION
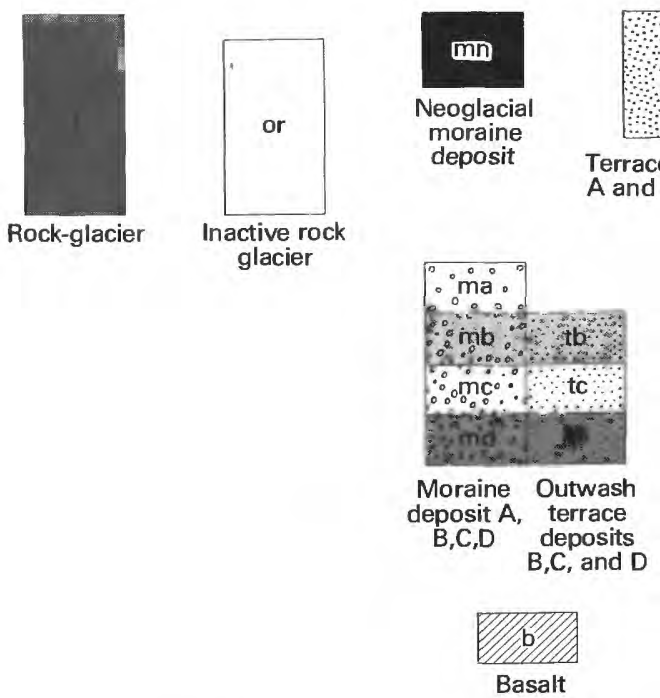

\begin{tabular}{|c|}
\hline me \\
\hline $\begin{array}{l}\text { Moraine } \\
\text { deposit E }\end{array}$
\end{tabular}

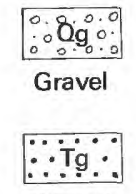

Gravel
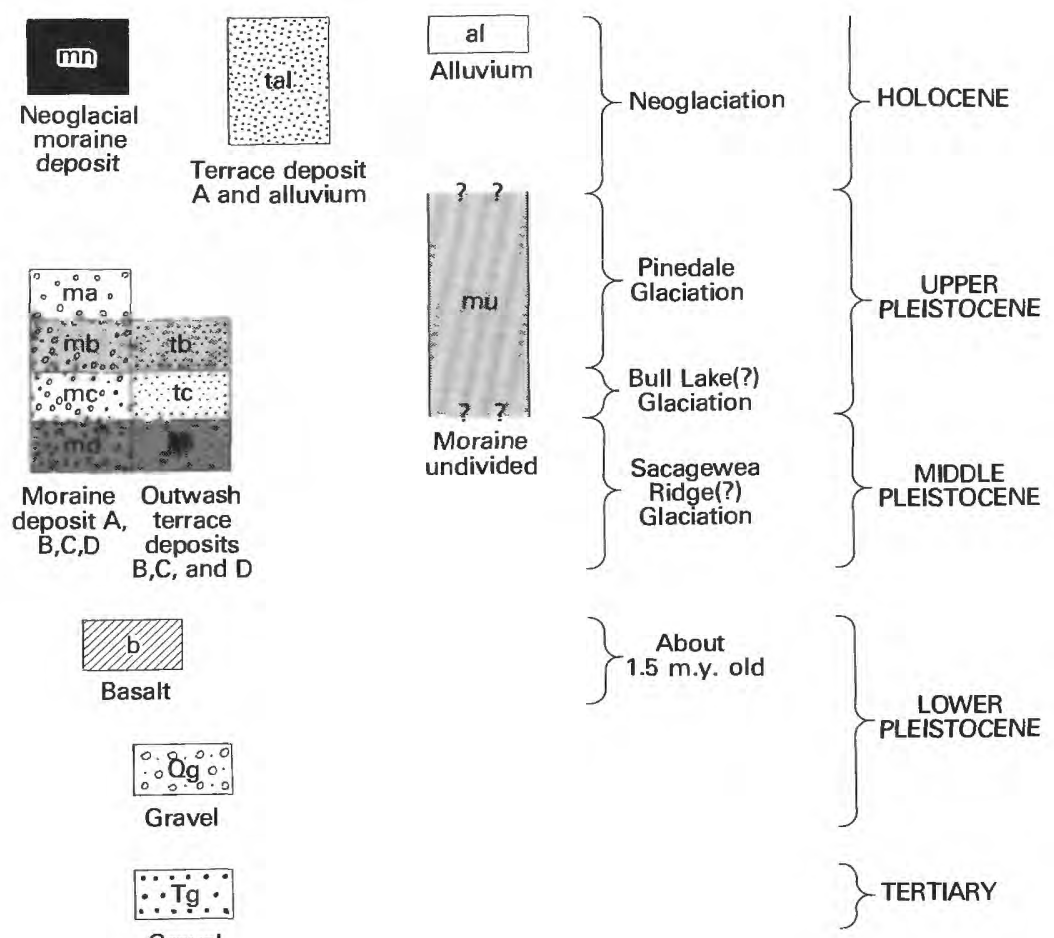

Whether the deformation of the sand was caused by overriding ice or by collapse due to melting of underlying ice is unknown, but I favor the latter hypothesis.

Moraine A is another $7 \mathrm{~km}$ up the Roaring Fork, about $4 \mathrm{~km}$ up Snowmass Creek and Maroon Creek, and $2 \mathrm{~km}$ up Castle Creek from moraine B (fig. 53). On Snowmass Creek are four closely spaced end moraines in the moraine A complex. Glaciers at this time did not spill from the Willow Creek drainage over the saddle east of Burnt Mountain, but they did spill over the saddle west of it.

In the mountain valleys, which are deep glacial troughs repeatedly filled with ice $300-400 \mathrm{~m}$ thick (fig. 54), geomorphic processes during the Holocene have tended to destroy end moraines. A few do survive. On East Maroon Creek two end moraines are well preserved at 2,895 and 2,926 m altitudes. Richmond, Malde, and Tweto (1965) recognized an end moraine near the junction of West Maroon and East Maroon Creeks, which has been mostly destroyed by deposition of outwash and alluvial material and by erosion. However, a lateral moraine just west of the postglacial gorge of East Maroon Creek suggests that an end moraine existed near the stream junction.

The natural dam of Crater Lake on West Maroon Creek is a large landslide believed by Richmond, Malde, and Tweto (1965) to overlie a moraine. That may be so, but as far as I could determine, all the evidence is concealed under the landslide.
At 2,895 m altitude on West Willow Creek is another recognizable end moraine. A succession of at least three end moraines is found in the Roaring Fork valley east of the Aspen quadrangle (Richmond and others, 1965; G. M. Richmond, unpub. mapping, 1963).

In the Castle Creek valley no well-preserved end moraine was mapped upstream from the complex at $2,438-2,499 \mathrm{~m}$ altitude. One may have existed at 2,680 $\mathrm{m}$ altitude near the Hope mine, but if so, it lacks well-defined geomorphic expression. Perhaps Holocene fan or landslide deposits conceal other end moraines.

End moraines are abundant in many cirques tributary to the main valleys (figs. $57,61 A$ ). In some cirques as many as four recognizable morainal loops are present. The end moraines are generally less than $7 \mathrm{~m}$ high and do not show on the topographic maps, but they are well defined when viewed on the ground. These end moraines are located at 3,109-4,084 $\mathrm{m}$ in altitude and are of different ages.

\section{OUTWASH TERRACE DEPOSITS}

The outwash terrace deposits (fig. 58) are composed of bedded gravel, sand, and rare discontinuous lenses of clay. Boulders are widespread and are as much as $3 \mathrm{~m}$ in diameter. Numerous logs from water wells in these deposits are all quite similar. Because these valley-fill deposits contain abundant water, many wells are not drilled entirely through them, and conse- 
$107)^{3}$

100

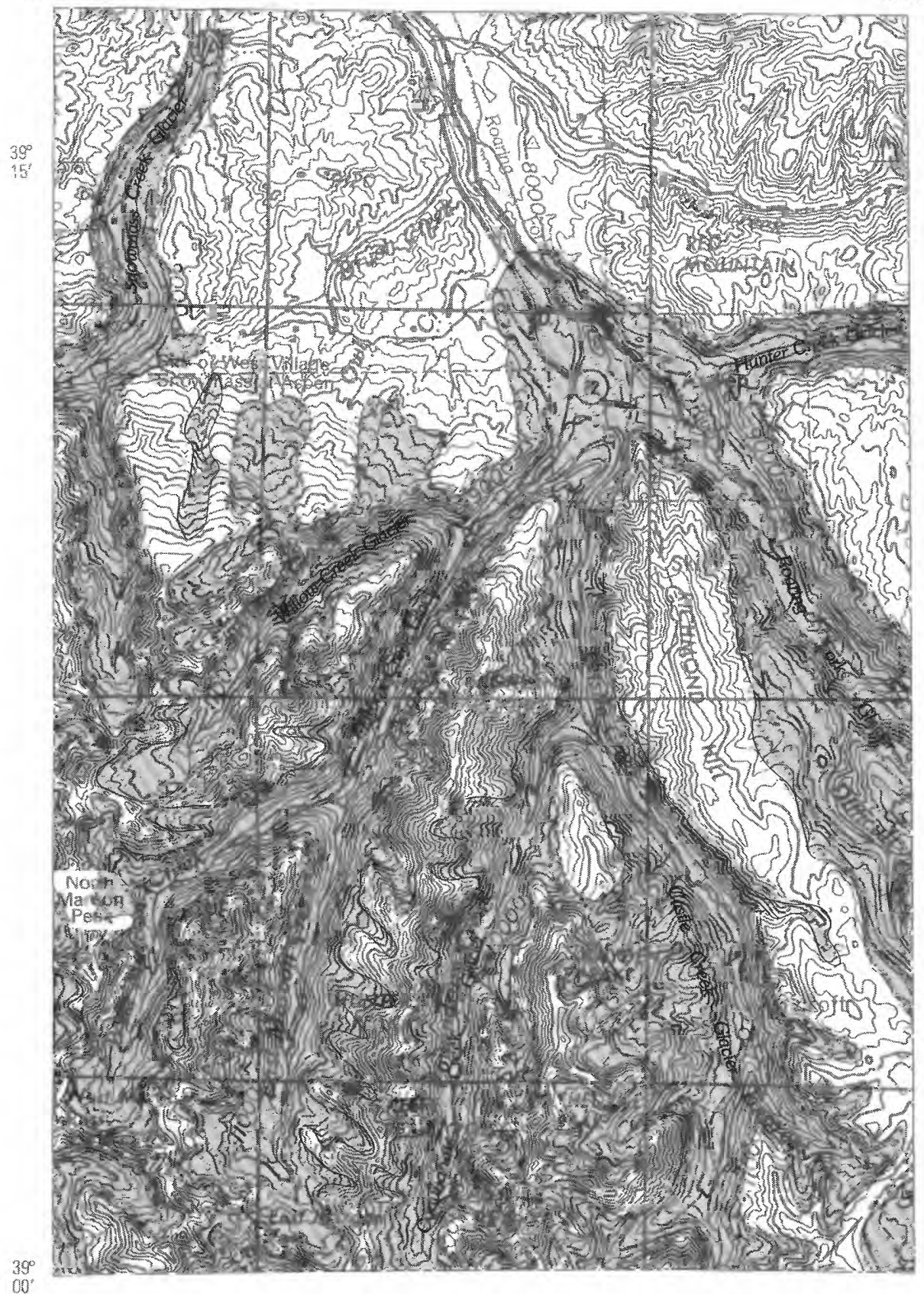

0

5

10 KILOMETERS

CONTOUR INTERVAL 200 FEET

NATIONAL GEODETIC VERTICAL DATUM OF 1929

$1 \mathrm{ft}=0.3048 \mathrm{~m}$

FIGURE 54.-Glaciers in the Aspen area during maximum extent of Bull Lake(?) Glaciation. Drawn on basis of moraines and topography in Bryant $(1969,1970,1971 \mathrm{a}, 1972 \mathrm{a})$ and Freeman (1972a). Base from A.M.S. 1:250,000, Leadville, 1957. 

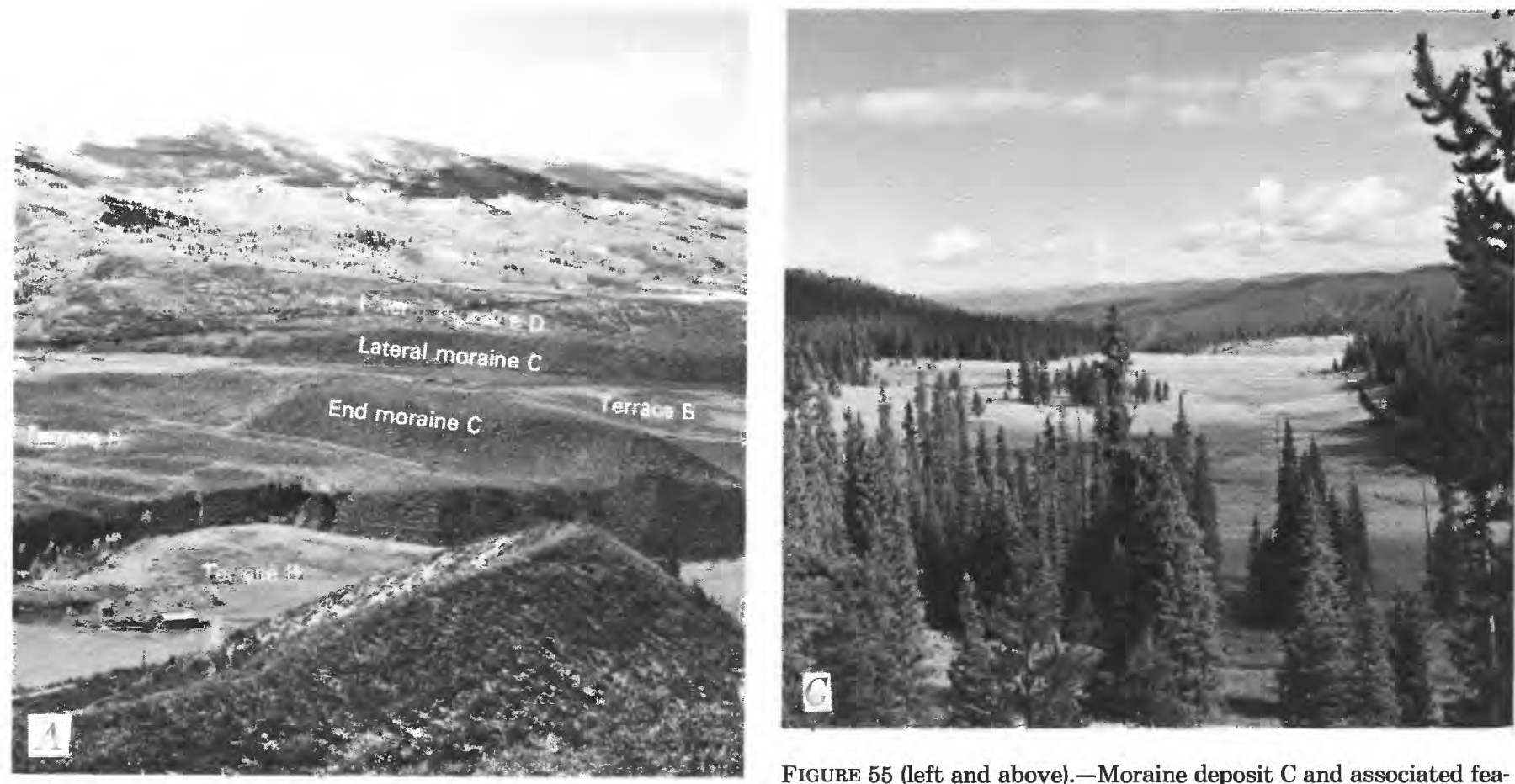

FiguRE 55 (left and above).-Moraine deposit $\mathrm{C}$ and associated features. $A$, View of remains of inner end moraine $\mathrm{C}$ from $2,590 \mathrm{~m}$ altitude on slope of Red Mountain, Aspen quadrangle. Terrace B surrounds moraine in center of photograph and is deeply incised by the Roaring Fork River. Hill in foreground is composed of Fort Hays Member of Mancos Shale. Beyond terrace is lateral moraine of outer loop of moraine C. Lateral moraine D is behind it. Gap in left part of skyline ridge allowed glaciers from Willow Creek to spill over into Owl Creek drainage at least three times during the Pleistocene. $B$, Scarp at head of landslide on west side of Snowmass Creek valley north of Eagle Mountain reveals that lateral moraine deposit $\mathrm{C}$ is composed of crudely bedded, poorly sorted gravels dipping away from the former glacier margin. Larger boulders are 1-2 $\mathrm{m}$ in diameter. $C$, Alluviated valley behind lateral moraine of Difficult Creek north of Fall Creek, Hayden Peak quadrangle. Bare slope beyond valley bottom is side of lateral moraine mapped as $\mathrm{C}$ in figure 53 , but could be partly D. View to northeast. 


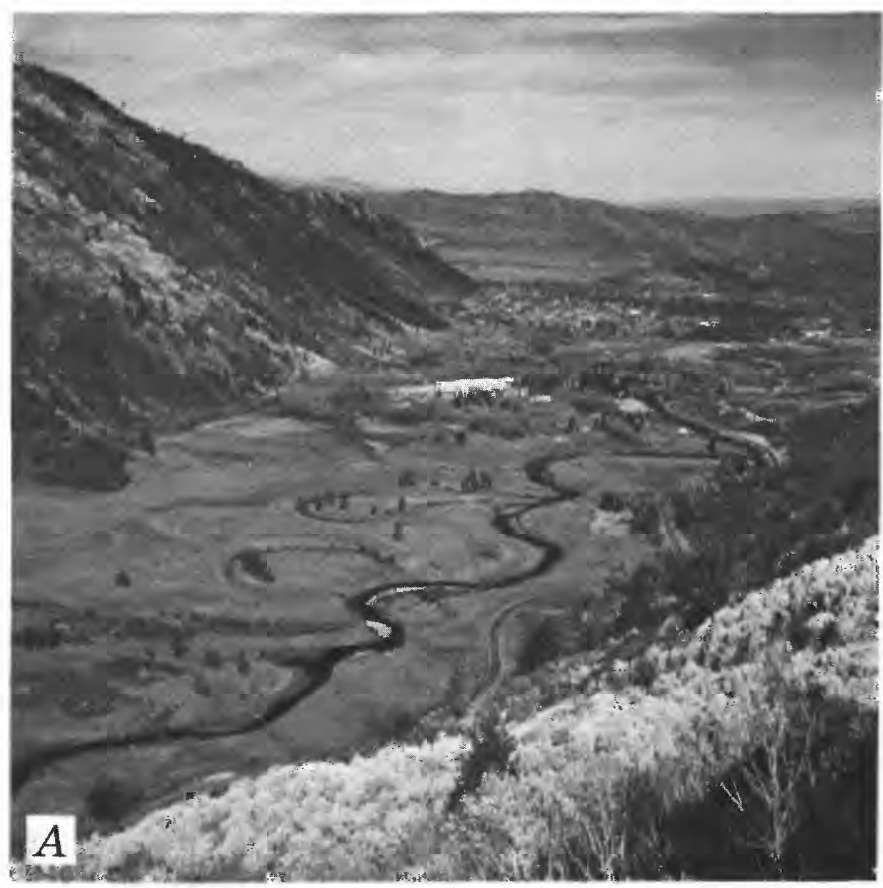

FIGURE 56.-Moraine deposit B. A, View northwest down the Roaring Fork River valley showing undissected alluviated valley behind moraine $B$, from $2,745 \mathrm{~m}$ altitude on the northeast side of the Roaring Fork River valley southeast of Aspen. City of Aspen in background is on outwash terrace $B$ graded to moraine.

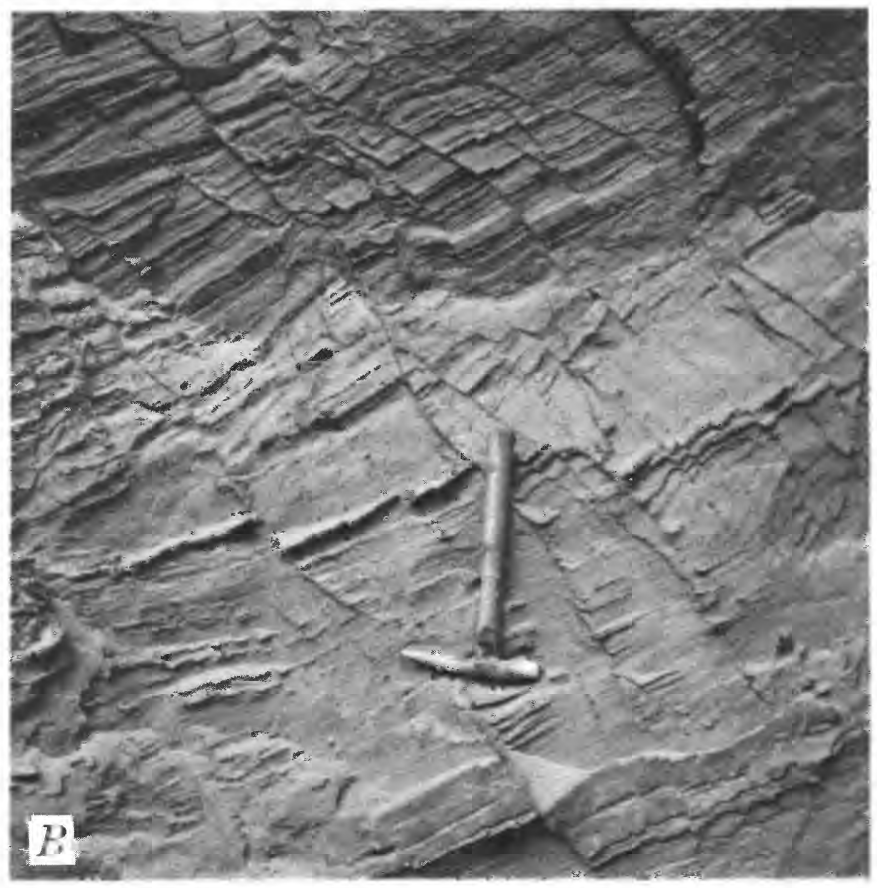

Moraine B occupies wooded area between meadows and town. Light-colored area is sand and gravel pit in moraine. Cutoff meanders in middle view. $B$, Bedded sands tilted and cut by faults of small displacement probably formed by collapse after melting of subjacent stagnant ice. Exposure in sand pit visible in $A$. quently we do not know much about their total thickness. Some wells as much as $50 \mathrm{~m}$ deep do not reach bedrock. Most of the records are from wells drilled on terrace $B$, and few well records from the upper terraces are available. Mine workings running beneath the Roaring Fork between East Aspen Mountain and Smuggler Mountain are at $200 \mathrm{~m}$ below the surface; that figure places an upper limit on the thickness of the valley fill there.

The outwash terraces and their deposits are correlated to the moraines and their deposits by their physiographic relations (figs. 53, 59). The most obvious relation between moraine and terrace is between the moraine just east of Aspen and the terrace on which the city is built. That terrace is graded to the moraine. Similarly, the moraine at the mouths of Castle and Maroon Creeks is graded to the same terrace. That moraine was considerably modified by melt water so that its contact with the outwash is quite gradational. Terrace $\mathrm{C}$ is found only downvalley from moraine $\mathrm{C}$, and terrace $\mathrm{D}$ is downvalley from moraine D. No terrace appears to be associated with the remains of the end moraine in the middle of the valley west of Red Butte; that moraine was mapped as part of moraine deposit $\mathrm{C}$. Terrace $\mathrm{A}$ is not continuous, and in the Woody Creek quadrangle (Freeman, 1972a) it oc- cupies the present meander belt of the Roaring Fork. This suggests that it formed under hydrologic conditions similar to the present, rather than being formed under the different conditions of the Pleistocene, as suggested by correlation to moraine A shown on the geologic map of the Aspen quadrangle (Bryant, 1971a). Terrace $A$ is about $5 \mathrm{~m}$ above the Roaring Fork at the city of Aspen, but downstream in the Woody Creek quadrangle it is about $12 \mathrm{~m}$ above the stream.

On the other hand, terrace A in the Snowmass Creek drainage of the Woody Creek quadrangle (Freeman, 1972a) occupies a good portion of the width of the valley and is probably an outwash terrace related to an end moraine. The main part of terrace A starts about $1.5 \mathrm{~km}$ north of the north edge of the Highland Peak quadrangle at an end moraine, which I designate as moraine B. A small area of terrace is found on Snowmass Creek just north of the Highland Peak quadrangle. Freeman (1972a) chose to map the end moraine near the quadrangle boundary as the outermost moraine deposit A; whereas I mapped the outermost moraine deposit $\mathrm{A}$ at $2 \mathrm{~km}$ upstream. I suggest that terrace deposit B of the Roaring Fork drainage in the Aspen and Woody Creek quadrangles correlates with Freeman's terrace deposit A of the Snowmass Creek drainage because both are the youngest widely 
developed terraces of their respective valleys (fig. 53), although the terrace in the Snowmass Creek drainage is only 9-12 m above the creek compared to 24-36 m above the Roaring Fork in the Woody Creek quadrangle. It follows that terrace B of Freeman (1972a), about $40 \mathrm{~m}$ above Snowmass Creek, must correlate with terrace $\mathrm{C}$ of the Roaring Fork valley, as indicated in figure 53. Snowmass Creek is a considerably smaller stream than the Roaring Fork River.

\section{AGE AND CORRELATION OF GLACIAL DEPOSITS}

Few detailed studies of glacial geology have been made in the immediate region. However, I would like to suggest some correlations with the glacial sequence studied by Nelson (1954) in the Fryingpan River drainage and by Miller (1971) on Lake Creek and East Brush Creek on the northwest margin of the Sawatch Range. Unfortunately, I have not made the quantitative studies of weathering, boulder frequency, and soil development that Nelson did. Correlations are made on physiographic expression and position. The relative ages of deposits in the local sequence are most certain; correlation with the sequence on the Fryingpan River is less certain; and correlation to some absolute time scale is quite speculative.

The oldest glacial deposits of moraine deposit E may be correlative with thick gravels on the ridges southwest and southeast of Snowmass in and west of the Woody Creek quadrangle (Freeman, 1972a; Welder, 1954). The gravels lie higher than the 1.5-m.y.-old basalt near Woody Creek (Freeman, 1972a; Larson and others, 1975). The gravels in Kobey Park in the Ruedi quadrangle (Freeman, 1972b) lie at

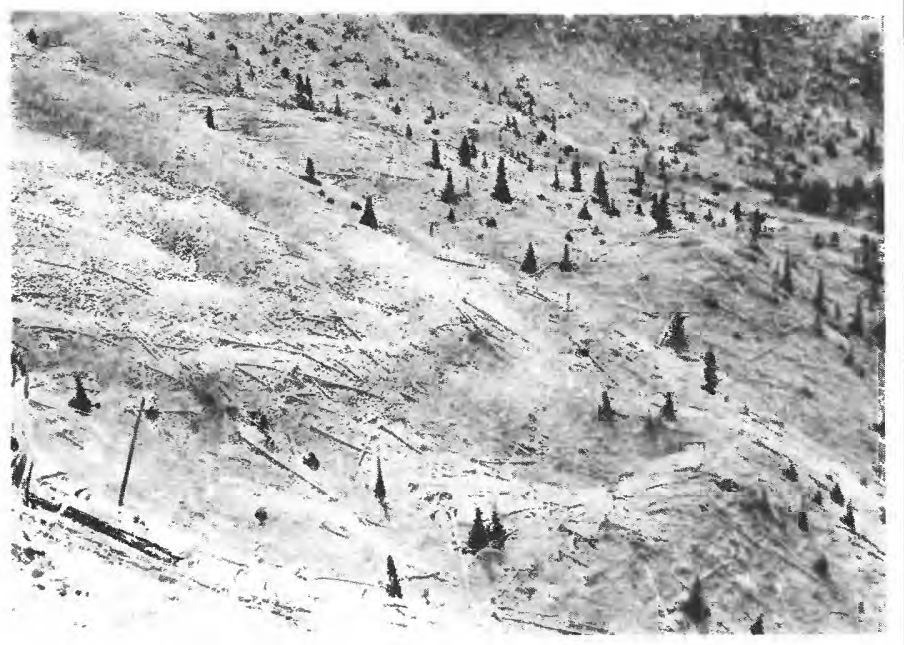

FIGURE 57.-Cirque moraines at $3,260-3,290 \mathrm{~m}$ altitude northeast of Hunter Peak, Maroon Bells quadrangle.

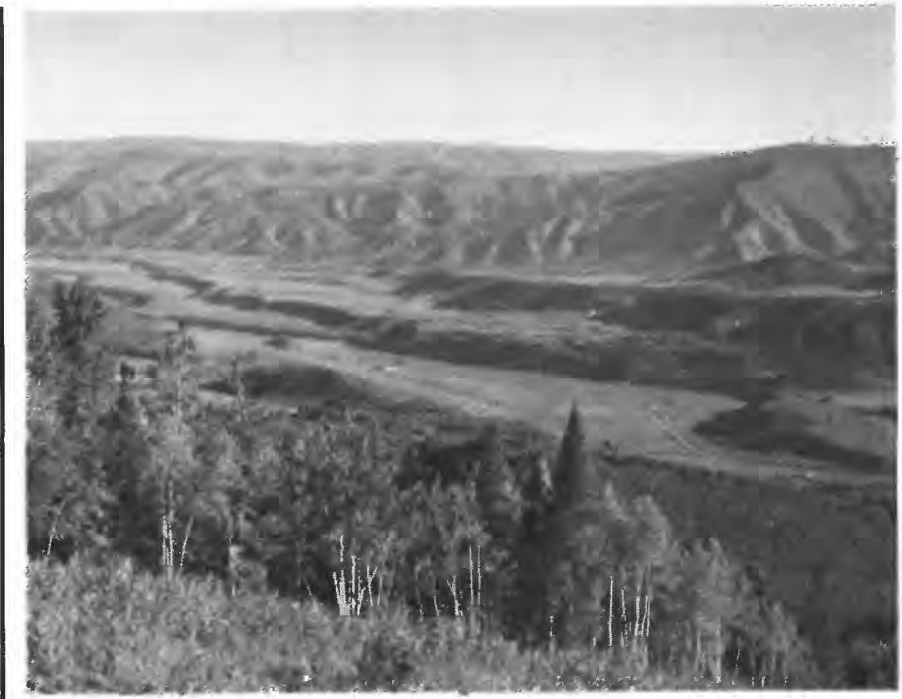

FIGURE 58.-Outwash terraces in the Roaring Fork River valley below Aspen viewed north from 2,915 m altitude on ridge southwest of Sterner Gulch, Aspen quadrangle. Lowest extensive terrace B heads at moraine east of the city of Aspen and is about $40 \mathrm{~m}$ above the river. Hill on it at right is part of inner end moraine $C$. Middle terrace $C$ heads at right middle of view and is about $90 \mathrm{~m}$ above the river. Highest terrace $D$ heads at right margin of photograph and is about $120 \mathrm{~m}$ above river.

much higher altitudes and may be related to gravels associated with 10-20-m.y.-old basalts on the high plateaus and interstream divides, such as Grand Mesa and the Flattops (fig. 59). The Roaring Fork River has cut down about $480 \mathrm{~m}$ since the high gravels southwest of Snowmass were deposited. If they are glacial outwash gravels, this cutting occurred during the Pleistocene. Since extrusion of the 1.5-m.y.-old basalt some $10 \mathrm{~km}$ upstream, the bed of the Roaring Fork River has been lowered $380 \mathrm{~m}$; so if the Pleistocene is 2 million years or longer in duration, the high-level gravels may be of Pleistocene age. No such high-level deposits are described by Nelson (1954) from the Fryingpan River drainage, but V. L. Freeman (oral commun., 1975) found small remnants of gravel $360 \mathrm{~m}$ above the Fryingpan River south of Ruedi, and farther north Miller (1971) found till $460 \mathrm{~m}$ above the valley bottom on a ridge north of East Brush Creek. Near Durango, Richmond (1965b) correlated gravels as much as $600 \mathrm{~m}$ above the Animas River with early Pleistocene glaciations.

Other deposits perhaps correlative with an early Pleistocene glaciation occur between 2,605 and 3,110 $m$ altitude on the divide between Capitol and Snowmass Creeks, in the Capitol Peak quadrangle.

Moraine and terrace deposits $\mathbf{D}$ were correlated with the Sacagawea Ridge Glaciation of the Wind River Mountains by Richmond, Malde, and Tweto (1965). 


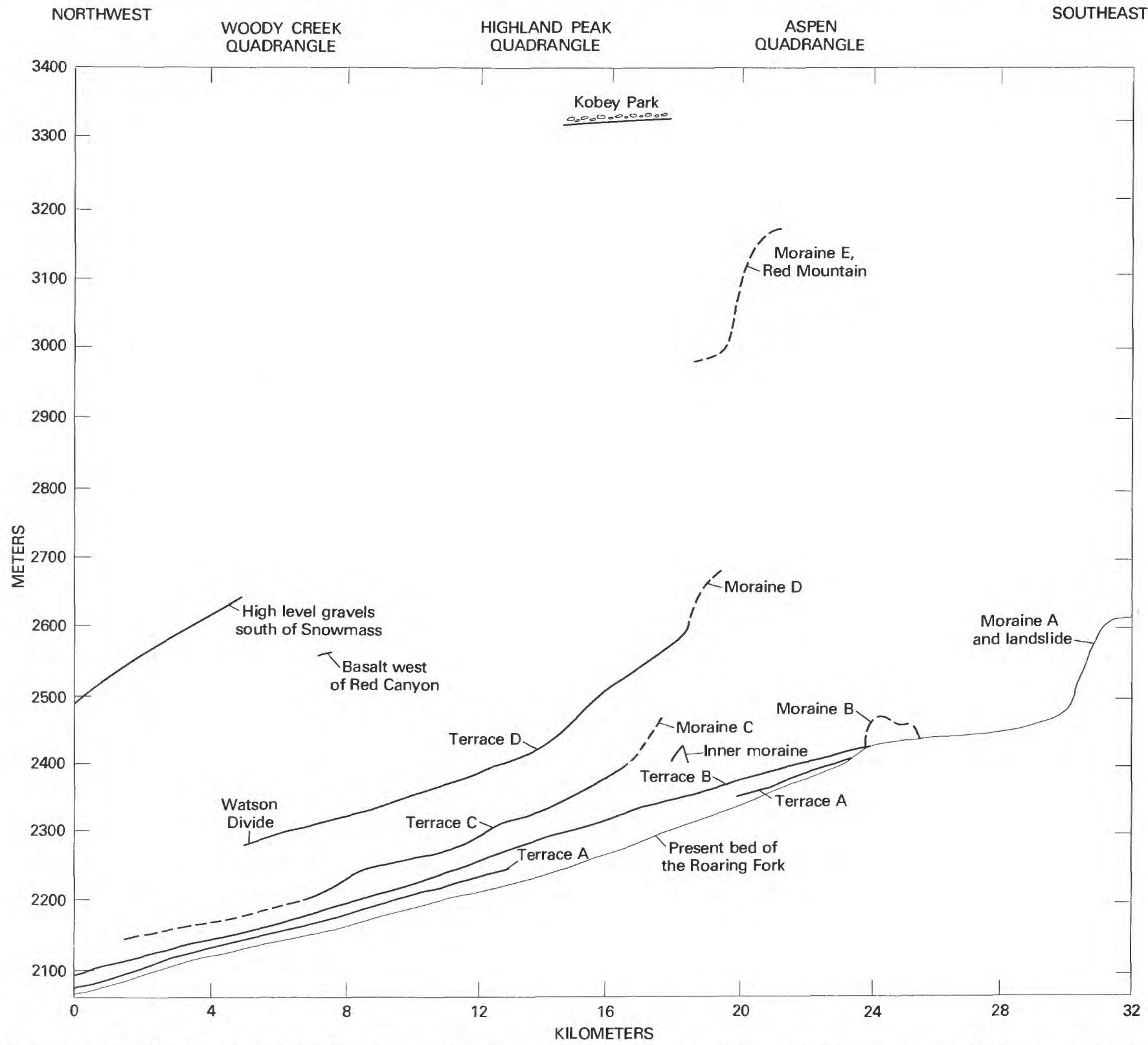

Figure 59.-Profile along the Roaring Fork River valley showing present stream grade, terrace levels, moraines, and older gravels. Modified from Bryant (1971a, 1972a) and Freeman (1972a, b). Dashed line indicates surface of moraine.

Those deposits may correlate (table 8) with the "Lime Creek stage" of Nelson (1954). Apparently, at the time when the gravels of terrace $\mathrm{D}$ were deposited, the Roaring Fork flowed over Watson Divide (Freeman, 1972a) and probably down the valley now occupied by East Sopris Creek. Gravels at Watson Divide contain material from the basalt flow on the north side of the Roaring Fork. This does not mean that all the canyon between Snowmass and the basalt flow was carved between the Sacagawea Ridge Glaciation and the present, for headward erosion along the Castle Creek fault zone had already almost captured the Roaring Fork by this time. Although Richmond (1965a) correlated the Sacagawea Ridge Glaciation with the Illinoian of the midcontinent, recent work has indicated that some deposits assigned to the Bull Lake are late Illinoian (Pierce and others, 1976). Consequently, the D terrace deposit is early or pre-Illinoian; thus, more time is indicated for diversion of the Roaring Fork and some $150 \mathrm{~m}$ of valley-cutting between deposition of terrace $\mathrm{D}$ and the present. Yet $240 \mathrm{~m}$ of valley-cutting apparently took place between the eruption of the 1.5-m.y.-old basalt and the deposition of terrace unit D (fig. 59). 
TABLE 8.-Correlation of Pleistocene and Holocene events, Roaring Fork and Fryingpan drainages

\begin{tabular}{|c|c|c|c|}
\hline Roaring Fork drainage & $\begin{array}{l}\text { Fryingpan drainage } \\
\text { (Nelson, 1954) }\end{array}$ & Glaciation & Age \\
\hline Rock glaciers and a few cirque moraines & & Neoglaciation & Holocene. \\
\hline $\begin{array}{l}\text { Cirque moraines and rock glaciers- } \\
\text { Valley moraines-- } \\
\text { upvalley from moraine A. } \\
\text { Moraine A (and terrace A?) } \\
\text { Moraine and terrace B }\end{array}$ & $\begin{array}{l}\text { "Chapman Gulch Glaciation" } \\
\text { "He11 Gate substage" } \\
\text { "Ivanhoe substage" }\end{array}$ & Pinedale & Late Pleistocene. \\
\hline Moraine and terrace $\mathrm{C}-$ & $\begin{array}{l}\text { "Bigelow substage"; } \\
\text { "Thomasvi1le substage" }\end{array}$ & Bu11 Lake(?) & \\
\hline $\begin{array}{l}\text { Capture of Foaring Fork by- } \\
\text { headward €rosion along Castle } \\
\text { Creek fault zone. } \\
\text { Moraine and terrace D }\end{array}$ & "Lime Creek stage" --_--- & Sacagawea Ridge(?) & Middle Pleistocene(?). \\
\hline $\begin{array}{l}\text { Extrusion of basalt } 1.5 \mathrm{~m} \cdot \mathrm{y} \text {. ago-- } \\
\text { Moraine E and gravels southwest-- } \\
\quad \text { of Snowmasis. }\end{array}$ & & & Early Pleistocene(?). \\
\hline Gravels at Kobey Park- & & & Pliocene(?). \\
\hline
\end{tabular}

Terrace and moraine deposits $\mathrm{C}$ are correlated with the "Bigelow and Thomasville substages" of Nelson (1954) (talole 8). The terminal moraines of those "substages;" are breached a similar amount, although the quantitative weathering data suggests some age difference between the Thomasville and Bigelow moraines. A distinct terrace was related to each of them by Nelson, but as mapped, the terrace related to the Bigelow cuts the Bigelow moraine. This terrace does not bear the same relation to the end moraines as the terraces and moraines I have correlated. Possibly Nelson's Higelow terrace is related to a "washed-out" end moraine south of Norrie. The streambed of the Fryingpan River upstream from Norrie appears less well established than below Norrie, for it contains swampy stretches of undissected alluvium. Therefore, I would correlate Nelson's Thomasville terrace, which is about $60 \mathrm{~m}$ above the Fryingpan River near Thomasville, with both the Thomasville and Bigelow moraines. That terrace height is greater than the $27-36 \mathrm{~m}$ reported by Nelson (1954) and is obtained from a terrace remnant just west of Thomasville shown on the 1970 Meredith 7.5-minute topographic quadrangle, which was not available at the time of Nelson's work. Miller (1971) on Lake Creek found two moraines which he correlated with the Thomasville and Bigelow of Nelson. The Roaring Fork valley must have contained at least two end moraines in the material mapped as moraine deposit $\mathrm{C}$, for a remnant of the younger one forms a hill $60 \mathrm{~m}$ high. engulfed by terrace $\mathrm{B}$ in the middle of the valley west of Red Butte. The moraine $C$ of the Aspen area forms massive moraines as do the Bigelow moraines of the Fryingpan River drainage. However, terrace $\mathrm{C}$ is somewhat higher above the Roaring Fork River than the Thomasville terrace is above the Fryingpan River. These deposits are tentatively correlated with the Bull Lake.

Moraine and terrace $\mathrm{B}$ and younger moraines are probably of Pinedale or Wisconsin age. The Roaring Fork River has scarcely breached the moraine above Aspen, and the same relation holds for the end moraines of the "Ivanhoe substage" in the Fryingpan River drainage (Nelson, 1954). The B end moraine in the Roaring Fork valley was probably underlain by stagnant ice after retreat of the glacier front so that a number of depressions formed where sand was first deposited from melt water and then disturbed by collapse by further melting of underlying ice. The presence of an untrenched alluviated valley behind this moraine suggests a Pinedale age for it.

Moraine A and moraines farther upvalley may correlate with Nelson's (1954) "Hell Gate substage and Chapman Gulch glaciation." In the Fryingpan River drainage these moraines are above $3,050 \mathrm{~m}$ altitude, but in the Aspen area they are as low as $2,560 \mathrm{~m}$ altitude on the Roaring Fork, $2,470 \mathrm{~m}$ on Castle Creek, 2,500 $\mathrm{m}$ on Maroon Creek, and 2,440 $\mathrm{m}$ on Snowmass Creek. On the Fryingpan River a lower four- to fiveloop end-morainal complex and an upper single-end moraine are mapped as "Hell Gate substage" (Nelson, 1954). In the Aspen area at least four or five end moraines are found upstream from moraine A, and as many as four end moraines are found in cirques tributary to the main valleys.

Probably very few of the cirque end moraines are Neoglacial. Birkeland and Miller (1973) and Currey 
(1974) gave evidence supporting the idea of Moss (1951) that the type Temple Lake moraine in the Wind River Mountains of Wyoming is pre-Altithermal in age and perhaps late Pinedale rather than early Neoglacial, as that term has been used in recent reports. They found that the Neoglacial moraines are much farther upvalley than the moraine at Temple Lake, and that the youngest moraine fronts an existing glacier. Carrara and Andrews (1973) concluded that the cirque moraines of the San Juan Mountains are late Pinedale, and Miller (1973) found only one Neoglacial cirque moraine in the northern Sawatch Range. Benedict (1973) found moraines near timberline in the northern Front Range to date from about $10,000-11,000$ years old.

Very fresh high-altitude moraines in sheltered localities near Castle Peak are probably Neoglacial (fig. $60)$. The principal mass of the moraine in the cirque heading on the north face of Castle Peak has three endmoraine ridges, which might be correlated with the Triple Lakes, Anderson, and Arapaho Peak advances of Benedict (1973) in the northern Front Range. The deposit of angular rock fragments between the lower end moraine and the upper two may be an incipient rock glacier; however, it lacks the characteristic ridged topography indicative of flow, and the end moraines are preserved. This mass of rock may constitute icecored moraine. A depression usually partly filled with snow occurs behind the innermost end moraine and marks the site of former ice (fig. 60A). Two small moraines at $3,900 \mathrm{~m}$ altitude on north-facing slopes northwest and north of Cathedral Peak and one north of Hayden Peak may also be Neoglacial. Moraines of Neoglacial and even late Pinedale age are lacking in many cirques. Rock glaciers substitute for moraines in those cirques.

Glaciers and a full set of Neoglacial deposits occur in the northern Front Range only about a degree in latitude north of the Elk Mountains (Benedict, 1968, 1973; Madole, 1972). The Elk Mountains probably have more precipitation in the winter than the Front Range, but the Front Range is much windier. Consequently, the snow there accumulates in sheltered localities in north- and east-facing cirques, and small variation in regional snowfall may lead to greater fluctuation in glaciation (Benedict, 1973).

The Fryingpan River drainage had a different regimen in the Pleistocene than the Roaring Fork drainage. Pinedale or late Pleistocene glaciers descended to a lower altitude in relation to Bull Lake(?) glaciers in the Roaring Fork than in the Fryingpan. The outwash terraces related to the various glacial episodes are more widely separated in the upper Roar-
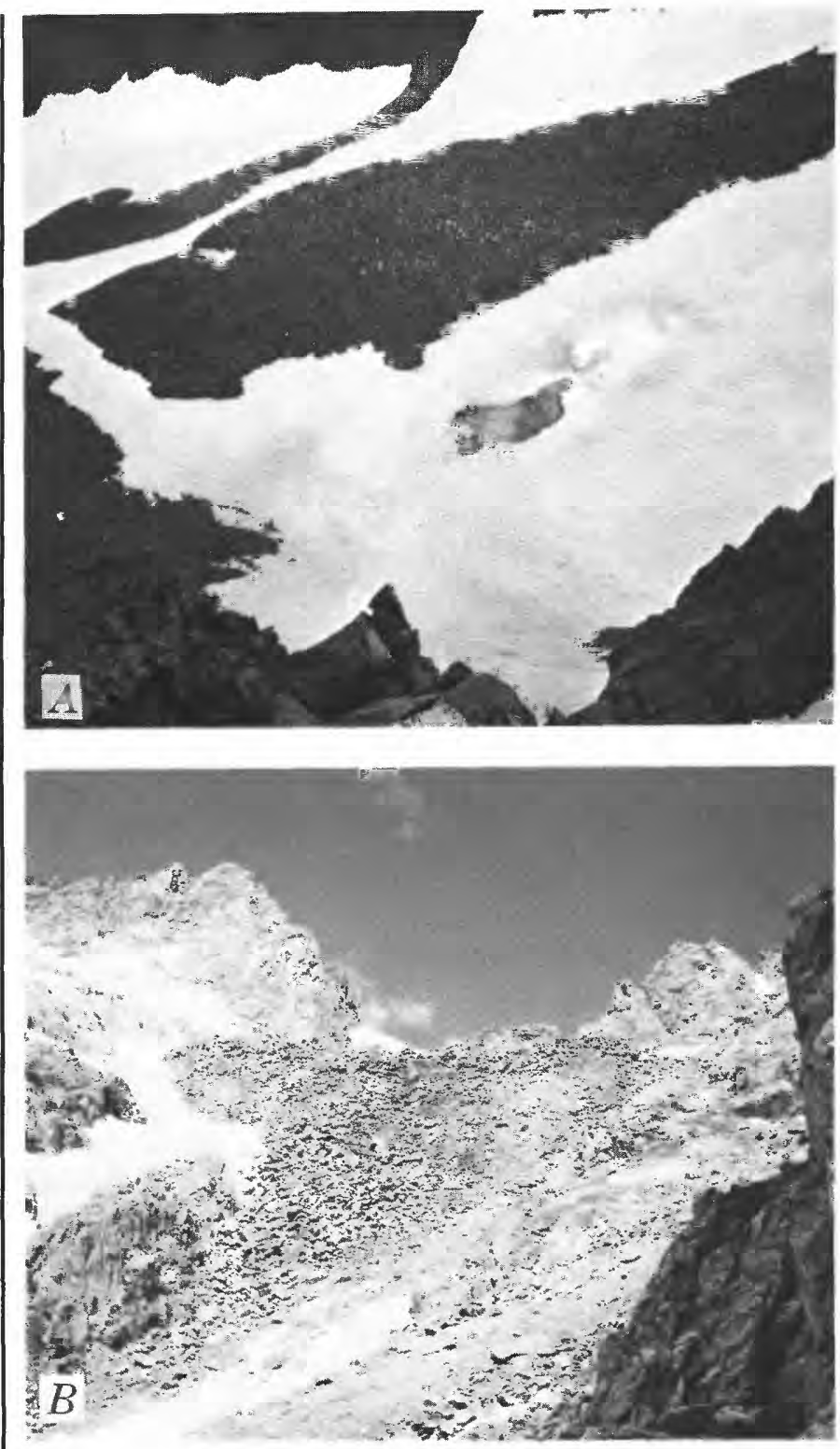

FIGURE 60.-Neoglacial moraines in Hayden Peak quadrangle. $A$, Two morainal loops and closed depression behind them at $4,084 \mathrm{~m}$ altitude in cirque on north side of Castle Peak, viewed from above on slope of Conundrum Peak. Larger blocks in moraine about $1 \mathrm{~m}$ in diameter. $B$, Moraine at $4,053 \mathrm{~m}$ altitude in small cirque north of Conundrum Peak, viewed from below. Larger boulders are 1-2 $\mathrm{m}$ in diameter. Typical exposures of granodiorite.

ing Fork than in the Fryingpan River drainage. This difference may be related to the capture of the upper course of the Roaring Fork River leading to increased rate of downcutting in the late Pleistocene. In addition, the outwash deposited during each glacial episode in the Roaring Fork drainage was probably thicker than that deposited in the Fryingpan River drainage. Glacial debris eroded from the Elk Mountains south of 
Aspen was brought into the valley west of Aspen in addition to that brought in by the Roaring Fork and Hunter Creek from the Sawatch Range.

\section{ROCK GLACIERS}

Many tens of rock glaciers occur in the high country of the Elk Mountains southwest of Aspen (fig. 53). Most of them are at altitudes between 3,770 and $3,350 \mathrm{~m}$, but a few extend to below $3,050 \mathrm{~m}$. Both cirque and valley wall types (Outcalt and Benedict, 1965) occur, but cirque types dominate. The largest rock glaciers are $1.8 \mathrm{~km}$ long and $0.45 \mathrm{~km}$ wide and the smallest less than $100 \mathrm{~m}$ long. The smallest rock glaciers, such as those in the large area of talus north of Buckskin Mountain, Maroon Bells quadrangle, consist of convex masses of talus that appears to have flowed. These small bodies may have quite a different origin than the larger bodies; these latter have the shape of ice glaciers and exhibit a complicated but orderly ridge-and-furrow surface topography whose pattern suggests viscous flow superposed on their convex cross profile (fig. $61 A$ ). The rock glaciers are 20-40 $\mathrm{m}$ thick and have steep fronts and margins (figs. $40 \mathrm{C}$, $61 B$ ). The surfaces are composed of angular blocks 0.1 $\mathrm{m}$ to several meters in diameter. Silt and sand are commonly exposed in their fronts, which are at steeper than the angle of repose and shed talus. Their fronts are the source of streams in places during the summer. A small pond occurs on the rock glacier north of Pyramid Peak, and on one rock glacier a stream was flowing on the surface of the rock glacier face when I crossed it.

Where rock glaciers and end moraines are found in the same cirque, the rock glaciers always cut the end moraines (fig. 61A). In other places, such as the cirque southwest of American Lake, Hayden Peak quadrangle, rock glaciers appear to have formed from morainal material augmented by talus from the valley wall.

Old rock glaciers, as mapped, are rock glaciers which have a well-developed cover of tundra vegetation, or, at lower altitudes, a forest cover. These rock glaciers are apparently inactive, for they do not have the steep fronts and sharply defined lobes of the rock glaciers lacking a full vegetative cover. The old rock glaciers have the convex cross profile of the active rock glaciers and they lack the terminal ridge of the cirque moraine complexes. The old rock glaciers are usually adjacent to or below active-appearing rock glaciers (fig. $61 \mathrm{C}$ ). In places the active rock glacier overrides the old rock glacier. This relation is well illustrated in the cirque southwest of Cathedral Peak (fig. 61C). Some of the active rock glaciers have scattered patches of tundra vegetation and even a few trees where their surface is below timberline. Lichen-covered rocks are common on their lower parts, and rocks lacking lichen are common at their heads; but no detailed studies of lichen distribution were made.

At the head of the rock glaciers in the higher more sheltered cirques snowbanks often remain all year. At the upper margin of the rock glacier in the cirque southeast of Pyramid Peak in 1963 glacial ice having small crevasses was visible. It is likely that ice occurs at the heads of other rock glaciers, although it may seldom be visible because of the snow cover.

Measurements over a 4-year period of the rock glacier north of Pyramid Peak and the one north of North Maroon Peak showed a maximum movement rate of $68 \mathrm{~cm}$ a year (Bryant, 1971b). The glaciers measured should be moving about as fast as any in the Aspen area judging by their aspect and setting. This movement rate exceeds maximum rates measured on other Colorado rock glaciers $(12.5 \mathrm{~cm} / \mathrm{yr}$, Miller, 1973; $20 \mathrm{~cm} / \mathrm{yr}$, Outcalt and Benedict, 1965; $22.5 \mathrm{~cm} / \mathrm{yr}$, White, 1971). Comparable movement rates have been measured on a rock glacier in Wyoming (Potter, 1972) and in Alaska (Wahrhaftig and Cox, 1959; Foster and Holmes, 1956).

\section{AGE OF ROCK GLACIERS}

A number of studies have recently been done on rock glaciers in Colorado (Benedict, 1967, 1968, 1973; White, 1971; Mahaney, 1973; Birkeland, 1973; Carrara and Andrews, 1973; Miller, 1973). In the Front Range at about lat $40^{\circ} \mathrm{N}$. (a degree north of the Elk Mountains), lichen growth curves have been established and used with success (Benedict, 1967, 1968; Mahaney, 1973). There, moraines and ice glaciers are about 100-300 years old (Arapaho Peak advance, Benedict, 1973); moraines and ice-cored and presently active rock glaciers date from 1,000 to 1,900 years ago (Audubon advance, Mahaney, 1972; Benedict, 1973), and vegetated moraines as much as $1.3 \mathrm{~km}$ downvalley date from 5,000 to 3,000 years ago (Triple Lakes advance, Benedict, 1973). Recent studies in the San Juan Mountains (Carrara and Andrews, 1973) and on Mount Sopris in the northwestern Elk Mountains (Birkeland, 1973) point out the difficulty of using lichen growth curves established elsewhere on different rock types. They found that many rock glaciers date from late Pinedale time, but that these rock glaciers either continued to be active, or were reactivated numerous times, during the Holocene. In the northern Sawatch Range, Miller (1973) found rock glaciers that formed 


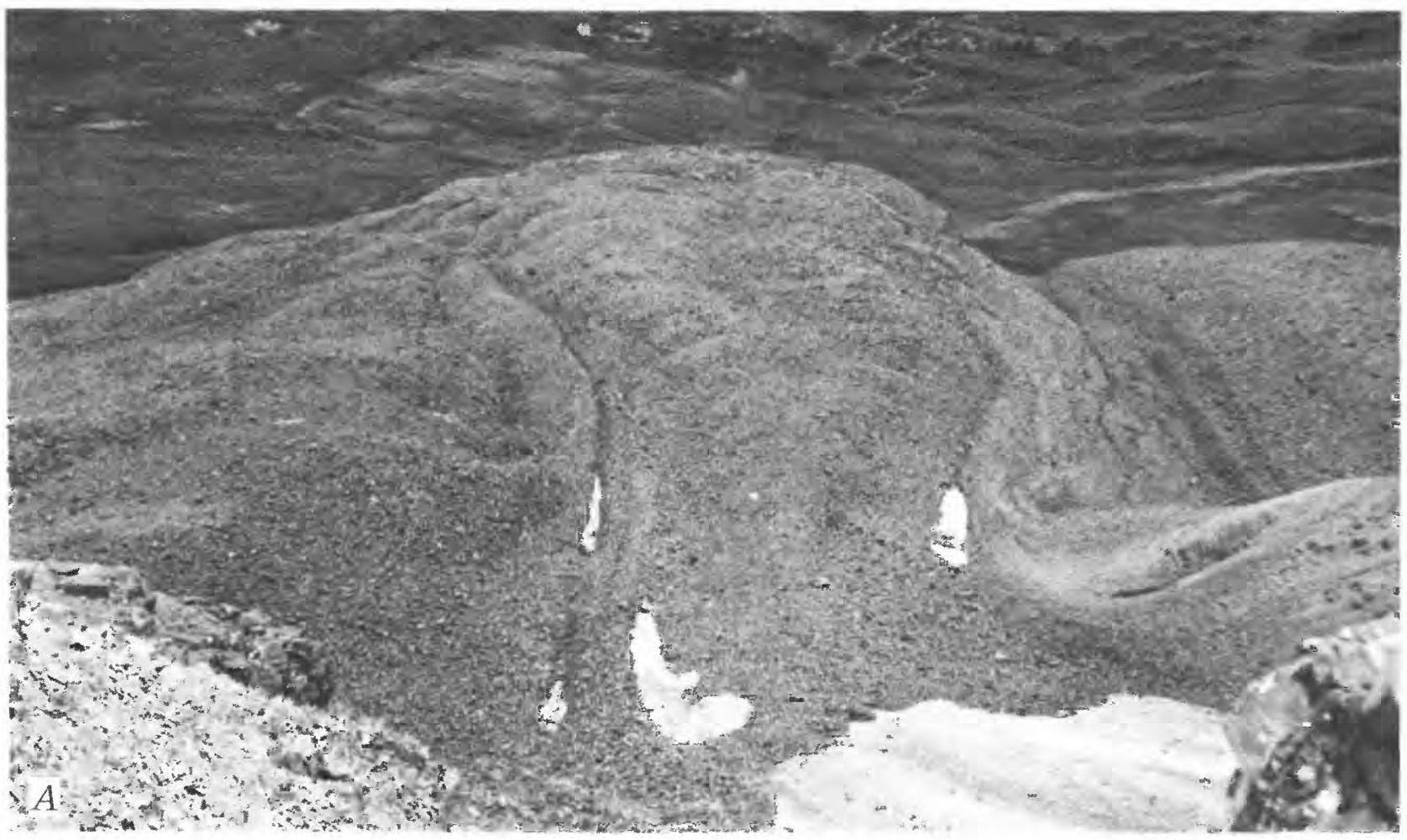

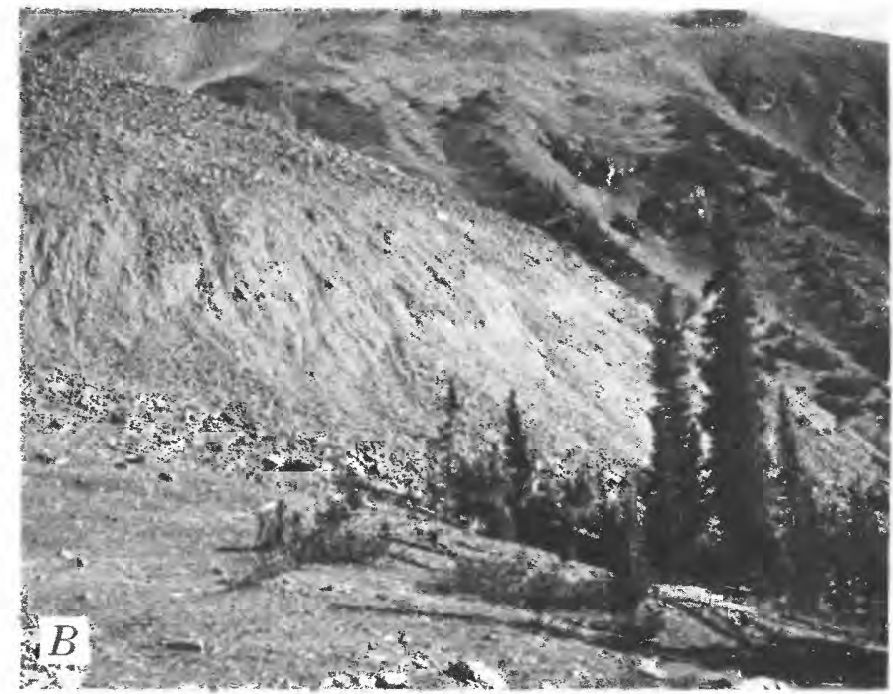

FiguRe 61.-Rock glaciers. A, Rock glacier at the head of West Maroon Creek viewed from ridge above. Main part of rock glacier is at altitude $3,660-3,536 \mathrm{~m}$ altitude. Typical pattern of ridges and swales suggesting flow. It cuts cirque moraine of late Pinedale(?) age on right (light-colored ridge). An outer cirque moraine extends down valley to right bend in stream gully (altitude $3,475 \mathrm{~m}$ ). B, Steep active front of south part of rock glacier in cirque west of Hunter Peak, Maroon Bells quadrangle (altitude $3,475 \mathrm{~m}$ ). Note silt and sand exposed in steep front, whereas no matrix is visible between large blocks on upper surface of glacier. $C$, Rock glaciers in cirque southwest of Cathedral Peak extending from 3,932 to $3,566 \mathrm{~m}$ altitude. Rock glacier at right has had some fine-grained as well as coarse rock on surface, and tundra vegetation is developed. This was mapped as old rock

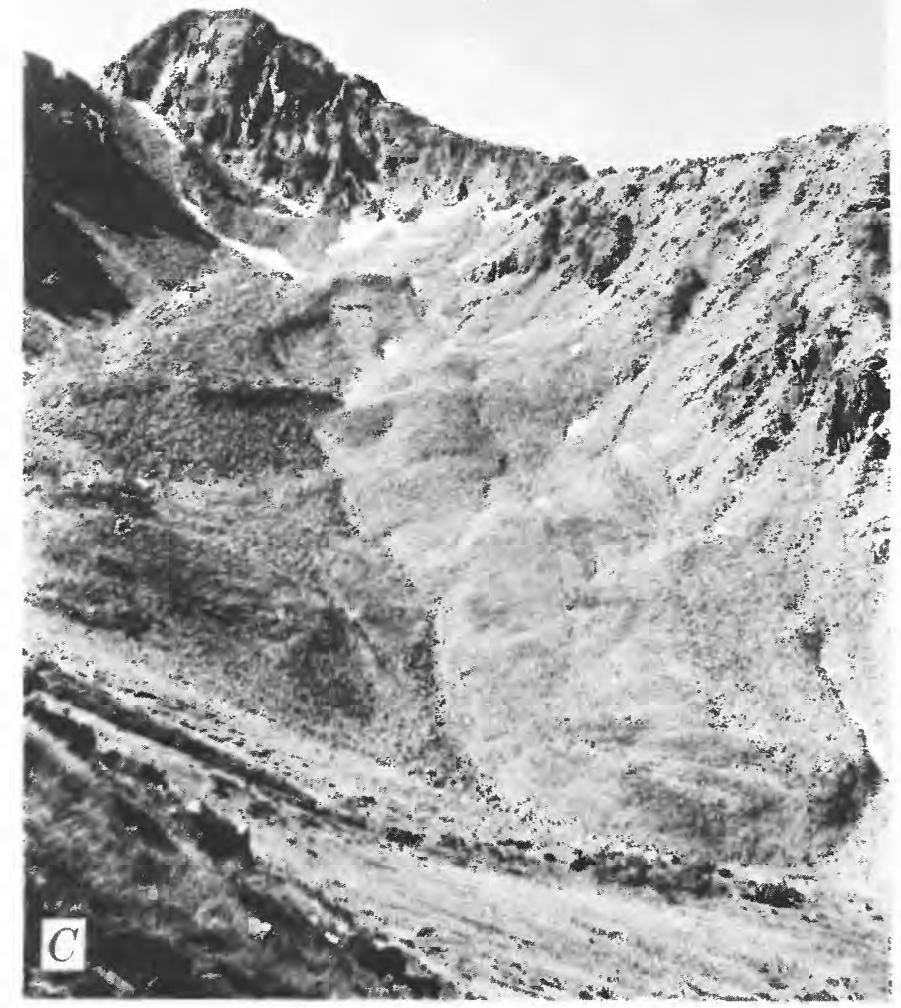

glacier. Rock glacier at upper left lacks interstitial fines on upper surface and vegetation; and it has high, steep margins, suggesting that it is active at present. 
during two earlier Neoglacial advances and are active now, but he found no rock glaciers that formed during the Gannett Peak Stade and only one Neoglacial moraine, which dated from the Temple Lake Stade. Yount (1970) found no rock glacier or moraine from the Gannett Peak Stade on the crest of the Sawatch Range east of Aspen.

Unfortunately, I had completed mapping of the high country of the Aspen area by the time the lichenometric studies of Benedict (1967) appeared; so I do not have information comparable with that of recent rock-glacier studies. However, in view of the studies cited previously it seems likely that the rock glaciers of the Aspen area originated at a number of times, although most of them are presently active. The old rock glaciers are inactive, but they may have formed at about the same time as parts of adjacent active rock glaciers. The rock glaciers formed after retreat of the Pinedale glaciers, and they are younger than most of the cirque moraines. Many of the rock glaciers at lower altitudes, such as below 3,505 m, may have formed during the late Pinedale; and the large ones which extend from the cirque headwalls down to that altitude may have a long complex history similar to that deduced by Birkeland (1973) for similar large rock glaciers on Mt. Sopris. Others may have formed during one or more advanced of the Neoglaciation, but judging from Miller's (1973) work perhaps very few formed in the Arapaho Peak advance. However, many of the rock glaciers are currently being supplied by talus and rockfall from adjacent peaks, and they have active advancing lobes or fronts.

\section{LANDSLIDE DEPOSITS}

Landslide deposits are numerous in the Aspen area, and they are composed of a variety of materials ranging from rock-glacier and morainal deposits to sandstone and quartz monzonite. They are most numerous on dip slopes of sedimentary rocks, but they also occur on steep terrane in fractured rock of any type. An outstanding example of a dip-slope landslide is in the cirque at the head of the West Fork of Brush Creek where glacial erosion cut through a dip slope on Dakota Sandstone, and after deglaciation, the unsupported Dakota slid down bedding in the underlying Morrison Formation. Landslides occur on steep moraine- or shale-covered slopes. In places steep talus or rock glacier may break loose and form landslides. On Conundrum Creek south of Silver Dollar Pond are two examples of this type of landslide (Bryant, 1969).

Landslides are composed of blocks as much as $10 \mathrm{~m}$ in diameter mixed with smaller ones, and commonly with silt and sand. Landslides in Mancos Shale mostly lack large blocks; some are mudflows.

Landslides characteristically have irregular hummocky topography that lacks either the orderly ridges of moraine or the flow lines and convex cross profile of rock glaciers (fig. 62). The largest landslides are $2 \mathrm{~km}$ across. Thicknesses vary greatly. Some of the dip-slope varieties must be only one to a few meters thick in places. For instance, a dike was traceable through a landslide on the west side of East Snowmass Creek. Such landslides may grade to colluvium, which lacks morphological evidence for mass movement. Others, such as the one on the south side of the Brush Creek-Snowmass Creek divide, must be at least 10 or more meters thick. Two unusually thick landslides are the one damming Crater Lake on West Maroon Creek and the one on the Roaring Fork at the southeast corner of the Aspen quadrangle. The one at Crater Lake may be as much as $50 \mathrm{~m}$ thick, and even thicker if no moraine underlies it. Most of the material came from the steep north end of the northwest ridge of Pyramid Peak, and glacial oversteepening combined with bedding dips toward the valley produced conditions favorable for landsliding. The landslide on the Roaring Fork was mapped as moraine on the geologic maps (Bryant, 1970, 1971a), but further study indicates that it is a landslide, having a cusp-shaped breakaway area in the northeast corner of the Hayden Peak quadrangle (fig. 62A). It contains in places angular pieces of Precambrian quartz monzonite as much as $7 \mathrm{~m}$ long. The landslide apparently overlies a moraine of late Pleistocene age exposed on Colorado State Highway 82. That landslide may be as much as $100 \mathrm{~m}$ thick.

The landslides are of various ages. Some are as old as Pleistocene. One landslide near Rustler Gulch is apparently older than a Pinedale lateral moraine. However, map relations indicate that much landsliding took place after retreat of the main valley glaciers so that most of the landslides are of very late Pleistocene and Holocene ages (fig. 62B). Some landslides are probably intermittently active at present. On Snowmass Creek a large landslide-mudflow took place in 1956 because of excessive soaking through a break in an irrigation ditch on a lateral moraine overlying Mancos Shale.

Harden (1976) gave a detailed analysis of landslides in the northwestern part of the Aspen area and pointed out their significance in land use planning.

\section{SOLIFLUCTION DEPOSITS}

Solifluction deposits were mapped above timberline more than at lower altitudes. Large areas of solifluction debris on the gentle surface on Precambrian rocks 

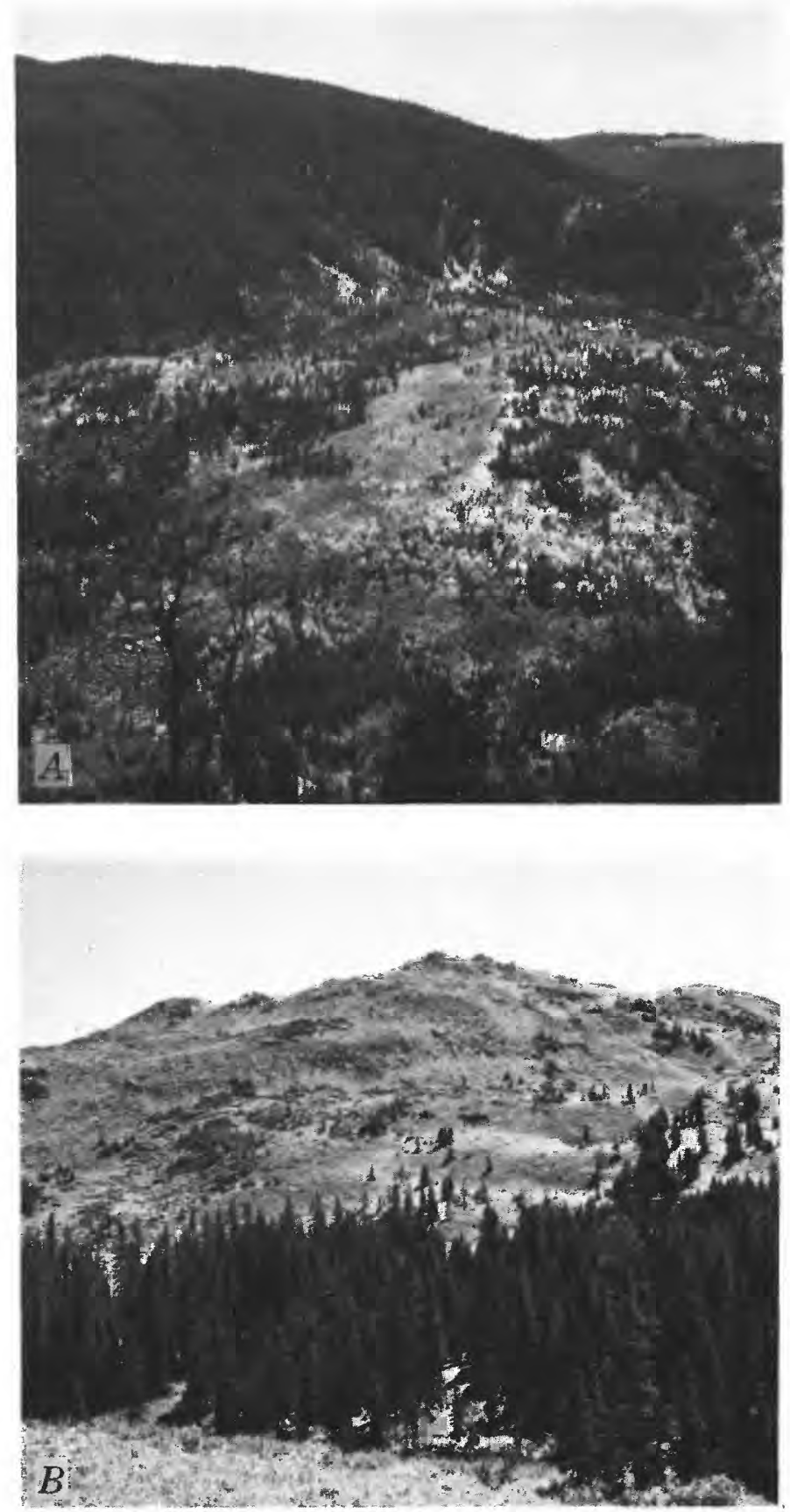

Figure 62.--Landslides. $A$, Landslide of Precambrian quartz monzonite south of Tagerts Lake, Aspen quadrangle (mapped as moraine on geologic quadrangle map (Bryant, 1971a)) viewed from $2,800 \mathrm{~m}$ altitude south across valley of the Roaring Fork River. Amphitheater at head. Very large angular blocks in lower right are as much as $6 \mathrm{~m}$ across. $B$, Landslide on south slope of ridge south of Rustler Gulch, Maroon Bells quadrangle. Maroon Formation above the Elk Range thrust slid down over Mancos Shale of the underblock after glacial erosion steepened the valley and glacier melted away. south of McArthur Mountain were not mapped (fig. 36). On the east side of the north end of Richmond Hill a large area of solifluction deposits was mapped where no outcrops or prospect pits showed how to map the many faults leading into the area.

Solifluction deposits consist of angular rock fragments in a matrix of silt and sand, all which have moved down a slope, which in many places is relatively gentle. They trade to talus or colluvium. Lobes or terraces are common surface features of these deposits, but they are subdued to absent in places.

The solifluction deposits are of Holocene and Pleistocene age. Most of the mapped deposits are between 3,660 and $3,960 \mathrm{~m}$ altitude and are probably now active, for permafrost is reported in the iron mine between altitudes 3,660 and $3,900 \mathrm{~m}$ at the head of Cooper Fork. The deposit on the east side of Richmond Hill is between 3,170 and $3,292 \mathrm{~m}$ altitude and probably not presently active.

\section{COLLUVIUM}

Colluvium is widespread in the Aspen area, and it was mapped above timberline much more thoroughly than at lower altitudes. It is well developed on dip slopes where it may grade to landslide. In gullies and cirques it grades to talus. In areas of complex geology, such as south of Aspen, it was mapped principally where it obscured the bedrock geology and where no prospect pits penetrated it. No colluvium was mapped on Smuggler Mountain or Red Mountain and very little in the northern part of the Highland Peak quadrangle.

Colluvium consists of poorly sorted material ranging from silt to boulders. The finer grained fractions usually are dominant, and the deposit supports vegetation. Although much of it is probably of Holocene age, some may be Pleistocene.

\section{TALUS}

Talus occupies large areas in the alpine country of the Aspen region. It occurs below steep cliffs on the sides of ridges and fringing the headwalls of cirques. Especially large aprons of talus are found on the west side of East Maroon Creek east of Pyramid Peak and in the cirques on the east side of that valley.

Talus is most widespread in areas underlain by hornfels (fig. $45 B$ ). The hornfels is highly jointed and readily breaks down through frost action, but the in- 
dividual fracture-bounded fragments are themselves quite resistant to weathering. Granodiorite is also an excellent source of talus, especially where fractured and silicified, as it is in some of the areas in which sulfides are disseminated.

Talus consists of angular rock fragments ranging from $1 \mathrm{~cm}$ to a meter in diameter. It is locally well sorted. It forms sheetlike deposits that are generally near or at the angle of repose. With increase in sand and silt content talus grades to colluvium; it also grades to alluvial fans and rock glaciers.

Talus as mapped has a variety of ages. Most of the talus in the high mountain country is probably late Pleistocene and Holocene in age. Many areas of talus are presently active, especially adjacent to the high peaks, such as Cathedral Peak and the Maroon Peaks; on almost any summer day one can hear rockfalls feeding those deposits. Other areas, such as that along the lower part of the talus apron on the west side of East Maroon Creek, are partly vegetated with young aspen trees. Those areas are presently inactive, although they are subject to snow avalanches in the winter. The talus there formed after the retreat of the glacier which occupied the valley of East Maroon Creek in the late Pleistocene.

\section{ALLUVIAL AND DEBRIS FAN DEPOSITS}

Alluvial and debris fan deposits are common features of the landscape of the Aspen region. They are best developed where short steep tributary valleys join a major valley. One area in which individual fans are most obvious is in the Roaring Fork valley 3-6 km upstream from Aspen. There, the fan-shaped deposits of each tributary encroach on the level alluvium on the floodplain of the main stream. In many places fans along a valley side coalesce so that the whole slope consists of fan deposits. This occurs on the north side of West Maroon Creek from Maroon Lake to the junction with East Maroon Creek and downstream along Maroon Creek.

The alluvial and debris fan deposits generally consist of poorly sorted material ranging from silt to boulders. They grade to talus or colluvium on their upslope margins and to alluvium on their downslope margins. Many of the deposits in the deep mountain valleys consist to a large extent of morainal material that was washed down fron the valley sides. Judging from their topographic expression many of the larger fans may be thicker than $30 \mathrm{~m}$. The size of the fans is not necessarily related to the size of the streams which deposited them but is more related to the supply of easily erodible bedrock or unconsolidated material, such as moraine or talus, in their drainage. Good examples of relatively larger fans derived from small drainages are on Castle Creek at Monument Gulch, on the gulch to the south, and on the gulch west of Elk Mountain Lodge. This relation is also shown by the development of fans where small valleys draining Mancos Shale join major valleys. One particularly bulky fan heading in a short tributary valley apparently dams West Maroon Creek to form Maroon Lake.

Many of the fans are active and could have debris deposited on them during floods. In the glaciated valleys they started to form after withdrawal of the glaciers in the late Pleistocene. It is likely that fan formation was quite vigorous immediately after deglaciation because of the abundant supply of unvegetated moraine on the valley sides. Fans in the northern part of the Highland Peak quadrangle outside the glaciated area probably have a longer history, and it is difficult to know when they started to form.

A few fans are dissected and no longer active. In the northwestern part of the Highland Peak quadrangle several older fans have their surfaces about $20 \mathrm{~m}$ above younger fans. The map relations suggest that these fans are younger than moraines but older than the fans of late Pleistocene and Holocene age. Fans overlying terraces in the Roaring Fork River valley are younger than the terrace they rest on. The one in the northwestern part of the Aspen quadrangle is not much dissected and could still be the site of deposition given the right conditions. However, fans in a similar position north of Woody Creek are deeply dissected (Freeman, 1972a) because their drainage goes across rather than along terrace.

Other older, not presently active, fans are what might be termed "hanging fans," which formed against the glacier margin at tributary valleys during late Pleistocene time. These occur along gullies tributary to Maroon and West Maroon Creeks north and northwest of Maroon Lake.

\section{ALLUVIUM}

Alluvium occurs in small areas on valley floors throughout the Aspen region. The largest alluvial deposit is along the Roaring Fork River valley upstream from Aspen and is as much as $0.7 \mathrm{~km}$ wide. 
There, the stream meanders and oxbow lakes and scars of abandoned meanders are well displayed (fig. 56 A). This deposit is probably underlain by outwash gravel, and it formed behind an only partially breached end moraine of Pinedale age. Other areas of alluvium formed behind postglacial alluvial fans. Areas in Hunter Creek and in Castle Creek near Ashcroft are excellent examples of places where this occurred. In other places alluvium formed in tributary valleys behind lateral moraines (fig. $55 \mathrm{C}$ ). Examples of such deposits are southeast of Richmond Hill and in the northwest corner of the Highland Peak quadrangle.

Alluvium consists of sand, silt, gravel, and peaty material on valley bottoms, and it includes some swamp deposits.

Smuggler Mountain is crossed by valleys believed to be controlled by fractures. Near the crest of the mountain, alluvium occurs locally in these valleys. The most notable area of alluvium is at Warren Lake where peat has been dug on a commercial basis. There, the peat is at least $1.8-2.1 \mathrm{~m}$ thick and contains scattered boulders of Precambrian rocks.

Logs of water wells in the alluvium along the Roaring Fork above Aspen are quite similar to those in the outwash deposits at and downstream from Aspen except that some have an interval at depths of $15 \mathrm{~m}$ and below that lacks boulders and gravel. All the logs show boulders in the upper part, although the surface of the alluvium appears to consist of fine-grained material. Perhaps at one time the valley was occupied by a lake dammed by the moraine $\mathrm{B}$. Then, when the ice formed moraine A below Tagert Lake, outwash was deposited above the finer material. Relatively thin deposits of sand and silt deposited in Holocene time blanket the present surface.

In the unglaciated valley of Woody Creek, some patches of older gravel were mapped, which probably correlate with the gravel $\mathrm{C}$ mapped in the lower Woody Creek valley by Freeman (1972b). In glacial episode C outwash dammed the Woody Creek valley and caused alluviation. Remnants of this gravel of late Pleistocene age occur as much as $10 \mathrm{~km}$ upstream from the mouth of Woody Creek.

Most of the alluvium is on active floodplains and thus is of late Holocene age at the surface. Alluviation began when the streams were dammed by fans, moraines, or landslides; so the bottom of the alluvium would be as old as the formation of the deposit forming the dam.

\section{ECONOMIC GEOLOGY}

\section{DEPOSITS OF LARAMIDE AGE}

Aspen and the satellitic districts of Lenado and Richmond Hill (fig. 63) constitute a famous silver-leadzinc mining district in which the greatest activity was in the 1880's and 1890's. Total production has been $101,000,000$ ounces of silver, 294,000 tons of lead, and 11,000 tons of zinc (Henderson, 1926; Mineral Yearbooks of the U.S. Bureau of Mines. ${ }^{2}$ Much has been written about the ore deposits, especially during their period of high production (Brunton, 1888; Emmons, 1888; Henrich, 1889; Newberry, 1890; Sivyer, 1888; Spurr, 1898, 1909; Bastin, 1924; Knopf, 1926; Rohlfing, 1938; Vanderwilt, 1935b). Results of more recent commodity and exploration studies have been given by Boyd and Bromley (1953), Volin and Hild (1950), and Heyl (1964). The classic study was that of Spurr (1898), and his descriptions of presently inaccessible mines are of great interest to anyone studying the area.

Lovering (1972) described some jasperoid samples from the Aspen district. Distribution of prospects and productive areas in the Aspen quadrangle was shown by Bryant (1972e).

Aspen is located in the belt of Tertiary intrusives and ore deposits apparently controlled by shear zones formed in Precambrian time (fig. 3; Tweto and Sims, 1963). The projection of the Homestake shear zone intersects the margin of the Sawatch uplift at Aspen (fig. 48), and both Laramide intrusive rocks and much faulting occur at this intersection.

I agree with earlier studies that faults controlled the ore deposition in the Aspen district. The principal disagreement among various geologists has been whether part of the control was by regional beddingplane faults at the Belden-Leadville contact (the Silver fault) and at the contact between limestone and dolomite in the Leadville (fig. 6; the Contact fault, Spurr, 1898) or whether these favorable horizons for ore are sedimentary contacts (Emmons, 1888; Vanderwilt, 1935b; Rohlfing, 1938; Maslyn, 1976). As I have pointed out, breccias along the limestone-dolomite contact in the Leadville do exist on Aspen Mountain, but I interpret them as being the result of solution collapse and filling during the Leadville-Belden erosional interval. These breccias are mineralized on Aspen Mountain, and, in that area, control of some ore bodies was stratigraphic, although access of the ore-bearing solutions was probably through the numerous faults there.

${ }_{2}^{2}$ Production figures are cited here in units of the original reports. 


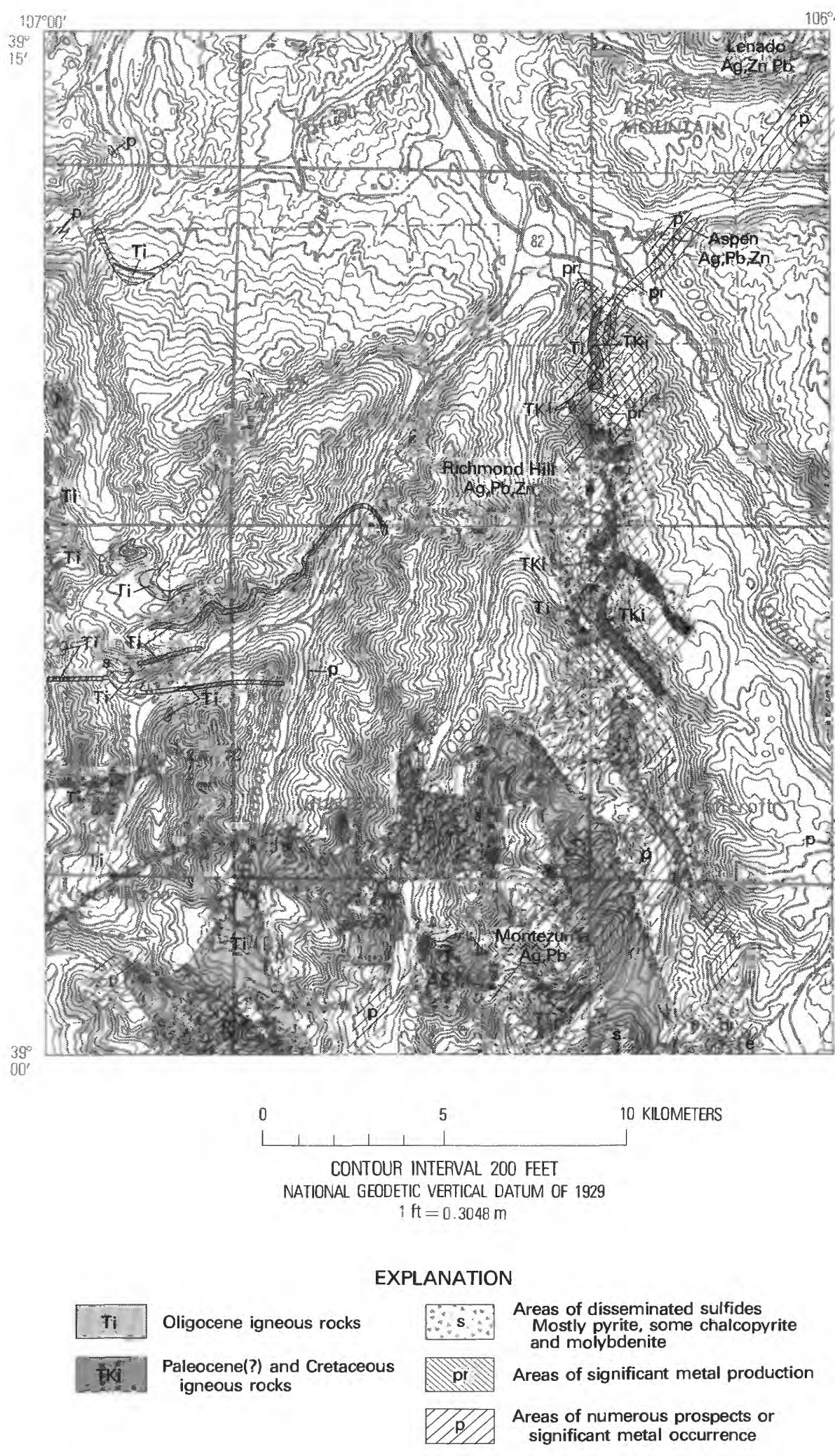

FIGURE 63.-Areas of production, prospects, disseminated sulfides, and Oligocene and Laramide igneous rocks. Base from A.M.S. 1:250,000, Leadville, 1957. 
Relations along the Leadville-Belden contact are more complicated. Much faulting occurs at the contact and in the Belden Formation along the margin of the Sawatch Range. Most of the faults are not apparent on the surface because neither the Belden nor its contact with the Leadville is well exposed. Mine workings furnish the main exposures, and disagreement exists among those who have looked at many mine workings.

High-angle faults parallel or nearly parallel with bedding occur in the workings on Aspen Mountain and Smuggler Mountain (Spurr, 1898; D. P. Rohlfing, unpub. mapping). In the Smuggler Mine, Spurr (1898, p. 77) had difficulty separating his Silver fault from the Clark fault, a high-angle fault about parallel with bedding. Tailings from prospect dumps north of Hunter Creek and near Lenado indicate a fault along the Belden-Leadville contact. It is in this region that the limestone in the upper part of the Leadville is cut out. The limestone reappears on Larkspur Mountain where Belden is in stratigraphic contact with the Leadville (Freeman, 1972b). North of Hunter Creek the fault at the east contact of the Belden apparently cuts down to the Sawatch Quartzite in one fault block. Spurr $(1898$, p. 132$)$ reported that the fault truncates beds in mine workings just south of Hunter Creek.

Another complication in the faulting in the Aspen mining district is the possibility of early Laramide bedding-plane slip in the Belden Formation associated with the formation of the Elk Range thrust. Many faults, folds, and breccias occur in the Belden, and it has not yet been possible to be certain of their relations. Some of the breccias may even be of sedimentary origin. In the northern part of the Aspen quadrangle I have interpreted a structural discontinuity in the Belden as being along the heel of that thrust. To the south, at the head of Castle Creek, I believe the heel of the thrust to be stratigraphically higher and at the Belden-Gothic contact.

I think that much faulting occurs along the Leadville-Belden contact, but that locally some contacts are unfaulted, such as south of Express Creek. However, on the surface from Aspen Mountain north to the edge of the Aspen quadrangle, I believe that the contact is a fault subparallel to steeply to moderately dipping bedding.

The ores in the Aspen district, including Richmond Hill and Lenado, are believed to be of Laramide age. They were emplaced along and adjacent to faults believed to have formed during the later stages of uplift of the Sawatch Range, and they are also older than some of the movement along those faults. They bear a similar relation to that faulting as do dated Laramide igneous rocks, which occur at Aspen and Richmond Hill but not at Lenado.

Since the Midnight mine in the Richmond Hill area closed in 1952, no significant amount of metal has been produced in the vicinity of Aspen. In 1966-68 Aspen Consolidated Mining Co., a subsidiary of McCulloch Oil Co., milled dump material from the Smuggler and Mollie Gibson mines. Utah Mining and Construction Co. conducted some exploration on a contract basis in the Smuggler mine in 1968 and 1969.

In 1968 Silver Dawn Mining Company did some trenching and sampling in Annie Basin. They obtained some high values from near-surface samples, which led to considerable publicity. Probably, those values were enhanced by secondary enrichment, as no mining resulted.

Analyses of samples of rock of possible commercial interest that I found on the surface in the Aspen mining district and available from drill holes in Lenado are given in table 9. These have from 1 to more than 10 percent zinc, a few tenths to more than 10 percent lead, and 5-10 ounces of silver per ton. Cadmium in amounts as much as several tenths of a percent is probably associated with the zinc in sphalerite. Copper contents are $<0.1$ percent. High $\mathrm{Fe}$ and Mn contents are related to near-surface secondary enrichment in those elements. The samples from underground are generally poorer in those elements and richer in $\mathrm{Ca}$ and $\mathrm{Mg}$, except where highly silicified. In all samples the original rock was a limestone or dolomite, from either the Leadville or the Belden. Analyses of oxidized lead-zinc ore listed by Heyl (1964) are similar, although perhaps richer in lead and zinc. Arsenic and antimony were found in a sample he collected and arsenic in 3 and antimony in 1 of the 11 samples of table 9 . High barium values are from barite, a common gangue mineral.

As pointed out by Heyl (1964, p. C60), oxidized leadzinc ore containing silver remains in the old workings and in dumps in the Aspen and Lenado districts. Drilling by the U.S. Bureau of Mines in the Smuggler mine revealed intervals of as much as $10 \mathrm{~m}$ of rock containing 2-5 percent combined lead and zinc and, locally, a few ounces of silver. Flotation concentration tests of this ore were unsuccessful because of fine grain size, friability, and oxidation of the ore minerals (Volin and Hild, 1950). Some richer ore may exist below old workings that beneath Smuggler Mountain extended down to $2,012 \mathrm{~m}$ altitude or $730 \mathrm{~m}$ below the surface. However, maps of the workings show fewer stopes on the deeper levels, probably indicating that rich ore was not as widespread there as closer to the surface. The data, if they exist, needed to estimate the amount and 


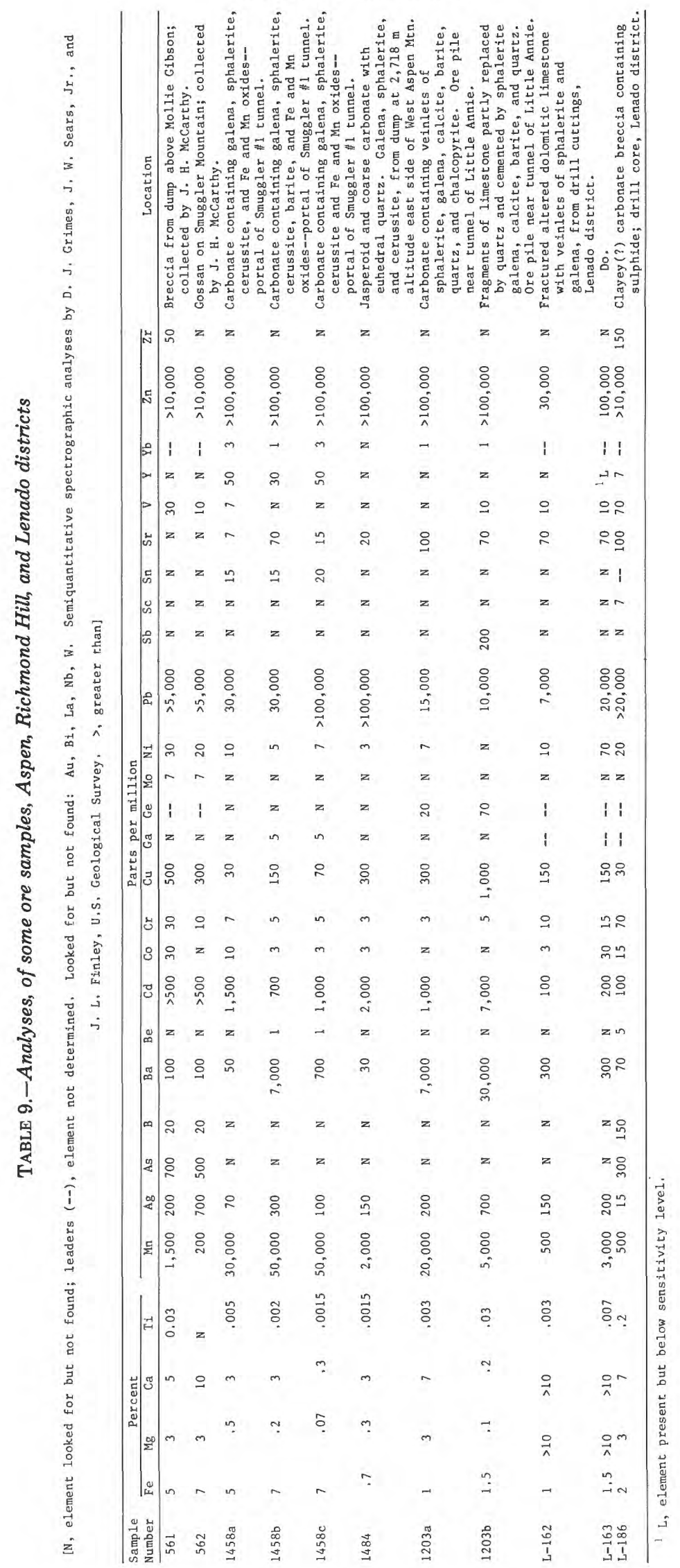


grade of ore available in the mining district are not available to me.

Two major exploration projects conducted during the 1960 's were partly financed by loans from the Office of Mineral Exploration. They were an extension of the Highland tunnel beneath Richmond Hill and core drilling in the Lenado area. These projects revealed new information on the geology and consequently are discussed here. I thank Messrs. Henry L. Stein and Edwin J. Smart for permission to publish data obtained during those projects.

\section{THE HIGHLAND TUNNEL}

The Highland tunnel is located at about $2,667 \mathrm{~m}$ altitude east of Castle Creek near the south edge of the Aspen 7.5-minute quadrangle. During the 1930's it was driven $355 \mathrm{~m} \mathrm{~N} .75^{\circ} \mathrm{E}$. into the valley side. In 1963 through 1966 Richmond Hill Exploration Co., Inc., extended it to a length of $1.7 \mathrm{~km}$ and did about $425 \mathrm{~m}$ of drifting and $275 \mathrm{~m}$ of drilling. The goal of the project was to cut a downward extension of the ore body of the Midnight mine. No ore body was en- countered, and small chalcopyrite-bearing veins were less numerous in the tunnel than on the surface, as indicated by prospects. The main point of interest in the Highland tunnel is additional control at depth of the geology of the Castle Creek fault zone. Some of the features can be correlated with those seen in the Hope tunnel driven in the 1920's at a similar altitude about $1,220 \mathrm{~m}$ to the south. John P. Kellogg and Richard Beck supervised the work in the Highland tunnel and prepared detailed maps that were of great use to me when I examined the tunnel.

The Highland tunnel (fig. 64) passed through steeply dipping Maroon Formation for about $660 \mathrm{~m}$. The Maroon is composed of grayish-red fine-grained calcareous sandstone and siltstone and has a few beds of silty limestone and limestone. However, some intervals of gray rock are present only 213-274 m from the portal and a few red beds are found as much as $487 \mathrm{~m}$ from the portal. Brown and gray sandy and silty limestone and calcareous siltstone and sandstone of the Gothic Formation of Langenheim (1952) occur for another $450 \mathrm{~m}$ along the tunnel. From 914 to $1,001 \mathrm{~m}$

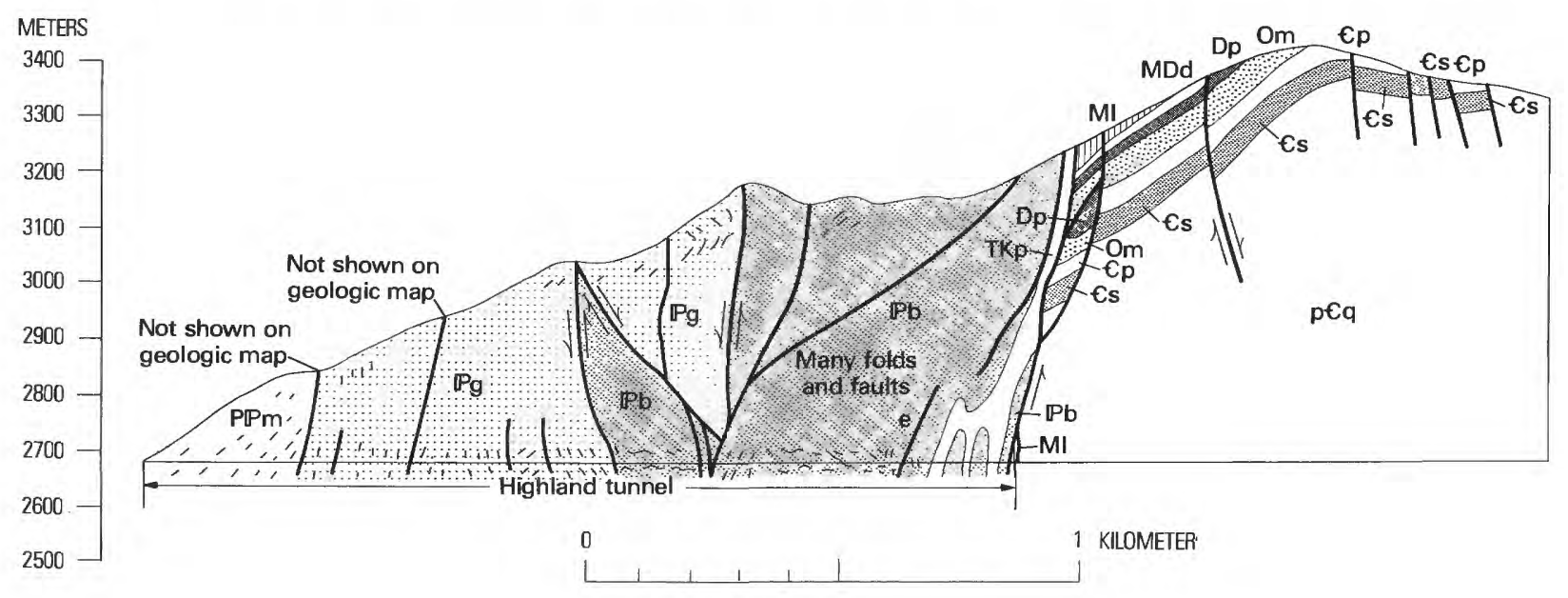

EXPLANATION

\begin{tabular}{|c|c|c|c|}
\hline TKp & Tertiary(?) and Cretaceous porphyry & $\mathrm{Om}$ & Ordovician Manitou Dolomite \\
\hline PPm & Permian and Pennsylvanian Maroon Formation & $€ p$ & Cambrian Peerless Formation \\
\hline $\mathrm{Pg}$ & Pennsylvanian Gothic Formation of Langenheim (1952) & $60 \mathrm{~s}$ & Cambrian Sawatch Quartzite \\
\hline $\mathrm{Pb}$ & Pennsylvanian Belden Formation, $\mathrm{e}=$ evaporite & $p € q$ & Precambrian quartz monzonite \\
\hline MI & Mississippian Leadville Limestone & & movement \\
\hline MDd & $\begin{array}{l}\text { Mississippian(?) and Devonian Dyer Dolomite } \\
\text { Devonian Parting Formation }\end{array}$ & & \\
\hline
\end{tabular}

Figure 64.-Cross section along the Highland tunnel. 
from the portal, gouge and breccia of mixed limestone and carbonaceous shale mark the Gothic-Belden contact. Folded, faulted, and brecciated dark-gray pyritebearing limestone, dolomitic limestone, and carbonaceous shale make up the Belden. A major zone of breccia and gouge occurs between 1,108 and 1,192 $\mathrm{m}$ from the portal. From 1,483 to $1,554 \mathrm{~m}$ is another wide breccia zone. At about $1,525 \mathrm{~m}$ the breccia contains numerous lenses of anhydrite. The tunnel passed through several intervals of white porphyry containing quartz and muscovite phenocrysts. The porphyry is highly fractured and has sheared contacts; some is very altered. At $1,706 \mathrm{~m}$ the tunnel passed through 3.4 $\mathrm{m}$ of fractured and brecciated dolomite and into Precambrian quartz monzonite. The dolomite, probably derived from the Leadville, occurs as a fault slice and pinches out $60 \mathrm{~m}$ to the south along the fault, as revealed by drifting.

About 50 fault zones are exposed in the tunnel. Some fault zones consist of $2-5 \mathrm{~cm}$ of gouge parallel with steeply dipping bedding planes, and others consist of breccia as much as $90 \mathrm{~m}$ thick. The lack of stratigraphic markers in the Pennsylvanian rocks makes it difficult to evaluate each fault, and all cross sections (fig. 64) are partly interpretive, despite the rather complete exposures in the tunnel. Especially difficult to evaluate is the Gothic-Maroon contact in the tunnel. Is the gradation through as much distance as the exposures suggest or is there repetition of the gradational zone by faulting? Drifting and drilling to the south of a point $1,554 \mathrm{~m}$ from the portal revealed at least $30 \mathrm{~m}$ stratigraphically of white anhydrite and associated gypsum, containing some interbeds of lightgray limestone and shale. At the tunnel and just south of it, the evaporite apparently interfingers with normal Belden rocks, so that only about $12 \mathrm{~m}$ of breccia containing blocks of anhydrite is exposed in the tunnel. The fault between the Belden and the Precambrian rocks trends $\mathrm{N} .45^{\circ}-60^{\circ} \mathrm{W}$. This trend was somewhat unexpected, since trends at the surface at about 3,261 $\mathrm{m}$ altitude are N. $10^{\circ} \mathrm{E}$. to N. $30^{\circ} \mathrm{W}$. However, on the 10th level of the Midnight mine at $2,987 \mathrm{~m}$ altitude (unpublished mapping, 1940-44, by John W Vanderwilt, supplied by Frank Willoughby) the Castle Creek fault trends $\mathrm{N}$. $30^{\circ}-45^{\circ} \mathrm{W}$. This change of trend with depth may indicate increased displacement on the Winnie fault with depth.

Information available from the Hope tunnel is not as detailed. According to Knopf (1926), "Maroon sandstones" (Maroon and Gothic Formations of this report) occur over a distance of about $1,280 \mathrm{~m}$ as measured in a straight line from the portal. This does not fit with the geology Knopf (1926) or I mapped on the surface. However, $30 \mathrm{~m}$ of evaporite occurs about the same distance from the porphyry sill as in the Highland tunnel. If one can project strikes from the two tunnels, the evaporite in the Belden and the Tertiary-Cretaceous porphyry are offset $120-150 \mathrm{~m}$ in map plan by the Hope fault, which must pass through the $300 \mathrm{~m}$ of rock separating the two tunnels.

The Winnie fault, which forms the north boundary of the fault block in which the face of the Highland tunnel is located, apparently dips about $55^{\circ}$ to the north judging from information in the Midnight tunnel. Even if its strike swings to the south as shown on the geologic map, that fault would not intersect the tunnel but would join a higher angle fault to the west.

\section{LENADO}

The Lenado project was carried on by Rheco-Lenado in the period 1967-69. John P. Kellogg and James N. Babcock supervised the work and logged the core, and I am indebted to them for much of my information and for the opportunity to examine some of the core. My interpretation of the geology differs somewhat from theirs. About 1,370 $\mathrm{m}$ of diamond drilling was done, based on existing information and on a geologic map and geochemical study (McCarthy and Gott, 1966). Very low core recovery in many holes made evaluation of the geology and mineralization somewhat unsatisfactory. However, the drilling did reveal a number of faults concealed beneath the surficial deposits of the Woody Creek valley. Those deposits averaged about $30 \mathrm{~m}$ thick at the drill sites. Faults, fractures, and breccia zones were encountered in so many places that it is likely that the details of the structure are much more complex than can be interpreted based on available data. One possible interpretation is given in figure 65 based on the hypothesis that dips in the rocks below the Belden are steep and that strikes are similar to those in the exposed fault blocks on the valley sides. Other interpretations can be made assuming shallow dips. Not enough data are available to determine the strike of the formations in each fault block. Another uncertainty is the possible stratigraphic significance of breccias. Kellogg and Babcock interpreted many of the breccias in the Belden as sedimentary. I question that interpretation, because I have not seen nearly as much breccia in the Belden outside thoroughly faulted areas as was encountered in the drill holes at Lenado. However, the Belden is seldom very well exposed; so it is possible that such breccias might be present and not detected on the surface. Subsequent underground exploration revealed features interpreted as fossil caves and sinkholes in the Lenado area (Maslyn, 1976).

Another controversial point of the geologic interpretation is the identification of the lone outcrop of 


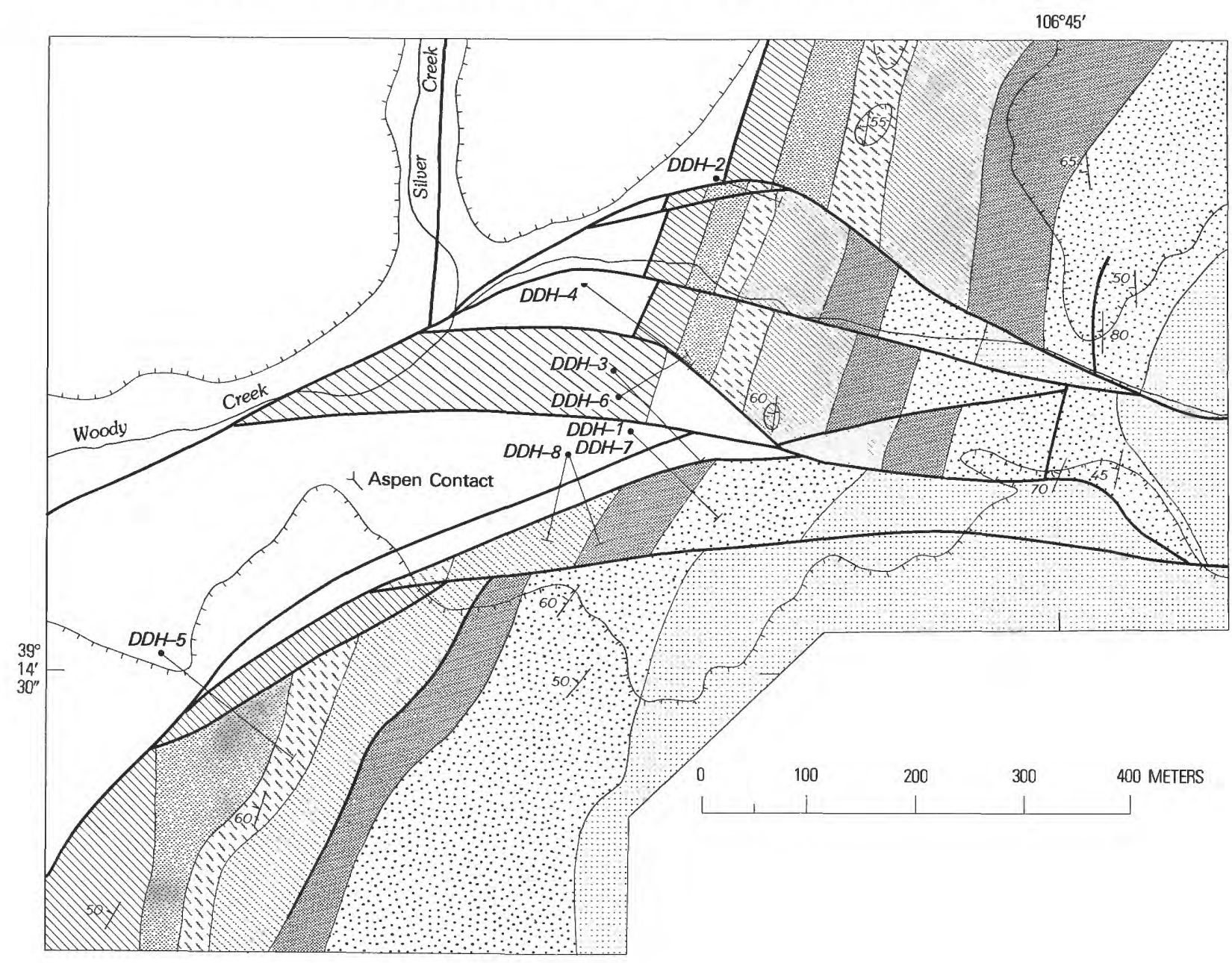

\section{EXPLANATION}

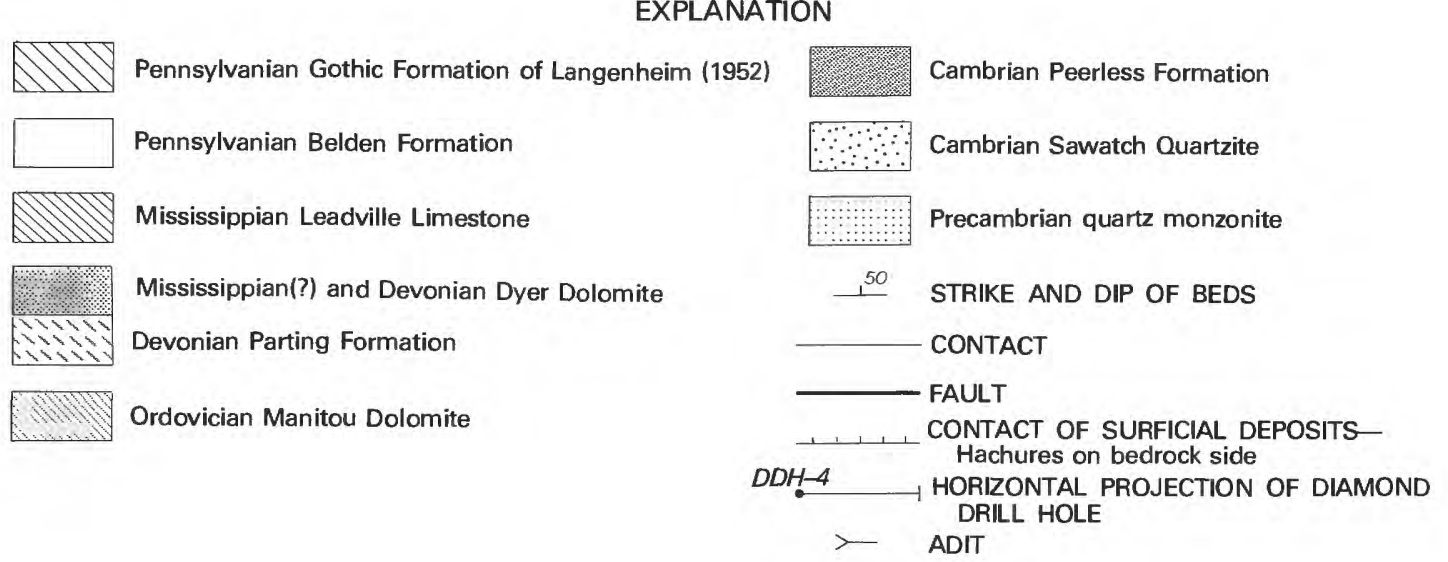

FIGURE 65.-Geologic map of the Lenado area, showing an interpretation of the geology under Woody Creek valley based on drill data and adjacent outcrops.

Manitou Dolomite in the fault zone south of Woody Creek. The rock in that outcrop is very fine grained, white, and siliceous, and it has an irregular bedding resembling that in the Manitou. In thin section it is composed principally of cryptocrystalline quartz. It resembles neither typical Manitou nor Parting, but I 
interpret it as silicified Manitou. If that outcrop were Parting rather than Manitou, the map would be somewhat different. In some of the cores carbonate rocks are bleached, making formation identifications uncertain.

Interpretation of the data from core drilling leads to the conclusion that the whole Woody Creek valley is underlain by a complex fault zone containing a number of fault blocks intermediate between the blocks north and south of the fault zone and containing one highly downfaulted block of Gothic Formation (fig. 65).

Drill holes 5, 7, and 8 suggest that the northern strand of the Lenado fault zone dips about $60^{\circ}$ to the south. None of the holes penetrated the southern strand. Apparently, no widespread mineralization of ore grade in the Belden Formation exists beneath the Woody Creek valley, although low-grade $(0.1-1$ percent) zinc mineralization occurs through considerable thicknesses of rock. Mineralization of ore grade is generally in fault zones, as in the Aspen Contact mine (Spurr, 1898). Only part of the fault zones have been penetrated, and in very few places did drilling encounter the Belden-Leadville contact adjacent to a fault, which is a favorable horizon for ore deposition.

\section{ORE DEPOSITS OF MIDDLE TERTIARY AGE}

A variety of ore deposits are associated with the granodiorite plutons of the Elk Mountains and therefore are of middle Tertiary age. They include contact metasomatic iron, disseminated sulfide, and fissure-vein lead-zinc-silver deposits and copper-silver sandstone deposits (fig. 63).

\section{IRON DEPOSIT AT THE HEAD OF COOPER CREEK}

Iron deposits have been known in the Aspen area at the head of Cooper Creek near the southeast corner of the Hayden Peak quadrangle since the early 1880's (Devereaux, 1884, Leith, 1906; Harder, 1909; Harrer and Tesch, 1959), but they have only recently been exploited. In 1961 the first substantial mine operation started, but production really got underway a few years later. According to the May 11, 1967, Aspen Times, ore is mined at the rate of $3,175 \mathrm{t}$ (metric tons) a day. Since the mine is at $3,660 \mathrm{~m}$ altitude, operations are limited to summer and early fall, and a full year's production might be about $317,000 \mathrm{t}$ of ore.

The iron deposits occur 500-800 m horizontally from the margin of the White Rock pluton in highly recrystallized limestones of the Belden Formation (fig. 66 ), which have generally steep and irregular dips mostly towards the pluton. The ore appears to have been emplaced along steeply dipping northwesttrending fracture zones that probably formed during intrusion of the pluton. Although fractures furnished channels for the ore-bearing solutions, the bulk of the ore bodies formed by replacement of Belden limestone, now converted to marble. Ore occurs from altitudes of 3,600 to $3,840 \mathrm{~m}$, and I saw ore zones as much as $30 \mathrm{~m}$ thick. Assuming a blanketlike deposit parallel with the slope of the mountain and about $20 \mathrm{~m}$ thick, judging from the length of a few prospect tunnels that had penetrated the ore, Harder (1909) estimated 3-4 million tons of ore, but he also thought that more was actually likely to be available because of probable greater thickness of the deposit. On the surface, as suggested by exposures in mine roads in the middle 1960 's, the deposit certainly is irregular; and since it appears to be controlled by steeply dipping faults and bedding, parts of it may go to several times the depth assumed by Harder. However, granodiorite might be encountered a hundred meters or so below the surface.

The ore is composed of massive magnetite and minor amounts of pyrite. The country rock is dark-gray to white coarse- to fine-grained marble derived from Belden limestones. Most of the magnetite is granular but locally octahedral faces on magnetite grains in-

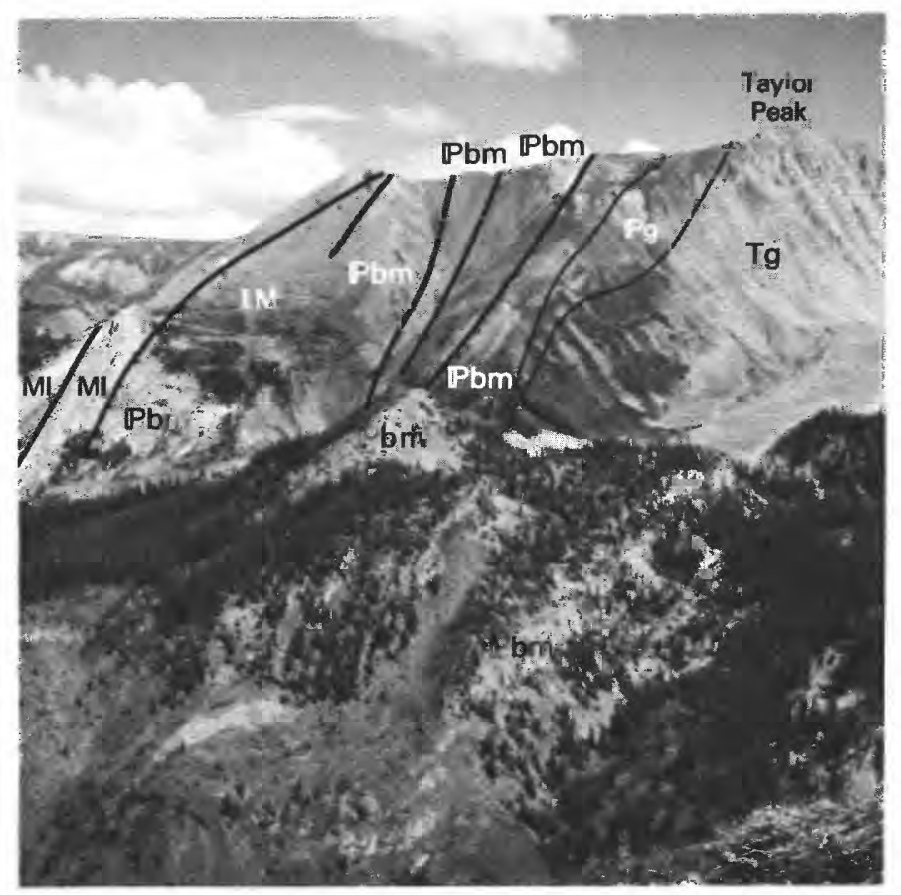

FIGURE 66.-Setting of Pitkin Iron Corp. mine, Hayden Peak quadrangle, viewed east from $3,666-\mathrm{m}$ knob on ridge south of Castle Creek. Photograph taken in 1964 before much mining took place. Tg, granodiorite; $\mathbb{P g}$, Gothic Formation hornfels; $\mathbb{P b m}$, Belden Formation marble; MI, Leadville Limestone. Heavy lines, faults; light lines, contacts. IM, iron mine. 
dicate the presence of some open spaces during ore deposition. On the surface the ore has considerable limonite and hematite due to weathering of pyrite and magnetite. Along some fractures weathering penetrates to depths of as much as $10 \mathrm{~m}$.

The most common gangue mineral is calcite. Barite and siderite also occur. Rarer gangue minerals are quartz and garnet. Monoclinic pyroxene and colorless amphibole were found in one inclusion in the ore. Some beds in the Belden are pyroxene hornfels, a rock type that is more typical of the metamorphosed Gothic Formation, which lies between the Belden outcrops and the White Rock pluton. One inclusion found in the ore contains an unusual blue-green chlorite having $2 V<10^{\circ}$ and $Y \approx 1.565$. X-ray study shows that it is rich in $\mathrm{Mg}$, and spectrographic analyses do not suggest that the color is related to the presence of unusual amounts of any minor element.

Some of the coarsely crystallized calcite that is found in the upper part of the Leadville north of the ore zone is dark gray. Semiquantitative spectrographic analysis revealed no good reason for the color. Analyses of two ore samples showed no metal values except for iron. Harrer and Tesch (1959) reported chemical analysis of a sample: 67.2 percent $\mathrm{Fe}, 0.02$ percent $\mathrm{P}, 0.63$ percent $\mathrm{S}, 1.8$ percent $\mathrm{Si}$; and 0.3 percent Mn. Spectrographic analysis showed 0.001-0.01 percent $\mathrm{Ga}, \mathrm{Pb}, \mathrm{Zr}, \mathrm{Cr}$; 0.01-0.1 percent $\mathrm{Cu}, \mathrm{Ti}, \mathrm{Co}$; and 0.1-1.0 percent $\mathrm{Mn}$.

\section{DISSEMINATED SULFIDE DEPOSITS}

Disseminated sulfides occur in granodiorite of the White Rock pluton and adjacent hornfels in areas as great as $9 \mathrm{~km}^{2}$ in the Maroon Bells and Hayden Peak quadrangles (fig. 63; Bryant, 1971c). The deposits are composed principally of pyrite, but locally copper and molybdenum occur in quantitites as great as several tenths of a percent. Molybdenite is most abundant in locally numerous quartz veins in highly altered granodiorite. At the surface large areas of pervasive alteration are absent, an unfavorable indication for large volumes of ore (Guilbert and Lowell, 1974, p. 103). However, no deep drilling has been done. Alteration and pyritization is younger than the bodies of porphyritic granodiorite which cut the White Rock pluton.

\section{FISSURE VEINS}

Pyritization has occurred along fractures and faults in hornfels and red beds of the Maroon Formation and in other formations throughout considerable areas above and adjacent to the White Rock pluton. Quartzpyrite and quartz-carbonate-pyrite veins have been deposited in some of the fractures. Locally, sphalerite, argentiferous galena, and very rare gold occur in these veins.

Production from these veins has been small. The best known productive locality has been the Montezuma mine just northeast of Castle Peak. There, according to an unpublished Bureau of Mines report by M. E. Volin, dated 1948, argentiferous galena, sphalerite, and pyrite in a gangue of quartz, calcite, and barite form a vein less than a meter thick. In the period 1897-1915 about 6,700 tons of ore were mined. An unknown amount of very rich near-surface ore was mined shortly after the discovery of the vein in 1881 . Small amounts of ore have been shipped as recently as the early 1960's from the Montezuma mine.

Most of the veins observed during mapping in and around the White Rock pluton contain pyrite, and consist of carbonate, quartz, and barite. Traces of

Semiquantitative spectrographic analyses by J. M. Motooka and E, L. Mosier, Gold analyses by J, G, Frisken, T. R. Miller, U.S. Geological Survey. N; element looked for and not found; L, element is present in undetermined for but not found: $\mathrm{Cd}, \mathrm{W}, \mathrm{Sn}]$

\begin{tabular}{|c|c|c|c|c|c|c|c|c|c|c|c|c|c|c|c|c|c|c|c|c|c|c|c|c|c|c|c|}
\hline \multirow{3}{*}{$\begin{array}{l}\text { Sample } \\
\text { Number }\end{array}$} & \multirow[b]{3}{*}{$\overline{\mathrm{Fe}}$} & \multirow{2}{*}{\multicolumn{2}{|c|}{ Percent }} & \multicolumn{24}{|c|}{ Semiquantitative spectrographic analyses } \\
\hline & & & & \multirow[b]{2}{*}{$\mathrm{Ti}$} & \multicolumn{23}{|c|}{ Parts per million (ppm) } \\
\hline & & $\mathrm{Mg}$ & $\mathrm{Ca}$ & & Mn & $\mathrm{Ag}$ & As & $\mathrm{Au}$ & B & $\mathrm{Ba}$ & $\mathrm{Be}$ & $B \mathbf{i}$ & Co & $\mathrm{Cr}$ & $\mathrm{Cu}$ & La & Mo & $\mathrm{Nb}$ & $\mathrm{Ni}$ & $\mathrm{Pb}$ & $\mathrm{Sb}$ & sc & $\mathrm{Sr}$ & $\mathrm{V}$ & $\mathrm{Y}$ & Zn & $\mathbf{Z r}$ \\
\hline & & & & & \multicolumn{23}{|c|}{ Conundrum Basin } \\
\hline 1700 & 2 & 0.5 & 0.2 & 0.5 & 300 & 3 & $\mathrm{~N}$ & $\mathrm{~N}$ & $\mathrm{~N}$ & 500 & $\mathrm{~L}$ & $\mathrm{~N}$ & 5 & 5 & 30 & 20 & $\mathrm{~N}$ & 10 & $\mathrm{~N}$ & 200 & $\mathrm{~N}$ & 15 & $\mathrm{~N}$ & 200 & 15 & $\mathrm{~N}$ & 200 \\
\hline 1701 & 3 & .2 & .1 & .2 & 300 & 1 & $\mathrm{~N}$ & $\mathrm{~N}$ & $\mathrm{~N}$ & 500 & $\mathrm{~L}$ & $\mathrm{~N}$ & $\mathrm{~N}$ & 20 & 10 & $\mathrm{~N}$ & $\mathrm{~N}$ & $\mathrm{~L}$ & 5 & 200 & $\mathrm{~N}$ & L & $\mathrm{N}$ & 100 & 10 & $\mathrm{~N}$ & 100 \\
\hline 1702 & 5 & .5 & 5 & .02 & 5,000 & 1.5 & 500 & $\mathrm{~N}$ & $\mathrm{~N}$ & 20 & $\mathrm{~L}$ & L & 7 & 5 & 100 & $\mathrm{~N}$ & $\mathrm{~N}$ & $\mathrm{~L}$ & 7 & 20 & $\mathrm{~N}$ & L & $\mathbb{N}$ & 15 & 20 & N & $\mathrm{N}$ \\
\hline \multirow[t]{2}{*}{1703} & 3 & .5 & 5 & .07 & 2,000 & 50 & 200 & $\mathrm{~N}$ & $\mathrm{~N}$ & $>5,000$ & $\mathrm{~N}$ & $\mathrm{~L}$ & 7 & 10 & 1,000 & 50 & 5 & $\mathrm{~L}$ & 10 & 2,000 & 200 & $\mathrm{~L}$ & 2,000 & 20 & 15 & 500 & 70 \\
\hline & & & & & \multicolumn{23}{|c|}{ Pine Creek Area } \\
\hline 2064 & 15 & $\mathrm{~N}$ & $\mathrm{~L}$ & 0.001 & 20 & 300 & $\mathrm{~N}$ & $\mathrm{~N}$ & $\mathrm{~L}$ & 100 & L & $\mathrm{L}$ & 7 & $\mathrm{~N}$ & 70 & $\mathrm{~N}$ & $\mathrm{~N}$ & $\mathrm{~N}$ & $\mathrm{~L}$ & 100 & $\mathrm{~N}$ & $\mathrm{~N}$ & N & 15 & $\mathrm{~N}$ & 200 & $\mathrm{~N}$ \\
\hline 2065 & 10 & $\mathrm{~N}$ & .07 & $\mathrm{~N}$ & 100 & 7 & 300 & $\mathrm{~N}$ & $\mathrm{~N}$ & $\mathrm{~N}$ & $\mathrm{~L}$ & 10 & L & $\mathrm{N}$ & 30 & $\mathrm{~N}$ & $\mathrm{~N}$ & $\mathrm{~N}$ & L & 150 & $\mathrm{~N}$ & $\mathrm{~N}$ & $\mathrm{~N}$ & 10 & $\mathrm{~L}$ & 700 & $\mathrm{~N}$ \\
\hline $2066 \mathrm{a}$ & 15 & .2 & $\mathrm{~L}$ & .1 & 30 & 10 & $\mathrm{~N}$ & $\mathrm{~N}$ & $\mathrm{~L}$ & 20 & $\mathrm{~L}$ & $\mathrm{~L}$ & 30 & 50 & 30 & $\mathrm{~N}$ & $\mathrm{~N}$ & $\mathrm{~N}$ & 20 & 100 & $\mathrm{~N}$ & 5 & $\mathrm{~N}$ & 50 & 10 & $\mathrm{~N}$ & 150 \\
\hline $2066 \mathrm{~b}$ & 5 & .3 & .3 & .15 & 30 & 500 & $\mathrm{~L}$ & 10 & 70 & 20 & $\mathrm{~L}$ & 20 & 15 & 30 & 30 & 20 & $\mathrm{~N}$ & $\mathrm{~N}$ & 20 & 1,000 & $\mathrm{~N}$ & 10 & $\mathrm{~N}$ & 50 & 10 & 1,000 & 300 \\
\hline 2067 & 10 & $\mathrm{~L}$ & .15 & .007 & 150 & 10 & 500 & $\mathrm{~N}$ & $\mathrm{~N}$ & 20 & $\mathrm{~N}$ & 10 & 7 & $\mathrm{~N}$ & 150 & $\mathrm{~N}$ & N & $\mathrm{N}$ & L & 150 & N & $\mathrm{N}$ & N & $\mathrm{N}$ & 1 & 300 & N \\
\hline 2068 & 5 & .3 & .1 & .15 & 20 & 1 & $\mathrm{~N}$ & $\mathrm{~N}$ & 700 & $\mathrm{~N}$ & L & L & 30 & 15 & 7 & L & $\mathrm{N}$ & $\mathrm{N}$ & 20 & 100 & N & 5 & $\mathrm{~N}$ & 50 & $\mathrm{~L}$ & $\mathrm{~N}$ & 100 \\
\hline $2069 a$ & 7 & 1 & 15 & .007 & 5,000 & .5 & $\mathrm{~N}$ & $\mathrm{~N}$ & $\mathrm{~N}$ & $\mathrm{~N}$ & $\mathrm{~N}$ & $\mathrm{~L}$ & 5 & $\mathrm{~N}$ & 50 & $\mathrm{~L}$ & $\mathrm{~N}$ & $\mathrm{~N}$ & 5 & 20 & $\mathrm{~N}$ & 20 & 150 & 15 & 50 & $\mathrm{~N}$ & $\mathrm{~N}$ \\
\hline $2069 \mathrm{~b}$ & 5 & 1 & 5 & .05 & 1,000 & $\mathrm{~N}$ & N & $\mathrm{N}$ & L & 50 & $\mathrm{~N}$ & $\mathrm{~N}$ & 50 & 10 & 10 & 50 & $\mathrm{~N}$ & $\mathrm{~N}$ & 150 & L & $\mathrm{N}$ & 5 & $\mathrm{~N}$ & 20 & 30 & $\mathrm{~N}$ & 50 \\
\hline $2069 c$ & 3 & .02 & .3 & .003 & 100 & $\mathrm{~N}$ & $\mathrm{~N}$ & $\mathrm{~N}$ & L & $\mathrm{N}$ & $\mathrm{N}$ & $\mathrm{N}$ & 30 & $\mathrm{~N}$ & L & 20 & $\mathrm{~N}$ & $\mathrm{~N}$ & 20 & $\mathrm{~N}$ & $\mathrm{~N}$ & N & $\mathrm{N}$ & $\mathrm{N}$ & 15 & $\mathrm{~N}$ & $\mathrm{~N}$ \\
\hline
\end{tabular}


malachite, azurite, galena, and sphalerite occur locally. Galena and sphalerite are most common in the veins south and east of Castle Peak.

Spectrographic analyses of samples of veins from some prospects at the head of Conundrum Creek and in the Pine Creek drainage, Hayden Peak quadrangle, show that anomalous amounts of silver, gold, lead, zinc, and copper occur; but some samples lack anomalous amounts of any of those metals. A few samples showed anomalous amounts of arsenic, antimony, or bismuth (table 10). The two best samples $(2,066$ and 2,064$)$ would be ore if enough material of that tenor were available.

Fluid inclusions in samples of some of the veins associated with the White Rock pluton are small, two phase, secondary, and have filling temperatures of $200^{\circ}-325^{\circ} \mathrm{C}$, according to C. G. Cunningham, Jr. (written commun., 1973). These temperatures are comparable to those found for inclusions in altered rock and veins in the area of disseminated sulfides.

\section{COPPER-SILVER DEPOSITS IN DAKOTA SANDSTONE}

On Snowmass Creek on the east side of Eagle Mountain and on either side of the western edge of the Highland Peak quadrangle are several prospects in Dakota Sandstone. All these prospects are near or adjacent to the Snowmass Creek fault zone, and the ones in the Capitol Peak quadrangle are in a fault slice between two strands of the zone (fig. 67).

The most interesting prospect (loc. 2001, called Snowmass Creek mine on the geologic quadrangle map (Bryant, 1972a)) is the one east of Eagle Mountain where sulfides replace plant fragments in a bed rich in plant debris and are also disseminated in adjacent quartz sandstone where carbonaceous material is

associated with the White Rock pluton

Roemer, S. Rickard, W. Campbell, and

amount below sensitivity limit. Looked

\begin{tabular}{|c|c|}
\hline $\begin{array}{l}\text { Chemical } \\
\text { analyses }\end{array}$ & Rock type \\
\hline$\frac{(\mathrm{ppm})}{\mathrm{Au}}$ & Conundrum Basin-Continued \\
\hline $\begin{array}{l}0.2 \\
.02 \\
.3 \\
1.3\end{array}$ & $\begin{array}{l}\text { Pyritized and altered arkose along fracture; from prospect. } \\
\text { Pyritized arkose from vein along fracture or shear; from prospect. } \\
\text { Pyritized arkose by vein; from prospect. } \\
\text { Pyrite and galena in vein in arkose; from prospect. }\end{array}$ \\
\hline & Pine Creek Area-Continued \\
\hline $\begin{array}{r}1.80 \\
.06 \\
.08 \\
26.0 \\
.50\end{array}$ & $\begin{array}{l}\text { Quartz pyrite vein. } \\
\text { Quartz pyrite vein in fault. } \\
\text { Quartz pyrite vein parallel bedding; from prospect. } \\
\text { Galena pyrite quartz vein. } \\
\text { Quartz pyrite vein. }\end{array}$ \\
\hline $\begin{array}{l}.30 \\
.10 \\
.20 \\
.10\end{array}$ & $\begin{array}{l}\text { Pyrite cemented breccia in hornfels. } \\
\text { Pyrite calcite vein from prospect. } \\
\text { Pyrite quartz vein. } \\
\text { Pyrite quartz vein. }\end{array}$ \\
\hline
\end{tabular}

scarcer. U.S. Bureau of Mines records indicate that a small amount of copper-silver ore has been shipped from that prospect.

The Dakota Sandstone containing disseminated sulfides ranges from well-sorted fine-grained sandstone with a grain size of $0.1-0.2 \mathrm{~mm}$ to rather poorly sorted coarse-grained chert quartz sandstone with a grain size of several millimeters. Quartz overgrowths and interstitial silica occur locally. Clastic grains of zircon and tourmaline are common accessory minerals. Grains of feldspar and muscovite occur rarely in these sandstones. A light-brown micaceous mineral occurs between the clastic grains in many samples from the mineralized rock. Opaque minerals are interstitial to the clastic grains. In the most heavily mineralized sample studied in thin section, the opaque minerals partly replace the clastic grains. Except for the brown micaceous mineral mentioned, no other gangue mineral is associated with the sulfides, and the texture of the sandstones has not been affected by the mineralization. At locality 1907 some barite occurs on the joint planes.

Modal data (table 11) indicate that the sandstones from the Snowmass Creek mine containing disseminated sulfides have about 2-5 percent opaque minerals. Polished-section study indicates that the opaque minerals are predominantly bornite with lesser amounts of chalcocite, chalcopyrite, pyrite, and magnetite. Semiquantitative spectrographic analyses (table 12) show that these rocks contain 2-7 percent $\mathrm{Cu}, 0-0.3$ percent $\mathrm{Zn}, 200-1,500 \mathrm{ppm}$ (parts per million) $\mathrm{Ag}$, and as much as $3,000 \mathrm{ppm}$ Mo. The substantial amount of $\mathrm{Ag}$ is confirmed by chemical methods, although the values are somewhat lower, ranging from 75 to $325 \mathrm{ppm}$. Elements that are often associated with $\mathrm{Ag}, \mathrm{Cu}$, and $\mathrm{Zn}$, such as $\mathrm{Au}, \mathrm{As}, \mathrm{Bi}, \mathrm{Cd}$, and $\mathrm{Sb}$, are absent. The $\mathrm{Pb}$ content is low. Major elements are dominated by $\mathrm{Si}$, reflecting the quartzrich nature of the Dakota Sandstone. Aluminum reaches 1 percent in rocks having interstitial micaceous mineral. Alkalies were not detected or occur in very small amounts; $\mathrm{Ca}$ and $\mathrm{Mg}$ contents are low.

Sample 2001e is above average in opaque-mineral content. In addition to containing more $\mathrm{Cu}$ and $\mathrm{Ag}$, it contains more iron in pyrite and magnetite, as well as anomalous amounts of $\mathrm{Co}, \mathrm{Ni}$, and $\mathrm{Pb}$.

Samples 1907, 2005, and 2086 from the other prospects contain $0.15-1$ percent $\mathrm{Cu}, 0-7 \mathrm{ppm} \mathrm{Ag}$, and 5-700 ppm Mo, but they lack anomalous contents of other elements.

The suite of samples from the prospects in the fault slice of Dakota Sandstone in the Capitol Peak quadrangle contains $0.12-0.38$ percent organic carbon. Other samples were not analyzed for that element. 


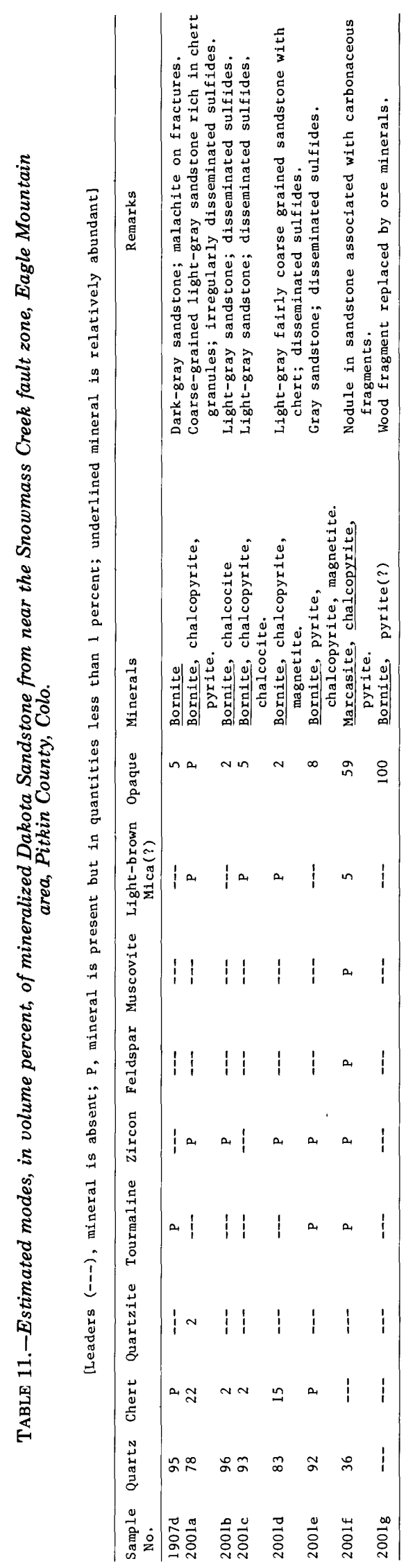



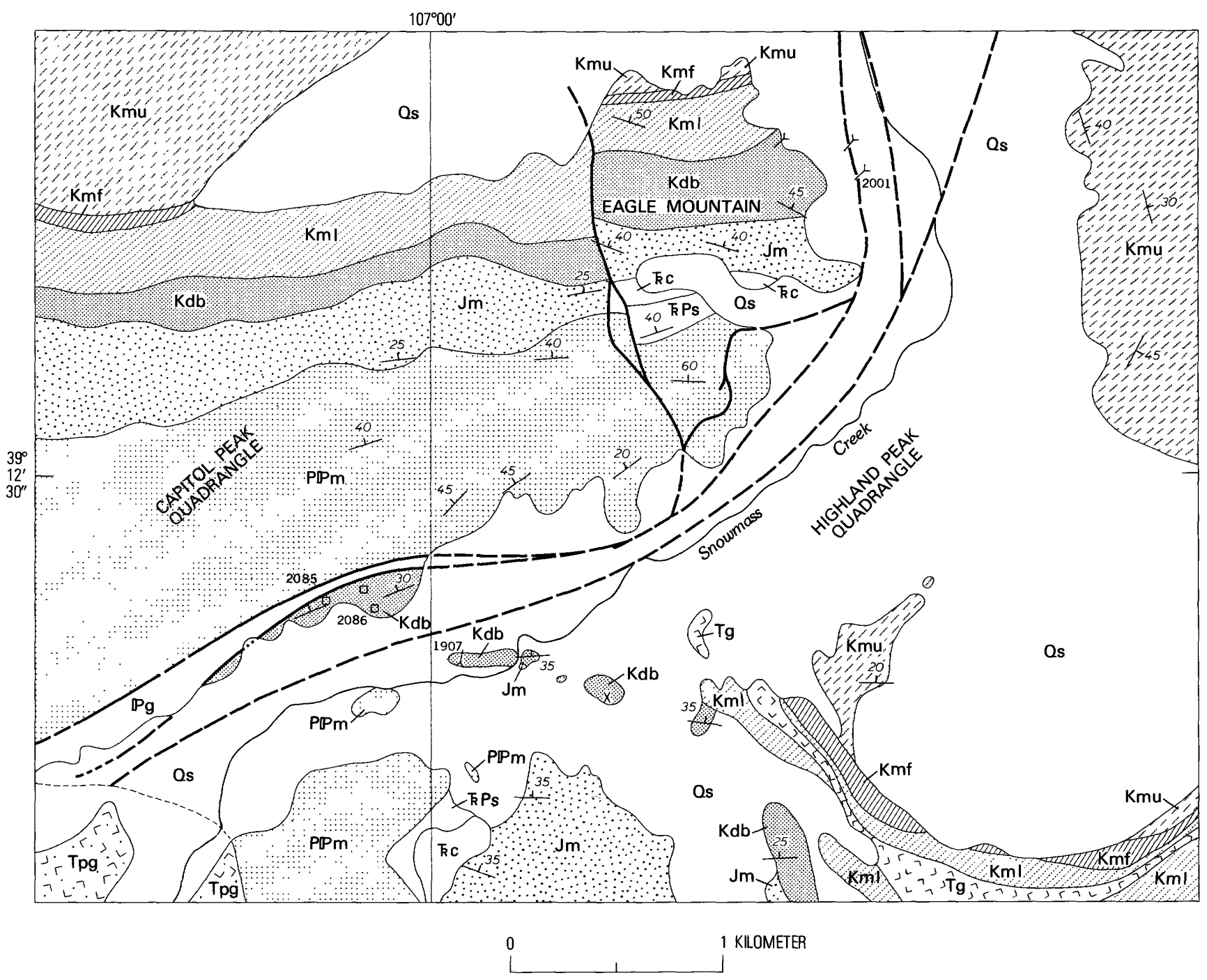

E $\quad X \quad P \quad L \quad A \quad N \quad A \quad T \quad I \quad O \quad N$

\begin{tabular}{|c|c|c|c|}
\hline Os & Quaternary surficial deposits & K Ps & Triassic and Permian State Bridge Formation \\
\hline Sîng & Tertiary porphyritic granodiorite & $P P M$ & Permian and Pennsylvanian Maroon Formation \\
\hline 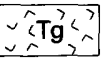 & Tertiary granodiorite & $\mathbb{P g}$ & Pennsylvanian Gothic Formation of Langenheim (1952), \\
\hline 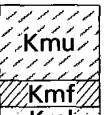 & $\begin{array}{l}\text { Cretaceous Mancos Shale } \\
\text { Kmu, upper member } \\
\text { Kmf, Fort Hays Limestone Member }\end{array}$ & & $\begin{array}{l}\text { CONTACT-Dashed where concealed } \\
\text { FAULT-Dashed under surficial deposits }\end{array}$ \\
\hline$\because \mathrm{Kml}$ & KmI, lower member & & STRIKE AND DIP OF BEDDING \\
\hline $\mathrm{Kdb}$ & Cretaceous Dakota Sandstone and Burro Canyon Formation & & ADIT-Number is analyzed sample \\
\hline$\because \mathrm{j} \min$ & $\begin{array}{l}\text { Jurassic Morrison Formation (locally thin Entrada Sandstone } \\
\text { included at base) }\end{array}$ & $\begin{array}{l}0 \\
x\end{array}$ & $\begin{array}{l}\text { SHAFT } \\
\text { PROSPECT PIT }\end{array}$ \\
\hline KC & Triassic Chinle Formation & & \\
\hline
\end{tabular}

FiguRE 67.-Geologic niap of the Eagle Mountain area showing location of prospects along the Snowniass Creek fault zone. 

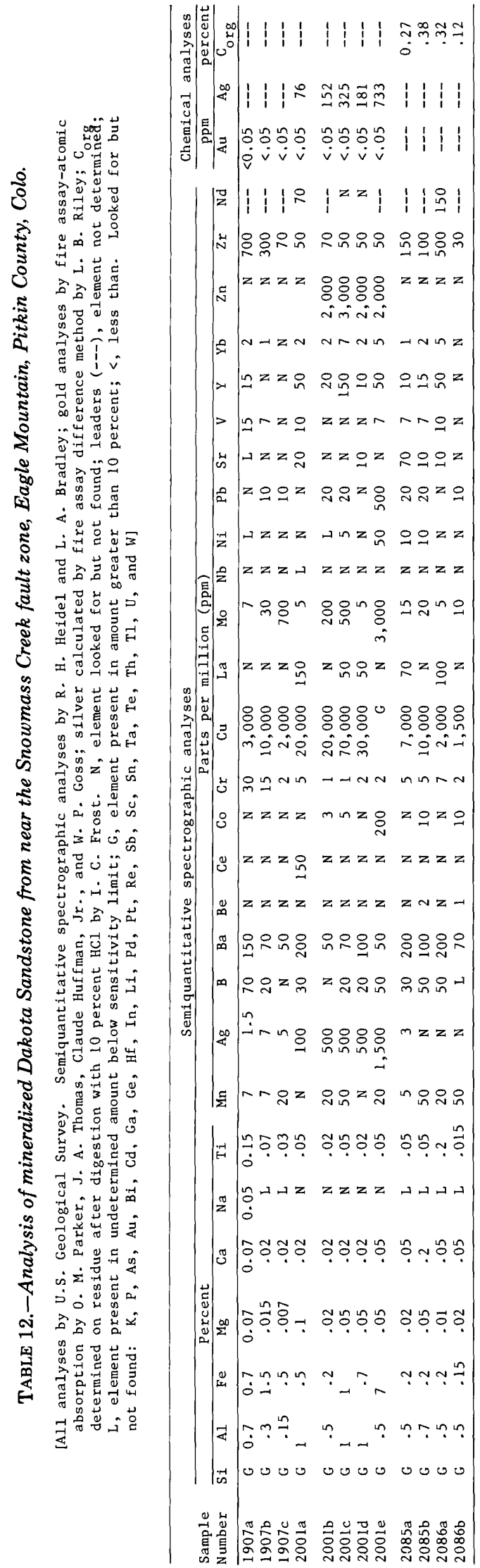
Thus, although mineralization occurs at various places in the Dakota Sandstone through a distance of $3.2 \mathrm{~km}$ along the Snowmass Creek fault zone near Eagle Mountain, the only place where the rock is known to have high silver values is at the Snowmass Creek mine.

The mineralization at the Snowmass Creek mine appears to be controlled by the carbonaceous beds in the Dakota Sandstone and by proximity to the fault zone. Nowhere else in the region has any such mineralization been reported from carbonaceous horizons in the Dakota.

\section{SILVER CONTENT OF THE COPPER SULFIDES}

Microprobe analyses of bornite, chalcocite, and chalcopyrite from the Snowmass Creek mine show silver in amounts as great as 1.9 weight percent in bornite and 2.7 weight percent for chalcocite in the four samples examined (table 13). No discrete silver mineral was recognized with the electron microprobe.

The quantities of silver in bornite and chalcocite compare with a maximum content of 0.1 percent silver in those minerals according to a compilation by Boyle (1968). He did state, however, that silver contents as high as 1 percent have been recorded for chalcocite from samples of uncertain purity. Thus, the silver content of selected grains of bornite from Snowmass Creek is about 20 times greater than that of previously reported bornite, and the silver content of the chalcocite is at least 2.7 times, and perhaps more, that of previously studied samples of that mineral.

\section{TABLE 13.-Microprobe analyses of silver-bearing copper sulfides from the Snowmass Creek mine}

[Analyses by G. A. Desborough, U.S. Geological Survey, 1972; analyses for separate areas of polished section]

\begin{tabular}{lll}
\hline $\begin{array}{c}\text { Range in } \\
\text { weight percent Ag }\end{array}$ & Mineral & $\begin{array}{c}\text { Number of } \\
\text { observations }\end{array}$ \\
\hline $0.7-1.3$ & Sample 2001b & 4 \\
$0.7-1.6$ & $\begin{array}{l}\text { bornite } \\
\text { chalcocite }\end{array}$ & 3 \\
\hline & bornite & 1 \\
\hline 1.0 & Sample 2001c & \\
\hline 0.1 & bornite & 1 \\
$0.7-0.9$ & chalcopyrite & 2 \\
$1.1-2.7$ & bornite & 2 \\
\hline & chalcocite & 2 \\
\hline $0.7-0,8$ & Sample 2001d & 3 \\
0.1 & bornite & 1 \\
0.8 & chalcopyrite & 2 \\
\hline & chalcocite & \\
\hline 0.1 & Sample 2001e & 3 \\
$0.6-0.8$ & bornite & 2 \\
$<0.05$ & --do --- & 4 \\
$0.6-1.9$ & pyrite & 3 \\
$0.5-1.0$ & bornite & \\
$0.6-0.8$ & --do --- & \\
\hline
\end{tabular}

\section{CONCLUSIONS}

The mineralization at Eagle Mountain differs somewhat from other known deposits in sandstone. Copper deposits occur in Triassic and Jurassic sandstones in Pennsylvania and New Jersey adjacent to basalt sills and in Precambrian conglomerates interbedded with mafic volcanics in Michigan. At Silver Reef in Utah silver is associated with copper in a Triassic sandstone containing plant remains. Vanadium and uranium also occur in this deposit. No general agreement on the source of the metals at Silver Reef has been reached, although Proctor (1953) believed that the elements were derived from volcanic ash beds in the Chinle Formation and redeposited in the sandstone bed where they were concentrated by solutions in circulating ground water and precipitation through contact with entombed plant debris in permeable buried stream channels. In many respects the deposit at Silver Reef is similar to the U-V-Cu deposits so widespread on the Colorado Plateau, which have no direct relation to igneous rocks and hydrothermal processes. Although the prospects at Eagle Mountain appear to have a similar type of stratigraphic control-precipitation of ore minerals by carbonaceous material in sandstone-they also have clear spatial relation to a fault zone, which had post-Dakota movement during emplacement of a granodiorite pluton. Thus, they appear to be low-temperature hydrothermal deposits related to the middle Tertiary igneous rocks.

The silver content of the copper sulfide minerals in the Snowmass Creek mine is high enough to make a significant contribution to the values in any ore there. However, since the silver is in the lattice of the copper sulfides, it cannot be separated form the copper before destruction of the sulfide minerals during smelting of the ore.

We do not have the information to allow us to judge what volume of rock might contain the values shown by samples $2001 \mathrm{a}-2001 \mathrm{e}$ (table 12). The prospect tunnel being driven in 1968 showed at least $10 \mathrm{~m}$ perpendicular to the strike of the bedding containing disseminated copper sulfides. The presence of other prospects containing as much as 1 percent $\mathrm{Cu}$ in the Dakota Sandstone along the Snowmass Creek fault zone indicates the presence of some mineralization associated with the fault zone over a distance of $3 \mathrm{~km}$, unless that mineralization occurred before most of the displacement along the fault. If the mineralization is fault controlled, as it appears to be, the intersection of the Fort Hays Limestone Member of the Mancos Shale with the fault zone might be another favorable place to prospect. The Fort Hays contains some small Ag-Pb- 
$\mathrm{Cu}-\mathrm{Zn}$ ore deposits in Lead King Basin south of the Snowmass pluton (Vanderwilt, 1937).

The geology of the fault zone beneath the surficial deposits of the Snowmass Creek valley may be much more complicated than suggested here, and that probability makes exploration by drill holes through the surficial deposits a venture of decidedly high risk.

\section{ORE DEPOSITS OF UNKNOWN AGE}

\section{GOLD HILL}

The Gold Hill area adjoins the Hayden Peak quadrangle on the east. It was extensively prospected, and in 1967 a small mill was still standing, although it did not appear to have been much used. The country

TABLE 14.-Analyses of rock

\begin{tabular}{|c|c|c|c|c|c|c|c|c|c|c|c|c|c|c|c|c|c|c|c|c|c|c|c|c|c|}
\hline \multirow{3}{*}{$\begin{array}{l}\text { Sample } \\
\text { Numbers }\end{array}$} & \multicolumn{25}{|c|}{ Semiquantitative spectrographic analyses } \\
\hline & \multicolumn{4}{|c|}{ Percent } & \multicolumn{21}{|c|}{ Parts per million } \\
\hline & $\mathrm{Fe}$ & $\mathrm{Mg}$ & $\mathrm{Ca}$ & $\mathrm{T} \mathbf{i}$ & Mn & $\mathrm{Ag}$ & $\mathrm{Au}$ & в & $\mathrm{Ba}$ & $\mathrm{Be}$ & Co & $\mathrm{Cr}$ & $\mathrm{Cu}$ & $\mathrm{La}$ & Mo & $\mathrm{Nb}$ & $\mathrm{Ni}$ & $\mathrm{Pb}$ & $\mathrm{Sc}$ & $\mathrm{Sr}$ & $\mathrm{v}$ & W & $\mathrm{Y}$ & $\mathrm{zn}$ & $\mathrm{Zr}$ \\
\hline 1024 & $>10$ & 0.015 & 0.03 & 0.05 & 1,500 & $\mathrm{~N}$ & N & $\mathrm{N}$ & 100 & $\mathrm{~N}$ & 15 & 5 & 1,000 & 30 & $\mathbf{N}$ & N & 15 & 15 & $\mathrm{~N}$ & 10 & 15 & N & 70 & N & $\mathbf{N}$ \\
\hline $1654 a$ & .1 & L & L & .002 & 20 & $\mathrm{~N}$ & $\mathrm{~N}$ & $\mathrm{~N}$ & $\mathrm{~L}$ & N & $\mathrm{N}$ & N & 10 & $\mathrm{~N}$ & $\mathrm{~N}$ & N & $\mathrm{N}$ & L & $\mathrm{N}$ & $\mathbf{N}$ & $\mathrm{N}$ & $\mathrm{N}$ & N & $\mathrm{N}$ & $\mathbb{N}$ \\
\hline $1654 \mathrm{~b}$ & 5 & .05 & L & .03 & 100 & 1 & L & $\mathrm{N}$ & 100 & 1 & 50 & 5 & 200 & $\mathrm{~N}$ & 10 & $\mathrm{~N}$ & 10 & 15 & N & N & 10 & $\mathrm{~N}$ & $\mathrm{~L}$ & $\mathrm{~N}$ & 50 \\
\hline $1654 c$ & 1 & .1 & L & .2 & 100 & $\mathrm{~N}$ & $\mathrm{~N}$ & $\mathbf{N}$ & 100 & L & 5 & 20 & 30 & 20 & $\mathrm{~N}$ & 10 & L & $\mathrm{L}$ & 7 & $\mathbf{N}$ & 50 & $\mathrm{~N}$ & 20 & $\mathbf{N}$ & 300 \\
\hline $1654 d$ & 7 & $\mathrm{~L}$ & $\mathrm{~L}$ & .015 & 700 & L & L & 30 & 30 & L & 15 & $\mathrm{~L}$ & 700 & L & 15 & L & 30 & 10 & L & $\mathbf{N}$ & 20 & N & 30 & $\mathrm{~L}$ & 50 \\
\hline $1654 \mathrm{e}$ & 1.5 & .2 & .05 & .15 & 200 & L & $\mathrm{N}$ & L & 150 & 1 & 7 & 30 & 150 & 30 & L & 10 & 10 & L & 5 & $\mathbf{N}$ & 30 & $\mathrm{~N}$ & 15 & N & 100 \\
\hline $1654 \mathrm{E}$ & 5 & .07 & L & .05 & 150 & 1.5 & 10 & 15 & 70 & 1.5 & 10 & 20 & 700 & 20 & 15 & L & 20 & L & L & 15 & $\mathrm{~N}$ & 15 & 50 & $\mathrm{~N}$ & 100 \\
\hline $1655 a$ & .3 & .1 & L & .07 & 100 & $\mathrm{~N}$ & N & $\mathrm{N}$ & 100 & L & L & 10 & 10 & L & $\mathrm{N}$ & L & 5 & $\mathrm{~N}$ & L & 15 & $\mathrm{~N}$ & 15 & 15 & $\mathrm{~N}$ & 10 \\
\hline $1655 \mathrm{~b}$ & 2 & .15 & L & .15 & 700 & 1.5 & $\mathrm{~L}$ & $\mathrm{~L}$ & 150 & 1 & 15 & 20 & 150 & 20 & N & L & 7 & $\mathrm{~N}$ & 5 & $\mathbf{N}$ & 20 & $\mathrm{~N}$ & 5 & N & 100 \\
\hline $1655 c$ & 7 & $\mathrm{~L}$ & L & .01 & 700 & 1.5 & L & 30 & L & $\mathrm{N}$ & 15 & L & 7,000 & L & 15 & L & 15 & $\mathrm{~L}$ & $\mathrm{~L}$ & $\mathbf{N}$ & 15 & $\mathrm{~N}$ & 10 & L & $\mathrm{L}$ \\
\hline $1656 a$ & 10 & .02 & L & .005 & 1,600 & $\mathrm{~N}$ & $\mathrm{~N}$ & $\mathrm{~N}$ & 20 & $\mathrm{~N}$ & 70 & L & 70 & $\mathrm{~N}$ & $\mathrm{~N}$ & $\mathrm{~L}$ & 50 & L & $\mathrm{N}$ & $\mathrm{N}$ & 15 & N & 100 & $\mathrm{~N}$ & N \\
\hline $1656 \mathrm{~b}$ & 10 & .02 & L & .02 & 5,000 & $\mathrm{~N}$ & $\mathrm{~N}$ & 15 & 150 & L & 200 & L & 2,000 & $\mathrm{~L}$ & 10 & L & 100 & $\mathrm{~L}$ & L & 50 & 10 & L & 20 & L & 20 \\
\hline $1658 \mathrm{a}$ & 10 & .1 & L & .1 & 700 & $\mathrm{~N}$ & $\mathrm{~N}$ & $\mathrm{~N}$ & 100 & L & 150 & $\mathrm{~L}$ & 150 & 30 & $\mathrm{~N}$ & L & 20 & $\mathrm{~N}$ & N & $\mathrm{N}$ & 15 & N & 15 & $\mathrm{~N}$ & 100 \\
\hline $1658 b$ & 10 & .2 & L & .3 & 5,000 & $\mathrm{~N}$ & $\mathrm{~N}$ & $\mathrm{~N}$ & 200 & L & 70 & 50 & 200 & $\mathrm{~N}$ & $\mathrm{~N}$ & 10 & 10 & $\mathbf{N}$ & 10 & $\mathrm{~N}$ & 50 & $\mathbb{N}$ & 20 & $\mathbf{N}$ & 100 \\
\hline $1658 \mathrm{c}$ & 10 & .05 & L & .03 & 1,500 & $\mathrm{~N}$ & N & 20 & 100 & L & 20 & 10 & 70 & L & 10 & L & 50 & $\mathrm{~L}$ & 5 & $L$ & 10 & $\mathrm{~N}$ & 15 & $\mathrm{~L}$ & 30 \\
\hline $1659 a$ & 2 & .1 & L & .2 & 300 & $\mathrm{~N}$ & $\mathbf{N}$ & $\mathbf{N}$ & 70 & $\mathrm{~L}$ & $\mathrm{~N}$ & 20 & 10 & 20 & $\mathrm{~N}$ & L & 5 & $\mathrm{~N}$ & 5 & $\mathrm{~N}$ & 20 & $\mathrm{~N}$ & 15 & $\mathbf{N}$ & 150 \\
\hline $1659 b$ & 2 & .15 & $\mathrm{~L}$ & .15 & 300 & $\mathrm{~N}$ & $\mathbb{N}$ & 10 & 150 & 1 & L & 30 & 70 & 20 & L & L & 10 & $\mathrm{~N}$ & 5 & $\mathbf{N}$ & 20 & $\mathrm{~N}$ & 10 & $\mathrm{~N}$ & 70 \\
\hline $1663 a$ & 10 & .03 & $\mathrm{~L}$ & .02 & 500 & 7 & 15 & $\mathbf{N}$ & $\mathrm{L}$ & L & 100 & $\mathrm{~L}$ & 2,000 & $\mathrm{~N}$ & $\mathrm{~N}$ & $L$ & 150 & 20 & $\mathrm{~N}$ & $\mathbb{N}$ & 10 & $\mathbb{N}$ & 20 & $\mathbf{N}$ & 10 \\
\hline $1663 b$ & 3 & .1 & $\mathrm{~L}$ & .07 & 700 & 1.5 & $\mathrm{~L}$ & 10 & 15 & L & 15 & 5 & 3,000 & 30 & 7 & 10 & 5 & L & 5 & $\mathrm{~N}$ & 30 & $\mathrm{~N}$ & 30 & $\mathrm{~L}$ & 15 \\
\hline $1665 a$ & 5 & .07 & $\mathrm{~L}$ & .1 & 1,000 & 5 & $\mathrm{~N}$ & $\mathbf{N}$ & 300 & $\mathrm{~N}$ & 5 & 10 & 20,000 & $\mathrm{~N}$ & 20 & L & 5 & $\mathrm{~N}$ & $\mathrm{~N}$ & $\mathbf{N}$ & 10 & $\mathrm{~N}$ & 15 & $\mathbf{N}$ & 50 \\
\hline $1665 b$ & 10 & .03 & $\mathrm{~L}$ & .015 & 3,000 & 1.5 & $\mathrm{~N}$ & 10 & $\mathrm{~L}$ & L & 15 & 5 & 10,000 & $\mathrm{~L}$ & 10 & L & 30 & L & L & L & $\mathrm{L}$ & $\mathrm{L}$ & 15 & $\mathrm{~L}$ & 20 \\
\hline $1665 c$ & 10 & .07 & L & .07 & 3,000 & 1.5 & N & 10 & L & $\mathrm{N}$ & 10 & 10 & 7,000 & L & 10 & L & 30 & $\mathrm{~L}$ & 5 & N & 15 & $\mathrm{~L}$ & 20 & L & 50 \\
\hline $1666 a$ & 5 & .2 & $\mathrm{~L}$ & .01 & 1,500 & $\mathrm{~N}$ & N & $\mathrm{N}$ & 10 & $\mathrm{~N}$ & 10 & L & 20 & $\mathrm{~N}$ & $\mathrm{~N}$ & $\mathrm{~L}$ & 10 & L & N & $\mathbf{N}$ & $L$ & $\mathrm{~N}$ & 30 & $\mathbb{N}$ & 10 \\
\hline $1666 \mathrm{~b}$ & 10 & .02 & $\mathrm{~L}$ & .02 & 500 & $\mathrm{~N}$ & N & 15 & $\mathrm{~L}$ & $\mathrm{~N}$ & 10 & $\mathrm{~L}$ & 150 & L & 7 & L & 30 & L & 7 & $\mathrm{~N}$ & 10 & $\mathbf{N}$ & 20 & L & $\mathbf{N}$ \\
\hline $1666 c$ & 15 & .02 & $\mathrm{~L}$ & .01 & 3,000 & $\mathbf{N}$ & $\mathrm{N}$ & 20 & $\mathrm{~L}$ & $\mathrm{~L}$ & 20 & L & 300 & L & 20 & L & 30 & $\mathrm{~L}$ & L & $\mathrm{N}$ & 15 & $\mathrm{~N}$ & 30 & 200 & N \\
\hline $1668 \mathrm{a}$ & 10 & $L$ & L & .005 & 700 & 1 & $\mathrm{~N}$ & $\mathrm{~N}$ & 50 & $\mathrm{~N}$ & 15 & L & 5,000 & N & $\mathrm{N}$ & $\mathrm{N}$ & 10 & 10 & $\mathrm{~N}$ & N & $\mathrm{L}$ & N & 30 & $\mathrm{~N}$ & $\mathrm{~N}$ \\
\hline $1668 \mathrm{~b}$ & 2 & .02 & $\mathrm{~L}$ & .015 & 300 & 7 & $\mathrm{~N}$ & L & L & $\mathrm{N}$ & 50 & 10 & 2,000 & L & 7 & L & 30 & $\mathrm{~L}$ & I. & $\mathrm{N}$ & $\mathrm{L}$ & $\mathbf{N}$ & 20 & $\mathbf{N}$ & 30 \\
\hline $1668 \mathrm{c}$ & 3 & .05 & $\mathrm{~L}$ & .015 & 500 & .7 & $\mathrm{~N}$ & $L$ & 50 & L & 50 & L & 1,500 & L & 5 & L & 30 & $\mathrm{~N}$ & L & $\mathbf{N}$ & $\mathrm{L}$ & $\mathrm{N}$ & 15 & $\mathbf{N}$ & L \\
\hline
\end{tabular}

\footnotetext{
1 Not shown in figure 68; precise location lost.
} 
rock consists of Precambrian muscovite-biotite schist and gneiss containing lenses and bodies of quartz monzonite and pegmatite. The prospects are on northeasttrending and steeply dipping shear zones. The individual shear zones are a meter or two thick and have considerable lateral continuity. They have $\mathrm{Fe}$ and $\mathrm{Mn}$ oxides in surface exposures, and chalcopyrite and

samples from the Gold hill area

atomic absorption by T. Roemer, S. Rickard, W. Campbe11, and R. Mille looked for but not found; $L$, element present in undetermined amount

\begin{tabular}{|c|c|c|}
\hline \multicolumn{2}{|c|}{ Chemical analyses } & \multirow{3}{*}{ Sample description } \\
\hline $\begin{array}{l}\text { Atomic } \\
\text { absorption } \\
\quad(\mathrm{ppm})\end{array}$ & $\begin{array}{l}\text { Combined fire } \\
\text { assay and atomic } \\
\text { absorption } \\
\text { (ppm) }\end{array}$ & \\
\hline $\mathrm{Au}$ & $\mathrm{Au}$ & \\
\hline 6.0 & -- & $\begin{array}{l}\text { Vein in gneiss containing quartz, Fe and } \mathrm{Mn} \\
\text { oxides and malachite. Prospect. }\end{array}$ \\
\hline .2 & -- & $\begin{array}{l}\text { Fractured quartz vein. Prospect on shear } \\
\text { zone. }\end{array}$ \\
\hline 33 & 24.4 & $\begin{array}{l}\text { Sheared and mineralized gneiss. Prospect } \\
\text { on shear zone. }\end{array}$ \\
\hline $\mathrm{N}$ & --- & Sheared gneiss. Prospect on shear zone. \\
\hline 13.0 & $9,9,9$ & $\begin{array}{l}\text { Quartz-carbonate vein in sheared gneiss. } \\
\text { Prospect on shear zone. }\end{array}$ \\
\hline .3 & -- & $\begin{array}{l}\text { Sheared and somewhat mineralized gneiss. } \\
\text { Prospect on shear zone. }\end{array}$ \\
\hline 34.0 & $17,18,18$ & $\begin{array}{l}\text { Sheared gneiss and margin of quartz-carbonate } \\
\text { vein. Prospect on shear zone. }\end{array}$ \\
\hline .08 & -- & $\begin{array}{l}\text { Sheared quartz vein with some pyrite and } \\
\text { malachite. Shear zone in quartzitic gneiss. }\end{array}$ \\
\hline .4 & -- & $\begin{array}{l}\text { Sheared gneiss with vuggy quartz vein. } \\
\text { Shear zone in quartzitic gneiss. }\end{array}$ \\
\hline 24.0 & $13,14,16$ & $\begin{array}{l}\text { Quartz-carbonate-chalcopyrite vein. Shear } \\
\text { zone in quartzitic gneiss. }\end{array}$ \\
\hline .3 & -- & $\begin{array}{l}\text { Vein in shear in gneiss. Shaft in sheared } \\
\text { and mineralized schist, gneiss, and } \\
\text { granitic rock. }\end{array}$ \\
\hline .5 & -- & $\begin{array}{l}\text { Gossan on quartz carbonate vein in sheared } \\
\text { gneiss. Shaft in sheared and mineralized } \\
\text { schist, gneiss, and granitic rock. }\end{array}$ \\
\hline $\mathrm{N}$ & -- & $\begin{array}{l}\text { Mineralized shear zone in gneiss. Adit on } \\
\text { irregular shear. }\end{array}$ \\
\hline .5 & -- & $\begin{array}{l}\text { Mineralized shear zone in gneiss. Adit on } \\
\text { irregular shear. }\end{array}$ \\
\hline .2 & --- & $\begin{array}{l}\text { Gossan on sheared and mineralized zone in } \\
\text { gneiss. Adit on irregular shear. }\end{array}$ \\
\hline $\mathrm{N}$ & --- & $\begin{array}{l}\text { Sheared gneiss. Adit in sheared and } \\
\text { brecciated quartzitic gneiss. }\end{array}$ \\
\hline .08 & -- & $\begin{array}{l}\text { Fractured silicified gneiss, Adit in } \\
\text { sheared and brecciated quartzitic gneiss. }{ }^{1}\end{array}$ \\
\hline 280 & 140 & $\begin{array}{l}\text { Vein in sheared gneiss. Adit on vein in } \\
\text { sheared gneiss. }\end{array}$ \\
\hline 36.0 & $15,18,16$ & $\begin{array}{l}\text { Sheared and altered gneiss. Adit on vein } \\
\text { in sheared gneiss. }\end{array}$ \\
\hline 7.2 & 5.2 & $\begin{array}{l}\text { Vein in gneiss containing pyrite and } \\
\text { malachite, Shear zone in schist layers } \\
\text { between } 2 \text { layers of granitic rock. }\end{array}$ \\
\hline 1.0 & -- & $\begin{array}{l}\text { Interior of Cu-bearing quartz-carbonate } \\
\text { vein. Shear zone in schist layers between } \\
2 \text { layers of granitic rock. }\end{array}$ \\
\hline 1.0 & -- & $\begin{array}{l}\text { Margin of Cu-bearing quartz-carbonate vein. } \\
\text { Shear zone in schist layers between } 2 \\
\text { layers of granitic rock. }\end{array}$ \\
\hline .1 & - & Vein in shear in gneiss. Dump of caved adit, \\
\hline $\mathrm{N}$ & -- & $\begin{array}{l}\text { Vuggy quartz vein in shear in gneiss; Fe and } \\
\text { Mn oxides. Dump of caved adit. }\end{array}$ \\
\hline .1 & -- & $\begin{array}{l}\text { Vein in gneiss with carbonate and Fe oxides. } \\
\text { Dump of caved adit. }\end{array}$ \\
\hline 200 & 98.3 & $\begin{array}{l}\text { Vein in sheared gneiss containing pyrite and } \\
\text { malachite. Prospect on vein in sheared } \\
\text { gneiss. }\end{array}$ \\
\hline 1.5 & -- & $\begin{array}{l}\text { Vein in gneiss containing Cu minerals, quartz, } \\
\text { and carbonate. Prospect on vein in sheared } \\
\text { gneiss. }\end{array}$ \\
\hline .06 & --- & $\begin{array}{l}\text { Vein in sheared gneiss containing cu minerals, } \\
\text { quartz, and carbonate. Prospect on vein in } \\
\text { sheared gneiss. }\end{array}$ \\
\hline
\end{tabular}

malachite are visible in some prospects. Silicified rock and thin quartz veins and chalcopyrite-bearing quartzcarbonate veins occur in some of the shear zones.

I sampled some of the prospects in connection with the Heavy Metals Program of the U.S. Geological Survey in the middle 1960's; some of the gold values obtained at that time were as high as $280 \mathrm{ppm}$ (table 14; fig. 68). The better values were obtained from vein samples, but even some of them were barren. The analyses show the expected high $\mathrm{Fe}$ and Mn contents, some very low silver values, scattered copper values as high as 2 percent, and almost no lead or zinc. The high gold values may be caused by enrichment near the surface, and they may be spotty and die out at depth. Some adits, such as numbers 1657,1663 , and 1666 (fig. 68 ), tested the shear zones $30-120 \mathrm{~m}$ below the surface. Perhaps unfavorable results in those prospects caused abandonment of the area. Probably little modern study has been made at Gold Hill.

Similar analytical data on samples from prospects in the Independence gold district $10 \mathrm{~km}$ to the northeast of Gold Hill shows that the gold is in quartz-pyritechalcopyrite veins locally accompanied by argentiferous galena. Those veins also have as much as 0.1 percent zinc, which is generally absent from the Gold Hill samples.

Whether these deposits are Precambrian or Tertiary is uncertain. The close association of the veins at Independence with the Grizzly Peak cauldron (Cruson, 1972) suggest that there the veins may be of middle Tertiary age. The veins at Gold Hill are several kilometers from either than igneous center or the White Rock pluton. Certainly the shear zones containing the veins may be of Precambrian age, and perhaps the veins themselves are of that age.

\section{REFERENCES CITED}

Abbott, J. T., 1972, Rb-Sr study of isotopic redistribution in a Precambrian mylonite-bearing shear zone, northern Front Range, Colorado: Geol. Soc. America Bull., v. 83, no. 2, p. 487-494.

Baars, D. L., compiler, 1972, Devonian System, in Geologic atlas of the Rocky Mountain region, United States of America; Rocky Mtn. Assoc. Geologists, p. 90-99.

Baker, A. A., Dane, C. H., and Reeside, J. B., Jr., 1936, Correlation of the Jurassic formations of parts of Utah, Arizona, New Mexico and Colorado: U.S. Geol. Survey Prof. Paper 183, 66 p.

Banks, N. G., 1970, Nature and origin of early and late cherts in the Leadville Limestone, Colorado: Geol. Soc. America Bull., v. 81, no. 10 , p. 3035-3048.

Barker, Fred, and Brock, M. R., 1965, Denny Creek Granodiorite Gneiss, Browns Pass Quartz Monzonite, and Kroenke Granodiorite, Mount Harvard quadrangle, Colorado: U.S. Geol. Survey Bull. 1224-A, p. A23-A26.

Barker, Fred, Peterman, Z. E., Henderson, W. T., and Hildreth, R. E., 1974, Rubidium-strontium dating of the trondhjemite of Rio Brazos, New Mexico, and of the Kroenke Granodiorite, Colorado: U.S. Geol. Survey Jour. Research, v. 2, no. 6, p. 705-709. 


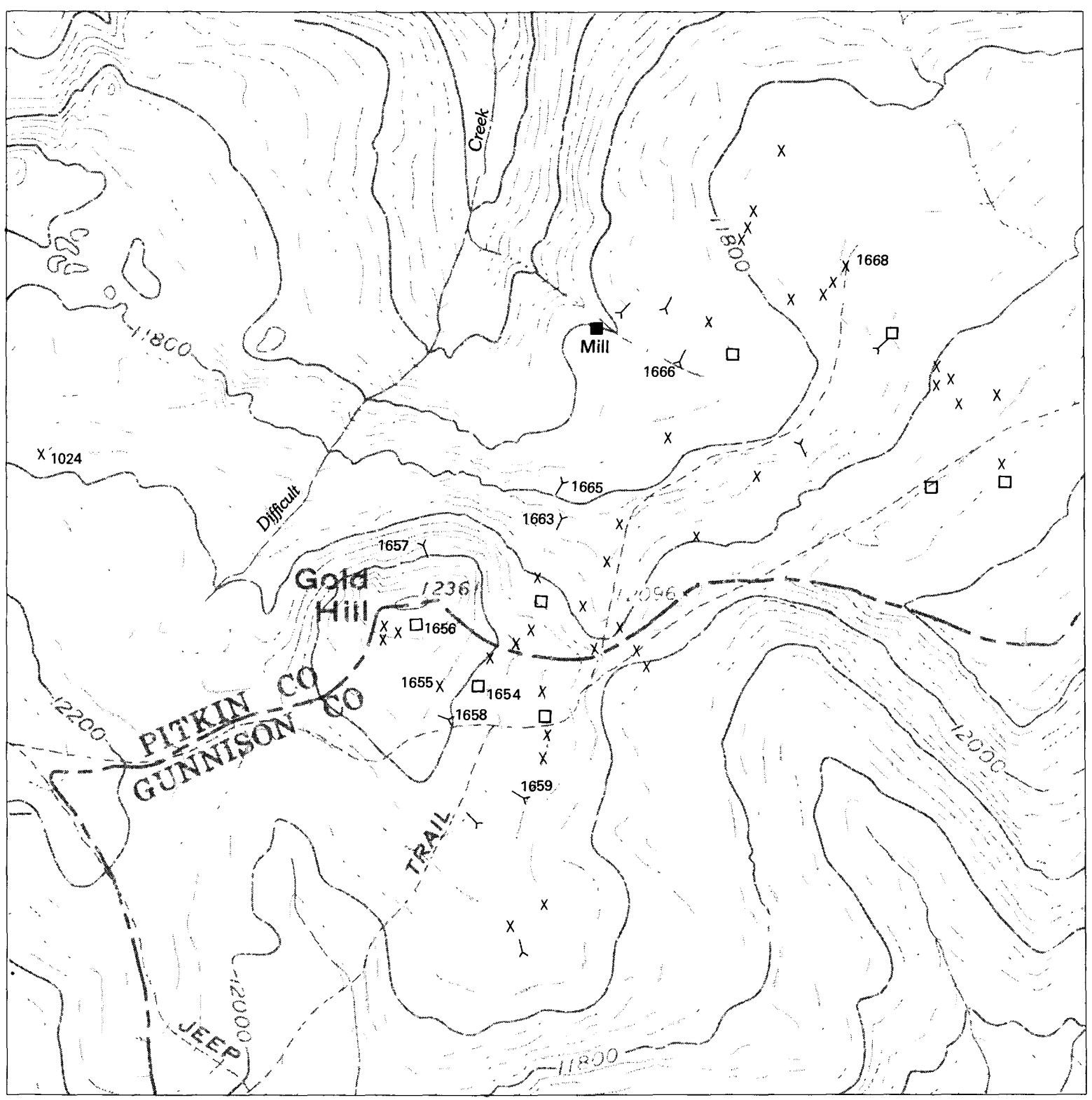

0 1 KILOMETER

CONTOUR INTERVAL 40 FEET

NATIONAL GEODETIC VERTICAL DATUM OF 1929

$1 \mathrm{ft}=0.3048 \mathrm{~m}$

EXPLANATION

$1663 \succ$ ADIT

$1654 \square$ SHAFT

1668 X PROSPECT PIT-

Number is analyzed sample

FIGURE 68.-Locations of prospects and localities of analyzed samples, Gold Hill area. Numbers indicate analyzed samples, table 14. Base from U.S. Geological survey 1:24,000, New York Peak, 1960. 
Bartleson, B. L., 1968, Stratigraphy and petrology of the Gothic Formation, Elk Mountains, Colorado: Colorado Univ. Ph.D. thesis, 216 p.; available from University Microfilms, Ann Arbor, Mich., no. 69-4341, 220 p.

1972, Permo-Pennsylvanian stratigraphy and history of the Crested Butte-Aspen region, in R. H. De Voto, ed., Paleozoic stratigraphy and structural evolution of Colorado: Colorado School Mines Quart., v. 67, no. 4, p. 187-248.

Bartleson, B. L., Bryant, Bruce, and Mutschler, F. E., 1968, Permian and Pennsylvanian stratigraphy and nomenclature, Elk Mountains, Colorado, in Geological Survey research 1968: U.S. Geol. Survey Prof. Paper 600-C, p. C53-C60.

Bass, N. W., and Northrop, S. A., 1950, South Canyon Creek dolomite member, a unit of Phosphoria age in Maroon Formation near Glenwood Springs, Colorado: Am. Assoc. Petroleum Geologists Bull., v. 34, no. 7, p. 1540-1551.

1963, Geology of Glenwood Springs quadrangle and vicinity, northwestern Colorado: U.S. Geol. Survey Bull. 1142-J, $74 \mathrm{p}$.

Bastin, E. S., 1924, Observations on the rich silver ores of Aspen, Colorado: U.S. Geol. Survey Bull. 750-C, p. 41-62.

Bateman, P. C., Clark, L. D., Huber, N. K., Moore, J. G., and Rinehart, C. D., 1963, The Sierra Nevada batholith-A synthesis of recent work across the central part: U.S. Geol. Survey Prof. Paper 414-D, $46 \mathrm{p}$.

Behre, C. H., Jr., 1932, The Weston Pass mining district, Lake and Park Counties, Colorado: Colorado Sci. Soc. Proc., v. 13, no. 3, p. 53-73.

Behrendt, J. C., and Bajwa, L. Y., 1972, Bouguer gravity map of Colorado: U.S. Geol. Survey open-file map scale 1:500,000.

Benedict, J. B., 1967, Recent glacial history of an alpine area in the Colorado Front Range, U.S.A., Part 1, Establishing a lichengrowth curve: Jour. Glaciology, v. 6, no. 48, p. 817-832.

1968, Recent glacial history of an alpine area in the Colorado Front Range, U.S.A., Part 2, Dating the glacial deposits: Jour. Glaciology, v. 7, no. 49, p. 77-87.

1973, Chronology of cirque glaciation, Colorado Front Range: Quaternary Research, v. 3, p. 584-599.

Berg, R. R., 1960, Cambrian and Ordovician history of Colorado, in Guide to the geology of Colorado: Geol. Soc. America, Rocky Mtn. Assoc. Geologists, and Colorado Sci. Soc., p. 10-17.

Berry, J. W., 1959, Climate of Colorado, in Climates of the States: U.S. ESSA Climatography of the United States, no. 60-5, 20 p. (revised and reprinted 1968).

Bickford, M. E., Wetherill, G. W., Barker, Fred, and Lee-Hu, ChinNan, 1969, Precambrian Rb-Sr chronology in the Needle Mountains, southwestern Colorado: Jour. Geophys. Research, v. 74, no. 6, p. $1660-1676$.

Birkeland, P. W., 1973, Use of relative age-dating methods in a stratigraphic study of rock glacier deposits, Mt. Sopris, Colorado, in Lichenometry: Arctic and Alpine Research, v. 5, no. 4, p. 401-416.

Birkeland, P. W., and Miller, C. D., 1973, Re-interpretation of the type Temple Lake moraine, and other neoglacial deposits, southern Wind River Mountains, Wyoming: Geol. Soc. America Abs. with Programs, v. 5, no. 6, p. 465-466.

Bloom, D. N., 1961, Devonian and Mississippian stratigraphy of central and northwestern Colorado, in Symposium on lower and middle Paleozoic rocks of Colorado, 12th Field Conf.: Rocky Mtn. Assoc. Geologists, p. 25-35.

Boggs, Sam, Jr., 1966, Petrology of Minturn Formation, east-central Eagle County, Colorado: Am. Assoc. Petroleum Geologists Bull., v. 50, no. 7, p. 1399-1422.
Boyd, F. S., Jr., and Bromley, C. P., 1953, Reconnaissance of the Aspen area, including the Smuggler mine, Pitkin County, Colorado: U.S. Atomic Energy Comm. Rept. RME-4031, 23 p.

Boyle, R. W., 1968, The geochemistry of silver and its deposits, with notes on geochemical prospecting for the element: Canada Geol. Survey Bull. 160, 264 p.

Brill, K. G., Jr., 1942, Late Paleozoic stratigraphy of Gore area, Colorado: Am. Assoc. Petroleum Geologists Bull., v. 26, no. 8, p. 1375-1397.

1944, Late Paleozoic stratigraphy, west-central and northwestern Colorado: Geol. Soc. America Bull., v. 55, no. 5, p.621-656.

1952, Stratigraphy in the Permo-Pennsylvanian zeugogeosyncline of Colorado and northern New Mexico: Geol. Soc. America Bull., v. 63, no. 8, p. 809-880.

1958, The Belden formation, in Symposium on Pennsylvanian rocks of Colorado and adjacent areas: Rocky Mtn. Assoc. Geologists, p. 103-105.

Brock, M. R., and Barker, Fred, 1972, Geologic map of the Mount Harvard quadrangle, Chaffee and Gunnison Counties, Colorado: U.S. Geol. Survey Geol. Quad. Map GQ-952.

Brunton, D. W., 1888, Aspen Mountain [Colorado]; its ores and their mode of occurrence: Eng. and Mining Jour., v. 46, p. $22-23,42-45$.

Bryant, Bruce, 1966, Possible window in the Elk Range thrust sheet near Aspen, Colorado, in Geological Survey research 1966: U.S. Geol. Survey Prof. Paper 550-D, p. D1-D8.

1969, Geologic map of the Maroon Bells quadrangle, Pitkin and Gunnison Counties, Colorado: U.S. Geol. Survey Geol. Quad. Map GQ-788.

1970, Geologic map of the Hayden Peak quadrangle, Pitkin and Gunnison Counties, Colorado: U.S. Geol. Survey Geol. Quad. Map GQ-863.

1971a, Geologic map of the Aspen quadrangle, Pitkin County, Colorado: U.S. Geol. Survey Geol. Quad. Map GQ-933. $1971 \mathrm{~b}$, Movement measurements on two rock glaciers in the eastern Elk Mountains, Colorado, in Geological Survey research 1971: U.S. Geol. Survey Prof. Paper 750-B, p. B108-B116.

1971c. Disseminated sulfide deposits in the eastern Elk Mountains, Colorado, in Geological Survey research 1971: U.S. Geol. Survey Prof. Paper 750-D, p. D13-D25.

1972a, Geologic map of the Highland Peak quadrangle, Pitkin County, Colorado: U.S. Geol. Survey Geol. Quad. Map GQ-932.

$1972 \mathrm{~b}$, Map showing areas of selected potential geologic hazards in the Aspen quadrangle, Pitkin County, Colorado: U.S. Geol. Survey Misc. Geol. Inv. Map I-785-A.

1972c, Map showing ground-water potential in the Aspen quadrangle, Pitkin County, Colorado: U.S. Geol. Survey Misc. Geol. Inv. Map I-785-B.

$1972 \mathrm{~d}$, Map showing relative ease of excavation in the Aspen quadrangle, Pitkin County, Colorado: U.S. Geol. Survey Misc. Geol. Inv. Map I-785-C.

1972e, Map showing mines, prospects, and areas of significant silver, lead, and zinc production in the Aspen quadrangle, Pitkin County, Colorado: U.S. Geol. Survey Misc. Geol. Inv. Map I-785-D.

1972f, Slope map of the Aspen quadrangle, Pitkin County, Colorado: U.S. Geol. Survey Misc. Geol. Inv. Map I-785-E. $1972 \mathrm{~g}$, Map showing relative permeability of rocks and surficial deposits of the Aspen quadrangle, Pitkin County, Colorado: U.S. Geol. Survey Misc. Geol. Inv. Map I-785-F. 
1972h, Map showing avalanche areas in the Aspen quadrangle, Pitkin County, Colorado: U.S. Geol. Survey Misc. Geol. Inv. Map I-785-G.

1972i, Map showing types of bedrock and surficial deposits in the Aspen quadrangle, Pitkin County, Colorado: U.S. Geol. Survey Misc. Geol. Inv. Map I-785-H.

Bush, J. H., and Bush, C. G., 1974, Revisions in Cambrian nomenclature in central Colorado: Mtn. Geologist, v. 11, no. 2, p. 59-69.

Cadigan, R. A., 1957, Lithologic studies, in Geologic investigations of radioactive deposits-Semiannual progress report for December 1, 1956 to May 31, 1957: U.S. Geol. Survey TE1-690, p. 354-366, issued by U.S. Atomic Energy Comm. Tech. Inf. Service Ext., Oak Ridge, Tenn.

1967, Petrology of the Morrison Formation in the Colorado Plateau region: U.S. Geol. Survey Prof. Paper 556, 113 p. 1971, Petrology of the Triassic Moenkopi Formation and related strata in the Colorado Plateau region, with a section on Stratigraphy, by J. H. Stewart: U.S. Geol. Survey Prof. Paper $692,70 \mathrm{p}$.

Campbell, J. A., 1970, Stratigraphy of Chaffee Group, (Upper Devonian), west-central Colorado: Am. Assoc. Petroleum Geologists Bull., v. 54, no. 2, p. 313-325.

1976, Upper Cambrian stromatolitic biostrome, Clinetop Member of the Dotsero Formation, western Colorado: Geol. Soc. America Bull., v. 87, p. 1331-1335.

Campbell, J. A., Bickford, H. L., and Janssen, R. J., 1976, Petrology of the Sawatch Sandstone, White River Plateau, westcentral Colorado: Geol. Soc. America, Abs. with programs, v. 8, no. 5, p. 573-574.

Candee, C. R., 1971, The geology of the Lincoln Gulch Stock, Pitkin County, Colorado: Geol. Soc. America Abs. with Programs, v. 3, no. 6, p. 372

Carrara, P. E., and Andrews, J. T., 1973, Problems and application of lichenometry to geomorphic studies, San Juan Mountains, Colorado, in Lichenometry: Arctic and Alpine Research, v. 5 , no. 4 , p. $373-384$.

Carter, W. D., 1957, Disconformity between Lower and Upper Cretaceous in western Colorado and eastern Utah: Geol. Soc. America Bull., v. 68, no. 3, p. 307-314.

Case, J. E., 1965, Gravitational evidence for a batholithic mass of low density along a segment of the Colorado mineral belt, in Abstracts for 1964: Geol. Soc. America Spec. Paper 82, p. 26.

Conley, C. D., 1972, Depositional and diagenetic history of the Mississippian Leadville Formation, White River Plateau, Colorado, in $\mathbf{R}$. H. De Voto, ed., Paleozoic stratigraphy and structural evolution of Colorado: Colorado School Mines Quart., v. 67 , no. 4, p. 103-135.

Craig, L. C., 1959, Measured sections of Morrison and adjacent formations: U.S. Geol. Survey open-file rept.

Craig, L. C., compiler, 1972, Mississippian system, in Geologic Atlas of the Rocky Mountain region, United States of America: Rocky Mtn. Assoc. Geologists, p. 100-110.

Craig, L. C., and others, 1955, Stratigraphy of the Morrison and related formations, Colorado Plateau region, a preliminary report: U.S. Geol. Survey Bull. 1009-E, p. 125-168.

Cross, Whitman, 1894, Description of the Pikes Peak sheet [Colorado]: US. Geol. Survey Geol. Atlas, Folio 7.

1899, Description of the Telluride quadrangle [Colorado]: U.S. Geol. Survey Geol. Atlas, Folio 57, 19 p.

Cruson, M. G., 1972, Grizzly Peak cauldron complex, Sawatch Range, Colorado: Geol. Soc. America Abs. with Programs, v. 4, no. 3, p. 142
Cunningham, C. G., Jr., 1976, Petrogenesis and postmagmatic geochemistry of the Italian Mountain intrusive complex, eastern Elk Mountains, Colorado: Geol. Soc. America Bull., v. 86 , p. 897-908.

Cunningham, C. G., [Jr.], Naeser, C. W., and Marvin, R. F., 1977, New ages for intrusive rocks in the Colorado mineral belt: U.S. Geol. Survey open-file report 77-573.

Currey, D. R., 1974, Probable pre-Neoglacial age of the type Temple Lake moraine, Wyoming: Arctic and Alpine Research, v. 6, no. 3, p. 293-300.

Dane, C. H., Cobban, W. A., and Kauffman, E. G., 1966, Stratigraphy and regional relationships of a reference section for the Juana Lopez Member, Mancos Shale, in the San Juan Basin, New Mexico: U.S. Geol. Survey Bull. 1224-H, 15 p.

Devereaux, W. B., 1884, Notes on iron ore deposits in Pitkin County, Colorado: Am. Inst. Mining, Metall., Petroleum Engineers Trans., v. 12, p. 638-641.

De Voto, R. H., 1972, Pennsylvanian and Permian stratigraphy and tectonism in central Colorado, in R. H. De Voto, ed., Paleozoic stratigraphy and structural evolution of Colorado: Colorado School Mines Quart., v. 67, no. 4, p. 139-185.

Dickinson, R. G., Leopold, E. B., and Marvin, R. F., 1968, Late Cretaceous uplift and volcanism on the north flank of the San Juan Mountains, Colorado, in R. C. Epis, ed., Cenozoic volcanism in the southern Rocky Mountains: Colorado School Mines Quart., v. 63, no. 3, p. 125-148.

Dickinson, W. R., 1975, Potash-depth (K-h) relations in continental margin and intra-oceanic magmatic arcs: Geology, v. 3, no. 2, p. 53-56.

Dings, M. G., and Robinson, C. S., 1957, Geology and ore deposits of the Garfield quadrangle, Colorado: U.S. Geol. Survey Prof. Paper 289, 110 p.

Doe, B. R., 1968, Lead and strontium isotopic studies of Cenozoic volcanic rocks in the Rocky Mountain region-A summary, in R. C. Epis, ed., Cenozoic volcanism in the southern Rocky Mountains: Colorado School Mines Quart., v. 63, no. 3, p. 149-174.

Doe, B. R., and Pearson, R. C., 1969, U-Th-Pb chronology of zircons from the St. Kevin Granite, northern Sawatch Range, Colorado: Geol. Soc. America Bull., v. 80, no. 12, p. 2495-2502.

Donnell, J. R., 1959, Mesaverde stratigraphy in the Carbondale area, northwestern Colorado, in Symposium on Cretaceous rocks of Colorado and adjacent areas: Rocky Mtn. Assoc. Geologists, p. 76-77.

Donner, H. F., 1936, Geology of the McCoy area, Eagle and Routt Counties, Colorado: Michigan Univ. Sc. D. thesis.

1949, Geology of the McCoy area, Eagle and Routt Counties, Colorado: Geol. Soc. America Bull., v. 60, no. 8, p. 1215-1247.

Emmons, S. F., 1886, Geology and mining industry of Leadville, Colorado: U.S. Geol. Survey Mon. 12, 770 p.

1888, Preliminary notes on Aspen, Colorado: Colorado Sci. Soc. Proc., v. 2, p. 251-277.

Emmons, S. F., Cross, Whitman, and Eldridge, G. A., 1894, Anthracite-Crested Butte folio, Colorado: U.S. Geol. Survey Geol. Atlas, Folio 9.

Emmons, S. F., Irving, J. D., and Loughlin, G. F., 1927, Geology and ore deposits of the Leadville mining district, Colorado: U.S. Geol. Survey Prof. Paper 148, 368 p.

Foster, H. L., and Holmes, G. W., 1965, A large transitional rock glacier in the Johnson River area, Alaska Range, in Geological Survey research 1965: U.S. Geol. Survey Prof. Paper 525-B, p. B112-B116. 
Freeman, V. L., 1971a, Stratigraphy of the State Bridge Formation in the Woody Creek quadrangle, Pitkin and Eagle Counties, Colorado: U.S. Geol. Survey Bull. 1324-F, 17 p.

1971b, Permian deformation in the Eagle basin, Colorado, in Geological Survey research 1971: U.S. Geol. Survey Prof. Paper 750-D, p. D80-D83.

1972a, Geologic map of the Woody Creek quadrangle, Pitkin and Eagle Counties, Colorado: U.S. Geol. Survey Geol. Quad Map GQ-967.

$1972 \mathrm{~b}$, Geologic map of the Ruedi quadrangle, Pitkin and Eagle Counties, Colorado: U.S. Geol. Survey Geol. Quad. Map GQ-1004.

Gaskill, D. L., 1956, Geology of the White Rock Mountain area, Gunnison County, Colorado: New Mexico Univ. unpub. M.S. thesis, $174 \mathrm{p}$.

Gaskill, D. L., and Godwin, L. H., 1963, Redefinition and correlation of the Ohio Creek Formation (Paleocene) in west-central Colorado, in Short papers in geology and hydrology: U.S. Geol. Survey Prof. Paper 475-C, p. C35-C38.

1966a, Geologic map of the Marble quadrangle, Gunnison and Pitkin Counties, Colorado: U.S. Geol. Survey Geol. Quad. Map GQ-512.

1966b, Geologic map of the Marcellina Mountain quadrangle, Gunnison County, Colorado: U.S. Geol. Survey Geol. Quad. Map GQ-511.

Gaskill, D. L., Godwin, L. H., and Mutschler, F. E., 1967, Geologic map of the Oh-Be-Joyful quadrangle, Gunnison County, Colorado: U.S. Geol. Survey Geol. Quad. Map GQ-578.

Gerhard, L. C., 1972, Canadian depositional environments and paleotectonics, central Colorado, in R. H. De Voto, ed., Paleozoic stratigraphy and structural evolution of Colorado: Colorado School Mines Quart., v. 67, no. 4, p. 1-36.

Gill, J. R., and Cobban, W. A., 1966, The Red Bird section of the Upper Cretaceous Pierre Shale in Wyoming, with a section on A new echinoid from the Cretaceous Pierre Shale of eastern Wyoming, by P. M. Kier: U.S. Geol. Survey Prof. Paper 393-A, 73 p.

1973, Stratigraphy and geologic history of the Montana Group and equivalent rocks, Montana, Wyoming, and North and South Dakota: U.S. Geol. Survey Prof. Paper 776, 37 p.

Gilluly, James, 1971, Plate tectonics and magmatic evolution: Geol. Soc. America Bull., v. 82, no. 9, p. 2383-2396.

Gilluly, James, and Reeside, J. B., Jr., 1928, Sedimentary rocks of the San Rafael Swell and some adjacent areas in eastern Utah: U.S. Geol. Survey Prof. Paper 150-D, p. 61-110.

Girty, G. H., 1903, The Carboniferous formations and faunas of Colorado: U.S. Geol. Survey Prof. Paper 16, 546 p.

Godwin, L. H., 1968, Geologic map of the Chair Mountain quadrangle, Gunnison and Pitkin Counties, Colorado: U.S. Geol. Survey Geol. Quad. Map GQ-704.

Godwin, L. H., and Gaskill, D. L., 1964, Post-Paleocene West Elk laccolithic cluster, west-central Colorado, in Geological Survey research 1964: U.S. Geol. Survey Prof. Paper 501-C, p. C66-C68.

Gratton, P. J. F., 1958, Igneous petrography of the White Rock Mountain area, Gunnison County, Colorado: Compass, v. 35, no. 2, p. 83-91.

Gregory, H. E., 1915, The igneous origin of the "glacial deposits" on the Navajo Reservation, Arizona and Utah: Am. Jour. Sci., ser. 4, v. 40, no. 236, p. 97-115.

Guilbert, J. M., and Lowell, J. D., 1974, Variations in zoning patterns in porphyry ore deposits: Canadian Mining and Metall. Bull., v. 67, no. 742, p. 99-109.
Hallgarth, W. E., 1967, Western Colorado, southern Utah, and northwestern New Mexico, Chapter I, in E. D. McKee, S. S. Oriel, and others, Paleotectonic investigations of the Permian system in the United States: U.S. Geol. Survey Prof. Paper 515, p. 171-197.

Hansen, W. R., 1971, Geologic map of the Black Canyon of the Gunnison River and vicinity, western Colorado: U.S. Geol. Survey Misc. Geol. Inv. Map I-584.

Hansen, W. R., and Peterman, Z. E., 1968, Basement-rock geochronology of the Black Canyon of the Gunnison, Colorado, in Geological Survey research 1968: U.S. Geol. Survey Prof. Paper 600-C, p. C80-C90.

Harden, C. P., 1976, Landslides near Aspen, Colorado: University of Colorado Institute for Arctic and Alpine Research, Occasional Paper 20,61 p.

Harder, E. C., 1909, The Taylor Peak and Whitepine iron-ore deposits, Colorado: U.S. Geol. Survey Bull. 380, p. 188-198.

Harrer, C. M., and Tesch, W. J., Jr., 1959, Reconnaissance of iron occurrences in Colorado: U.S. Bur. Mines Inf. Circ. 7918, 82 p.

Hatherton, Trevor, and Dickinson, W. R., 1969, The relationship between andesitic volcanism and seismicity in Indonesia, the Lesser Antilles and other island arcs: Jour. Geophys. Research. v. 74, no. 22, p. 5301-5310.

Haun, J. D., and Weimer, R. J. 1960, Cretaceous stratigraphy of Colorado, in Guide to the geology of Colorado: Geol. Soc. America, Rocky Mtn. Assoc. Geologists and Colorado Sci. Soc., p. 58-65.

Hayden, F. V., 1874, Sawatch Range-Morainal deposits of Taylor's Creek-Elk Mountains, etc., Chapter 3, in Geology, mineralogy, and mining industry, Pt. 1: U.S. Geol. and Geog. Survey Terr. [7th] Ann. Rept. (Hayden), p. 53-69.

1876 , General view of the geography and geology of the Elk Mountains-Eruptive granites-Rhyolites and dikes-Erosion on a grand scale-Local drift-deposits, Chapter 5, in Geology, mineralogy, and mining industry: U.S. Geol. and Geog. Survey Terr. [8th] Ann. Rept. (Hayden), p. 54-58.

Hedge, C. E., Peterman, Z. E., Case, J. E., and Obradovich, J. D., 1968, Precambrian geochronology of the northwestern Uncompahgre Plateau, Utah and Colorado, in Geological Survey research 1968: U.S. Geol. Survey Prof. Paper 600-C, p. C91-C96.

Henderson, C. W., 1926, Mining in Colorado, a history of discovery, development, and production: U.S. Geol. Survey Prof. Paper $138,263 \mathrm{p}$.

Henrich, Carl, 1889, Notes on the geology and on some of the mines of Aspen Mountain, Pitkin County, Colorado: Am. Inst. Mining Engineers Trans., v. 17, p. 156-206.

Heyl, A. V., 1964, Oxidized zinc deposits of the United States, Pt. 3, Colorado: U.S. Geol. Survey Bull. 1135-C, 98 p.

Hibbard, M. J., 1965, Origin of some feldspar phenocrysts and their bearing on petrogenesis: Am. Jour. Sci., v. 263, no. 3, p. 245-261.

Hills, R. C., 1891, Orographic and structural features of Rocky Mountain geology: Colorado Sci. Soc. Proc., v. 3, p. 362-458.

Holmes, W. H., 1876, Report on the Geology of the northwestern portion of the Elk Range, Chapter 6, in Geology, mineralogy, and mining industry: U.S. Geol. and Geog. Survey Terr. [8th] Ann. Rept. (Hayden), p. 59-71.

Huckenholz, H. G., 1963, A contribution to the classification of sandstones: Geol. Foren. Stockholm Forh., v. 85, p. 156-172.

Iradji, A. H., 1955, The geology of the northern Lenado area, Pitkin County, Colorado: Golden, Colorado School Mines M.S. thesis, $98 \mathrm{p}$. 
Isaacson, L. B., and Smithson, S. B., 1976, Gravity anomolies and granite emplacement in west-central Colorado: Geol. Soc. America Bull., v. 87, p. 22-28.

Johnson, J. H., 1944, Paleozoic stratigraphy of the Sawatch Range, Colorado: Geol. Soc. America Bull., v. 55, no. 3, p. 303-378.

Keller, W. D., 1962, Clay minerals in the Morrison Formation of the Colorado Plateau: U.S. Geol. Survey Bull. 1150, 90 p.

Kirk, Edwin, 1931, The Devonian of Colorado: Am. Jour. Sci., ser. 5, v. 22, p. $222-240$

Knopf, Adolph, 1926, Recent developments in the Aspen district, Colorado: U.S. Geol. Survey Bull. 785, p. 1-28.

Langenheim, R. L., Jr., 1952, Pennsylvanian and Permian stratigraphy in Crested Butte quadrangle, Gunnison County, Colorado: Am. Assoc. Petroleum Geologists Bull., v. 36, no. 4, p. 543-574.

1954, Correlation of Maroon formation in Crystal River valley, Gunnison, Pitkin, and Garfield Counties, Colorado: Am. Assoc. Petroleum Geologists Bull., v. 38, no. 8, p. 1748-1779.

1957, Jurassic stratigraphy in Elk Mountains, west-central Colorado: Am. Assoc. Petroleum Geologists Bull., v. 41, no. 11, p. 2576-2581.

Larson, E. E., Ozima, Minoru, and Bradley, W. C., 1975, Late Cenozoic basic volcanism in northwestern Colorado and its implications concerning tectonism and the origin of the Colorado River system, in B. C. Curtis, ed., Cenozoic history of the Southern Rocky Mountains: Geol. Soc. America Mem. 144, p. 155-178.

Leith, C. K., 1906, Iron ores of the western United States and British Columbia: U.S. Geol. Survey Bull. 285, p. 194-200.

Lipman, P. W., Mutschler, F. E., Bryant, Bruce, and Steven, T. A., 1969, Similarity of Cenozoic igneous activity in the San Juan and Elk Mountains, Colorado, and its regional significance, in Geological Survey research 1969: U.S. Geol. Survey Prof. Paper 650-D, p. D33-D42 [1970].

Lipman, P. W.,Prostka, H. J., and Christiansen, R. L., 1972, Early and Middle Cenozoic [pt.] 1 of Cenozoic volcanism and platetectonic evolution of the Western United States: Royal Soc. London Philos. Trans., ser. A, v. 271, no. 1213, p. 217-248.

Lochman-Balk, Christina, 1972, Cambrian System, in Geologic atlas of the Rocky Mountain region, United States of America: Rocky Mtn. Assoc. Geologists, p. 60-75.

Lovering, T. G., 1972, Jasperoid in the United States-its characteristics, origin, and economic significance: U.S. Geol. Survey Prof. Paper 710, 164 p.

Lovering, T. S., and Mallory, W. W., 1962, The Eagle Valley Evaporite and its relation to the Minturn and Maroon Formations, northwest Colorado, in Short papers in geology, hydrology, and topography: U.S. Geol. Survey Prof. Paper 450-D, p. D45-D48.

McCarthy, J. H., Jr., and Gott, G. B., 1966, The distribution of $\mathrm{Ag}, \mathrm{Pb}, \mathrm{Zn}, \mathrm{Sb}, \mathrm{As}$, and $\mathrm{Hg}$, in soils at Lenado, Aspen quadrangle, Colorado, with a Preliminary geologic map of the Lenado mining district, Pitkin County, Colorado, by Bruce Bryant: U.S. Geol. Survey open-file report.

McGookey, D. P., Haun, J. D., Hale, L. A., Goodell, H. G., McCubbin, D. G., Weimer, R. J., and Wulf, G. R., 1972, Cretaceous System, in Geologic atlas of the Rocky Mountain region, United States of America: Rocky Mtn. Assoc. Geologists, p. 190-228.

Mackay, I. H., 1953, Geology of the Thomasville-Woods Lake area, Eagle and Pitkin Counties, Colorado: Colorado School Mines Quart., v. 48, no. 4, 76 p.

McKee, E. D., Oriel, S. S., Ketner, K. B., MacLachlan, M. E., Goldsmith, J. W., MacLachlan, J. C., and Mudge, M. R., 1959, Paleotectonic maps of the Triassic System: U.S. Geol. Survey Misc. Geol. Inv. Map I-300.
McKee, E. D., Oriel, S. S., and others, 1967, Paleotectonic maps of the Permian System: U.S. Geol. Survey Misc. Geol. Inv. Map I-450.

McKee, E. D., Oriel, S. S., Swanson, V. E., MacLachlan, M. E., MacLachlan, J. C., Ketner, K. B., Goldsmith, J. W., Bell, R. Y., and Jameson, D. J., 1956, Paleotectonic maps of the Jurassic System, with a separate section on Paleogeography, by R. W. Imlay: U.S. Geol. Survey Misc. Geol. Inv. Map I-175.

Madole, R. F., 1972, Neoglacial facies in the Colorado Front Range: Arctic and Alpine Research, v. 4, no. 2, p. 119-130.

Mahaney, W. C., 1972, Audubon-New name for Colorado Front Range Neoglacial deposits formerly called "Arikaree": Arctic and Alpine Research, v. 4, no. 4, p. 355-357.

1973, Neoglacial chronology in the Fourth of July Cirque, central Colorado Front Range: Geol. Soc. America Bull., v. 84, no. 1, p. 161-170.

Mallory, W. W., 1966, Cattle Creek anticline, a salt diapir near Glenwood Springs, Colorado, in Geological Survey research 1966: U.S. Geol. Survey Prof. Paper 550-B, p. B12-B15.

1971, The Eagle Valley Evaporite, northwest Colorado-A regional synthesis: U.S. Geol. Survey Bull. 1311-E, p. E1-E37. compiler, 1972, Regional synthesis of the Pennsylvanian System, in Geologic Atlas of the Rocky Mountain region, United States of America: Rocky Mtn. Assoc. Geologists, p. 111-127.

Mamet, B. L., and Skipp, Betty, 1970, Lower Carboniferous calcareous foraminifera-preliminary zonation and stratigraphic implications for the Mississipian of North America: Int. Cong. Strat. Geol. Carboniferous, 6th, Sheffield, 1967, Compte Rendu, v. III, p. 1129-1146.

Maslyn, R. M., 1976, Late Mississippian paleokarst in the Aspen, Colorado area: Colo. School of Mines M.S. thesis, $96 \mathrm{p}$.

Meek, F. B., and Hayden, F. V., 1862, Descriptions of new Lower Silurian (Primordial), Jurassic, Cretaceous, and Tertiary fossils, collected in Nebraska, by the exploring expedition under the command of Capt. Wm. F. Raynolds, U.S. Top. Engrs., with some remarks on the rocks from which they were obtained: Acad. Nat. Sci. Philadelphia Proc., 1861, v. 13, p. 415-447.

Merrill, W. M., and Winar, R. M., 1958, Molas and associated formations in San Juan basin-Needle Mountains area, southwestern Colorado: Am. Assoc. Petroleum Geologists Bull., v. 42, no. 9, p. 2107-2132.

Middleton, G. V., 1960, Chemical composition of sandstones: Geol. Soc. America Bull., v. 71, no. 7, p. 1011-1026.

Miller, C. D., 1971, Quaternary glacial events in the northern Sawatch Range, Colorado: Colorado Univ. Ph. D. thesis, 86 p.; available from University Microfilms, Ann Arbor, Mich., no. 71-25,856, $139 \mathrm{p}$.

1973, Chronology of Neoglacial deposits in the northern Sawatch Range, Colorado, in Lichenometry: Arctic and Alpine Research, v. 5, no. 4, p. 385-400.

Mose, D. G., and Bickford, M. E., 1969, Precambrian geochronology in the Unaweep Canyon, west-central Colorado: Jour. Geophys. Research, v. 74, no. 6, p. 1677-1687.

Moss, J. H., 1951, Late glacial advances in the southern Wind River Mountains, Wyoming: Am. Jour. Sci., v. 249, no. 12, p. 865-883.

Murray, F. N., 1966, The stratigraphy and structural geology of the Grand Hogback Monocline, Colorado: Colorado Univ. Ph. D. thesis; available from University Microfilms, Ann Arbor, Mich., no. 66-9438, 274 p.

1969 , Flexural slip as indicated by faulted lava flows along the Grand Hogback Monocline, Colorado: Jour. Geology, v. 77, no. 3, p. 333-339. 
Mutschler, F. E., 1970, Geologic map of the Snowmass Mountain quadrangle, Pitkin and Gunnison Counties, Colorado: U.S. Geol. Survey Geol. Quad. Map GQ-853.

Nadeau, J. E., 1972, Mississippian stratigraphy of central Colorado, in $\mathrm{R}$. H. De Voto, ed., Paleozoic stratigraphy and structural evolution of Colorado: Colorado School Mines Quart., v. 67 , no. 4, p. 77-101.

Nelson, R. L., 1954, Glacial geology of the Frying Pan River drainage, Colorado: Jour. Geology, v. 62, no. 4, p. 325-343.

Newberry, J. S., 1890, Notes on the geology of the Aspen mining district [Colorado]: Am. Inst. Mining Engineers Trans., v. 18, p. 273-278.

Nockolds, S. R., 1954, Average chemical compositions of some igneous rocks: Geol. Soc. America Bull., v. 65, no. 10, p. 1007-1032.

Obradovich, J. D., and Cobban, W. A., 1975, A time scale for the Late Cretaceous of the western interior of North America, in W. G. E. Caldwell, ed., The Cretaceous System of the western interior of North America: Canada Geol. Assoc. Spec. Paper 13, p. 31-54.

Obradovich, J. D., Mutschler, F. E., and Bryant, Bruce, 1969, Potassium-argon ages bearing on the igneous and tectonic history of the Elk Mountains and vicinity, Colorado-A preliminary report: Geol. Soc. America Bull., v. 80, no. 9, p. 1749-1756.

Outcalt, S. I., and Benedict, J. B., 1965, Photo-interpretation of two types of rock glacier in the Colorado Front Range, U.S.A.: Jour. Glaciology, v. 5, no. 42, p. 849-856.

Pampe, W. R., 1970, Stratigraphy of the Devonian rocks of western Colorado: Earth Sci. Bull., v. 3, no. 1, p. 19-43.

Peale, A. C., 1874, Gunnison River-Elk Mountains-Roaring Fork, Chapter 4, in Geology, mineralogy, and mining industry, Pt. 1: U.S. Geol. and Geog. Survey Terr. [7th] Ann. Rept. (Hayden), p. 247-266.

Pearson, R. C., Hedge, C. E., Thomas, H. H., and Stern, T. W., 1966, Geochronology of the St. Kevin Granite and neighboring Precambrian rocks, northern Sawatch Range, Colorado: Geol. Soc. America Bull., v. 77, no. 10, p. 1109-1120.

Pearson, R. C., Tweto, Ogden, Stern, T. W., and Thomas, H. H., 1962, Age of Laramide porphyries near Leadville, Colorado, in Short papers in geology and hydrology: U.S. Geol. Survey Prof. Paper 450-C, p. C78-C80.

Peterman, Z. E., and Hedge, C. E., 1968, Chronology of Precambrian events in the Front Range, Colorado, in Internat. Conf., Edmonton, Alberta, 1967, Papers-Geochronology of Precambrian stratified rocks: Canadian Jour. Earth Sci., v. 5, no. 3, pt. 2, p. 749-756.

Pettijohn, F. J., 1957, Sedimentary rocks [2d ed.]: New York, Harper and Bros., $718 \mathrm{p}$

1963, Chemical composition of sandstones-excluding carbonate and volcanic sands, in Data of geochemistry [6th ed.]: U.S. Geol. Survey Prof. Paper 440-S, 21 p.

Pierce, K. L., Obradovich, J. D., and Friedman, Irving, 1976, Obsidian hydration dating and correlation of Bull Lake and Pinedale glaciations near West Yellowstone, Montana: Geol. Soc. America Bull., v. 87, p. 703-710.

Pollock, S. G., 1969, Petrology and structure of the Snowmass Creek Pluton, Pitkin County, Colorado, in Abstracts for 1968: Geol. Soc. America Spec. Paper 121, p. 623.

Poole, F. G., 1954, Geology of the southern Grand Hogback area, Garfield and Pitkin Counties, Colorado: Colorado. Univ. M.S. thesis, $128 \mathrm{p}$.

Poole, F. G., and Stewart, J. H., 1964, Chinle Formation and Glen Canyon Sandstone in northeastern Utah and northwestern Colorado, in Geological Survey research 1964: U.S. Geol. Survey Prof. Paper 501-D, p. D30-D39.
Potter, Noel, Jr., 1972, Ice-cored rock glacier, Galena Creek, Northern Absaroka Mountains, Wyoming: Geol. Soc. America Bull., v. 83, no. 10, p. 3025-3058.

Prather, T. L., 1964, Stratigraphy and structural geology of the Elk Mountains, Colorado: Colorado Univ. Ph. D. thesis, 106 p.; available from University Microfilms, Ann Arbor, Mich., no. $65-4267,153 \mathrm{p}$.

Proctor, P. D., 1953, Geology of the Silver Reef (Harrisburg) mining district, Washington Copunty, Utah: Utah Geol. Mineralog. Survey Bull. 44, 169 p.

Rankin, C. H., Jr., 1944, Stratigraphy of the Colorado group, Upper Cretaceous, in northern New Mexico: New Mexico School Mines Bull. 20, 27 p.

Raup, O. B., 1966, Clay mineralogy of Pennsylvanian redbeds and associated rocks flanking ancestral Front Range of central Colorado: Am. Assoc.Petroleum Geologists Bull., v. 50, no. 2, p. 251-268.

Ray, L. L., 1940, Glacial chronology of the southern Rocky Mountains: Geol. Soc. America Bull., v. 51, no. 12, pt. 1, p. 1851-1917.

Richmond, G. M., 1965a, Glaciation of the Rocky Mountains, in The Quaternary of the United States: Princeton, N. J., Princeton, Univ. Press, p. 217-230.

1965b, Quaternary stratigraphy of the Durango area, San Juan Mountains, Colorado, in Geological Survey research 1965: U.S. Geol. Survey Prof. Paper 525-C, p. C137-C143.

Richmond, G. M., Malde, H. E., and Tweto, O. L., 1965, Glaciation of the Colorado Plateau and Southern Rocky Mountains in Colorado, Pt. 1, in Guidebook for Field Conference E, Northern and Middle Rocky Mountains-International Association of Quaternary Research, 7th Congress, U.S.A., 1965; Lincoln, Nebr., Nebraska Acad. Sci., p. 117-125.

Rohlfing, D. P., 1938, The Colorado mineral belt and the Aspen mining district, Pitkin County, Colorado: Colorado Mining Assoc. Mining Year Book 1937, v. 25, p. 16-17, 62-64, 90.

Schultz, L. G., 1963, Clay minerals in Triassic rocks of the Colorado Plateau: U.S. Geol. Survey Bull. 1147-C, 71 p.

Singewald, Q. D., 1947, Preliminary geologic map and sections of the upper Blue River area, Summit County, Colorado [with text]: U.S. Geol. Survey, scale 1:31,250.

Sivyer, L. D., 1888, The geology of the Aspen, Colorado, ore deposits: Eng. and Mining Jour., v. 45, p. 195-196, 212.

Slebir, E. J., 1957, The geology of the North Cement Creek area, Gunnison County, Colorado: Colorado School Mines M.S. thesis, $93 \mathrm{p}$.

Spurr, J. E., 1898, Geology of the Aspen mining district, Colorado: U.S. Geol. Survey Mon. 31, 260 p.

1909, Ore deposition at Aspen, Colorado: Econ. Geology, v. 4 , p. 301-320.

Stark, J. T., 1934, Reverse faulting in the Sawatch Range: Geol. Soc. America Bull., v. 46, no. 6, p. 1001-1016.

Stark, J. T., and Barnes, F. F., 1935, Geology of the Sawatch Range, Colorado: Colorado Sci. Soc. Proc., v. 13, no. 8, p. 467-479.

Steven, T. A., 1975, Middle Tertiary volcanic field in the Southern Rocky Mountains, in B. F. Curtis, ed., Cenozoic history of the Southern Rocky Mountains: Geol. Soc. America Mem. 144, p. 75-94.

Steven, T. A., and Epis, R. C., 1968, Oligocene volcanism in south-central Colorado, in R. C. Epis, ed., Cenozoic volcanism in the southern Rocky Mountains: Colorado School Mines Quart., v. 63 , no. 3, p. 241-258. 
Stewart, J. H., Poole, F. G., and Wilson, R. F., 1972a, Stratigraphy and origin of the Triassic Moenkopi Formation and related strata in the Colorado Plateau region with a section on Sedimentary petrology, by R. A. Cadigan: U.S. Geol. Survey Prof. Paper 691, $195 \mathrm{p}$.

$1972 \mathrm{~b}$, Stratigraphy and origin of the Chinle Formation and related Upper Triassic strata in the Colorado Plateau region, with a section on Sedimentary petrology, by R. A. Cadigan, and a section on Conglomerate studies, by William Thordarson, H. F. Albee, and J. H. Stewart: U.S. Geol. Survey Prof. Paper 690, 336 p.

Stokes, W. L., 1952, Lower Cretaceous in Colorado Plateau: Am. Assoc. Petroleum Geologists Bull., v. 36, no. 9, p. 1766-1776.

Stokes, W. L., and Phoenix, D. A., 1948, Geology of the EgnarGypsum valley area, San Miguel and Montrose Counties, Colorado: U.S. Geol. Survey Oil and Gas Inv. Prelim. Map 93.

Thordarson, William, Albee, H. F., and Stewart, J. H., 1972, Conglomerate studies, in J. H. Stewart, F. G. Poole, and R. F. Wilson, Stratigraphy and origin of the Chinle Formation and related Upper Triassic strata in the Colorado Plateau region: U.S. Geol. Survey Prof. Paper 690, p. 62-76.

Turner, F. J., 1968, Metamorphic petrology-Mineralogical and field aspects: New York, McGraw-Hill Book Co., 403 p.

Tweto, Ogden, 1949, Stratigraphy of the Pando area, Eagle County, Colorado: Colorado Sci. Soc. Proc., v. 15, no. 4, p. 149-235.

1960, Pre-ore age of faults at Leadville, Colorado, in Short papers in the geological sciences: U.S. Geol. Survey Prof. Paper 400-B, p. B10-B11.

1974, Geologic map and sections of the Holy Cross quadrangle, Eagle, Lake, Pitkin, and Summit Counties, Colorado: U.S. Geol. Survey Misc. Inv. Map Ser. Map I-830 [1975].

1975, Laramide (Late Cretaceous-Early Tertiary) orogeny in the Southern Rocky Mountains, in B. C. Curtis, ed., Cenozoic history of the Southern Rocky Mountains: Geol. Soc. America Mem. 144, p. 1-44.

1977, Tectonic history of west-central Colorado, in H. K. Veal, ed., Exploration frontiers of the Central and southern Rockies: Rocky Mtn. Assoc. Geologists, p. 11-22.

Tweto, Ogden, and Lovering, T. S., 1977, Geology of the Minturn 15-minute quadrangle, Eagle and Summit Counties, Colorado and general geology of the Gilman mining district: U.S. Geol. Survey Prof Paper 956, 96 p.

Tweto, Ogden, Moench, R. H., and Reed, J. C., Jr., 1978, Geologic map of the Leadville $1^{\circ} \times 2^{\circ}$ quadrangle, northwestern Colorado: U.S. Geol. Survey Misc. Geol. Inv. Map I-999.

Tweto, Ogden, and Pearson, R. C., 1964, St. Kevin Granite, Sawatch Range, Colorado, in Short papers in geology and hydrology: U.S. Geol. Survey Prof. Paper 475-D, p. D28-D32.

Tweto, Ogden, and Sims, P. K., 1963, Precambrian ancestry of the Colorado mineral belt: Geol. Soc. America Bull., v. 74, no. 8, p. 991-1014.

U.S. Geological Survey, 1971, Geological Survey research 1971: U.S. Geol. Survey Prof. Paper 750-A, 418 p. [1972].

U.S. Geological Survey and American Association of Petroleum Geologists, 1961, Tectonic map of the United States, exclusive of Alaska and Hawaii: 2 sheets, scale 1:2,500,000 [1962].
Vanderwilt, J. W, 1935a, Stratigraphy of the Pennsylvanian Hermosa Formation in Elk Mountains, Gunnison County, Colorado: Am. Assoc. Petroleum Geologists Bull., v. 19, no. 11, p. 1668-1677.

$1935 \mathrm{~b}$, Revision of the structure and stratigraphy of the Aspen district, Colorado, and its bearing on the ore deposits: Econ. Geology, v. 30, no. 3, p. 223-241.

1937, Geology and mineral deosits of the Snowmass Mountain area, Gunnison County, Colorado: U.S. Geol. Survey Bull. 884,184 p. [1938].

Volin, M. E., and Hild, J. H., 1950, Investigation of Smuggler lead-zinc mine, Aspen, Pitkin County, Colorado: U.S. Bur. Mines Rept. Inv. 4696, $47 \mathrm{p}$.

Waagé, K. M., 1955, Dakota group in northern Front Range foothills, Colorado: U.S. Geol. Survey Prof. Paper 274-B, p. 15-51.

Wahrhaftig, Clyde, and Cox, Allan, 1959, Rock glaciers in the Alaska Range: Geol. Soc. America Bull., v. 70, no. 4, p. 383-436.

Walker, T. R., 1967a, Formation of red beds in modern and ancient deserts: Geol. Soc. America Bull., v. 78, no. 3, p. 353-368.

$1967 \mathrm{~b}$, Color of Recent sediments in tropical Mexico-A contribution to the origin of red beds: Geol. Soc. America Bull., v. 78, no. 7, p. 917-920.

Warner, D. L., 1964, Mancos-Mesaverde (Upper Cretaceous) intertonguing relations, southeast Piceance Basin, Colorado: Am. Assoc. Petroleum Geologists Bull., v. 48, no. 7, p. 1091-1107.

Waterman, H. D., 1955, Geology of the Ashcroft area, Pitkin County, Colorado: Golden, Colorado School Mines, M.S. thesis, $77 \mathrm{p}$.

Weimer, R. J., 1960, Upper Cretaceous stratigraphy, Rocky Mountain area: Am. Assoc. Petroleum Geologists Bull., v. 44, no. 1, p. 1-20.

Welder, G. E., 1954, Geology of the Basalt area, Eagle and Pitkin Counties, Colorado: Boulder, Colorado Univ. M. A. thesis, 72 p.

Wetherill, G. W., and Bickford, M. E., 1965, Primary and metamorphic Rb-Sr chronology in central Colorado: Jour. Geophys. Research, v. 70, no. 18, p. 4669-4686.

White, S. E., 1971, Rock glacier studies in the Colorado Front Range, 1961 to 1968: Arctic and Alpine Research, v. 3, no. 1, p. 43-64.

Winkler, H. G. F., 1967, Petrogenesis of metamorphic rocks [2d ed.]: New York, Springer-Verlag, $237 \mathrm{p}$.

Young, R. G., 1955, Sedimentary facies and intertonguing in the Upper Cretaceous of the Book Cliffs, Utah-Colorado: Geol. Soc. America Bull., v. 66, no. 2, p. 177-201.

1960, Dakota Group of Colorado Plateau: Am. Assoc. Petroleum Geologists Bull., v. 44, no. 2, p. 156-194.

Yount, J. C., 1970, A neoglacial chronology for the Independence Pass area, (Sawatch range), Colorado using graph-theoretic classification methods: Colorado Univ. M.S. thesis, 93 p.

Zapp, A. D., and Cobban, W. A., 1960, Some Late Cretaceous strand lines in northwestern Colorado and northeastern Utah, In Short papers in the geological sciences: U.S. Geol. Survey Prof. Paper 400-B, p. B246-B249.

Zietz, Isidore, and Kirby, J. R., Jr., 1972, Aeromagnetic map of Colorado: U.S. Geol. Survey Geophys. Inv. Map GP-836, 1:500,000.

Zoerner, F. P., 1973, Structure in the Pearl Pass-Italian Creek quadrangles, Colorado: Geol. Soc. America Abs. with Programs, v. 5, no. 6, p. 525. 
STRATIGRAPHIC SECTIONS 1-4 
Section 1.-Manitou Dolomite, Peerless Formation, and Sawatch Quartzite

[Measured on east side of ridge between two southerly forks of Express Creek; base of section at 3,590 m altitude, Hayden Peak quadrangle. Measured by Bruce Bryant and D. G. Morse]

Manitou Dolomite:

Thickness (meters)

48. Dolomite, poorly exposed at top of formation .......

47. Dolomite, light-greenish-gray to light-gray; weathers yellowish gray $\ldots \ldots \ldots \ldots \ldots \ldots \ldots \ldots \ldots \ldots$

46. Dolomite, medium-light-gray ...............

45. Dolomite, light-gray; weathers yellowish gray ......

44. Dolomite, medium-gray ....................

43. Dolomite, medium-light-gray; weathers medium light gray to yellowish gray; beds $15 \mathrm{~cm}$ to $1.8 \mathrm{~m}$; stringers of white to light-gray chert over a $0.6-\mathrm{m}$ interval $0.3 \mathrm{~m}$ from base and a few lenses of white chert $20.7 \mathrm{~m}$ above base ...................

42. Dolomite, medium-light-gray, medium-dark-gray, and yellowish-gray; weathers yellowish gray and medium light gray; beds $2.5-30 \mathrm{~cm}$, a few shaly partings; lenses and stringers of medium-darkgray chert $2.5-5 \mathrm{~cm}$ thick

41. Dolomite, medium-light-gray; weathers medium gray to yellowish gray; beds $0.6-2.4 \mathrm{~m}$, a few shaly part-

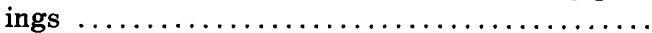

40. Sandstone, dolomitic and sandy dolomite; grades to medium-light-gray dolomite; beds $0.6-1.2 \mathrm{~m}$; some medium-gray shale partings ................

39. Dolomite, pale-yellowish-brown, grades to mediumlight-gray dolomite.$\ldots \ldots \ldots \ldots \ldots \ldots \ldots \ldots$.

38. Dolomite, pale-yellowish-brown; contains numerous grayish-brown to medium-gray shale partings in

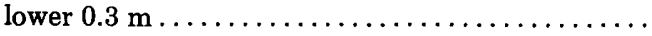

37. Sandstone, dolomitic, pale-yellowish-brown ........

36. Dolomite, medium-light-gray to yellowish-gray; beds 1-10 cm; a few gray shaly partings ............

Thickness of Manitou Dolomite.............

Peerless Formation:

35. Dolomite and sandy dolomite, grayish-orange ......

34. Sandstone, dolomitic, grayish-orange to pale-yellowish-brown; contains $0.3-\mathrm{m}$ bed grayish-orangepink dolomitic quartzite ..................

33. Dolomite and sandy dolomite, grayish-orange; contains yellowish-brown dolomitic sandstone beds $2.5-30 \mathrm{~cm} . . . \ldots \ldots \ldots \ldots \ldots \ldots \ldots \ldots . . \ldots \ldots$

32. Dolomite, sandy, grayish-orange, and dolomitic sandstone $\ldots \ldots \ldots \ldots \ldots \ldots \ldots \ldots \ldots \ldots \ldots$

31. Dolomite, dusky-red to grayish-red $(5 R Y / 2)$, sandy, shaly, and somewhat calcareous; becomes interbedded with grayish-orange sandy dolomite at top ...

30. Dolomite and sandy dolomite, grayish-orange to moderate-yellowish-brown, thin-bedded; contains light-olive-gray to medium-light-gray shale and dolomitic shale beds and a $0.3-\mathrm{m}$ bed of sandy dolomite containing dusky-red shaly dolomite fragments ............................

29. Shale, light-brownish-gray to medium-light-gray ...

28. Dolomite, sandy, thinly laminated ..............

27. Shale and dolomitic shale, light-olive-gray; a few thin beds of dolomite .....................
Section 1.-Manitou Dolomite, Peerless Formation, and Sawatch Quartzite-Continued

Thickness (meters)

Peerless Formation-Continued

26. Dolomite, sandy dolomite, dolomitic sandstone, shaly dolomite, and dolomitic shale, grayishorange to moderate-yellowish-brown, thin-bedded; shaly beds light-olive-gray; beds $0.3-7.6 \mathrm{~cm} . . .$. .

25. Shale, somewhat dolomitic, greenish-gray to lightolive-gray; a few thin beds of shaly dolomite......

24. Dolomite, calcareous, grayish-orange, coarse-grained; contains generally flat dusky-red shaly dolomite fragments to $1.2 \mathrm{~cm}$ long ...................

23. Sandstone, dolomitic, yellowish-gray; weathers grayish orange to light brown ..................

22. Limestone, shaly and somewhat sandy, grayishorange to light-brown-weathering; shale in irregular partings .........................

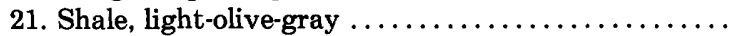

20. Limestone, sandy, and limy sandstone; grayish orange; weathers pale yellowish brown, dark yellowish brown, and moderate yellowish brown;

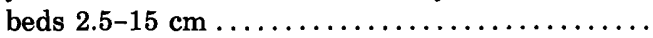

Thickness of Peerless Formation .

Sawatch Quartzite:

19. Quartzite and sandstone, calcareous, white to grayish-orange-pink .........................

18. Quartzite and sandstone, calcareous, grayish-orangepink to dark-yellowish-brown ................

17. Quartzite, white, vitreous; contains a few $2.5-30-\mathrm{cm}$ beds of calcareous sandstone ................

16. Sandstone, calcareous, light-brown; weathers moder-

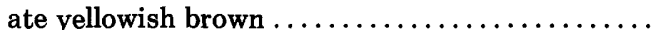

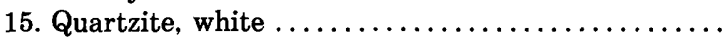

14. Sandstone, calcareous; weathers moderate yellowish brown to dark yellowish brown; irregular, lumpy bedding..$\ldots \ldots \ldots \ldots \ldots \ldots \ldots \ldots \ldots \ldots \ldots \ldots$.

13. Quartzite, white; contains a few dark-yellowishbrown lenses of calcareous sandstone ............

12. Quartzite, light-gray, and dolomitic quartzite weathering pale yellowish brown to moderate yellowish brown; beds $5-60 \mathrm{~cm} \ldots \ldots \ldots \ldots \ldots \ldots \ldots \ldots$.

11. Quartzite, white, vitreous ..................

10. Quartzite, dolomitic, light-brownish-gray to pale red; weathers dark yellowish brown $(10 Y R 4 / 2)$ to moderate yellowish brown $(10 Y R$ 5/4) ..........

9. Quartzite, very light gray to white..............

8. Quartzite, light-brownish-gray (5 $Y R$ 6/1), fine-

$3.0 \quad \begin{array}{r}\text { grained } \ldots \ldots \ldots \ldots \ldots \ldots \ldots \ldots \ldots \ldots \ldots \ldots \ldots \ldots \\ \text { 7. Quartzite, white; grain size } 0.5 \mathrm{~mm} \text { and less; small }\end{array}$ scale crossbedding ......................

6. Quartzite, white; weathers to a somewhat rusty

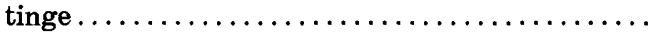

5. Quartzite, pale-yellowish-brown (10 YR 6/2) .......

4. Quartzite, light-grayish-orange (10 YR 7/4); crossbedded; scattered quartz pebble and granule beds

3. Quartzite, white, crossbedded, grain size $0.5-2 \mathrm{~mm}$; scattered quartz-granule beds ................

2. Quartzite, white, crossbedded; quartz pebbles to 1 $\mathrm{cm}$ and granules in basal $60 \mathrm{~cm}$ and $12-\mathrm{cm}$ bed $2 \mathrm{~m}$

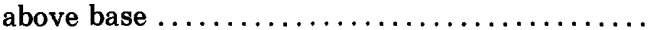
Thickness of Sawatch Quartzite .........

1. Granite, coarse-grained. 
SECTION 2.-Morrison Formation (part), Entrada Sandstone, Chinle Formation, Maroon Formation, and Gothic Formation (part) of Langenheim (1952)

[This section is probably as close to a type section of the Maroon Formation as can be obtained. Its base is in Rustler Gulch in the southwest corner of the Maroon Bells quadrangle, and it runs approximately along the divide between Snowmass and Maroon Creeks to the 4,036-m peak south of Baldy Mountain in the Highland Peak quadrangle. No complete section of the Maroon Formation is available on Maroon Creek because of surficial deposits. The section is a composite of individually measured sections. The sections are connected by tracing beds from the top of one to the bottom of the next higher section in the field or on aerial photographs. Some faults cross the section, but their displacements are in a few tens of meters, and beds can usually be matched across them. I estimate that the accuracy of the thickness of the entire section is approximately \pm 150 $\mathrm{m}$. Bottom of the highest section at $3,603 \mathrm{~m}$ altitude in gully west of $4,036-\mathrm{m}$ peak on the East Snowmass-Willow Creek divide; section south side of gully on a N. $70^{\circ} \mathrm{E}$. trend. Section measured by Bruce Bryant and E. S. Grew]

\section{Thickness} (meters)

Morrison Formation (part):

316. Limestone, gray; contains charophytes .........

315. Sandstone, light-greenish-gray, calcareous; contains lenses of gray limestone and of gray and mottled red, white, and gray chert.............

314. Siltstone, calcareous; weathers yellowish gray ....

313. Limestone, medium-gray; clastic grains of gray limestone and a few of quartz ..............

312. Sandstone, calcareous; weathers light gray $(N 7)$ and yellowish gray (5 $Y$ 8/1); bedding irregular; grades upward to limestone ...............

311. Sandstone, medium-bluish-gray (5 $B 5 / 1)$, calcareous; weathers yellowish gray; beds $0.3 \mathrm{~m}$ and less separated by medium-gray $(N 5)$ to medium-darkgray $(N 4)$ shaly siltstone, silty shale, and shaly limestone beds $8-20 \mathrm{~cm}$ thick .............

Partial thickness of Morrison Formation ..... 16.3

Entrada Sandstone :

310. Sandstone, yellowish-gray, crossbedded, poorly sorted; grain size $4 \mathrm{~mm}$ in coarser beds ..........

309. Quartzite, very light gray $(N 9)$ to yellowish-gray (5 $Y 8 / 1$ ), crossbedded, thinly laminated; contains rounded grains of quartz, gray and moderate-red chert, and rare grains of feldspar as much as $1 \mathrm{~cm}$ in diameter . . . . . . . . . . . . . . . . . . . . . .

Thickness of Entrada Sandstone

Unconformity

Chinle Formation:

308. Covered; grayish-brown (5 YR 3/2) siltstone and calcareous siltstone float ..................

307. Conglomerate, limestone-pebble, mottled pale-red (5 $R 6 / 2$ ) to grayish-red $(10 R 4 / 2)$ and lightgreenish-gray (5 $G Y$ 8/1); pebbles as much as 2.5

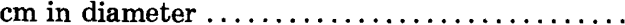

306. Covered; bench $\ldots \ldots \ldots \ldots \ldots \ldots \ldots \ldots \ldots \ldots \ldots \ldots, 17.7$ Thickness of Chinle Formation ..........

Unconformity

Maroon Formation:

305. Siltstone, thin-bedded; fine-grained sandstone .... 304. Sandstone, pale-reddish-brown, fine-grained, thinbedded; carbonized plant fragments ...........
SECTION 2.-Morrison Formation (part), Entrada Sandstone, Chinle Formation, Maroon Formation, and Gothic Formation (part) of Langenheim (1952)-Continued

Thickness (meters)

Maroon Formation-Continued

303. Sandstone, fine-grained, siltstone, calcareous; beds $2.5-30 \mathrm{~cm} . \ldots \ldots \ldots \ldots \ldots \ldots \ldots \ldots \ldots . \ldots \ldots$

302. Arkose, dark-reddish-brown, calcareous, micaceous; contains fragments of siltstone as much as $2 \mathrm{~cm}$ in diameter ...........................

301. Arkose and siltstone, moderate-reddish-brown .... 300. Arkose, calcareous, micaceous, crossbedded, thinly laminated, fine- to medium-grained ............

299. Siltstone and fine-grained arkose, moderate to dark-reddish-brown, calcareous, micaceous .....

298. Arkose, dark-reddish-brown to moderate-reddishbrown, calcareous, micaceous, crossbedded; contains heavy-mineral partings, fragments of siltstone to $2.5 \mathrm{~cm}$ length ..................

297. Siltstone and fine- to medium-grained calcareous and micaceous arkose; graded bedding; some sandstones thinly laminated; some crossbedded; chippy-weathering siltstone forms benches. Analyzed sample MA440 of sandy siltstone from this interval (table 3, col. 5) ................ 143.3

296. Arkose, moderate-reddish-brown to dark-reddishbrown, calcareous, micaceous, fine- to mediumgrained; beds $2.5-90 \mathrm{~cm}$ thick; a few interbeds of siltstone ............................

295. Arkose, dark-reddish-brown, coarse-grained, calcareous; contains beds of crossbedded pebble and cobble conglomerate as much as $0.6 \mathrm{~m}$ thick; cobbles of Precambrian rock as much as $15 \mathrm{~cm}$ in diameter; grades to overlying unit .............

294. Arkose, dark-reddish-brown, calcareous, micaceous, fine- to medium-grained; graded bedding; scattered beds of dark-reddish-brown to moderatereddish-brown calcareous, chippy-weathering siltstone ...........................

293. Arkose, dark-reddish-brown to moderate-reddishbrown (10 $R 4 / 6)$, calcareous, micaceous; a few thin beds contain pebbles of Precambrian rock..

292. Conglomerate and arkose; conglomerate in beds 2.5-25 cm thick; pebbles of Precambrian rock as much as $11 \mathrm{~cm}$ in diameter; irregular light-gray to white bleached zone ....................

291. Arkose, dark-reddish-brown (10 $R$ 3/4), calcareous, micaceous, medium- to coarse-grained; beds 1.2-20 cm, crossbedded; a few thin beds containing pebbles of Precambrian rock .............

[This bed approximately projected to top of section measured starting at gully at about $3,710 \mathrm{~m}$ altitude northwest of saddle south of $3,986-\mathrm{m}$ peak on Willow Creek-East Snowmass Creek ridge just north of the south boundary of the Maroon Bells quadrangle; trend of section about N. $35^{\circ} \mathrm{E}$., top of section is at gully to north where small unmapped fault is located]

290. Arkose, moderate-reddish-brown, crossbedded, thin-bedded, coarse- to fine-grained ...........

289. Siltstone, moderate-reddish-brown, calcareous ....

288. Arkose, pale-red, thin-bedded, crossbedded; some pebble beds and lenses of conglomerate .........

287. Arkose, moderate-reddish-brown, silty, fine- to medium-grained..$\ldots \ldots \ldots \ldots \ldots \ldots \ldots \ldots$

286. Arkose, moderate-red, massive-weathering; scattered pebbles $2.5 \mathrm{~cm}$ in diameter ............
17.4 
Section 2.-Morrison Formation (part), Entrada Sandstone, Chinle Formation, Maroon Formation, and Gothic Formation (part) of Langenheim (1952)-Continued

Maroon Formation - Continued

285. Arkose, moderate-red (5 $R 5 / 4$ ), medium- to finegrained, thin-bedded, crossbedded; some muddy partings and siltstone beds

284. Arkose, pale-reddish-brown to moderate-red (5 $R$ $5 / 4)$, coarse-grained ......................

283. Arkose, moderate-reddish-brown, fine-grained ....

282. Arkose, moderate-red (5 $R$ 5/4), coarse-grained; $2.5-5-\mathrm{cm}$ bleached lenses and stringers .........

281. Arkose, medium-grained ................... 280. Arkose, dark-reddish-brown, fine-grained, silty, calcareous, micaceous ....................

279. Arkose, moderate-reddish-brown, coarse-grained, crossbedded

Thickness 6

[This bed projected to top of section with top at contact of Tertiary porphyritic granodiorite body at 3,992 $\mathrm{m}$ altitude east of pass at head of East Snowmass Creek and bottom at about $3,880 \mathrm{~m}$ east side of pass, Maroon Bells quadrangle. Trend of section N. $70^{\circ} \mathrm{E}$. Colors may be slightly modified by contact metamorphism near porphyritic granodiorite contact]

278. Arkose, coarse-grained, crossbedded; scattered pebbles; a few siltstone beds ................

277. Arkose, pale-reddish-brown, thin-bedded, calcareous, fine- to medium-grained ................

276. Arkose, coarse-grained, crossbedded; conglomerate-filled channels as much as $1 \mathrm{~m}$ thick contain cobbles of Precambrian rock and of siltstone as much as $23 \mathrm{~cm}$ in diameter................

275. Arkose, medium- to fine-grained, silty ..........

274. Arkose, grayish-red (5 $R 4 / 2$ ), coarse-grained, crossbedded; contains channel conglomerates as much as $0.6 \mathrm{~m}$ thick containing cobbles of Precambrian rock as much as $13 \mathrm{~cm}$ in diameter .............

273. Arkose, moderate- to dark-reddish-brown, finegrained, thin-bedded ....................

272. Arkose, dusky-red, medium- to coarse-grained, calcareous, micaceous .....................

[This bed projected to the top of the 3,959-m peak on the divide between Snowmass Creek and East Snowmass Creek in the Highland Peak quadrangle where top of this part of section is located; bottom is in the Maroon Bells quadrangle at $3,627 \mathrm{~m}$ on northeast side main gully southwest of the $3,959-\mathrm{m}$ peak]

271. Arkose, thin-bedded, fine-grained ............. 270. Arkose, grayish-red, coarse-grained, crossbedded .

269. Siltstone and fine-grained thin-bedded arkose, dark- to moderate-reddish-brown; locally moderate reddish orange and dusky red; grades to unit below

268. Arkose, moderate- to pale-reddish-brown finegrained to pale-red coarse-grained, calcareous, micaceous, some thin moderate-reddish-brown calcareous siltstone beds. Analyzed sample MB1042 (table 3, col. 4) is arkose from this material ..............................

267. Arkose, pale-reddish-brown, fine-grained, calcare-

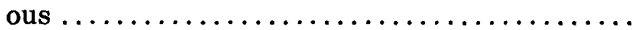

266. Arkose, pale-red, coarse-grained, crossbedded; contains channel conglomerates and scattered pebbles and cobbles as much as $15 \mathrm{~cm}$ in diameter...
SEction 2.-Morrison Formation (part), Entrada Sandstone, Chinle Formation, Maroon Formation, and Gothic Formation (part) of Langenheim (1952)-Continued

\section{Thickness} (meters)

Maroon Formation-Continued

265. Arkose, moderate-reddish-orange, fine-grained, calcareous, thin-bedded, crossbedded ...........

264. Arkose, coarse- to medium-grained, thin-bedded, crossbedded, calcareous, micaceous ...........

263. Arkose and siltstone, pale-reddish-brown, finegrained, calcareous ......................

262. Arkose, coarse-grained; contains scattered pebbles of Precambrian rock; quartz, chert, and brown siltstone as much as $5 \mathrm{~cm}$ in diameter; massiveweathering bedding units have internal beds $1.2-5 \mathrm{~cm}$ thick and crossbedding; channel conglomerates as much as $1 \mathrm{~m}$ thick .............

261. Arkose, medium-grained .................

260. Arkose, pale-reddish-brown (10 $R$ 5/4), fine- to medium-grained, calcareous ................

259. Arkose, coarse-grained, calcareous, micaceous; pebble conglomerate in channels $15 \mathrm{~cm}$ thick ....

258. Siltstone, moderate-reddish-orange, calcareous; lenses out to southeast ..................

257. Arkose, dusky-red, crossbedded, coarse-grained; channel conglomerate at base cuts into underlying unit .............................

256. Arkose, pale-reddish-brown, silty, calcareous, finegrained; irregular beds; grayish-red thinly laminated arkose .......................

255. Arkose and conglomerate, pale-red to moderatered; conglomerate beds generally $15-30 \mathrm{~cm}$ thick and contain pebbles $2.5-5 \mathrm{~cm}$ in diameter; crossbedded; pebbles and cobbles locally scattered in arkose; maximum cobble size $15 \mathrm{~cm} . .$. .

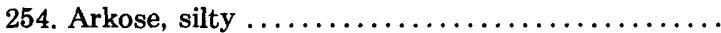

253. Arkose, medium- to coarse-grained, calcareous, micaceous, crossbedded; beds of conglomerate containing pebbles and cobbles of Precambrian rock as much as $15 \mathrm{~cm}$ in diameter; a few duskyred muddy partings ......................

252. Arkose, thin-bedded, silty .................

251. Arkose, dusky-red and dark-reddish-brown, calcareous, micaceous; contains lenses of pebble conglomerate as much as $0.6 \mathrm{~m}$ thick and $3.8 \mathrm{~m}$ long; some arkose beds thin bedded and crossbedded .

250. Arkose, medium- to fine-grained, crossbedded, micaceous, thin-bedded; grades to underlying

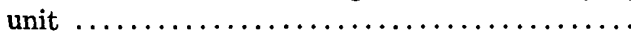

249. Arkose, silty, fine-grained, crossbedded .........

248. Arkose, medium-grained, thin-bedded, crossbedded; contains a $0.6 \cdot \mathrm{m}$ bed of coarse-grained arkose and conglomerate containing pebbles of Precambrian rock.......................

247. Arkose, moderate-reddish-brown, silty, calcareous; bedding obscure .......................

246. Arkose, dusky-red (5 $R$ 3/4), moderate-reddishbrown (10 $R 4 / 6)$ to dusky-brown, calcareous, micaceous, medium- to coarse-grained, thinly laminated, crossbedded; contains a few pebble beds, beds of silty arkose, and muddy partings . .

245. Arkose, silty, fine-grained ...................

244. Arkose, dusky-red (5 $R$ 3/4), calcareous, micaceous; irregular bedding 
SECTION 2.-Morrison Formation (part), Entrada Sandstone, Chinle Formation, Maroon Formation, and Gothic Formation (part) of Langenheim (1952)-Continued

[Following interval calculated by tracing beds in the field and on aerial and ground photographs and by dip. Much of this interval is exposed on the Maroon Bells and the rugged ridge to the north where measurement on the ground would be difficult]

Maroon Formation-Continued 243. Calculated interval

['Top of section is on peak at 4,026 m altitude in the Snowmass Mountain quadrangle south. west of Belleview Mountain; bottom is at about $3,841 \mathrm{~m}$ altitude on ridge northwest of West Maroon Pass, Maroon Bells quadrangle. Section is on or near ridge crest]

242. Arkose, pale-red, coarse-grained; channel conglomerate and scattered pebbles; pebbles to $10 \mathrm{~cm}$ in diameter; gray limestone makes up 50 percent of the pebbles

241. Arkose, dark-reddish-brown, fine-grained .........

240. Siltstone, moderate-red to dusky-red, calcareous, micaceous ...........................

239. Arkose and channel conglomerate; gray limestone pebbles predominant....................

238. Siltstone and arkose, dark-reddish-brown; grades to underlying unit ......................

237. Arkose, pale-red, coarse-grained, pebbly ..........

236. Arkose and siltstone ......................

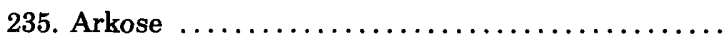

234. Conglomerate; cobbles to $15 \mathrm{~cm}$ in diameter; gray limestone makes up 50 percent of cobbles .......

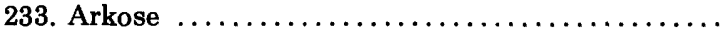

232. Siltstone and silty limestone .................

231. Arkose, grayish-red (10 $R$ 4/2), coarse-grained, crossbedded $\ldots \ldots \ldots \ldots \ldots \ldots \ldots \ldots \ldots \ldots$.

230. Siltstone and silty limestone ..................

229. Arkose, coarse-grained; contains $0.3-\mathrm{m}$ bed of channel conglomerate containing limestone $(50$ percent) and dolomite (20 percent) pebbles .........

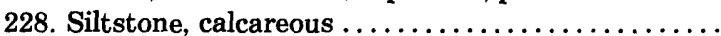

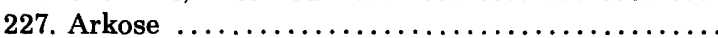

226. Siltstone, very calcareous .................

225. Limestone, grayish-red to gray, silty and sandy ...

224. Siltstone, calcareous .......................

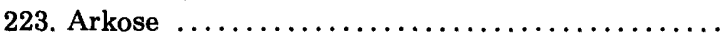

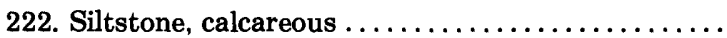

221. Arkose, pale-reddish-brown to moderate-reddishbrown, fine-grained; contains $0.3 \mathrm{~m}$ gray limestone pebble bed .....................

220. Arkose, coarse-grained .....................

219. Siltstone, pale-brown, calcareous ..............

218. Limestone, light-brownish-gray to light-olive-gray,

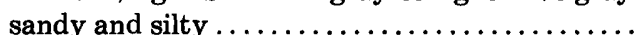

217. Arkose, fine-grained; siltstone interbeds .........

216. Siltstone containing beds of silty limestone as much as $8 \mathrm{~cm}$ thick; grades to underlying unit...

215. Arkose, grayish-red to moderate-reddish-brown, calcareous, micaceous, silty

214. Siltstone, grayish-red (5 $R 4 / 2)$ calcareous: contain $0.3-\mathrm{m}$ beds of light-greenish-gray-weathering olive-gray silty limestone ..................

213. Arkose, fairly coarse grained; contains scattered pebble beds as much as $15 \mathrm{~cm}$ thick; 50 percent of the pebbles are gray limestone ...............

212. Siltstone and fine-grained arkose; calcareous .......

211. Arkose, grayish-red, fairly coarse grained ........

SECTION 2.-Morrison Formation (part), Entrada Sandstone, Chinle Formation, Maroon Formation, and Gothic Formation (part) of Langenheim (1952)-Continued

Maroon Formation-Continued

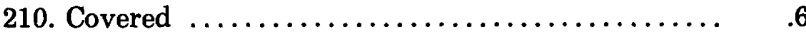

209. Arkose, coarse-grained .................... 2.7

208. Arkose and siltstone ................... 6

207. Arkose, pale-red to light-gray; grades to grayish red and dark reddish brown ................

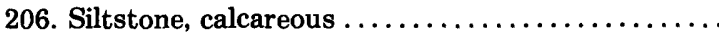

205. Arkose, light-red, coarse-grained; scattered pebbles and a $0.3-\mathrm{m}$ pebble bed containing Precambrian rock (40 percent) and gray and white limestone (40 percent) . . . . . . . . . . . . . . .

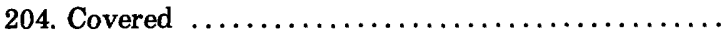

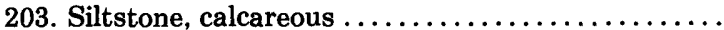

202. Arkose, pale-red, grayish-red to dark-reddishbrown; contains a few pebbles ...............

201. Siltstone, moderate-reddish-brown, calcareous ....

200. Arkose, pale-red; a few pebbles near base; upper part dusky red, calcareous, and micaceous; contains a $10-\mathrm{cm}$ pebble bed in which 40 percent of the pebbles are gray limestone...$\ldots \ldots \ldots \ldots$.

199. Siltstone, moderate-reddish-brown, calcareous ....

198. Arkose, pale-red (10 $R 6 / 2$ ), coarse-grained ........

197. Arkose and siltstone, grayish-red, moderate-reddish-orange to moderate-reddish-brown; calcareous . . . . . .....................

meters

196. Arkose, fine-grained

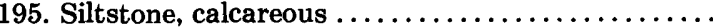

194. Arkose, grayish-red, calcareous . . . . . . . . . . . .

193. Siltstone, gray, calcareous . . . . . . . . . . . . . .

192. Limestone, medium-gray, light-gray- to yellowish gray-weathering, silty ...................

191. Siltstone and fine-grained arkose; calcareous ......

190. Siltstone, calcareous . . ...................

189. Arkose, fine-grained, crossbedded .............

188. Siltstone, calcareous; contains a few lenses of silty limestone $\ldots \ldots \ldots \ldots \ldots \ldots \ldots \ldots \ldots .$.

187. Arkose, fine-grained, crossbedded .............

186. Siltstone, grayish-red, hackly weathering, calcare-

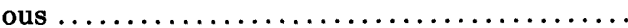

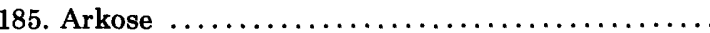

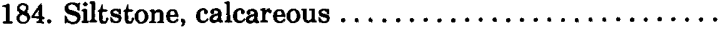

183. Arkose, grayish-red, fine-grained, crossbedded ....

182. Siltstone.$\ldots \ldots \ldots \ldots \ldots \ldots \ldots \ldots \ldots \ldots \ldots \ldots \ldots$

181. Limestone, light-brownish-gray to light-olive-gray, silty, grades downward to siltstone ............

180. Siltstone . . . . . . . . . . . . . . . . . . . . . .

179. Arkose, grayish-red (5 $R 4 / 2$ ), crossbedded; few siltstone beds and partings of dark-reddish brown mudstone..$\ldots \ldots \ldots \ldots \ldots \ldots \ldots$.

178. Arkose, pale- to moderate-reddish-brown, calcareous, micaceous, fine-grained, silty and muddy ...

177. Siltstone and limestone, light-olive-gray, sandy, grades downward to siltstone ................

176. Arkose, grayish-red, crossbedded ..............

175. Limestone, light-brownish-gray, silty; grades downward to siltstone $\ldots \ldots \ldots \ldots \ldots \ldots \ldots \ldots \ldots$

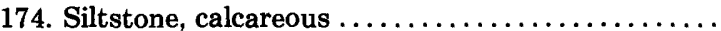

173. Arkose, light-brownish-gray to moderately reddish brown, calcareous 
SECTION 2.-Morrison Formation (part), Entrada Sandstone, Chinle Formation, Maroon Formation, and Gothic Formation (part) of Langenheim (1952)-Continued

Maroon Formation-Continued

172. Arkose, pale-red, grayish-red to moderate-reddish brown, crossbedded, medium- to coarse-grained contains channel conglomerates as much as 30 cm thick; pebbles of Precambrian rock dominant in one bed; gray limestone in others ...........

171. Siltstone, moderate-reddish-brown, calcareous ....

170. Conglomerate; gray limestone pebbles dominant . .

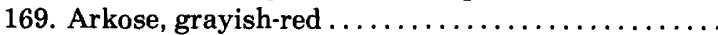

168. Limestone and calcareous siltstone ............

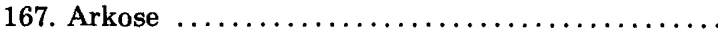

166. Limestone, grayish-red to light-brownish-gray, silty $\ldots \ldots \ldots \ldots \ldots \ldots \ldots \ldots \ldots \ldots . \ldots \ldots \ldots$

165. Arkose, pale-red to light-gray; channel conglomerate as much as $30 \mathrm{~cm}$ thick at base composed of pebbles of gray limestone (60 percent), Precambrian rock (15 percent), and sandstone, dolomite, and quartz (25 percent) as much as $13 \mathrm{~cm}$ in diameter .............................

164. Siltstone, grayish-red, calcareous; grades downward to limestone ......................

163. Limestone, light-gray; contains lenses and beds of pale-red silty limestone ...................

162. Arkose, grayish-red, coarse-grained, crossbedded .

161. Arkose, pale-red, calcareous ..................

160. Limestone, grayish-red- and light-olive-gray-mottled, silty $\ldots \ldots \ldots \ldots \ldots \ldots \ldots \ldots \ldots \ldots \ldots$

159. Siltstone, grayish-red, calcareous; grades to calcareous medium- to coarse-grained arkose ......

[Bottom of section at about 3,84I m altitude on ridge south of Belleview Peak on projection of beds from top of peak south of West Maroon Pass. Section is continued from top of that peak S. $60^{\circ} \mathrm{W}$. along ridge to east end of 3,853-m knob in Snowmass Mountain quadrangle, south down slope]

158. Arkose, grayish-red and pale-red; contains pebbles and beds of pebble conglomerate in which gray limestone is the dominant rock type ...........

157. Covered; probably siltstone ..................

156. Arkose, grayish-red, calcareous, micaceous, thinly

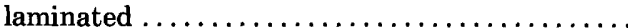

155. Siltstone, moderate-reddish-brown, calcareous, micaceous; contains lenses and beds of grayishred to brownish-gray to light-olive-gray calcareous siltstone and one bed of arkose ......

154. Arkose, grayish-red ......................

153. Limestone, light-brownish-gray, silty; a mediumgray limestone bed $2.5-8 \mathrm{~cm}$ thick at top .......

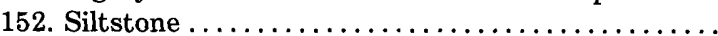

151. Arkose, grayish-red to pale-red, crossbedded; contains local channel conglomerates as much as $1 \mathrm{~m}$ thick composed of gray limestone ( 60 percent), Precambrian rocks (15 percent), quartz, chert, and dolomite (25 percent), and a few beds of siltstone .............................

150. Siltstone and fine-grained arkose, moderate-reddish-brown, calcareous, micaceous ............

149. Arkose, pale-red .........................

148. Siltstone, moderate-reddish-brown, calcareous, micaceous; contains lenses of arkose ...........
SECTION 2.-Morrison Formation (part), Entrada Sandstone, Chinle Formation, Maroon Formation, and Gothic Formation (part) of Langenheim (1952)-Continued

\section{Maroon Formation-Continued}

Thickness (meters)

147. Arkose, grayish-red, fairly coarse grained, micaceous, calcareous; contains channel conglomerate with cobbles of gray limestone as much as $20 \mathrm{~cm}$

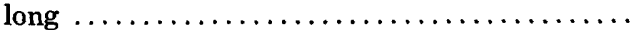

146. Limestone, medium-gray, thin-bedded, silty, and grayish-red calcareous micaceous siltstone......

145. Siltstone, grayish-red to dark-reddish-brown, micaceous, calcareous; contains lenses and irregular beds of medium-gray silty limestone ..........

144. Limestone, gray, silty; grades downward to arkose 143. Arkose, grayish-red and pale-red, coarse-grained, calcareous, micaceous; contains a few pebbles of gray limestone..$\ldots \ldots \ldots \ldots \ldots \ldots \ldots \ldots$.

142. Siltstone $\ldots \ldots \ldots \ldots \ldots \ldots \ldots \ldots \ldots \ldots \ldots \ldots \ldots$ 141. Limestone, medium-gray; grades downward to siltstone $\ldots \ldots \ldots \ldots \ldots \ldots \ldots \ldots \ldots \ldots \ldots \ldots$

140. Siltstone, calcareous ......................

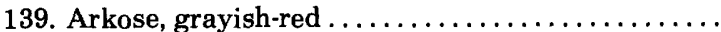

138. Siltstone, moderate-reddish-brown to dark-reddishbrown, calcareous; grades downward to arkose..

137. Arkose, grayish-red, coarse-grained, crossbedded; contains channel conglomerate in which 30 percent of the pebbles are gray limestone .........

136. Limestone, medium- to dark-gray; grades downward to siltstone ........................

135. Siltstone, grayish-red, calcareous ..............

134. Arkose, grayish-red, crossbedded; contains $15-\mathrm{cm}$ pebble bed; 50 percent of pebbles are gray limestone..$\ldots \ldots \ldots \ldots \ldots \ldots \ldots \ldots \ldots \ldots$.

133. Siltstone, grayish-red and dark-reddish-brown, calcareous; contains a thin bed of pale-olive sandstone ...............................

132. Siltstone; calcareous and sandy limestone, lightolive-gray; weathers pale yellowish orange ......

131. Arkose, gray to grayish-red and pale-red, coarsegrained $\ldots \ldots \ldots \ldots \ldots \ldots \ldots \ldots \ldots \ldots \ldots \ldots$

130. Limestone, light-gray to medium-gray, silty .......

129. Siltstone, calcareous; a few beds of arkose ........

128. Limestone, pale-red (5 $R 6 / 2$ ), silty; grades to siltstone, sandstone, and gray limestone-pebble channel conglomerate ....................

127. Arkose, grayish-red, coarse-grained ............. 126. Limestone, medium-gray, pale-yellowish-brownweathering, thin-bedded, silty .............

125. Arkose and conglomerate, grayish-red; crossbedded conglomerate beds $15 \mathrm{~cm}$ thick composed of pebbles of gray limestone ( 50 percent); a few beds of grayish-red to moderate-reddish-brown calcareous siltstone ......................

124. Arkose and siltstone containing lenses of lime-

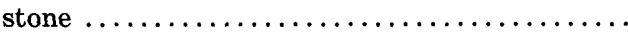

123. Siltstone containing $2.5-5 \mathrm{~cm}$ lenses of brownishgray to medium-gray silty limestone ...........

122. Siltstone; grades to coarse-grained, crossbedded, grayish-red, calcareous, micaceous arkose. Analyzed sample ME1978 of arkose (table 3, col.

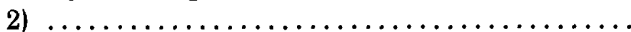


SECTION 2.-Morrison Formation (part), Entrada Sandstone, Chinle Formation, Maroon Formation, and Gothic Formation (part) of Langenheim (1952)-Continued

Maroon Formation-Continued

121. Siltstone, calcareous; contains scattered lenses of

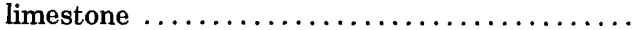

120. Limestone, medium-dark-gray ...............

119. Siltstone, pale-red to grayish-red (10 $R$ 4/2) grades to conglomerate containing $2.5-\mathrm{cm}$ pebbles of gray limestone $\ldots \ldots \ldots \ldots \ldots \ldots \ldots \ldots \ldots$

118. Arkose, grayish-red; silty arkose ..............

117. Limestone, greenish-gray (5 $G Y$ 6/1), thin-bedded; grades to grayish-red calcareous siltstone.......

116. Arkose, grayish-red ........................

115. Siltstone, grayish-red, calcareous, micaceous; contains a few beds of sandstone ..............

114. Arkose, grayish-red, crossbedded ..............

113. Siltstone, dark-reddish-brown, calcareous, muddy; contains round globs of grayish-red very calcareous siltstone as much as $30 \mathrm{~cm}$ long......

112. Siltstone, grayish-red, calcareous ..............

111. Arkose, grayish-red, coarse-grained, crossbedded; contains local channel conglomerates as much as $1 \mathrm{~m}$ thick containing cobbles as much as $13 \mathrm{~cm}$ in diameter; cobbles composed of gray limestone (50 percent), dolomite (15 percent), Precambrian metamorphic and plutonic rocks (15 percent); quartz, sandstone, and chert (20 percent) .......

110. Limestone, medium-light-gray, silty, lenticular ....

109. Arkose, grayish-red, micaceous, calcareous, finegrained

108. Arkose, light-gray, crossbedded, coarse-grained ...

107. Arkose and siltstone, grayish-red to reddishbrown, calcareous. Separated from underlying siltstone by a Tertiary porphyritic granodiorite dike $(14.3 \mathrm{~m}$ thick $) . \ldots \ldots \ldots \ldots \ldots \ldots \ldots \ldots$

106. Siltstone, grayish-red $(10 R 4 / 2)$ to dark-reddishbrown; contains a few beds of grayish-red arkose

105. Arkose, light-gray to pale-red and grayish-red,

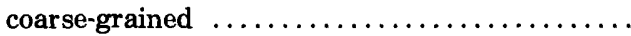

104. Siltstone, dark-reddish-brown, calcareous, micaceous..$\ldots \ldots \ldots \ldots \ldots \ldots \ldots \ldots \ldots \ldots$.

103. Siltstone, light-greenish-gray (5 $G 8 / 1$ ), calcareous; to medium-gray silty limestone ............

102. Arkose, light-olive-gray, calcareous; contains beds of sandy and silty limestone $1.2-10 \mathrm{~cm}$ thick... .

101. Limestone, siltstone, and light-olive-gray calcareous arkose; beds of sandy and silty limestone

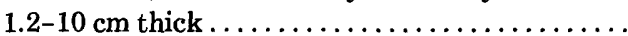

100. Limestone, medium-dark-gray; contains sandy and

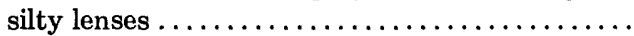

99. Siltstone, calcareous; grades downward to limestone $\ldots \ldots \ldots \ldots \ldots \ldots \ldots \ldots \ldots \ldots \ldots$

98. Limestone, medium-dark-gray, silty ..........

97. Arkose, pale-red to medium-light-gray, coarsegrained; grades downward to arkose ............

96. Arkose, moderate-reddish-brown; grades downward to grayish-red arkose .................

95. Arkose, grayish-red; grades downward to siltstone

94. Siltstone, grayish-red (10 $R 4 / 2)$, muddy, calcareous $\ldots \ldots \ldots \ldots \ldots \ldots \ldots \ldots \ldots \ldots \ldots \ldots$.
Section 2.-Morrison Formation (part), Entrada Sandstone, Chinle Formation, Maroon Formation, and Gothic Formation (part) of Langenheim (1952)-Continued (meters)
(mickness

Maroon Formation-Continued

93. Arkose, grayish-red (5 $R 4 / 2$ ), crossbedded, finegrained..$\ldots \ldots \ldots \ldots \ldots \ldots \ldots \ldots \ldots \ldots \ldots$

92. Arkose, light-olive-gray to pale-red; contains a 0.3 -cm thick pebble bed in which gray limestone is the predominant rock type $\ldots \ldots \ldots \ldots \ldots \ldots$.

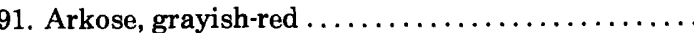

90. Siltstone, dark-reddish-brown, calcareous ........

89. Arkose, grayish-red to medium-gray, calcareous, crossbedded..$\ldots \ldots \ldots \ldots \ldots \ldots \ldots \ldots \ldots$.

88. Siltstone, light-olive-gray, thin-bedded, calcareous

87. Arkose, grayish-red, silty, calcareous ...........

86. Arkose, medium-gray to brownish-gray, moderateyellowish-brown-weathering, thin-bedded,

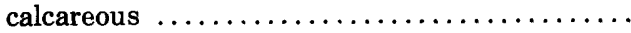

85. Siltstone and limestone, medium-gray, thinbedded..$\ldots \ldots \ldots \ldots \ldots \ldots \ldots \ldots \ldots \ldots \ldots \ldots \ldots$.

84. Siltstone and mudstone, grayish-red and darkreddish-brown, calcareous ...................

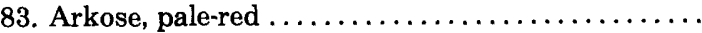

82. Siltstone, grayish-red (5 $R 4 / 2)$, calcareous .......

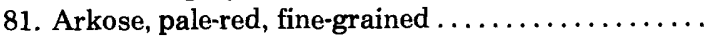

80. Arkose, light-olive-gray, pale-yellowish-orangeweathering, calcareous .....................

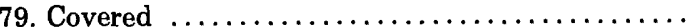

78. Arkose, medium-light-gray to medium-dark-gray ..

77. Siltstone, medium-light-gray to medium-dark-gray, pale-yellowish-orange-weathering, thin-bedded, calcareous

hicknes (meters)

4.6

1.5

1.2

5.7

6.1

2.1

4.0

.6

1.5

2.7

1.2

76. Covered; probably mainly siltstone; a bed of lightgray silty limestone crops out ..............

75. Arkose, pale-red to light-gray, pale-grayish-orangeweathering, calcareous, micaceous. Analyzed sample ME1198 (table 3, col. 3) .............

74. Arkose, calcareous; grades to light-olive-gray, pale-yellowish-orange-weathering silty limestone

73. Arkose, pale-yellowish-brown, calcareous; some finer grained grayish-red beds . . . . . . . . . . .

72. Arkose, grayish-orange, calcareous .............

71. Limestone, grayish-orange, silty ..............

70. Arkose, moderate-yellowish-brown (10 $G R$ 5/4), calcareous ...........................

69. Siltstone and shaly siltstone, dark-reddish-brown, thin-bedded

68. Hornfels from siltstone Separated from underlying sandstone by $16.8-\mathrm{m}$-thick Tertiary porphyritic granodiorite dike .................

67. Somewhat hornfelsized fine-grained calcareous sandstone ............................

66. Arkose, pale-red to grayish-red, coarse-grained, thinly laminated, micaceous, calcareous; contains gray limestone pebbles in some beds ...........

65. Arkose, grayish-yellow, coarse-grained ..........

64. Arkose, grayish-red, thin-bedded, calcareous, micaceous.$\ldots \ldots \ldots \ldots \ldots \ldots \ldots \ldots \ldots \ldots \ldots \ldots$.

63. Arkose, coarse-grained; scattered pebbles ........

62. Arkose, grayish-red, calcareous; grades downward to limestone...$\ldots \ldots \ldots \ldots \ldots \ldots \ldots \ldots$. 
SECTION 2.-Morrison Formation (part), Entrada Sandstone, Chinle Formation, Maroon Formation, and Gothic Formation (part) of Langenheim (1952)-Continued

Maroon Formation-Continued

61. Limestone, medium-light-gray and light-brownishgray, thinly laminated $\ldots \ldots \ldots \ldots \ldots \ldots \ldots \ldots$.

60. Arkose and siltstone, grayish-red (10 $R$ 4/2), calcareous, micaceous .....................

59. Limestone, silty $\ldots \ldots \ldots \ldots \ldots \ldots \ldots \ldots \ldots \ldots \ldots$

58. Arkose and siltstone, grayish-red .............

57. Arkose, grayish-red, coarse-grained; contains a pebble bed $\ldots \ldots \ldots \ldots \ldots \ldots \ldots \ldots \ldots \ldots$.

56. Siltstone, grayish-red to dark-reddish-brown ......

55. Arkose, grayish-red, fairly coarse grained .........

54. Siltstone, grayish-red to dark-reddish-brown, calcareous ............................

53. Arkose, grayish-red, fairly coarse grained .........

52. Conglomerate; maximum pebble size $5 \mathrm{~cm}$; pebbles gray limestone (50 percent), brown dolomite (15 percent); Precambrian metamorphic and plutonic rocks (20 percent) quartz, chert and others (15

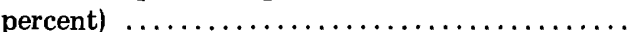

51. Siltstone, grayish-red, calcareous $\ldots \ldots \ldots \ldots \ldots$

50. Arkose, pale-red (5 $R$ 6/2); and grayish-red (5 $R$ $4 / 2$ ) fine-grained arkose and siltstone ..........

49. Limestone and calcareous siltstone, mediumgray, pale-yellowish-orange-(10 $Y R \quad 8 / 6)$-weather-

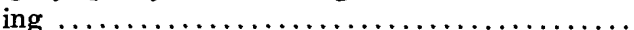

48. Arkose, grayish-red, coarse-grained, thinly laminated..$\ldots \ldots \ldots \ldots \ldots \ldots \ldots \ldots \ldots \ldots \ldots$

47. Siltstone, grayish-red $(10 R 4 / 2)$, micaceous, calcareous ..............................

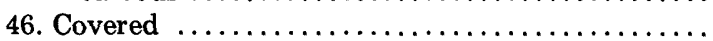

45. Arkose, pale-red, coarse-grained, crossbedded; contains a few beds of grayish-red $(10 R \quad 4 / 2)$ calcareous siltstone .......................

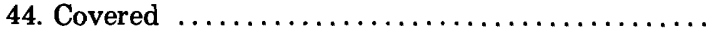

43. Arkose, pale-red, coarse-grained; contains scattered pebbles ..........................

42. Arkose, grayish-red, fine-grained; a few mudstone partings $\ldots \ldots \ldots \ldots \ldots \ldots \ldots \ldots \ldots \ldots \ldots \ldots \ldots$.

41. Arkose, grayish-red (10 $R$ 4/2) and light-gray, medium-grained ........................

40. Arkose; contains limestone-pebble conglomerate with lesser amounts of Precambrian rock, quartz, chert, jasper, and dolomite; pebbles to $5 \mathrm{~cm}$ in diameter ...........................

39. Siltstone, grayish-red (5 $R 4 / 2$ ), pale-red- to lightred-weathering, calcareous; grades downward to limestone .............................

38. Limestone, medium-light-gray; chemical analysis sample ME642 (table 3, col. 1) ...............

37. Arkose, moderately light gray to grayish-red (5R 4/2), thin-bedded

36. Arkose, grayish-red, fine-grained, calcareous ......

35. Siltstone, dark-reddish-brown to grayish-red (10 $R$ 4/2), thin-bedded, calcareous ...............

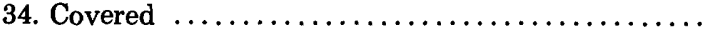

33. Arkose, pale-olive (10 Y 6/2), coarse-grained .......

32. Arkose, dusky-yellow $(5 Y 6 / 4) \ldots \ldots \ldots \ldots \ldots \ldots$.
SECTION 2.-Morrison Formation (part), Entrada Sandstone, Chinle Formation, Maroon Formation, and Gothic Formation (part) of Langenheim (1952)-Continued

Maroon Formation-Continued

31. Limestone, silty; lenses ...................

Thickness (meters)

30. Arkose, pale-red $(10 R 6 / 2)$ to grayish-red $(10 R 4 / 2)$; contains a few beds of dark-reddish-brown muddy arkose beds and numerous conglomerate beds 30 $\mathrm{cm}$ or less thick composed predominantly of gray limestone but also dolomite, quartzite, and Precambrian rock ......................

29. Mudstone, grayish-red; dark-reddish-brown partings; lenses of calcareous siltstone, thin-bedded

28. Arkose, grayish-red, thin-bedded, coarse-grained . .

27. Siltstone; contains lenses of limestone ...........

26. Arkose, pale-red $(10 R 6 / 2) \ldots \ldots \ldots \ldots \ldots \ldots \ldots$

25. Conglomerate; contains medium-gray limestone, white limestone, quartz, dolomite, and granitic pebbles as much as $10 \mathrm{~cm}$ in diameter .........

24. Arkose, thin-bedded, fine-grained to mediumgrained; muddy partings . . . . . . . . . . . . .

23. Siltstone, thin-bedded, calcareous ..............

22. Arkose, pale-red (5 $R$ 6/2), coarse-grained, calcareous, micaceous .......................

21. Siltstone, grayish-red, calcareous; contains lenses of limestone ...........................

20. Arkose and siltstone, pale-red (5 $R 6 / 2$ ), pale-reddish-brown-weathering, calcareous ...........

19. Arkose, grayish-red, pale-reddish-brown-weathering, medium-grained, calcareous, micaceous .....

18. Arkose, light-greenish-gray to greenish-gray, grayish-yellow weathering, coarse- to medium-grained

17. Siltstone and arkose, grayish-red, thin-bedded ....

16. Limestone and silty limestone, moderate-light-gray to reddish-gray; lensy beds .................

15. Arkose and siltstone with limestone lenses, grayish-red, pale-reddish-brown-weathering .........

14. Arkose, light-brownish-gray and brownish-gray, grayish-orange-weathering, fine-grained; lightbrownish-gray thin-bedded silty limestone ......

13. Siltstone, pale-reddish-brown, light-brownish-grayweathering, calcareous; contains grayish-red limestone lenses $0.5-8 \mathrm{~cm}$ thick and as much as $15 \mathrm{~cm}$ long, and medium-gray, grayish-orangeweathering calcareous siltstone containing lenses of limestone ............................

12. Covered (contact estimated by float) $\ldots \ldots \ldots \ldots \ldots, 29.9$

Thickness of Maroon Formation (rounded to nearest 10 meters) $\ldots \ldots \ldots \ldots \ldots \ldots \ldots \ldots, 3,170$

Gothic Formation of Langenheim (1952) (part):

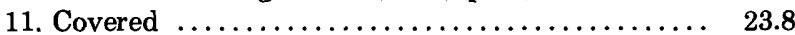

10. Arkose, light-greenish-gray to grayish-green, coarse-grained, calcareous; massive bed ........

9. Arkose, light-gray to olive-gray, calcareous, micaceous, coarse-grained, thin-bedded ............

8. Limestone, dark-gray .....................

7. Limestone, medium-gray, sandy .............
5.5

2.4 .6 
SECTION 2.-Morrison Formation (part), Entrada Sandstone, Chinle Formation, Maroon Formation, and Gothic Formation (part) of Langenheim (1952)-Continued

Gothic Formation of Langenheim (1952) (part)-Continued

6. Arkose, light-olive-gray, coarse-grained, calcareous, micaceous; contains a $10-\mathrm{cm}$ bed of darkgray siltstone $\ldots \ldots \ldots \ldots \ldots \ldots \ldots \ldots \ldots \ldots$.

5. Arkose, medium-gray, fine-grained to coarsegrained, calcareous; beds $0.5-20 \mathrm{~cm} \ldots \ldots \ldots \ldots$.

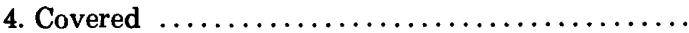

3. Shale, dark-gray, silty; contains beds of dark-gray light-gray-weathering shaly siltstone 0.3-1.2 m thick; only locally calcareous .........

2. Limestone, dark-gray; beds $1-15 \mathrm{~cm}$ thick; beds of micaceous silty shale ...................

1. Shale and siltstone, dark-gray, thin-bedded; some beds of micaceous arkose $5 \mathrm{~cm}$ thick and some silty limestone .......................... Partial thickness of Gothic Formation ....... 60.9

[Section ends at $3,383 \mathrm{~m}$ altitude in gully northwest of Rustler Gulch at east margin of Snowmass Mountain quadrangle]

SECTION 3.-Dakota Sandstone (part), Burro Canyon Formation, Morrison Formation, Entrada Sandstone, Chinle Formation, and State Bridge Formation

[Base of section at $3,191 \mathrm{~m}$ altitude and south of fault in steep gully on east side of East Snowmass Creek SE $1 / 4$ sec. 15, T. 10 S., R. 86 W., Highland Peak quadrangle. Azimuth of section about $\mathrm{S} .5^{\circ} \mathrm{E}$.; all of section is south of fault. Section measured by Bruce Bryant and S. G. Pollock]

Dakota Sandstone (part):

78. Siltstone, medium-gray, sandy; light-bluish-gray silty sandstone, and dark-gray shale ............

77. Sandstone, white to yellowish-gray, crossbedded; containing some lenses of quartz, chert, and feldspar granules ........................

76. Sandstone, light-bluish-gray, silty .............

75. Shale, dark-gray, silty ....................

74. Sandstone, white to yellowish-gray, medium-grained, grayish-orange-weathering, crossbedded; grains of dark-gray chert and pink feldspar; a few thin granule beds . . . . . . . . . . . . . . . . . . . . .

Partial thickness of Dakota Sandstone.......

Burro Canyon Formation:

73. Sandstone, very light gray, fairly fine grained, grayish-orange-weathering; scattered granules of quartz, chert, and feldspar; contains thin intervals of light-bluish-gray silty shale; sandstone beds

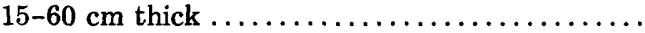

72. Sandstone, very light gray, fairly fine grained, grayish-orange-weathering; scattered granules of quartz, chert, and feldspar

71. Sandstone; same as above but contains thin interbeds of light-bluish-gray silty shale; sandstone beds $15-60 \mathrm{~cm}$ thick ......................

70. Sandstone, very light gray, fairly fine grained; grayish-orange-weathering; scattered granules of quartz, chert, and feldspar ................. (meters)
SECTION 3.-Dakota Sandstone (part), Burro Canyon Formation, Morrison Formation, Entrada Sandstone, Chinle Formation, and State Bridge Formation-Continued

Burro Canyon Formation-Continued

69. Conglomerate in white sandstone matrix; pebbles of quartz and chert to $1 \mathrm{~cm}$ in diameter; weathers grayish orange $\ldots \ldots \ldots \ldots \ldots \ldots \ldots \ldots \ldots, \quad 3.4$

Thickness of Burro Canyon Formation ....... 20.5

Morrison Formation:

68. Claystone and siltstone, interbedded and intergrading greenish-gray, grayish-red, to dusky-red and medium-bluish-gray; greens predominate; a few thin beds of fine-grained sandstone .............

67. Siltstone, interbedded greenish-gray and grayish-

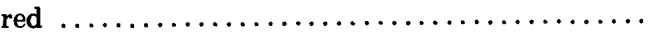

66. Claystone or siltstone, locally calcareous, mediumbluish-gray to grayish-red-mottled and interbedded; beds $0.3-1 \mathrm{~m}$ thick ....................

65. Siltstone, calcareous, interbedded grayish-red and greenish-gray; grades to grayish red locally mottled with green $\ldots \ldots \ldots \ldots \ldots \ldots \ldots \ldots \ldots \ldots$.

64. Sandstone, greenish-gray to medium-light-gray, fine-grained, calcareous . ..................

63. Siltstone, interbedded greenish-gray and grayishred; beds $2.5 \mathrm{~cm}$ to $1 \mathrm{~m}$ thick ................

62. Sandstone, greenish-gray (5 $G$ 6/1), fine-grained, calcareous .............................

61. Claystone, grayish-red with greenish-gray mottling -

60. Siltstone, grayish-red, calcareous ..............

59. Siltstone, grayish-red with some greenish-gray interbeds and mottling $\ldots \ldots \ldots \ldots \ldots \ldots \ldots \ldots \ldots$

58. Limestone, grayish-yellow-green, silty ...........

57. Siltstone, predominantly grayish red .............

56. Siltstone and fine-grained sandstone, grayishgreen $(10 G Y 5 / 2) \ldots \ldots \ldots \ldots \ldots \ldots \ldots \ldots \ldots$

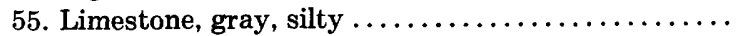

54. Siltstone, greenish-gray (5 $G 6 / 1$ ) to grayish-red, calcareous, locally mottled .................

53. Sandstone, medium-dark-gray, calcareous; grades to gray limestone at top ....................

52. Siltstone, greenish-gray, calcareous $(5 G Y 6 / 1$ and

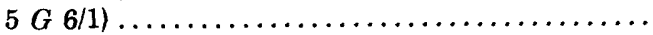

51. Limestone, gray, and calcareous siltstone .........

50. Siltstone, greenish-gray, calcareous (5 GY 6/1 and

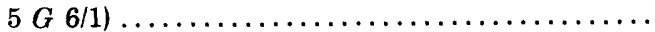

49. Siltstone, greenish-gray to medium-bluish-gray and grayish-red, very calcareous ................

48. Limestone, grayish-yellow-green, medium-grayweathering; contains charophytes .............

47. Sandstone, medium-light-gray, medium-grained; calcareous, crossbedded; some coarser beds have dark-gray siltstone(?) fragments to $1 \mathrm{~cm}$ in diameter .............................

46. Siltstone, limy, and silty limestone; grayish yellow green with lenses of grayish red; grades to limestone at top .........................

45. Limestone, medium-gray, yellowish-gray-weathering

44. Siltstone, grayish-red $(5 R 4 / 2)$, very calcareous .....

43. Sandstone, greenish-gray, calcareous, lenticular .... 
SeCtion 3.-Dakota Sandstone (part), Burro Canyon Formation, Morrison Formation, Entrada Sandstone, Chinle Formation, and State Bridge Formation-Continued

Morrison Formation-Continued

42. Limestone and calcareous siltstone, interbedded and intergrading grayish-red and grayish-yellow-green

41. Sandstone, greenish-gray, calcareous ............

40. Siltstone, grayish-yellow, calcareous .............

39. Siltstone, grayish-red, calcareous ..............

38. Siltstone, grayish-yellow-green, calcareous .........

37. Limestone, grayish-red; silty and calcareous silt-

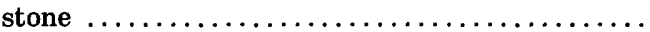

36. Limestone, medium-gray; beds $8 \mathrm{~cm}$ to $1 \mathrm{~m}$ thick; joint-controlled calcite veinlets; becomes silty upward; light bluish gray weathering ............

35. Limestone, grayish-yellow green, silty; contains less silty lenses ...........................

34. Limestone, medium-gray; silty, light-bluish-grayweathering; has limestone fragments near base ...

33. Siltstone, greenish-gray, calcareous; one $10-\mathrm{cm}$ bed of gray limestone .......................

32. Limestone, medium-gray . ..................

31. Sandstone, pale-yellowish-green; somewhat calcare-

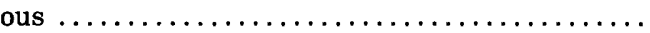

30. Limestone; weathers light olive gray .............

29. Limestone, medium-gray; contains small mediumgray to medium-bluish-gray chert stringers and

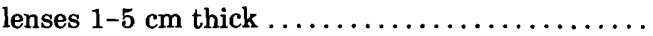

28. Limestone, medium-gray, silty, yellowish-gray-

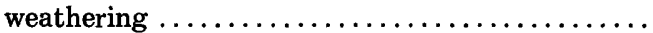

27. Sandstone, bluish-white, medium-grained, calcareous, crossbedded; beds 0.9-1.5 m thick; weathers pinkish gray; grades to moderate-orange-pink- to yellowish-gray-weathering, light-brown sandy limestone at top ........................

26. Sandstone, light-bluish-gray, medium- to finegrained calcareous, yellowish-gray-weathering; contains some beds of light-greenish-gray siltstone

25. Limestone, medium-light-gray to medium-dark-gray, shaly, yellowish-gray-weathering; very calcareous sandstone and sandy limestone; laminae $0.5-5 \mathrm{~mm}$

24. Sandstone, yellowish-gray (5 $Y 7 / 2$ ), calcareous; contains some coarser grains at base; some shaly limestone interbedded along strike

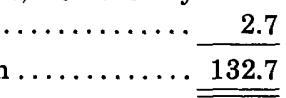

Entrada Sandstone:

23. Sandstone, pinkish-gray, crossbedded; contains laminae and scattered 1-2-mm quartz and chert

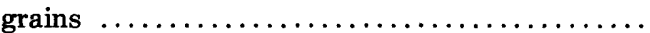

22. Sandstone, yellowish-gray (5 $Y 8 / 1$ ), crossbedded, medium- to coarse-grained; has 1-2-mm quartz and rare grains of chert in a finer grained matrix; larger bedding units $0.9-1.2 \mathrm{~m}$ thick; laminae $3 \mathrm{~mm}$ to

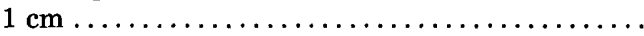

Thickness of Entrada Sandstone

Thickness (meters)
Section 3.-Dakota Sandstone (part), Burro Canyon Formation, Morrison Formation, Entrada Sandstone, Chinle Formation, and State Bridge Formation-Continued

\section{Unconformity}

1.8 Chinle Formation:

\section{Unconformity}

State Bridge Formation:

7. Siltstone, very light gray to yellowish-gray, mottled dusky-red $(5 R 3 / 4) \ldots \ldots \ldots \ldots \ldots \ldots \ldots \ldots$

6. Siltstone, dark-reddish-brown (10 $R$ 3/4), massive calcareous; hackly fracture ................. 
SeCtion 3.-Dakota Sandstone (part), Burro Canyon Formation. Morrison Formation, Entrada Sandstone, Chinle Formation, and State Bridge Formation-Continued

State Bridge Formation:-Continued Thickness (meters)

5. Conglomerate containing lenses of sandstone .......

4. Sandstone and conglomerate, moderate-reddishbrown; contains pebbles and cobbles............

3. Conglomerate; largest pebbles $10 \mathrm{~cm}$; composed of quartz, fine-grained granitic rock; low-grade metamorphic rock, and minor amounts of lightgray limestone.........................

2. Sandstone, moderate-orange-pink $(10 R 7 / 4)$ to moderate-reddish-orange $(10 R 6 / 6)$; pebbles of quartz, quartzite, and siltstone and lenses of conglomerate as much as $2.5 \mathrm{~cm}$ thick

Thickness of State Bridge Formation ........ $\overline{24.1}$

Unconformity

Maroon Formation (part):

Siltstone, moderate-red (5 $R 4 / 6)$ to grayish-red $(10 R 4 / 2)$, calcareous; beds $5-60 \mathrm{~cm} \ldots \ldots \ldots \ldots \ldots$.

SECTION 4.-Dakota Sandstone and Burro Canyon Formation

[This section is on the northwest side of West Willow Creek valley; bottom of section is at $3,377 \mathrm{~m}$ altitude $\mathrm{N} .42^{\circ} \mathrm{W}$. of hill 12015 on Willow-West Willow ridge, Highland Peak quadrangle. Section measured by Bruce Bryant and S. G. Pollock]

Mancos Shale (part):

29. Shale, dark-gray to medium-gray.

Dakota Sandstone:

28. Sandstone, light-olive-gray, fine-grained; beds 2.5-55 cm thick; partings of carbonaceous shale .........

27. Shale and siltstone, medium-dark-gray to dark-gray

26. Sandstone, medium-gray, fine-grained, light-olivegray- to grayish-black-weathering .............

25. Shale and siltstone, medium-dark-gray ...........

24. Sandstone, dark-gray, carbonaceous; mottled light and dark gray on weathered surface ............

23. Shale and siltstone, dark-gray; a few sandstone beds and lenses ..........................

22. Sandstone, light-gray to yellowish-gray, locally dark gray and carbonaceous; grain size $0.2-0.4$ $\mathrm{mm}$; beds $15-60 \mathrm{~cm} . \ldots \ldots \ldots \ldots \ldots \ldots \ldots \ldots$.

21. Shale, siltstone, and sandstone, dark-gray to medium-gray; sandstone beds as much as $15 \mathrm{~cm}$ thick .................................

20. Sandstone, light-olive-gray, fine-grained, dark-yellowish-orange- to light-brown-weathering ........

19. Siltstone, medium-dark-gray
SeCtion 4.-Dakota Sandstone and Burro Canyon Formation -Continued

Thickness

Dakota Sandstone-Continued

18. Shale and siltstone, medium-dark-gray to darkgray $\ldots \ldots \ldots \ldots \ldots \ldots \ldots \ldots \ldots \ldots \ldots, \quad 1.2$

17. Sandstone, medium-grained, fine-grained . ...... $\quad .9$

16. Shale, medium-dark-gray to dark-gray, somewhat carbonaceous ...........................

15. Sandstone, coarse-grained; pebbles of gray chert to $1 \mathrm{~cm}$ in diameter; some feldspar .............

14. Sandstone, medium-light-gray, fine-grained; a few fragments of carbonaceous material; light gray to grayish orange and dark yellowish orange weathering $\ldots \ldots \ldots \ldots \ldots \ldots \ldots \ldots \ldots \ldots \ldots \ldots \ldots, 1.5$

13. Claystone, medium-gray to medium-light-gray .....

12. Sandstone; quartz and some feldspar with a grain size of $0.2 \mathrm{~mm}$; a few thin beds with a grain size of 2-3 $\mathrm{mm}$; weathers grayish orange, light brown, moderate brown, and grayish red; forms cliff .... 10.7

Thickness of Dakota Sandstone .......... $\quad 4 \quad 46.0$

Burro Canyon Formation:

11. Claystone, medium-gray and light-gray ..........

10. Sandstone, siltstone, and claystone, light-gray to medium-light-gray; sandstone beds $0.3-1 \mathrm{~m}$ thick .

9. Claystone and siltstone, light-bluish-gray to greenish-gray (5 $G$ 6/1); a few beds of sandstone 2.5-15 cm thick ...............................

8. Sandstone, grain size $0.2 \mathrm{~mm}$; weathers light gray, grayish orange to light brown; some specks of $\mathrm{Fe}$ oxide .................................

7. Claystone, greenish-gray $(5 G Y 6 / 1) \ldots \ldots \ldots \ldots \ldots \ldots$

6. Sandstone, very light gray; grain size $0.2 \mathrm{~mm}$; scattered grains of feldspar and opaque minerals; beds 0.3-1 $\mathrm{m}$; some thin partings of very light gray siltstone; weathers pale yellowish orange to moderate brown .........................

5. Conglomerate, gray to white; pebbles of quartz chert and quartzite as much as $2 \mathrm{~cm}$ in diameter. .

4. Sandstone, similar to bed $6 \ldots \ldots \ldots \ldots \ldots \ldots \ldots, 7.9$ Thickness of Burro Canyon Formation ...... Morrison Formation (part):

3. Claystone, light-bluish-gray 1.5

2. Siltstone and claystone, grayish-red (5 $R$ 4/2) $\ldots \ldots \ldots \quad 3.0$

1. Siltstone and claystone; greenish-gray $(5 G 6 / 1)$ to light-bluish-gray $(5 B 7 / 1) \ldots \ldots \ldots \ldots \ldots \ldots \ldots .2 .7$ Partial thickness of Morrison Formation ..... 



\section{INDEX}

[Italic page numbers indicate major references]

A

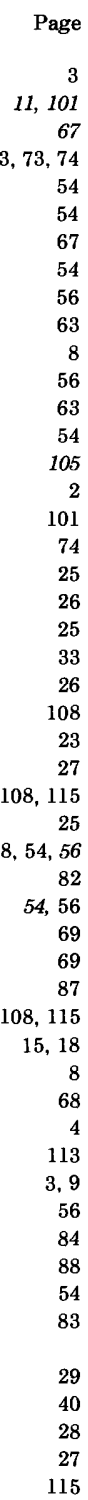

Page

101

67
3,74

54
Access $\ldots \ldots \ldots \ldots \ldots \ldots \ldots \ldots \ldots \ldots \ldots$

Age determinations,$\ldots \ldots \ldots \ldots \ldots \ldots \ldots \ldots \ldots$
Alaskite $\ldots \ldots \ldots \ldots \ldots \ldots \ldots \ldots \ldots \ldots \ldots \ldots$

Albite....

alaskite porphyry

aplite porphyry ....

hornblende porphyry

hornblende quartz diorite.

Allanite.

(n.

granodiorite .......................

hornblende quartz diorite .................

Altitude

American Lake ..........................

Andalusite

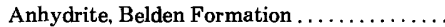

Gothic Formation ...

Highland tunnel . .

Maroon Formation

Monument Gulch . . .

Belden Formation

Anthracospirifer rockymontanus. .............

Antimony

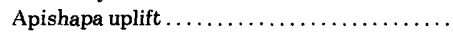

Aplite ....

Castle Creek fault zone ................

porphyry $\ldots \ldots \ldots \ldots \ldots \ldots \ldots \ldots \ldots \ldots$

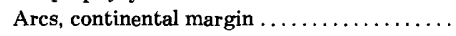
volcanic.

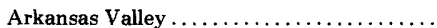

Arsenic

Ashcroft

Ashcroft Mountain, Precambrian rocks ......

Ashflow tuffs

Aspen, history $\ldots \ldots \ldots \ldots \ldots \ldots \ldots \ldots \ldots$

Aspen Contact mine

Aspen Mountain.

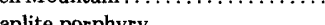

faults ...

glaciation

hornblende quartz diorite

Aspen 7.5-minute quadrangle, Maroon Forma tion ....

State Bridge Formation . . . . . . . . . . . Atokan fusulinds, Elk Range thrust

Aviculopecten sp...................... Azurite

B

Baculites compressus zone ................ Baculites perplexus zone...

80
52,53

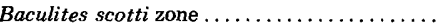

Baldy Mountain .

Barite

, n...................

Basalt flows

Battlement Mesa

Gothic Formatio

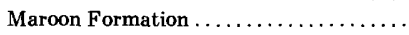

State Bridge Formation .
Belden Formation $\ldots \ldots \ldots \ldots \ldots \ldots, 21,23,25,73,82$ aplite porphyry

hornblende quartz diorite

map relations

red beds.

Belden-Gothic contact .................. 80, 108

Belden-Leadville contact, faulting . . .

Bellerophon (Pharkidonotus) sp. ............

Bellerophontid gastropod, East Maroon Creek

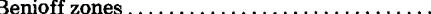

Bigelow moraine. .

Bigelow thrust

Biomicrites

Biotite quartz diorite $\ldots \ldots \ldots \ldots \ldots \ldots \ldots, \quad 8,12$

Bismuth ................................... 115

Black Canyon

Blastomylonite ....

Block faulting

Boulder shaft

achiopods, Belden Formation .............

Gothic Formation

Richmond Hill ...

Broken Rib Member, Dyer Dolomite..........

Brush Creek

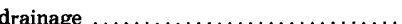

Brush Creek-Snowmass Creek divide, landslides ....

Brushy Basin Member

Bryozoa, Richmond Hill . .

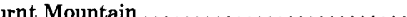

Morrison Formation

Burro Canyon Formation ........... 49, 50, 137, 139

Bushwacker shaft .............................

Butte fault ........................ 82

Cadmium...$\ldots \ldots \ldots \ldots \ldots \ldots \ldots \ldots \ldots$

Calcisphaera laevis

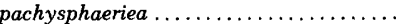

Calc-silicate minerals $\ldots \ldots \ldots \ldots \ldots \ldots \ldots$

Cambrian rock ....

Capitol Creek, Entrada Sandstone ............

Capitol Creek-Snowmass Creek divide ........

Capitol Creek valley

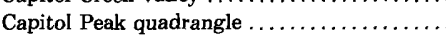
Dakota Sandstone ...

Carlsbad twinned microcline ...

Castle Butte

Manitou Dolomite.

Parting Formation

Castle Butte Member . . . . . . . . . . . . . .

Castle Creek

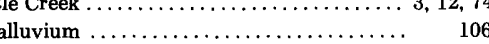

aplite $\ldots \ldots \ldots \ldots \ldots \ldots \ldots \ldots \ldots \ldots \ldots \ldots$

Belden Formation.

Dyer Dolomite

fan deposits...

(n....................

Gothic Formation .................

gypsum $\ldots \ldots \ldots \ldots \ldots \ldots \ldots \ldots \ldots \ldots \ldots \ldots \ldots \ldots \ldots \ldots \ldots \ldots \ldots, 25,110$
Hope tunnel $\ldots \ldots \ldots \ldots \ldots \ldots \ldots \ldots$

hornblende quartz diorite . . . . . . . . . . 54

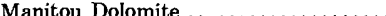

moraines

\section{|}

Castle Creek-Continued

White Rock pluton .

Page

$28,33,80,83,98$

Eagle Valley Formation .............. 79

Maroon Formation ................... $\quad 87$

quartz porphyry ................... $\quad 55$

State Bridge Formation . . . .

Castle Creek valley .................. 24, 84, 87

Belden Formation .................. 23

Castle Peak .......................... 2

Cataract Creek ....................... 63

Cathedral Lake-Montezuma mine area ....... $\quad 86$

Cedar Mountain Formation .............. $\quad 49$

Central Colorado trough .................. $\quad 22$

See also Eagle basin.

Cephalopods, Gothic Formation............ $\quad 27$

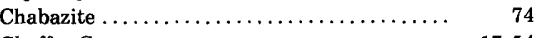

Chaffee Group .................... 17,54

Charophyte remains, Morrison Formation .... 48

Chernyshinella ....................... 22

Chert .............................. 35, 41

Belden Formation . . . . . . . . . . .

Chinle Formation .................. 44

Burro Canyon Formation .............. $\quad 49$

Entrada Sandstone ................ $\quad 46$

Leadville Limestone .................. $\quad 22$

Morrison Formation ................ $\quad 47$

Treasure Mountain dome .............. 23

Chinle Formation ................ 41, 44, 131, 137 depocenter $\ldots \ldots \ldots \ldots \ldots \ldots \ldots \ldots \ldots, \quad 45$

$\begin{array}{ll}\text { depocenter } \ldots \ldots \ldots \ldots \ldots \ldots \ldots \ldots \ldots \ldots \ldots \ldots \ldots \ldots \ldots \ldots \ldots \ldots \ldots & 45\end{array}$

fossils $\ldots \ldots \ldots \ldots \ldots \ldots \ldots \ldots \ldots \ldots \ldots, \quad 46$

red beds $\ldots \ldots \ldots \ldots \ldots \ldots \ldots \ldots \ldots \ldots, \quad 45$

Clark fault ........................ 35, 108

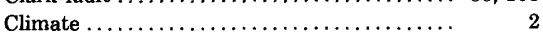

Clinetop Member, Dotsero Formation ....... $\quad 17$

Coffee Pot Member, Dyer Dolomite.......... $\quad 20$

Colluvium ......................... 104

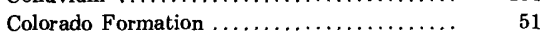

Colorado mineral belt . . . . . . . . . . . . . 72, 88

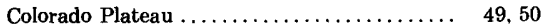

Colorado River drainage ................... $\quad 2$

Colpites kansasensis ................... $\quad 27$

Commodity reports .................... 4

Composita ovata ...................... $\quad 27$

Contact fault $\ldots \ldots \ldots \ldots \ldots \ldots \ldots \ldots \ldots \ldots, \quad 81$

Conundrum Creek ............... 29, 41, 44, 73, 79

Belden Formation ................. 23

Gothic Formation .................. $\quad 25$

landslide deposits $\ldots \ldots \ldots \ldots \ldots \ldots \ldots \ldots \ldots, \quad 103$

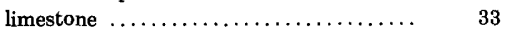

metals, anomalous ................. $\quad 115$

Conundrum Creek valley ............... 34,63

Conundrum Creek window $\ldots \ldots \ldots \ldots \ldots, 63,73,74,82,85$

Conundrum Peak ..................... 59

Cooper Creek ....................... 39, 59

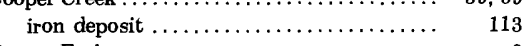

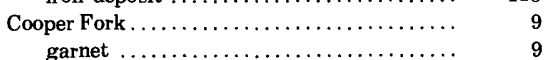

Copper ........................ 108, 114, 115

Copper-silver deposits, Dakota Sandstone .... 115

Copper sulfides, silver content ............ $\quad 119$

Corals .......................... $\quad 22$

Correlations, Cambrian and Ordovician rocks . $\quad 16$

Cozy Point ............................ $\quad 52$

Cozzette Member ....................... $\quad 52$

Crater Lake, landslides ................. 103

natural dam $\ldots \ldots \ldots \ldots \ldots \ldots \ldots \ldots \ldots, \quad 93$ 
Crested Butte 15-minute quadrangle, Belden Formation

Cross Creek Granite.

Custal River...

22
11
2,81

2,81

49

\section{$\mathrm{D}$}

\begin{tabular}{|c|c|}
\hline \multicolumn{2}{|c|}{ Dakota Group..$\ldots \ldots \ldots \ldots \ldots \ldots \ldots \ldots \ldots$} \\
\hline & \\
\hline copper-silver deposits $\ldots \ldots \ldots \ldots \ldots \ldots$ & 115 \\
\hline landslide deposit ....... & 103 \\
\hline Deadmans Gulch Formation.. & 15,16 \\
\hline Deposition, Gothic Formation & 40 \\
\hline Maroon Formation ......... & 40 \\
\hline Difficult Creek valley, quartz monzonite. & 9 \\
\hline Dikes, Quaternary diabase $\ldots \ldots \ldots \ldots \ldots$ & 72 \\
\hline Tertiary diabase...$\ldots \ldots$ & 72 \\
\hline Dinosaurs, Morrison Formation ..... & 49 \\
\hline Diorite, biotite quartz ............ & 8,12 \\
\hline hornblende quartz & 54 \\
\hline quartz $\ldots \ldots \ldots \ldots$ & 7,58 \\
\hline Disseminated sulfides .............. & 63 \\
\hline Domatoceras sp....................... & 27,28 \\
\hline Dotsero Formation $\ldots \ldots \ldots \ldots \ldots \ldots \ldots \ldots$, & 17 \\
\hline Doubletop thrust $\ldots \ldots \ldots \ldots \ldots \ldots \ldots \ldots \ldots$ & 81 \\
\hline Durango, gravels $\ldots \ldots \ldots \ldots \ldots \ldots \ldots \ldots$. & 97 \\
\hline
\end{tabular}

Dyer Dolomite ...................... 18, 19, 20

E

Eagle basin $\ldots \ldots \ldots \ldots \ldots \ldots \ldots \ldots, 5,22,73,79,85$ Elk Range thrust zone.............. $\quad 82$ evaporite deposits ................. $\quad 40$

fusulinid sequence $\ldots \ldots \ldots \ldots \ldots \ldots \ldots, \quad 28$

Gothic Formation ..................

Maroon Formation .................. 36

Pennsylvanian sequence .............. 22

Triassic sequence ................... 22

Eagle Mountain $\ldots \ldots \ldots \ldots \ldots \ldots \ldots \ldots \ldots, 49,79,86$

Dakota Sandstone ................. 115

Maroon Formation ................... $\quad 35$

Eagle Valley Evaporite ................... $\quad 28$

Eagle Valley Formation .............. 28, 29, 79

Earlandia .................................... 22

East Aspen Mountain ....................

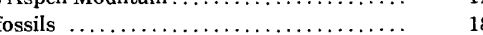

East Brush Creek .................... $\quad 97$

East Maroon-Conundrum ridge . . ......... 33

East Maroon Creek ................. 59, 63,93

rock composition $\ldots \ldots \ldots \ldots \ldots \ldots \ldots, \quad 28$

talus .......................... 104

Trepospira sp.................... $\quad 28$

East Snowmass Creek, Chinle Formation ..... State Bridge Formation.

East Snowmass Creek valley, Entrada Sandstone

East Snowmass Creek-Willow Creek divide...

Eastern Uinta Mountains ..................

Economic geology ....

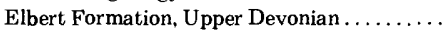

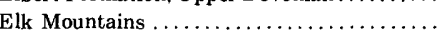

Elk Range thrust zone .................

glaciers .......................... 90, 100

Mancos Shale .....................

Maroon Formation ....................

Morrison Formation ................ 49

rock composition $\ldots \ldots \ldots \ldots \ldots \ldots \ldots \ldots, 58,69$

Snowmass pluton .................. $\quad 85$

Treasure Mountain dome ............. $\quad 87$

White Rock pluton ................. $\quad 85$

Elk Range, geologic map ............... 4

Elk Range thrust fault zone ........ 39, 59, 80, 81, 87 Atokan fusulinds $\ldots \ldots \ldots \ldots \ldots \ldots \ldots \ldots, \quad 28$ formation ....................... 108

Entrada Formation . . . . . . . . . . . . . . . $\quad 79$

Entrada Sandstone ................. 46, 131, 137

Eotubertina ........................ 22
Erosion, glacial $\ldots \ldots \ldots \ldots \ldots \ldots \ldots \ldots \ldots, \quad \begin{array}{r}\text { Page } \\ 7\end{array}$

Euphemites sp....................... 27

Evaporites..............25, 26, 27, 33, 34, 40,79

Exiteloceras jenneyi zone............... 52, 53,80

Express Creek .................... 4, 12, 21,81

Parting Formation $\ldots \ldots \ldots \ldots \ldots$ plant fragments .................... 28

Express Creek-Castle Creek ridge ........... 28

Express Creek valley, Leadville Limestone .... 21

Precambrian rocks ...................

\section{F}

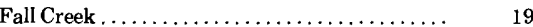

Fans, alluvial and debris $\ldots \ldots \ldots \ldots \ldots \ldots \ldots, \quad 105$ hanging $\ldots \ldots \ldots \ldots \ldots \ldots \ldots \ldots \ldots, 105$

Faults ....................... 80,84,88, 106 Aspen Mountain area ............... 54 bedding-plane, Aspen mining district ..... 81,85 Bigelow thrust $\ldots \ldots \ldots \ldots \ldots \ldots \ldots \ldots \ldots, 84$

block faulting $\ldots \ldots \ldots \ldots \ldots \ldots \ldots \ldots \ldots$

Butte $\ldots \ldots \ldots \ldots \ldots \ldots \ldots \ldots \ldots \ldots \ldots$
Castle Creek fault zone $\ldots \ldots \ldots \ldots 23,33,43,55,79$, $80,82,83,84,87,98$

Clark .................... 35, 108

Contact fault $\ldots \ldots \ldots \ldots \ldots \ldots \ldots \ldots, \quad 81$

Doubletop thrust .................. 81

Elk Range thrust . ... 28, 39, 59, 80, 81, 82, 87, 108

Highland tunnel zone .............. 111

Homestead shear zone $\ldots \ldots \ldots \ldots \ldots, 76,77,85,88$

Hope ....................... 111

Hunters Hill thrust ................ $\quad 80$

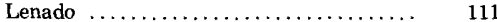

Red Table Mountain ................. $\quad 83$

Silver $\ldots \ldots \ldots \ldots \ldots \ldots \ldots \ldots \ldots \ldots \ldots \ldots \ldots \ldots \ldots \ldots \ldots \ldots \ldots \ldots \ldots, 82,81,108$

Smuggler Mountain ................ 85, 108

Snowmass Creek ................... 79,87

Winnie ........................... $\quad 111$

Woody Creek valley ................ 111

See also Shears.

Fault zones, Highland tunnel

Felsic porphyries, composition .

Fibrolite

Fish plates

Flattops

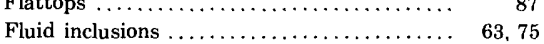

Folds .............................................. 85

Foliation, Precambrian rocks ..............

Foraminifera, Leadville Limestone ...........

Formations, basal Paleozoic .............. 12

Belden ....................21, 22, 23, 25, 54 $55,56,59,73,74,82$

Burro Canyon ............... 49, 50, 137, 139

carbonate ........................ 5, 12

Cedar Mountain ................... 49

Chinle............. 23, 41, 44, 45, 46, 131, 137

Colorado .

Cross Creek Granite................. 11

Curtis ........................................ 49

Dakota Sandstone ........ 49, 50, 86, 103, 115, 119

Deadmans Gulch .................. 15, 16

Dotsero ........................... 17

Dyer Dolomite ................. 18, 19, 20

Eagle Valley $\ldots \ldots \ldots \ldots \ldots \ldots \ldots \ldots \ldots \ldots \ldots \ldots \ldots \ldots \ldots \ldots \ldots \ldots \ldots \ldots, 28,79$

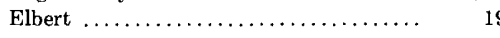

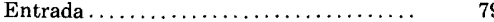

Entrada Sandstone ............. 46, 131, 137

Fremont Limestone ................. 18

Gilman Sandstone $\ldots \ldots \ldots \ldots \ldots \ldots \ldots \ldots, 18,20$

Gothic .............. 23, 25, 27, 28, 31, 34, 36 $40,72,81,82,83,86,110,131$

Green River

82
46

See also Entrada Sandstone.

Harding Quartzit

Hell Gate Porphyry

Kroenke Granodiorite . ................

Leadville Limestone $\ldots .18,20,21,22,23,73,79,81$

Mancos Shale ............. 50, 51, 52, 80, 81 .

$82,84,86,103,105,139$
Formations-Continued

Page

Manitou Dolomite..... 15, 16, 17, 18, 54, 112, 130

Maroon .......23, 25, 28, 29, 46, 47, 79, 84, 131

See also subheadings under Maroon Formation.

Maroon Conglomerate ............... 29

Mesaverde $\ldots \ldots \ldots \ldots \ldots \ldots \ldots \ldots \ldots \ldots, 52,80,82$

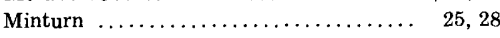

Moenkopi .................... 24, 41

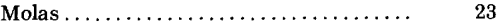

Montana .................................. 51

Morrison ............... 34, 41, 46, 47, 131, 137

Mount Garfield .................. 53

Mount Princeton Quartz Monzonite...... 58

Mount Zion Porphyry ............... 57

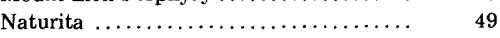

Ohio Creek ....................... 80

Pando Porphyry .................... $\quad 57$

Parting $\ldots \ldots \ldots \ldots \ldots \ldots \ldots \ldots \ldots \ldots \ldots, 17,18,19$

Peerless ................... 14, 15, 16, 17, 130

Pikes Peak Granite ................ 7, 11

Price River ..................... $\quad 52$

St. Kevin Granite .................. 7,11

Sawatch ...................... 14

Sawatch Quartzite ..... 12, 14, 16, 17, 54, 91, 130

Shinarump ...................... 46

Silver Plume Granite ................... $\quad 7$

State Bridge ....... 23, 29, 40, 41, 43, 79, 83, 137

Wasatch $\ldots \ldots \ldots \ldots \ldots \ldots \ldots \ldots \ldots, \quad 59$

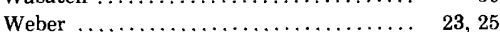

Weber Limestone ................. $\quad 29$

Weber Sandstone ................... $\quad 36$

Weber Shale .......................... 23

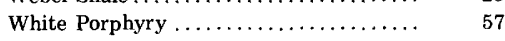

Fort Hays Limestone Member ............ 51,119

Fossil collections $\ldots \ldots \ldots \ldots \ldots \ldots \ldots \ldots \ldots, 18,52$

Fossil plants, Express Creek ............... $\quad 28$

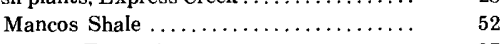

Maroon Formation ................. $\quad 37$

Fossils.......................... 17

Anthracospirifer rockymontanus ........ 27

$\begin{array}{ll}\text { Atokan } \ldots \ldots \ldots \ldots \ldots \ldots \ldots \ldots \ldots \ldots & 28\end{array}$

Aviculopecten sp. ................. $\quad 27$

Baculites compressus zone............ 80 perplexus zone................. 52,53

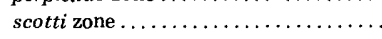

Belden Formation ..................

Bellerophon (Pharkidonotus) sp...........

Bellerophontid gastropod.....

Calcisphaera laevis.

$$
\text { pachysphaeriea }
$$

Chernyshinella

Chinle Formation

Colpites kansasensis

Composita ouata ............

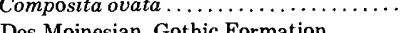

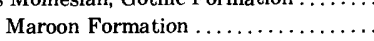

Domatoceras sp .....................

Earlandia ..........................

East Aspen Mountain ...............

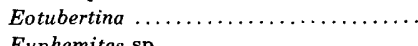

Euphemites sp....................... $\quad 27$

Exiteloceras jenneyi zone ............ 52, 53, 80

Gothic Formation .................. 27

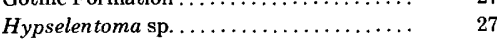

Ianthinopsis (Soleniscus) sp. ........... 27

Inocermus deformis ................. 51

Knishtites (Retispira) nodocostatus ...... $\quad 27$

Latiendothyra sp. ................. $\quad 22$

Leadville Limestone ................ $\quad 22$

Linoproductus prattenianus ............ 27

Liroceras sp ..................... $\quad 27$

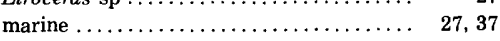

Curtis Formation ................ 49

Maroon Formation ................. 28, 37

Mooreoceras normale ................. $\quad 27$

Myalina sp. ..................... $\quad 27$

Naticopsid Trachydomia sp ..............

$\begin{array}{ll}\text { Naticopsis (Naticopsis) sp ............... } & 27 \\ \text { Palaeoneilo sp..................... } & 27\end{array}$ 


\begin{tabular}{|c|c|}
\hline \multicolumn{2}{|l|}{ Fossil-Continued } \\
\hline Palaeospiroplectar & 22 \\
\hline Paracaligella .... & 22 \\
\hline Parathurammina & 22 \\
\hline Pharkidonotus... & 27 \\
\hline Plagioglypta sp. . & 27 \\
\hline Radiosphaera.... & 22 \\
\hline Schizodus sp..... & $2^{\prime}$ \\
\hline Septabrunsiina $\mathrm{sp}$ & 2 \\
\hline Septaglomospiran & 2 \\
\hline Shansiella carbon & 2 \\
\hline Soleniscus ...... & 2 \\
\hline South Canyon Cre & 4 \\
\hline Spinoendothyria & 2 \\
\hline Stegocoelia $\mathrm{sp} \ldots$ & 2 \\
\hline Trachydomia sp. . & 2 \\
\hline Trempealeauan . & 1 \\
\hline Trepospira sp.... & \\
\hline Tuberendothyra & 2 \\
\hline Fremont Limestone . & \\
\hline Front Range uplift .. & \\
\hline Fryingpan River ... & $, 97,99$ \\
\hline Belden Formatior & \\
\hline Gothic Formatio & \\
\hline ssulinid sequence, $\mathrm{E}$ & \\
\hline
\end{tabular}

G

Galena ........................... $\quad 59$ argentiferous $\ldots \ldots \ldots \ldots \ldots \ldots \ldots \ldots \ldots 114,121$ Garfield 15-minute quadrangle ........... 16,57 Garnet $\ldots \ldots \ldots \ldots \ldots \ldots \ldots \ldots \ldots \ldots . \ldots, 73,74$ Gartra Member, Chinle Formation ......... 44 Gastropods, Gothic Formation ............ 27

Gilman Sandstone ..................... 18,20

Glacial deposits, age $\ldots \ldots \ldots \ldots \ldots \ldots \ldots \ldots . \quad 97$

Glacial geology $\ldots \ldots \ldots \ldots \ldots \ldots \ldots \ldots \ldots, \quad 88$

Glaciation $\ldots \ldots \ldots \ldots \ldots \ldots \ldots \ldots \ldots \ldots, 8,8,90$

Glaciers, Bigelow moraine . . . . . . . . . . . 99

Castle Creek ..................... 90

Castle Creek moraine ............... 96, 99

Elk Mountains .................... 90, 100

erosion

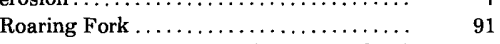

Roaring Fork-Castle Creek-Maroon Creek $\quad 91$

rock glaciers ....................2, 100,101

Sacagawea Ridge Glaciation ........... 97

Sawatch Range glaciers ............. 90, 97

Snowmass Creek................... 91

Thomasville moraine ............... $\quad 99$

Glauconite, Peerless Formation ............ 15

Glenwood Canyon, correlation, Peerless Dolomite. ..

Glenwood Springs $\ldots \ldots \ldots \ldots \ldots \ldots \ldots \ldots \ldots$

fossil collections

Maroon Formation

quartz feldspar $\ldots \ldots \ldots \ldots \ldots \ldots \ldots \ldots \ldots, \quad 31$

Gold $\ldots \ldots \ldots \ldots \ldots \ldots \ldots \ldots \ldots \ldots \ldots \ldots, 59,114,115$

Gold Hill, ore deposits ................ $\quad 120$

Gordon, quoted $\ldots \ldots \ldots \ldots \ldots \ldots \ldots \ldots \ldots, \quad 28$

Gothic-Belden contact, Highland tunnel ...... 111

Gothic Formation............. 23, 25, 34, 72, 82, 131 brachiopods ..................... 27 cephalopods . . . . . . . . . . . . . . . . . $\quad 27$ deposition ..................... 23, 40 Des Moinesian fossils ............... 28,36 fault $\ldots \ldots \ldots \ldots \ldots \ldots \ldots \ldots \ldots \ldots \ldots .81,86$

gastropods $\ldots \ldots \ldots \ldots \ldots \ldots \ldots \ldots \ldots, \quad 27$

Highland tunnel .................. 110

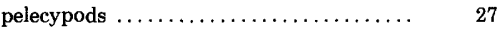

Red Butte .......................... 83

rock composition $\ldots \ldots \ldots \ldots \ldots \ldots \ldots, 23,25,27$

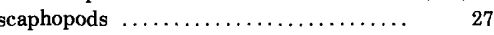

Snowmass pluton ................ 81

thickness . . . . ............. 23, 25, 28, 31

Gothic Formation of Langenheim. See Gothic Formation.

Gothic-Maroon contact, Highland tunnel .....

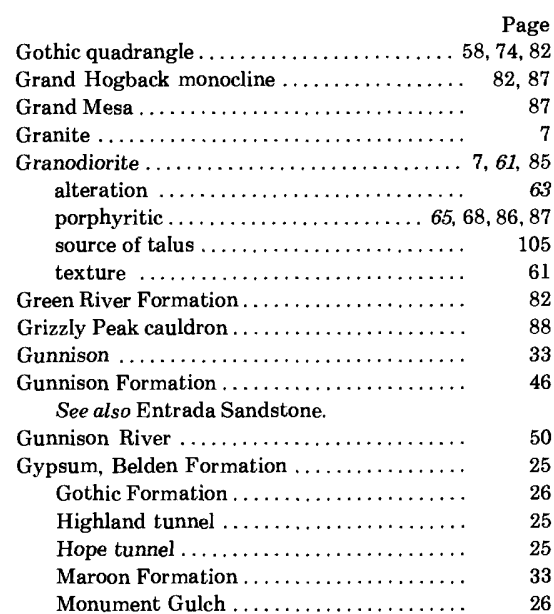

\section{$\mathrm{H}$}

Hanging fans .................. 105

Harding Quartzite .................... 18

Hardscrabble Mountain, State Bridge Formation $\ldots \ldots \ldots \ldots \ldots \ldots \ldots \ldots, 43$

Hayden Peak quadrangle $\ldots \ldots \ldots \ldots \ldots \ldots \ldots, 2,28,85$

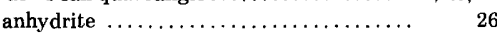

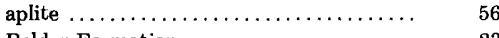

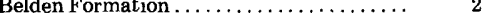

Castle Creek fault zone ................

Chinle Formation $\ldots \ldots \ldots \ldots \ldots \ldots \ldots \ldots$

Elk Range thrust fault zone ............

hornblende quartz diorite $\ldots \ldots \ldots \ldots \ldots \ldots, \quad 54$

iron deposits .................... 113

landslide $\ldots \ldots \ldots \ldots \ldots \ldots \ldots \ldots \ldots, \quad 103$

Precambrian rocks ................. 7

quartz porphyry ................. $\quad 55$

rock glaciers $\ldots \ldots \ldots \ldots \ldots \ldots \ldots \ldots \ldots, \quad 101$

sulfide deposits $\ldots \ldots \ldots \ldots \ldots \ldots \ldots \ldots, \quad 114$

White Rock pluton ................. $\quad 59$

Hayden Survey $\ldots \ldots \ldots \ldots \ldots \ldots \ldots \ldots \ldots \ldots, \quad 4,58$

Haymaker Gulch, Gothic Formation ......... 28

Hell Gate porphyry ................... 11

Hematite ....................... 40, 72, 74

Maroon Formation .................. 35

Peerless Formation . . . . . . . . . . . . $\quad 15$

Smuggler Mountain ................. 11

State Bridge Formation ............. 41

Highland Peak quadrangle $\ldots \ldots \ldots \ldots \ldots 85,86,90,96$

Burro Canyon Formation............. 49

Dakota Sandstone $\ldots \ldots \ldots \ldots \ldots \ldots \ldots, 49,115$

hornblende porphyry $\ldots \ldots \ldots \ldots \ldots \ldots \ldots .67$

Mancos Shale ........

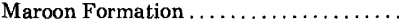

Morrison Formation ...............

State Bridge Formation ................ 40

Highland tunnel $\ldots \ldots \ldots \ldots \ldots .25,56,81,84,110,111$

Highlands Ski area .....................

Chinle Formation ................... 45

History, economic, Aspen .............. 4 geologic, general .................. 5

Holy Cross quadrangle, fossils ............ 17

Homestead shear zone $\ldots \ldots \ldots \ldots \ldots \ldots, 76,77,85,88$

Hope fault $\ldots \ldots \ldots \ldots \ldots \ldots \ldots \ldots \ldots \ldots, \quad 111$

Hope mine $\ldots \ldots \ldots \ldots \ldots \ldots \ldots \ldots \ldots \ldots, \quad 54,55$ Gothic Formation $\ldots \ldots \ldots \ldots \ldots \ldots \ldots, \quad \begin{array}{r}25 \\ 25,110\end{array}$

Hope tunnel $\ldots \ldots \ldots \ldots \ldots \ldots \ldots \ldots \ldots \ldots \ldots \ldots \ldots \ldots \ldots \ldots \ldots \ldots \ldots \ldots \ldots \ldots \ldots, 110$

Hornblende $\ldots \ldots \ldots \ldots \ldots \ldots \ldots \ldots \ldots, 61,63,65,67$

Hornblende porphyry ................... $\quad 67$

$\begin{array}{rr}\text { Hornblende quartz diorite } \ldots \ldots \ldots \ldots \ldots \ldots \ldots & 54 \\ \text { chemical analyses } \ldots \ldots \ldots \ldots \ldots \ldots \ldots \ldots & 54\end{array}$

Hornfels, Belden Formation.............. 23 source of talus ..................... 104

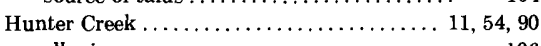
alluvium $\ldots \ldots \ldots \ldots \ldots \ldots \ldots \ldots \ldots, 106$
Hunter Creek valley $\ldots \ldots \ldots \ldots \ldots \ldots \ldots \ldots . \quad \begin{array}{r}\text { Page } \\ 91\end{array}$

quartz monzonite ................... 9

Hunters Hill thrust fault ................. $\quad 80$

Hydrothermal alteration $\ldots \ldots \ldots \ldots \ldots \ldots \ldots \ldots, 65,75$

Hypselentoma sp. ................... 27

Ianthinopsis (Soleniscus) sp.............. 27

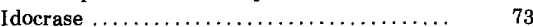

Igneous rocks, chemical analysis ........... 68

Illite, Morrison Formation................ 48

Ilmenite $\ldots \ldots \ldots \ldots \ldots \ldots \ldots \ldots \ldots \ldots, \quad 54$

Independence Pass .................... 3, 68

Independent gold district, ore deposits ...... $\quad 121$

Inoceramus deformis ................... $\quad 51$

Iron $\ldots \ldots \ldots \ldots \ldots \ldots \ldots \ldots \ldots \ldots, 7,108$

Iron deposits $\ldots \ldots \ldots \ldots \ldots \ldots \ldots \ldots \ldots \ldots .59,113$

Copper Creek ..................... 113

Italian Mountain Intrusive Complex, Oligocene $\ldots \ldots \ldots \ldots \ldots \ldots \ldots \ldots, 58,65$

\section{$\mathrm{J}, \mathbf{K}$}

Jacque Mountain Limestone Member ......... $\begin{array}{ll}\text { Joints } \ldots \ldots \ldots \ldots \ldots \ldots \ldots \ldots \ldots \ldots \ldots \ldots \ldots \ldots & 88 \\ \text { Juana Lopez Member, Mancos Shale } \ldots \ldots \ldots \ldots & 51\end{array}$

Keefe Peak ... $\ldots \ldots \ldots \ldots \ldots \ldots \ldots \ldots \ldots \ldots$

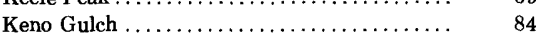

Knishtites (Retispira) nodocostatus .......... 27

Kobey Park, gravels .................. $\quad 97$

Kroenke Granodiorite ................... 11

\section{$\mathbf{L}$}

Lake Creek ......................... 97, 99

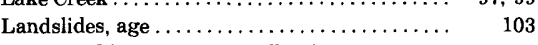
Larkspur Mountain, Leadville Limestone ..... $\quad 22$ rock composition ................. 108 Latiendothyra sp. .................... $\quad 22$ Lead $\ldots \ldots \ldots \ldots \ldots \ldots \ldots \ldots \ldots \ldots \ldots \ldots \ldots \ldots \ldots \ldots \ldots \ldots \ldots \ldots \ldots, 108,115$ production $\ldots \ldots \ldots \ldots \ldots \ldots \ldots \ldots \ldots, 106$ Leadville-Belden contact ............... $\quad 23,81$ Leadville district $\ldots \ldots \ldots \ldots \ldots \ldots \ldots \ldots \ldots, 19,57$ Leadville Limestone ........... 18, 20, 21, 73, 79, 81 Belden Formation.................. 23 hornblende quartz diorite ............ 54 petrology $\ldots \ldots \ldots \ldots \ldots \ldots \ldots \ldots \ldots \ldots, 22$

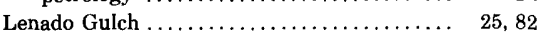

Lenado mining district ................. 106 Lenado project $\ldots \ldots \ldots \ldots \ldots \ldots \ldots \ldots \ldots, \quad 111$ Lincoln Gulch, quartz monzonite .......... $\quad 12$ Lincoln Gulch stock, analysis . . . . . . . . . $\quad 68$

Lineation, alined minerals ............... $\quad 76$

Linoproductus prattenianus .............. $\quad 27$

Liroceras sp. ....................... $\quad 27$

M

Mafic minerals $\ldots \ldots \ldots \ldots \ldots \ldots \ldots \ldots \ldots . \quad 3,65$

Magnesium ......................... 108

Magnetite $\ldots \ldots \ldots \ldots \ldots \ldots \ldots \ldots \ldots \ldots \ldots \ldots \ldots \ldots \ldots, 72,74$ granodiorite $\ldots \ldots \ldots \ldots \ldots \ldots \ldots \ldots \ldots, \quad 63,65$ hornblende quartz diorite ............ 54

Maroon Formation ..................

Malachite $\ldots \ldots \ldots \ldots \ldots \ldots \ldots \ldots, \quad 115$

Mancos Shale ................. 50,51, 86, 139 ammonite zone $\ldots \ldots \ldots \ldots \ldots \ldots \ldots \ldots, \quad 80$

bentonite beds .................... 51

Castle Creek fault zone ................. 84

Elk Range fault ................... 81

fan deposits ..................... 105

fossiliferous calcerenite ............. 51

Gothic Formation ................. 82

landslides ...................... 103

plant fragments ................... 52

Manganese ........................ 108

Manitou Dolomite $\ldots \ldots \ldots \ldots \ldots \ldots \ldots \ldots \ldots \ldots \ldots \ldots \ldots, 16,17,18,54,130$

(1)

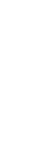




\begin{tabular}{|c|c|}
\hline Maniton Dolomite Continud & Minorale Continued \\
\hline Manitou Dolomite-Continued & Minerals-Continued \\
\hline Woody Creek ............ & azurite ......... \\
\hline Manitou Park, fossils ................. & barite $\ldots \ldots \ldots \ldots \ldots \ldots \ldots \ldots \ldots \ldots \ldots \ldots \ldots \ldots \ldots$ \\
\hline 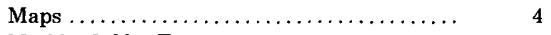 & biotite $\ldots \ldots \ldots \ldots \ldots \ldots \ldots \ldots \ldots 7,33,72,73,77$ \\
\hline Marble, BeIden Formation . . . . . . . . . . . 23, 59, 73 & bismuth......................... $\quad 115$ \\
\hline Marble quadrangle $\ldots \ldots \ldots \ldots \ldots \ldots \ldots \ldots, \quad 81,82$ & chabazite $\ldots \ldots \ldots \ldots \ldots \ldots \ldots \ldots \ldots$ \\
\hline Marine fossils $\ldots \ldots \ldots \ldots \ldots \ldots \ldots \ldots \ldots$ & chalcopyrite ....... \\
\hline Maroon Bells $\ldots \ldots \ldots \ldots \ldots \ldots \ldots \ldots \ldots \ldots, \quad 65$ & copper $\ldots \ldots \ldots \ldots \ldots \ldots \ldots \ldots \ldots \ldots, 108,114,115$ \\
\hline Maroon Bells quadrangle $\ldots \ldots \ldots \ldots \ldots 29,33,74,80,87$ & corundum ........ \\
\hline Belden Formation ..................... $\quad 23$ & $8,54,56,67,72,74$ \\
\hline Chinle Formation $\ldots \ldots \ldots \ldots \ldots \ldots \ldots \ldots$ & ........... $\quad 7$ \\
\hline Dakota Sandstone .................. & $\ldots \ldots \ldots \ldots \ldots \quad 59$ \\
\hline Entrada Sandstone $\ldots \ldots \ldots \ldots \ldots \ldots$ & $\ldots \ldots 9,73,74,100,101$ \\
\hline Gothic Formation .................. & $\ldots \ldots \ldots \ldots 59,114,115$ \\
\hline granodiorite $\ldots \ldots \ldots \ldots \ldots \ldots \ldots \ldots$ & $\ldots \ldots \ldots \ldots \ldots 25,26,33$ \\
\hline hornblende porphyry $\ldots \ldots \ldots \ldots \ldots \ldots$ & hematite $\ldots \ldots \ldots \ldots \ldots \ldots 11,15,35,40,41,72,74$ \\
\hline Morrison Formation ............... & idocrase $\ldots \ldots \ldots \ldots \ldots \ldots \ldots \ldots \ldots \ldots \ldots$ \\
\hline sulfide deposits $\ldots \ldots \ldots \ldots \ldots \ldots \ldots \ldots$ & $\ldots \ldots \ldots \ldots \ldots \ldots, \ldots$ \\
\hline Maroon Bells-Snowmass Wilderness . . . . . . . & ilmenite $\ldots \ldots \ldots \ldots \ldots \ldots \ldots \ldots \ldots \ldots$, \\
\hline Maroon Conglomerate $\ldots \ldots \ldots \ldots \ldots \ldots \ldots . \ldots$ & iron deposits $\ldots \ldots \ldots \ldots \ldots \ldots \ldots \ldots 59,108,113$ \\
\hline Maroon Creek $\ldots \ldots \ldots \ldots \ldots \ldots \ldots \ldots 3,29,90,96,99$ & lead $\ldots \ldots \ldots \ldots \ldots \ldots \ldots \ldots \ldots, 7,106,108,115$ \\
\hline Chinle Formation $\ldots \ldots \ldots \ldots \ldots \ldots \ldots \ldots$ & magnetite $\ldots \ldots \ldots \ldots \ldots \ldots, 35,54,63,65,72,74$ \\
\hline fan deposits . . . . . . . . . . . . 105 & malachite $\ldots \ldots \ldots \ldots \ldots \ldots \ldots \ldots \ldots \ldots \ldots \ldots$ \\
\hline lower $\ldots \ldots \ldots \ldots \ldots \ldots \ldots \ldots \ldots \ldots, 47,49,51$ & molybdenite.................. 59,63, 114 \\
\hline Maroon Formation ................. 41 & natrolite $\ldots \ldots \ldots \ldots \ldots \ldots \ldots \ldots \ldots \ldots \ldots \ldots$ \\
\hline Maroon Creek valley $\ldots \ldots \ldots \ldots \ldots \ldots \ldots$ & phyllonite ........................ \\
\hline $\begin{array}{r}\text { Maroon Formation } \ldots \ldots \ldots \ldots \ldots \ldots 25,28,29,41,46, \\
47,79,84,86,131\end{array}$ & $\begin{array}{l}\text { pyrite } \ldots \ldots \ldots \ldots \ldots \ldots \ldots \ldots \ldots \ldots \ldots \ldots \ldots \ldots \ldots \ldots \ldots \ldots \ldots \ldots \ldots \ldots, 59,74,114 \\
\text { rutile } \ldots \ldots \ldots \ldots \ldots \ldots \ldots \ldots\end{array}$ \\
\hline age $\ldots \ldots \ldots \ldots \ldots \ldots \ldots \ldots \ldots \ldots \ldots \ldots \ldots \ldots \ldots$ & scaptolite $\ldots \ldots \ldots \ldots \ldots \ldots \ldots \ldots \ldots, 73,74,75$ \\
\hline Castle Creek fault zone...$\ldots \ldots \ldots \ldots \ldots$ & sillimanite $\ldots \ldots \ldots \ldots \ldots \ldots \ldots \ldots \ldots \ldots$ \\
\hline chemical analyses $\ldots \ldots \ldots \ldots \ldots \ldots \ldots$ & silver $\ldots \ldots \ldots \ldots \ldots \ldots \ldots \ldots 7,59,106,108,115$ \\
\hline deposition..$\ldots \ldots \ldots \ldots \ldots \ldots \ldots \ldots$ & sphalerite $\ldots \ldots \ldots \ldots \ldots \ldots \ldots \ldots 59,108,114$ \\
\hline Des Moinesian fossils . .............. & stilbite $\ldots \ldots \ldots \ldots \ldots \ldots \ldots \ldots \ldots \ldots \ldots$ \\
\hline Elk Range thrust zone.............. & thomsonite ..................... \\
\hline Highland tunnel $\ldots \ldots \ldots \ldots \ldots \ldots \ldots \ldots$ & tourmaline $\ldots \ldots \ldots \ldots \ldots \ldots \ldots \ldots \ldots$ \\
\hline marine fossils $\ldots \ldots \ldots \ldots \ldots \ldots \ldots \ldots$ & tremolite $\ldots \ldots \ldots \ldots \ldots \ldots \ldots \ldots \ldots$ \\
\hline plant fragments $\ldots \ldots \ldots \ldots \ldots \ldots \ldots \ldots$ & wollastonite $\ldots \ldots \ldots \ldots \ldots \ldots \ldots \ldots$. \\
\hline pyrite $\ldots \ldots \ldots \ldots \ldots \ldots \ldots \ldots \ldots \ldots \ldots \ldots \ldots \ldots \ldots \ldots \ldots$ & zeolites $\ldots \ldots \ldots \ldots \ldots \ldots \ldots \ldots \ldots \ldots \ldots$ \\
\hline red beds $\ldots \ldots \ldots \ldots \ldots \ldots \ldots \ldots \ldots, 35,40,72,114$ & $\operatorname{zinc} \ldots \ldots \ldots \ldots \ldots \ldots \ldots \ldots \ldots, 7,106,108,115$ \\
\hline rock composition $\ldots \ldots \ldots \ldots \ldots \ldots \ldots, 23,29,34$ & zircon $\ldots \ldots \ldots \ldots \ldots \ldots \ldots \ldots \ldots \ldots \ldots \ldots \ldots$ \\
\hline thickness $\ldots \ldots \ldots \ldots \ldots \ldots \ldots \ldots \ldots \ldots \ldots$ & Mines, Aspen Contact.................. \\
\hline White Rock pluton ................. & Boulder shaft $\ldots \ldots \ldots \ldots \ldots \ldots \ldots \ldots$ \\
\hline Maroon sandstones $\ldots \ldots \ldots \ldots \ldots \ldots \ldots$ & Bushwacker shaft .................. \\
\hline McArthur Mountain area, Precambrian rocks. & Castle Creek, Hope tunnel ............. \\
\hline Members, Broken Rib.................. & Cathedral Lake-Montezuma mine area ... \\
\hline Brushy Basin $\ldots \ldots \ldots \ldots \ldots \ldots \ldots \ldots$ & Cooper Creek ..................... \\
\hline Castle Butte ...................... & Gold Hill area $\ldots \ldots \ldots \ldots \ldots \ldots \ldots$ \\
\hline Clinetop $\ldots \ldots \ldots \ldots \ldots \ldots \ldots \ldots \ldots$ & Highland tunnel $\ldots \ldots \ldots \ldots 25,56,81,84,110,111$ \\
\hline Cozzette $\ldots \ldots \ldots \ldots \ldots \ldots \ldots \ldots \ldots \ldots \ldots \ldots \ldots \ldots$ & Hope $\ldots \ldots \ldots \ldots \ldots \ldots \ldots \ldots \ldots \ldots \ldots \ldots \ldots \ldots \ldots \ldots, 54,55$ \\
\hline Fort Hays Limestone ............. 51, 119 & Hope tunnel $\ldots \ldots \ldots \ldots \ldots \ldots \ldots \ldots \ldots 25,110$ \\
\hline Gartra $\ldots \ldots \ldots \ldots \ldots \ldots \ldots \ldots \ldots \ldots 44,45,46$ & Leadville mining district $\ldots \ldots \ldots \ldots \ldots \ldots \quad 19,57$ \\
\hline Jacque Mountain Limestone .......... $\quad 28$ & Lenado mining district ............. $\quad 106$ \\
\hline Juana Lopez..................... $\quad 51$ & Midnight $\ldots \ldots \ldots \ldots \ldots \ldots \ldots \ldots \ldots 108,110$ \\
\hline Peerless Shale $\ldots \ldots \ldots \ldots \ldots \ldots \ldots \ldots \ldots \quad 12,16$ & Midnight shaft $\ldots \ldots \ldots \ldots \ldots \ldots \ldots \ldots \ldots$ \\
\hline Redeliff $\ldots \ldots \ldots \ldots \ldots \ldots \ldots \ldots \ldots \ldots$ & Midnight tunnel $\ldots \ldots \ldots \ldots \ldots \ldots \ldots \ldots$ \\
\hline Rollins Sandstone..$\ldots \ldots \ldots \ldots \ldots \ldots$ & Montezuma $\ldots \ldots \ldots \ldots \ldots \ldots \ldots \ldots \ldots, 74,114$ \\
\hline 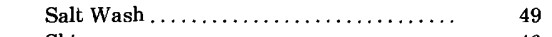 & Park Regent shaft ................ $\quad 91$ \\
\hline Shinarump $\ldots \ldots \ldots \ldots \ldots \ldots \ldots \ldots \ldots$ & Richmond Hill mining district .......... \\
\hline Sloane Peak ..................... & Ruby beds $\ldots \ldots \ldots \ldots \ldots \ldots \ldots \ldots$ \\
\hline South Canyon Creek ................ & Smuggler $\ldots \ldots \ldots \ldots \ldots \ldots \ldots \ldots \ldots$ \\
\hline White Quail $\ldots \ldots \ldots \ldots \ldots \ldots \ldots \ldots \ldots \ldots$ & Snowmass Creek .................. \\
\hline Mesaverde Formation $\ldots \ldots \ldots \ldots \ldots \ldots \ldots 52,80,82$ & Spar Gulch workings . . . . . . . . . . . \\
\hline Paleocene flora $\ldots \ldots \ldots \ldots \ldots \ldots \ldots \ldots \ldots$ & Minturn Formation .................. \\
\hline Mesaverde Group $\ldots \ldots \ldots \ldots \ldots \ldots \ldots \ldots \ldots$ & Minturn quadrangle $\ldots \ldots \ldots \ldots \ldots \ldots \ldots \ldots$ \\
\hline Metamorphism $\ldots \ldots \ldots \ldots \ldots \ldots \ldots \ldots 23,50,59,72$ & fossils $\ldots \ldots \ldots \ldots$ \\
\hline chemistry $\ldots \ldots \ldots \ldots \ldots \ldots \ldots \ldots \ldots \ldots$ & Moenkopi Formation ................. \\
\hline conditions $\ldots \ldots \ldots \ldots \ldots \ldots \ldots \ldots$ & Molas Formation $\ldots \ldots \ldots \ldots \ldots \ldots \ldots \ldots$ \\
\hline Mica schist $\ldots \ldots \ldots \ldots \ldots \ldots \ldots \ldots \ldots \ldots \ldots \ldots \ldots \ldots \ldots \ldots, 11$ & Molybdenite $\ldots \ldots \ldots \ldots \ldots \ldots \ldots \ldots \ldots \ldots 59,63,114$ \\
\hline Midnight mine $\ldots \ldots \ldots \ldots \ldots \ldots \ldots \ldots \ldots, 108,110$ & Molybdenum $\ldots \ldots \ldots \ldots \ldots \ldots \ldots \ldots \ldots \ldots \ldots \ldots$ \\
\hline Midnight shaft $\ldots \ldots \ldots \ldots \ldots \ldots \ldots \ldots \ldots \ldots \ldots \ldots$ & Montana Formation ...... \\
\hline Midnight tunnel $\ldots \ldots \ldots \ldots \ldots \ldots \ldots \ldots \ldots$ & Montezuma mine $\ldots \ldots \ldots \ldots \ldots \ldots \ldots \ldots, 74,114$ \\
\hline Migmatite $\ldots \ldots \ldots \ldots \ldots \ldots \ldots \ldots \ldots \ldots \ldots$ & Monument Gulch $\ldots \ldots \ldots \ldots \ldots \ldots \ldots \ldots . \quad 26$ \\
\hline Mineralization $\ldots \ldots \ldots \ldots \ldots \ldots \ldots \ldots \ldots$ & fan deposits $\ldots \ldots \ldots \ldots \ldots \ldots \ldots \ldots$ \\
\hline Minerals, alaskite $\ldots \ldots \ldots \ldots \ldots \ldots \ldots \ldots \ldots \ldots, \quad 67$ & Monzonite, Mount Princeton Quartz ......... \\
\hline allanite $\ldots \ldots \ldots \ldots \ldots \ldots \ldots \ldots \ldots, 8,54,56,63$ & muscovite-biotite quartz $\ldots \ldots \ldots \ldots \ldots$ \\
\hline andalusite $\ldots \ldots \ldots \ldots \ldots \ldots \ldots \ldots \ldots, \quad 74$ & porphyritic quartz $\ldots \ldots \ldots \ldots \ldots \ldots \ldots . \quad 8,11$ \\
\hline anhydrite $\ldots \ldots \ldots \ldots \ldots \ldots \ldots \ldots \ldots, 25,26,33$ & quartz $\ldots \ldots \ldots \ldots \ldots \ldots \ldots \ldots \ldots, 9,11,12,68,84$ \\
\hline antimony $\ldots \ldots \ldots \ldots \ldots \ldots \ldots \ldots \ldots, 108,115$ & Mooreoceras normale .................. $\quad 27$ \\
\hline apatite $\ldots \ldots \ldots \ldots \ldots \ldots \ldots 7,35,46,48,54,63,67$ & Moraines $\ldots \ldots \ldots \ldots \ldots \ldots \ldots \ldots \ldots \ldots$ \\
\hline$\ldots \ldots \ldots \ldots \ldots \ldots \ldots \ldots \ldots \ldots \ldots \ldots, 108,115$ & Morrison Formation ......... 34, 41, 46, 47, 131, 137 \\
\hline
\end{tabular}

Morrision Formation-Continued

landslide deposit . . . . . . . . . . . . . . . 103

Mosquito Range .......................

Mount Garfield Formation ..............

Mt. Harvard quadrangle ................. 76

Mount Princeton batholith .............. 57

Mount Princeton Quartz Monzonite ......... 58

Mt. Sopis .......................... 81

Mount Zion Porphyry ................ 57

Murchisonid gastropod ................. 27

Muscovite-biotite granite ............... 9

Muscovite-biotite quartz monzonite ......... 8

$\begin{array}{lr}\text { Myalina sp. } \ldots \ldots \ldots \ldots \ldots \ldots \ldots \ldots \ldots \ldots \ldots \ldots \ldots \ldots \ldots \ldots \ldots \ldots \ldots & 27 \\ \text { Myrmekite . . } & 8 \ldots \ldots \ldots \ldots \ldots \ldots\end{array}$

N, $\mathrm{O}$

Naticopsid Trachydomia sp. .............. Naticopsis (Naticopsis) sp.

Natrolite...

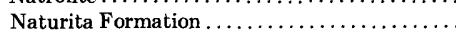

North Thompson Creek

Northern Sawatch Range .........................

Oh-Be-Joyful 7.5-minute quadrangle ........ $\quad 80$

Ohio Creek Formation.................... 80

Ostracod remains, Morrison Formation ....... 48

Owl Creek ...................... 3, 51, 90, 91

Owl Creek drainage .................. 51

Owl Creek valley ...................... 91

$\mathrm{P}$

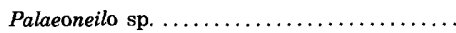

Palaeospiroplectammina

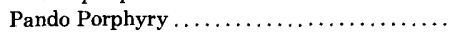

Paracaligella ......

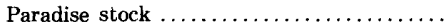

Parathurammina

Park Regent shaft

Parting Formation

fossils ....

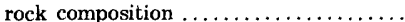

Parting quartzite series ..................

Pearl Pass quadrangle ................. $80,82,8$

Maroon Formation .................

Pectenoid pelecypod ....................

Pedernal uplift $\ldots \ldots \ldots \ldots \ldots \ldots \ldots \ldots \ldots \ldots, 25$

Peerless Formation ................ 14, 15, 16, 17, 130

Peerless Shale Member ................... 16 Sawatch Quartzite ................. 12, 16

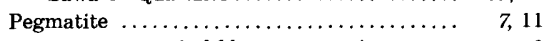
quartz-potassic feldspar-muscovite ...... 8

Perthite $\ldots \ldots \ldots \ldots \ldots \ldots \ldots \ldots \ldots \ldots, \quad 11$

Phenocrysts $\ldots \ldots \ldots \ldots \ldots \ldots \ldots \ldots . \ldots \ldots \ldots \ldots \ldots \ldots \ldots, 56,63,65,67$

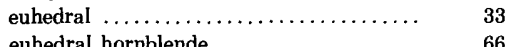
euhedral hornblende $\ldots \ldots \ldots \ldots \ldots \ldots \ldots .66$

hornblende ..................... 67

plagioclase $\ldots \ldots \ldots \ldots \ldots \ldots \ldots \ldots \ldots, 66,67$

potassic feldspar ..................... $\quad 66$

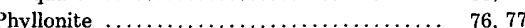

Pikes Peak Granite .................. 7, 71

Pine Creek drainage, anomalous metals ....... $\quad 115$

Pitkin County ...................... 19, 20

Plagioglypta sp. ..................... 27

Plant fragments, Express Creek ............. 28 Mancos Shale .....................

Maroon Formation ................ 37

Pleurotomacean Hypselentoma sp. ..........

Pluton, White Rock. See White Rock pluton.

Plutonism

Porphyries, felsic, composition ............. 56

Porphyritic granodiorite ................

Porphyritic quartz monzonite ............... 8,11

chemical analysis ..................

Prophyry, albite alaskite ............... 54

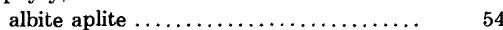

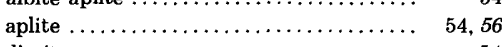

diorite $\ldots \ldots \ldots \ldots \ldots \ldots \ldots \ldots \ldots, 54$

7

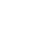

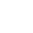




\begin{tabular}{|c|c|}
\hline \\
\hline & \\
\hline \multicolumn{2}{|l|}{ Porphyry-Continued } \\
\hline \multicolumn{2}{|l|}{ Mount Zion $\ldots \ldots \ldots \ldots \ldots \ldots \ldots \ldots \ldots \ldots$} \\
\hline \multicolumn{2}{|l|}{ 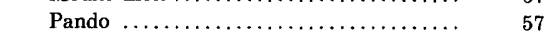 } \\
\hline 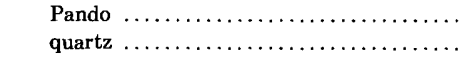 & 54,55 \\
\hline \\
\hline & \\
\hline \multirow{2}{*}{\multicolumn{2}{|c|}{$\begin{array}{r}\text { Precambrian rocks } \ldots \ldots \ldots \ldots \ldots \ldots \ldots \ldots \\
\text { chronology } \ldots \ldots \ldots \ldots \ldots \ldots \ldots \ldots \ldots\end{array}$}} \\
\hline & \\
\hline \multicolumn{2}{|l|}{ Precipitation.$\ldots \ldots \ldots \ldots \ldots \ldots \ldots \ldots \ldots \ldots$} \\
\hline \multicolumn{2}{|l|}{ Price River Formation $\ldots \ldots \ldots \ldots \ldots \ldots$} \\
\hline \multirow{2}{*}{\multicolumn{2}{|c|}{ Pseudozygopleurid gastropod $\ldots \ldots \ldots \ldots \ldots$}} \\
\hline \multirow{2}{*}{\multicolumn{2}{|c|}{$\begin{array}{l}\text { Pyramid Peak, landslides } \ldots \ldots \ldots \ldots \ldots \ldots \ldots \ldots \\
\text { Pyrite } \ldots \ldots \ldots \ldots \ldots \ldots \ldots \ldots \ldots \ldots \ldots \ldots \ldots\end{array}$}} \\
\hline & \\
\hline \multicolumn{2}{|l|}{$\begin{array}{r}\text { Pyrite } \ldots \ldots \ldots \ldots \ldots \ldots \ldots \ldots \ldots \ldots \ldots \ldots \ldots \ldots \ldots \ldots \ldots \\
\quad \text { Belden Formation } \ldots \ldots \ldots \ldots \ldots \ldots \ldots \ldots \ldots\end{array}$} \\
\hline \multirow{2}{*}{\multicolumn{2}{|c|}{$\begin{array}{l}\text { Maroon Formation } \ldots \ldots \ldots \ldots \ldots \ldots \ldots \ldots \\
\text { quartz porphyry } \ldots \ldots \ldots \ldots \ldots \ldots \ldots \ldots\end{array}$}} \\
\hline & \\
\hline White Rock pluton $\ldots \ldots \ldots \ldots \ldots \ldots \ldots$ & \\
\hline
\end{tabular}

\section{Q}

Quadrangles, Aspen 7.5-minute . Capitol Peak ................... 86, 97, 115 Crested Butte .................... 29 Crested Butte 15-minute ........... 22, 25, 28

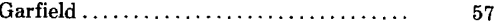
Garfield 15 -minute ................. 16 Gothic $\ldots \ldots \ldots \ldots \ldots \ldots \ldots \ldots \ldots \ldots, 58,74,82$ Hayden Peak...... 2, 7, 23, 26, 28, 45, 54, 55, 56, $59,80,83,85,101,103,113,114$ Highland Peak ........... 34, 40, 47, 49, 51, 67, $85,86,90,96,115$ Marble ........................ 81, 82 Maroon Bells ......... 23, 25, 29, 33, 45, 46, 47, $50,59,67,74,80,87,114$ Minturn $\ldots \ldots \ldots \ldots \ldots \ldots \ldots \ldots \ldots \ldots \quad 17,28$ Mt. Harvard .................... 76 Oh-Be-Joyful 7.5-minute ............. $\quad 80$ Pearl Pass $\ldots \ldots \ldots \ldots \ldots \ldots \ldots \ldots \ldots \ldots, 8,8,82,83$ Ruedi .............. 23, 29, 31, 39, 81, 85, 97 Snowmass Mountain . ............. 80, 82, 87 Taylor Park ...................... 83 Woody Creek ......... 34, 37, 41, 44, 45, 49, 52, $72,80,83,85,86,96,97$

Quartz diorite .................... 7,58

Quartz feldspar gneiss ................. 31

Quartz monzonite $\ldots \ldots \ldots \ldots \ldots \ldots \ldots \ldots \ldots, 7,9,11,12$

chemical analysis ................. 11

Quartz porphyry $\ldots \ldots \ldots \ldots \ldots \ldots \ldots \ldots \ldots, \quad 54,55$

Quartz-potassic feldspar-muscovite pegmatite

Quartzite

Chinle Formation ....................

Maroon Formation . . . . . . . . . . . . . . 29

Parting Formation .................. $\quad 19$

Treasure Mountain dome ............. 23

Queens Gulch ...................... $\quad 82$

fossils $\ldots \ldots \ldots \ldots \ldots \ldots \ldots \ldots \ldots \ldots, 18$

Queens Gulch road $\ldots \ldots \ldots \ldots \ldots \ldots \ldots \ldots, 54,84$

Radiosphaera $\ldots \ldots \ldots \ldots \ldots \ldots \ldots \ldots \ldots \ldots, \quad 22$

Red beds, Belden Formation . . . . . . . . . . . $\quad 74$

Chinle Formation $\ldots \ldots \ldots \ldots \ldots \ldots \ldots \ldots, \quad 45$
Maroon Formation $\ldots \ldots \ldots \ldots \ldots \ldots \ldots, 4,72$

Maroon Formation $\ldots \ldots \ldots \ldots \ldots \ldots \ldots, 35,40,72$
Red Butte $\ldots \ldots \ldots \ldots \ldots \ldots \ldots \ldots \ldots \ldots \ldots, 41,83$

Chinle Formation .................... 44

Entrada Sandstone $\ldots \ldots \ldots \ldots \ldots \ldots \ldots, \quad 46$

Mancos Shale $\ldots \ldots \ldots \ldots \ldots \ldots \ldots \ldots \ldots, \quad 51$

Morrison Formation ................ $\quad 47$

Red Mountain ...................... 29, 31

deposits.......................

Red Table Mountain fault .............. 83

Redcliff Member........................ 21

Richmond Hill $\ldots \ldots \ldots \ldots \ldots \ldots \ldots, 4,10,54,56,84,88$ brachiopods ..................... 22

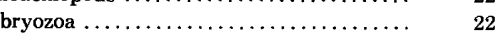

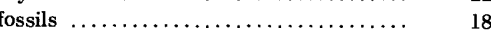
mining district $\ldots \ldots \ldots \ldots \ldots \ldots \ldots \ldots, \quad 106$ solifluction deposits ............... 104
Rio Grande trough $\ldots \ldots \ldots \ldots \ldots \ldots \ldots \ldots \ldots$

Roaring Fork-Castle Creek-Maroon Creek glacier .....................

Roaring Fork drainage $\ldots \ldots \ldots \ldots \ldots \ldots \ldots \ldots$

Roaring Fork glacier $\ldots \ldots \ldots \ldots \ldots \ldots \ldots \ldots, 91$

Roaring Fork River $\ldots \ldots \ldots \ldots \ldots \ldots 52,88,96,98,99$ alluvium ....................... 106

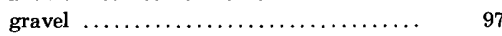
landslide.....

Roaring Fork syncline $\ldots \ldots \ldots \ldots \ldots \ldots, 83,85,86,87$

Roaring Fork valley $\ldots \ldots \ldots \ldots \ldots, 51,56,83,90,93,99$ climate $\ldots \ldots \ldots \ldots \ldots \ldots \ldots \ldots \ldots, 2$

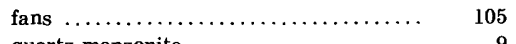
quartz monzonite ................. 9

$\begin{array}{lr}\text { Rock glaciers } \ldots \ldots \ldots \ldots \ldots \ldots \ldots \ldots \ldots \ldots \ldots & 101 \\ \text { Rollins Sandstone Member } \ldots \ldots \ldots \ldots \ldots \ldots & 53\end{array}$

Rubidium-strontium determinations $\ldots \ldots \ldots \ldots .11$

Ruby beds $\ldots \ldots \ldots \ldots \ldots \ldots \ldots \ldots \ldots \ldots \ldots, \quad 59$

Ruedi quadrangle $\ldots \ldots \ldots \ldots \ldots \ldots \ldots . \ldots 31,81,85,97$ Belden Formation ................... Eagle Valley Formation .............. $\quad 29$

Maroon Formation ................. $\quad 39$

Rutile ........................... 63

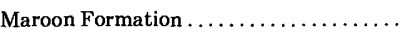

State Bridge Formation.

\section{$\mathrm{S}$}

Sacagawea Ridge Glaciation .....

St. Kevin Granite, Precambrian Y . . .

Salt Wash Member

San Juan Basin .....

San Juan Mountains ...

Molas Formation . . .

San Juan region .

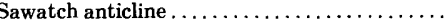

Sawatch Formation ...

Sawatch migmatite ...................

Sawatch Quartzite ............. 12, 16, 17, 54, 91, 130

fossils $\ldots \ldots \ldots \ldots \ldots \ldots \ldots \ldots \ldots, \quad 14$

Sawatch Range $\ldots \ldots \ldots \ldots \ldots \ldots 2,7,17,20,28,54,80$ $\begin{array}{ll}\text { Belden Formation ..................... } & 23 \\ & \end{array}$ Elk Range thrust fault zone $\ldots \ldots \ldots \ldots \ldots, \quad 82$

faulting $\ldots \ldots \ldots \ldots \ldots \ldots \ldots \ldots \ldots \ldots, \quad 108$

glaciers $\ldots \ldots \ldots \ldots \ldots \ldots \ldots \ldots \ldots \ldots, 90,97$

Gothic Formation

Grizzly Peak cauldron

Mount Princeton batholith .................

rubidium-strontium determinations ......

shear zones.

Sawatch Range uplift ................... 5,7

Sawatch schist $\ldots \ldots \ldots \ldots \ldots \ldots \ldots \ldots \ldots \ldots, \quad 7$

Scaphopods, Gothic Formation .............

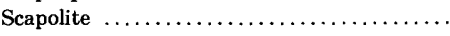

Schist, mica .........................

Schizodus sp.

Schofield syncline

Septabrunsiina sp.

Septaglomospiranella dainae

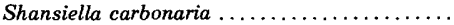

Shears $\ldots \ldots \ldots \ldots \ldots \ldots \ldots \ldots \ldots \ldots \ldots \ldots$
Shelf sequence, Cambrian through Mississip-

Shelf sequence, Cambrian through Mississip
pian $\ldots \ldots \ldots \ldots \ldots \ldots \ldots \ldots \ldots \ldots$

Shell fragments $\ldots \ldots \ldots \ldots \ldots \ldots \ldots \ldots \ldots$

Shinarump Member

Silicification

Sillimanite



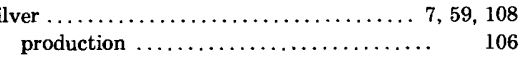

Snowmass Creek mine ................ $\quad 115$

Silver fault $\ldots \ldots \ldots \ldots \ldots \ldots \ldots \ldots \ldots \ldots 22,81,108$

Silver Plume Granite ................... 7

Sloane Peak Member, Lower Triassic ........ 41

Smuggler mine, faults ................. 108

Smuggler Mountain $\ldots \ldots \ldots \ldots \ldots \ldots \ldots \ldots, \quad 3,91$

alluvium $\ldots \ldots \ldots \ldots \ldots \ldots \ldots \ldots \ldots \ldots, 106$

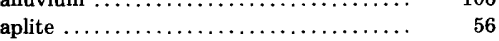

faults $\ldots \ldots \ldots \ldots \ldots \ldots \ldots \ldots \ldots \ldots, 85,108$

$\begin{array}{lr}\text { hornblende quartz diorite } \ldots \ldots \ldots \ldots \ldots \ldots & 54 \\ \text { quartz monzonite } \ldots \ldots \ldots \ldots \ldots \ldots \ldots \ldots & 10\end{array}$
Smuggler Mountain-Continued

Sawatch uplift

Page

89

Snowmass Creek .............. 2, 49, 86, 91, 93, 99

Dakota Sandstone ................. 115

outwash landforms ................... 2

Snowmass Creek canyon ................ 48, 65

Snowmass Creek drainage ................ 96

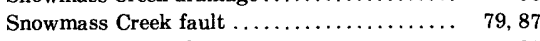

Snowmass Creek glacier ................ 91

Snowmass Creek mine $\ldots \ldots \ldots \ldots \ldots \ldots \ldots . \quad 115$

Snowmass Creek valley $\ldots \ldots \ldots \ldots \ldots \ldots \ldots \quad \mathbf{8 6 , 9 1}$

Snowmass Mountain quadrangle $\ldots \ldots \ldots \ldots \ldots \quad 80,87$

Mancos Shale $\ldots \ldots \ldots \ldots \ldots \ldots \ldots \ldots, \quad 82$

Snowmass pluton .......... 28, 58, 59, 81, 85, 86, 87

Soleniscus ...................... 27

South Canyon Creek Member, Permian fos-

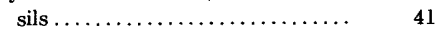

ripple marks $\ldots \ldots \ldots \ldots \ldots \ldots \ldots \ldots \ldots, \quad 44$

Spar Gulch, Leadville Limestone ............ 21

mine workings $. \ldots \ldots \ldots \ldots \ldots \ldots \ldots \ldots, 21$

Sphalerite ...................... 59, 108, 114

Spinoendothyra spinosa ................ 22

State Bridge Formation .......... 29, 40, 79, 83, 137 depocenter $\ldots \ldots \ldots \ldots \ldots \ldots \ldots \ldots \ldots, 43$

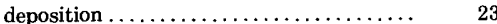
ripple marks ...................... 41 rock composition $\ldots \ldots \ldots \ldots \ldots \ldots \ldots \ldots, 23,41$

Stegocoelia sp. ...................... $\quad 27$

Sterner Gulch ....................

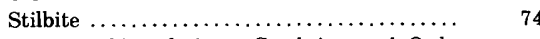

Stratigraphic relations, Cambrian and Ordovician rocks $\ldots \ldots \ldots \ldots \ldots \ldots \ldots, \quad 16$

Structural features, Apishapa uplift ......... $\quad 25$ central Colorado trough . . . . . . . . . . 5,22 Conundrum Creek window ...... 63, 73, 74, 82, 85 Front Range uplift ................. $\quad 25$

Grand Hogback monocline ............ 82, 87

Pedernal uplift $\ldots \ldots \ldots \ldots \ldots \ldots \ldots \ldots \ldots . .25$

Rio Grande trough .................. 5

Roaring Fork syncline $\ldots \ldots \ldots \ldots \ldots 83,85,86,87$

Sawatch Range uplift .............. 5,7

Schofield syncline $\ldots \ldots \ldots \ldots \ldots \ldots \ldots \ldots, 82$

Uncompahgre highland $\ldots \ldots \ldots \ldots \ldots 23,31,79$

Uncompahgre uplift . . . . . . 5, 23, 25, 31, 40, 79, 85

White River uplift ................ 16, 17

Structure

Phanerozoic .................... $\quad 79$

Studies, previous ......................

Sulfides, disseminated $\ldots \ldots \ldots \ldots \ldots \ldots \ldots \ldots, 63,114$

Surficial deposits .....................

\section{$\mathbf{T}$}

Talus .....

Taylor Lake, Precambrian rocks ............ 9

Taylor Park ..................... 16, 87

Deadmans Gulch Formation........... $\quad 15$

porphyritic quartz monzonite $\ldots \ldots \ldots \ldots, 9,12$

Taylor Park quadrangle ................. $\quad 83$

Taylor Pass, Precambrian rocks ............. 9

Sawatch Quartzite .................... 12

Taylor Pass road ......................

$\begin{array}{lr}\text { Taylor Peak, Belden Formation } \ldots \ldots \ldots \ldots \ldots & 24 \\ & \end{array}$

$\begin{array}{lr}\text { Taylor River ........................ } & 2,84 \\ \text { Tertiary Tincup Quartz Monzonite Porphyry .. } & 58\end{array}$

Thompson Creek ..................... 52

Thomasville moraine $\ldots \ldots \ldots \ldots \ldots \ldots \ldots \ldots ., 99$

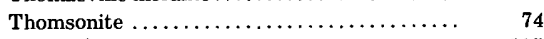

$\begin{array}{lr}\text { Tourmaline } \ldots \ldots \ldots \ldots \ldots \ldots \ldots \ldots \ldots & 115 \\ \text { Tourtelotte Park Parting Formation } \ldots \ldots \ldots\end{array}$

Tourtelotte Park, Parting Formation ..........

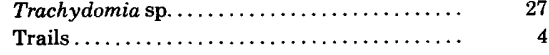

Transgressive sea $\ldots \ldots \ldots \ldots \ldots \ldots \ldots \ldots \ldots, \quad 21$

Treasure Mountain dome $\ldots \ldots \ldots \ldots \ldots \ldots \ldots, 25,87$

Belden Formation .................. 23

Entrada Sandstone ................. 46

Trempealeauan fossils .................. 17

Tremolite $\ldots \ldots \ldots \ldots \ldots \ldots \ldots \ldots \ldots \ldots \ldots \ldots \ldots \ldots \ldots \ldots$
Trepospira sp. $\ldots \ldots \ldots \ldots \ldots \ldots \ldots \ldots$ 


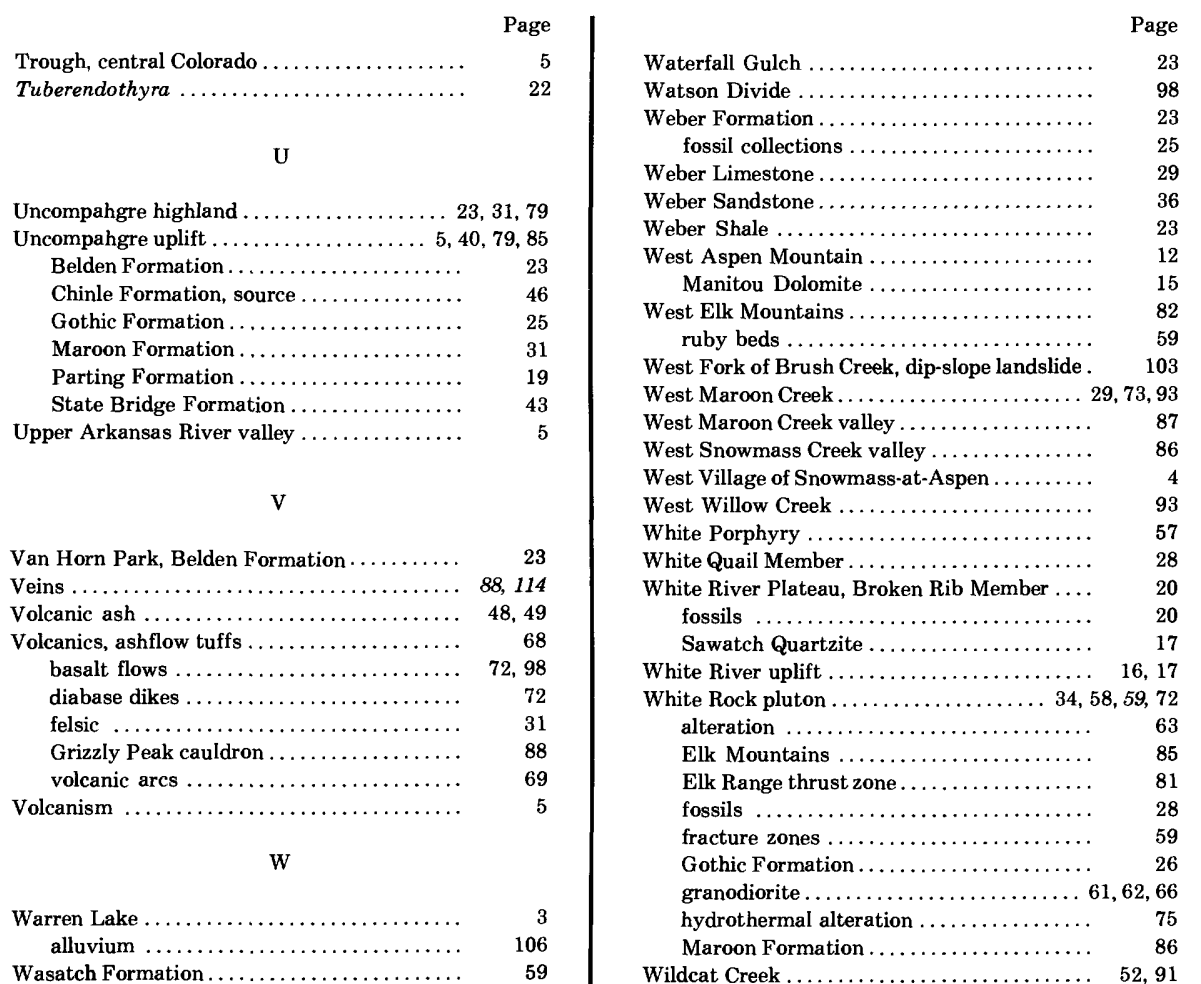

Wildcat Creek valley

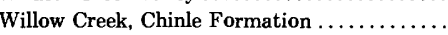
Entrada Sandstone

Morrison Formation . ..................

Willow Creek valley .....................

State Bridge Formation ................

Wind River Mountains .................. 97

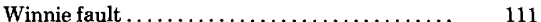

Wollastonite $\ldots \ldots \ldots \ldots \ldots \ldots \ldots \ldots \ldots \ldots \ldots, \quad 73$

Woody Creek $\ldots \ldots \ldots \ldots \ldots \ldots \ldots \ldots \ldots, 3,16,29,31,36$

alluvium ........................ 106

Manitou Dolomite ................... 112

Sawatch Quartzite ................. 12

Woody Creek quadrangle .......... 41, 72, 85, 96, 97

Castle Creek fault zone ................ 83

Chinle Formation ...................

Curtis Formation . . . . . . . . . $49 \ldots \ldots \ldots \ldots \ldots \ldots \ldots$

fossils $\ldots \ldots \ldots \ldots \ldots \ldots \ldots \ldots \ldots, \quad 80$

Mancos Shale ................... 52,86

Maroon Formation .................. 34, 37, 44

Woody Creek valley $\ldots \ldots \ldots \ldots \ldots \ldots \ldots \ldots \ldots, \quad 25$

faults ......................... 111

$\mathrm{X}, \mathrm{Y}, \mathrm{Z}$

Xenocrysts $\ldots \ldots \ldots \ldots \ldots \ldots \ldots \ldots \ldots \ldots \ldots \ldots \ldots$

Yochelson, quoted $\ldots \ldots \ldots \ldots \ldots \ldots \ldots \ldots . \quad 28$

Zeolites $. \ldots \ldots \ldots \ldots \ldots \ldots \ldots \ldots \ldots \ldots \ldots \ldots, \quad \mathbf{7 4}$

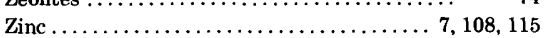
production $\ldots \ldots \ldots \ldots \ldots \ldots \ldots \ldots \ldots \ldots \ldots \ldots \ldots \ldots, 108,115$ 